\title{
Sustainable Synthesis by 3d Transition Metal Electro-Catalyzed C-H Activation
}

\author{
Dissertation \\ for the award of the degree \\ "Doctor rerum naturalium" \\ of the Georg-August-Universität Göttingen
}

within the doctoral program of chemistry

of the Georg-August-Universität School of Science (GAUSS)

Submitted by

Cuiju Zhu

From Hubei (China)

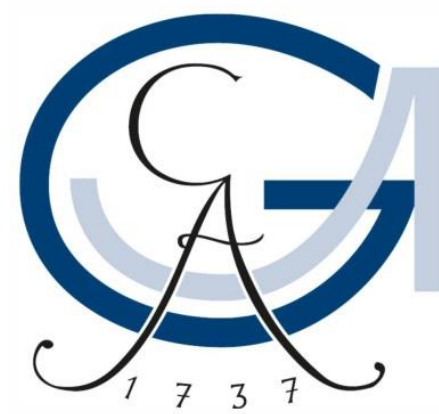

Göttingen, 2019 



\section{Thesis Committee}

Prof. Dr. Lutz Ackermann, Institute of Organic and Biomolecular Chemistry Prof. Dr. Alexander Breder, Institut für Organische Chemie, Regensburg/Institute of Organic and Biomolecular Chemistry, Göttingen

\section{Members of the Examination Board}

Reviewer: Prof. Dr. Lutz Ackermann, Institute of Organic and Biomolecular Chemistry, Göttingen

Second Reviewer: Prof.Dr. Alexander Breder, Institut für Organische Chemie, Regensburg/Institute of Organic and Biomolecular Chemistry, Göttingen

\section{Further members of the Examination Board}

Prof. Dr. Konrad Koszinowski, Institute of Organic and Biomolecular Chemistry, Göttingen

Prof. Dr. Manuel Alcarazo, Institute of Organic and Biomolecular Chemistry, Göttingen

Dr. Holm Frauendorf, Institute of Organic and Biomolecular Chemistry, Göttingen

Dr. Michael John, Institute of Organic and Biomolecular Chemistry, Göttingen 



\section{Table of Contents}

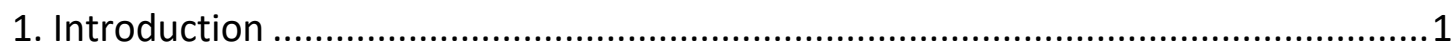

1.1 Transition Metal-Catalyzed C-H Functionalization ........................................

1.1.1 Transition Metal-Catalyzed Cross-Couplings vs. C-H Activation....................1

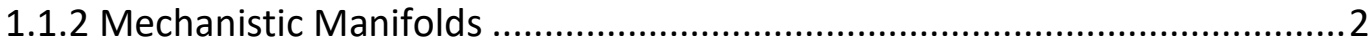

1.2 Cobalt(III)-Catalyzed C-H Activation .......................................................... 5

1.2.1 Early Examples of Cobalt-Catalyzed C-H Activation .................................6

1.2.2 C-H Activation with Well-Defined Cobalt Complexes................................

1.2.2 High-Valent Cobalt(III)-Catalyzed C-H Activations ....................................

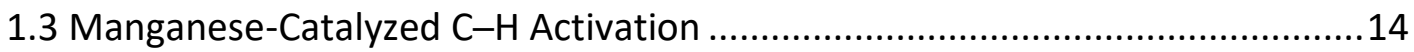

1.3.1 Early Examples of Manganese-Catalyzed C-H Functionalization ................14

1.3.2 Manganese(I)-Catalyzed C-H Functionalization ......................................18

1.3.3 Low-Valent Manganese(II)-Catalyzed C-H Functionalizations....................22

1.4 Electrochemical Transition Metal-Catalyzed C-H Activation...........................23

1.4.1 Electrocatalytic Palladium-Catalyzed Transformations............................23

1.4.2 Electrocatalytic Cobalt-Catalyzed Transformations ................................26

1.4.3 Electrocatalyzed Transformations by Other Transition Metals .................28

1.5 Low-Valent Iron-Catalyzed C-H Activation .................................................... 30

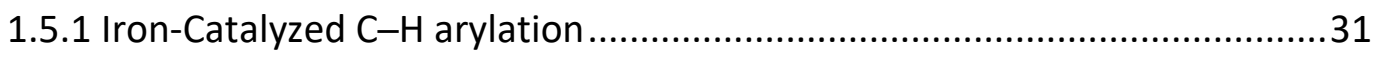

1.5.2 Iron-Catalyzed C-H Activation through Triazole Assistance ......................33

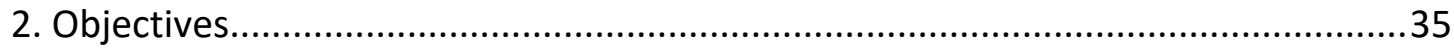

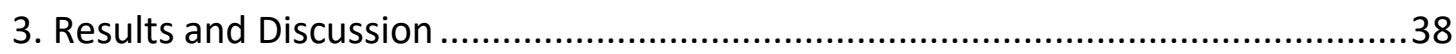

3.1 Domino C-H Activation/Directing Group Migration/Alkyne Annulation: Unique

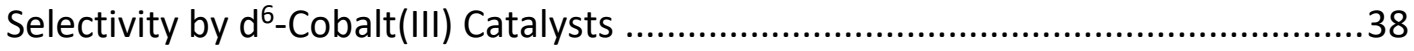

3.1.1 Optimization Studies for Cobalt-Catalyzed Domino Annulation.................39

3.1.2 Scope of Cobalt(III)-Catalyzed C-H/C-N Functionalization ........................40 
3.1.3 Mechanistic Studies

3.1.4 Late-Stage Modifications .46

3.1.5 Proposed Catalytic Cycle 47

3.2 Manganese(I)-Catalyzed C-H Activation/Diels-Alder/retro-Diels-Alder Domino Alkyne Annulation

3.2.1 Optimization of Domino C-H Activation/Diels-Alder/retro-Diels-Alder .....49

3.2.2 Scope of Manganese(I)-Catalyzed C-H Activation/Diels-Alder/retro-Diels-

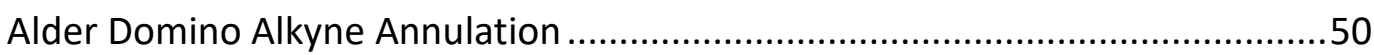

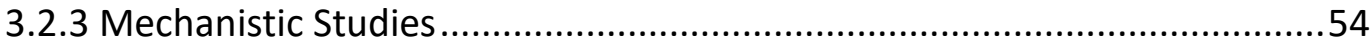

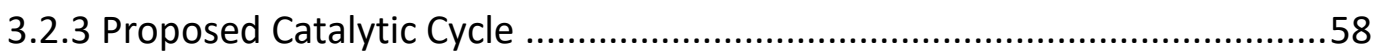

3.3 Manganese(II/III/I)-Catalyzed C-H Arylations in Continuous Flow...................60

3.3.1 Optimization of $\mathrm{C}-\mathrm{H}$ Arylation in Continuous Flow.................................60

3.3.2 Scope of Manganese-Catalyzed C-H Arylation .......................................62

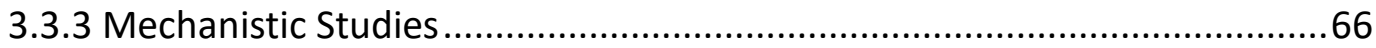

3.3.3 Synthetic Utility of Manganese-Catalyzed C-H Arylation .........................69

3.4 Metallaelectrocatalyses: Electricity for Resource-Economic Iron-Catalyzed C-H

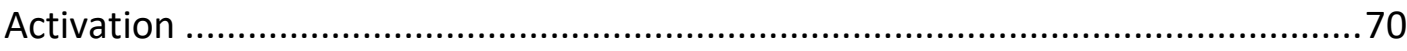

3.4.1 Optimization of the Ferraelectro-catalyzed C-H Arylation ........................70

3.4.2 Scope of Ferraelectrocatalytic C-H Arylation.......................................72

3.4.3 Comparison of Electrochemical Oxidation versus Chemical Oxidation ......74

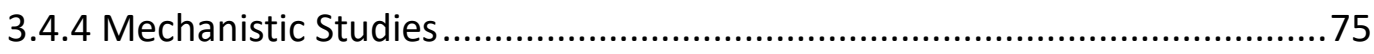

3.4.5 Gram-Scale of Ferraelectro-Catalyzed C-H Arylation .............................82

3.4.5 Manganaelectro-Catalyzed C-H Activation ............................................ 82

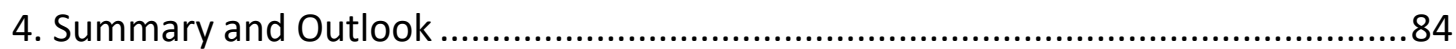

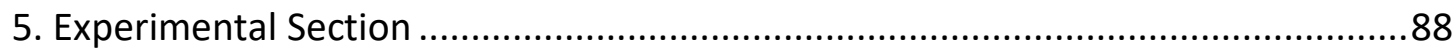

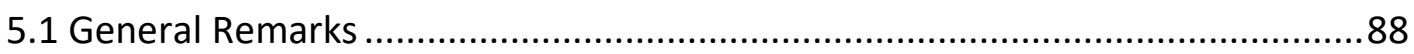

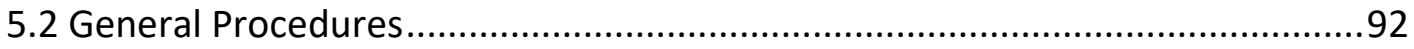

5.3 Domino C-H Activation/Directing Group Migration/Alkyne Annulation: Unique

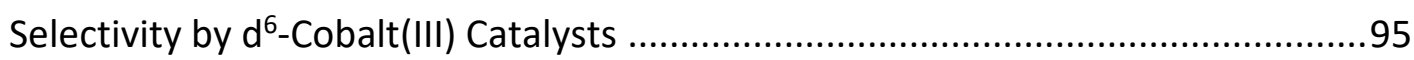

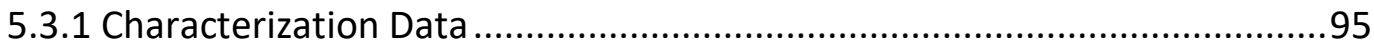


5.4 Manganese(I)-Catalyzed C-H Activation Domino Alkyne Annulation by Transformable Pyridines

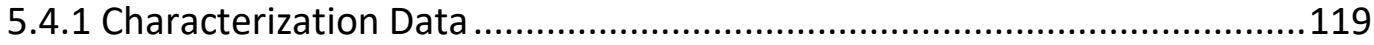

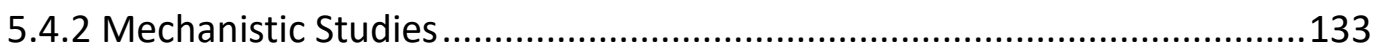

5.5 Manganese(II/III/I)-Catalyzed C-H Arylations in Continuous Flow..................142

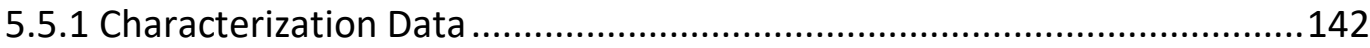

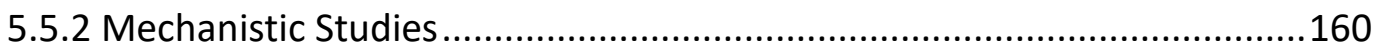

5.6 Metallaelectrocatalyses: Electricity for Resource-Economic Iron- and Manganese-Catalyzed C-H Activation ............................................................168

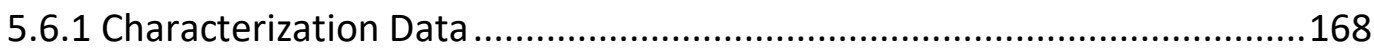

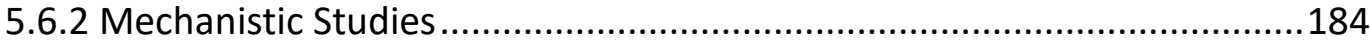

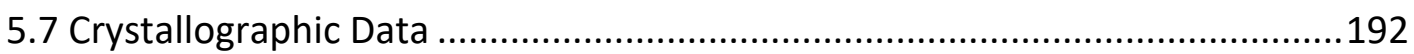

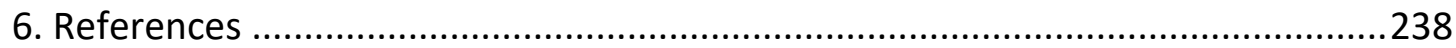

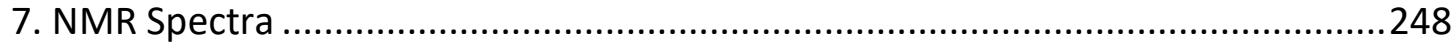

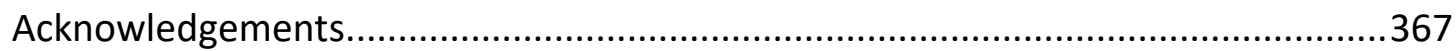

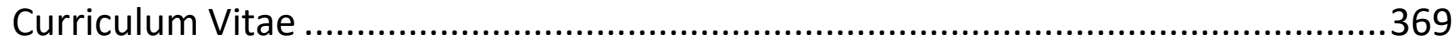




\section{List of Abbreviations}

\begin{tabular}{|c|c|}
\hline Ac & acetyl \\
\hline acac & acetyl acetonate \\
\hline Alk & alkyl \\
\hline AMLA & ambiphilic metal-ligand activation \\
\hline aq. & aqueous \\
\hline $\operatorname{Ar}$ & aryl \\
\hline atm & atmospheric pressure \\
\hline BHT & 2,6-di-tert-butyl-4-methylphenol \\
\hline BIES & base-assisted internal electrophilic substitution \\
\hline $\mathrm{Bn}$ & benzyl \\
\hline Boc & tert-butyloxycarbonyl \\
\hline $\mathrm{Bu}$ & butyl \\
\hline $\mathrm{Bz}$ & benzoyl \\
\hline calc. & calculated \\
\hline cat. & catalytic \\
\hline CMD & concerted-metalation-deprotonation \\
\hline conv. & conversion \\
\hline$C p^{*}$ & cyclopentadienyl \\
\hline Cy & cyclohexyl \\
\hline$\delta$ & chemical shift \\
\hline$d$ & doublet \\
\hline DCB & 2,3-dichlorobutane \\
\hline DCE & 1,2-dichloroethane \\
\hline DCIB & 1,2-dichloroisobutane \\
\hline dd & doublet of doublet \\
\hline DFT & density functional theory \\
\hline DG & directing group \\
\hline
\end{tabular}




\begin{tabular}{|c|c|}
\hline DME & dimethoxyethane \\
\hline DMF & $N, N$-dimethylformamide \\
\hline$d t$ & doublet of triplet \\
\hline El & electron ionization \\
\hline dppe & 1,2-bis(diphenylphosphino)ethane \\
\hline equiv & equivalent \\
\hline ES & electrophilic substitution \\
\hline ESI & electronspray ionization \\
\hline Et & ethyl \\
\hline FG & functional group \\
\hline g & gram \\
\hline GC & gas chromatography \\
\hline $\mathrm{h}$ & hour \\
\hline Hal & halogen \\
\hline Het & hetero atom \\
\hline Hept & heptyl \\
\hline Hex & hexyl \\
\hline HFIP & 1,1,1,3,3,3-hexafluoro-2-propanol \\
\hline HPLC & high performance liquid chromatography \\
\hline HR-MS & high resolution mass spectrometry \\
\hline $\mathrm{Hz}$ & Hertz \\
\hline$i$ & iso \\
\hline IR & infrared spectroscopy \\
\hline IES & internal electrophilic substitution \\
\hline J & coupling constant \\
\hline KIE & kinetic isotope effect \\
\hline L & ligand \\
\hline
\end{tabular}




\begin{tabular}{|c|c|}
\hline$m$ & meta \\
\hline $\mathrm{m}$ & multiplet \\
\hline M & molar \\
\hline$[\mathrm{M}]^{+}$ & molecular ion peak \\
\hline Me & methyl \\
\hline Mes & mesityl \\
\hline $\mathrm{mg}$ & milligram \\
\hline $\mathrm{MHz}$ & megahertz \\
\hline $\min$ & minute \\
\hline $\mathrm{mL}$ & milliliter \\
\hline $\mathrm{mmol}$ & millimol \\
\hline M. p. & melting point \\
\hline MS & mass spectrometry \\
\hline$m / z$ & mass-to-charge ratio \\
\hline NCTS & $N$-cyano-4-methyl- $N$-phenyl benzenesulfonamide \\
\hline NMTS & $N$-cyano- $N$-(4-methoxy)phenyl- $p$-toluenesulfonamide \\
\hline NMP & N-methylpyrrolidinone \\
\hline NMR & nuclear magnetic resonance \\
\hline 0 & ortho \\
\hline $\mathrm{OA}$ & oxidative addition \\
\hline OPV & oil pump vacuum \\
\hline$p$ & para \\
\hline $\mathrm{Ph}$ & phenyl \\
\hline PMP & para-methoxyphenyl \\
\hline PIP & 2-(Pyridin-2-yl)isopropyl \\
\hline Piv & pivaloyl \\
\hline ppm & parts per million \\
\hline $\operatorname{Pr}$ & propyl \\
\hline
\end{tabular}




$\begin{array}{ll}\text { PTSA } & \text { p-Toluenesulfonic acid } \\ \text { py } & \text { pyridyl } \\ \text { pym } & \text { pyrimidine } \\ \text { pyr } & \text { pyrazol } \\ \text { q } & \text { quartet } \\ \text { RT } & \text { room temperature } \\ \text { S } & \text { singlet } \\ \text { sat. } & \text { saturated } \\ \text { SPS } & \text { solvent purification system } \\ t & \text { tert } \\ \text { t } & \text { triplet } \\ \text { T } & \text { temperature } \\ \text { TAM } & \text { triazolyldimethylmethyl } \\ \text { TBAF } & \text { tetra- } n \text {-butylammonium fluoride } \\ \text { TFA } & \text { trifluoroacetic acid } \\ \text { TFE } & 2,2,2 \text {-trifluoroethanol } \\ \text { THF } & \text { tetrahydrofuran } \\ \text { TLC } & \text { thin layer chromatography } \\ \text { TM } & \text { transition metal } \\ \text { TMEDA } & N, N, N \text { ', } N \text { '-tetramethylethane-1,2-diamine } \\ \text { TMP } & 2,2,6,6 \text {-tetramethylpiperidine } \\ \text { TMS } & \text { trimethylsilyl } \\ \text { TS } & \text { transition state } \\ \text { weight by volume } \\ \text { Th }\end{array}$





\section{Introduction}

\subsection{Transition Metal-Catalyzed C-H Functionalization}

Organic synthesis is the transformative science that enables selective molecular engineering with notable applications towards biochemistry and material sciences as well as agrochemical and pharmaceutical industries, among others. Thus far, molecular syntheses have largely involved the generation of a huge number of undesired by-products, the depletion of limited natural resources and overall high energy consumption. ${ }^{[1]}$ In order to obviate or at least reduce these drawbacks, the development of transition metal-catalyzed $\mathrm{C}-\mathrm{H}$ functionalization has attracted significant attention, resulting in both environmentally-benign and economicallyattractive processes compared with traditional organic synthetic routes. Among them are the use of catalytic transformations, the avoidance of unnecessary prefunctionalization and auxiliaries to increase the atom economy, ${ }^{[2]}$ and the use of mild reaction conditions ${ }^{[3]}$ towards full resource economy. ${ }^{[4]}$

\subsubsection{Transition Metal-Catalyzed Cross-Couplings vs. C-H Activation}

The beginning of transition metal-catalyzed coupling chemistry can be traced back to inter alia the early copper-catalyzed reactions by Glaser ${ }^{[5]}$ and Ullmann. ${ }^{[6]}$ In the past several decades, transition metal-catalyzed cross-coupling reactions have been well developed and widely applied in organic synthesis, and provide useful methods to construct complex scaffolds. ${ }^{[7]}$ For example, Suzuki-Miyaura, ${ }^{[8]}$ Stille, ${ }^{[9]}$ CorriuKumada, ${ }^{[10]}$ Hiyama, ${ }^{[11]}$ and Negishi cross-coupling reactions, ${ }^{[12]}$ have been well studied and are nowadays established as powerful methods in the toolbox of organic chemists (Scheme 1.1). These important contributions were recognized with the award of the Nobel Prize in Chemistry to Heck, Negishi and Suzuki in 2010. 


$$
\begin{aligned}
& \mathrm{R}-\mathrm{X}+\mathrm{M}-\mathrm{R}^{\prime} \stackrel{\text { cat. } \mathrm{Pd}(0)}{\longrightarrow} \mathrm{R}-\mathrm{R}^{\prime} \\
& \mathrm{M}=\mathrm{B}(\mathrm{OH})_{2}: \text { Suzuki-Miyaura } \\
& \mathrm{M}=\mathrm{SnR} \mathrm{R}_{3}: \text { Stille } \\
& \mathrm{M}=\mathrm{ZnX}: \text { Negishi } \\
& \mathrm{M}=\mathrm{MgX}_{\text {Kumada }} \\
& \mathrm{M}=\mathrm{SiR}_{3}: \text { Hiyama }
\end{aligned}
$$

Scheme 1.1. Transition metal-catalyzed cross-coupling reactions.

It is well known that traditional cross-coupling requires two fully pre-functionalized starting materials, namely organic (pseudo)halides and organometallic reagents. ${ }^{[13]}$ Therefore, the direct functionalization of $\mathrm{C}-\mathrm{H}$ bonds is extremely desirable in terms of the step- and atom-economy of organic syntheses (Scheme 1.2).

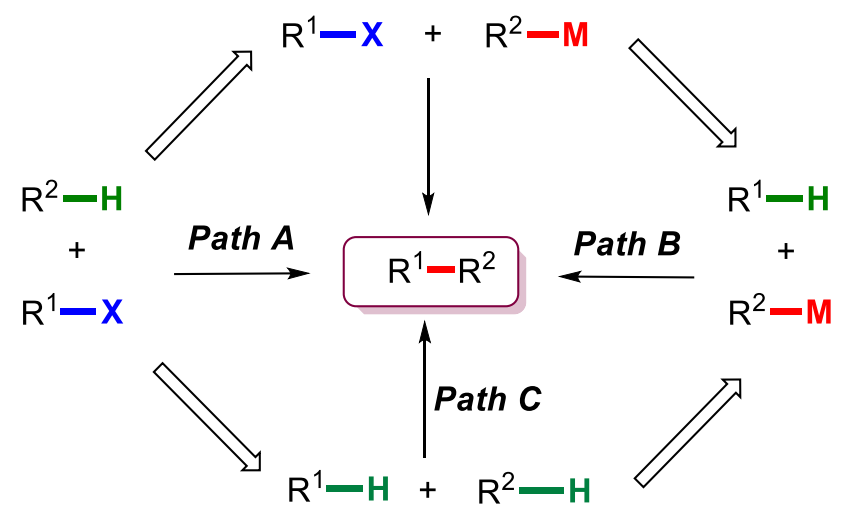

Scheme 1.2. $\mathrm{C}-\mathrm{H}$ activation versus cross-couplings.

\subsubsection{Mechanistic Manifolds}

For transition metal-catalyzed $\mathrm{C}-\mathrm{H}$ functionalizations, the catalytic cycle can often be divided into three main steps (Scheme 1.3): (i) the $\mathrm{C}-\mathrm{H}$ activation, (ii) the functionalization of the organometallic intermediate, and finally (iii) the regeneration of the active catalyst. 


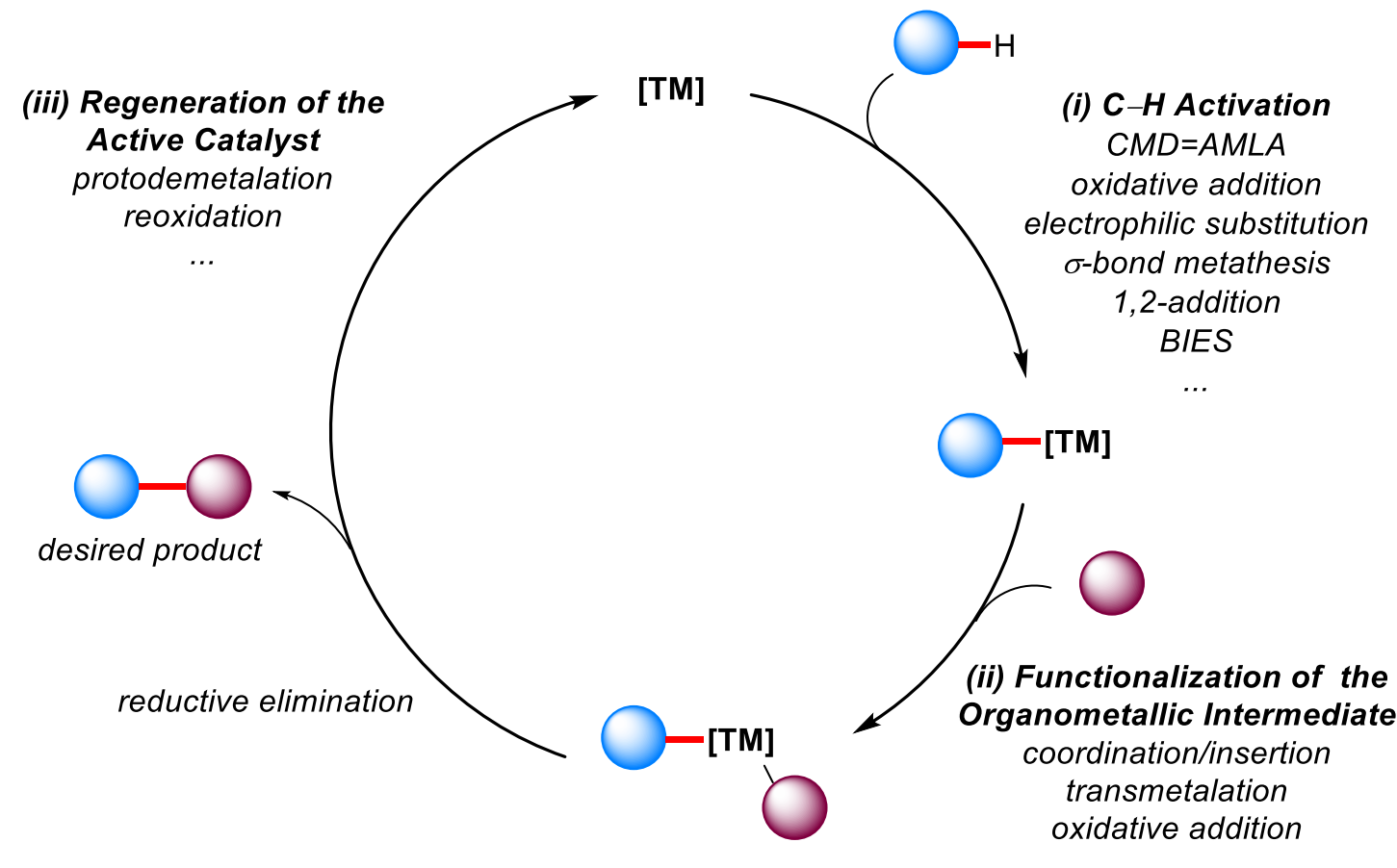

Scheme 1.3. Generalized catalytic cycle for transition metal-catalyzed C-H activation.

In general terms, the $\mathrm{C}-\mathrm{H}$ cleavage event is the key step of the mechanism. Computational chemistry has made a particularly strong contribution to the understanding of the range of possible mechanisms for the $\mathrm{C}-\mathrm{H}$ scission. ${ }^{[14]}$ The $\mathrm{C}-\mathrm{H}$ activation processes can be classified according to five main different mechanisms (Scheme 1.4). 
a) oxidative addition

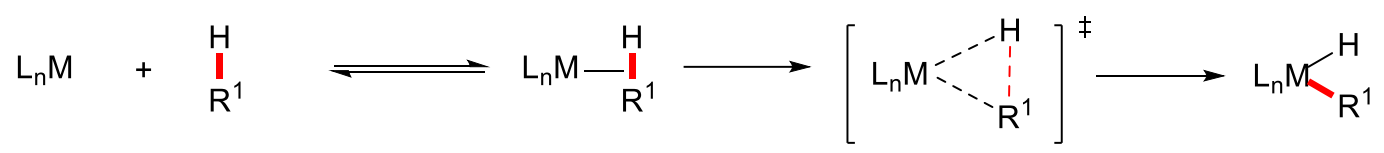

b) $\sigma$-bond metathesis

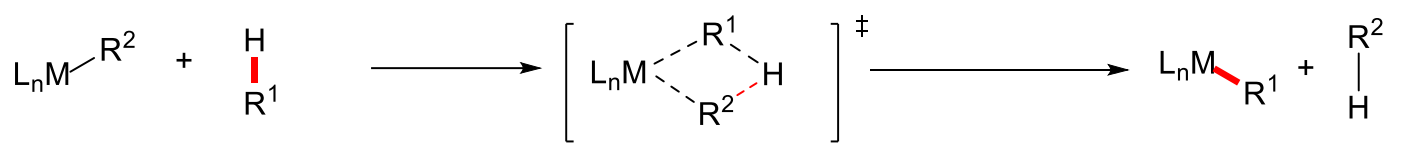

c) 1,2-addition

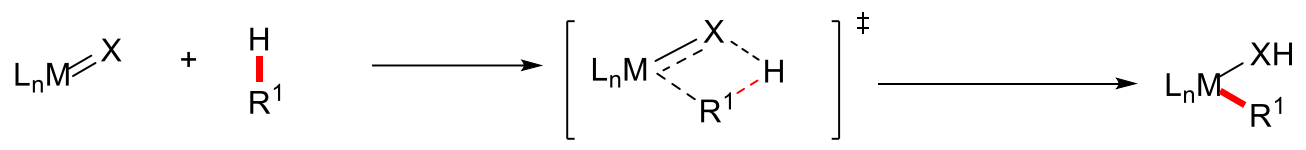

d) electrophilic substitution

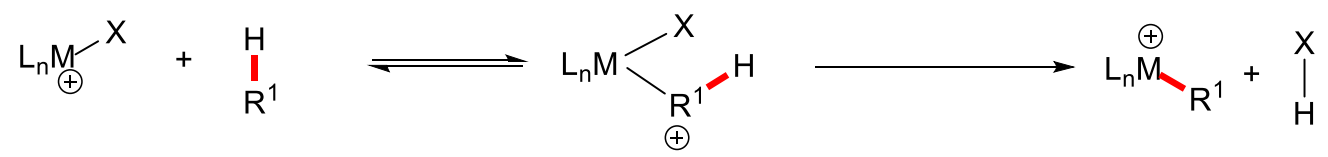

e) base-assisted metalation

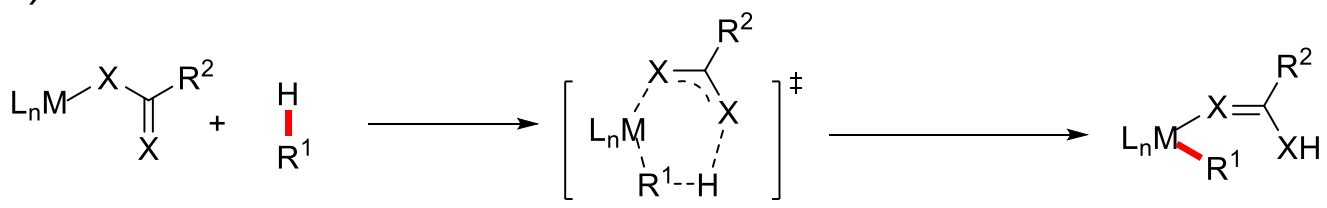

Scheme 1.4. Modes of action for various $\mathrm{C}-\mathrm{H}$ cleavage mechanisms by transition metals.

Oxidative addition to cleave $\mathrm{C}-\mathrm{H}$ bonds was mostly observed with electron-rich complexes of late transition metals. ${ }^{[15]}$ For early transition metals with $\mathrm{d}^{0}$-configuration, this mode of action is obviously not feasible. In contrast, $\sigma$-bond metathesis and 1,2- addition are possible ways to achieve $\mathrm{C}-\mathrm{H}$ activation with early transition metals, ${ }^{[14 a]}$ while electrophilic substitution was proposed for cationic complexes of late transition metals. ${ }^{[16]}$ In recent years, the base-assisted $\mathrm{C}-\mathrm{H}$ activation has gained major attraction as a model for $\mathrm{C}-\mathrm{H}$ cleavage in $\mathrm{C}-\mathrm{H}$ functionalizations by an isohypsic pathway. ${ }^{[15]}$

Further investigations indicated that several distinct transition states could be involved in the base-assisted $\mathrm{C}-\mathrm{H}$ metalation step (Scheme 1.5). ${ }^{[15-16]}$ 


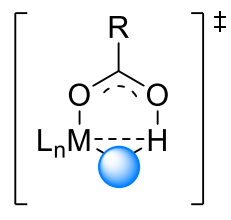

$\mathrm{CMD}=\mathrm{AMLA}$

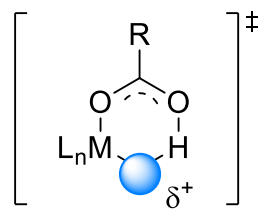

BIES

Scheme 1.5. Transition state models for base-assisted $\mathrm{C}-\mathrm{H}$ metalation.

Intramolecular electrophilic substitution (IES) ${ }^{[17]}$ is the mechanism for alkoxide bases and relies on a highly strained, thus high-energy, four-membered transition state. Concerted metalation-deprotonation $(\mathrm{CMD})^{[18]}$ and ambiphilic metal-ligand activation $(A M L A)^{[19]}$ were independently disclosed and describe the interaction of metal, carboxylate-ligand and $\mathrm{C}-\mathrm{H}$ bond, especially for electron-deficient substrates, such as perfluoroarenes or pyridine- $N$-oxides. In sharp contrast, base-assisted internal electrophilic substitution (BIES) ${ }^{[20]}$ was proposed to explain the preferred reactivity of electron-rich substrates in the majority of such transformations.

Thus far, the vast majority of $\mathrm{C}-\mathrm{H}$ functionalizations was accomplished by costintensive and toxic $4 \mathrm{~d}$ and $5 \mathrm{~d}$ transition metal catalysts, such as palladium, ${ }^{[21]}$ iridium, ${ }^{[22]}$ rhodium, ${ }^{[23]}$ and ruthenium. ${ }^{[24]}$ Here, new opportunities are represented by the development of $3 \mathrm{~d}$ transition metal-catalyzed $\mathrm{C}-\mathrm{H}$ activation, with possible benefits due to the significantly lower toxicity, high natural abundance and costeffective nature of the employed metal catalysts. ${ }^{[25]}$

\subsection{Cobalt(III)-Catalyzed C-H Activation}

Cobalt is one of the more abundant elements in the Earth crust, with a concentration of approximately $25 \mathrm{ppm}$, compared to $1 \mathrm{ppb}$ for noble metals, such as iridium and rhodium. ${ }^{[26]}$ As a result, significant attention has recently been directed towards the use of less expensive, more abundant, and cost-efficient cobalt catalysts. ${ }^{[27]}$ The identification of cobalt complexes as a suitable catalysts for promoting $\mathrm{C}-\mathrm{H}$ 
functionalisations relates to the relatively well-developed field of rhodium-catalyzed $\mathrm{C}-\mathrm{H}$ functionalisation. ${ }^{[23 e, 28]}$ Yet, a notable challenge is constituted by the fact that the electronic properties of the $3 \mathrm{~d}$ transition metal cobalt significantly differ from those of the $4 \mathrm{~d}$ or $5 \mathrm{~d}$ homologues in terms of electronegativity and spin orbit couplings, among others. ${ }^{[25,29]}$ The reduced electronegativity of cobalt as compared to the homologous group 9 elements translates into more nucleophilic organometallic cobalt intermediates, which allow for unprecedented reaction pathways in transition metalcatalyzed $\mathrm{C}-\mathrm{H}$ activations as well as significantly improved positional and chemoselectivities. ${ }^{[30]}$

\subsubsection{Early Examples of Cobalt-Catalyzed C-H Activation}

Cobalt-catalyzed C-C bond formation has been known since 1941 by Kharasch and Fields. ${ }^{[31]}$ An early example of cobalt-catalyzed $\mathrm{C}-\mathrm{H}$ functionalization was developed by Murahashi, ${ }^{[32]}$ providing a low-valent cobalt-catalyzed carbonylation protocol. This protocol provided access to phthalimidine $\mathbf{2}$ or indazolone $\mathbf{4}$ through an annulation reaction of carbon monoxide with Schiff-bases using $\mathrm{Co}_{2}(\mathrm{CO})_{8}$ as the catalyst (Scheme 1.6).<smiles>C(=Nc1ccccc1)c1ccccc1</smiles>

1<smiles>c1ccc(/N=N/c2ccccc2)cc1</smiles>

3

$$
\begin{gathered}
\begin{array}{c}
\mathrm{Co}_{2}(\mathrm{CO})_{8}(11 \mathrm{~mol} \%) \\
\mathrm{CO}(100-200 \mathrm{~atm})
\end{array} \\
\underset{\mathrm{C}_{6} \mathrm{H}_{6}, 220-230^{\circ} \mathrm{C}}{\longrightarrow}
\end{gathered}
$$

$$
\begin{gathered}
\underset{\mathrm{Co}_{2}(\mathrm{CO})_{8}(11 \mathrm{~mol} \%)}{\mathrm{CO}(150 \mathrm{~atm})} \\
\mathrm{C}_{6} \mathrm{H}_{6}, 190^{\circ} \mathrm{C}
\end{gathered}
$$

4: $55 \%$

Scheme 1.6. Cobalt-catalyzed carbonalytion of benzaldimine 1 and azobenzene 3 .

Despite these early advances, the most significant applications of cobalt in catalysis have been noted in the field of hydroformylation ${ }^{[33]}$ and the development of the Pauson-Khand reaction. ${ }^{[34]}$ Further advances in cobalt-catalyzed $\mathrm{C}-\mathrm{H}$ functionalization were made by Kochi in $1973 .{ }^{[35]}$ They presented the first example of high-valent 
cobalt(III)-mediated trifluoroacetylation of aromatic compounds operating via a proposed single electron transfer (SET) mechanism and stoichiometric in cobalt complex (Scheme 1.7).

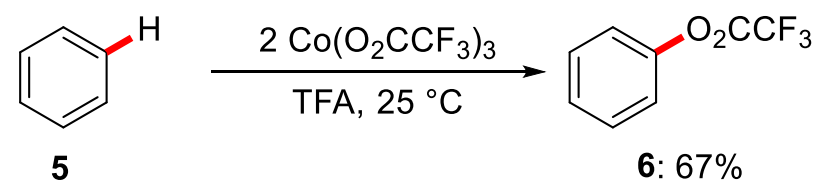

Scheme 1.7. Stoichiometric cobalt(III)-mediated trifluoroacetylation of arene $\mathbf{5}$.

\subsubsection{C-H Activation with Well-Defined Cobalt Complexes}

As to the elementary step of $\mathrm{C}-\mathrm{H}$ cobaltation, Klein and co-workers showed that the cyclometalated cobalt complex $\mathbf{9}$ can be prepared by treating azobenzene 7 with $\left[\mathrm{Co}\left(\mathrm{CH}_{3}\right)\left(\mathrm{PMe}_{3}\right)_{4}\right](8)\left(\right.$ Scheme 1.8). ${ }^{[36]}$

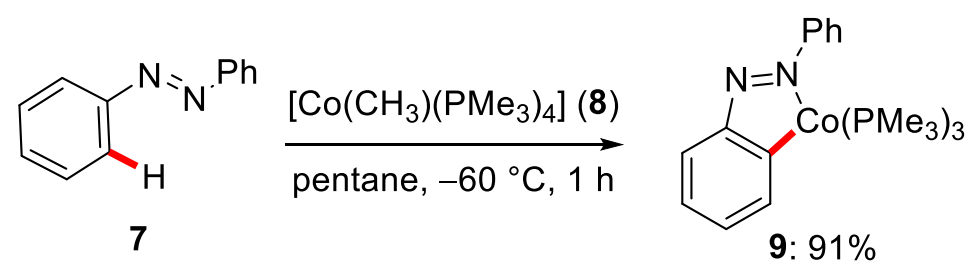

Scheme 1.8. Stoichiometric $\mathrm{C}-\mathrm{H}$ metalation using complex 8.

In subsequent studies, Klein found that various substrates containing different donor groups, featuring oxygen, ${ }^{[37]}$ nitrogen, ${ }^{[38]}$ sulfur, ${ }^{[39]}$ and phosphorus, ${ }^{[40]}$ also formed cyclocobaltated complexes (Scheme 1.9). The cyclometalation was not restricted to the formation of five-membered cobaltacycles, but also the formation of sixmembered complex 11 and even less favorable four-membered cobaltacycle $\mathbf{1 3}^{[41]}$ could be realized as well. 


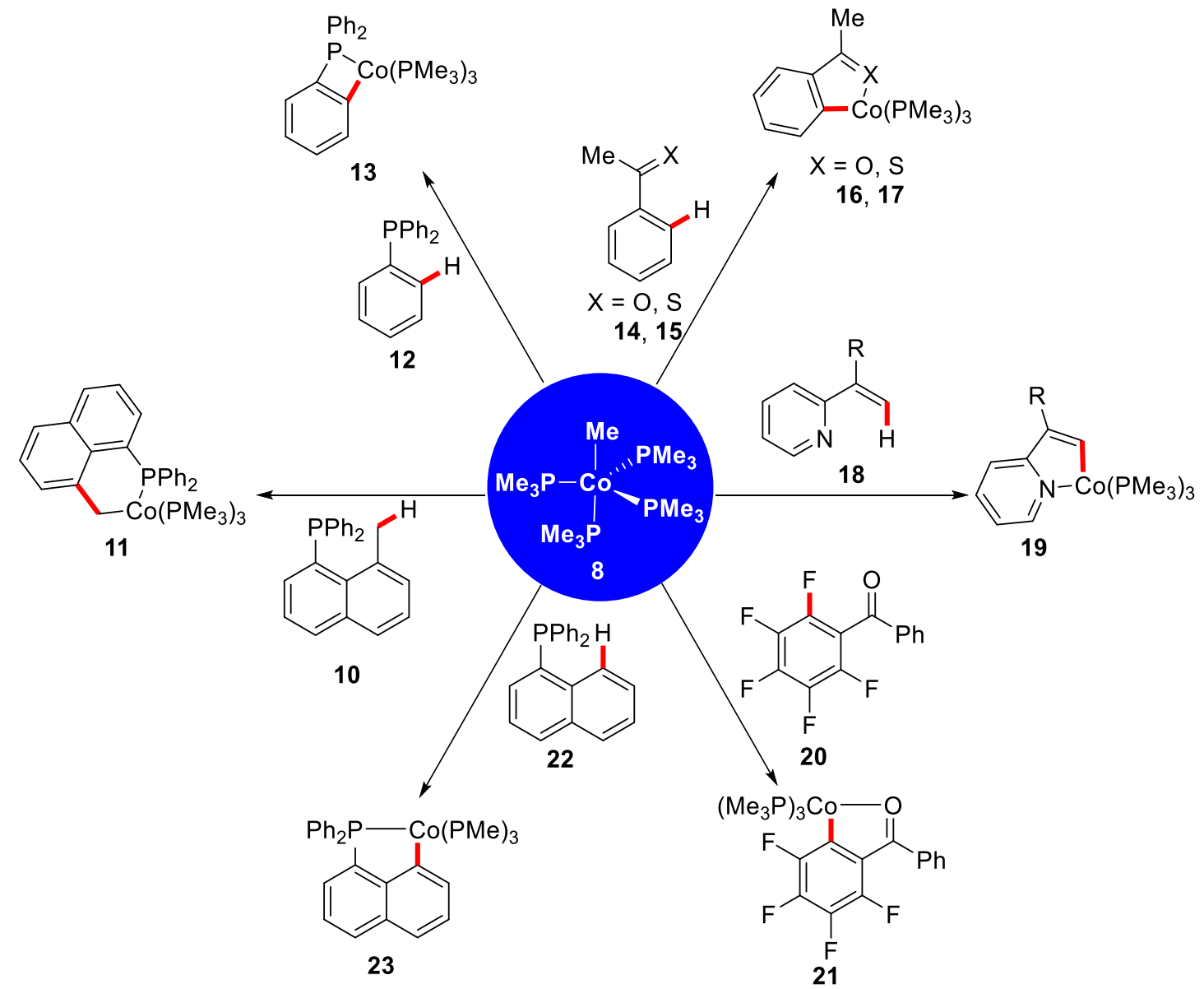

Scheme 1.9. Cyclocobaltated complexes prepared by $\mathrm{C}-\mathrm{H}$ and $\mathrm{C}-\mathrm{F}$ activation using stoichiometric complex 8.

In an early example, the low-valent catalytic approach was developed by Kisch and coworkers in 1994, reporting the ortho-alkenylation of aromatic azo compounds. ${ }^{[2]}$ Thereafter, low-valent cobalt-catalyzed $\mathrm{C}-\mathrm{H}$ functionalizations have been rapidly developed over the last 10 years by the groups of Yoshikai, ${ }^{[43]}$ Nakamura, ${ }^{[44]}$ and Ackermann, ${ }^{[45]}$ among others. ${ }^{[46]}$ It is noteworthy that, in most of these studies, the active catalyst is ill-defined, being generated in situ from a cobalt salt, a (pre-)ligand and an organometallic species, resulting in a somewhat limited functional group tolerance. The development of catalytic protocols using well-defined high-valent cobalt complexes thus remained a challenge. 


\subsubsection{High-Valent Cobalt(III)-Catalyzed C-H Activations}

A significant advance in the field of cobalt(III) catalysis was made by Matsunaga/Kanai

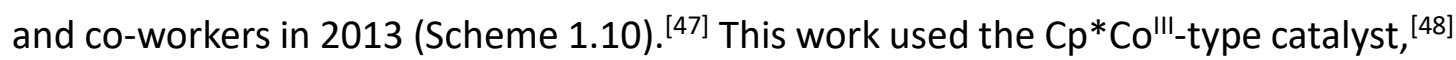
whereby the $\left[\mathrm{Cp}^{*} \mathrm{Co}\left(\mathrm{C}_{6} \mathrm{H}_{6}\right)\right]\left(\mathrm{PF}_{6}\right)_{2}$ complex was shown to catalyze the coupling of 2arylpyridine $\mathbf{2 4}$ with $N$-sulfonyl imines $\mathbf{2 5}$ and $\alpha, \beta$-unsaturated ketones $\mathbf{2 6}$. The same group also extended this protocol to indole-based substrates. ${ }^{[49]}$

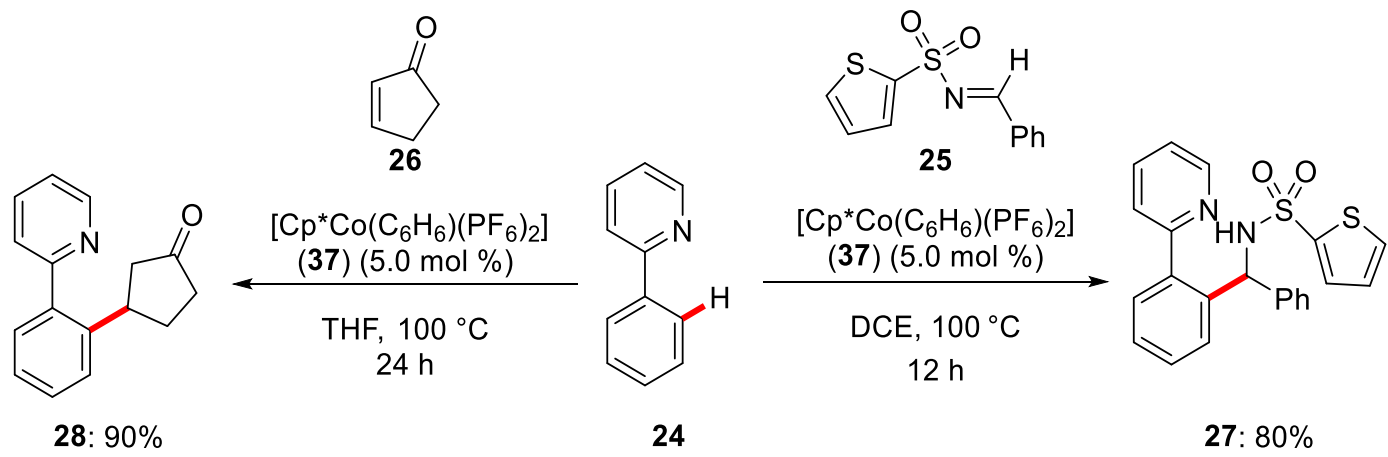

Scheme 1.10. Cp*Co(III)-catalyzed hydroarylation of electrophiles.

Subsequently, the Matsunaga group showed the C2-selective alkenylation of indoles 29 bearing a carbamoyl directing group, which was realized with a $\mathrm{Cp}^{*} \mathrm{Co}^{\text {III }}$ catalyst and KOAc as the additive (Scheme 1.11a). ${ }^{[50]}$ Remarkably, while the judicious choice of the carbamate directing group and the use of a different cationic complexes allowed for either the formation of the thermodynamically more stable cyclized product $\mathbf{3 3}$ $(\text { Scheme } 1.11 b)^{[30]}$ or the tetrasubstituted alkenes 34 (Scheme 1.11c). ${ }^{[51]}$ Interestingly, $\mathrm{Cp} * \mathrm{Rh}(\mathrm{III})$ catalysts were found to be inefficient in this transformations. The unique reactivity of cobalt(III) catalysts highlighted the different electronegativity of cobalt as compared to rhodium. ${ }^{[51-52]}$ 
(a) Alkenylation

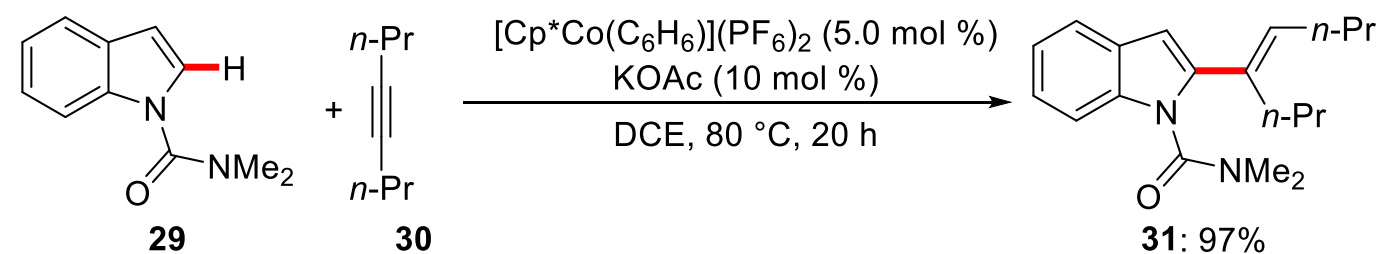

(b) Pyrroloindolone synthesis<smiles>CC#CC#[C+]c1ccccc1</smiles>

32

$$
\left.\right|_{\mathrm{Ph}} ^{\mathrm{Me}}
$$

30<smiles>CC1=C(c2ccccc2)C(=O)n2c1cc1ccccc12</smiles>

33: $78 \%$

(c) Alkenylation/directing group migration<smiles>O=C(N1CCOCC1)n1ccc2ccccc21</smiles>

32
$\left.\left[\mathrm{Cp}{ }^{*} \mathrm{Co}(\mathrm{MeCN})_{3}\right]\left(\mathrm{SbF}_{6}\right)_{2}\right](5.0 \mathrm{~mol} \%)$ KOAC (20 mol \%) DCE, $90^{\circ} \mathrm{C}, 20 \mathrm{~h}$<smiles>O=C(C(=C(c1ccccc1)c1ccccc1)c1cc2ccccc2[nH]1)N1CCOCC1</smiles>

34: $87 \%$

Scheme 1.11. Cp*Co(III)-catalyzed addition onto alkynes.

More recently, Matsunaga/Kanai and co-workers further demonstrated that the airstable $\left[\mathrm{Cp}^{*} \mathrm{Co}(\mathrm{CO}) \mathrm{I}_{2}\right]$ complex, in combination with a silver salt $\left(\mathrm{AgSbF}_{6}\right)$, displayed superior activity for a $\mathrm{C}-\mathrm{N}$ forming protocol when compared to the $\left[\mathrm{Cp} * \mathrm{Co}\left(\mathrm{C}_{6} \mathrm{H}_{6}\right)\right]\left(\mathrm{PF}_{6}\right)_{2}$ catalyst. ${ }^{[27 a]}$

\subsubsection{Cp*Co(III)-Catalyzed Allylations}

Recently, $\mathrm{C}-\mathrm{H}$ allylations have been reported with different allylating reagents (Scheme 1.12). The Ackermann and Glorius groups independently described the allylation of pyrimidylindoles with allylic electrophiles via a $\beta-O$ elimination pathway (Scheme 1.12a).. ${ }^{[53]}$ Moreover, Matsunaga reported the dehydrative allylation of indoles with allylic alcohols through a $\beta$-hydroxide elimination pathway (Scheme 1.12b). ${ }^{[54]}$ This chemistry was utilized for a broad range of substrate. ${ }^{[55]}$ 


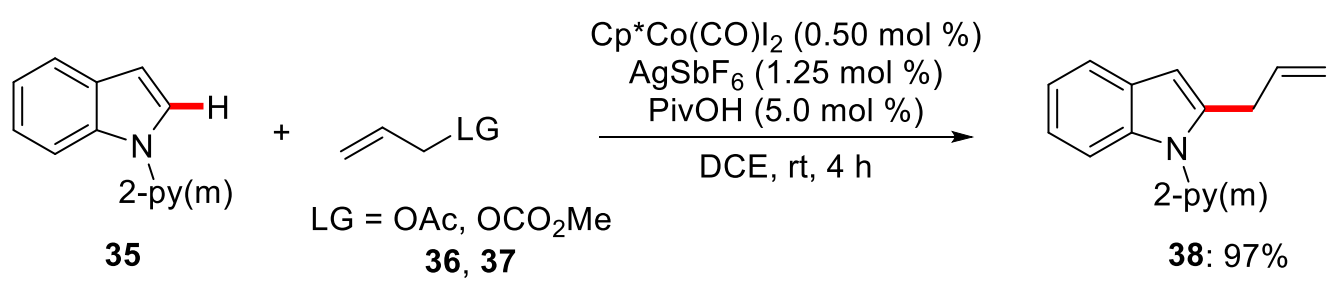

b) Matsunaga<smiles>[R6]n1ccc2cc3ccccc3n21</smiles>

35

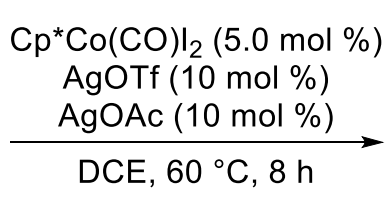

39

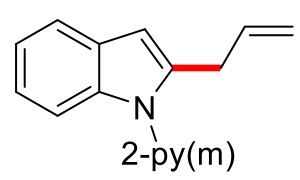

38: $99 \%$

Scheme 1.12. $\mathrm{Cp}^{*} \mathrm{Co}(\mathrm{III})$-catalyzed $\mathrm{C}-\mathrm{H}$ allylations.

Meanwhile, the Ackermann group reported the unique Z-selective allylation via $\mathrm{C}-\mathrm{H} / \mathrm{C}-\mathrm{C}$ activation by cobalt(III) catalysis under mild conditions (Scheme 1.13). Remarkably, this reaction showed a broad substrate scope and delivered the thermodynamically less stable (Z)-alkenes with excellent levels of diastereoselectivity. This conversion was found to be more efficient and selective with the $\left[\mathrm{Cp} * \mathrm{Co}(\mathrm{CO}) I_{2}\right]$ catalyst as compared with the analogous $\left[\mathrm{Cp}^{*} \mathrm{RhCl}_{2}\right]_{2}$ catalyst.

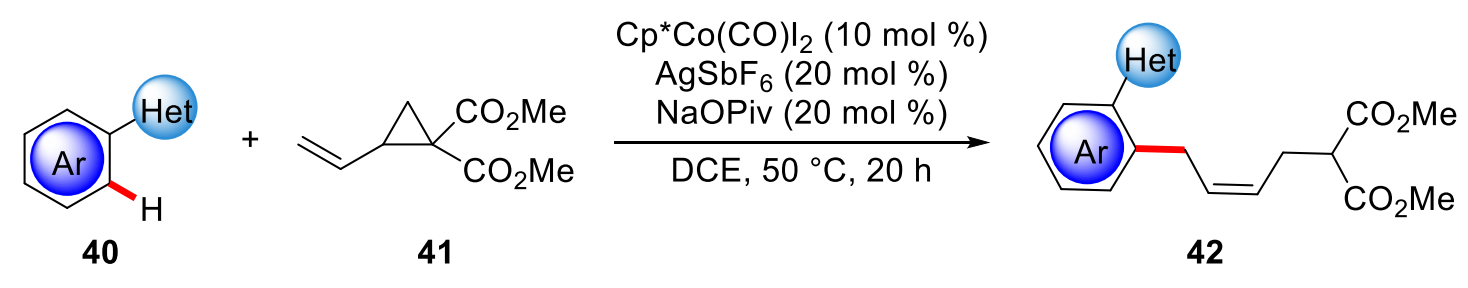

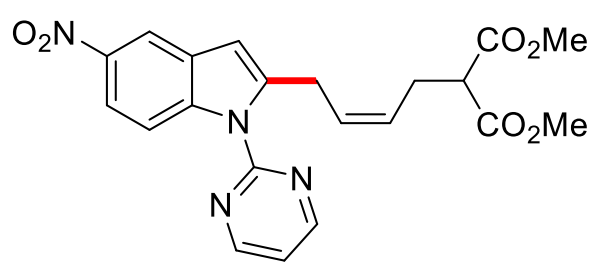

43: $88 \%(E / Z: 1: 17)$

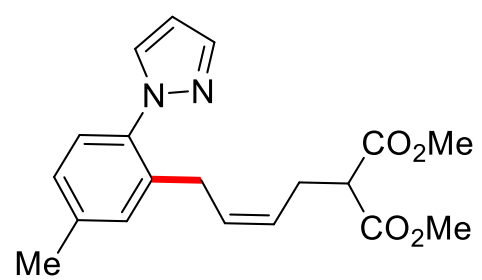

44: $69 \%(E / Z: 1: 19)$

Scheme 1.13. $\mathrm{Cp} * \mathrm{Co}(\mathrm{III})$-catalyzed $\mathrm{C}-\mathrm{H}$ allylation via $\mathrm{C}-\mathrm{H} / \mathrm{C}-\mathrm{C}$ activation. 
A plausible catalytic cycle is based on an initial $\mathrm{C}-\mathrm{H}$ cobaltation by the cationic cobalt species $\mathbf{4 5}$, resulting in the formation of complex $\mathbf{4 6}$. Subsequently intermediate $\mathbf{4 6}$ is coordinated by the allyl alcohol derivative. Thereafter, migratory insertion of the allylic double bond into the Co-C bond yields the key intermediate 47 . Finally, the product is released via $\beta$-oxygen elimination, which is about $2.4 \mathrm{kcal} / \mathrm{mol}$ more favorable than a $\beta$-hydride elimination (Scheme 1.14).

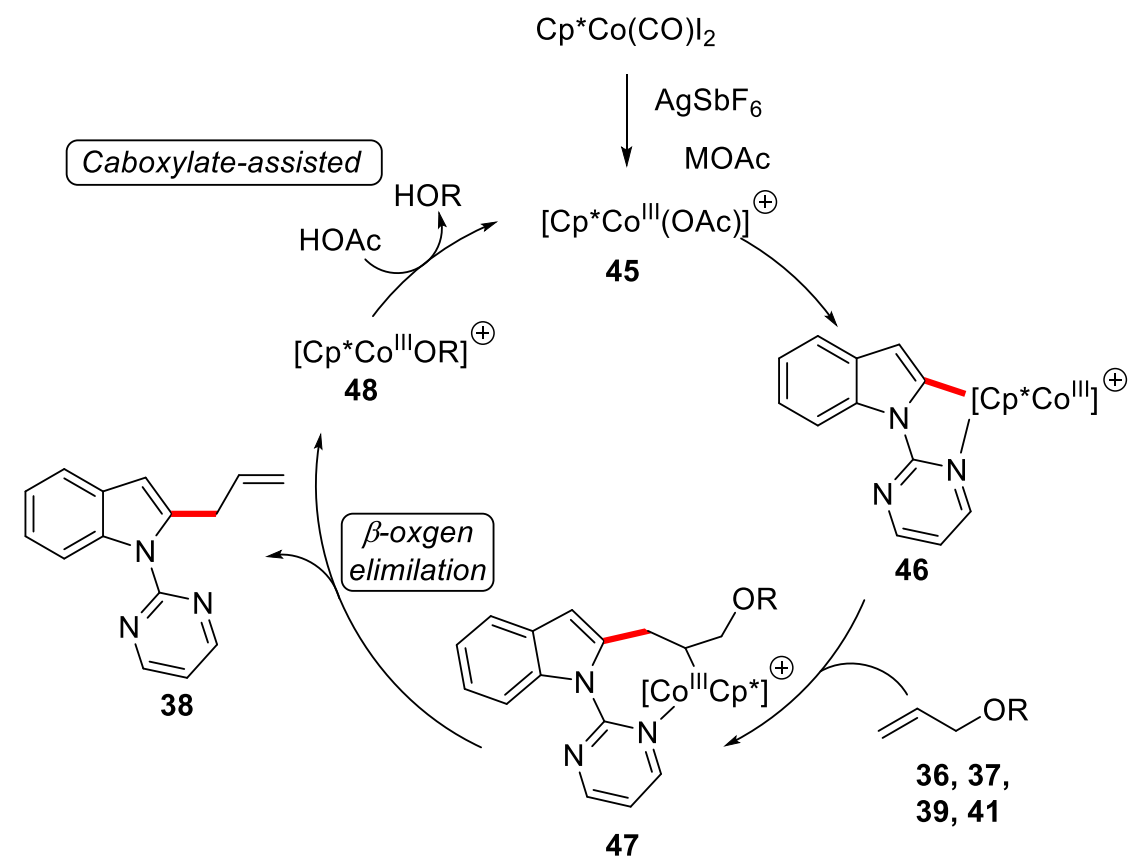

Scheme 1.14. Plausible catalytic cycle for $\mathrm{Cp} * \mathrm{Co}(\mathrm{III})$-catalyzed $\mathrm{C}-\mathrm{H} / \mathrm{C}-\mathrm{C}$ allylations.

\subsubsection{Cp*Co(III)-Catalyzed Allenylation}

Ma developed a rhodium-catalyzed $\mathrm{C}-\mathrm{H}$ bond allenylation with activated propargyl carbonates. ${ }^{[56]}$ Inspired by the Ma group's work, the Sundararaju group recently reported a dehydrative $\mathrm{C}-\mathrm{H}$ allenylation from propargyl alcohols with phenylpyrazoles 49 via $\beta$-hydroxyl elimination (Scheme 1.15). ${ }^{[57]}$<smiles>[NH3+]c1ccccc1-n1cccn1</smiles>

49

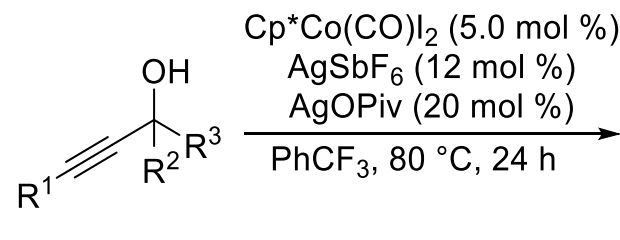

50<smiles>[R]C([R])=C=C([R])c1ccccc1-n1cccn1</smiles>

51

Scheme 1.15. $\mathrm{Cp} * \mathrm{Co}(\mathrm{III})$-Catalyzed $\mathrm{C}-\mathrm{H}$ Allenylation. 


\subsubsection{Cp*Co(III)-Catalyzed C(sp $\left.{ }^{3}\right)-H$ activation}

Significant achievements have been made in $\mathrm{Cp} * \mathrm{Co}(\mathrm{III})$-catalyzed $\mathrm{C}\left(\mathrm{sp}^{2}\right)-\mathrm{H}$ functionalization. Recently, Sundararaju and coworkers reported a carboxylate- assisted $\mathrm{Cp} * \mathrm{Co}(\mathrm{III})$-catalyzed $\mathrm{C}\left(\mathrm{sp}^{3}\right)-\mathrm{H}$ alkenylation ${ }^{[58]}$ (Scheme 1.16a) and amidation $^{[59]}$ (Scheme 1.16b) of activated 8-methylquinoline 52.

a) $C\left(s p^{3}\right)-H$ alkenylation<smiles>[H][R1]c1ccc[nH+]c1</smiles>

52<smiles>[R]C#[R]</smiles>

53<smiles>[R]C([R])=CCc1c[R1]cc2cccnc12</smiles>

b) $C\left(s p^{3}\right)-H$ amidation<smiles></smiles>

52<smiles>[R]c1noc(=O)o1</smiles>

55

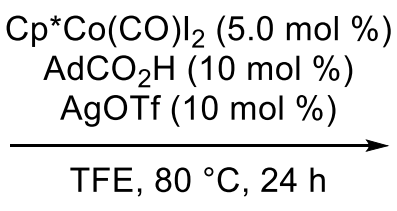

TFE, $80^{\circ} \mathrm{C}, 24 \mathrm{~h}$

$\mathrm{Cp}^{*} \mathrm{Co}(\mathrm{CO}) \mathrm{I}_{2}(5.0 \mathrm{~mol} \%)$

$\mathrm{AgSbF}_{6}(20 \mathrm{~mol} \%)$

NaOPiv $(20 \mathrm{~mol} \%)$

DCE, $100^{\circ} \mathrm{C}, 12 \mathrm{~h}$<smiles>[R]C(=O)NCc1c[R1]cc2cccnc12</smiles>

56

Scheme 1.16. $\mathrm{Cp}{ }^{*} \mathrm{Co}(\mathrm{III})$-catalyzed $\mathrm{C}\left(\mathrm{sp}^{3}\right)-\mathrm{H}$ alkenylation and amidation.

\subsubsection{Asymmetric Cp*Co(III)-Catalyzed C-H Activation}

The full control of selectivity is of paramount importance to achieve synthetically meaningful $\mathrm{C}-\mathrm{H}$ activations. The Ackermann group developed the first asymmetric Cp*Co(III)- catalyzed $\mathrm{C}-\mathrm{H}$ activation. ${ }^{[60]}$ Moreover, the design of a novel chiral acid enabled cobalt(III)-catalyzed $\mathrm{C}-\mathrm{H}$ alkylations on indoles with high regio- and enantioselectivities (Scheme 1.17).

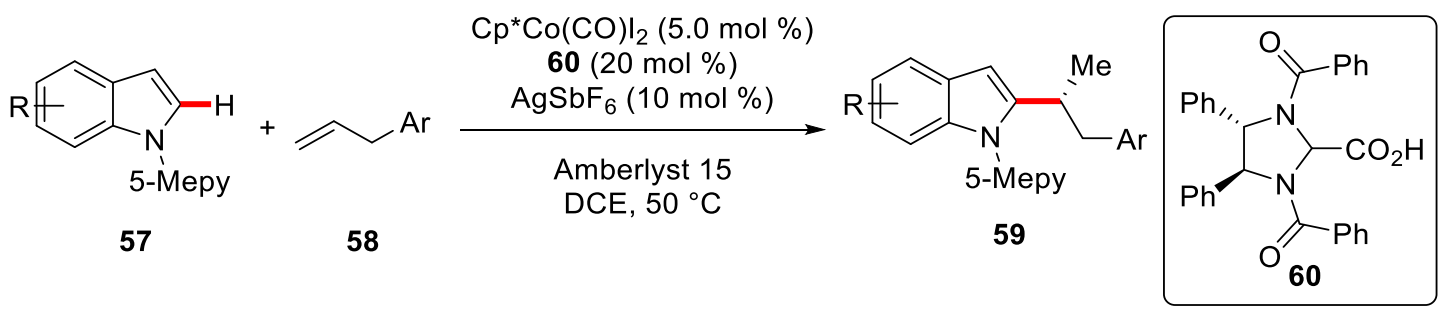

Scheme 1.17. First example of $\mathrm{Cp} * \mathrm{Co}(\mathrm{III})$-catalyzed asymmetric $\mathrm{C}-\mathrm{H}$ activations. 


\subsection{Manganese-Catalyzed C-H Activation}

Precious transition metals, such as palladium, rhodium, and iridium, play a predominant role in the field of $\mathrm{C}-\mathrm{H}$ activation, which has met with great success in the last 20 years. Unfortunately, the high costs, ${ }^{[53 a]}$ low abundance, ${ }^{[61]}$ and toxicities ${ }^{[62]}$ of these metals limit their further applications in pharmaceutical industries. Thus, manganese is an attractive, efficient, and the third most naturaly abundant transition metal. Moreover, the valence electron configuration of elemental manganese and the wide range of possible oxidation states of manganese $(-3$ to +7$)$ holds great potential in organometallic chemistry and catalysis.

\subsubsection{Early Examples of Manganese-Catalyzed C-H Functionalization}

The inspiration for developing metal-catalyzed $\mathrm{C}-\mathrm{H}$ functionalizations is largely based on the studies of stoichiometric $\mathrm{C}-\mathrm{H}$ activations with metal complexes. The first example of a manganese-mediated $\mathrm{C}-\mathrm{H}$ activation was arguably reported by Stone and Bruce in 1970, who achieved the synthesis of the manganese complex 62 from azobenzene 7 and $\left[\mathrm{MnMe}(\mathrm{CO})_{5}\right](\mathbf{6 1})$ through a stoichiometric $\mathrm{C}-\mathrm{H}$ activation event (Scheme 1.18). ${ }^{[63]}$

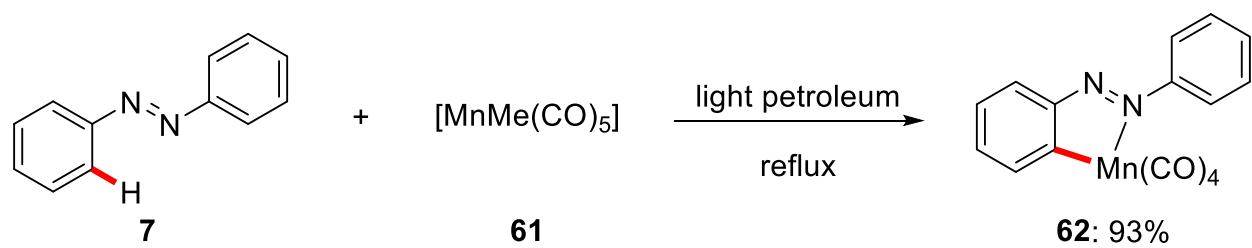

Scheme 1.18. Pioneering example of stoichiometric $\mathrm{C}-\mathrm{H}$ activation by manganese(I).

Thereafter, a large number of reactions of well-defined manganacycles via stoichiometric $\mathrm{C}-\mathrm{H}$ activation have been disclosed by the groups of Nicholson/Main, ${ }^{[64]}$ Woodgate, ${ }^{[65]}$ and Liebeskind, ${ }^{[66]}$ among others. So far, a variety of directing groups, ${ }^{[67]}$ which contain nitrogen, ${ }^{[68]}$ oxygen, ${ }^{[69]}$ and phosphorous, ${ }^{[70]}$ have been utilized and thus indicated the synthetic versatility and potential of manganese-mediated $\mathrm{C}-\mathrm{H}$ 
activations (Scheme 1.19).

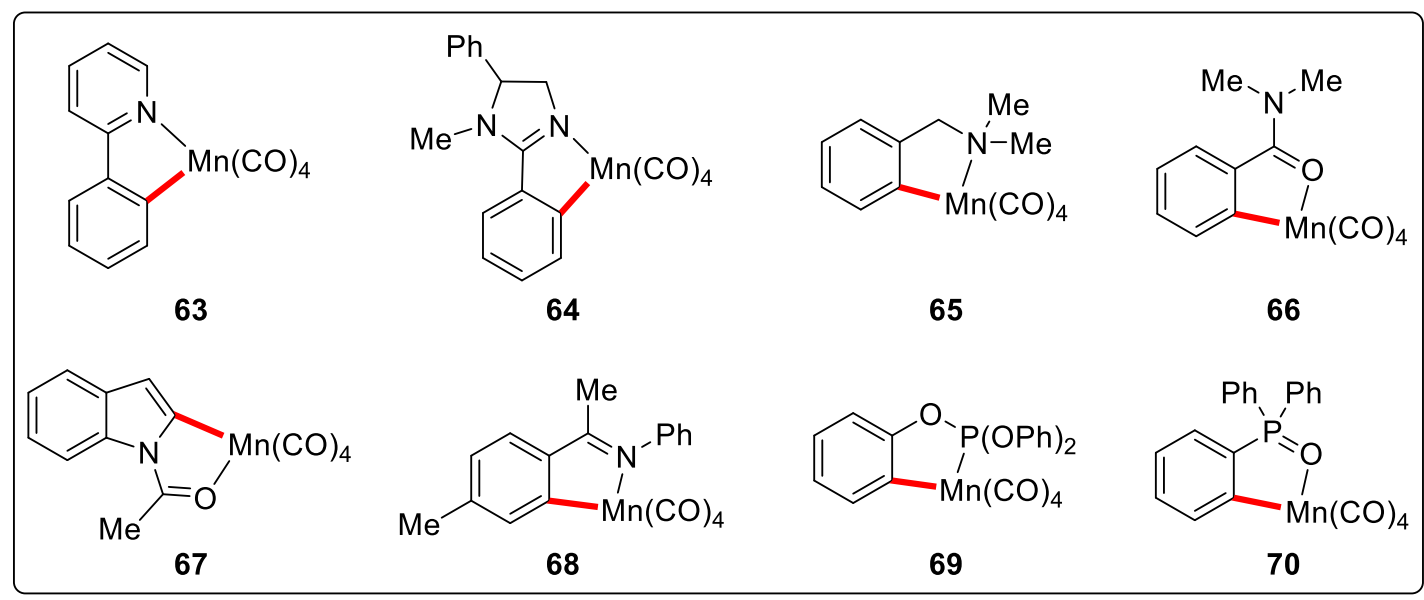

Scheme 1.19. Selected complexes synthesized by $\mathrm{C}-\mathrm{H}$ activation with $\left[\mathrm{MnR}(\mathrm{CO})_{5}\right]$.

40 years have passed until the first directed manganese(I)-catalyzed $\mathrm{C}-\mathrm{H}$ activation was reported by Kuninobu and Takai in 2007. They initially investigated stoichiometric $\mathrm{C}-\mathrm{H}$ activation and insertion of aldehydes with the manganese complex $\left[\mathrm{MnBr}(\mathrm{CO})_{5}\right]$ (Scheme 1.20a). Only trace amounts of product 76 were obtained with catalytic amounts of the manganese complex. At the outset of their optimization studies, triethylsilane turned out to be the reagent of choice for achieving catalytic turnover (Scheme 1.20b). ${ }^{[71]}$ 
a) stoichiometric manganese(I)-mediated $\mathrm{C}-\mathrm{H}$ addition to aldehydes<smiles>Cn1ccnc1-c1ccccc1</smiles>

71
1) $\mathrm{PhMe}, 100{ }^{\circ} \mathrm{C}, 5 \mathrm{~min}$

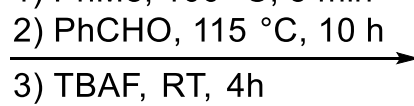

72<smiles>Cn1ccnc1-c1ccccc1C(O)c1ccccc1</smiles>

73: $52 \%$

b) manganese(I)-catalyzed $\mathrm{C}-\mathrm{H}$ activation<smiles>[R]C1CN(C)C(c2ccccc2)=N1</smiles>

74

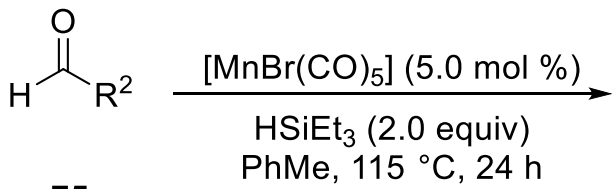

75<smiles>[R]C1CN(C)C(c2ccccc2C([R])OCC)=N1</smiles>

76

Scheme 1.20. Stoichiometric manganese(I)-mediated and manganese(I)-catalyzed hydroarylation of aldehydes.

A plausible catalytic cycle was proposed based on mechanistic studies as presented in Scheme 1.21. The catalytically active manganese(I) species $\mathbf{7 2}$ was proposed to facilitate $\mathrm{C}-\mathrm{H}$ activation by oxidative addition, thereby delivering a putative manganese(III) hydride species 77. Subsequently, migratory insertion of the polar carbonyl bond into the nucleophilic carbon-manganese bond takes place. Finally, the the silyl-protected benzylic alcohol $\mathbf{7 9}$ is formed through reductive elimination facilitated by triethylsilane. Thereafter, $\mathrm{C}-\mathrm{H}$ activation regenerates the active manganese(I) catalyst and molecular hydrogen. 
<smiles>[R]C(OCC)c1ccccc1-c1nccn1C</smiles>

79

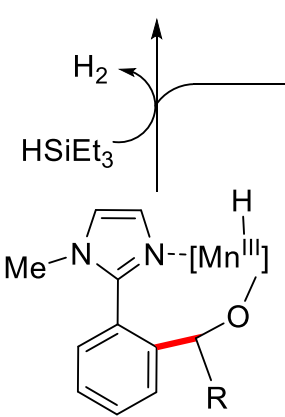

78<smiles>Cn1ccnc1-c1ccccc1</smiles>

71

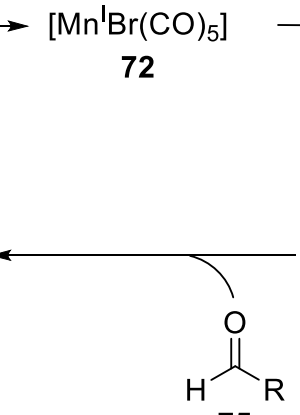

75

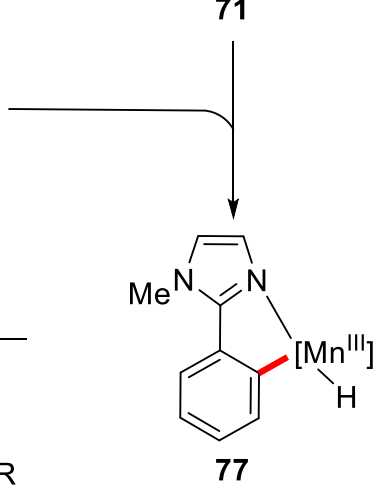

77

Scheme 1.21. Proposed catalytic cycle for the manganese(I)-catalyzed C-H addition to aldehydes.

In contrast, Wang and co-workers developed a silane-free manganese(I)-catalyzed C$\mathrm{H}$ addition to aldehydes 75, albeit with stoichiometric amounts of $\mathrm{ZnBr}_{2}$ and $\mathrm{Me}_{2} \mathrm{Zn}$ (Scheme 1.22a). Moreover, the authors were able to extend the substrate scope to electrophilic nitriles 82 (Scheme 1.22b). ${ }^{[72]}$

a) Manganese(I)-catalyzed $\mathrm{C}-\mathrm{H}$ addition to aldehydes<smiles>c1ccc(-c2ccccn2)cc1</smiles>

24<smiles>[R]C=O</smiles>

75

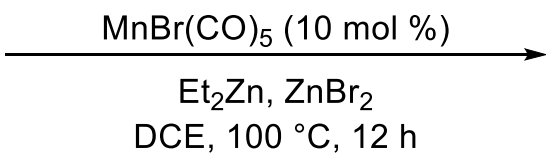

DCE, $100^{\circ} \mathrm{C}, 12 \mathrm{~h}$<smiles>[R]C(O)c1ccccc1-c1ccccn1</smiles>

80

b) Manganese(I)-catalyzed C-H addition to nitriles<smiles>c1ccc(-c2ccccn2)cc1</smiles>

24<smiles>[R]C#N</smiles>

81

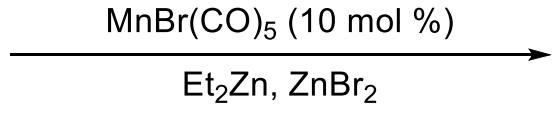

DCE, $100{ }^{\circ} \mathrm{C}, 6 \mathrm{~h}$ then $\mathrm{H}^{+}$<smiles>[R]C(=O)c1ccccc1-c1ccccn1</smiles>

82

Scheme 1.22. Manganese(I)-catalyzed C-H addition to aldehydes 75 and nitriles $\mathbf{8 1}$. 


\subsubsection{Manganese(I)-Catalyzed C-H Functionalization}

\subsubsection{Manganese(I)-Catalyzed C-H Allylations}

Ackermann and co-workers developed the first manganese-catalyzed $\mathrm{C}-\mathrm{H}$ allylation of arenes by employing allyl carbonates 39 as the allylating reagent. The corresponding allylated ketones $\mathbf{8 4}$ were obtained with excellent diastereoselectivities, upon acidic workup (Scheme 1.23a). By analogy to the above described allylation method, the group of Ackermann devised another manganese(I)-catalyzed decarboxylative allylation via $\mathrm{C}-\mathrm{H} / \mathrm{C}-\mathrm{O}$ functionalization, using dioxolanones 86 as the allylating reagents. Moreover, the high robustness of the manganese(I) catalytic system was reflected by using $\mathrm{H}_{2} \mathrm{O}$ as the optimal reaction medium and the reaction was fully tolerant of air (Scheme 1.23b).

a) Manganese(I)-catalyzed $\mathrm{C}-\mathrm{H}$ allylation with allyl carbonates

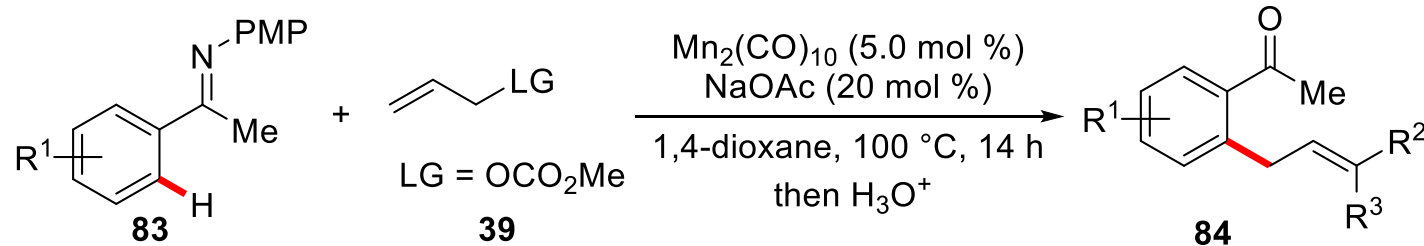

b) Manganese(I)-catalyzed $\mathrm{C}-\mathrm{H}$ allylation with dioxolanones<smiles>[R][R]C([R])c1ccccc1</smiles>

85<smiles>[Z1]C1OC(=O)OC1C=C</smiles>

86

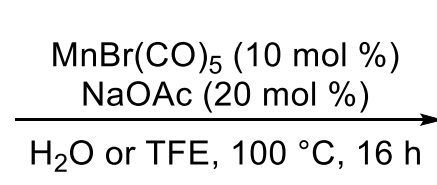

$\mathrm{H}_{2} \mathrm{O}$ or TFE, $100^{\circ} \mathrm{C}, 16 \mathrm{~h}$
$\mathrm{R}^{1}$<smiles>[R]N=C([R])c1ccccc1C/C=C\C([R])O</smiles>

87

Scheme 1.23. Manganese(I)-catalyzed C-H allylations.

\subsubsection{Manganese(I)-Catalyzed C-H Activations with Propargylic Carbonates}

Glorius described a manganese-catalyzed regioselective $\mathrm{C}-\mathrm{H}$ allenylation of indoles $\mathbf{3 7}$ with propargylic carbonates 88 through a $\beta$-oxygen elimination pathway (Scheme 1.24a). ${ }^{[73]}$ Importantly, Ackermann achieved the full control of chemoselectivity in manganese-catalyzed $\mathrm{C}-\mathrm{H}$ functionalization of indoles $\mathbf{3 7}$ with propargylic carbonates 
90. ${ }^{[74]}$ By the judicious choice of the additive, alkenylated products 91 and allenylated products 92 can be selectively furnished. Notably, for the first time in base metalcatalyzed $\mathrm{C}-\mathrm{H}$ functionalizations, a continuous flow system was exploited, thereby shortening the reaction time to $20 \mathrm{~min}$ and leading to improved mass and heat transfer control (Scheme 1.24b).

a) Manganese(l)-catalyzed $\mathrm{C}-\mathrm{H}$ allenylation<smiles></smiles>

37

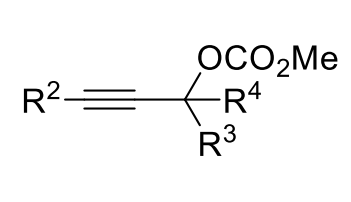

88

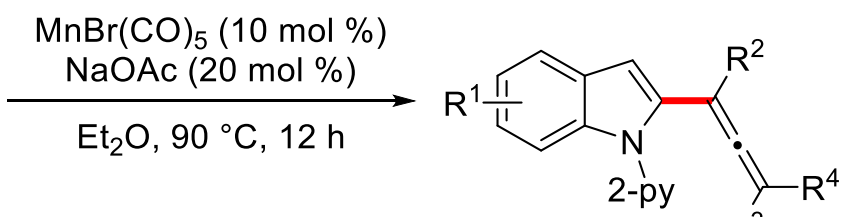

$89 R^{3}$

b) Control of chemoselectivity in manganese(I)-catalyzed hydroarylations with alkynes in flow<smiles>O=Pn1ccc2ccccc21</smiles>
$\mathrm{MnBr}(\mathrm{CO})_{5}$ $(10 \mathrm{~mol} \%)$
Additive $(20 \mathrm{~mol} \%)$<smiles>C#CC1(C)COC(=O)O1</smiles>

90

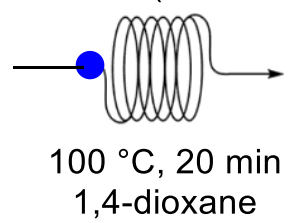<smiles>[R17]n1c(/C=C\C)cc2ccccc21</smiles>

91<smiles>C=CC1(C)C[OH+]C(=O)O1</smiles><smiles>C/C=C\C</smiles><smiles>CC(=C=Cc1cc2ccccc2n1[18O])CO</smiles>

92

additive HOAC $\quad 95 \%$ none

Scheme 1.24. Manganese(I)-catalyzed C-H allenylation and alkenylation.

Likewise, Glorius and co-workers reported on a manganese(I)-catalyzed annulation of propargyl carbonates 88 with imines 93 to generate isoquinolines $\mathbf{9 4}$. Notably, the use of alkynes with a leaving group in $\beta$-position led to high levels of regioselectivity in the annulation reaction. Based on their mechanistic studies, the authors proposed that a $\beta$-oxygen elimination occurs to deliver an allenylated intermediate, which subsequently undergoes cyclization to deliver the desired isoquinoline products 94 (Scheme 1.25). ${ }^{[75]}$ 
<smiles>[R]C(=N)c1ccccc1</smiles>

93

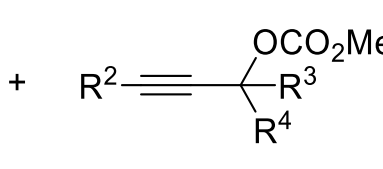

88

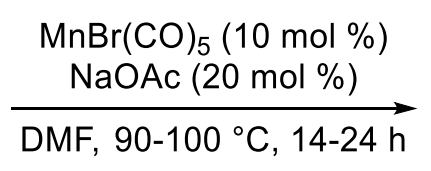

DMF, $90-100^{\circ} \mathrm{C}, 14-24 \mathrm{~h}$<smiles>[R]c1nc([R])c2ccccc2c1[R]</smiles>

94

Scheme 1.25. Manganese(I)-catalyzed $\mathrm{C}-\mathrm{H}$ annulation via $\beta$-oxygen elimination.

\subsubsection{Manganese(I)-Catalyzed C-H/Het-H Annulations}

Annulation reactions are among the most fundamental and useful transformation in organic synthesis. ${ }^{[15]}$ They provide a straightforward and step-economical method for the synthesis of heterocycles, which are important motifs in pharmaceuticals, natural products and agrochemicals. ${ }^{[76]}$ In 2015, Ackermann and coworkers developed the first manganese-catalyzed $\mathrm{C}-\mathrm{H}$ annulation of acrylates 96 by ketimines 95 , thus providing access to valuable $\beta$-amino acid esters (Scheme 1.26). Mechanistically, a key feature of this annulation process is an intramolecular attack of the carbon-manganese bond to the ketimine, thereby delivering intermediate 99. Subsequently, proto-demetallization delivers the desired product 97.

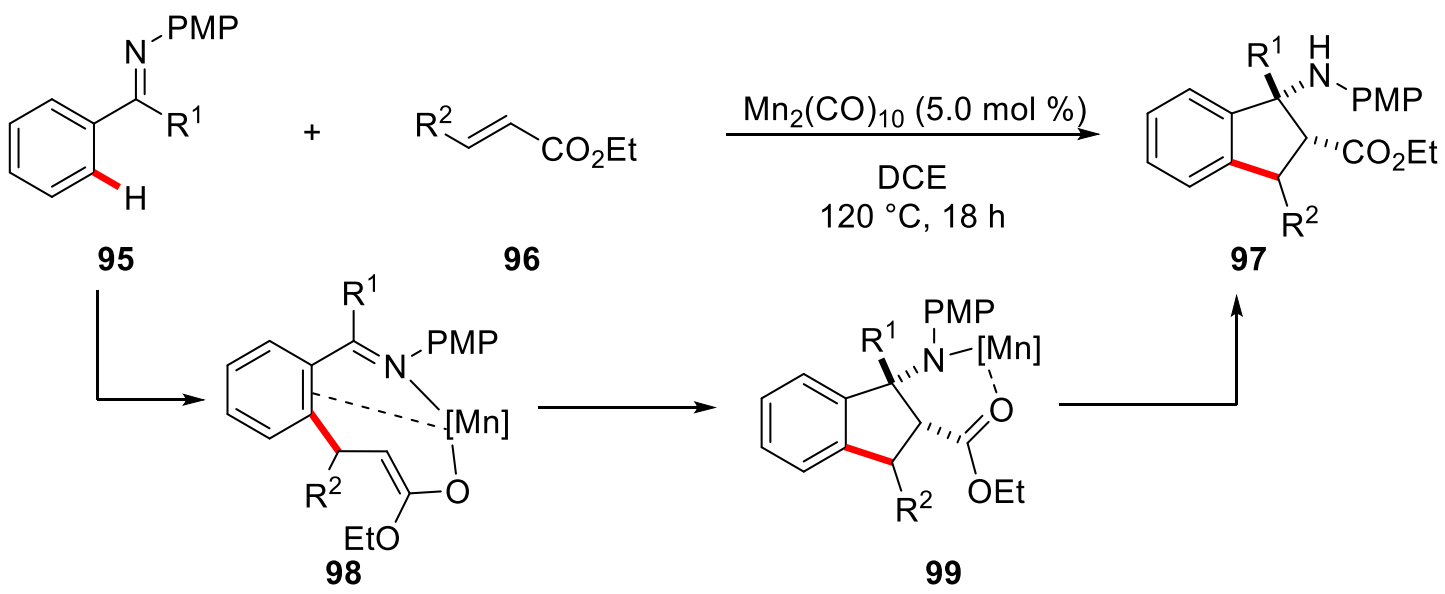

Scheme 1.26. Manganese(I)-catalyzed synthesis of cis- $\beta$-amino acid derivatives 97.

Afterwards, the Ackermann group reported on the first manganese(I)-catalyzed $\mathrm{C}-\mathrm{H}$ annulation with methylenecyclopropanes (MCPs) 100, delivering a variety of densely functionalized polycyclic anilines. After migratory insertion of the MCP $\mathbf{1 0 0}$ into the 
manganese-carbon bond, the key $\mathrm{C}-\mathrm{C}$ cleavage step takes place to deliver intermediate 102, which then undergoes an intramolecular nucleophilic attrack to form the 103. Thereafter, a proto-demetalation releases the desired product 101 (Scheme 1.27). ${ }^{[77]}$<smiles>[R]/C(=N\c1ccccc1)c1ccccc1</smiles>

95

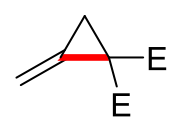

100

1) $\mathrm{MnBr}(\mathrm{CO})_{5}(10 \mathrm{~mol} \%)$ $\underset{\text { 1,4-dioxane, } 80^{\circ} \mathrm{C}, 24 \mathrm{~h}}{\stackrel{\mathrm{NaOAc}}{(20 \mathrm{~mol} \%)}}$

2) $\mathrm{ZnCl}_{2}, 23^{\circ} \mathrm{C}, 1 \mathrm{~h}$ $\mathrm{E}=\mathrm{CO}_{2} \mathrm{Et}$<smiles></smiles>
$\mathrm{R}^{1} \mathrm{~N}-\mathrm{Mn}(\mathrm{CO})_{4}$

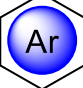

103

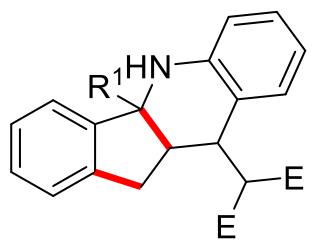

101

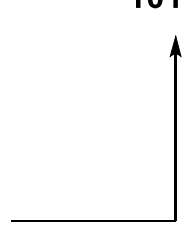

102

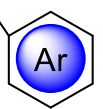

Scheme 1.27. Manganese(I)-catalyzed annulation via $\mathrm{C}-\mathrm{H} / \mathrm{C}-\mathrm{C}$ functionalization.

Thereafter, Rueping and Wang independently reported on manganese(I)-catalyzed C$\mathrm{H}$ hydroarylations of allenes with indoles 35. Notably, a unique cascade reaction consisting of a $\mathrm{C}-\mathrm{H}$ hydroarylation and subsequent Smiles rearrangement was observed (Scheme 1.28). ${ }^{[78]}$

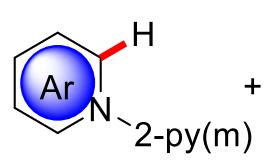

35<smiles>[R]C=C=C([R])COCC</smiles>

104

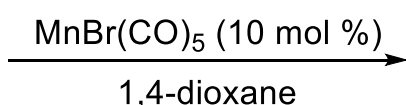

$100{ }^{\circ} \mathrm{C}, 24 \mathrm{~h}$

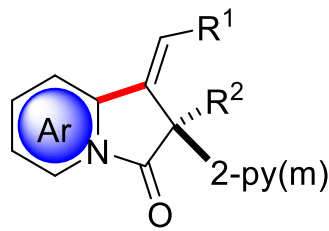

105

Scheme 1.28. Manganese(I)-catalyzed 1,2-diheteroarylation of allenes.

Furthermore, Ackermann developed the first manganese(I)-catalyzed carbonylative annulation for the synthesis of pyrido[1,2-a]pyrimidin-4-ones 108. Detailed 
mechanistic studies proposed a facile insertion of $\mathrm{CO}$ into the manganese complex. Then, a migratory insertion of the alkyne deliveres an eight-membered metallacycle. Finally, the desired product is formed by imine extrusion. Moreover, the outstanding synthetic utility of the manganese catalysis was reflected by the versatile late-stage diversification of numerous marketed drugs and natural products (Scheme 1.29). ${ }^{\text {[9] }}$

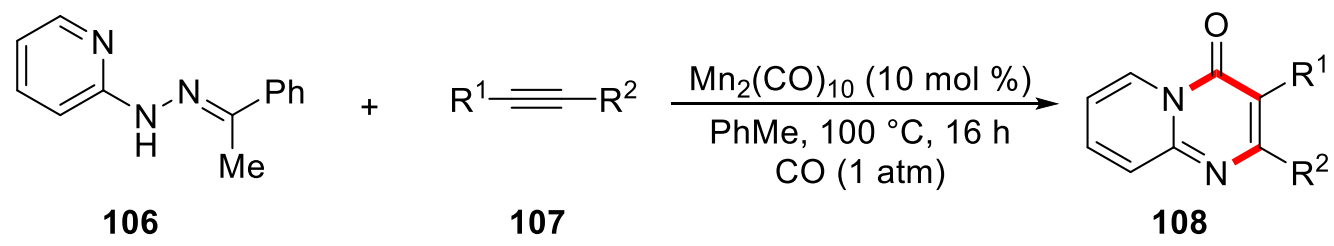

Scheme 1.29. Manganese(I)-catalyzed carbonylative annulation.

\subsubsection{Low-Valent Manganese(II)-Catalyzed C-H Functionalizations}

Despite considerable advances in manganese(I)-catalyzed $\mathrm{C}-\mathrm{H}$ functionalization, this approach is limited to multiple bond migratory insertions. Recently, the Ackermann group reported the first low-valent $\mathrm{MnCl}_{2}$-catalyzed $\mathrm{C}-\mathrm{H}$ alkylation with alkyl halides. The unprecedented low-valent manganese-catalyzed $\mathrm{C}-\mathrm{H}$ activation occurred under zinc-free reaction conditions in the absence of any expensive phosphine ligands, providing versatile access to $\mathrm{C}-\mathrm{H}$ alkylated benzamides through assistance of the removable TAM ${ }^{[80]}$ (triazolyl-methyl) group (Scheme 1.30). ${ }^{[81]}$

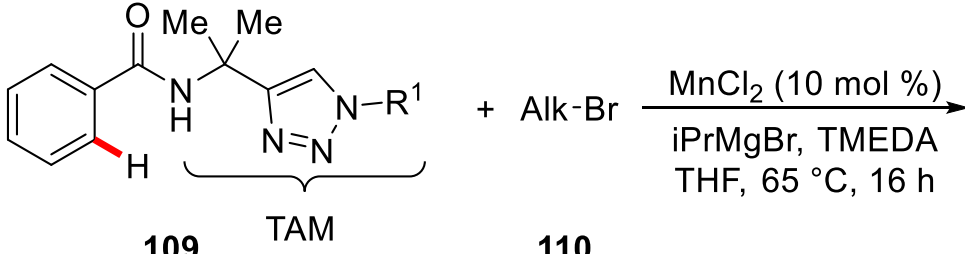
109<smiles>O=C(N[Te][W])c1ccccc1[Al]</smiles>

111

Scheme 1.30. Low-valent $\mathrm{MnCl}_{2}$-catalyzed $\mathrm{C}-\mathrm{H}$ alkylation.

Taking inspiration from this elegant work, Nakamura reported a similar $\mathrm{MnCl}_{2}-$ catalyzed $\mathrm{C}-\mathrm{H}$ methylation of amides. ${ }^{[82]}$ By contrast, Ackermann developed $\mathrm{MnCl}_{2}-$ catalyzed $\mathrm{C}-\mathrm{H}$ alkylation with primary as well as challenging secondary halides and heterocyclic azines 112 (Scheme 1.31). ${ }^{[83]}$ 


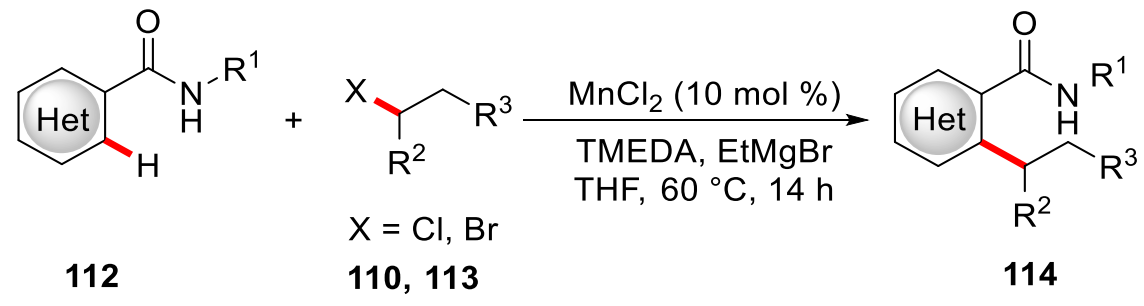

Scheme 1.31. Low-valent $\mathrm{MnCl}_{2}$-catalyzed secondary alkylation on heterocycles 112 .

\subsection{Electrochemical Transition Metal-Catalyzed C-H Activation}

Electroorganic synthesis have become an established, useful, and environmentallybenign alternative to classic organic synthesis for the oxidation or reduction of organic compounds. ${ }^{[84]}$ Since dangerous and toxic redox reagents are replaced by electric current and the overall energy consumption is reduced. ${ }^{[85]}$

\subsubsection{Electrocatalytic Palladium-Catalyzed Transformations}

In an early contribution, a palladium(II/0)-catalyzed Fujiwara-Moritani-type C-H alkenylation reaction was devised by Amatore and Jutand in 2007. The main challenge for the palladium(II)-catalyzed Heck-type reaction is the recycling of palladium(0) back to a catalytically active palladium(II) species. Thus, various drastic oxidants have been used in stoichiometric amounts, such as silver(I), copper(II), $t-\mathrm{BuOOH}$, and benzoquinone. In contrast, by applying electricity, a catalytic amount of hydroquinone will be oxidized to benzoquinone at the anode in each catalytic cycle albeit in a divided cell mainfold (Scheme 1.32). ${ }^{[86]}$ 


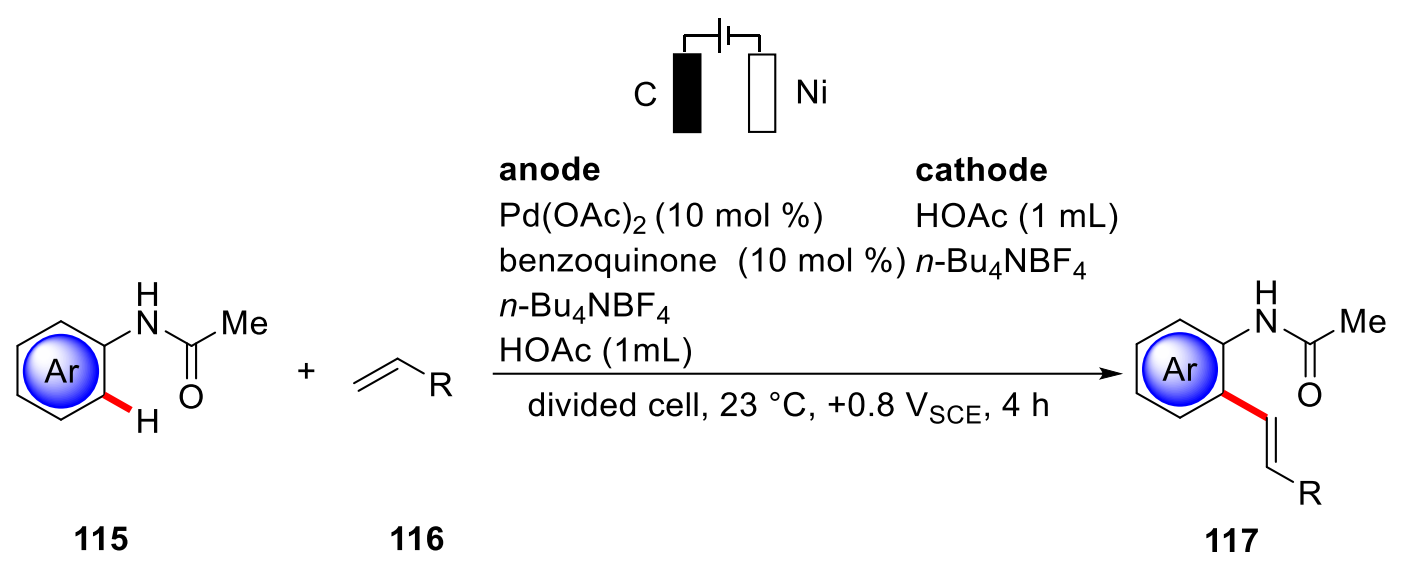

Scheme 1.32. Electrocatalytic palladium-catalyzed Fujiwara-Moritani reaction.

In 2009, Kakiuchi disclosed a palladium-catalyzed halogenation using electrochemical $\mathrm{C}-\mathrm{H}$ functionalization by palladium catalysis. Electricity was here required for the generation of an electrophilic $\mathrm{Cl}^{+}$cation from $\mathrm{HCl}_{(\mathrm{aq})}$ (Scheme 1.33). ${ }^{[87]}$ Later, they extended the palladium-catalysis to the homodimerization of phenylpyridines $\mathbf{2 4}$ in the presence of stoichiometric or co-catalytic amounts of iodine. ${ }^{[88]}$

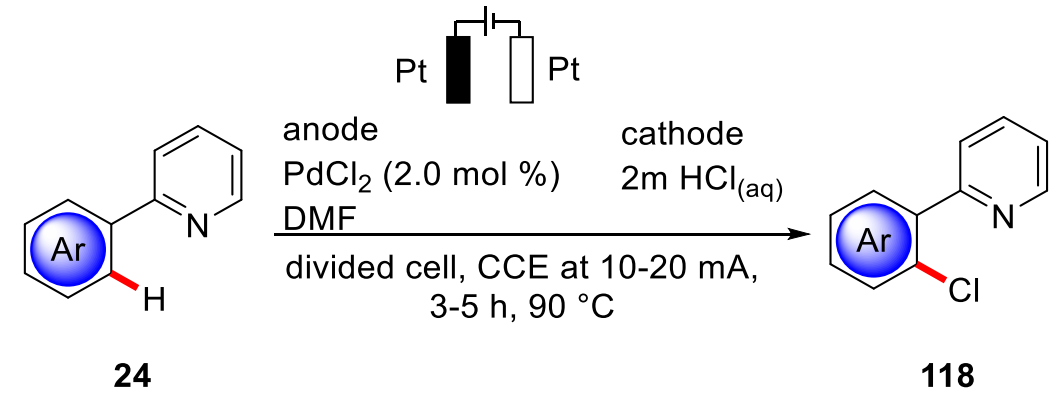

Scheme 1.33. Electrochemical halogenation of phenylpyridines.

Thus far, electrochemical $\mathrm{C}-\mathrm{H}$ activation was severely limited to transformations of $\mathrm{C}\left(\mathrm{sp}^{2}\right)-\mathrm{H}$ bonds. More recently, Mei reported the $\mathrm{C}\left(\mathrm{sp}^{3}\right)-\mathrm{H}$ oxygenation by electrochemical palladium catalysis again in a divided cell setup (Scheme 1.34). ${ }^{[89]}$ 


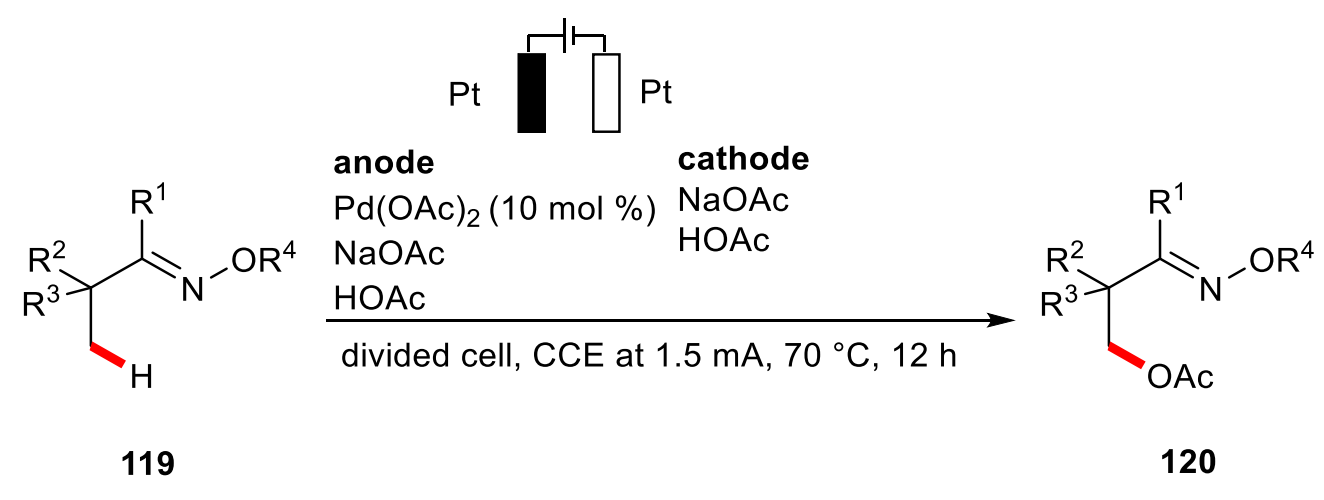

Scheme 1.34. Palladium-catalyzed oxygenation of $\mathrm{C}\left(\mathrm{sp}^{3}\right)-\mathrm{H}$ bonds.

The catalytic cycle is initiated by a base-assisted ${ }^{[15]}$ type $\mathrm{C}-\mathrm{H}$ activation with palladium complex 121 to furnish intermediate $\mathbf{1 2 2}$. Complex 121 is directly oxidized at the anode to form a palladium(III) or palladium(IV) species 123. Finally, reductive elimination from the high-valent palladium center gives palladium(II)-product complex 124, which can undergo ligand exchange to furnish the product 120 (Scheme 1.35). Based on the same strategy, Mei and co-workers demonstrated the electrocatalytic palladiumcatalyzed methylation and acylation of oximes. ${ }^{[90]}$ 


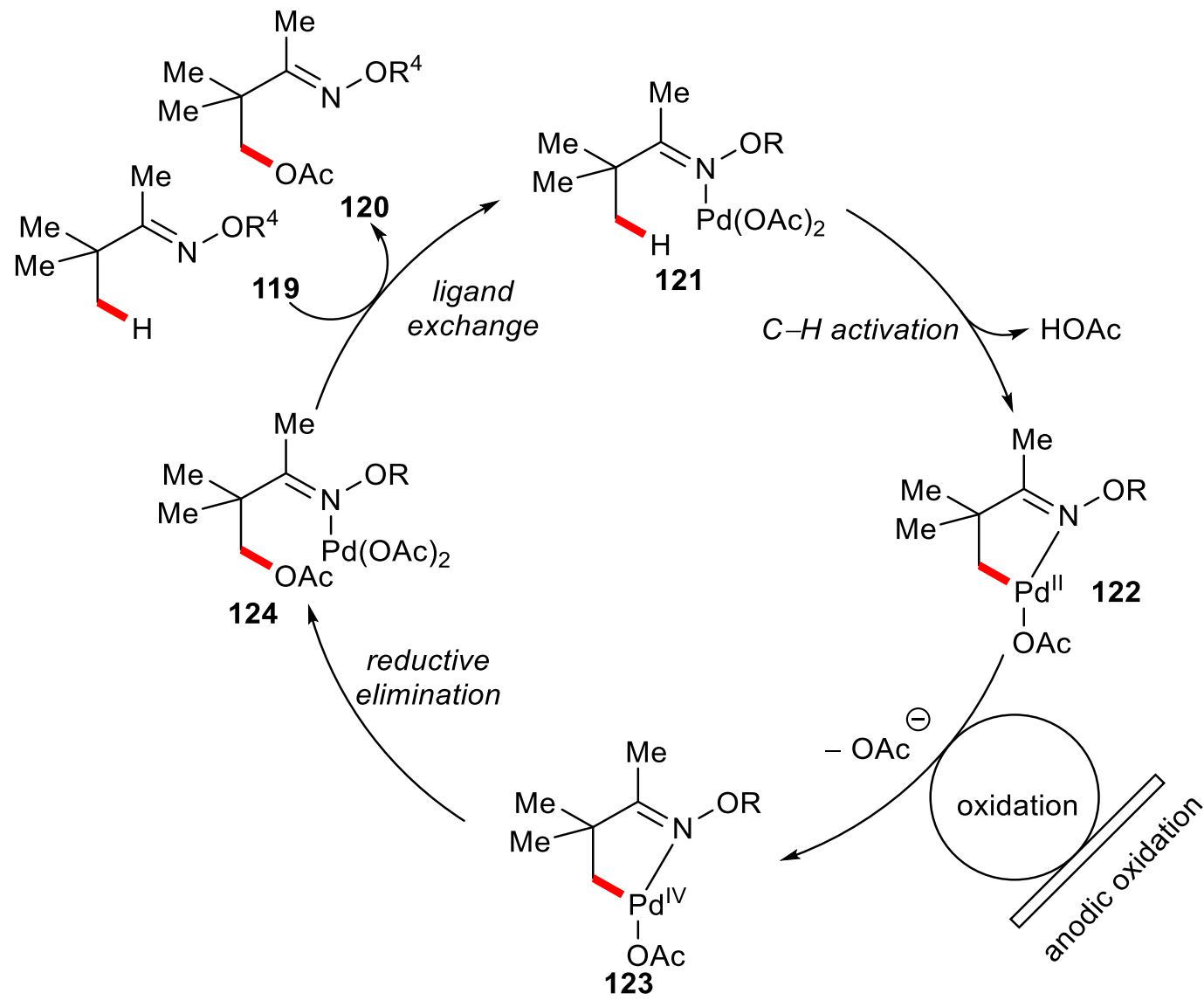

Scheme 1.35. Plausible mechanism for the palladium-catalyzed $\mathrm{C}-\mathrm{H}$ oxygenation.

\subsubsection{Electrocatalytic Cobalt-Catalyzed Transformations}

Cobalt-catalyzed electrochemical cross-couplings are known for over a decade through the pioneering work from Périchon and Gosmini. ${ }^{[1]}$ However, cobalt-catalyzed electrochemical $\mathrm{C}-\mathrm{H}$ activation remained elusive. Recently, a breakthrough was realized by the merger of electrochemical cobalt-catalyzed $\mathrm{C}-\mathrm{H}$ activation, which was first viable for the $\mathrm{C}-\mathrm{H}$ oxygenation of benzamides $125 .{ }^{[92]}$ Later, this approach was extended to electrochemical $\mathrm{C}-\mathrm{H} / \mathrm{N}-\mathrm{H}$ alkyne annulations. ${ }^{[93]}$ Thereafter, Ackermann established the cobalt-catalyzed $\mathrm{C}-\mathrm{H}$ amination of benzamides employing a $\mathrm{N}, \mathrm{O}-$ bidentate directing group. ${ }^{[94]}$ Afterwards, Lei disclosed a less-effective transformation using 8-aminoquinoline (AQ) as the directing group. ${ }^{[95]}$ Furthermore, Ackermann could achieve the unprecedented removal of the hydrazide directing group by a simple electro-reductive $\mathrm{N}-\mathrm{N}$ cleavage in an undivided cell using $\mathrm{Sml}_{2}$ as the catalyst. ${ }^{[96]}$ More 
recently, Ackermann devised the first electrocatalytic $\mathrm{C}-\mathrm{H}$ activation with allenes $\mathbf{1 3 5}$ which was characterized by excellent levels of chemo-, position-, and regioselectivity. ${ }^{\left[{ }^{[7]}\right.}$ (Scheme 1.36)
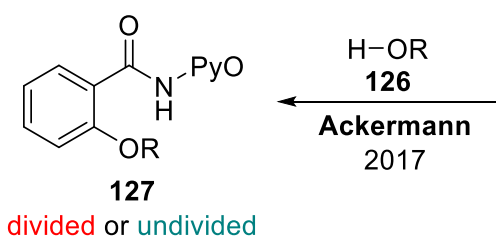

divided or undivided<smiles>[R]Nc1ccccc1C(=O)N[O-]</smiles>
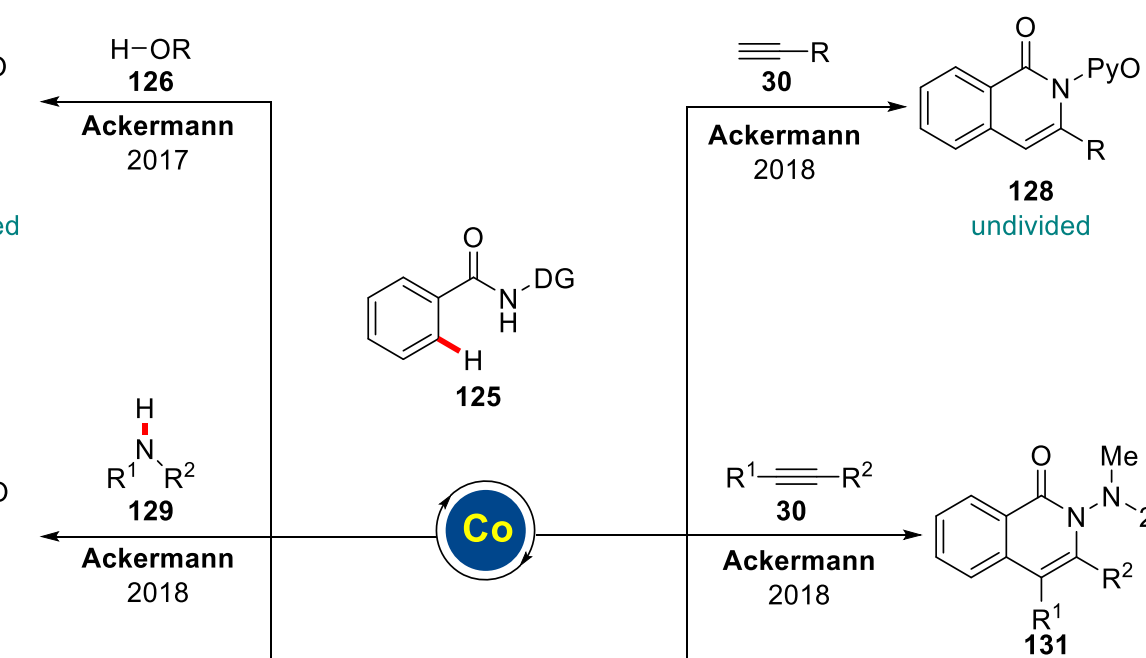

$$
130
$$

undivided<smiles>CN([P])NN1C(=O)c2ccccc2/C1=N\C(C)(C)C</smiles>
$\mathrm{R}-\mathrm{N} \equiv \mathrm{C}$ or $\mathrm{CO}$<smiles>CN(P)NN1C(=O)c2ccccc2C1=O</smiles>
132 2019

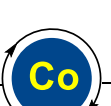

$\mathrm{R}^{1} \frac{\overline{\overline{30}}}{\mathrm{R}^{2}}$ Ackerman

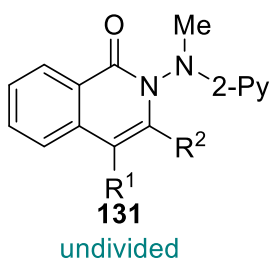

Scheme 1.36. Versatile $\mathrm{C}-\mathrm{H}$ activation by cobaltaelectrocatalysis.

Based on mechanistic observations, the cobalt(II) precatalyst is oxidized at the anode to yield the active cobalt(III) catalyst, which is then coordinated by the substrate. Subsequently, insertion and reductive elimination form the desired products and a cobalt(I) species, which can undergo anodic oxidation to re-generate the cobalt(II) catalyst (Scheme 1.37). 


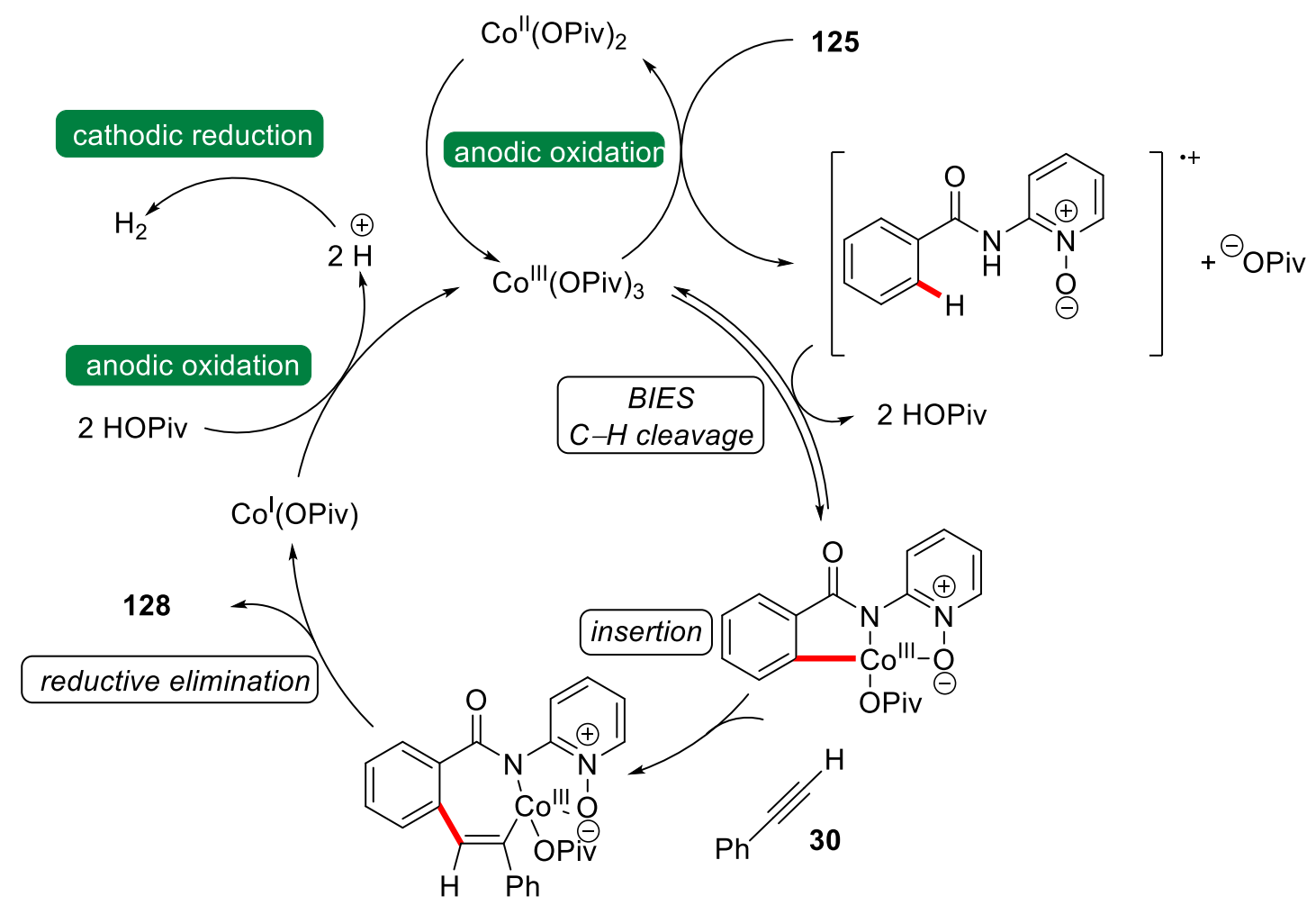

Scheme 1.37. Representative plausible mechanism for the cobalt-catalyzed electrochemical $\mathrm{C}-\mathrm{H}$ activation.

\subsubsection{Electrocatalyzed Transformations by Other Transition Metals}

Ackermann recently reported on the first electrochemical $\mathrm{C}-\mathrm{H}$ activation under rhodium catalysis to realize cross-dehydrogenative alkenylations with weakly coordinating benzoic acids $\mathbf{1 3 7}$ and the procedure also proved applicable to amides 138 and indoles 35 (Scheme 1.38a). ${ }^{[98]}$ Subsequently, the same group demonstrated rhodaelectro-catalyzed $\mathrm{C}-\mathrm{H}$ activations, for $[2+2+2]$ cycloadditions, which set the stage for the synthesis of novel non-planar polycyclic aromatic hydrocarbons (PAHs) from simple arylboronic acids 142 and alkynes 30 (Scheme 1.38b). ${ }^{[99]}$ Based on detailed mechanistic studies, they proposed a rhodium(III) to rhodium(I) pathway for rhodaelectro-catalyzed $\mathrm{C}-\mathrm{H}$ activation. 
a) Electrooxidative rhodium-catalyzed $\mathrm{C}-\mathrm{H}$ alkenylation

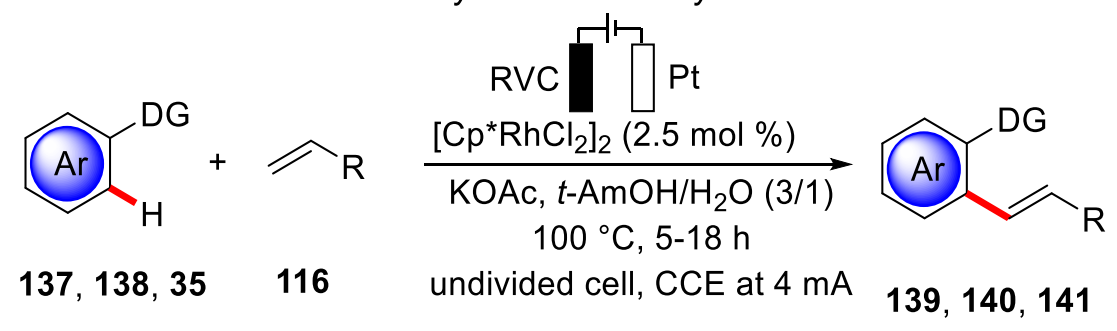<smiles>CCCOCC1OC(=O)c2ccccc21</smiles>

139: $85 \%$<smiles>CCCCOC(=O)CC1c2ccccc2C(=O)N1C</smiles>

140: $51 \%$<smiles>CCCCOC(=O)C=Cc1cc2ccccc2n1-c1ncccn1</smiles>

141: $50 \%$

b) Electrooxidative rhodium-catalyzed $\mathrm{C}-\mathrm{H}$ annulation by versatile double electrocatalysis

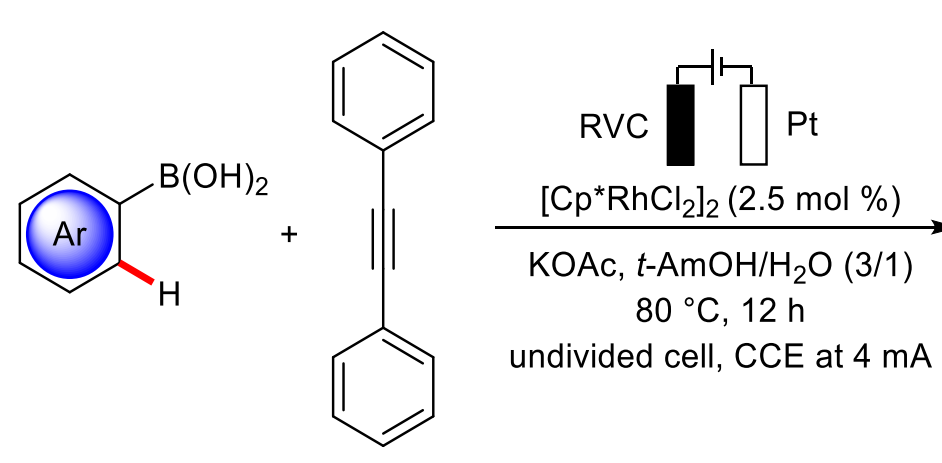

142<smiles>c1ccc(-c2c(-c3ccccc3)c(-c3ccccc3)c3ccccc3c2-c2ccccc2)cc1</smiles>

143<smiles></smiles>

DDQ $(20 \mathrm{~mol} \%)$ $\left.\begin{array}{c}n-\mathrm{Bu}_{4} \mathrm{NBF}_{4}, \mathrm{CH}_{2} \mathrm{Cl}_{2} / \mathrm{TFA}(9: 1) \\ 23^{\circ} \mathrm{C}, 1-2 \mathrm{~h}, \mathrm{CCE} \text { at } 6 \mathrm{~mA}\end{array}\right] \mathrm{RVC} \square \mathrm{Pt}$

144

Scheme 1.38. Rhodaelectro-catalyzed C-H functionalization.

Xu group developed the ruthenium-catalyzed electrochemical [3+2] annulation of aniline to access indoles (Scheme 1.39a). ${ }^{[100]}$ Concurrently, Ackermann developed a 
ruthenium-catalyzed synthesis of isocoumarines by $\mathrm{C}-\mathrm{H} / \mathrm{O}-\mathrm{H}$ annulation. Noteworthily, it showed for the first time weakly coordinating benzoic acids as substrates for ruthenium-catalyzed electrochemical C-H activation (Scheme 1.39b). ${ }^{[101]}$

a) Ruthenium-catalyzed electrochemical indole synthesis

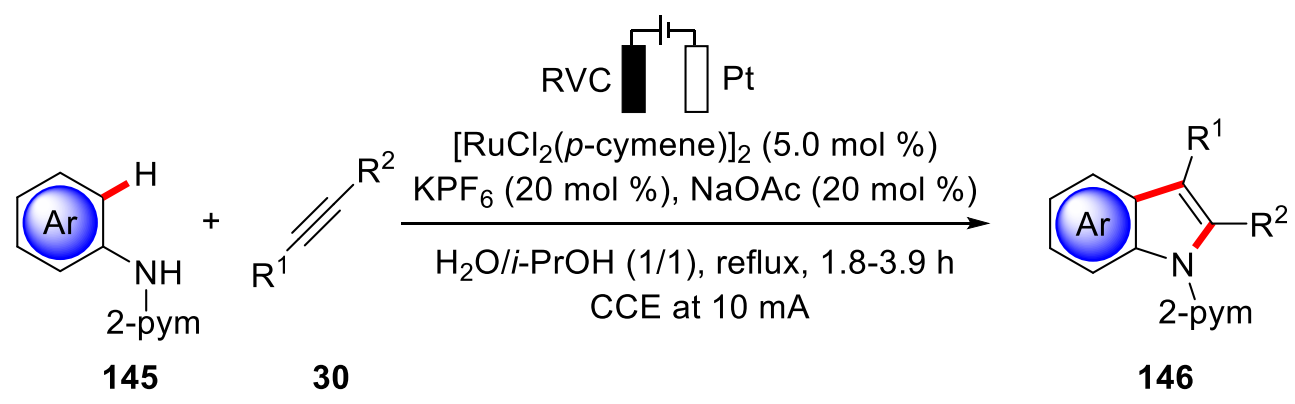

b) Ruthenaelectro-catalyzed $\mathrm{C}-\mathrm{H} / \mathrm{O}-\mathrm{H}$ annulation

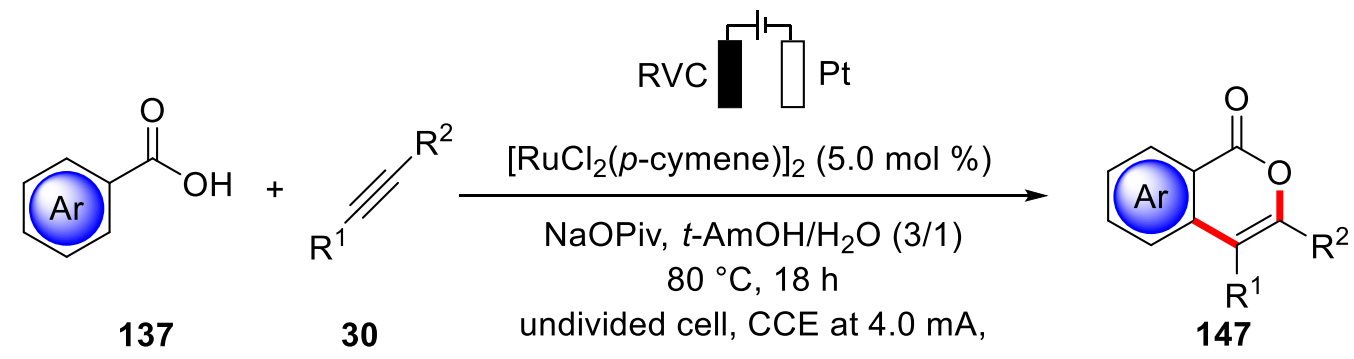

Scheme 1.39. Electrooxidative ruthenium-catalyzed C-H functionalization.

Recently, Ackermann reported on the first electrochemical nickel-catalyzed $\mathrm{C}-\mathrm{H}$ aminations ${ }^{[102]}$ It is noteworthy that the studies highlight a distinct working mode by fast C-H scission, involving a scarce nickel(IV) intermediate (Scheme 1.40).

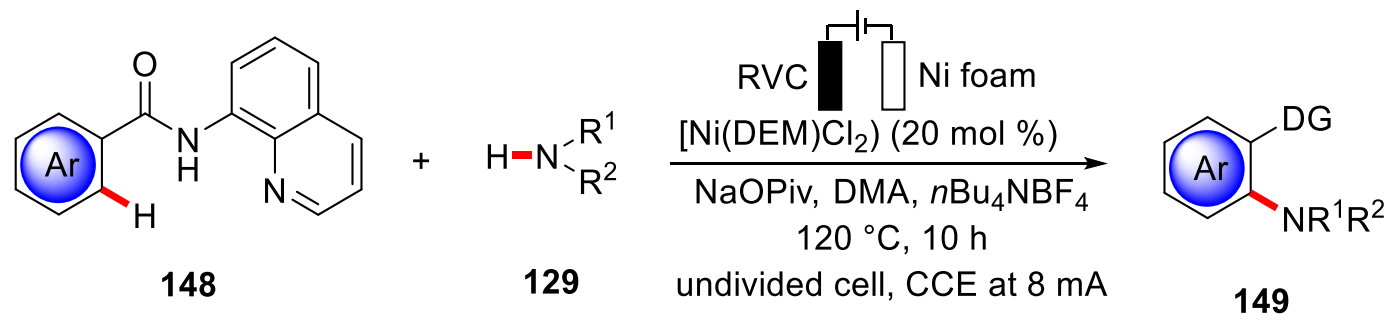

Scheme 1.40. Electrooxidative nickel-catalyzed $\mathrm{C}-\mathrm{H}$ aminations.

\subsection{Low-Valent Iron-Catalyzed C-H Activation}

iron is the most abundant metal in the earth's crust after aluminium. ${ }^{[103]}$ Moreover, 
various iron compounds are present in biological systems and are an essential part of important metabolic processes, such as in cytochrome P450. These unique properties prompted the use of iron catalysts in pharmaceutical and agrochemical industries or for the synthesis of cosmetics, among others. ${ }^{[104]}$ Inspired by early contributions in the field of catalytic cross-coupling ${ }^{[105]} \mathrm{C}-\mathrm{C}$ bond forming, the researchers explored the use of iron catalysts for developing $\mathrm{C}-\mathrm{H}$ activation strategies. Indeed, low-valent iron species were found to be instrumental for the activation of thermodynamically stable $\mathrm{C}\left(\mathrm{sp}^{2}\right)-\mathrm{H}$ as well as $\mathrm{C}\left(\mathrm{sp}^{3}\right)-\mathrm{H}$ bonds under mild reaction conditions, providing a stepand atom-economical approach for the formation of new $\mathrm{C}-\mathrm{C}$ and $\mathrm{C}-\mathrm{Het}$ bonds. ${ }^{[25,}$ 106]

\subsubsection{Iron-Catalyzed $\mathrm{C}-\mathrm{H}$ arylation}

Inspired by early studies on iron-catalyzed cross-coupling reactions, ${ }^{[107]}$ Nakamura, Yoshikai, and coworkers discovered an unusual $\mathrm{C}-\mathrm{H}$ activation within an attempted cross-coupling of 2-bromopyridine with an in situ generated diphenylzinc reagent. Thus, product $8 \mathrm{~b}$ was also observed, which was suggested to be formed by an ironcatalyzed $\mathrm{C}-\mathrm{H}$ arylation of the initially formed 2-phenylpyridine $24 .^{[108]}$ This observation and the subsequent detailed optimization studies of the key reaction parameters led to the development of an efficient low-valent iron-catalyzed $\mathrm{C}-\mathrm{H}$ arylation. Interestingly, additional a broad of scope, such as 2 -arypyrimidine $150,{ }^{[108]}$ 2-arylpyrazole $49,{ }^{[108]}$ ketimines $83^{[109]}$ and benzamide $138^{[110]}$, were found to be competent in the $\mathrm{C}-\mathrm{H}$ arylation manifold (Scheme 1.41). 


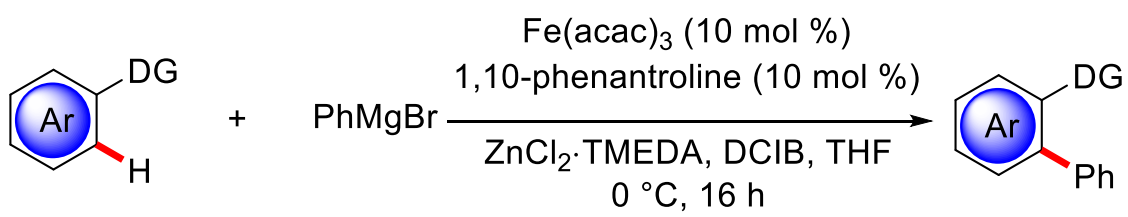

$24,49,83,138,150 \quad 151 b$

$152,153,154,, 155,156$<smiles>c1ccc(-c2ccccc2-c2ccccc2)cc1</smiles>

152: $81 \%$<smiles>c1ccc(-c2ncccc2-c2ccccn2)cc1</smiles>

153: $81 \%$<smiles>c1ccc(-c2ccccc2-n2cccn2)cc1</smiles>

154: $59 \%$<smiles>C/C(=N\N=[W])c1ccccc1-c1ccccc1</smiles>

155: $100 \%^{a}$<smiles>CNC(=O)c1ccccc1-c1ccccc1</smiles>

156: $78 \%^{a}$

a: dtbyp as ligand

Scheme 1.41. iron-catalyzed $\mathrm{C}-\mathrm{H}$ arylation.

The use of 8-aminoquinoline 148 as a powerful directing group was originally established by Daugulis for palladium-catalyzed functionalizations of unactivated $\mathrm{C}\left(\mathrm{sp}^{3}\right)-\mathrm{H}$ bonds. ${ }^{[111]}$ In sharp contrast, Nakamura reported on iron catalysts in combination with the diphosphine ligand $\mathrm{dppz}$ for the arylation of unactivated $\mathrm{C}\left(\mathrm{sp}^{3}\right)-$ $\mathrm{H}$ bonds by 8 -aminoquinoline-assistance. ${ }^{[112]}$<smiles>CC(Cc1ccccc1)(Cc1ccccc1)C(=O)Nc1cccc2c1N=CCC2</smiles>

157

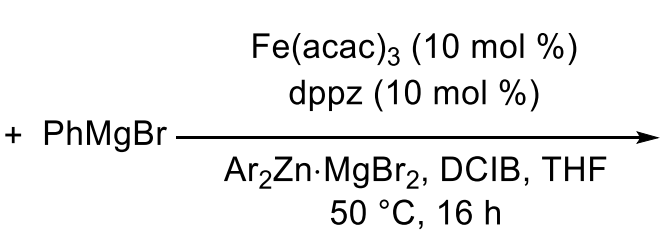

$151 b$<smiles>CC(Cc1ccccc1)(Cc1ccccc1)C(=O)Nc1cccc2cccnc12</smiles>

158: $80 \%$

Scheme 1.42. iron-catalyzed $\mathrm{C}\left(\mathrm{sp}^{3}\right)-\mathrm{H}$ arylation.

The 8-aminoquinoline auxiliary is difficult to removal usually requires harsh reaction conditions. Thus, a major advance developed by Ackermann group in iron-catalyzed $\mathrm{C}-\mathrm{H}$ activation was accomplished by introducing a modular family of easily accessible triazole-based TAM groups. ${ }^{[113]}$ In 2014, Ackermann group identified the easily accessible 1,2,3-triazole as an enabling motif in bidentate directing groups for the ironcatalyzed $\mathrm{C}\left(\mathrm{sp}^{2}\right)-\mathrm{H}$ and $\mathrm{C}\left(\mathrm{sp}^{3}\right)-\mathrm{H}$ arylations (Scheme 1.43). ${ }^{[80]}$ Notably, it clearly 
revealed the TAM group to display an improved directing group compared with 8aminoquinoline auxiliary.

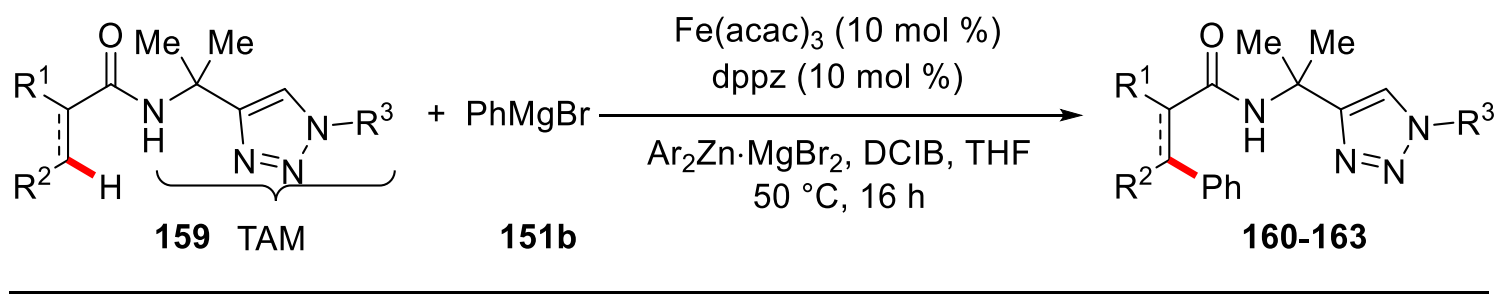<smiles>[14CH3]NC(=O)c1ccccc1-c1ccccc1</smiles>

160: $72 \%$<smiles>Cc1cccc(-c2ccccc2)c1C(=O)N[14CH3]</smiles>

161: $90 \%$<smiles>[14CH3]NC(=O)NC(=O)/C=C\c1ccccc1</smiles>

162: $57 \%$<smiles></smiles>

163: $68 \%$

Scheme 1.43. iron-catalyzed $\mathrm{C}\left(\mathrm{sp}^{2}\right)-\mathrm{H}$ and $\mathrm{C}\left(\mathrm{sp}^{3}\right)-\mathrm{H}$ arylation by TAM groups.

\subsubsection{Iron-Catalyzed C-H Activation through Triazole Assistance}

The modular nature of the triazole group set the stage for the versatile $\mathrm{C}-\mathrm{H}$ activation under iron catalysis. In 2016, Ackermann group reported iron-catalyzed C-H allylation by less expensive and readily available allyl chlorides 164 which were found to be suitable electrophiles (Scheme 1.44a). ${ }^{[114]}$ Later, The Ackermann group successfully employed the triazole directing group to enable the first iron-catalyzed $\mathrm{C}-\mathrm{H}$ alkynylation with alkynyl bromides 166 proceeding with excellent levels of chemo- and siteselectivities (Scheme 1.44b). ${ }^{[115]}$ Ackermann group devised an iron-catalyzed synthesis of isoquinolones 169 via the $\mathrm{C}-\mathrm{H} / \mathrm{N}-\mathrm{H}$ annulation of alkynes 30 by the proper choice of the triazole group (Scheme 1.44c). ${ }^{[116]}$ Very recently Ackermann group reported on the first use of allenes $\mathbf{1 0 4}$ for iron-catalyzed $\mathrm{C}-\mathrm{H}$ annulations under external oxidant-free conditions (Scheme 1.44d). The use of allenyl acetates 104 hence allowed for the synthesis of isoquinolones $\mathbf{1 7 1}$ with high yields and functional group tolerance. Importantly, a strong influence of the directing group was observed for the synthesis of exo-methylene isoquinolines $\mathbf{1 7 0}$ with gem-disubstituted triazolyl amides 
159 under the same reaction conditions.

a) Iron-catalyzed $\mathrm{C}-\mathrm{H}$ allylation

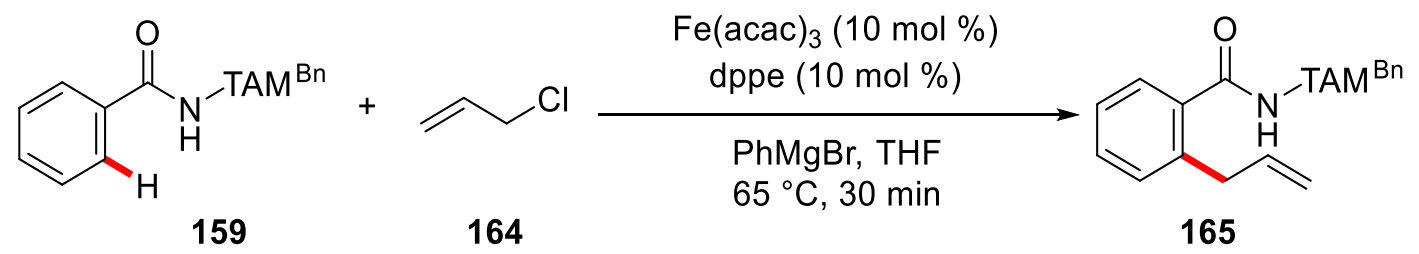

b) Iron-catalyzed $\mathrm{C}-\mathrm{H}$ alkynylation

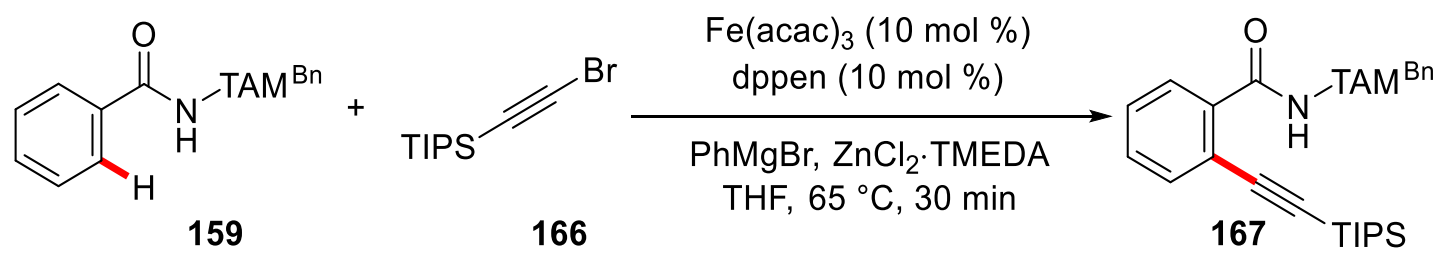

c) Iron-catalyzed $\mathrm{C}-\mathrm{H}$ alkyne annulation<smiles>O=C(N[Tl])c1ccccc1</smiles>

168

d) Iron-catalyzed $\mathrm{C}-\mathrm{H}$ allenes annulation

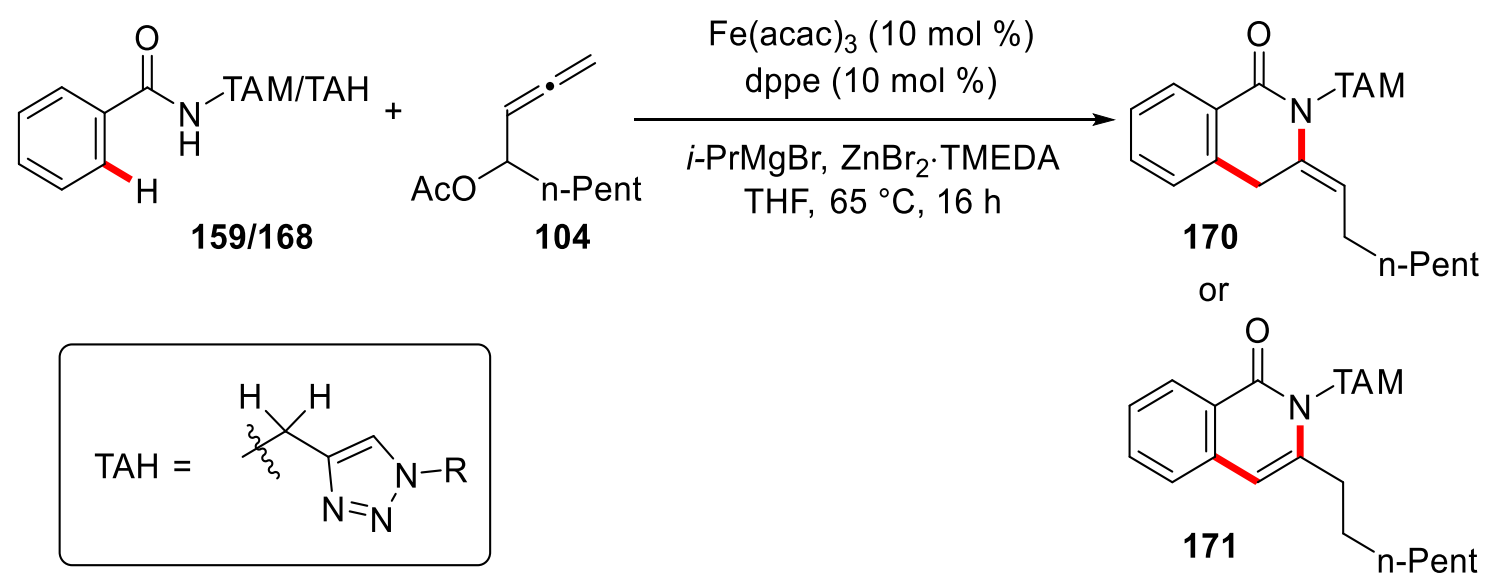

Scheme 1.44. iron-catalyzed $\mathrm{C}-\mathrm{H}$ activation through triazole assistance. 


\section{Objectives}

Transition metal-catalyzed $\mathrm{C}-\mathrm{H}$ activations have emerged as increasingly powerful tools for sustainable organic syntheses. ${ }^{[117]}$ Remarkable advances in this area have been achieved by Prof. Dr. Lutz Ackermann and coworkers, which are mainly focused on the development of chemo- and site-selective syntheses of valuable organic molecules, with applications to pharmaceutical chemistry, materials sciences and peptide assembly. ${ }^{[25]}$ In this context, the development of novel base metal-catalyzed and electrocatalytic $\mathrm{C}-\mathrm{H}$ activation reactions by environmentally-benign, less expensive and earth-abundant cobalt, manganese and iron catalysts should be investigated.

Inspired by the success of cobalt(III) complexes as catalysts for a cascade alkyne annulation via the release of the carbamate directing group, ${ }^{[30]}$ we decided to probe the newly chemoselectivity in cobalt(III)-catalyzed cascade $\mathrm{C}-\mathrm{H}$ activation/directing group migration/alkyne annulation of 2-pyridylpyridones 172 with propargylic carbonates 88. Interestingly, the completely unprecedented products $\mathbf{1 7 3}$ could be obtained.
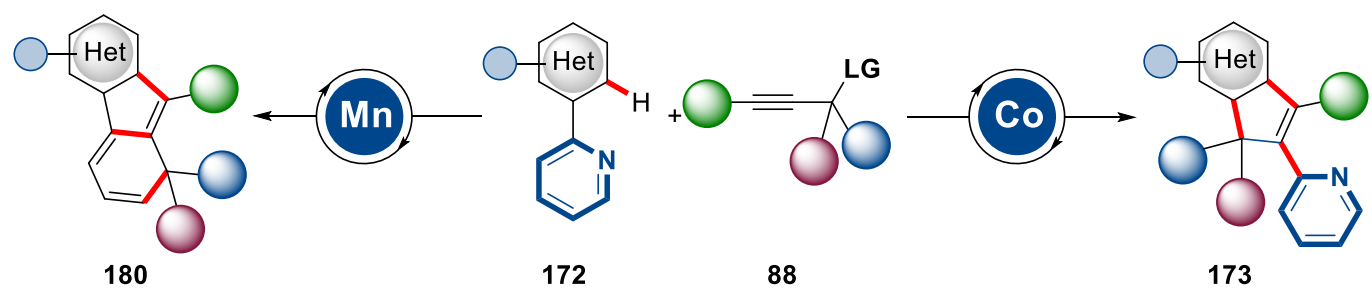

Scheme 2.1. Base metal-catalyzed C-H/C-N/C-C Annulation of pyridones 172 .

With previous achievements on sustainable $3 \mathrm{~d}$ transition metal-catalyzed $\mathrm{C}-\mathrm{H}$ activation, ${ }^{[106 a, 118]}$ it was demonstrated that cobalt(III) catalysis ${ }^{[27 a, 29]}$ and manganese(I) catalysis $^{[71,74-75,77-79,119]}$ feature similar reactivity and selectivities. ${ }^{[120]}$ In stark contrast, we initiated the development of the first manganese-catalyzed dehydrocyanative Domino $\mathrm{C}-\mathrm{H}$ allenylation ${ }^{[56-57,73]}{ }^{[121]}$ on pyridones ${ }^{[122]}$ by transformable pyridyl 
groups.(Scheme 2.1).

Particularly, arene $\mathrm{C}-\mathrm{H}$ arylations have been identified as powerful alternatives to traditional cross-couplings, avoiding the use and multi-step preparation of prefunctionalized arenes. ${ }^{[123]}$ While the majority of arene $\mathrm{C}-\mathrm{H}$ arylations was thus far accomplished with precious, toxic transition metals, ${ }^{[123]}$ recent focus has shifted towards the use of more sustainable $3 d$ transition metals. ${ }^{[25]}$ Despite of tremendous advances in redox-neutral manganese $(\mathrm{I})^{[124]}$ catalysis, arene $\mathrm{C}-\mathrm{H}$ arylations with earthabundant, less toxic manganese complexes have as of yet proven elusive. Here, the first manganese(II/III/I)-catalyzed organometallic versatile azine $\mathrm{C}-\mathrm{H}$ arylations should be developed. (Scheme 2.2). What's more, it is of great significance to develop a new tool using continuous flow for the safe handling of reactive reagents on scale by improved control of heat and mass transfer (Scheme 2.2).

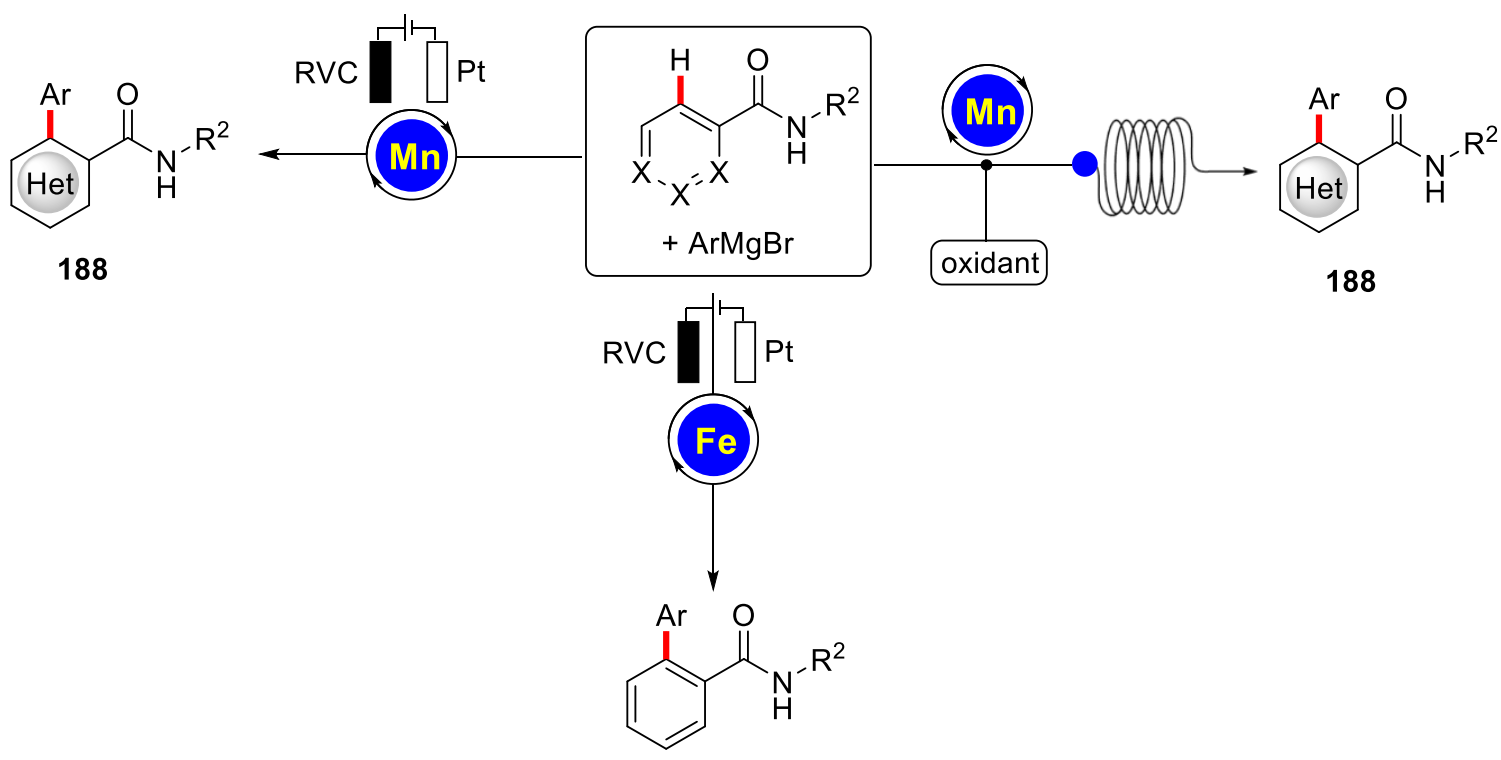

192

Scheme 2.2. Continuous flow and electrocatalytic manganese- or iron-catalyzed C-H arylations.

In recent years, a tremendous progress has been achieved in utilizing low valent iron catalysts for $\mathrm{C}-\mathrm{H}$ functionalizations. All documented iron-catalyzed $\mathrm{C}-\mathrm{H}$ arylations continue to be strongly limited by the need for superstoichiometric quantities of the 
vicinal-dichloride dichloroisobutane (DCIB) as the sacrificial oxidant. ${ }^{[118 d]}$ Unfortunately, DCIB is elusive on commercial scale, features considerable safety hazards, generates overstoichiometric amounts of corrosive byproducts, and is toxic, which overall significantly deteriorates the environmental footprint of oxidative iron catalysis. Importantly, DCIB is also characterized by costs that are comparable to those of the typical noble transition metal catalyst $\mathrm{Pd}(\mathrm{OAc})_{2}$, hence jeopardizing the inherent green nature of the iron-catalyzed $\mathrm{C}-\mathrm{H}$ activation approach. Thus, a strategy for the unprecedented DCIB-free, iron-catalyzed $\mathrm{C}-\mathrm{H}$ arylation through the action of userfriendly electricity ${ }^{[4,84,125]}$ as green oxidant was intended (Scheme 2.2). 


\section{Results and Discussion}

\subsection{Domino C-H Activation/Directing Group Migration/Alkyne}

\section{Annulation: Unique Selectivity by $\mathrm{d}^{6}$-Cobalt(III) Catalysts}

Indolizinones are versatile heterocycles that are widely founded as the key structural motifs present in molecules with medicinal benefits, natural products and diverse bioactivities, such as the antitumor agent camptothecin and A58365A. (Scheme 3.1). ${ }^{[126]}$ A novel rhodium-catalyzed $\mathrm{C}-\mathrm{H}$ allenylation of amides with propargyl carbonates was developed. ${ }^{[56]}$ Additionally, Glorius ${ }^{[73]}$ and Sundararaju ${ }^{[57]}$ reported the Earth-abundant manganese $\left({ }^{[118 b]}{ }^{[1}\right.$ and cobalt(III)-catalyzed ${ }^{[25,29]} \mathrm{C}-\mathrm{H}$ allenylation of indoles and pyrazoles. Furthermore, our group recently reported an unprecedented manganese-catalyzed dehydrocyanative Domino- $\mathrm{C}-\mathrm{H}$ annulation. ${ }^{[127]}$

With advances in transition metal-catalyzed C-H activation, ${ }^{[106 a, 118]}$ there are indeed aspects in $\mathrm{C}-\mathrm{H}$ functionalizations, such as reactivity and stereoselectivity that can be controlled not only by the judicious choice of ligands, but also by the distinctive features of the metal. In this regard, there are several reports on the distinct chemoselectivities for cobalt(III) complexes as compared to the corresponding rhodium(III) catalysis. However, there is still no example to explore the distinct selectivity features between cobalt(III) and manganese(I) catalysis. We hence decided to explore the feasibility of cobalt(III)-catalyzed cascade $\mathrm{C}-\mathrm{H}$ annulation of 2pyridinepyridone $\mathbf{1 7 2 a}$ with propargylic carbonate $\mathbf{8 8 a}$.

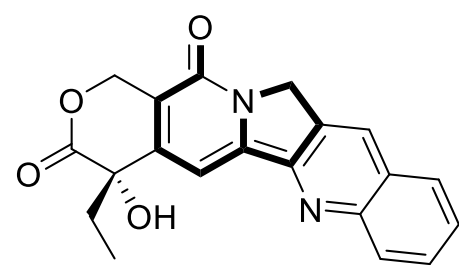

camptothecin<smiles>O=C(O)CCc1cc(O)c2n(c1=O)CCC2</smiles>

A58365a

Scheme 3.1. Selected bioactive indolizin-5(3H)-one-containing compounds. 


\subsubsection{Optimization Studies for Cobalt-Catalyzed Domino Annulation}

We probed the effect exerted by representative transition-metal complexes, additives and solvents on the envisioned $\mathrm{C}-\mathrm{H}$ annulation of pyridone $172 \mathrm{a}$ with propargylic carbonate 88a (Table 3.1). Sodium acetate as additive delivered the desired product 173aa in moderate yields, whereas sodium pivalate was the least effective additive (entries 1-3). Lower reaction temperatures were detrimental to the reaction outcome (entry 4). Furthermore, no reaction was observed when omitting the cobalt(III) catalyst, which is a clear hint for cobalt catalysis to be operative in this reaction. In contrast, rhodium(III) catalysis led to a significant drop in reactivity (entry 6). Furthermore, ruthenium(II) catalysis and cationic sandwich complex $\left.\left.\left[\mathrm{Cp} * \mathrm{Co}(\mathrm{MeCN})_{3}\right]\left(\mathrm{SbF}_{6}\right)_{2}\right)\right]$ were not competent catalysts for the $\mathrm{C}-\mathrm{H}$ annulation (entries 7 and 8). Interestingly, solvent TFE by far outcompeted DCE and $\mathrm{PhCF}_{3}$ (entries 9-11), delivering the desired product 173aa in $52 \%$. Thereafter, a series of additives were tested, and HOAc led to a significant increase in reactivity (entries 12-14). Remarkably, the catalytic performance was only moderately affected by the absence of the silver additive (entry 15).

Table 3.1. Optimization of the cobalt-catalyzed annulation. ${ }^{\text {[a] }}$<smiles></smiles>

$172 a$

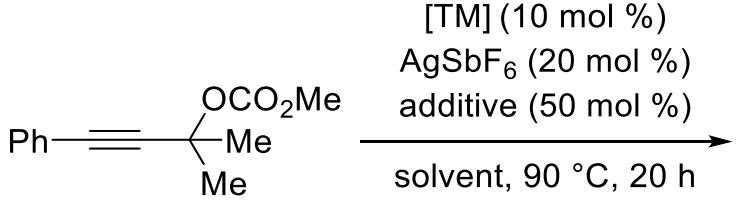

$88 a$

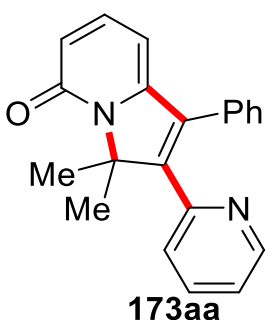

$173 a$

\begin{tabular}{lllll}
\hline Entry & {$[\mathrm{TM}]$} & Additive & Solvent & Yield (\%) \\
\hline 1 & {$\left[\left.\mathrm{Cp} * \mathrm{Co}(\mathrm{CO})\right|_{2}\right]$} & -- & HFIP & 20 \\
2 & {$\left[\left.\mathrm{Cp} * \mathrm{Co}(\mathrm{CO})\right|_{2}\right]$} & NaOPiv & HFIP & 14 \\
3 & {$\left[\left.\mathrm{Cp} * \mathrm{Co}(\mathrm{CO})\right|_{2}\right]$} & NaOAC & HFIP & 46 \\
4 & {$\left[\left.\mathrm{Cp} * \mathrm{Co}(\mathrm{CO})\right|_{2}\right]$} & NaOAC & HFIP & -- [b] \\
5 & --- & NaOAC & HFIP & --- \\
\hline
\end{tabular}




\begin{tabular}{|c|c|c|c|c|}
\hline 6 & {$\left[\mathrm{Cp} * \mathrm{RhCl}_{2}\right]_{2}$} & $\mathrm{NaOAc}$ & HFIP & 17 \\
\hline 7 & {$\left[\mathrm{RuCl}_{2}(p \text {-cymene })\right]_{2}$} & $\mathrm{NaOAc}$ & HFIP & --- \\
\hline 8 & {$\left[\mathrm{Cp} * \mathrm{Co}(\mathrm{MeCN})_{3}\right]\left(\mathrm{SbF}_{6}\right)_{2}$} & HOAC & TFE & $6^{[c]}$ \\
\hline 9 & {$\left[\mathrm{Cp} * \mathrm{Co}(\mathrm{CO}) \mathrm{I}_{2}\right]$} & $\mathrm{NaOAc}$ & DCE & --- \\
\hline 10 & {$\left[\mathrm{Cp} * \mathrm{Co}(\mathrm{CO}) \mathrm{I}_{2}\right]$} & $\mathrm{NaOAc}$ & $\mathrm{PhCF}_{3}$ & --- \\
\hline 11 & {$\left[\mathrm{Cp} * \mathrm{Co}(\mathrm{CO}) \mathrm{I}_{2}\right]$} & $\mathrm{NaOAc}$ & TFE & 52 \\
\hline 12 & {$\left[\mathrm{Cp} * \mathrm{Co}(\mathrm{CO}) \mathrm{I}_{2}\right]$} & $\mathrm{AgOAc}$ & TFE & 56 \\
\hline 13 & {$\left[\mathrm{Cp} * \mathrm{Co}(\mathrm{CO}) \mathrm{I}_{2}\right]$} & HOAC & TFE & 81 \\
\hline 14 & {$\left[\mathrm{Cp} * \mathrm{Co}(\mathrm{CO}) \mathrm{I}_{2}\right]$} & --- & TFE & 42 \\
\hline 15 & {$\left[\mathrm{Cp} * \mathrm{Co}(\mathrm{CO}) \mathrm{I}_{2}\right]$} & HOAC & TFE & $55^{[c]}$ \\
\hline
\end{tabular}

[a] Reaction conditions: 172a (0.50 mmol), 88a (1.50 mmol), [TM] (10 mol \%), AgSbF 6 $(20 \mathrm{~mol} \%)$, additive $(50 \mathrm{~mol} \%)$, solvent $(2.0 \mathrm{~mL}), 90^{\circ} \mathrm{C}, 20 \mathrm{~h}$. Yields of isolated products. [b] At $50^{\circ} \mathrm{C}$. [c] Without $\mathrm{AgSbF}_{6}$.

\subsubsection{Scope of Cobalt(III)-Catalyzed C-H/C-N Functionalization}

\subsubsection{Cobalt(III)-Catalyzed C-H/N-O Functionalization with Substituted Pyridones}

\section{2}

With the optimized $\mathrm{C}-\mathrm{H}$ activation/pyridine migration manifold in hand, we explored the versatility of the $\mathrm{C}-\mathrm{H}$ Domino annulation employing a representative set of various substituted pyridones 172 (Scheme 3.2). First, various substituents in the C4-position of the pyridine $\mathbf{1 7 2 b}, \mathbf{1 7 2 d}, \mathbf{1 7 2} \mathrm{e}, \mathbf{1 7 2 f}$ and $\mathbf{1 7 2} \mathrm{g}$ were tested, such as bromo, chloro, carboxylate, trifluoromethyl and methyl groups. Notably, all functional groups were fully tolerated, delivering the desired annulation products in good yields ranging from $52 \%$ to $75 \%$ and high chemoselectivities. Furthermore, the substitution pattern on the pyridyl-directing group did not influence the reactivity, with overall very good yields. Furthermore, sterically demanding substituents in C5-position was probed, furnishing 
<smiles>[R]c1ccc(=O)n(-c2ncc[R7]2[H])c1</smiles>

172

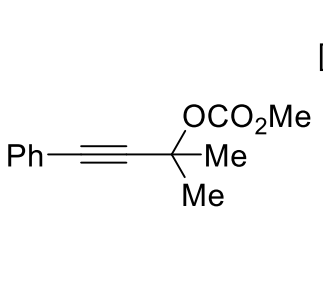

$88 a$

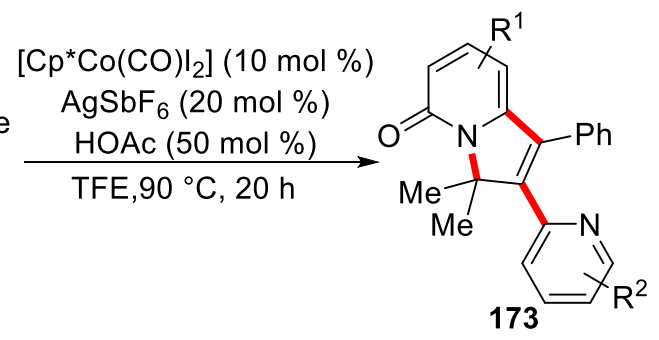<smiles>CC1(C)C(c2ccccn2)=C(c2ccccc2)c2cccc(=O)n21</smiles>

173aa: $81 \%$

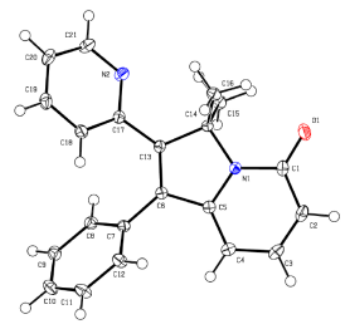

CCDC: 1963220<smiles>CC1(C)C(c2ccccn2)=C(c2ccccc2)c2cc(Br)cc(=O)n21</smiles>

173ba: $67 \%$<smiles>CC1(C)C(c2ccccn2)=C(c2ccccc2)c2cc3ccccc3c(=O)n21</smiles>

173ca: $55 \%$

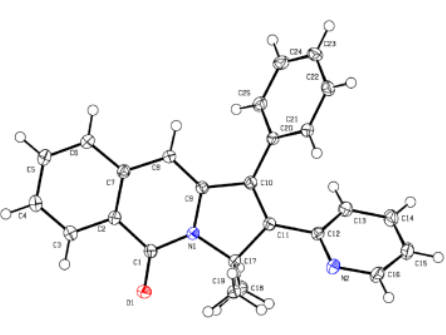

CCDC: 1963222

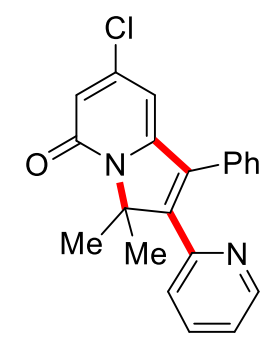

173da: $55 \%$<smiles>CC(=O)c1cc2n(c(=O)c1)C(C)(C)C(c1ccccn1)=C2c1ccccc1</smiles>

173ea: $52 \%$<smiles>CC1(C)C(c2ccccn2)=C(c2ccccc2)c2cc(C(F)(F)F)cc(=O)n21</smiles>

173fa: $52 \%$<smiles>Cc1cc2n(c(=O)c1)C(C)(C)C(c1ccccn1)=C2c1ccccc1</smiles>

173ga: $75 \%$<smiles>CC1(C)C(c2ccc(Cl)cn2)=C(c2ccccc2)c2cccc(=O)n21</smiles>

173ja: $72 \%$

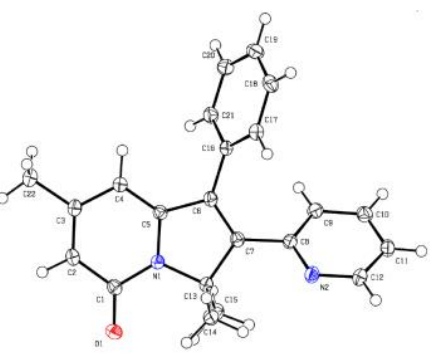

CCDC: 1963221<smiles>CC1(C)C(c2ccc(F)cn2)=C(c2ccccc2)c2cccc(=O)n21</smiles>

173ha: $63 \%$<smiles>Cc1ccc(C2=C(c3ccccc3)c3cccc(=O)n3C2(C)C)nc1</smiles>

173ia: $61 \%$<smiles>CC1(C)C(c2ccc(C(F)(F)F)cn2)=C(c2ccccc2)c2cccc(=O)n21</smiles>

173ka: $60 \%$<smiles>CC1(C)C(c2ccccn2)=C(c2ccccc2)c2c(C(F)(F)F)ccc(=O)n21</smiles>

173la: $64 \%$<smiles>CC(C)OCCNc1ccc2n(c1=O)C(C)(C)C(c1ccccn1)=C2c1ccccc1</smiles>

173ma: $56 \%$ 


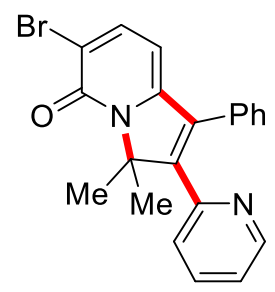

173na: $66 \%$

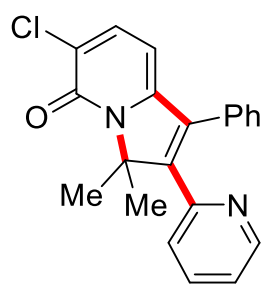

173oa: $70 \%$

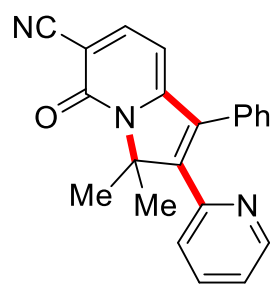

173pa: $75 \%$

Scheme 3.2. Cobalt(III)-catalyzed $\mathrm{C}-\mathrm{H} / \mathrm{N}-\mathrm{O}$ functionalization with substituted pyridones 172.

the desired products 173la in good yield. Finally, a wealth of valuable electrophilic functional groups in C3-position, including sulphonamide, bromo, chloro, and even sensitive cyano were fully tolerated, serving as a handle for future late-stage modifications. The cobalt(III) catalyst was characterized by high levels of chemo- and position-selectivity. The connectivity of the indolizinones 173aa, 173ca, and 173ga was unambiguously confirmed by X-ray crystallographic analysis.

\subsubsection{Cobalt(III)-Catalyzed C-H/N-O Functionalization with Substituted Propargylic}

\section{Carbonates 88}

Furthermore, a comprehensive study as to the scope of the alkyne $\mathbf{8 8}$ was performed (Scheme 3.3). A variety of alkynes $\mathbf{8 8}$ featuring various electron-donating or electronwithdrawing groups, and even heteroarenes, such as thiophene $\mathbf{8 8} \mathbf{g}$, delivered the desired product 173ag with high catalytic efficacy. It is noteworthy that valuable functional groups were fully tolerated by the chemo-selective cobalt catalyst likewise. However, additional sterically substituents adjacent to the oxygen atom of the carbonate group were not well tolerated, with methyl (1-(phenylethynyl)cyclopropyl) carbonate 88I, methyl (1-(phenylethynyl)cyclopentyl) carbonate $\mathbf{8 8 m}$ and methyl (1(phenylethynyl)cyclohexyl) carbonate $\mathbf{8 8 n}$ remaining untouched when submitted to the reaction conditions. This outcome is likely explained by an excessive steric hindrance near the catalyst-coordinating oxygen atom of the alkyne group. Indeed, the reactivity of cobalt(III) is greatly affected by steric factors due to its small ionic radius. ${ }^{[27 d, 52 a]}$ 


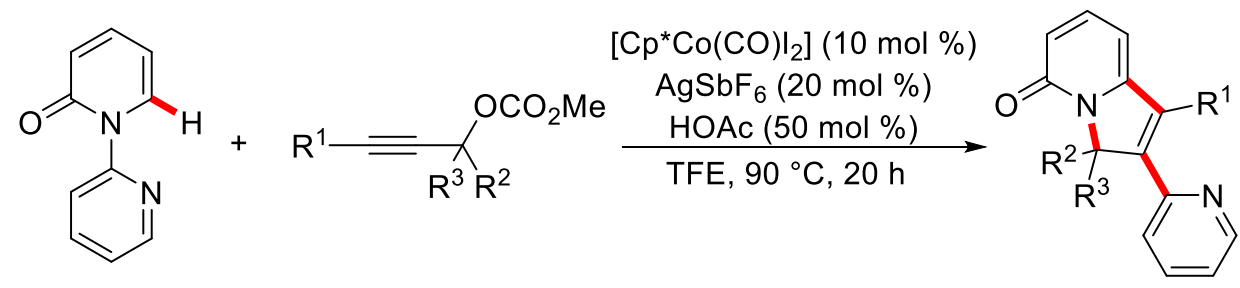

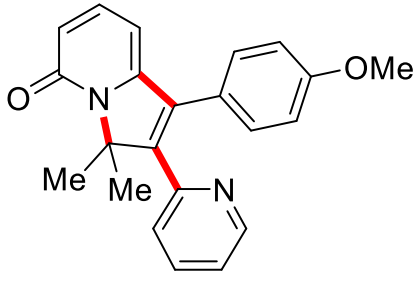

173ac: $67 \%$

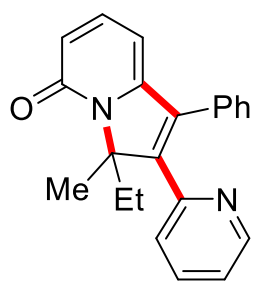

173af: $83 \%$

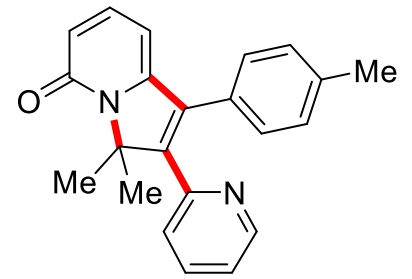

173ai: $61 \%$

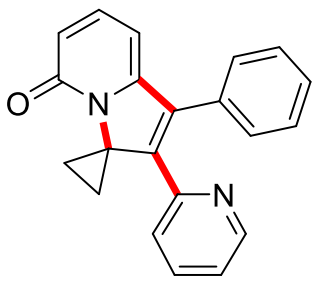

173al: ---

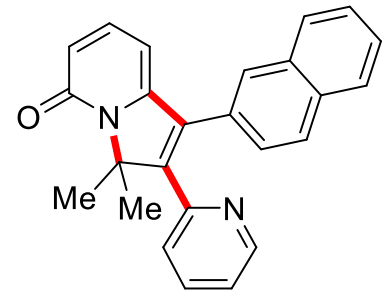

173ad: $58 \%$

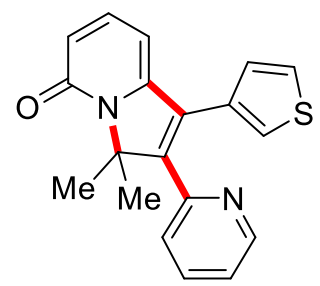

173ag: $62 \%$

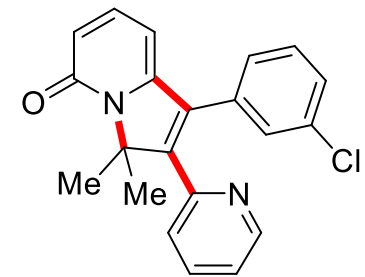

173aj: 55\%

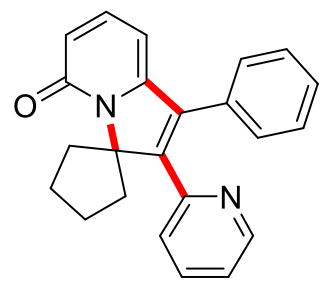

173am: ---

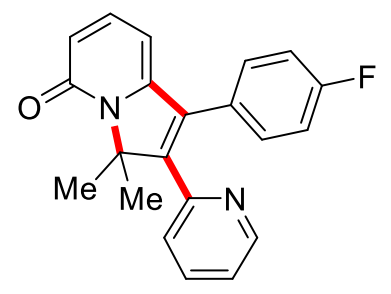

173ae: $84 \%$<smiles></smiles>

173ah: $57 \%$

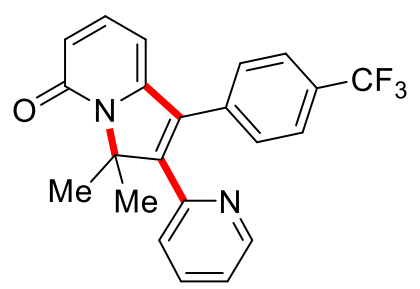

173ak: $55 \%$

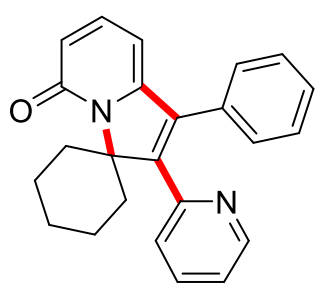

173an: ---

Scheme 3.3. Cobalt(III)-catalyzed $\mathrm{C}-\mathrm{H} / \mathrm{N}-\mathrm{O}$ functionalization with substituted propargylic carbonates $\mathbf{8 8}$. 


\subsubsection{Mechanistic Studies}

\subsubsection{Effect of Leaving and Directing Groups}

The key importance of the leaving and the directing groups for the cobalt-catalyzed C$\mathrm{H}$ activation/pyridine migration Domino annulation transformation is evident through a set of control experiments (Scheme 3.4). The regioselectivity of the alkyne insertion can be controllable by a chelating moiety and the steric hindrance of propargylic compounds $\mathbf{8 8}$. Further experiments showed that the nature of the substrate and the directing group played a crucial role in the transformation. Indoles 35, 2phenylpyridine $\mathbf{2 4}$ as well as 2-pyrrolpyridine 172aa unfortunately delivered no or only traces of the desired products under identical reaction condition. Moreover, the use of the directing groups like pyrimidine 172ab, aryl 172ac and isoquinoline 172ad turned out to be unsuccessful.

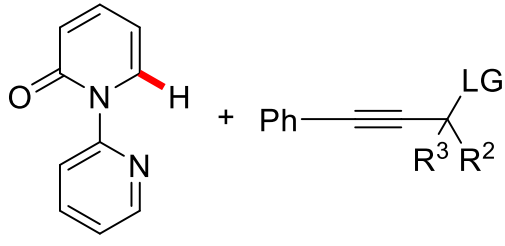

$172 a$
$\left[\mathrm{Cp}{ }^{*} \mathrm{Co}(\mathrm{CO}) \mathrm{I}_{2}\right](10 \mathrm{~mol} \%)$ $\mathrm{AgSbF}_{6}(20 \mathrm{~mol} \%)$ HOAc $(50 \mathrm{~mol} \%)$ TFE, $90^{\circ} \mathrm{C}, 20 \mathrm{~h}$

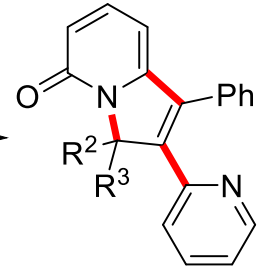

172aa

(3)

Scheme 3.4. Effect of leaving groups and substracts structure. 


\subsubsection{Competition Experiments}

Given the unique selectivity features of the cobalt(III) catalyst, we conducted mechanistic studies to delineate its mode of action. To this end, competition experiments between electron-rich and electron-deficient pyridones $\mathbf{1 7 2} \mathrm{g} / \mathbf{1 7 2} \mathrm{f}$ as well as electron-rich and electron-deficient alkynes $\mathbf{8 8 i} / \mathbf{8 8 k}$ were conducted. For pyridones 172, a competition experiment of 4-methyl pyridones $\mathbf{1 7 2} \mathrm{g}$ with 4trifluoromethyl pyridones $\mathbf{1 7 2 f}$ displayed a clear preference for the more electron-rich pyridones 172 in favor of the 4-methyl substituted arene $\mathbf{1 7 2 g}$ (Scheme 3.5a). This observation is in good agreement with a base-assisted intramolecular electrophilictype substitution (BIES) ${ }^{[20 c, 20 d, 20 f]}$ mechanism by a cationic cobalt catalyst. For the alkynes 88, a similar competition experiment was conducted, showing a clear preference for electron-rich alkyne 88i over trifluoro alkyne 88k (scheme 3.5b).

(a) Competition experiments between pyridiones 172<smiles></smiles>

$172 g / 172 f$<smiles></smiles>

$172 \mathrm{i} / 172 \mathrm{~h}$

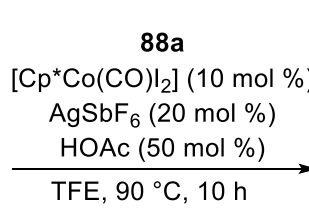

TFE, $90^{\circ} \mathrm{C}, 10 \mathrm{~h}$

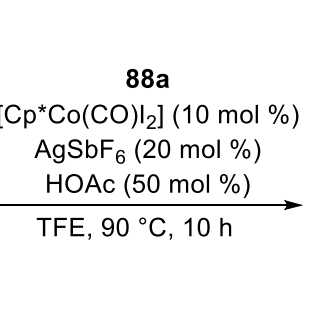

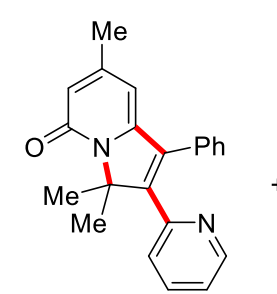

173ga: $26 \%$

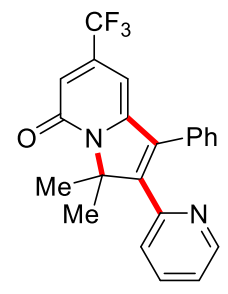

173fa: traces

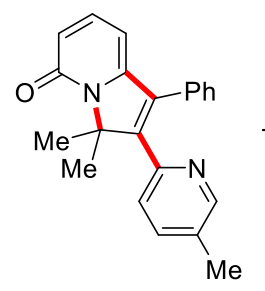

173ia: $37 \%$

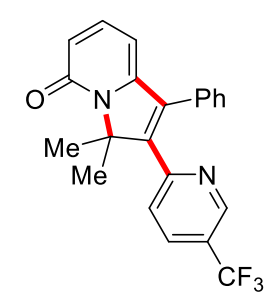

173ha: $12 \%$

(b) Competition experiment between alkynes 88

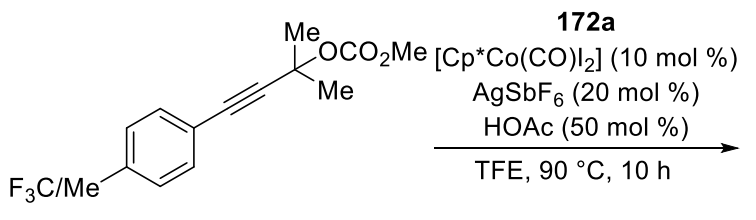

88i/88k

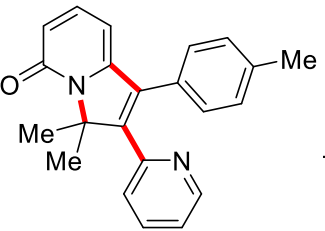

173ai: $30 \%$

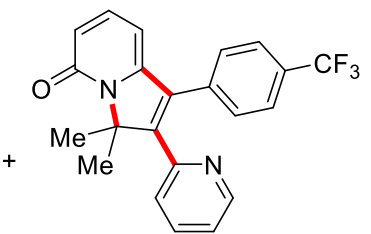

173ak: $10 \%$

Scheme 3.5. Competition experiments. 


\subsubsection{H/D-Exchange Experiments}

Furthermore, deuteration studies using $[D]_{3}$-TFE as the co-solvent showed significant $\mathrm{H} / \mathrm{D}$-corporation in the reisolated starting material. A deuterium incorporation of $90 \%$ in $\mathrm{C} 2$-position suggested a facile and reversible $\mathrm{C}-\mathrm{H}$ activation event, highlighting an organometallic $\mathrm{C}-\mathrm{H}$ activation mechanism (Scheme 3.6).<smiles></smiles>

$172 a$

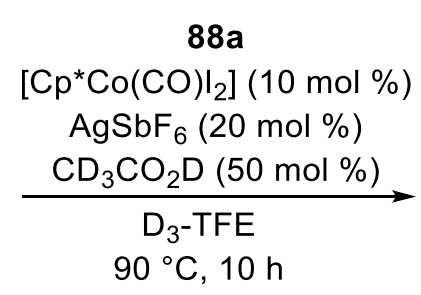

$90^{\circ} \mathrm{C}, 10 \mathrm{~h}$<smiles>O=c1cccc([18OH])n1-c1ccccn1</smiles>

$[D]_{1}-172 a: 10 \%$

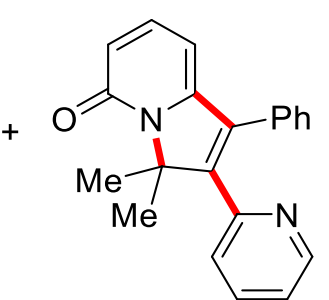

173aa: $73 \%$

Scheme 3.6. H/D exchange experiments.

\subsubsection{Kinetic Isotope Effect}

The kinetic isotope effect (KIE) of the cobalt(III)-catalyzed $\mathrm{C}-\mathrm{H}$ activation was determined by independent experiments of substrates $172 a$ and $[D]_{1}-172 a$, resulting in a minor value of $k_{\mathrm{H}} / k_{\mathrm{D}} \approx 1.3$ (Scheme 3.7). The minor kinetic isotope effect illustrated that the $\mathrm{C}-\mathrm{H}$ cobaltation is not rate-determining step, providing an additional support for the fast $\mathrm{C}-\mathrm{H}$ scission.

$88 a$<smiles>O=c1cccc([18OH])n1-c1ccccn1</smiles>

$172 \mathrm{a}$ or $[D]_{1}-172 \mathrm{a}$

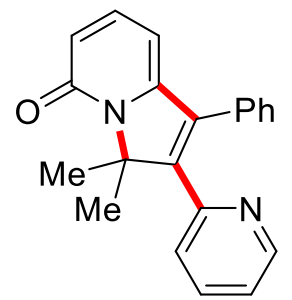

173aa

Scheme 3.7. Kinetic isotope effect experiment.

\subsubsection{Late-Stage Modifications}

The synthetic utility of our regioselective annulation reaction was reflected by the facile late-stage modifications towards the formation of products 138 and 139 
(Scheme 3.8).

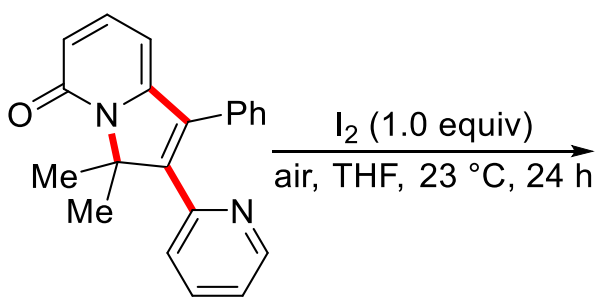

173aa<smiles>CC1(C)C(c2ccccn2)=C(c2ccccc2)c2ccc(Br)c(=O)n21</smiles>

173na

88ah

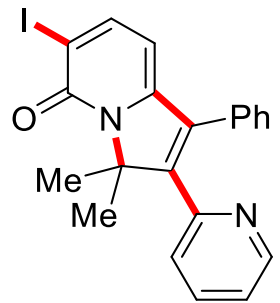

174: $58 \%$

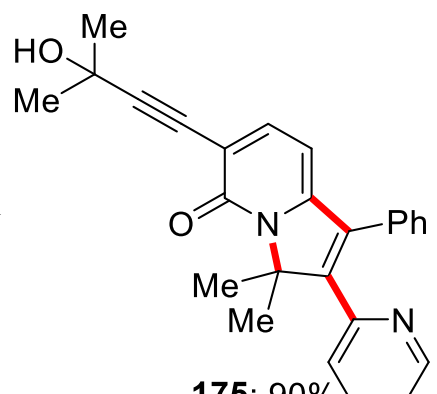

Scheme 3.8. Late-stage modifications.

\subsubsection{Proposed Catalytic Cycle}

Based on our mechanistic studies and precedent literature reports, ${ }^{[78,128]}$ we propose that the cobalt(III)-catalyzed Domino $\mathrm{C}-\mathrm{H}$ activation commences by a reversible $\mathrm{C}-\mathrm{H}$ activation, followed by a migratory alkyne insertion, providing key intermediate $\mathbf{1 7 8}$ (Scheme 3.9). Thereafter, the nucleophilicity of $\mathrm{Co}-\mathrm{C}$ bond could leads to the migration of the pyridine group rather than a $\beta$-oxygen elimination. ${ }^{[54,129]}$ Finally, an intramolecular nucleophilic substitution for the displacement of the carbonate furnishes the final cyclized product 173. 


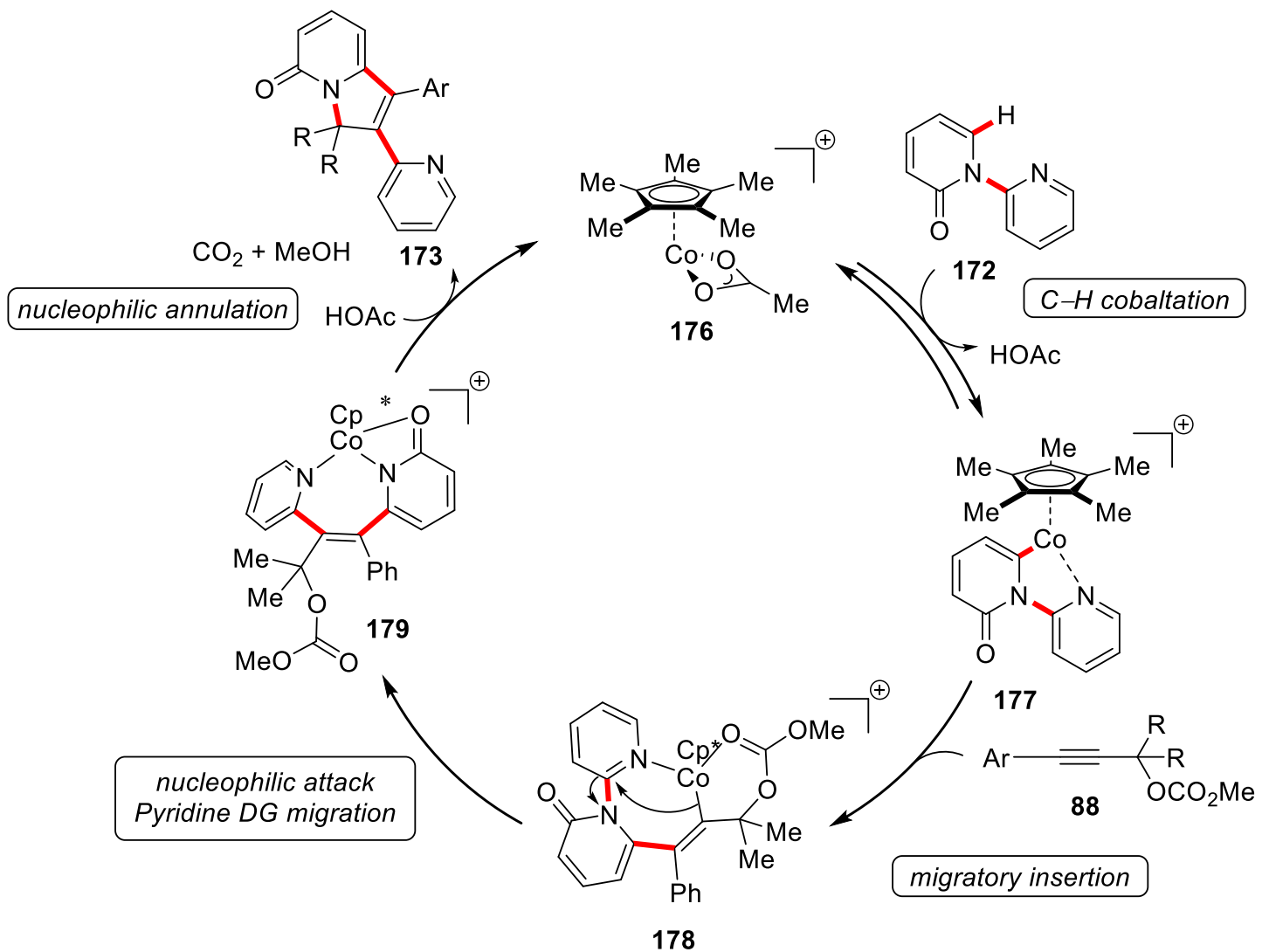

Scheme 3.9. Plausible catalytic cycle for cobalt-catalyzed Domino $\mathrm{C}-\mathrm{H}$ activation.

\subsection{Manganese(I)-Catalyzed C-H Activation/Diels-Alder/retro-Diels-}

\section{Alder Domino Alkyne Annulation}

The use of inexpensive $\mathrm{MnBr}(\mathrm{CO})_{5}$ for $\mathrm{C}-\mathrm{H}$ functionalization reaction has been intensively studied in the last few years. ${ }^{[25,118 b, 124 d]}$ In this regard, not only the costefficiency of these metals is of prime importance, but also a systematic study of their unique reactivity profile is essential for making considerable advances in transition metal-catalysis.

Domino reactions have the potential to simplify reactions by forming several bonds in a one-pot fashion, which allows for the minimization of waste compared to stepwise reactions. ${ }^{[130]}$ Drawing inspiration from the work of our program on sustainable $\mathrm{C}-\mathrm{H}$ activation, $^{[131]}$ a manganese(I)-catalyzed Domino-C-H activation/Diels-Alder/retroDiels-Alder transformations remained unprecedented at the outset of this work. 


\subsubsection{Optimization of Domino C-H Activation/Diels-Alder/retro-Diels-Alder}

The optimization studies for the Domino C-H annulation/Diels-Alder/retro-Diels-Alder reaction were initiated by testing representative bases, additives and solvents with the pyridone 172a with propargylic carbonate $\mathbf{8 8 a}$ (Table 3.2). In order to understand the requirements of the transformation, different bases and additives were tested. Indeed, the desired $\mathrm{C}-\mathrm{H}$ transformation was effective with $\mathrm{NaOAc}$ as the base, and $\mathrm{BPh}_{3}$ as the additive (entries 1-7). Subsequently, several different manganese(I) catalysts were tested for this Domino reaction (entries 8-9), and it turned out that the $\mathrm{MnBr}(\mathrm{CO})_{5}$ as the catalyst of choice (entries 8). In addition, simple dirhenium(0) decacarbonyl and cationic sandwich complex $\left.\left.\left[\mathrm{Cp} * \mathrm{Co}(\mathrm{MeCN})_{3}\right]\left(\mathrm{SbF}_{6}\right)_{2}\right)\right]$ were not competent catalysts for the $\mathrm{C}-\mathrm{H}$ annulation (entries 10 and 11 ). To our delight, the reaction efficacy could be improved by DME as the optimal solvent (entries 12-16). A control experiment revealed that the $\mathrm{C}-\mathrm{H}$ functionalization did not occur without the $\mathrm{MnBr}(\mathrm{CO})_{5}$ catalyst (entry 17). Finally, control experiments under ambient air or catalytic water additive confirmed the sensitivity of this catalytic system (entries 18-19).

Table 3.2. Optimization of Domino $\mathrm{C}-\mathrm{H}$ activation/Diels-Alder/retro-Diels-Alder. ${ }^{\text {[a] }}$<smiles>O=c1ccccn1-c1ccccn1</smiles>

$172 a$

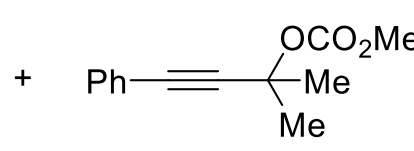

$88 a$

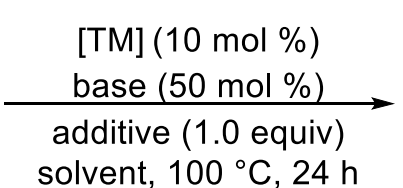
solvent, $100{ }^{\circ} \mathrm{C}, 24 \mathrm{~h}$<smiles>CC1(C)C=CC=c2c1c(-c1ccccc1)c1cccc(=O)n21</smiles>

180 aa

\begin{tabular}{llllll}
\hline Entry & {$[\mathrm{TM}]$} & Base & Additive & Solvent & Yield (\%) \\
\hline 1 & $\mathrm{MnBr}(\mathrm{CO})_{5}$ & $\mathrm{NaOAC}$ & --- & PhMe & 17 \\
2 & $\mathrm{MnBr}(\mathrm{CO})_{5}$ & $\mathrm{Cy}_{2} \mathrm{NH}$ & --- & $\mathrm{PhMe}$ & --- \\
3 & $\mathrm{MnBr}(\mathrm{CO})_{5}$ & $\mathrm{NaOAC}$ & $\mathrm{ZnCl}_{2}$ & $\mathrm{PhMe}$ & --- \\
\hline
\end{tabular}




\begin{tabular}{|c|c|c|c|c|c|}
\hline 4 & $\mathrm{MnBr}(\mathrm{CO})_{5}$ & $\mathrm{NaOAC}$ & $\mathrm{ZnBr}_{2}$ & PhMe & --- \\
\hline 5 & $\mathrm{MnBr}(\mathrm{CO})_{5}$ & $\mathrm{NaOAC}$ & AgOTf & PhMe & --- \\
\hline 6 & $\mathrm{MnBr}(\mathrm{CO})_{5}$ & $\mathrm{NaOAC}$ & $\mathrm{FeCl}_{3}$ & PhMe & --- \\
\hline 7 & $\mathrm{MnBr}(\mathrm{CO})_{5}$ & $\mathrm{NaOAC}$ & $\mathrm{BPh}_{3}$ & PhMe & 35 \\
\hline 8 & $\mathrm{MnBr}(\mathrm{CO})_{5}$ & $\mathrm{NaOAc}$ & $\mathrm{BPh}_{3}$ & PhMe & $60^{[b]}$ \\
\hline 9 & $\mathrm{Mn}_{2}(\mathrm{CO})_{10}$ & $\mathrm{NaOAC}$ & $\mathrm{BPh}_{3}$ & PhMe & --- \\
\hline 10 & $\operatorname{Re}_{2}(\mathrm{CO})_{10}$ & $\mathrm{NaOAc}$ & $\mathrm{BPh}_{3}$ & PhMe & --- \\
\hline 11 & {$\left[\mathrm{Cp} * \mathrm{Co}(\mathrm{MeCN})_{3}\right]\left(\mathrm{SbF}_{6}\right)_{2}$} & $\mathrm{NaOAc}$ & $\mathrm{BPh}_{3}$ & PhMe & --- \\
\hline 12 & $\operatorname{MnBr}(\mathrm{CO})_{5}$ & $\mathrm{NaOAC}$ & $\mathrm{BPh}_{3}$ & $\mathrm{Et}_{2} \mathrm{O}$ & --- \\
\hline 13 & $\mathrm{MnBr}(\mathrm{CO})_{5}$ & $\mathrm{NaOAC}$ & $\mathrm{BPh}_{3}$ & 1,4-dioxane & 28 \\
\hline 14 & $\operatorname{MnBr}(\mathrm{CO})_{5}$ & $\mathrm{NaOAc}$ & $\mathrm{BPh}_{3}$ & $\mathrm{CH}_{2} \mathrm{Cl}_{2}$ & 46 \\
\hline 15 & $\mathrm{MnBr}(\mathrm{CO})_{5}$ & $\mathrm{NaOAC}$ & $\mathrm{BPh}_{3}$ & THF & 50 \\
\hline 16 & $\operatorname{MnBr}(\mathrm{CO})_{5}$ & $\mathrm{NaOAC}$ & $\mathrm{BPh}_{3}$ & DME & 71 \\
\hline 17 & --- & $\mathrm{NaOAC}$ & $\mathrm{BPh}_{3}$ & DME & --- \\
\hline 18 & $\operatorname{MnBr}(\mathrm{CO})_{5}$ & $\mathrm{NaOAc}$ & $\mathrm{BPh}_{3}$ & DME & $---[c]$ \\
\hline 19 & $\mathrm{MnBr}(\mathrm{CO})_{5}$ & $\mathrm{NaOAc}$ & $\mathrm{BPh}_{3}$ & DME & $---[d$ \\
\hline
\end{tabular}

${ }^{[a]}$ Reaction conditions: $172 \mathrm{a}(0.25 \mathrm{mmol}), 88 \mathrm{a}(0.38 \mathrm{mmol})$, [TM] $(10 \mathrm{~mol} \%)$, base (50 $\mathrm{mol} \%)$, additive $(0.25 \mathrm{mmol})$, solvent $(1.0 \mathrm{~mL}), 100{ }^{\circ} \mathrm{C}, 24 \mathrm{~h}$. Yields of isolated products. ${ }^{[b]} \mathrm{MnBr}(\mathrm{CO})_{5}$ (20 mol \%) was used. ${ }^{[c]}$ Under air. ${ }^{[\mathrm{d}]} \mathrm{H}_{2} \mathrm{O}(10 \mathrm{~mol} \%)$ was added.

3.2.2 Scope of Manganese(I)-Catalyzed C-H Activation/Diels-Alder/retro-Diels-Alder Domino Alkyne Annulation

3.2.2.1 Manganese-catalyzed Domino C-H activation/Diels-Alder/retro-Diels-Alder with Pyridones 172

Under the optimized reaction conditions for the manganese(I)-catalyzed $\mathrm{C}-\mathrm{H}$ functionalization / Diels-Alder/retro-Diels-Alder Domino reaction, we explored its versatility with differently-substituted pyridones 172 (Scheme 3.10). Initially, various 
substituents of $C 3, C 4, C 5$ - substituted pyridines $\mathbf{1 7 2 b}, \mathbf{1 7 2 c}, \mathbf{1 7 2 d}, \mathbf{1 7 2 e}, \mathbf{1 7 2 f}$ were tested, without a trend concerning the electronic properties and overall moderate to good yields. Interestingly, the sterically congested naphthalene-derived pyridone $\mathbf{1 7 2} \mathbf{g}$ afforded the corresponding product 180ga with good yield. Notably, different substituents in the $\mathrm{C4}$ and C5-position to the directing group delivered the corresponding product with high yield. In contrast, when sterically shieldly substituents in the C3 and C6-position of pyridine directing group were employed, unfortunately only traces of the desired products were obtained, probably due to steric effects in the Diels-Alder and retro-Diels-Alder reaction. Furthermore, the connectivity of the indolones $180 \mathrm{aa}, 180 \mathrm{da}, 180 \mathrm{ea}$, and $180 \mathrm{ga}$ was unambiguously confirmed by X-ray crystallographic analysis. 


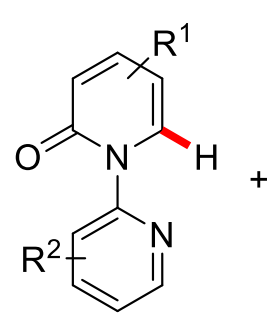

172<smiles>CC1(C)C=CC=c2c1c(-c1ccccc1)c1cccc(=O)n21</smiles>

180aa: $71 \%$<smiles>CC1(C)C=CC=c2c1c(-c1ccccc1)c1cc(Cl)cc(=O)n21</smiles>

180da: $55 \%$<smiles></smiles>

180fa: $75 \%$<smiles>CC1=CC=c2c(c(-c3ccccc3)c3cccc(=O)n23)C1(C)C</smiles>

180ia: $76 \%$

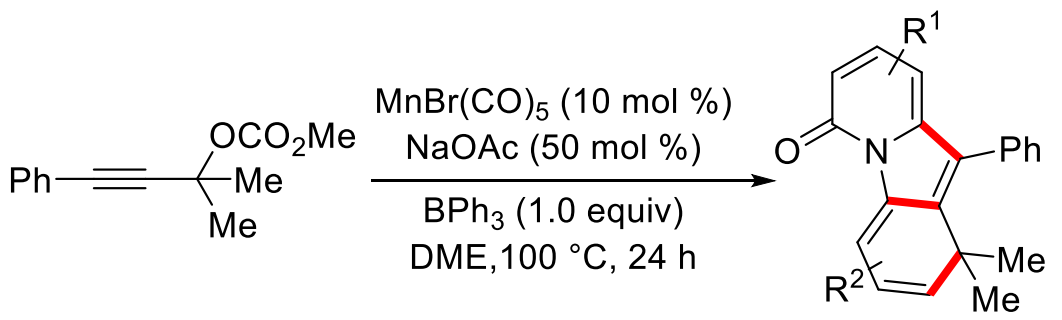

180

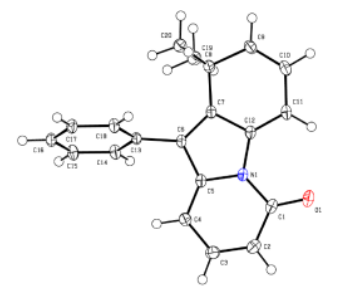

CCDC: 1889479

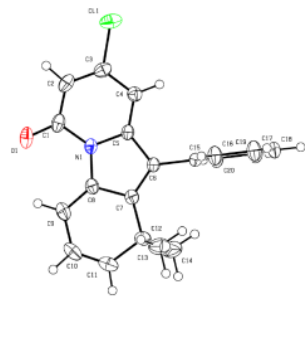

CCDC: 1889474

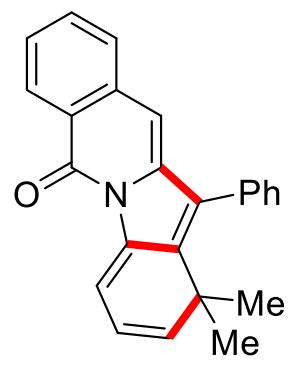

180ga: $61 \%$<smiles>CC1(C)C(C(F)(F)F)=CC=c2c1c(-c1ccccc1)c1cccc(=O)n21</smiles>

180ja: $56 \%$<smiles></smiles>

180ba: $68 \%$

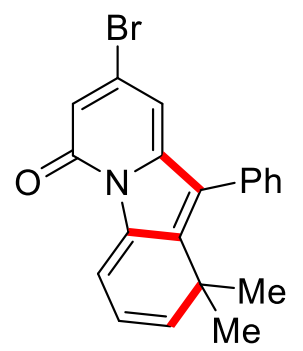

180ea: $64 \%{ }^{[\mathrm{a}]}$

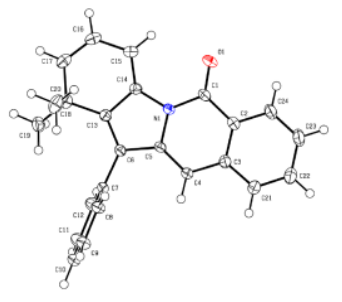

CCDC: 1889477<smiles>CC1=CC(C)(C)c2c(-c3ccccc3)c3cccc(=O)n3c2=C1</smiles>

180ha: $63 \%$

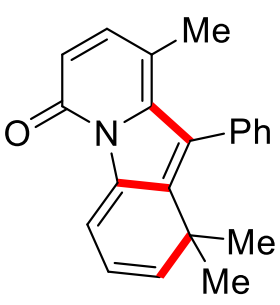

180ca: $53 \%$

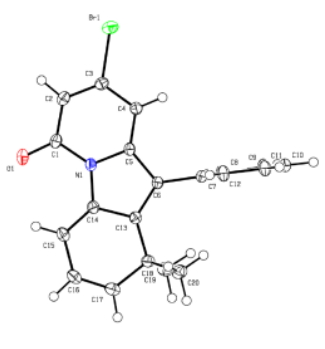

CCDC: 1889472<smiles>CC1(C)C(Cl)=CC=c2c1c(-c1ccccc1)c1cccc(=O)n21</smiles>

180ka: 53\%

Scheme 3.10. Manganese-catalyzed Domino C-H activation/Diels-Alder/retro-DielsAlder reaction with pyridones 172. [a] $\mathrm{MnBr}(\mathrm{CO})_{5}(20 \mathrm{~mol} \%)$. 


\subsubsection{Manganese-catalyzed Domino C-H activation/Diels-Alder/retro-Diels-Alder}

with propargylic carbonates 88

Thereafter, the effect of the substitution pattern of the propargylic carbonates $\mathbf{8 8}$ were studied (Scheme 3.11). First, terminal alkyne 88b and alkyl alkyne 88c were employed, furnishing the desired products 180ac and 180ad in good to excellent yield. Additionally, the functionalization via a five-, six- and even seven-membered cycle with substrate $\mathbf{8 8 f}, \mathbf{8 8 g}$ and $\mathbf{8 8 h}$ turned out to be favourable, delivering excellent yield of the desired products under otherwise identical reaction condition. Remarkably, a cyclohexene substituents of $\mathbf{8 8 \mathbf { i }}$ was tolerated, with a minor drop in the activity, probably due to a competing coordination to manganese catalysis. Furthermore, a variety of alkynes $\mathbf{8 8}$ featuring heteroarenes, such as thiophene $\mathbf{8 8 \mathbf { j }}$ and indole $\mathbf{8 8 \mathbf { k }}$, delivered the desired products 180aj and 180ak with high catalytic efficacy. It is noteworthy that a valuable alkene functional group was fully tolerated by the chemoselective manganese catalyst likewise. 


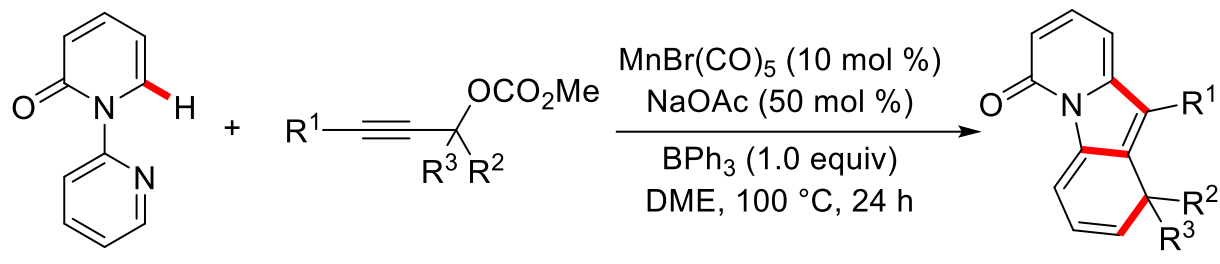

$172 a$

88

180

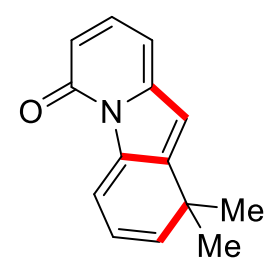

180ab: $60 \%$

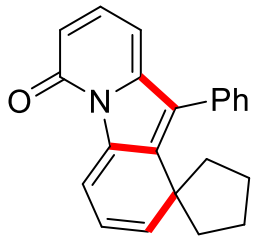

180af: $58 \%$

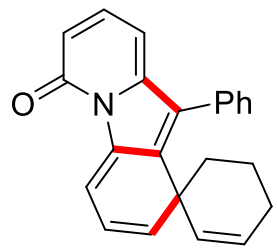

180ai: $50 \%$

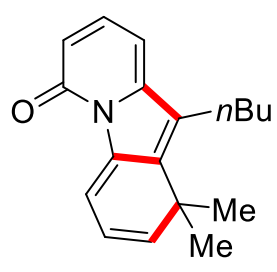

180ac: $70 \%$

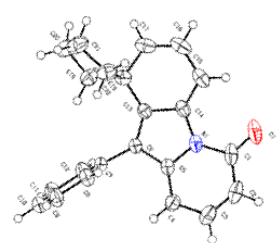

CCDC: 1889473

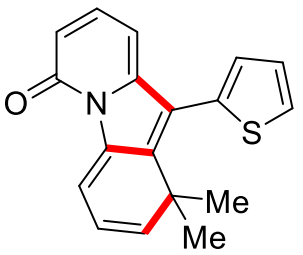

180aj: $61 \%$

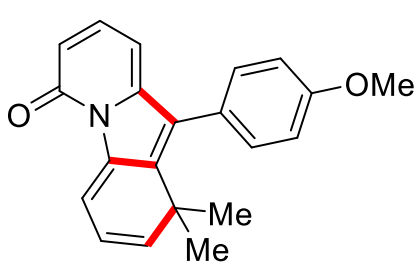

180ad: $72 \%$

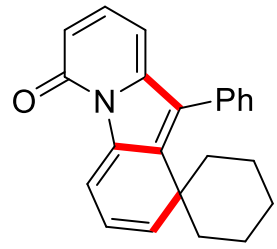

180ag: $65 \%$

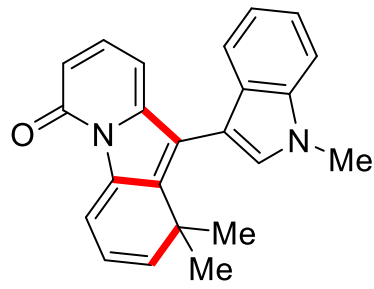

180ak: $60 \%$

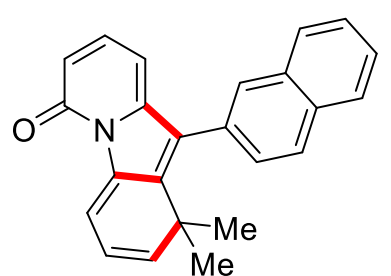

180ae: $74 \%$

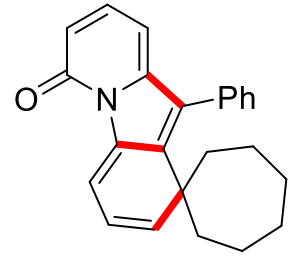

180ah: $62 \%$

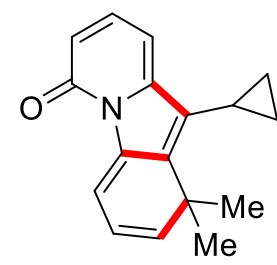

180al: $61 \%$

Scheme 3.11. Manganese-catalyzed Domino C-H activation/Diels-Alder/retro-DielsAlder with propargylic carbonates $\mathbf{8 8}$.

\subsubsection{Mechanistic Studies}

Given the unique selectivity features of the manganese(I) catalyst, we conducted mechanistic studies to delineate its mode of action. Hence, experimental and

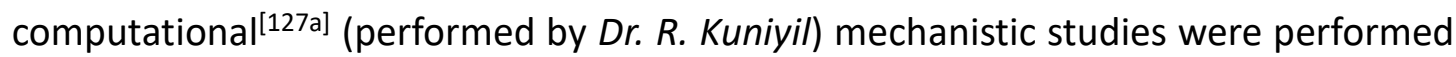
in order to gain insights into the reaction's mechanism.

\subsubsection{H/D-Exchange Experiments}

To rationalize the $\mathrm{C}-\mathrm{H}$ activation mechanism, a catalytic reaction in the presence of deuterated co-solvent $\mathrm{CD}_{3} \mathrm{OD}$ was conducted in the absence of propargylic carbonate 
88a. Starting material 172 a could be reisolated and deuterium incorporation was observed in the C- 6 position with $90 \%$ deuteration. This finding is indicative of a reversible $\mathrm{C}-\mathrm{H}$ metalation. Furthermore, a catalytic reaction in the presence of deuterated co-solvent $\mathrm{CD}_{3} \mathrm{OD}$ was carried out under otherwise unchanged reaction conditions. In the starting material 172a and the product 180aa significant amounts of H/D-exchange in the C6- and C3-positions of the pyridone were detected. The H/Dscrambling in the C3-position of the product can be explained by a reversible electrophilic activation (Scheme 3.12).<smiles>O=c1ccccn1-c1ccccn1</smiles>

$172 a$

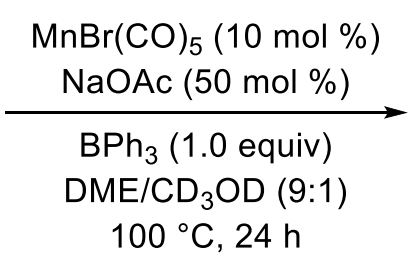

$100^{\circ} \mathrm{C}, 24 \mathrm{~h}$<smiles>O=c1cccc(-c2ccccc2)n1-c1ccccn1</smiles>

$[\mathrm{D}]_{n}-172 \mathrm{a}: 94 \%$<smiles>O=c1cccc2ccccn12</smiles>

$172 a$

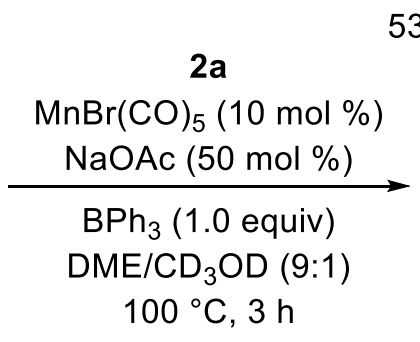

$100{ }^{\circ} \mathrm{C}, 3 \mathrm{~h}$

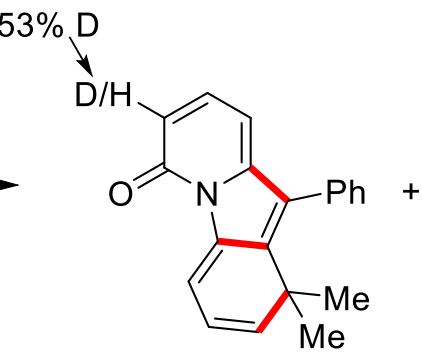

$[D]_{n}-180$ aa: $20 \%$<smiles></smiles>

$[D]_{n}-172 a: 78 \%$

Scheme 3.12. H/D exchange experiments.

\subsubsection{Kinetic Isotope Effect}

To gain a deeper mechanistic understanding of the $\mathrm{C}-\mathrm{H}$ activation elementary step, a KIE-experiment by comparison of independent reaction rates of 2-pyridylpyridone (172a) and [D] $]_{1}-172 a$ was performed. In this reaction, a KIE of $k_{H} / k_{D} \approx 1.2$ was obtained (Scheme 3.13), indicating that the $\mathrm{C}-\mathrm{H}$ manganesation is not the rate-determining step of this reaction. 

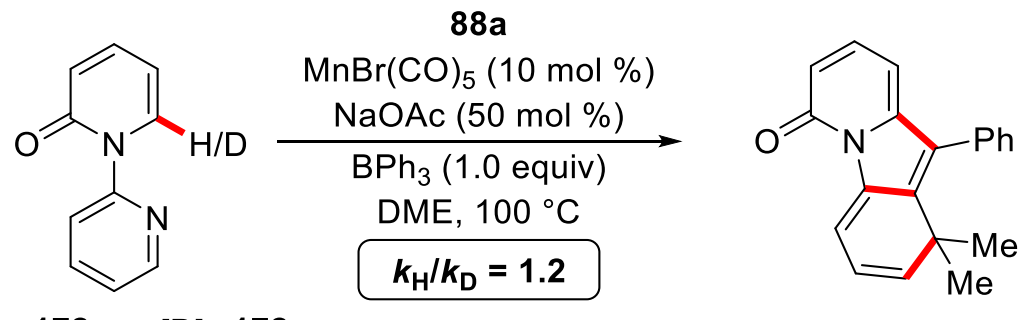

$172 \mathrm{a}$ or $[\mathrm{D}]_{1}-172 \mathrm{a}$

180 aa

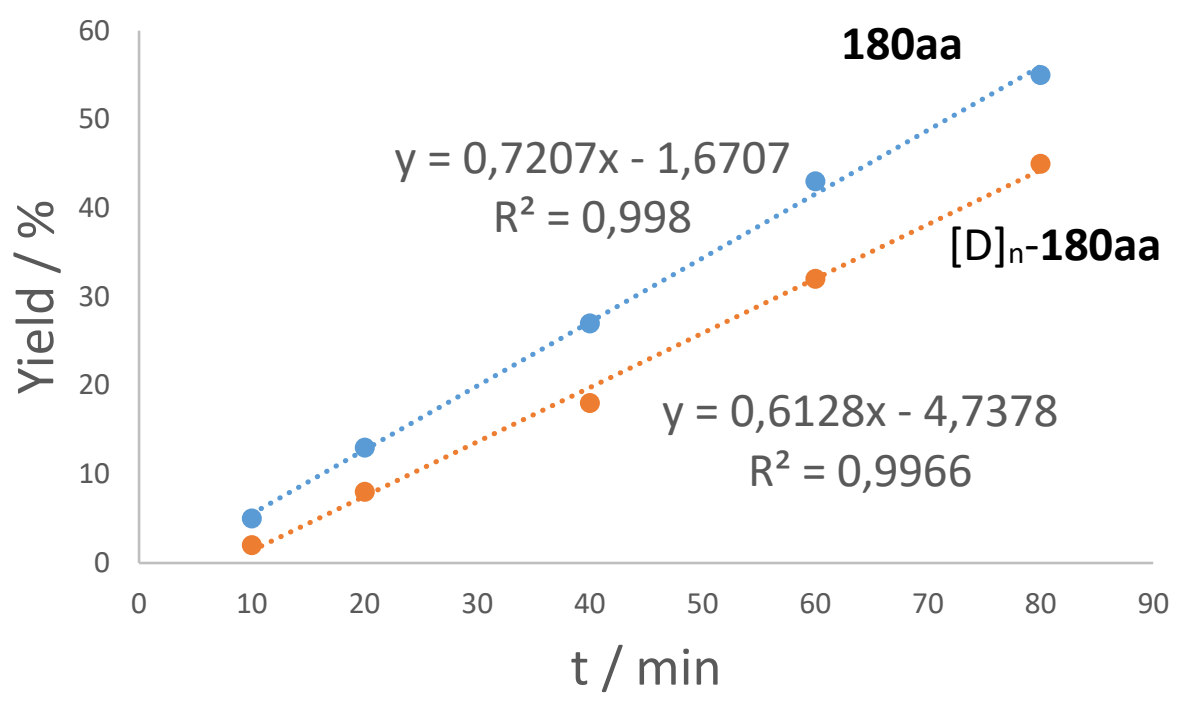

Scheme 3.13. Kinetic isotope effect experiment.

\subsubsection{Late-stage modifications}

To highlight the synthetic potential of the devised manganese-catalyzed $\mathrm{C}-\mathrm{H}$ annulation, several modifications of the isolated products 180 were performed. The generated alkyl indolones $\mathbf{1 8 1}$ were generated via hydrogenation by a palladium on chacoal catalytic system. (Scheme 3.14).
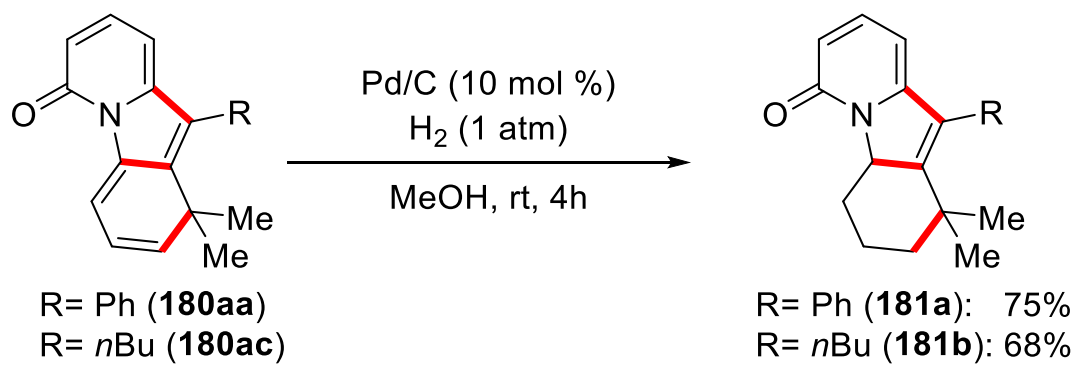

Scheme 3.14. late-stage modifications. 


\subsubsection{Domino C-H activation/Diels-Alder/retro-Diels-Alder with Cyclometalated}

\section{Complex}

Subsequently, we further investigate the mechanism of the manganese(I)-catalyzed C$\mathrm{H}$ annulation. The novel five-membered manganacycle 146, which is proposed to be an intermediate in the catalytic cycle, was synthesized according to a modified literature procedure ${ }^{[129]}$ (Scheme 3.15a). Furthermore, it was studied whether the desired product 180 aa could be obtained by the reaction of the pyridone $172 \mathrm{a}$ with propargylic carbonate 88a. Notably, the well-defined complex $\mathbf{1 8 2}$ was found to be competent both in catalytic as well as stoichiometric $\mathrm{C}-\mathrm{H}$ activations (Scheme 3.15b and c), thus providing support for organomanganese 182 being a key intermediate in the $\mathrm{C}-\mathrm{H}$ activation manifold.

(a) synthesis of complex 182<smiles></smiles>

$172 a$

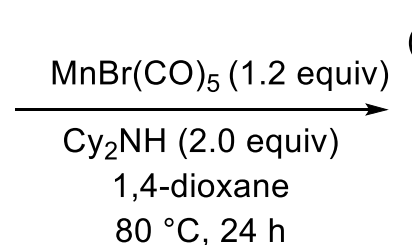

$80^{\circ} \mathrm{C}, 24 \mathrm{~h}$<smiles>CC(C)[n+]1nc2cccc(=O)n2c2ccccc21</smiles>

182: $76 \%$

(b) complex 182 as catalyst<smiles>O=c1cccc2ccccn12</smiles>

$172 a$

$$
\begin{aligned}
& 182(10 \mathrm{~mol} \%) \\
& \underset{\mathrm{NaOAc}(50 \mathrm{~mol} \%)}{\longrightarrow} \\
& \text { DME, } 100^{\circ} \mathrm{C}, 24 \mathrm{~h}
\end{aligned}
$$

(c) stoichiometric transformation

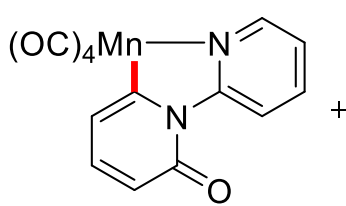

182

$$
\text { 88a } \underset{\mathrm{NaOAc}(50 \mathrm{~mol} \%)}{\stackrel{\mathrm{NPh}}{\mathrm{N}(1.0 \text { equiv })}}
$$

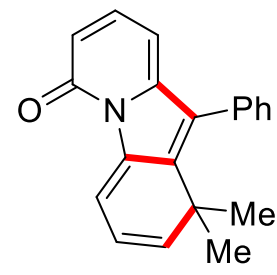

180aa: $65 \%$

Scheme 3.15. Domino $\mathrm{C}-\mathrm{H}$ activation/Diels-Alder/retro-Diels-Alder with cyclometalated complex. 


\subsubsection{Domino C-H activation/Diels-Alder/retro-Diels-Alder with allene}

In addition, the importance of the allene intermediate for subsequent Diels-Alder as well as a retro-Diels-Alder step after the $\mathrm{C}-\mathrm{H}$ activation was studied (scheme 3.16). To substantiate the plausibility of an allene intermediate, the C4-substituted pyridone $172 \mathrm{e}$ and $88 \mathrm{a}$ was performed by the same reaction for a shortened reaction time. The allene intermediate $\mathbf{1 8 3}$ was isolated in $20 \%$ yield. Afterwards, it was studied whether the desired product 180aa can be provided by the reaction of the key allene intermediate 183 without manganese catalysis. The reaction proved viable in $64 \%$ yield with the same chemoselectivity as for the catalytic transformation. This observation indicates that the allene 183 , which proved to be a key intermediate of the catalytic reaction.<smiles></smiles>

$172 \mathrm{e}$<smiles>CC(C)=C=C(c1ccccc1)c1cc(Br)cc(=O)n1-c1ccccn1</smiles>

183

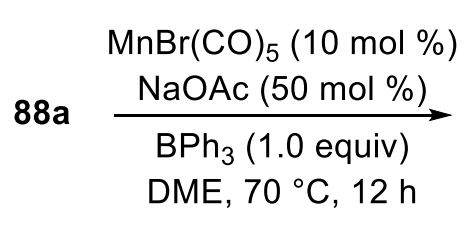

DME, $70{ }^{\circ} \mathrm{C}, 12 \mathrm{~h}$<smiles>CC(C)=C=C(c1ccccn1)c1cc(Br)cc(=O)n1-c1ccccc1</smiles>

183: $20 \%$<smiles>CC1(C)C=CC=c2c1c(-c1ccccc1)c1cc(Br)cc(=O)n21</smiles>

180ea: $64 \%$

Scheme 3.16. Domino C-H activation/Diels-Alder/retro-Diels-Alder with allene.

\subsubsection{Proposed Catalytic Cycle}

The manganese(I)-catalyzed $\mathrm{C}-\mathrm{H}$ activation/Diels-Alder/retro-Diels-Alder Domino alkyne annulation of pyridones $\mathbf{1 7 2}$ most likely proceeds via a reversible and facile BIES-type $\mathrm{C}-\mathrm{H}$ activation, which is supported by the results obtained from the H/Dexchange experiments (Scheme 3.12) and the KIE study (Scheme 3.13). Based on our 
mechanistic studies and literature precedents, we propose a plausible catalytic cycle to be initiated by an acetate-assisted organometallic $\mathrm{C}-\mathrm{H}$ activation through chelation assistance (Scheme 3.17). Thereafter, alkyne insertion occurs to deliver the intermediate 185 , which subsequently undergoes $\beta$-oxygen elimination, ${ }^{[129]}$ thus forming the allene intermediate 186. Finally, a $\mathrm{BPh}_{3}$-mediated [4+2] Diels-Alder reaction, followed by base-induced elimination of $\mathrm{HCN}$ through retro-Diels-Alder reaction, provides the desired product 180aa.

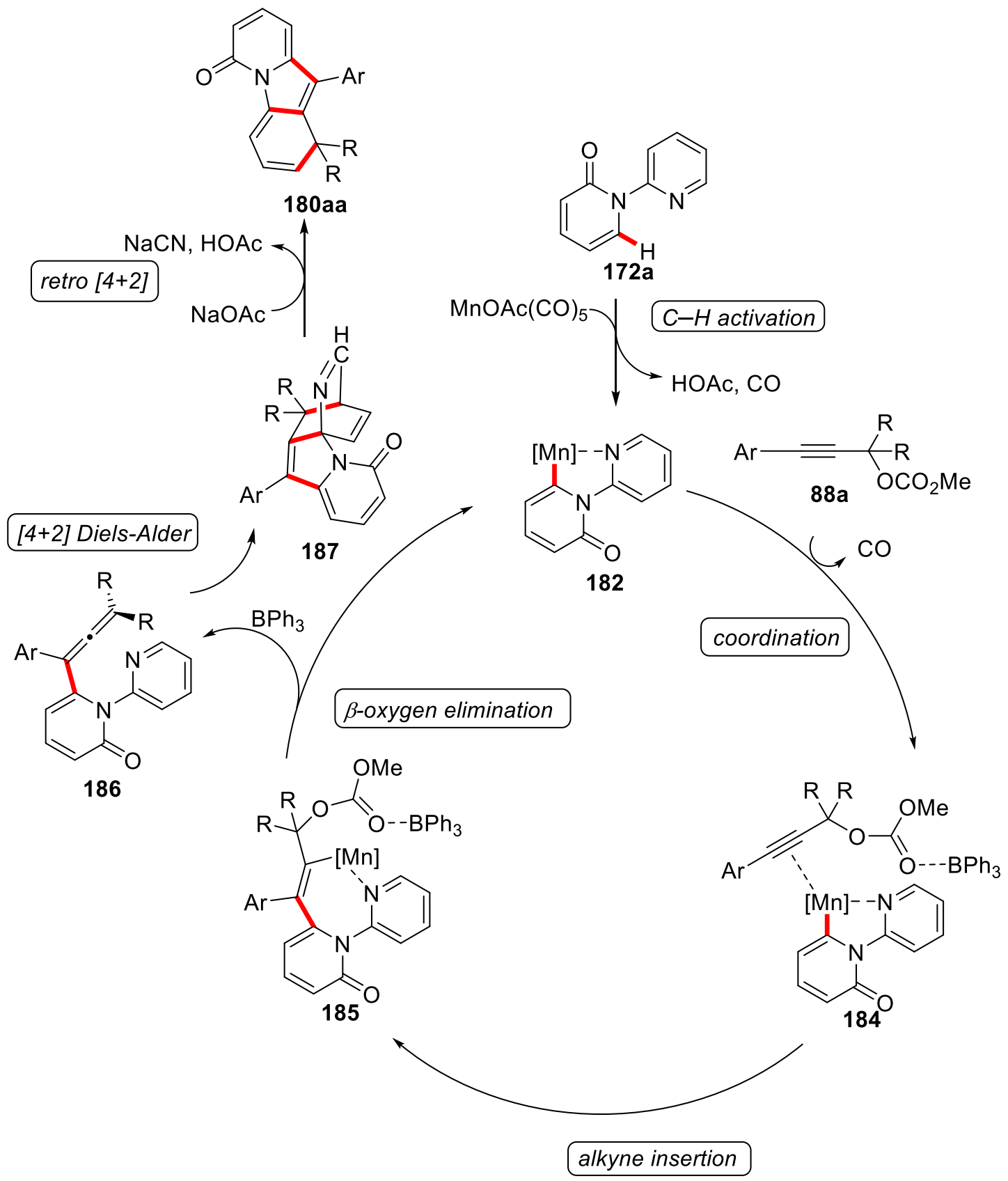

Scheme 3.17. Plausible catalytic cycle for Domino $\mathrm{C}-\mathrm{H}$ activation 


\subsection{Manganese(II/III/I)-Catalyzed C-H Arylations in Continuous Flow}

$\mathrm{C}-\mathrm{H}$ activation has emerged as a transformative platform in molecular synthesis. ${ }^{[117 c,}$ 132] Particularly, arene $\mathrm{C}-\mathrm{H}$ arylations have been identified as powerful alternatives to traditional cross-couplings, avoiding the use and multi-step preparation of prefunctionalized arenes. ${ }^{[123]}$ Despite the significant progress in arene $\mathrm{C}-\mathrm{H}$ arylations in recent years, most methodologies either required harsh reaction conditions or were restricted to precious, toxic noble transition metal catalysts. ${ }^{[123]}$ Recently, the focus has shifted towards the use of more sustainable $3 d$ transition metals. ${ }^{[29,106 a, 118 e, 133]}$ Thereby, the development of the first manganese-catalyzed arene $\mathrm{C}-\mathrm{H}$ arylations use of continuous flow technology ${ }^{[134]}$ on the privileged pyridine motif represented a promising objective.

\subsubsection{Optimization of $\mathrm{C}-\mathrm{H}$ Arylation in Continuous Flow}

The optimization studies were commenced by exploring several reaction conditions for the desired manganese-catalyzed $\mathrm{C}-\mathrm{H}$ arylation in continuous flow (Table 3.3). A preliminary oxidant optimization identified DCIB as the optimal oxidant (entries 1, 2 and 6). Both flow rate and pressure had a minor effect on the overall efficacy (entries 1-5). Control experiments highlighted the essential role of TMEDA and the neocuproine ligand (entries 8-13). Lower reaction temperatures were detrimental to the reaction outcome (entries 14-15). Finally, the unique performance of the manganese catalysis regime was reflected by iron, copper, nickel, ruthenium, and even palladium catalysts falling short in delivering the desired product 188aa (entries 1620). 
Table 3.3. Optimization of $\mathrm{C}-\mathrm{H}$ arylation in continuous flow. ${ }^{[\mathrm{a}]}$
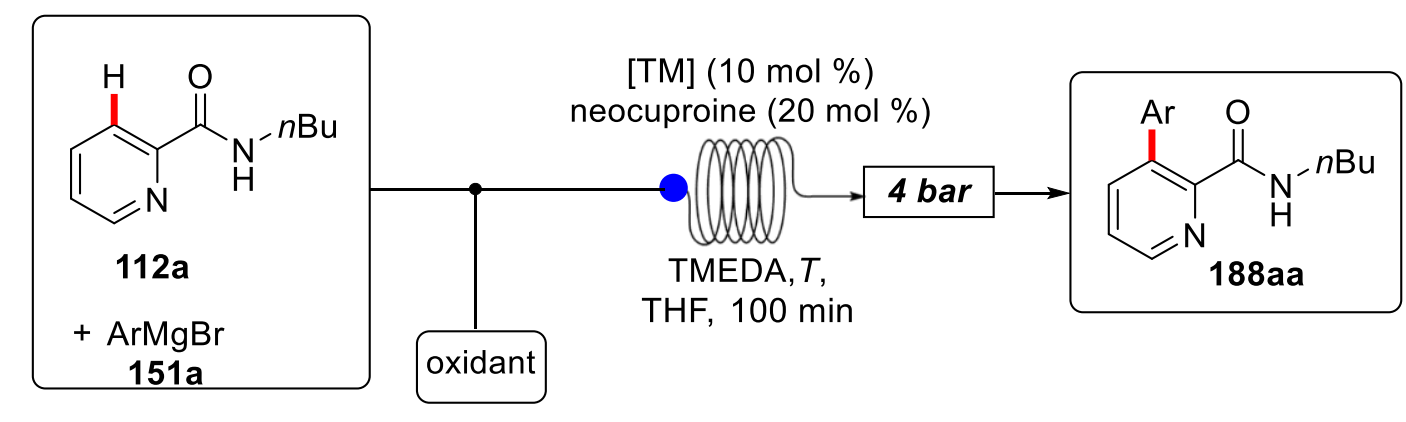

\begin{tabular}{|c|c|c|c|c|c|}
\hline Entry & [TM] & Oxidant & Rate / ( $\mu \mathrm{L} / \mathrm{min})$ & $T /{ }^{\circ} \mathrm{C}$ & yield (\%) \\
\hline 1 & $\mathrm{MnCl}_{2}$ & $\mathrm{DClB}$ & 200 & 80 & 53 \\
\hline 2 & $\mathrm{MnCl}_{2}$ & $\mathrm{DCB}$ & 100 & 80 & 61 \\
\hline 3 & $\mathrm{MnCl}_{2}$ & $\mathrm{DCB}$ & 100 & 80 & $70^{[b]}$ \\
\hline 4 & $\mathrm{MnCl}_{2}$ & DCIB & 100 & 80 & 74 \\
\hline 5 & $\mathrm{MnCl}_{2}$ & $\mathrm{DCIB}$ & 100 & 80 & $72^{[c]}$ \\
\hline 6 & $\mathrm{MnCl}_{2}$ & --- & 100 & 80 & $<5$ \\
\hline 7 & --- & $\mathrm{DCIB}$ & 100 & 80 & 13 \\
\hline 8 & $\mathrm{MnCl}_{2}$ & $\mathrm{DCIB}$ & 100 & 80 & $59^{[d]}$ \\
\hline 9 & $\mathrm{MnCl}_{2}$ & $\mathrm{DCIB}$ & 100 & 80 & $65^{[\mathrm{e}]}$ \\
\hline 10 & $\mathrm{MnCl}_{2}$ & $\mathrm{DCIB}$ & 100 & 80 & $59^{[f]}$ \\
\hline 11 & $\mathrm{MnCl}_{2}$ & $\mathrm{DCIB}$ & 100 & 80 & $44^{[\mathrm{g}]}$ \\
\hline 12 & $\mathrm{MnCl}_{2}$ & $\mathrm{DClB}$ & 100 & 80 & $43^{[\mathrm{h}]}$ \\
\hline 13 & $\mathrm{MnCl}_{2}$ & $\mathrm{DCIB}$ & 100 & 80 & $62^{[\mathrm{i}]}$ \\
\hline 14 & $\mathrm{MnCl}_{2}$ & $\mathrm{DCIB}$ & 100 & 60 & 18 \\
\hline 15 & $\mathrm{MnCl}_{2}$ & $\mathrm{DClB}$ & 100 & 100 & 72 \\
\hline 16 & $\mathrm{Fe}(\mathrm{acac})_{3}$ & $\mathrm{DClB}$ & 100 & 80 & --- \\
\hline 17 & $\mathrm{Cu}(\mathrm{OAc})_{2}$ & $\mathrm{DClB}$ & 100 & 80 & --- \\
\hline 18 & $(\mathrm{DME}) \mathrm{NiCl}_{2}$ & $\mathrm{DCIB}$ & 100 & 80 & --- \\
\hline 19 & $\mathrm{RuCl}_{3} \cdot \mathrm{nH}_{2} \mathrm{O}$ & $\mathrm{DClB}$ & 100 & 80 & --- \\
\hline 20 & $\mathrm{PdCl}_{2}$ & $\mathrm{DClB}$ & 100 & 80 & --- \\
\hline
\end{tabular}


[a] Reaction conditions: 112a (0.25 mmol), 151a (1.00 mmol), [TM] (10 mol \%), neocuproine (20 mol \%), TMEDA (0.50 mmol), oxidant $(0.75 \mathrm{mmol})$, THF (0.5 M). Yield of isolated products. ${ }^{[b]} 2$ bar back pressure. ${ }^{[c]} 6$ bar back pressure. ${ }^{[d]}$ Without neocuproine. ${ }^{[\mathrm{e}]}$ Neocuproine (10 mol \%). ${ }^{[\mathrm{f}]}$ Neocuproine (40 mol \%). ${ }^{[\mathrm{g}]}$ Without TMEDA. ${ }^{[\mathrm{h}]} 2,2^{\prime}$-dipyridyl (20 mol \%) as the ligand. ${ }^{[i]}$ 1,10-phenanthroline (20 mol \%) as the ligand.

\subsubsection{Scope of Manganese-Catalyzed C-H Arylation}

\subsubsection{Scope of Manganese-Catalyzed C-H Arylation in Flow}

With the optimized manganese-catalyzed $\mathrm{C}-\mathrm{H}$ arylation identified, the robustness in the modification of diversely decorated amides $\mathbf{1 1 2}$ in continuous flow was probed (Scheme 3.18). Thus, a variety of pyridines 112 were smoothly converted by weak amide-chelation assistance. The manganese-catalyzed $\mathrm{C}-\mathrm{H}$ arylation occurred without racemization of chiral amide $\mathbf{1 1 2} \mathbf{j}$ and proved tolerant of inter alia reactive conjugated styrene 112i. To our delight, the low-valent manganese catalysis regime was not limited to the 2-pyridyl pattern but proved amenable to the direct diversification of structural isomers $\mathbf{1 1 2 l}-\mathbf{0}$ as well as diazine $\mathbf{1 1 2 p}$ likewise. The flow manganesecatalyzed $\mathrm{C}-\mathrm{H}$ arylation was conveniently performed in only 100 minutes, avoiding special high-pressure equipment. This feature on an exothermic $\mathrm{C}-\mathrm{H}$ functionalization illustrates the beneficial asset of improved mass transfer and heat dissipation in flow conditions to prevent runaway reactions. 


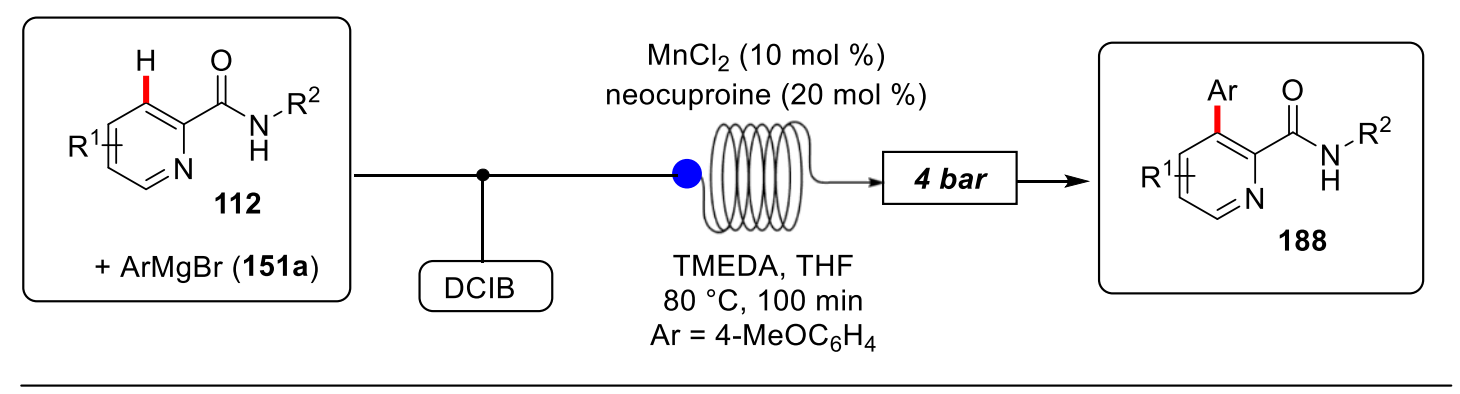<smiles>[R]NC(=O)c1ncccc1Br</smiles>

$\mathrm{R}^{2}=n \mathrm{Bu}$ (188aa): $74 \%$

$\mathrm{R}^{2}=\mathrm{Bn}(\mathbf{1 8 8 \mathrm { ba }}): \quad 65 \%$

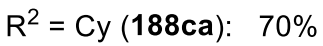<smiles>O=C(NC1CCCc2ccccc21)c1ncccc1Br</smiles>

188ga: $79 \%$<smiles>O=C(NC(c1ccccc1)c1ccccc1)c1ncccc1Br</smiles>

188ja: $68 \%$

(99\% ee)<smiles>CCCCNC(=O)c1cncc(C)c1Br</smiles>

188ma: $71 \%$<smiles>[R]c1ccc(CNC(=O)c2ncccc2Br)cc1</smiles>

$\mathrm{R}^{3}=$ OMe (188da): $61 \%$ $\mathrm{R}^{3}=\mathrm{F}$ (188ea): $\quad 75 \%$<smiles>O=C(NCCc1ccccc1)c1ncccc1Br</smiles>

188ha: $74 \%$<smiles>CCCCNC(=O)c1ncc(-c2ccccc2)cc1Br</smiles>

188ka: $54 \%$<smiles>[R]NC(=O)c1ccncc1Br</smiles>

$\mathrm{R}^{2}=n \mathrm{Bu}$ (188na): $50 \%$ $\mathrm{R}^{2}=\mathrm{Bn}(188 \mathrm{oa}): 52 \%$<smiles>O=C(NCc1ccccc1F)c1ncccc1Br</smiles>

188fa: $66 \%$<smiles>CCCCNC(=O)c1ncc(/C=C/c2ccccc2)cc1[Al]</smiles>

188ia: $60 \%$<smiles>CCCCCNC(=O)c1cnccc1Br</smiles>

188Ia: $77 \%$

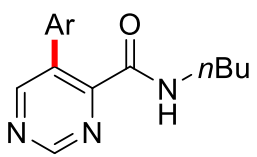

188pa: $53 \%$

Scheme 3.18. Scope of manganese-catalyzed $\mathrm{C}-\mathrm{H}$ arylation with amides $\mathbf{1 1 2}$ in flow.

Thereafter, we tested the versatility of the manganese catalysis manifold with respect to the arylating component (Scheme 3.19). Thus, different substitution patterns as well as valuable functional groups on the aryl magnesium bromide $\mathbf{1 5 1}$ were extensively tested. Furthermore, a variation of substituents in the para-position of the aryl magnesium bromide 151 led to overall good to excellent yields. 


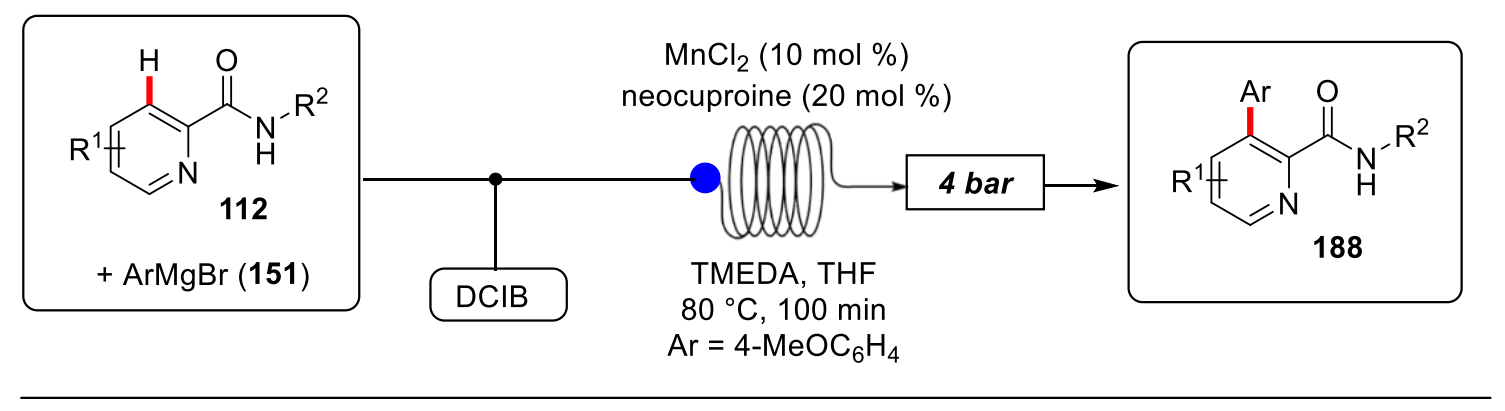

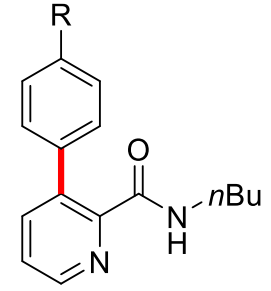

$\mathrm{R}=\mathrm{OMe}$ (188aa): $74 \%$

$R=H(188 a b): 80 \%$

$\mathrm{R}=\mathrm{Me}$ (188ac): $76 \%$

$\mathrm{R}=t-\mathrm{Bu}$ (188ad): $73 \%$

$\mathrm{R}=\mathrm{Ph}$ (188ae): $50 \%$

$R=F$ (188af): $65 \%$

$\mathrm{R}=\mathrm{NMe}_{2}$ (188ag): $55 \%$<smiles>[R]c1cccc(-c2cccnc2C(=O)NCCCC)c1</smiles><smiles>CCCCNC(=O)c1ncccc1-c1ccc2ccccc2c1</smiles>

$\mathrm{R}=$ OMe (188ah): $67 \%$ $R=F(188 a i): \quad 60 \%$<smiles>CCCCNC(=O)c1ncccc1-c1ccsc1</smiles>

188ak: $51 \%$ 188aj: $59 \%$<smiles>Cc1cc(C)c(C(=O)NC(C)c2ccccc2)c(C(C)C)c1</smiles>

188jl: $54 \%^{[a]}$<smiles>CCCCNC(=O)c1ncccc1-c1ccc(OC)cc1</smiles>

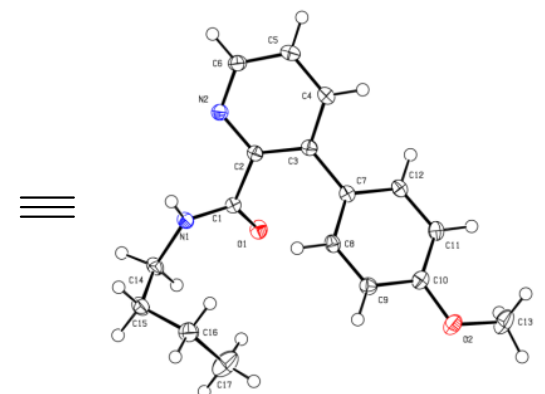

Scheme 3.19. Scope of manganese-catalyzed $\mathrm{C}-\mathrm{H}$ arylation in flow. ${ }^{[a]} \mathbf{1 1 2} \mathbf{j}(0.25$ mmol), MesMgBr (1.00 mmol), $\mathrm{MnCl}_{2}$ (20 mol \%), TMEDA (0.50 mmol), $n \mathrm{BuBr}(0.75$ $\mathrm{mmol})$, THF (1.0 M).

Furthermore, substituents in the meta-position were well tolerated and afforded the desired arylated products 188ah, 188ai. Thereby, the heteroaromatic thiophene was introduced. Finally, the sterically congested mesityl group did not influence the reactivity, delivering a tri-ortho-substituted biheteroaryl $\mathbf{1 8 8} \mathbf{j l}$ in good yield. The 
connectivity of the thus obtained products $\mathbf{1 8 8}$ was unambiguously established by Xray diffraction analysis.

\subsubsection{Scope of Manganese-Catalyzed C-H Arylation in Batch}

The manganese-catalyzed $\mathrm{C}-\mathrm{H}$ arylation regime was not limited to continuous flow technology, but could also be conducted in batch, thereby delivering the desired products 188, albeit with longer reaction times (Scheme 3.20).<smiles>[R]NC(=O)c1ncc[R1]c1[Y17]</smiles>

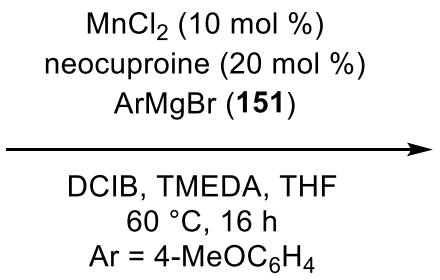<smiles>[R]NC(=O)c1ncc[R1]c1[13CH3]</smiles><smiles>[R]NC(=O)c1ncccc1Br</smiles>

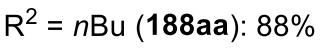
$\mathrm{R}^{2}=\mathrm{Bn}(\mathbf{1 8 8 \mathrm { ba }}): 70 \%$ $\mathrm{R}^{2}=\mathrm{Cy}$ (188ca): $74 \%$<smiles>O=C(NC1CCCc2ccccc21)c1ncccc1Br</smiles>
188ga: $86 \%$<smiles>CC(NC(=O)c1ncccc1Br)c1ccccc1</smiles>

188ja: $72 \%$ (99\% ee)

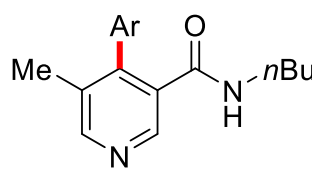

188ma: $80 \%$<smiles>[R1]c1ccc(CNC(=O)c2ncccc2Br)cc1</smiles>

$\mathrm{R}^{3}=$ OMe (188da): $64 \%$ $R^{3}=F($ 188ea): $\quad 82 \%$<smiles>O=C(NCCc1ccccc1)c1ncccc1Br</smiles>

188ha: $89 \%$<smiles>CCCCNC(=O)c1ncc(-c2ccccc2)cc1Br</smiles>

188ka: 56\%<smiles>[R]NC(=O)c1ccncc1Br</smiles>

$\mathrm{R}^{2}=n \mathrm{Bu}$ (188na): $60 \%$ $\mathrm{R}^{2}=\mathrm{Bn}$ (1880a): $58 \%$<smiles>CCCCNC(=O)c1ncc(/C=C/c2ccccc2)cc1Br</smiles>

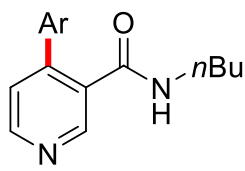

188la: $93 \%$

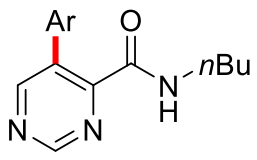

188pa: $50 \%$ 


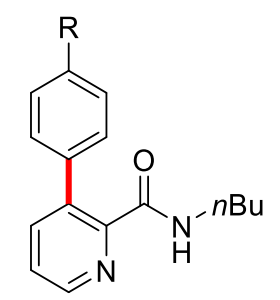

$\mathrm{R}=\mathrm{OMe}(188 \mathrm{aa}): 88 \%$

$R=H(188 a b): 88 \%$

$\mathrm{R}=\mathrm{Me}(188 \mathrm{ac}): 84 \%$

$\mathrm{R}=t-\mathrm{Bu}(188 \mathrm{ad}): 86 \%$

$\mathrm{R}=\mathrm{Ph}(188 \mathrm{ae}): 52 \%$

$R=F$ (188af): $78 \%$

$\mathrm{R}=\mathrm{NMe}_{2}$ (188ag): $62 \%$

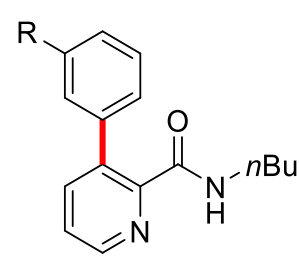

$\mathrm{R}=\mathrm{OMe}($ 188ah): $76 \%$

$R=F($ 188ai): $70 \%$<smiles>CCCCNC(=O)c1ncccc1-c1ccsc1</smiles>

188ak: $51 \%$<smiles>CCCCCCCCCNC(=O)c1ncccc1-c1ccc2ccccc2c1</smiles>

188aj: $68 \%$

Scheme 3.20. Scope of manganese-catalyzed $\mathrm{C}-\mathrm{H}$ arylation in batch.

\subsubsection{Mechanistic Studies}

Given the unique versatility of the novel manganese-catalyzed low-valent $\mathrm{C}-\mathrm{H}$ arylation, we became attracted to delineating its mode of action. Hence, experimental and computational| ${ }^{[135]}$ (performed by Dr. J. C. A. Oliveira) mechanistic studies were performed in order to gain insights into the reaction's mechanism.

\subsubsection{Competition Experiments}

In addition, competition experiments between electron-rich and electron-deficient arylating component $\mathbf{1 5 1}$ as well as intramolecular competition with substrates $\mathbf{1 1 2}$ were carried out by comparing the reaction rates. Intermolecular competition experiment indicated that electron-rich arylating components were preferentially transferred (Scheme 3.21). For the amides 117, a competition experiment of $\mathrm{C}(2)-\mathrm{H}$ amide $\mathbf{1 1 2 a}$ and $\mathrm{C}(3)-\mathrm{H}$ amide $\mathbf{1 1 2}$ d displayed a fast $\mathrm{C}(3)-\mathrm{H}$ functionalization occurred faster than the one at the position $\mathrm{C}(2)-\mathrm{H}$. 


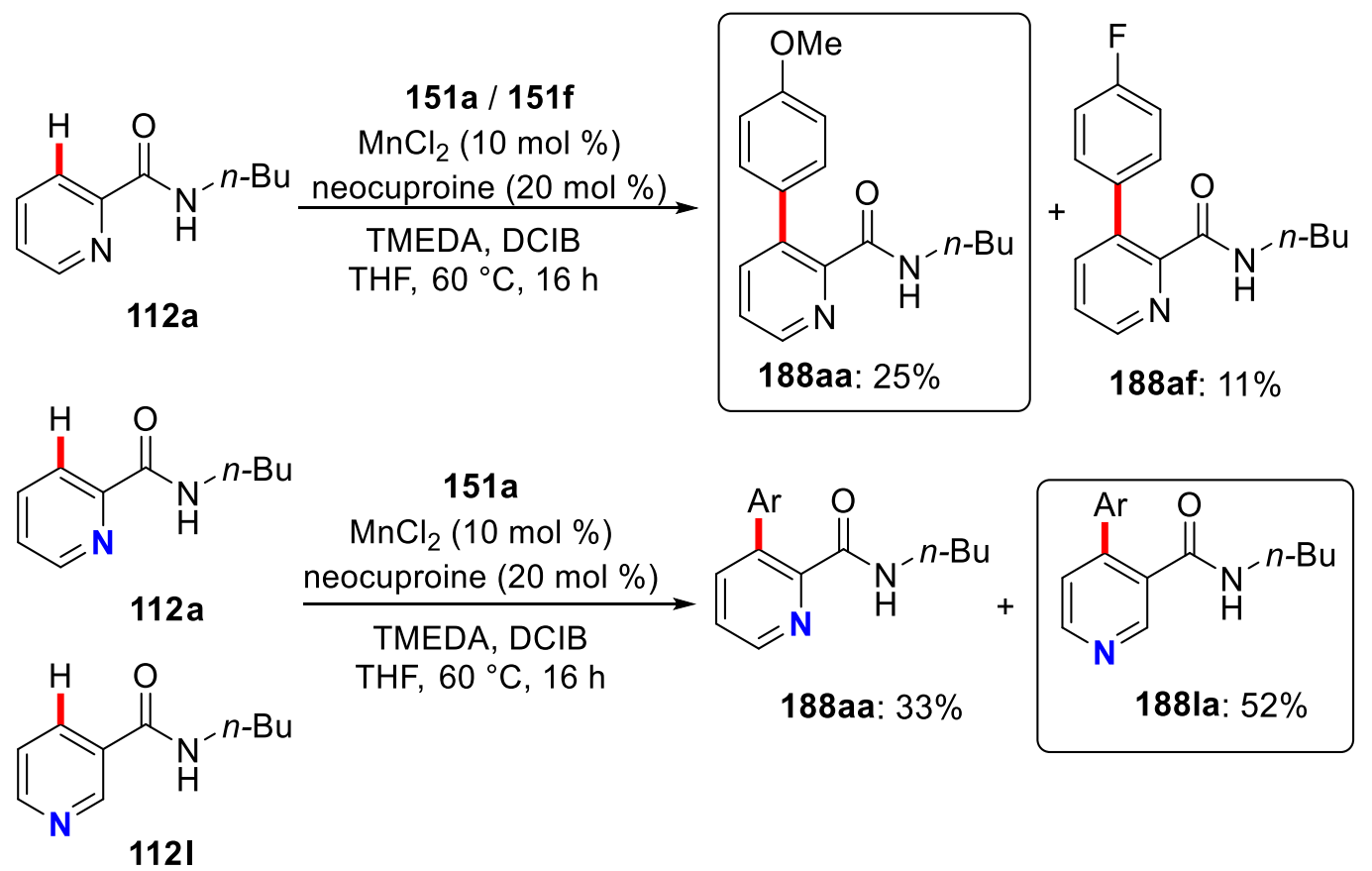

Scheme 3.21. competition experiments.

\subsubsection{Kinetic Isotope Effect}

The kinetic isotope effect (KIE) of the manganese(II/III/I)-catalyzed $\mathrm{C}-\mathrm{H}$ arylations reaction was measured by comparison of independent reaction rates for substrate 112a and its isotopically labeled analogue $[D]_{1-1}-112 a$, resulting in a minor value of $k_{\mathrm{H}} / k_{\mathrm{D}} \approx 1.4$, which suggests a facile and not turnover-limiting $\mathrm{C}-\mathrm{H}$ activation to be operative (Scheme 3.22). The observed KIE is in good agreement with the results obtained from the DFT studies by Dr. J. C. A. Oliveira, suggesting a ligand-to-ligand hydrogen transfer (LLHT), which enabled the proto-demetalation by delivering the proton from the substrate $112 \mathrm{a}$ by releasing an anisole.<smiles>CCCCNC(=O)c1ncccc1Br</smiles>

$112 \mathrm{a} /[\mathrm{D}]_{1}-112 \mathrm{a}$

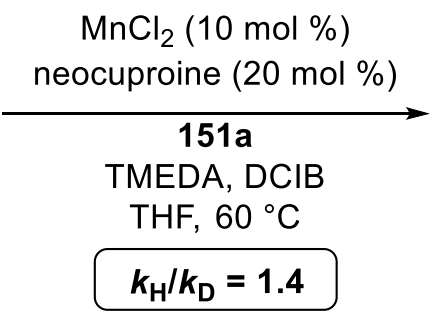<smiles>CCCCNC(=O)c1ncccc1Br</smiles>

188aa 


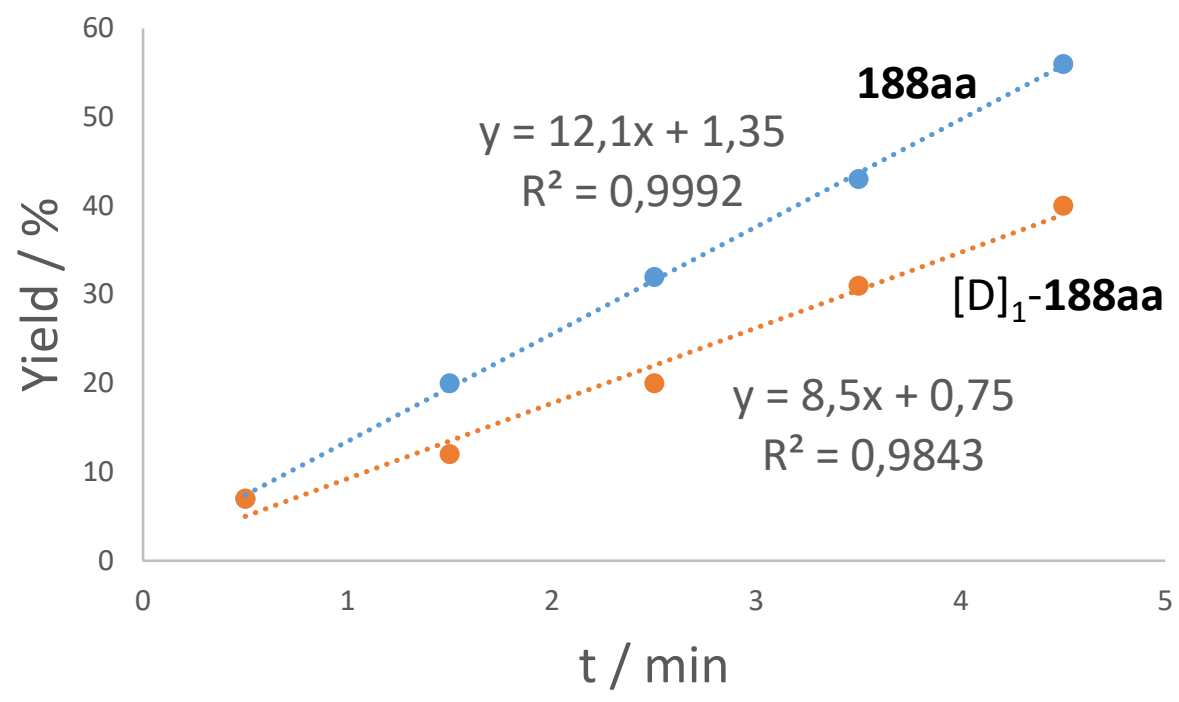

Scheme 3.22. Kinetic isotope effect experiment.

\subsubsection{Manganese-Catalyzed C-H Arylations with Well-Defined Catalyst}

Furthermore, it was studied whether the desired product 188aa could be obtained with the single-component manganese-neocuproine complex 189 (Scheme 3.23). ${ }^{[136]}$ The reaction displayed a comparable catalytic efficacy as the in-situ generated system. These findings indicate the neocuproine being coordinated to manganese, while the TMEDA additive is proposed to stabilize the Grignard reagent by preventing its aggregation.<smiles>CCCCNC(=O)c1ccccn1</smiles>

$112 a$

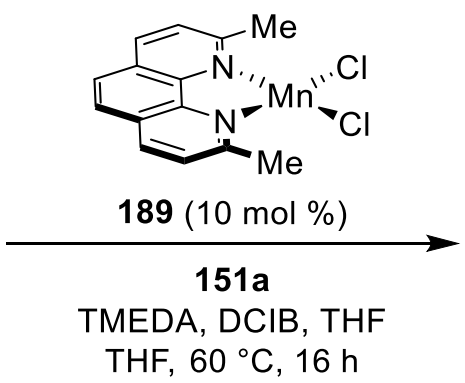

$\mathrm{THF}, 60{ }^{\circ} \mathrm{C}, 16 \mathrm{~h}$<smiles>CCCCNC(=O)c1ncccc1Br</smiles>

188aa: $86 \%$

Scheme 3.23. Manganese-catalyzed $\mathrm{C}-\mathrm{H}$ arylations with cyclometalated complex. 


\subsubsection{Synthetic Utility of Manganese-Catalyzed C-H Arylation}

The synthetic utility of our manganese-catalyzed $\mathrm{C}-\mathrm{H}$ arylation in continuous flow was illustrated by the gram-scale synthesis of product $188 \mathrm{aa}$ in only 100 minutes (Scheme 3.24a). Moreover, the selective methylation of the aryl group was achieved using $\mathrm{FeCl}_{3}$, dppen as an in-site generated catalyst. Furthermore, the annulation product 191 was obtained by using $\mathrm{POCl}_{3}$ in a microwave reactor at $150{ }^{\circ} \mathrm{C} .{ }^{[137]}$ (Scheme $3.24 \mathrm{~b}$ ).

\section{(a) gram scale in flow}

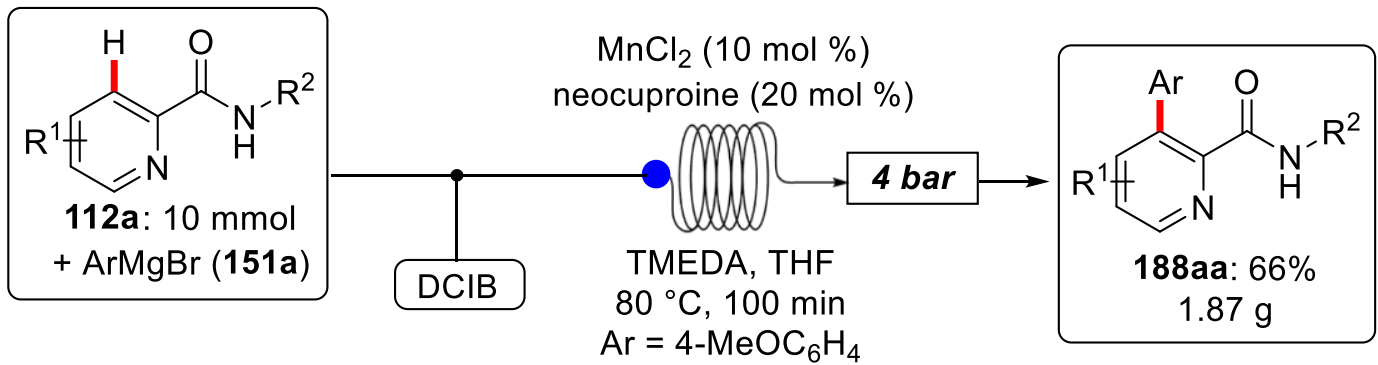

\section{(b) late-stage modification}<smiles>[R]NC(=O)c1ccccn1</smiles>

\section{Mn}
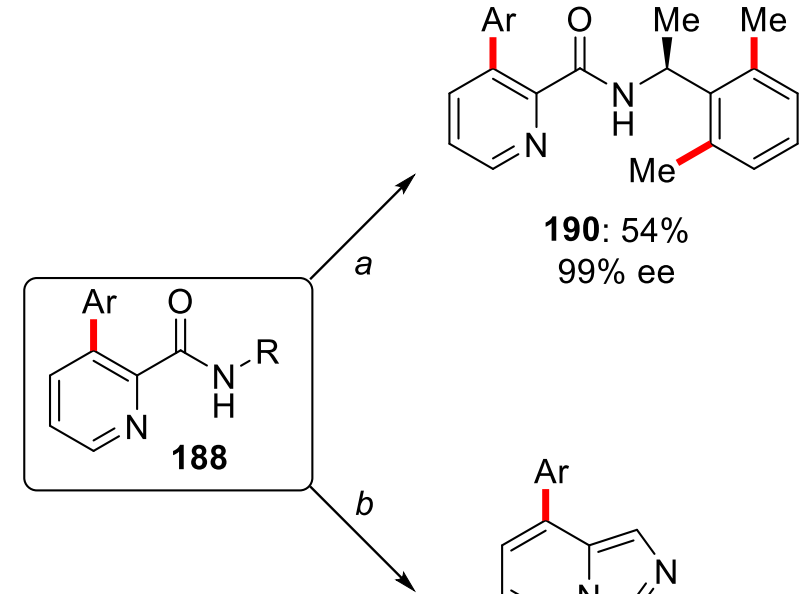

190: $54 \%$

$99 \%$ ee

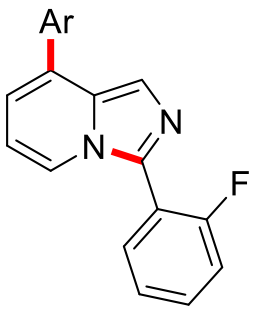

191: $53 \%$

Scheme 3.24. Synthetic utility of manganese-catalyzed C-H arylation. Reaction conditions: ${ }^{a} \mathrm{FeCl}_{3}(15 \mathrm{~mol} \%)$, dppen, $\mathrm{MeMgBr}, \mathrm{ZnCl} 2 \cdot \mathrm{TMEDA}, \mathrm{DCB}, \mathrm{THF}, 60{ }^{\circ} \mathrm{C}, 16 \mathrm{~h} .{ }^{b}$ $\mathrm{POCl}_{3}, 150^{\circ} \mathrm{C}, \mu \mathrm{w}, 45 \mathrm{~min}$. 


\subsection{Metallaelectrocatalyses: Electricity for Resource-Economic Iron-}

\section{Catalyzed C-H Activation}

Major achievements in the research area of iron-catalyzed $\mathrm{C}-\mathrm{H}$ arylations continue to be strongly limited by the need for superstoichiometric quantities of the vicinaldichloride dichloroisobutane (DCIB) as the sacrificial oxidant. ${ }^{[118 d]}$ Unfortunately, DCIB is elusive on commercial scale, features considerable safety hazards, generates overstoichiometric amounts of corrosive byproducts, and is toxic, which overall significantly deteriorates the environmental footprint of oxidative iron catalysis. Therefore, a significantly more sustainable approach would be the iron-catalyzed $\mathrm{C}-\mathrm{H}$ activations through the action of user-friendly electricity.

\subsubsection{Optimization of the Ferraelectro-catalyzed C-H Arylation}

The optimization studies were set out to identify reaction conditions for the elusive electrooxidative iron-catalyzed $\mathrm{C}-\mathrm{H}$ arylation of TAM-benzamide 159 bearing a peptide-isosteric click-triazole ${ }^{[20,138]}$ in a user-friendly undivided cell setup (Table 3.4). After considerable preliminary experimentation, we observed that the desired electrochemical $\mathrm{C}-\mathrm{H}$ arylation product 192 was obtained at an exceedingly mild reaction temperature of $40{ }^{\circ} \mathrm{C}$, when using a RVC anode, along with a platinum cathode (entries 1-3). Notably, the electrochemical C-H activation was even operative at room temperature, reflecting the outstanding performance of the metallaelectrocalysis manifold (entry 4). Among a representative set of iron sources, $\mathrm{Fe}(\mathrm{acac})_{3}$ was found to be optimal (entries 5-6). ${ }^{[42]}$ Control experiments confirmed the essential role of the electricity, the iron catalyst and the additive (entries 7-14). The iron-catalyzed electrooxidative $\mathrm{C}-\mathrm{H}$ arylation proved likewise viable in the biomassderived ${ }^{[139]}$ solvent $2-\mathrm{MeTHF}^{[42]}$ further substantiating the sustainable nature of our 
metallaelectrocatalysis (entry 15).

Table 3.4. Optimization of the ferraelectrocatalyzed $\mathrm{C}-\mathrm{H}$ arylation. ${ }^{\text {[a] }}$

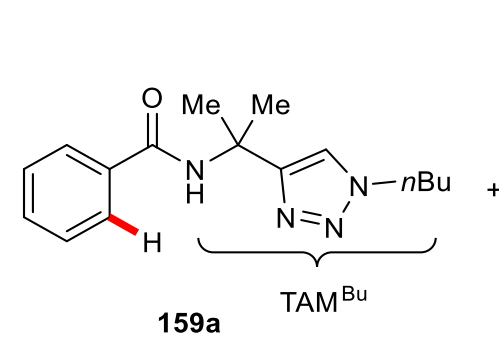

\begin{tabular}{|c|c|c|c|}
\hline Entry & {$[\mathrm{Fe}]$} & $T\left[{ }^{\circ} \mathrm{C}\right]$ & Yield [\%] \\
\hline 1 & $\mathrm{Fe}(\text { acac })_{3}$ & 60 & $75^{[\mathrm{b}]}$ \\
\hline 2 & $\mathrm{Fe}(\text { acac })_{3}$ & 60 & 90 \\
\hline 3 & $\mathrm{Fe}(\mathrm{acac})_{3}$ & 40 & 95 \\
\hline 4 & $\mathrm{Fe}(\mathrm{acac})_{3}$ & 23 & 74 \\
\hline 5 & $\mathrm{FeCl}_{3}$ & 40 & 80 \\
\hline 6 & $\mathrm{FeCl}_{2}$ & 40 & 72 \\
\hline 7 & $\mathrm{Fe}(\text { acac })_{3}$ & 40 & $10^{[c]}$ \\
\hline 8 & $\mathrm{Fe}(\mathrm{acac})_{3}$ & 40 & $86^{[d]}$ \\
\hline 9 & $\mathrm{Fe}(\text { acac })_{3}$ & 40 & $28^{[\mathrm{e}]}$ \\
\hline 10 & --- & 40 & --- \\
\hline 11 & $\mathrm{Fe}(\mathrm{acac})_{3}$ & 40 & $---[f]$ \\
\hline 12 & $\mathrm{Fe}(\mathrm{acac})_{3}$ & 40 & $76^{[\mathrm{g}]}$ \\
\hline 13 & $\mathrm{Fe}(\mathrm{acac})_{3}$ & 40 & ---_h] \\
\hline 14 & $\mathrm{Fe}(\mathrm{acac})_{3}$ & 40 & $---[i]$ \\
\hline 15 & $\mathrm{Fe}(\mathrm{acac})_{3}$ & 40 & $73^{[j]}$ \\
\hline 16 & $\mathrm{Fe}(\mathrm{acac})_{3}$ & 40 & $---[k]$ \\
\hline 17 & $\mathrm{Fe}(\mathrm{acac})_{3}$ & 40 & $56^{[l]}$ \\
\hline 18 & $\mathrm{Fe}(\mathrm{acac})_{3}$ & 40 & $87^{[\mathrm{m}]}$ \\
\hline 19 & $\mathrm{Fe}(\mathrm{acac})_{3}$ & 40 & $---[n]$ \\
\hline 20 & $\mathrm{Fe}(\mathrm{acac})_{3}$ & 40 & $73 \%^{[0]}$ \\
\hline 21 & $\mathrm{Fe}(\mathrm{acac})_{3}$ & 40 & ---_p] \\
\hline 22 & $\mathrm{Fe}(\mathrm{acac})_{3}$ & 40 & $66^{[q]}$ \\
\hline 23 & $\mathrm{Fe}(\text { acac })_{3}$ & 40 & $60^{[r]}$ \\
\hline 24 & $\mathrm{Fe}(\mathrm{acac})_{3}$ & 23 & $75^{[s]}$ \\
\hline
\end{tabular}

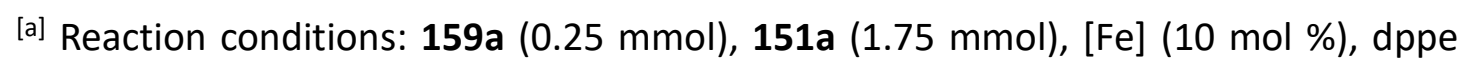
(10 mol \%), $\mathrm{ZnCl}_{2} \cdot$ TMEDA $(0.75 \mathrm{mmol})$, THF $(5.0 \mathrm{~mL}), 6 \mathrm{~h}$, constant current electrolysis 
(CCE) at $5 \mathrm{~mA}$, undivided cell, RVC as anode $(10 \mathrm{~mm} \times 15 \mathrm{~mm} \times 6 \mathrm{~mm})$, Pt-plate as cathode $(10 \mathrm{~mm} \times 15 \mathrm{~mm} \times 0.25 \mathrm{~mm})$, isolated yield. ${ }^{[b]} \mathrm{RVC}$ as cathode. ${ }^{[c]}$ Without electricity, under $\mathrm{N}_{2} .{ }^{[\mathrm{d}]}$ under $\mathrm{N}_{2} .{ }^{[\mathrm{e}]}$ Without electricity, under air. ${ }^{[\mathrm{f}]}$ TMEDA instead of $\mathrm{ZnCl}_{2} \cdot$ TMEDA. ${ }^{\text {[g] }} \mathrm{ZnBr}_{2} \cdot$ TMEDA instead of $\mathrm{ZnCl}_{2} \cdot$ TMEDA. ${ }^{[\mathrm{h}}$ $\mathrm{MnCl}_{2} \cdot$ TMEDA instead of

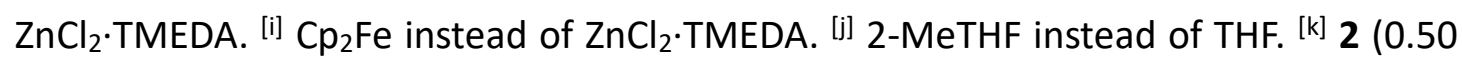
mmol). ${ }^{[l]} 2$ (1.0 mmol). ${ }^{[\mathrm{m}]} 5 \mathrm{~h} .{ }^{[\mathrm{n}]}$ divided cell. ${ }^{[0]} \mathrm{Ni}$ foam as cathode. ${ }^{[p]} \mathrm{Mg}$-plate as anode and cathode. ${ }^{[\mathrm{q}]} \mathrm{Fe}(\mathrm{acac})_{3}(5 \mathrm{~mol} \%) .{ }^{[\mathrm{r}]}$ constant potential electrolysis at $2 \mathrm{~V}$. ${ }^{[\mathrm{s}]}$ With IKA ElectraSyn.

However, decreasing the amount of the arylating component 151a gave a remarkably poor yield, presumably due to the homocoupling of 151a and lower basicity of 151a (entries 16-17). Interestingly, the divided cell in contrast fell short in the desired catalytic transformation (entry 19). The ferraelectrocatalysis was also conveniently conducted with commercially available equipment, mirroring its user-friendly nature (entry 24).

\subsubsection{Scope of Ferraelectrocatalytic C-H Arylation}

With the optimized conditions for the metallaelectrooxidative iron-catalyzed $\mathrm{C}-\mathrm{H}$ arylation being identified, we next probed its robustness with a representative set of benzamides 159 (Scheme 3.25). Various benzamides 159 were efficiently converted to the arylation products with high efficacy. Differently $N$-substituted triazoles $\mathbf{1 5 9}$ were selectively converted into the desired products 192-194. Among others, a wealth of alkyl, aryl and halogenated substituents were fully tolerated in the transformation, affording products 195-204 in moderate to good yield. Moreover, heteroarene thiophene and ferrocene delivered the desired arylated products $\mathbf{2 0 5}$ and $\mathbf{2 0 6}$ with high catalytic efficacy. Moreover, the electrochemical $\mathrm{C}-\mathrm{H}$ activation approach was not limited to TAM-benzamides. Indeed, the synthetically useful pyridine PIP- 
derivative ${ }^{[140]} \mathbf{2 0 7}$ and $\mathbf{2 0 8}$ also proved to be amenable to the $\mathrm{C}-\mathrm{H}$ activation likewise.
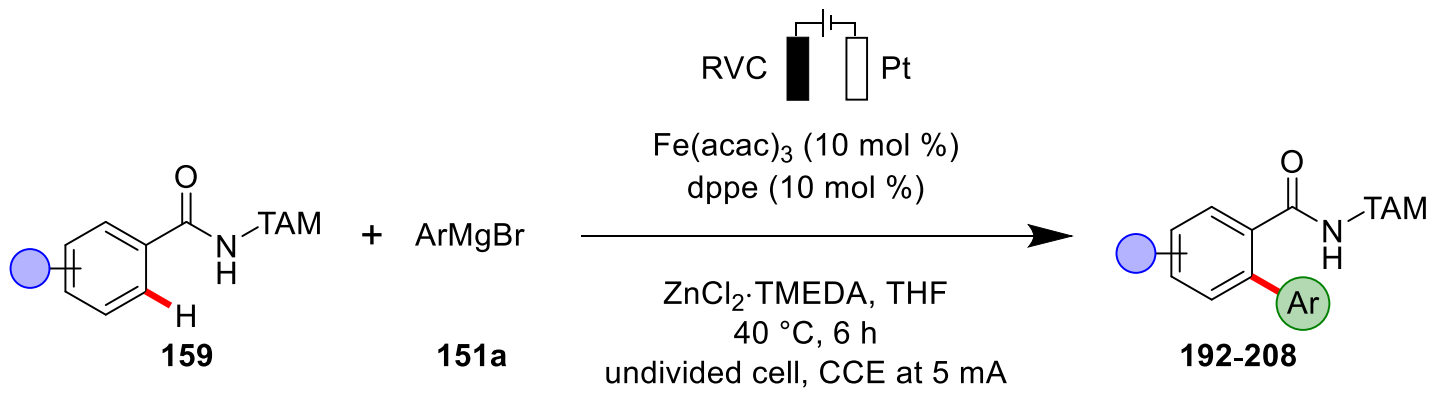<smiles>CCCCn1cc(C(C)(C)NC(=O)c2ccccc2Br)nn1</smiles>

192: $95 \%$<smiles></smiles>

195: $96 \%$<smiles>CC(C)NC(=O)c1ccc(F)cc1Br</smiles>

198: $93 \%$<smiles>[14CH3]NC(=O)c1ccc(C(F)(F)F)cc1Br</smiles>

201: $54 \%$<smiles>O=C(N[14C]([Mg])=[W])c1cc2ccccc2cc1Br</smiles>

204: $72 \%$<smiles>CC(C)(NC(=O)c1ccccc1Br)c1cn(C[Ge])nn1</smiles>

193: $98 \%$<smiles>CC(C)(C)c1ccc(C(=O)N[Al+2])c(Br)c1</smiles>

196: $98 \%$<smiles>CC(C)(C)[Al]NC(=O)c1ccc(Cl)cc1Br</smiles>

199: $52 \%$<smiles>CC(C)(C)NC(=O)c1cccc(F)c1Br</smiles>

202: $53 \%$<smiles>C[14C](C)NC(=O)c1ccsc1[Al]</smiles>

205: $78 \%$<smiles>CC(C)(NC(=O)c1ccccc1Br)c1cn(Cc2ccccc2)nn1</smiles>

194: $85 \%$

197: $93 \%$<smiles>Cc1ccc(C(=O)N[Al+2])c(Br)c1</smiles>

200: $79 \%$<smiles>COc1ccc(Br)c(C(=O)N[Al+2]c2ccccc2)c1</smiles>

203: $68 \%$

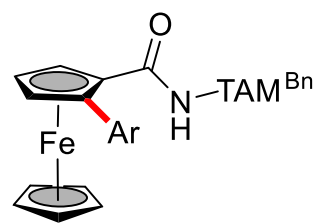

206: $70 \%$<smiles>COc1ccc(C(=O)NC(C)(C)c2ccccn2)c(Br)c1</smiles>

Scheme 3.25. Robustness of the ferraelectrochemical C-H arylation of amides $\mathbf{1 5 9}$. 
Thereafter, the effect of the substitution pattern was studied in the iron-catalyzed metallaelectrochemical $\mathrm{C}-\mathrm{H}$ arylation (Scheme 3.26). Diversely functionalized arylation motifs were efficiently converted to the desired products 209-214 in good to excellent yield. Moreover, the heteroaromatic thiophene was well tolerated with moderate yield.

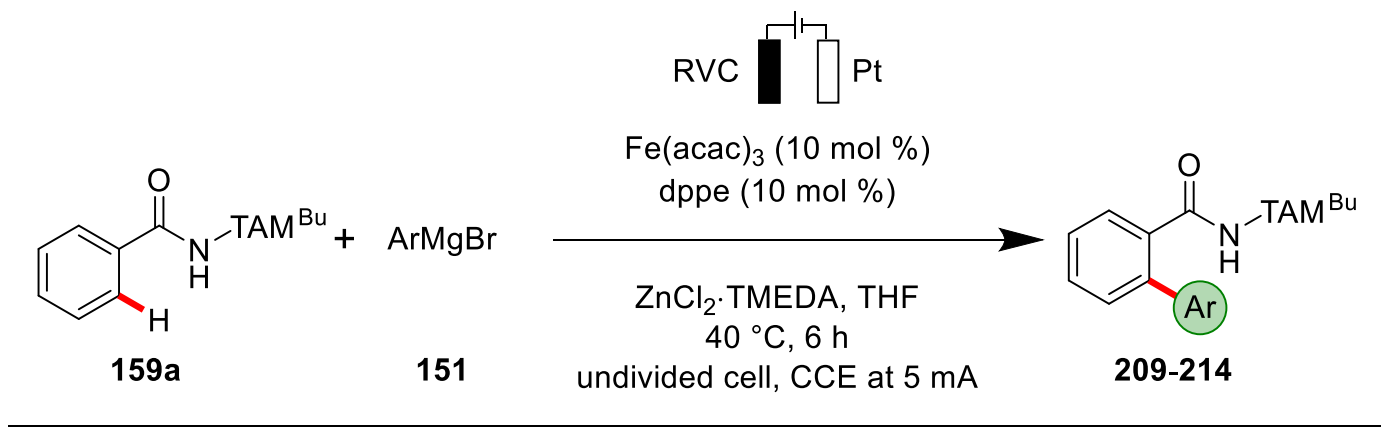

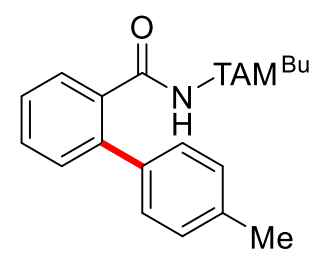

209: $77 \%$<smiles>Cc1cc(C)cc(-c2ccccc2C(=O)N[I+](C)(C)C)c1</smiles>

212: $84 \%$<smiles>CC(C)(C)c1ccc(-c2ccccc2C(=O)N[Te+](C)(C)C)cc1</smiles>

210: $76 \%$

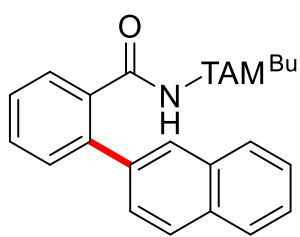

213: $88 \%$<smiles></smiles>

211: $98 \%$

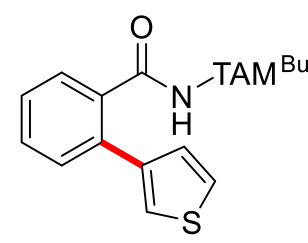

214: $63 \%$

Scheme 3.26. Robustness of the metallaelectrochemical C-H arylation.

\subsubsection{Comparison of Electrochemical Oxidation versus Chemical Oxidation}

To gain further advantage regarding the Ferraelectrocatalytic $\mathrm{C}-\mathrm{H}$ arylation, the competition experiment between DCIB-free electrochemical and the DCIB-mediated transformation was conducted. The results revealed a preferential reactivity in favor of the ferraelectrocatalysis. Thus, both the isolated yields (Scheme 3.27a) and the kinetic profile (Scheme 3.27b) were found to be considerably improved by the 
electrocatalysis.

(a) Electrochemical versus Chemical Oxidation

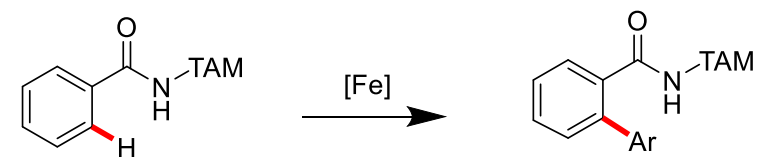

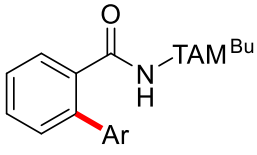

192: $52 \% 95 \%$<smiles>O=C(N[TeH2])c1ccccc1Br</smiles>

194: $50 \% 85 \%$<smiles>CC(C)(C)c1ccc(C(=O)N[14CH3])c(Br)c1</smiles>

196: $41 \% 98 \%$

$$
\square=\mathrm{DCIB} \quad \square=\text { electricity }
$$

(b) Kinetic Studies by ${ }^{19} F-N M R$

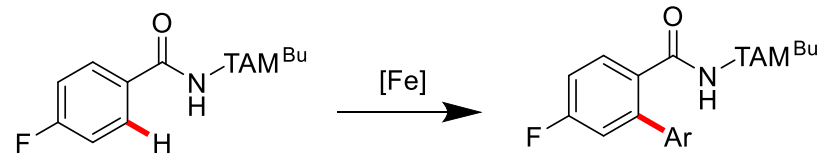

198

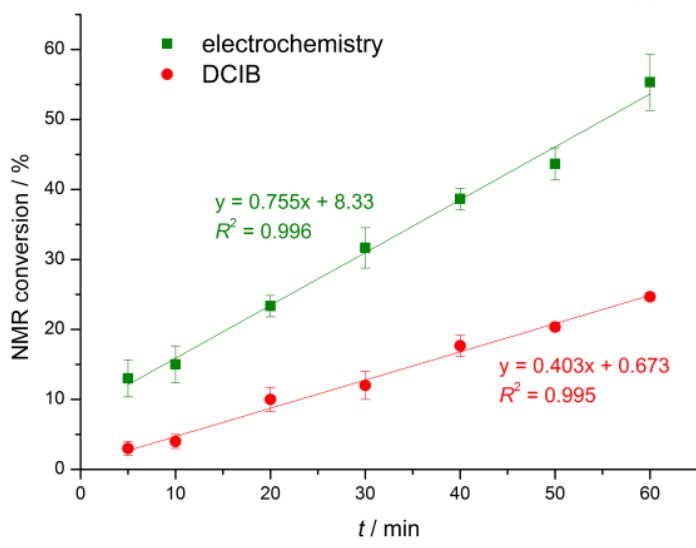

Scheme 3.27. Ferraelectrocatalysis: mechanistic insights.

\subsubsection{Mechanistic Studies}

After evaluating the robustness of the electrochemical iron-catalyzed $\mathrm{C}-\mathrm{H}$ arylation in terms of functional group tolerance on both coupling partners, detailed mechanistic studies were conducted. Thus, the Faradaic efficacy of the reaction was calculated. 
This can be done based on the observed yield.

$$
\text { Efficacy }=\frac{\mathrm{n}^{*} \mathrm{y}^{*} \mathrm{z}^{*} \mathrm{~F}}{\mathrm{t}^{*} \mathrm{I}}
$$

In the equation, $n$ is the amount of starting material in mol, $y$ is the yield observed for a given reaction, $z$ the number of electrons needed to achieve turnover, $F$ is the Faraday constant, $t$ is the reaction time in seconds and $/$ the applied current in ampere (coulomb per second). Based on this equation, the electron efficacy was calculated for the $\mathrm{C}-\mathrm{H}$ arylation of benzamide $159 \mathrm{a}$ :

$$
\frac{0.00025 \mathrm{~mol} * 0.95 * 2 * 96485 \mathrm{C} / \mathrm{mol}}{21600 \mathrm{~s} * 0.005 \mathrm{C} / \mathrm{s}}=0.424
$$

The Faradaic efficacy for the given reaction was thus calculated to be $42 \%$, which is corresponding to a charge of $4.48 \mathrm{~F}$ passed through the solution per each mole of the substrate 159a.

\subsubsection{Competition Experiments}

To gain further insights into the $\mathrm{C}-\mathrm{H}$ activation mechanism, a competition experiment between electron-rich and electron-deficient amides 159 was preformed. It revealed a preferential reactivity in favor of the more electron-rich substrate (Scheme 3.28). This is however not in line with an $\mathrm{C}-\mathrm{H}$ oxidative addition or a concerted-metalationdeprotonation (CMD) pathway. ${ }^{[140]}$ Instead, it can be explained in terms of a ligand-toligand hydrogen transfer(LLHT ${ }^{[14 a]}$ pathway or base-assisted internal electrophilictype substitution (BIES) ${ }^{[20 \mathrm{a}-\mathrm{c}, 20 \mathrm{~g}, 141]}$ working mode. 


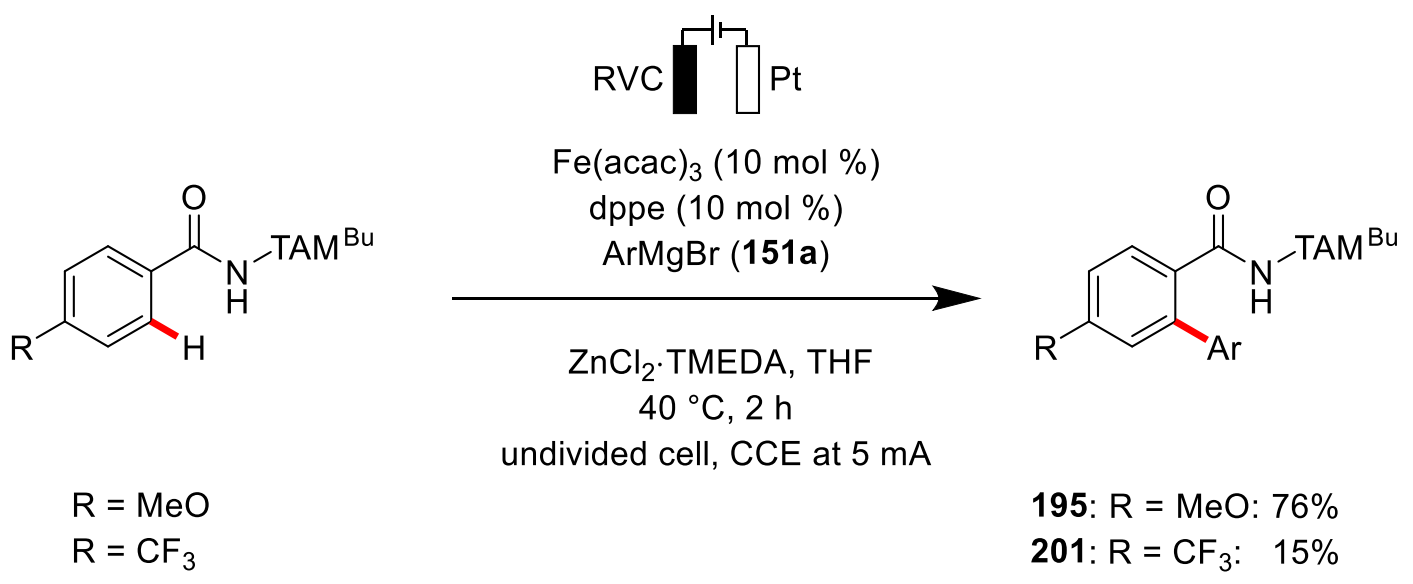

Scheme 3.28. Competition experiments.

\subsubsection{Kinetic Isotope Effect}

Subsequently, a KIE experiment by comparison of the initial rates of independent reactions with substrate $159 a$ and its deuterated analogue $\left[D_{5}\right]-159 a$ was conducted. The experiments revealed a KIE of $k_{\mathrm{H}} / k_{\mathrm{D}} \approx 1.2$ (Scheme 3.29). A KIE of this magnitude suggests that the $\mathrm{C}-\mathrm{H}$ cleavage step is not turnover-limiting and provides evidence for a facile and reversible $\mathrm{C}-\mathrm{H}$ activation event.

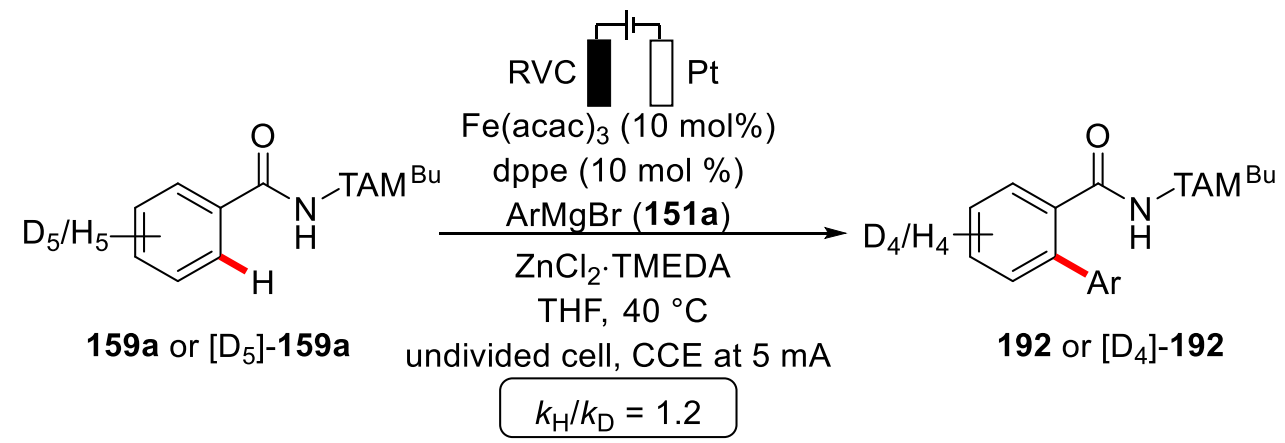




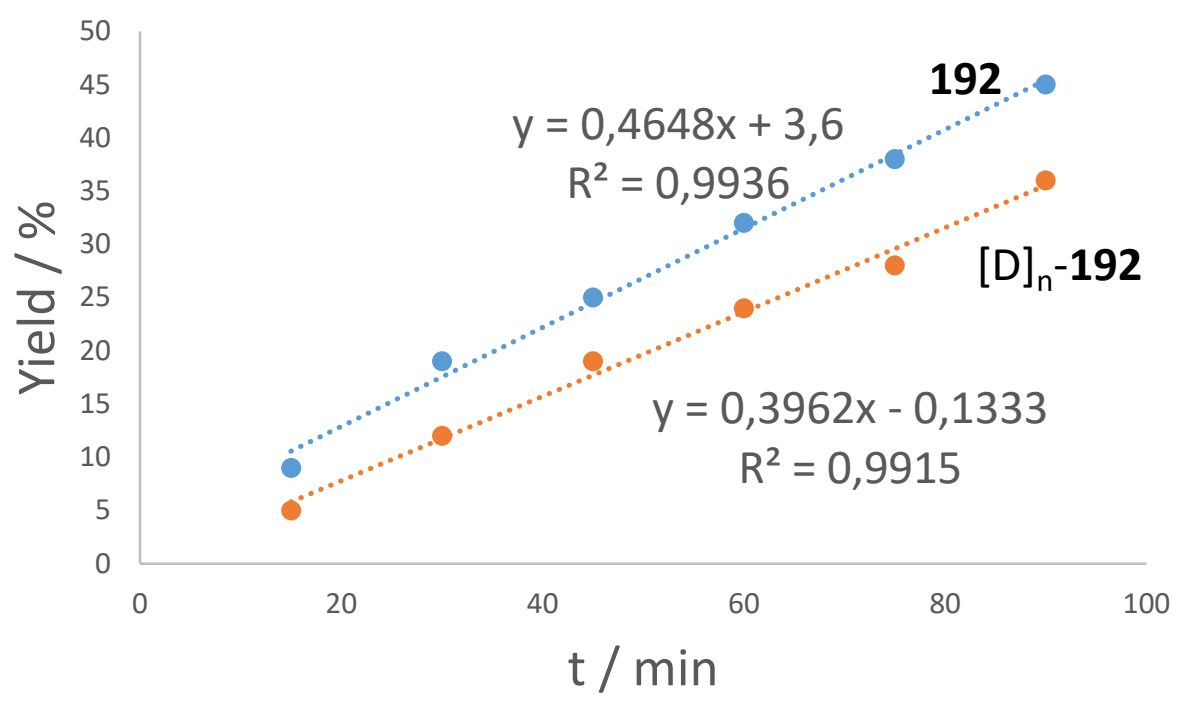

Scheme 3.29. Kinetic profile with substrates $159 a$ or $\left[D_{5}\right]-159 a$.

\subsubsection{Cyclic Voltammetry}

Detailed mechanistic studies by cyclic voltammetry (performed by $M$. Stangier) showed a reversible $\mathrm{Fe}^{\prime \prime} / \mathrm{Fe}^{\text {III }}$ oxidation event of the iron catalyst (red) at $\mathrm{E}_{1 / 2}=-1.3 \mathrm{~V} v \mathrm{~s}$. $\mathrm{Fc}^{0 /+}$, which disappeared upon addition of the arylating reagent $\mathbf{2}$ (Scheme 3.30, green). This finding is in good agreement with a previous report by Jutand on the formation of a $\left[\mathrm{PhFe}^{\prime}(\mathrm{acac})\right]^{-}$species, ${ }^{[142]}$ which was shown to be reversibly oxidized to the corresponding iron(II) and iron(III) species at oxidation potentials of $E_{1 / 2}=-0.6 \mathrm{~V}$ and $\mathrm{E}_{1 / 2}=-0.1 \mathrm{~V} v s . \mathrm{Fc}^{0 /+}$, respectively. These cyclic voltammetry studies on the ironcatalyzed $\mathrm{C}-\mathrm{H}$ arylation provide experimental mechanistic insights into an iron(II/III/I) manifold by oxidation-induced reductive elimination, with more general implications to low-valent iron-catalyzed $\mathrm{C}-\mathrm{H}$ activation. 


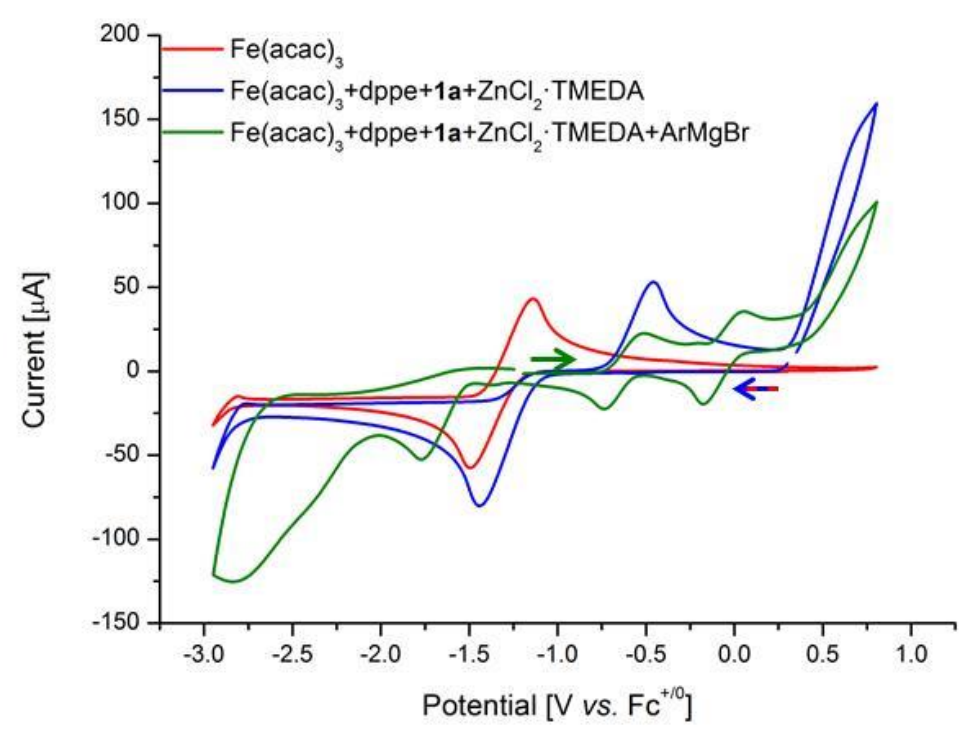

Scheme 3.30. Cyclic voltammetry recorded at $100 \mathrm{mV} / \mathrm{s}$ with $n \mathrm{Bu}_{4} \mathrm{NPF}_{6}(0.1 \mathrm{M}$ in THF), concentrations of substrates $5 \mathrm{mM}(\mathrm{ArMgBr} 20 \mathrm{mM})$. 


\subsubsection{SEM Analysis}

While we thus rationalized the anodic oxidation elementary steps, we next interrogated the nature of the cathodic event. Here, detailed analyses of the electrode material by means of Scanning Electron Microscopy-Energy-Dispersive X-ray Spectroscopy (SEM-EDS) (performed by P. Liu) clearly highlighted the crucial role of the zinc additive at the surface of the electrode. Thus, the zinc additive serves multiple roles, including the adjustment of the conductivity. (Scheme 3.31).

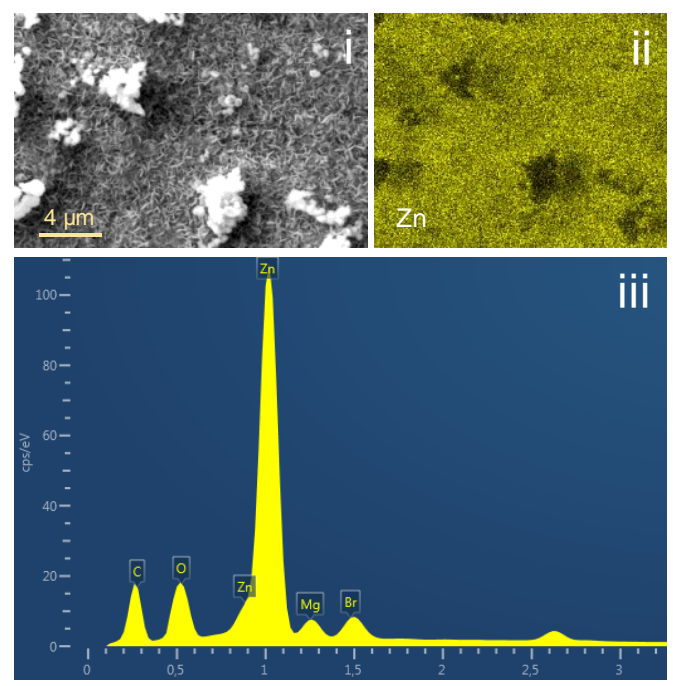

Scheme 3.31. SEM studies on the post-catalysis cathode material. i) SEM image of deposition. ii) SEM-EDS mapping with location of zinc. iii) Elemental distribution.

\subsubsection{Plausible Catalytic Cycle}

Based on these mechanistic studies, a proposed catalytic cycle for the ironelectrocatalytic $\mathrm{C}-\mathrm{H}$ functionalization commences by a facile organometallic $\mathrm{C}-\mathrm{H}$ cleavage, which is supported by the results obtained from the the KIE study (Scheme 3.29) and the DFT calculations by Dr. J. C. A. Oliveira. Thereafter, the key anodic singleelectron-transfer (SET) oxidation and subsequent transmetalation occur to furnish a five-membered ferra(III)cycle 218. As shown in Scheme 3.30, also one electron oxidation of intermediate $\mathbf{2 1 7}$ seems possible based on our CV data. Subsequently, reductive elimination occurs, delivering the desired product 192 and the key iron (I) 
intermediate 220. Finally, the catalytically active iron(II) intermediate $\mathbf{2 1 5}$ is regenerated by anodic oxidation (Scheme 3.32).

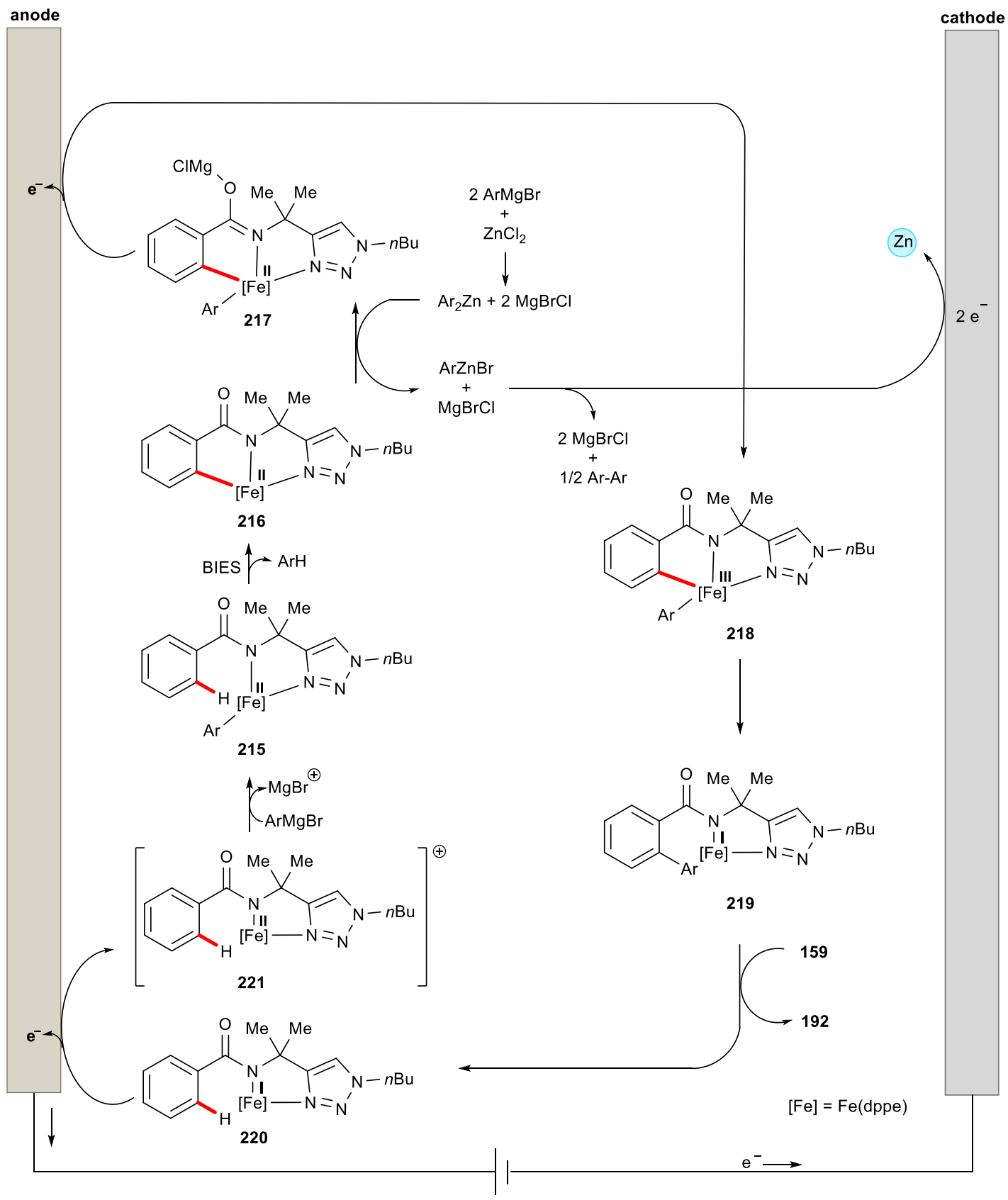

Scheme 3.32. The plausible catalytic cycle. 


\subsubsection{Gram-Scale of Ferraelectro-Catalyzed C-H Arylation}

Importantly, the robustness of our strategy for electrochemical DCIB-free C-H arylations was further illustrated by the gram-scale synthesis of product 192 with comparable levels of efficacy (Scheme 3.33). It is noteworthy that 1.40 gram of the isolated desired product 192 were obtained in 11 hours under mild reaction condition.

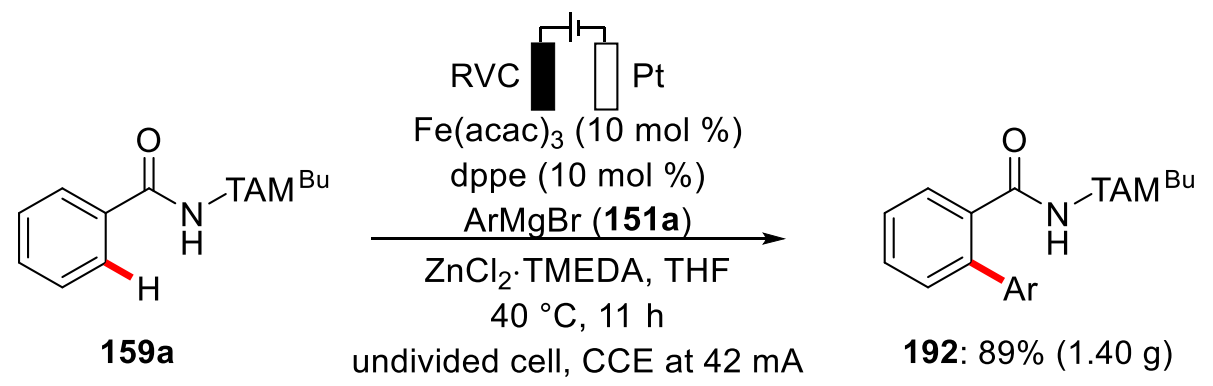

Scheme 3.33. Gram-scale synthesis of 192.

\subsubsection{Manganaelectro-Catalyzed C-H Activation}

Given the overall excellent performance of the iron catalyst, the generality of the metallaelectrocatalysis strategy was reflected by the merger of electrosynthesis with further benign transition metals. Indeed, unprecedented electrochemical manganesecatalyzed $\mathrm{C}-\mathrm{H}$ arylation was also realized under otherwise identical reaction conditions. In summary, all tested manganaelectro-catalyzed $\mathrm{C}-\mathrm{H}$ arylations occured efficiently to yield the desired products, indicating the broad nature of our approach beyond iron catalysis, featuring here cost-effective, non-toxic $\mathrm{MnCl}_{2}$ as the catalyst (Scheme 3.34). 


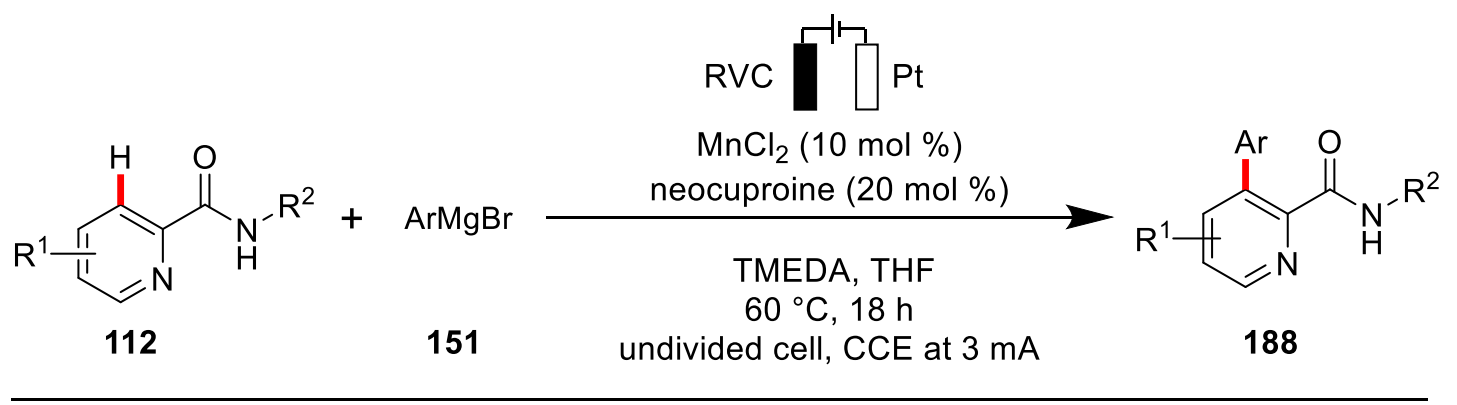<smiles>CCCCNC(=O)c1ncccc1-c1ccc(OC)cc1</smiles>

188aa: $70 \%$<smiles>CCCCNC(=O)c1ncccc1-c1ccccc1</smiles>

188ab: $75 \%$<smiles>COc1ccc(-c2cccnc2C(=O)NCCc2ccccc2)cc1</smiles>

188ha: $70 \%$<smiles>CCCCNC(=O)c1ncccc1-c1ccc(C(C)(C)C)cc1</smiles>

188ad: $73 \%$<smiles>CCCCNC(=O)c1ccncc1-c1ccc(OC)cc1</smiles>

188na: $65 \%$<smiles>CCCCNC(=O)c1ncccc1-c1cccc(F)c1</smiles>

188ai: $70 \%$

Scheme 3.34. Zinc-free manganaelectro-catalyzed $\mathrm{C}-\mathrm{H}$ arylation. 


\section{Summary and Outlook}

The sustainable and cost-efficient synthesis of key structural motifs for the preparation of pharmaceuticals, crop-protection agents, and functional materials remains one of the biggest challenges in terms of declining resources and a heightened awareness of the ecological costs associated with many processes. Recently, the direct functionalization of $\mathrm{C}-\mathrm{H}$ bonds has emerged as an environmentally-benign platform avoids lengthy syntheses and has attracted substantial interest from both academia and the chemical industries. While major progress was initially achieved with noble transition metal catalysts, the use of inexpensive and earth-abundant $3 \mathrm{~d}$ metals has gained significant momentum within the last decade.

In the first project, the first example of a complexity-increasing cascade reaction to access various indolizinone alkaloid derivatives in a step-economical manner was developed (Scheme 4.1). Thus, a versatile cobalt(III) catalyst displayed a unique chemo- and regio-selectivity for an efficient protocol comprised $\mathrm{C}-\mathrm{H}$ activation, $\mathrm{C}-\mathrm{N}$ cleavage, pyridine migration and twofold $\mathrm{C}-\mathrm{C}$ formation, which notably could not be achieved with rhodium(III) and manganese(I) catalysts. The mechanistic findings, including $H / D$ exchange, competition experiments and KIE studies, revealed a reversible and facile BIES-type $\mathrm{C}-\mathrm{H}$ metalation pathway to be involved.<smiles>[R]c1ccc(=O)n(-c2c[R]#ccn2)c1</smiles>

172

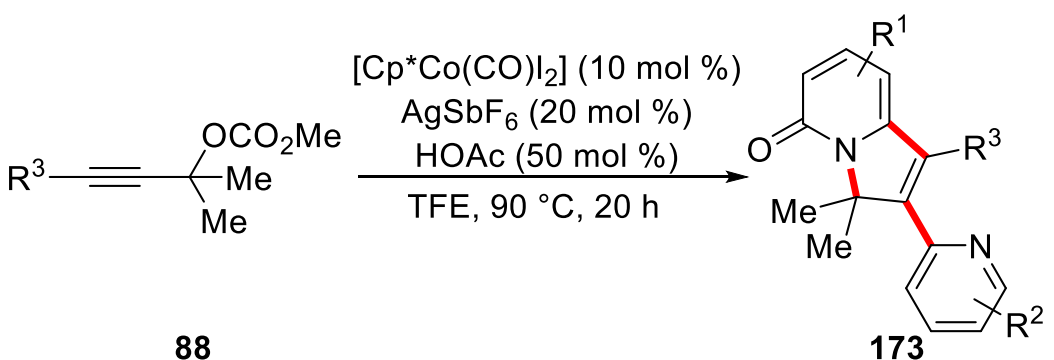

173

C-H/C-N clevage

Earth-abundant Cobalt, ample scope $D G$ pyridine migration

Annulation indolizin-5(3H)-one scaffolds

Scheme 4.1. $\mathrm{Cp} * \mathrm{Co}(\mathrm{III})$-catalyzed cascade annulation $\mathrm{C}-\mathrm{H} / \mathrm{C}-\mathrm{N}$ functionalization for the synthesis of indolizinones. 
Thereafter, significant development of a complexity-increasing Domino reaction consisting of $\mathrm{C}-\mathrm{H}$ activation, Diels-Alder reaction and retro-Diels-Alder reaction were realized using $\operatorname{MnBr}(\mathrm{CO})_{5}$ catalysis (Scheme 4.2). The dehydrocyanative alkyne annulation was achieved by a versatile manganese(I) catalyst through fast organometallic $\mathrm{C}-\mathrm{H}$ activation. Our findings feature pyridine as a transformable directing group towards indolone alkaloid derivatives in a step-economical manner. Mechanistic studies provided strong support for an acetate-assisted organometallic C$\mathrm{H}$ activation through chelation assistance. In striking contrast to the analogous chemoselective cobalt(III) catalyses, this reaction appeared to be complementary, which bears great potential for new uniquely selective synthetic methods based on $\operatorname{MnBr}(\mathrm{CO})_{5}$ catalysis.<smiles>[R]c1ccc(=O)n(-c2nccc[R]2[H])c1</smiles>

172

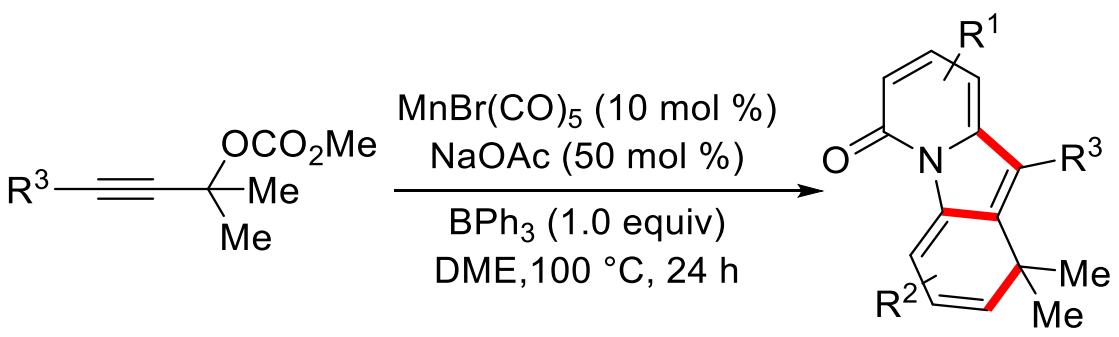

88
180

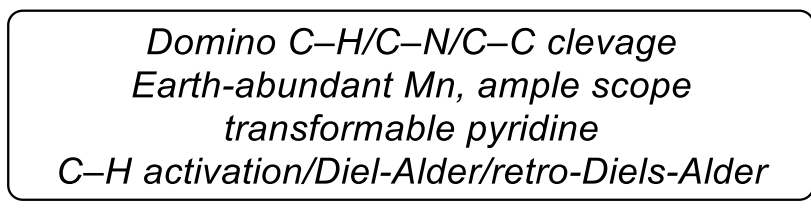

Scheme 4.2. Manganese(I)-catalyzed C-H activation/Diels-Alder/retro-Diels-Alder

Domino alkyne annulation.

In the third project, the first manganese(II/III/I)-catalyzed $\mathrm{C}-\mathrm{H}$ arylations in continuous flow technology were achieved (Scheme 4.3). ${ }^{[134]}$ Within this reaction, an expedient substrate scope for $\mathrm{C}-\mathrm{H}$ functionalizations on synthetically useful pyridines was highlighted with high levels of positional selectivity, notably using a most user-friendly $\mathrm{MnCl}_{2}$-based catalyst. Extensive mechanistic studies, including detailed experimental mechanistic studies, provided support for a facile LLHT C-H activation regime. Our findings highlight the practical importance of low-valent transition metal-catalyzed C- 
$\mathrm{H}$ functionalizations in user-friendly continuous flow.

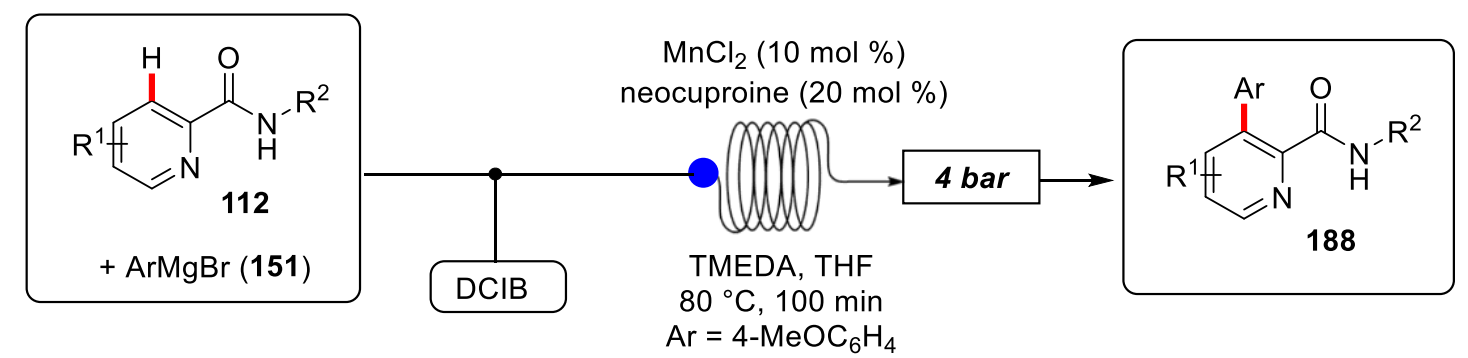

$$
\begin{gathered}
\text { Mn: } \boldsymbol{C}-\boldsymbol{H} \text { Activation in flow } \\
\text { facile } \mathrm{C}-\mathrm{H} \text { cleavage } \\
\text { bioactive pyridines } \\
\text { non-toxic \& sustainable } \mathrm{MnCl}_{2} \\
\text { versatile late-stage diversification }
\end{gathered}
$$

Scheme 4.3. Manganese-catalyzed $\mathrm{C}-\mathrm{H}$ arylation in continuous flow.

In the last two projects, toxic and cost-intensive dihalide oxidants were for the first time replaced by electricity as a green and sustainable oxidant, allowing for versatile iron- and manganese-catalyzed $\mathrm{C}-\mathrm{H}$ activations (Scheme 4.4 and 4.5). The unprecedented ferraelectrocatalytic $\mathrm{C}-\mathrm{H}$ arylation enabled direct arylations with ample scope, even efficiently occurring at room temperature. The strategy set the stage for avoiding chemical oxidants in low-valent metal-catalyzed $\mathrm{C}-\mathrm{H}$ activation, featuring non-toxic, Earth-abundant iron $\mathrm{Fe}(\mathrm{acac})_{3}$ catalysts. Detailed analyses by experiment, spectroscopy and computation unravelled key insights into the role of additives within an iron(II/III/I) manifold, which should prove invaluable for the future design of iron-catalyzed electrochemical strong bond activations.

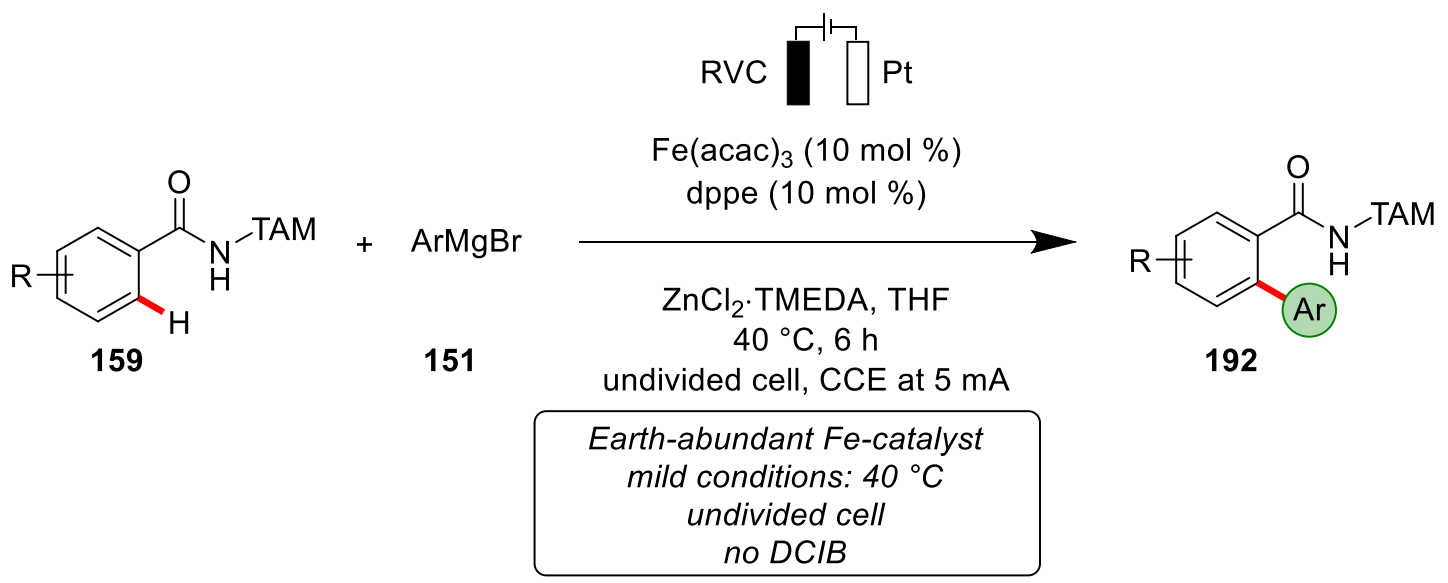

Scheme 4.4. Iron-electro-catalyzed C-H arylations. 
<smiles>[R]NC(=O)c1ncc[R1]c1[14CH3]</smiles>

112

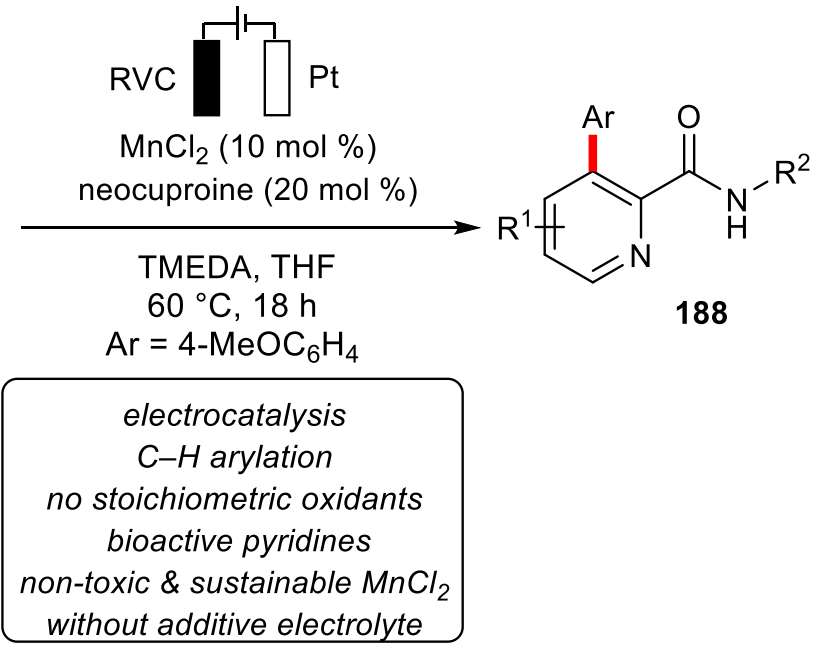

Scheme 4.5. Zinc-free manganaelectro-catalyzed C-H arylations. 


\section{Experimental Section}

\subsection{General Remarks}

The catalysis in water or under an atmosphere of air were conducted in the sealed tubes or Schlenk tubes. Unless otherwise noted, other reactions were performed under $\mathrm{N}_{2}$ atmosphere using pre-dried glassware and standard Schlenk techniques. If not otherwise noted, yields refer to isolated compounds, estimated to be $>95 \%$ pure as determined by ${ }^{1} \mathrm{H}-\mathrm{NMR}$.

\section{Vacuum}

The following pressures were measured on the used vacuum pump and were not corrected: membrane pump vacuum (MPV): 0.5 mbar, oil pump vacuum (OPV): 0.1 mbar.

\section{Melting Points (M.p.)}

Melting points were measured using a Stuart ${ }^{\circledR}$ Melting Point Apparatus SMP3 from BARLOWORLD SCIENTIFIC. The reported values are uncorrected.

\section{Chromatography}

Analytical thin layer chromatography (TLC) was performed on $0.25 \mathrm{~mm}$ silica gel 60Fplates (MACHEREY-NAGEL) with $254 \mathrm{~nm}$ fluorescent indicator from MERCK. Plates were visualized under UV-light or developed by treatment with a $\mathrm{KMnO}_{4}$ solution followed by careful applying a heat gun. Chromatographic purification of products was accomplished by flash column chromatography on MERCK silica gel, grade 60 (0.040$0.063 \mathrm{~mm}$ and $0.063-0.200 \mathrm{~mm})$.

\section{Gas Chromatograpgy (GC)}

The conversions of the reactions were monitored applying coupled gas 
chromatography/mass spectrometry using G1760C GCDplus with mass detector HP 5971, 5890 Series // with mass detector HP 5972 from HEWLETT-PACKARD and 7890A GC-System with mass detector 5975C (Triplex-Axis-Detector) from AGILENT TECHNOLOGIES equipped with HP-5MS columns $(30 \mathrm{~m} \times 0.25 \mathrm{~mm} \times 0.25 \mathrm{~m})$ were used.

\section{Gel permeation chromatography (GPC)}

GPC purifications were performed on a JAI system (JAI-LC-9260 II NEXT) equipped with two sequential columns (JAIGEL-2HR, gradient rate: 5.000; JAIGEL-2.5HR, gradient rate: 20.000; internal diameter $=20 \mathrm{~mm}$; length $=600 \mathrm{~mm}$; Flush rate $=10.0 \mathrm{~mL} / \mathrm{min}$ and chloroform (HPLC-quality with $0.6 \%$ ethanol as stabilizer) was used as the eluent.

\section{Infrared Spectroscopy}

Infrared spectra were recorded with a BRUKER Alpha-P ATR FT-IR spectrometer. Liquid samples were measured as a film, solid samples neat. The analysis of the spectra was carried out using the software from BRUKER OPUS 6. The absorption is given in wave numbers $\left(\mathrm{cm}^{-1}\right)$ and the spectra were recorded in the range of $4000-400 \mathrm{~cm}^{-1}$. In situIR studies were performed on METTLER TOLEDO ReactIR ${ }^{\text {TM }} 15$ with an iC IR 4.3 software.

\section{Mass Spectrometry}

Electron-ionization (EI) mass spectra were recorded on a Jeol AccuTOF instrument at $70 \mathrm{eV}$. Electrospray-ionization (ESI) mass spectra were obtained on Bruker micrOTOF and maXis instruments. All systems are equipped with time-of-flight (TOF) analyzers. The ratios of mass to charge $(\mathrm{m} / \mathrm{z})$ are reported and the intensity relative to the base peak $(I=100)$ is given in parenthesis.

\section{Nuclear Magnetic Resonance Spectroscopy (NMR)}

Nuclear magnetic resonance (NMR) spectra were recorded on VARIAN Inova 500, 600, VARIAN Mercury 300, VX 300, VARIAN Avance 300, VARIAN VNMRS 300 and BRUKER Avance III 300, 400 and HD 500 spectrometers. All chemical shifts are given as $\delta$-values 
in ppm relative to the residual proton peak of the deuterated solvent or its carbon atom, respectively. ${ }^{1} \mathrm{H}$ and ${ }^{13} \mathrm{C}$ NMR spectra were referenced using the residual proton or solvent carbon peak (see table), respectively. ${ }^{13} \mathrm{C}$ and ${ }^{19} \mathrm{~F}$ NMR were measured as proton-decoupled spectra.

\begin{tabular}{ccc} 
& ${ }^{1} \mathrm{H}-\mathrm{NMR}$ & ${ }^{13} \mathrm{C}-\mathrm{NMR}$ \\
\hline $\mathrm{CDCl}_{3}$ & 7.26 & 77.16 \\
{$[\mathrm{D}]_{6}$-DMSO } & 2.50 & 39.52
\end{tabular}

The observed resonance-multiplicities were described by the following abbreviations: $s$ (singlet), $d$ (doublet), $t$ (triplet), q (quartet), hept (heptet), $m$ (multiplet) or analogous representations. The coupling constants $J$ are reported in Hertz $(\mathrm{Hz})$. Analysis of the recorded spectra was carried out with MestReNova 10 software.

\section{Electrochemistry}

Platinum electrodes (10 mm×15 mm× $0.25 \mathrm{~mm}, 99.9 \%$; obtained from ChemPur $^{\circledR}$ Karlsruhe, Germany) and RVC electrodes (10 mm×15 mm×6 mm, SIGRACELL ${ }^{\circledR}$ GFA 6 EA, obtained from SGL Carbon, Wiesbaden, Germany) were connected using stainless steel adapters. Electrolysis was conducted using an AXIOMET AX-3003P potentiostat in constant current mode, CV studies were performed using a Metrohm Autolab PGSTAT204 workstation and Nova 2.0 software. Divided cells separated by a P4glassfrit were obtained from Glasgerätebau Ochs Laborfachhandel e. K. (Bovenden, Germany).

\section{Solvents}

Solvents for column chromatography or reactions not sensitive to air and moisture were distilled under reduced pressure prior to use. All solvents for reactions involving air- or moisture sensitive compounds were dried, distilled and stored under inert atmosphere according to the following procedures:

Purified by solvent purification system (SPS-800, M. Braun): $\mathrm{CH}_{2} \mathrm{Cl}_{2}$, toluene, 
tetrahydrofuran, dimethylformamide, diethylether.

1,2-Dichloroethane (DCE) was dried over $\mathrm{CaH}_{2}$ for $8 \mathrm{~h}$, degassed and distilled under reduced pressure.

1,2-Dimethoxyethane (DME) was dried over sodium and freshly distilled under $\mathrm{N}_{2}$

1,1,1,3,3,3-Hexafluoropropan-2-ol (HFIP) was distilled from $3 \AA$ molecular sieves.

Toluene (PhMe), Tetrahydrofuran (THF), Dichloromethane (DCM) and ethyl ether

$\left(\mathrm{Et}_{2} \mathrm{O}\right)$ were purified using a solvent purification system (SPS-800) from M. BRAUN.

2,2,2-Trifluoroethanol (TFE) was stirred over $\mathrm{CaSO}_{4}$ and distilled under reduced pressure.

Water $\left(\mathbf{H}_{2} \mathbf{O}\right)$ was degassed by repeated Freeze-Pump-Thaw degassing procedure.

1,4-Dioxane and $\mathrm{Di}$-(n-butyl)-ether $\left(n \mathrm{Bu}_{2} \mathrm{O}\right)$ were distilled from sodium benzophenone ketyl.

\section{Chemicals}

Chemicals obtained from commercial sources with purity above $95 \%$ were used without further purification. $\mathrm{ArMgBr}$ were prepared from aromatic bromo and magnesium turnings in anhydrous THF under nitrogen atmosphere and titrated before use with $\mathrm{I}_{2} / \mathrm{LiCl}^{[143]}$

The following compounds are known and were synthesized according to previously described methods:

$\mathrm{Cp}^{*} \mathrm{Col}_{2}(\mathrm{CO}),{ }^{[47]}$ pyridones $\mathbf{1 7 2 ,},{ }^{[144]}$ propargylic carbonates $\mathbf{8 8},{ }^{[145]}$ heterocycles azine 112, ${ }^{[146]}$ TAM-benzamide 159. ${ }^{[80]}$

The following compounds were kindly synthesized and provided by the persons listed below:

Karsten Rauch: $\left[\mathrm{RuCl}_{2}(p \text {-cymene })\right]_{2},\left[\mathrm{Cp} * \mathrm{RhCl}_{2}\right]_{2}$, dry and/or degassed solvents (DCE, 1,4-dioxane, PhMe, DME).

Dr. Hui Wang: $\mathrm{Cp}^{*} \mathrm{Col}_{2}(\mathrm{CO}),\left[\mathrm{Cp} * \mathrm{Co}(\mathrm{MeCN})_{3}\right]\left(\mathrm{SbF}_{6}\right)_{2}, \mathbf{8 8 a}$.

M. Sc. Nikolaos Kaplaneris: indole 35, 172a.

M. Sc. Uttam Dhawa: 172aa. 
M. Sc. Korkit Korvorapun: 172a.

M. Sc. Zhigao Shen: amides 112. TAM-benzamide 159.

\subsection{General Procedures}

General Procedure A: Domino C-H Activation/Directing Group Migration/Alkyne Annulation: Unique Selectivity by $d^{6}$-Cobalt(III) Catalysts

Pyridones 172 (0.50 mmol, 1.0 equiv), propargylic carbonates 88 (1.50 mmol, 3.0 equiv), $\mathrm{Cp}^{*} \mathrm{Co}(\mathrm{CO}) \mathrm{I}_{2}(24.0 \mathrm{mg}, 10 \mathrm{~mol} \%), \mathrm{AgSbF}_{6}(34.4 \mathrm{mg}, 20 \mathrm{~mol} \%), \mathrm{HOAc}(15.0 \mathrm{mg}$, $50 \mathrm{~mol} \%)$, and TFE $\left(2.0 \mathrm{~mL}\right.$ ) were placed in a $25 \mathrm{~mL}$ Schlenk pressure tube under $\mathrm{N}_{2}$ atmosphere, and stirred at $90{ }^{\circ} \mathrm{C}$ for $20 \mathrm{~h}$. After cooling to ambient temperature, the mixture was transferred into a round bottom flask with $\mathrm{CH}_{2} \mathrm{Cl}_{2}(20 \mathrm{~mL})$ and concentrated in vacuo. Purification by column chromatography on silica gel ( $n$ hexane/EtOAc: $3 / 1 \rightarrow 1 / 1$ ) afforded the desired products 173 .

\section{General Procedure B: Manganese(I)-Catalyzed C-H Activation Domino Alkyne} Annulation by Transformable Pyridines

Pyridones 172 (0.25 mmol, 1.0 equiv), propargylic carbonates 88 (0.38 mmol, 1.5 equiv), $\mathrm{MnBr}(\mathrm{CO})_{5}(6.9 \mathrm{mg}, 10 \mathrm{~mol} \%), \mathrm{NaOAc}(10 \mathrm{mg}, 50 \mathrm{~mol} \%), \mathrm{BPh}_{3}$ (60 mg, 1.0 equiv), and DME (1.0 mL) were placed in a $25 \mathrm{~mL}$ Schlenk pressure tube under $\mathrm{N}_{2}$ atmosphere, and stirred at $100{ }^{\circ} \mathrm{C}$ for $24 \mathrm{~h}$. After cooling to ambient temperature, the mixture was transferred into a round bottom flask with $\mathrm{CH}_{2} \mathrm{Cl}_{2}(20 \mathrm{~mL})$ and concentrated in vacuo. Purification by column chromatography on silica gel afforded the desired products 180 .

\section{General procedure C: Manganese(II/III/I)-catalyzed C-H arylation in flow}

A $5 \mathrm{~mL}$ oven-dried round-bottom Schlenk flask was charged with amides 112 (0.25 mmol, 1.0 equiv), $\mathrm{MnCl}_{2}$ (3.1 mg, $\left.10 \mathrm{~mol} \%\right)$, neocuproine (10.4 mg, $20 \mathrm{~mol} \%$ ) and TMEDA (74 $\mu \mathrm{L}, 2.0$ equiv) in THF $(0.10 \mathrm{~mL})$ and $\operatorname{ArMgBr}(0.4 \mathrm{~mL}, 4.0$ equiv, $2.5 \mathrm{~m}$ in THF) under $\mathrm{N}_{2}$ atmosphere. A solution of 1,2-dichloro-2-methylpropane (DCIB) (88 $\mu \mathrm{L}$, 
3.0 equiv) in THF $(0.40 \mathrm{~mL})$ was prepared. The solutions were charged in separate syringes pumps (Vapourtec $\mathrm{V}-3$ ) operating at a flow rate of $100 \mu \mathrm{L} / \mathrm{min}$. The two solutions were mixed with a T-joint connection. Subsequently, the solution was pumped into the inlet of the $10 \mathrm{~mL}$ standard heated reactor with 100 min residence time. The back pressure was set to 4.0 bar and the temperature of the reactor was set at $80^{\circ} \mathrm{C}$. Using the Flow Wizard system, the solution was collected automatically. Next, a saturated aqueous $\mathrm{NH}_{4} \mathrm{Cl}(15 \mathrm{~mL})$ was added and the reaction mixture was extracted with EtOAc $(3 \times 15 \mathrm{~mL})$. The combined organic layers were dried over $\mathrm{Na}_{2} \mathrm{SO}_{4}$, filtered and concentrated in vacuo. The crude product was purified by column chromatography on silica gel.

\section{General procedure D: Manganese(II/III/I)-catalyzed C-H arylation in batch}

To a stirred solution of amides 112 (0.25 mmol, 1.0 equiv), $\mathrm{MnCl}_{2}$ (3.1 mg, $10 \mathrm{~mol} \%$ ), neocuproine (10.4 mg, $20 \mathrm{~mol} \%$ ) and TMEDA (74 $\mu \mathrm{L}, 2.0$ equiv) in THF (0.40 mL), $\operatorname{ArMgBr}(0.40 \mathrm{~mL}, 4.0$ equiv, $2.5 \mathrm{~m}$ in THF) was added dropwise over $30 \mathrm{~s}$. Then, the mixture was stirred for $1 \mathrm{~min}$ at ambient temperature, and a solution of 1,2-dichloro2-methylpropane (DCIB) ( $88 \mu \mathrm{L}, 3.0$ equiv) in THF $(0.10 \mathrm{~mL})$ was added to the reaction mixture. Then, the mixture was placed in a pre-heated oil bath at $60^{\circ} \mathrm{C}$. After stirring for $16 \mathrm{~h}$, a saturated aqueous $\mathrm{NH}_{4} \mathrm{Cl}(15 \mathrm{~mL})$ was added and the reaction mixture was extracted with EtOAc $(3 \times 15 \mathrm{~mL})$. The combined organic layers were dried over $\mathrm{Na}_{2} \mathrm{SO}_{4}$, filtered and concentrated in vacuo. The crude product was purified by column chromatography on silica gel.

\section{General Procedure E: Ferraelectrocatalyzed C-H Arylation}

The electrocatalysis was carried out in an undivided cell with a RVC anode $(10 \mathrm{~mm} \times$ $15 \mathrm{~mm} \times 6 \mathrm{~mm})$ and a platinum cathode $(10 \mathrm{~mm} \times 15 \mathrm{~mm} \times 0.25 \mathrm{~mm})$. A solution of $\operatorname{ArMgBr}(0.88 \mathrm{~mL}, 7.0$ equiv, $2.0 \mathrm{M}$ in THF) was slowly added to a mixture of amide 159 (0.25 mmol, 1.00 equiv), Fe(acac) $3(8.8 \mathrm{mg}, 10 \mathrm{~mol} \%)$, dppe $(10.0 \mathrm{mg}, 10 \mathrm{~mol} \%)$ and 
$\mathrm{ZnCl}_{2} \cdot \mathrm{TMEDA}$ (189 mg, 3.00 equiv) were placed in a $10 \mathrm{~mL}$ cell and dissolved in THF $(5 \mathrm{~mL})$. Electrolysis was performed at $40^{\circ} \mathrm{C}$ with a constant current of $5 \mathrm{~mA}$ maintained for $6 \mathrm{~h}(4.50 \mathrm{~F} / \mathrm{mol})$. At ambient temperature, a saturated aqueous $\mathrm{NH}_{4} \mathrm{Cl}$ solution $(10 \mathrm{~mL})$ was added and the RVC anode was washed with EtOAc $(3 \times 2 \mathrm{~mL})$ in an ultrasonic bath. The combined phases were extracted with EtOAc $(3 \times 10 \mathrm{~mL})$ and then dried over $\mathrm{Na}_{2} \mathrm{SO}_{4}$. Evaporation of the solvents and purification by column chromatography on silica gel ( $n$-hexane/EtOAc) yielded the desired products 192-214.

\section{General procedure F: Manganaelectrocatalyzed C-H Arylation}

The electrocatalysis was carried out in an undivided cell with a RVC anode $(10 \mathrm{~mm} \times$ $15 \mathrm{~mm} \times 6 \mathrm{~mm})$ and a platinum cathode $(10 \mathrm{~mm} \times 15 \mathrm{~mm} \times 0.25 \mathrm{~mm})$. A solution of $\operatorname{ArMgBr}(0.5 \mathrm{~mL}, 4.0$ equiv, $2.0 \mathrm{~m}$ in THF) was slowly added to a mixture of amide $\mathbf{1 1 2}$ (0.25 mmol, 1.00 equiv), $\mathrm{MnCl}_{2}$ (3.1 mg, $10 \mathrm{~mol} \%$ ), neocuproine (10.4 mg, $20 \mathrm{~mol} \%$ ) and TMEDA (74 $\mu \mathrm{L}$, 2.0 equiv) were placed in a $10 \mathrm{~mL}$ cell and dissolved in THF $(5 \mathrm{~mL})$. Electrolysis was performed at $60^{\circ} \mathrm{C}$ with a constant current of $3 \mathrm{~mA}$ maintained for $18 \mathrm{~h}$. At ambient temperature, a saturated aqueous $\mathrm{NH}_{4} \mathrm{Cl}$ solution $(10 \mathrm{~mL})$ was added and the RVC anode was washed with EtOAc $(3 \times 2 \mathrm{~mL})$ in an ultrasonic bath. The combined phases were extracted with EtOAc $(3 \times 10 \mathrm{~mL})$ and then dried over $\mathrm{Na}_{2} \mathrm{SO}_{4}$. Evaporation of the solvents and purification by column chromatography on silica gel ( $n$-hexane/EtOAc) yielded the desired product 188. 


\subsection{Domino C-H Activation/Directing Group Migration/Alkyne Annulation: Unique Selectivity by $\mathrm{d}^{6}$-Cobalt(III) Catalysts}

\subsubsection{Characterization Data}<smiles>CC1(C)C(c2ccccn2)=C(c2ccccc2)c2cccc(=O)n21</smiles>

3,3-Dimethyl-1-phenyl-2-(pyridin-2-yl)indolizin-5(3H)-one (173aa): The general procedure A was followed using $2 \mathrm{H}$-[1,2'-bipyridin]-2-one (172a) (86.1 mg, $0.50 \mathrm{mmol}$ ) and methyl (2-methyl-4-phenylbut-3-yn-2-yl)carbonate (88a) (328 mg, $1.50 \mathrm{mmol}$ ). Purification by column chromatography on silica gel ( $n$-hexane/EtOAc: $1 / 1$ ) yielded 173aa (127 mg, 81\%) as a white solid. M.p.: $123-124{ }^{\circ} \mathrm{C} .{ }^{1} \mathbf{H}-\mathbf{N M R}\left(400 \mathrm{MHz}, \mathrm{CDCl}_{3}\right) \delta$ $=8.61(\mathrm{dd}, J=4.8,1.8 \mathrm{~Hz}, 1 \mathrm{H}), 7.39-7.27(\mathrm{~m}, 4 \mathrm{H}), 7.27-7.19(\mathrm{~m}, 3 \mathrm{H}), 7.08(\mathrm{ddd}, J=7.6$, 4.8, $1.2 \mathrm{~Hz}, 1 \mathrm{H}$ ), 6.83 (ddd, $J=8.0,1.2,1.2 \mathrm{~Hz}, 1 \mathrm{H}$ ), 6.33 (dd, J = 9.0, $1.2 \mathrm{~Hz}, 1 \mathrm{H}$ ), 6.04 $(\mathrm{dd}, J=6.9,1.2 \mathrm{~Hz}, 1 \mathrm{H}), 2.03(\mathrm{~s}, 6 \mathrm{H}) .{ }^{13} \mathrm{C}-\mathrm{NMR}\left(100 \mathrm{MHz}, \mathrm{CDCl}_{3}\right) \delta=162.2\left(\mathrm{C}_{q}\right), 152.5$ $\left(\mathrm{C}_{\mathrm{q}}\right), 150.7\left(\mathrm{C}_{\mathrm{q}}\right), 150.4\left(\mathrm{C}_{\mathrm{q}}\right), 149.3(\mathrm{CH}), 138.9(\mathrm{CH}), 135.6(\mathrm{CH}), 133.2\left(\mathrm{C}_{\mathrm{q}}\right), 131.8\left(\mathrm{C}_{\mathrm{q}}\right)$, $129.3(\mathrm{CH}), 128.9(\mathrm{CH}), 128.6(\mathrm{CH}), 125.7(\mathrm{CH}), 122.5(\mathrm{CH}), 118.9(\mathrm{CH}), 100.0(\mathrm{CH}), 75.1$ $\left(\mathrm{C}_{\mathrm{q}}\right), 21.1\left(\mathrm{CH}_{3}\right)$. IR (ATR): 1654, 1577, 1529, 1462, 1443, 1154, 793, 701, 617, $498 \mathrm{~cm}^{-}$ 1. MS (ESI) $m / z$ (relative intensity): 651 (7) [2M+Na $]^{+}, 315$ (100) [M+H] ${ }^{+}$. HR-MS (ESI) $\mathrm{m} / \mathrm{z}$ calcd for $\mathrm{C}_{21} \mathrm{H}_{19} \mathrm{~N}_{2} \mathrm{O}[\mathrm{M}+\mathrm{H}]^{+} 315.1492$, found 315.1495. The compound 173aa was also unambiguously characterized by X-ray crystallographic diffraction analysis (vide infra). 


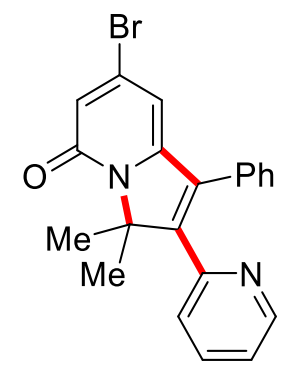

7-Bromo-3,3-dimethyl-1-phenyl-2-(pyridin-2-yl)indolizin-5(3H)-one (173ba): The general procedure $\mathrm{A}$ was followed using 4-bromo-2H-[1,2'-bipyridin]-2-one (172b) (126 mg, $0.50 \mathrm{mmol}$ ) and methyl (2-methyl-4-phenylbut-3-yn-2-yl)carbonate (88a) (328 mg, $1.50 \mathrm{mmol}$ ). Purification by column chromatography on silica gel ( $n$ hexane/EtOAc: $1 / 1$ ) yielded 173ba (132 mg, 67\%) as a white solid. M.p.: 200-201 ${ }^{\circ} \mathrm{C}$. ${ }^{1} \mathrm{H}-\mathrm{NMR}\left(400 \mathrm{MHz}, \mathrm{CDCl}_{3}\right) \delta=8.63(\mathrm{ddd}, J=4.8,1.9,0.9 \mathrm{~Hz}, 1 \mathrm{H}), 7.39-7.34(\mathrm{~m}, 4 \mathrm{H})$, 7.23 (ddd, $J=5.6,2.7,1.4 \mathrm{~Hz}, 2 \mathrm{H}$ ), 7.12 (ddd, $J=7.6,4.8,1.1 \mathrm{~Hz}, 1 \mathrm{H}$ ), 6.85 (dd, J = 8.0, $1.1 \mathrm{~Hz}, 1 \mathrm{H}), 6.58(\mathrm{~d}, J=1.9 \mathrm{~Hz}, 1 \mathrm{H}), 6.18(\mathrm{~d}, J=1.9 \mathrm{~Hz}, 1 \mathrm{H}), 2.03(\mathrm{~s}, 6 \mathrm{H}) .{ }^{13} \mathrm{C}-\mathrm{NMR}(100$ $\left.\mathrm{MHz}, \mathrm{CDCl}_{3}\right) \delta=160.6\left(\mathrm{C}_{\mathrm{q}}\right), 152.5\left(\mathrm{C}_{\mathrm{q}}\right), 151.8\left(\mathrm{C}_{\mathrm{q}}\right), 150.6\left(\mathrm{C}_{\mathrm{q}}\right), 149.3(\mathrm{CH}), 135.7(\mathrm{CH})$, $135.2\left(\mathrm{C}_{q}\right), 132.4\left(\mathrm{C}_{\mathrm{q}}\right), 131.1\left(\mathrm{C}_{\mathrm{q}}\right), 129.2(\mathrm{CH}), 129.1(\mathrm{CH}), 128.9(\mathrm{CH}), 125.7(\mathrm{CH}), 122.8$ (CH), $120.5(\mathrm{CH}), 104.0(\mathrm{CH}), 75.3\left(\mathrm{C}_{\mathrm{q}}\right), 21.1\left(\mathrm{CH}_{3}\right) . \mathrm{IR}$ (ATR): 1652, 1583, 1518, 1462, 887, 790, $702 \mathrm{~cm}^{-1}$. MS (ESI) $\mathrm{m} / \mathrm{z}$ (relative intensity): 393 (100) $[\mathrm{M}+\mathrm{H}]^{+}$. HR-MS (ESI) $m / z$ calcd for $\mathrm{C}_{21} \mathrm{H}_{18} \mathrm{~N}_{2} \mathrm{OBr}[\mathrm{M}+\mathrm{H}]^{+}$393.0597, found 393.0602.

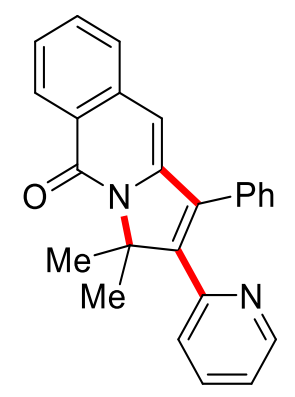

3,3-Dimethyl-1-phenyl-2-(pyridin-2-yl)pyrrolo[1,2-b]isoquinolin-5(3H)-one (173ca): The general procedure A was followed using 2-(pyridin-2-yl)isoquinolin-1(2H)-one (172c) (111 mg, $0.50 \mathrm{mmol})$ and methyl (2-methyl-4-phenylbut-3-yn-2-yl)carbonate (88a) (328 mg, $1.50 \mathrm{mmol})$. Purification by column chromatography on silica gel $(n-$ hexane/EtOAc: $1 / 1)$ yielded $173 \mathrm{ca}(100 \mathrm{mg}, 55 \%)$ as a white solid. M.p.: $208-209{ }^{\circ} \mathrm{C}$. ${ }^{1} \mathrm{H}-\mathrm{NMR}\left(300 \mathrm{MHz}, \mathrm{CDCl}_{3}\right) \delta=8.69(\mathrm{ddd}, J=5.0,1.9,0.9 \mathrm{~Hz}, 1 \mathrm{H}), 8.47$ (dd, $J=8.1,1.50$ 
$\mathrm{Hz}, 1 \mathrm{H}), 7.65-7.54(\mathrm{~m}, 1 \mathrm{H}), 7.51-7.31(\mathrm{~m}, 8 \mathrm{H}), 7.16(\mathrm{ddd}, J=7.6,4.8,1.1 \mathrm{~Hz}, 1 \mathrm{H}), 6.94$ $(\mathrm{dd}, J=8.0,1.1 \mathrm{~Hz}, 1 \mathrm{H}), 6.43(\mathrm{~s}, 1 \mathrm{H}), 2.15(\mathrm{~s}, 6 \mathrm{H}) .{ }^{13} \mathrm{C}-\mathrm{NMR}\left(100 \mathrm{MHz}, \mathrm{CDCl}_{3}\right) \delta=160.6$ $\left(C_{q}\right), 144.1\left(C_{q}\right), 143.0\left(C_{q}\right), 139.5(C H), 138.3\left(C_{q}\right), 136.4\left(C_{q}\right), 133.1\left(C_{q}\right), 132.3\left(C_{q}\right)$, $132.0(\mathrm{CH}), 130.7(\mathrm{CH}), 128.3(\mathrm{CH}), 128.1(\mathrm{CH}), 128.0(\mathrm{CH}), 126.4(\mathrm{CH}), 125.8(\mathrm{CH})$, $123.9\left(\mathrm{C}_{\mathrm{q}}\right), 120.0(\mathrm{CH}), 111.0(\mathrm{CH}), 99.4(\mathrm{CH}), 38.4\left(\mathrm{C}_{\mathrm{q}}\right), 28.8\left(\mathrm{CH}_{3}\right)$. IR (ATR): 1652, 1621, $1600,1583,1563,1462,1431,1353,1334,701 \mathrm{~cm}^{-1}$. MS (ESI) $\mathrm{m} / z$ (relative intensity): 751 (15) $[2 \mathrm{M}+\mathrm{Na}]^{+}, 365(100)[\mathrm{M}+\mathrm{H}]^{+}$. HR-MS (ESI) $\mathrm{m} / z$ calcd for $\mathrm{C}_{25} \mathrm{H}_{21} \mathrm{~N}_{2} \mathrm{O}[\mathrm{M}+\mathrm{H}]^{+}$ 365.1648, found 365.1649 . The compound $173 \mathrm{ca}$ was also unambiguously characterized by X-ray crystallographic diffraction analysis (vide infra).

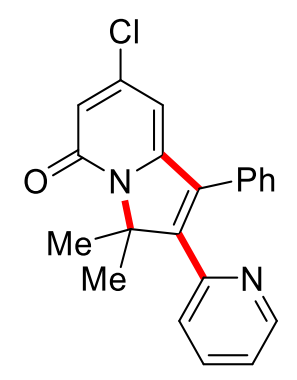

7-Chloro-3,3-dimethyl-1-phenyl-2-(pyridin-2-yl)indolizin-5(3H)-one (173da): The general procedure A was followed using 4-chloro-2H-[1,2'-bipyridin]-2-one (172d) (103 mg, $0.50 \mathrm{mmol}$ ) and methyl (2-methyl-4-phenylbut-3-yn-2-yl)carbonate (88a) (328 mg, $1.50 \mathrm{mmol}$ ). Purification by column chromatography on silica gel ( $n$ hexane/EtOAc: $1 / 1$ ) yielded $173 \mathrm{da}$ (95.9 mg, 55\%) as a white solid. M.p.: $192-193{ }^{\circ} \mathrm{C}$. ${ }^{1} \mathrm{H}-\mathrm{NMR}\left(400 \mathrm{MHz}^{\mathrm{COCl}} \mathrm{CDC}_{3}\right) \delta=8.60(\mathrm{ddd}, J=4.8,1.8,1.0 \mathrm{~Hz}, 1 \mathrm{H}), 7.93(\mathrm{~d}, J=7.6 \mathrm{~Hz}$, 1H), 7.46-7.30 (m, 4H), 7.27-7.20 (m, 2H), 7.13 (ddd, J = 7.6, 4.8, 1.0 Hz, 1H), 6.87 (dd, $J=7.9,1.0 \mathrm{~Hz}, 1 \mathrm{H}), 5.88(\mathrm{~d}, J=7.6 \mathrm{~Hz}, 1 \mathrm{H}), 2.06(\mathrm{~s}, 6 \mathrm{H}) .{ }^{13} \mathrm{C}-\mathrm{NMR}\left(100 \mathrm{MHz}, \mathrm{CDCl}_{3}\right) \delta=$ $158.7\left(\mathrm{C}_{\mathrm{q}}\right), 152.2\left(\mathrm{C}_{\mathrm{q}}\right), 151.4\left(\mathrm{C}_{\mathrm{q}}\right), 150.8\left(\mathrm{C}_{\mathrm{q}}\right), 149.4(\mathrm{CH}), 147.9(\mathrm{CH}), 135.7(\mathrm{CH}), 133.0$ $\left(\mathrm{C}_{q}\right), 131.5\left(\mathrm{C}_{\mathrm{q}}\right), 129.3(\mathrm{CH}), 129.1(\mathrm{CH}), 128.8(\mathrm{CH}), 125.8(\mathrm{CH}), 122.7(\mathrm{CH}), 101.3(\mathrm{CH})$, $91.4\left(C_{q}\right), 76.5\left(C_{q}\right), 21.1\left(C_{3}\right) . I R(A T R):$ 1727, 1691, 1610, 1547, 1484, 1399, 1131, 1037, 881, $726 \mathrm{~cm}^{-1}$. MS (ESI) $\mathrm{m} / \mathrm{z}$ (relative intensity): 349 (100) [M+H] ${ }^{+}$. HR-MS (ESI) $m / z$ calcd for $\mathrm{C}_{21} \mathrm{H}_{18} \mathrm{~N}_{2} \mathrm{OCl}[\mathrm{M}+\mathrm{H}]^{+} 349.1102$, found 349.1104 . 


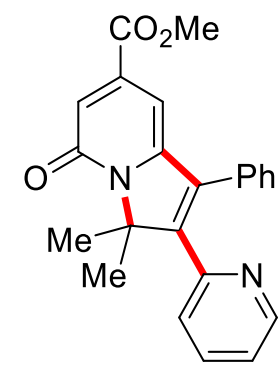

Methyl 3,3-dimethyl-5-oxo-1-phenyl-2-(pyridin-2-yl)-3,5-dihydroindolizine-7carboxylate (173ea): The general procedure A was followed using methyl 2-oxo- $2 \mathrm{H}$ [1,2'-bipyridine]-4-carboxylate $(\mathbf{1 7 2 e})(115 \mathrm{mg}, 0.50 \mathrm{mmol})$ and methyl (2-methyl-4phenylbut-3-yn-2-yl)carbonate (88a) (328 mg, $1.50 \mathrm{mmol}$ ). Purification by column chromatography on silica gel ( $n$-hexane/EtOAc: $1 / 1$ ) yielded $173 e a(96.8 \mathrm{mg}, 52 \%)$ as a white solid. M.p.: ${ }^{165-166}{ }^{\circ} \mathrm{C} .{ }^{1} \mathbf{H}-\mathrm{NMR}\left(400 \mathrm{MHz}, \mathrm{CDCl}_{3}\right) \delta=8.66$ (ddd, J = 4.9, 1.9, $1.0 \mathrm{~Hz}, 1 \mathrm{H}), 7.42-7.34(\mathrm{~m}, 4 \mathrm{H}), 7.31-7.23(\mathrm{~m}, 2 \mathrm{H}), 7.14(\mathrm{ddd}, J=7.6,4.9,1.0 \mathrm{~Hz}, 1 \mathrm{H})$, $7.02(\mathrm{~d}, J=1.6 \mathrm{~Hz}, 1 \mathrm{H}), 6.87(\mathrm{dd}, J=8.0,1.0 \mathrm{~Hz}, 1 \mathrm{H}), 6.55(\mathrm{~d}, J=1.6 \mathrm{~Hz}, 1 \mathrm{H}), 3.86(\mathrm{~s}$, 3H), $2.07(\mathrm{~s}, 6 \mathrm{H}) .{ }^{13} \mathrm{C}-\mathrm{NMR}\left(100 \mathrm{MHz}, \mathrm{CDCl}_{3}\right) \delta=165.7\left(\mathrm{C}_{\mathrm{q}}\right), 161.7\left(\mathrm{C}_{\mathrm{q}}\right), 152.2\left(\mathrm{C}_{\mathrm{q}}\right), 151.7$ $\left(C_{q}\right), 151.1\left(C_{q}\right), 149.4(C H), 140.4(C H), 135.7\left(C_{q}\right), 133.2\left(C_{q}\right), 131.5\left(C_{q}\right), 129.4(C H)$, $129.1(\mathrm{CH}), 128.8(\mathrm{CH}), 125.8(\mathrm{CH}), 122.8(\mathrm{CH}), 120.6(\mathrm{CH}), 98.6(\mathrm{CH}), 75.5\left(\mathrm{C}_{\mathrm{q}}\right), 52.7$ $\left(\mathrm{CH}_{3}\right), 21.0\left(\mathrm{CH}_{3}\right)$. IR (ATR): 1730, 1661, 1593, 1531, 1463, 1442, 1251, 1086, 775, 703 $\mathrm{cm}^{-1}$. MS (ESI) m/z (relative intensity): $767(43)[2 \mathrm{M}+\mathrm{Na}]^{+}, 395(100)[\mathrm{M}+\mathrm{Na}]^{+}, 373(78)$ $[\mathrm{M}+\mathrm{H}]^{+}$. HR-MS (ESI) $m / z$ calcd for $\mathrm{C}_{23} \mathrm{H}_{21} \mathrm{~N}_{2} \mathrm{O}_{3}[\mathrm{M}+\mathrm{H}]^{+} 373.1547$, found 373.1546 .<smiles>CC1(C)C(c2ccccn2)=C(c2ccccc2)c2cc(C(F)(F)F)cc(=O)n21</smiles>

\section{3,3-Dimethyl-1-phenyl-2-(pyridin-2-yl)-7-(trifluoromethyl)indolizin-5(3H)-one}

(173fa): The general procedure A was followed using methyl 2-oxo-2H-[1,2'bipyridine]-4-carboxylate (172f) (120.0 mg, $0.50 \mathrm{mmol}$ ) and methyl (2-methyl-4- 
phenylbut-3-yn-2-yl)carbonate (88a) (328 mg, $1.50 \mathrm{mmol}$ ). Purification by column chromatography on silica gel ( $n$-hexane/EtOAc: $1 / 1)$ yielded $173 \mathrm{fa}(99.4 \mathrm{mg}, 52 \%)$ as a white solid. M.p.: $151-153{ }^{\circ} \mathrm{C} .{ }^{1} \mathrm{H}-\mathrm{NMR}(400 \mathrm{MHz}, \mathrm{CDCl} 3) \delta=8.66$ (ddd, $J=4.8,1.8$, $0.9 \mathrm{~Hz}, 1 \mathrm{H}), 7.43-7.37(\mathrm{~m}, 4 \mathrm{H}), 7.29-7.23(\mathrm{~m}, 2 \mathrm{H}), 7.15(\mathrm{ddd}, J=7.6,4.8,1.1 \mathrm{~Hz}, 1 \mathrm{H})$, $6.87(\mathrm{dd}, J=8.0,1.1 \mathrm{~Hz}, 1 \mathrm{H}), 6.64(\mathrm{dd}, J=1.8,0.9 \mathrm{~Hz}, 1 \mathrm{H}), 6.16(\mathrm{~d}, J=1.8 \mathrm{~Hz}, 1 \mathrm{H}), 2.07$ (s, 6H). ${ }^{13} \mathrm{C}-\mathrm{NMR}\left(100 \mathrm{MHz}, \mathrm{CDCl}_{3}\right) \delta=160.8\left(\mathrm{C}_{\mathrm{q}}\right), 152.7\left(\mathrm{C}_{\mathrm{q}}\right), 152.1\left(\mathrm{C}_{\mathrm{q}}\right), 151.9\left(\mathrm{C}_{\mathrm{q}}\right)$, $149.4(\mathrm{CH}), 141.1\left(\mathrm{q},{ }^{2} \mathrm{~J}_{\mathrm{C}-\mathrm{F}}=33.3 \mathrm{~Hz}, \mathrm{C}_{\mathrm{q}}\right), 135.8(\mathrm{CH}), 132.8\left(\mathrm{C}_{\mathrm{q}}\right), 131.2\left(\mathrm{C}_{\mathrm{q}}\right), 129.2(\mathrm{CH})$, $129.1(\mathrm{CH}), 129.0(\mathrm{CH}), 125.8(\mathrm{CH}), 122.9(\mathrm{CH}), 122.6$ (q, $\left.{ }^{1} \mathrm{~J}_{\mathrm{C}-\mathrm{F}}=274.1 \mathrm{~Hz}, \mathrm{C}_{\mathrm{q}}\right), 116.1$ (q, $\left.{ }^{3} J_{C-F}=4.2 \mathrm{~Hz}, \mathrm{CH}\right), 95.0\left(q,{ }^{3} \mathrm{C}_{\mathrm{C}-\mathrm{F}}=3.0 \mathrm{~Hz}, \mathrm{CH}\right), 75.8\left(\mathrm{C}_{\mathrm{q}}\right), 21.0\left(\mathrm{CH}_{3}\right) .{ }^{19} \mathrm{~F}-\mathrm{NMR}(376 \mathrm{MHz}$, $\left.\mathrm{CDCl}_{3}\right) \delta=-66.1$ (s). IR (ATR): 2050, 1672, 1603, 1538, 1466, 1281, 1175, 1138, 751, $702 \mathrm{~cm}^{-1}$. MS (ESI) m/z (relative intensity): $787(20)[2 \mathrm{M}+\mathrm{Na}]^{+}, 405(18)[2 \mathrm{M}+\mathrm{Na}]^{+}, 383$ (100) $[\mathrm{M}+\mathrm{H}]^{+}$. HR-MS (ESI) $m / z$ calcd for $\mathrm{C}_{22} \mathrm{H}_{18} \mathrm{~N}_{2} \mathrm{OF}{ }_{3}[\mathrm{M}+\mathrm{H}]^{+} 383.1367$, found 383.1366 .

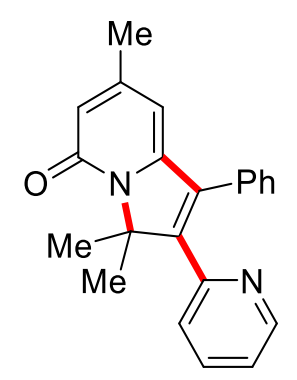

3,3,7-Trimethyl-1-phenyl-2-(pyridin-2-yl)indolizin-5(3H)-one (173ga): The general procedure A was followed using 4-methyl-2H-[1,2'-bipyridin]-2-one (172g) $(93.1 \mathrm{mg}$, $0.50 \mathrm{mmol}$ ) and methyl (2-methyl-4-phenylbut-3-yn-2-yl)carbonate (88a) (328 mg, $1.50 \mathrm{mmol}$ ). Purification by column chromatography on silica gel ( $n$-hexane/EtOAc: $1 / 1$ ) yielded 173ga (123 mg, 75\%) as a white solid. M.p.: $126-127{ }^{\circ} \mathrm{C} .{ }^{1} \mathbf{H}-\mathrm{NMR}$ (400 MHz, $\left.\mathrm{CDCl}_{3}\right) \delta=8.63(\mathrm{dd}, J=4.6,1.4 \mathrm{~Hz}, 1 \mathrm{H}), 7.40-7.31(\mathrm{~m}, 4 \mathrm{H}), 7.24(\mathrm{dd}, J=6.2,3.1 \mathrm{~Hz}, 2 \mathrm{H})$, $7.10(\mathrm{dd}, J=7.8,4.6 \mathrm{~Hz}, 1 \mathrm{H}), 6.85(\mathrm{~d}, J=7.8 \mathrm{~Hz}, 1 \mathrm{H}), 6.12(\mathrm{~s}, 1 \mathrm{H}), 5.82(\mathrm{~s}, 1 \mathrm{H}), 2.10(\mathrm{~s}$, 3H), $2.06(\mathrm{~s}, 6 \mathrm{H}) .{ }^{13} \mathrm{C}-\mathrm{NMR}\left(100 \mathrm{MHz}, \mathrm{CDCl}_{3}\right) \delta=160.5\left(\mathrm{C}_{\mathrm{q}}\right), 152.5\left(\mathrm{C}_{\mathrm{q}}\right), 150.9\left(\mathrm{C}_{\mathrm{q}}\right), 150.0$ $\left(\mathrm{C}_{\mathrm{q}}\right), 149.7\left(\mathrm{C}_{\mathrm{q}}\right), 149.2(\mathrm{CH}), 135.6(\mathrm{CH}), 135.5(\mathrm{CH}), 133.2\left(\mathrm{C}_{\mathrm{q}}\right), 131.9\left(\mathrm{C}_{\mathrm{q}}\right), 129.3(\mathrm{CH})$, 
$128.9(\mathrm{CH}), 128.5(\mathrm{CH}), 125.6(\mathrm{CH}), 122.4(\mathrm{CH}), 102.7(\mathrm{CH}), 74.5\left(\mathrm{C}_{\mathrm{q}}\right), 21.5\left(\mathrm{CH}_{3}\right), 21.3$ $\left(\mathrm{CH}_{3}\right)$. IR (ATR): 1655, 1584, 1531, 1462, 1433, 1349, 1156, 791, 734, $701 \mathrm{~cm}^{-1}$. MS (ESI) $m / z$ (relative intensity): $329(100)[\mathrm{M}+\mathrm{H}]^{+}$. HR-MS (ESI) $m / z$ calcd for $\mathrm{C}_{22} \mathrm{H}_{21} \mathrm{~N}_{2} \mathrm{O}[\mathrm{M}+\mathrm{H}]^{+}$ 329.1648, found 329.1653. The compound 173ga was also unambiguously characterized by X-ray crystallographic diffraction analysis (vide infra).

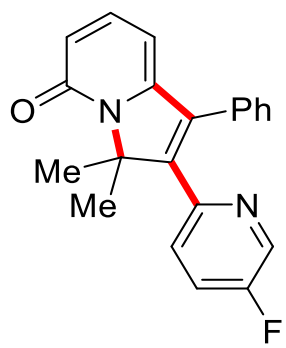

2-(5-Fluoropyridin-2-yl)-3,3-dimethyl-1-phenylindolizin-5(3H)-one (173ha): The general procedure A was followed using 5'-fluoro- $2 \mathrm{H}$-[1,2'-bipyridin]-2-one (172h) (95.1 mg, $0.50 \mathrm{mmol}$ ) and methyl (2-methyl-4-phenylbut-3-yn-2-yl)carbonate (88a) (328 mg, $1.50 \mathrm{mmol}$ ). Purification by column chromatography on silica gel ( $n$ hexane/EtOAc: $1 / 1$ ) yielded $173 \mathrm{ha}(104.7 \mathrm{mg}, 63 \%)$ as a white solid. M.p.: $177-178^{\circ} \mathrm{C}$. ${ }^{1} \mathbf{H}-\mathbf{N M R}\left(400 \mathrm{MHz}, \mathrm{CDCl}_{3}\right) \delta=8.49(\mathrm{dd}, J=3.0,0.6 \mathrm{~Hz}, 1 \mathrm{H}), 7.42-7.33(\mathrm{~m}, 3 \mathrm{H}), 7.30$ $7.19(\mathrm{~m}, 3 \mathrm{H}), 7.09$ (ddd, $J=8.8,8.1,3.0 \mathrm{~Hz}, 1 \mathrm{H}), 6.87$ (ddd, $J=8.8,4.4,0.6 \mathrm{~Hz}, 1 \mathrm{H}), 6.36$ (dd, $J=9.1,1.1 \mathrm{~Hz}, 1 \mathrm{H}), 6.04(\mathrm{dd}, J=6.9,1.1 \mathrm{~Hz}, 1 \mathrm{H}), 2.05(\mathrm{~s}, 6 \mathrm{H}) .{ }^{13} \mathrm{C}-\mathrm{NMR}(100 \mathrm{MHz}$, $\left.\mathrm{CDCl}_{3}\right) \delta=162.1\left(\mathrm{C}_{\mathrm{q}}\right), 158.3\left(\mathrm{~d},{ }^{1} \mathrm{~J}_{\mathrm{C}-\mathrm{F}}=259.5 \mathrm{~Hz}, \mathrm{C}_{\mathrm{q}}\right), 150.3\left(\mathrm{C}_{\mathrm{q}}\right), 149.5\left(\mathrm{C}_{\mathrm{q}}\right), 148.5\left(\mathrm{~d},{ }^{4} \mathrm{C}_{\mathrm{C}-\mathrm{F}}\right.$ $\left.=4.5 \mathrm{~Hz}, \mathrm{C}_{\mathrm{q}}\right), 138.9(\mathrm{CH}), 137.6\left(\mathrm{~d},{ }^{2} \mathrm{~J}_{\mathrm{C}-\mathrm{F}}=23.5 \mathrm{~Hz}, \mathrm{CH}\right), 133.3(\mathrm{CH}), 131.8(\mathrm{CH}), 129.3$ (CH), $129.1(\mathrm{CH}), 128.8(\mathrm{CH}), 126.8\left(\mathrm{~d},{ }^{3} J_{\mathrm{C}-\mathrm{F}}=4.3 \mathrm{~Hz}, \mathrm{CH}\right), 122.6\left(\mathrm{~d},{ }^{2} \mathrm{~J}_{\mathrm{C}-\mathrm{F}}=18.5 \mathrm{~Hz}, \mathrm{CH}\right)$, $119.1(\mathrm{CH}), 100.1(\mathrm{CH}), 75.1\left(\mathrm{C}_{\mathrm{q}}\right), 21.1\left(\mathrm{CH}_{3}\right) .{ }^{19} \mathrm{~F}-\mathrm{NMR}\left(376 \mathrm{MHz}, \mathrm{CDCl}_{3}\right) \delta=-126.53$ (dd, $J=8.1,4.5 \mathrm{~Hz}$ ). IR (ATR): 1654, 1584, 1531, 1473, 1229, 1177, 798, 736, 700, 420 $\mathrm{cm}^{-1}$. MS (ESI) $m / z$ (relative intensity): 329 (100) $[\mathrm{M}+\mathrm{H}]^{+}$. HR-MS (ESI) $\mathrm{m} / z$ calcd for $\mathrm{C}_{21} \mathrm{H}_{18} \mathrm{FN}_{2} \mathrm{O}[\mathrm{M}+\mathrm{H}]^{+}$329.1648, found 329.1648. 


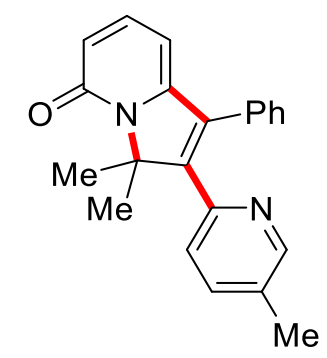

3,3-Dimethyl-2-(5-methylpyridin-2-yl)-1-phenylindolizin-5(3H)-one (173ia): The general procedure A was followed using 5'-methyl-2H-[1,2'-bipyridin]-2-one (172i) (93.1 mg, $0.50 \mathrm{mmol}$ ) and methyl (2-methyl-4-phenylbut-3-yn-2-yl)carbonate (88a) (328 mg, $1.50 \mathrm{mmol}$ ). Purification by column chromatography on silica gel ( $n$ hexane/EtOAc: $1 / 1$ ) yielded $173 i a(100.2 \mathrm{mg}, 61 \%)$ as a white solid. M.p.: $190-191^{\circ} \mathrm{C}$. ${ }^{1} \mathrm{H}-\mathrm{NMR}\left(400 \mathrm{MHz}, \mathrm{CDCl}_{3}\right) \delta=8.46(\mathrm{~d}, J=2.0 \mathrm{~Hz}, 1 \mathrm{H}), 7.36-7.31(\mathrm{~m}, 4 \mathrm{H}), 7.29-7.21(\mathrm{~m}$, 2H), $7.18(\mathrm{dd}, J=8.0,2.0 \mathrm{~Hz}, 1 \mathrm{H}), 6.76(\mathrm{~d}, J=8.0 \mathrm{~Hz}, 1 \mathrm{H}), 6.30(\mathrm{~s}, 1 \mathrm{H}), 5.97(\mathrm{~s}, 1 \mathrm{H}), 2.26$ (s, 3H), $2.06(\mathrm{~s}, 6 \mathrm{H}) .{ }^{13} \mathrm{C}-\mathrm{NMR}\left(100 \mathrm{MHz}, \mathrm{CDCl}_{3}\right) \delta=162.2\left(\mathrm{C}_{\mathrm{q}}\right), 150.8\left(\mathrm{C}_{\mathrm{q}}\right), 150.7\left(\mathrm{C}_{\mathrm{q}}\right)$, $149.7(\mathrm{CH}), 149.5\left(\mathrm{C}_{\mathrm{q}}\right), 138.5(\mathrm{CH}), 136.1(\mathrm{CH}), 132.7\left(\mathrm{C}_{\mathrm{q}}\right), 132.2\left(\mathrm{C}_{\mathrm{q}}\right), 132.1\left(\mathrm{C}_{\mathrm{q}}\right), 129.3$ (CH), $128.8(\mathrm{CH}), 128.4(\mathrm{CH}), 125.1(\mathrm{CH}), 104.9(\mathrm{CH}), 100.1(\mathrm{CH}), 74.9\left(\mathrm{C}_{\mathrm{q}}\right), 21.2\left(\mathrm{CH}_{3}\right)$, $18.2\left(\mathrm{CH}_{3}\right)$. IR (ATR): 1652, 1583, 1530, 1475, 1445, 1347, 1176, 797, 734, $700 \mathrm{~cm}^{-1}$. MS (ESI) $m / z$ (relative intensity): $329(100)[\mathrm{M}+\mathrm{H}]^{+}$. HR-MS (ESI) $m / z$ calcd for $\mathrm{C}_{22} \mathrm{H}_{21} \mathrm{~N}_{2} \mathrm{O}$ $[\mathrm{M}+\mathrm{H}]^{+} 329.1648$, found 329.1648 .

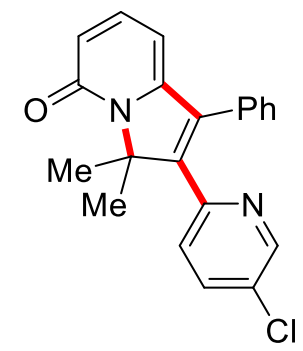

2-(5-Chloropyridin-2-yl)-3,3-dimethyl-1-phenylindolizin-5(3H)-one (173ja): The general procedure $A$ was followed using 5'-chloro-2H-[1,2'-bipyridin]-2-one (172j) (103.3 mg, $0.50 \mathrm{mmol}$ ) and methyl (2-methyl-4-phenylbut-3-yn-2-yl)carbonate (88a) (328 mg, $1.50 \mathrm{mmol}$ ). Purification by column chromatography on silica gel ( $n$ - 
hexane/EtOAc: $1 / 1)$ yielded 173 ja (126 mg, 72\%) as a white solid. M.p.: $163-164{ }^{\circ} \mathrm{C}$. ${ }^{1} \mathrm{H}-\mathrm{NMR}\left(400 \mathrm{MHz}, \mathrm{CDCl}_{3}\right) \delta=8.59(\mathrm{~d}, J=2.3 \mathrm{~Hz}, 1 \mathrm{H}), 7.42-7.36(\mathrm{~m}, 3 \mathrm{H}), 7.34(\mathrm{dd}, J=$ 8.5, $2.5 \mathrm{~Hz}, 1 \mathrm{H}), 7.31-7.20(\mathrm{~m}, 3 \mathrm{H}), 6.80(\mathrm{dd}, J=8.5,0.7 \mathrm{~Hz}, 1 \mathrm{H}), 6.36(\mathrm{~s}, 1 \mathrm{H}), 6.02(\mathrm{~d}$, $J=6.7 \mathrm{~Hz}, 1 \mathrm{H}), 2.06(\mathrm{~s}, 6 \mathrm{H}) .{ }^{13} \mathrm{C}-\mathrm{NMR}\left(100 \mathrm{MHz}, \mathrm{CDCl}_{3}\right) \delta=162.2\left(\mathrm{C}_{\mathrm{q}}\right), 150.4\left(\mathrm{C}_{\mathrm{q}}\right), 150.3$ $\left(C_{q}\right), 149.3\left(C_{q}\right), 148.2(C H), 138.7(C H), 135.4(C H), 133.9\left(C_{q}\right), 131.7\left(C_{q}\right), 131.1\left(C_{q}\right)$, $129.2(\mathrm{CH}), 129.2(\mathrm{CH}), 128.9(\mathrm{CH}), 126.3(\mathrm{CH}), 119.5(\mathrm{CH}), 100.4(\mathrm{CH}), 75.1\left(\mathrm{C}_{\mathrm{q}}\right), 21.2$ $\left(\mathrm{CH}_{3}\right)$. IR (ATR): 1652, 1582, 1528, 1458, 1445, 1155, 1110, 858, 799, $703 \mathrm{~cm}^{-1}$. MS (ESI) $m / z$ (relative intensity): 349 (100) $[\mathrm{M}+\mathrm{H}]^{+}$. HR-MS (ESI) $m / z$ calcd for $\mathrm{C}_{21} \mathrm{H}_{18} \mathrm{~N}_{2} \mathrm{OCl}$ $[\mathrm{M}+\mathrm{H}]^{+}$349.1102, found 349.1102.

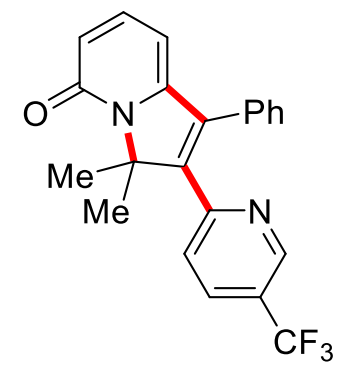

\section{3,3-Dimethyl-1-phenyl-2-(5-(trifluoromethyl)pyridin-2-yl)indolizin-5(3H)-one}

(173ka): The general procedure A was followed using 5'-(trifluoromethyl)-2H-[1,2'bipyridin]-2-one (172k) (103.3 mg, $0.50 \mathrm{mmol}$ ) and methyl (2-methyl-4-phenylbut-3yn-2-yl)carbonate (88a) (328 mg, $1.50 \mathrm{mmol}$ ). Purification by column chromatography on silica gel ( $n$-hexane/EtOAc: $1 / 1)$ yielded 173 ja (114.7 mg, 60\%) as a white solid. M.p.: 155-156 ${ }^{\circ} \mathrm{C} .{ }^{1} \mathrm{H}-\mathrm{NMR}\left(400 \mathrm{MHz}, \mathrm{CDCl}_{3}\right) \delta=8.91$ (dd, $\left.J=2.5,0.8 \mathrm{~Hz}, 1 \mathrm{H}\right), 7.59$ (ddd, $J=$ 8.3, 2.5, $0.8 \mathrm{~Hz}, 1 \mathrm{H}$ ), 7.41 (ddd, J = 5.7, 4.0, $2.1 \mathrm{~Hz}, 3 \mathrm{H}$ ), 7.34-7.24 (m, 3H), 6.98 (dd, J $=8.4,0.8 \mathrm{~Hz}, 1 \mathrm{H}), 6.39(\mathrm{~s}, 1 \mathrm{H}), 6.05(\mathrm{~d}, J=6.8 \mathrm{~Hz}, 1 \mathrm{H}), 2.10(\mathrm{~s}, 6 \mathrm{H}) .{ }^{13} \mathrm{C}-\mathrm{NMR}(100 \mathrm{MHz}$, $\left.\mathrm{CDCl}_{3}\right) \delta=156.0\left(\mathrm{C}_{\mathrm{q}}\right), 155.9\left(\mathrm{C}_{\mathrm{q}}\right), 150.1\left(\mathrm{C}_{\mathrm{q}}\right), 148.9\left(\mathrm{C}_{\mathrm{q}}\right), 146.1\left(\mathrm{q},{ }^{3} \mathrm{~J}_{\mathrm{C}-\mathrm{F}}=4.0 \mathrm{~Hz}, \mathrm{CH}\right)$, $138.7(\mathrm{CH}), 135.4\left(\mathrm{C}_{q}\right), 132.7\left(\mathrm{q},{ }^{3} \mathrm{~J}_{\mathrm{C}-\mathrm{F}}=3.5 \mathrm{~Hz}, \mathrm{CH}\right), 131.5\left(\mathrm{C}_{q}\right), 129.3(\mathrm{CH}), 129.2(\mathrm{CH})$, $129.1(\mathrm{CH}), 125.2(\mathrm{CH}), 124.9\left(\mathrm{q},{ }^{2} \mathrm{~J}_{\mathrm{C}-\mathrm{F}}=33.2 \mathrm{~Hz}, \mathrm{C}_{\mathrm{q}}\right), 123.3\left(\mathrm{q},{ }^{1} J_{\mathrm{C}-\mathrm{F}}=272.4 \mathrm{~Hz}, \mathrm{C}_{\mathrm{q}}\right), 119.9$ (CH), $100.9(\mathrm{CH}), 75.3\left(\mathrm{C}_{\mathrm{q}}\right), 21.2\left(\mathrm{CH}_{3}\right)$. IR (ATR): 1655, 1588, 1531, 1327, 1166, 1131, 1081, 852, 799, $702 \mathrm{~cm}^{-1}$. MS (ESI) $\mathrm{m} / \mathrm{z}$ (relative intensity): $383(100)[\mathrm{M}+\mathrm{H}]^{+}$. HR-MS (ESI) $m / z$ calcd for $\mathrm{C}_{22} \mathrm{H}_{18} \mathrm{~N}_{2} \mathrm{OF}_{3}[\mathrm{M}+\mathrm{H}]^{+} 383.1366$, found 383.1367 . 


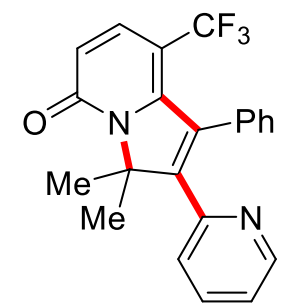

\section{3,3-Dimethyl-1-phenyl-2-(pyridin-2-yl)-8-(trifluoromethyl)indolizin-5(3H)-one}

(173la): The general procedure A was followed using 5-(trifluoromethyl)-2H-[1,2'bipyridin]-2-one (172I) (120.1 mg, $0.50 \mathrm{mmol}$ ) and methyl (2-methyl-4-phenylbut-3yn-2-yl)carbonate (88a) (328mg, $1.50 \mathrm{mmol})$. Purification by column chromatography on silica gel ( $n$-hexane/EtOAc: $1 / 1)$ yielded 173 la (122.4 mg, $64 \%$ ) as a white solid. M.p.: 112-113 ${ }^{\circ} \mathrm{C} .{ }^{1} \mathrm{H}-\mathrm{NMR}\left(400 \mathrm{MHz}, \mathrm{CDCl}_{3}\right) \delta=8.66$ (ddd, $\left.J=4.8,1.9,0.9 \mathrm{~Hz}, 1 \mathrm{H}\right), 7.69$ (dd, $J=7.5,0.9 \mathrm{~Hz}, 1 \mathrm{H}), 7.47-7.33(\mathrm{~m}, 4 \mathrm{H}), 7.25$ (ddd, $J=5.4,3.0,1.1 \mathrm{~Hz}, 2 \mathrm{H}), 7.16$ (ddd, $J$ $=7.5,4.8,1.1 \mathrm{~Hz}, 1 \mathrm{H}), 6.89(\mathrm{dd}, J=7.9,1.1 \mathrm{~Hz}, 1 \mathrm{H}), 6.12$ (dd, J = 7.5, $0.7 \mathrm{~Hz}, 1 \mathrm{H}), 2.09$ (s, 6H). ${ }^{13} \mathrm{C}-\mathrm{NMR}\left(100 \mathrm{MHz}, \mathrm{CDCl}_{3}\right) \delta=162.0\left(\mathrm{C}_{\mathrm{q}}\right), 157.9\left(\mathrm{C}_{\mathrm{q}}\right), 154.1\left(\mathrm{C}_{\mathrm{q}}\right), 151.8\left(\mathrm{C}_{\mathrm{q}}\right)$, $149.4(\mathrm{CH}), 138.6\left(\mathrm{q},{ }^{3} \mathrm{~J}_{\mathrm{C}-\mathrm{F}}=5.0 \mathrm{~Hz}, \mathrm{CH}\right), 135.8(\mathrm{CH}), 132.7\left(\mathrm{C}_{\mathrm{q}}\right), 131.1\left(\mathrm{C}_{\mathrm{q}}\right), 129.3(\mathrm{CH})$, $129.2(\mathrm{CH}), 129.0(\mathrm{CH}), 125.8(\mathrm{CH}), 123.4\left(\mathrm{q},{ }^{1} J_{\mathrm{C}-\mathrm{F}}=271.2 \mathrm{~Hz}, \mathrm{C}_{\mathrm{q}}\right), 123.0(\mathrm{CH}), 117.6(\mathrm{q}$, $\left.{ }^{2} J_{\mathrm{C}-\mathrm{F}}=30.1 \mathrm{~Hz}, \mathrm{C}_{\mathrm{q}}\right), 98.0(\mathrm{CH}), 76.4\left(\mathrm{C}_{\mathrm{q}}\right), 21.2\left(\mathrm{CH}_{3}\right) .{ }^{19} \mathrm{~F}-\mathrm{NMR}\left(376 \mathrm{MHz}, \mathrm{CDCl}_{3}\right) \delta=-4.46$ (s). IR (ATR): 1666, 1553, 1463, 1314, 1153, 1128, 1062, 787, 732, $702 \mathrm{~cm}^{-1}$. MS (ESI) $m / z$ (relative intensity): $383(15)[\mathrm{M}+\mathrm{H}]^{+}$. HR-MS (ESI) $m / z$ calcd for $\mathrm{C}_{22} \mathrm{H}_{18} \mathrm{~N}_{2} \mathrm{OF}_{3}$ $[\mathrm{M}+\mathrm{H}]^{+}$383.1366, found 383.1365.

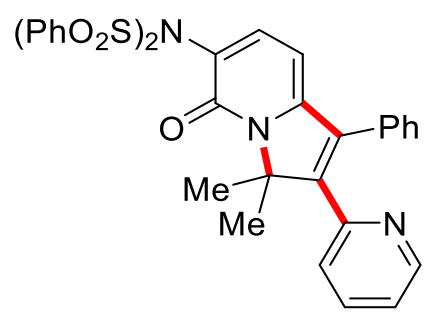

$N$-(3,3-Dimethyl-5-oxo-1-phenyl-2-(pyridin-2-yl)-3,5-dihydroindolizin-6-yl)-N-

(phenylsulfonyl)benzenesulfonamide (173ma): The general procedure A was followed using $N$-(2-oxo-2H-[1,2'-bipyridin]-3-yl)-N- 
(phenylsulfonyl)benzenesulfonamide $(\mathbf{1 7 2 m})(233.8 \mathrm{mg}, 0.50 \mathrm{mmol})$ and methyl (2methyl-4-phenylbut-3-yn-2-yl)carbonate (88a) (328mg, $1.50 \mathrm{mmol}$ ). Purification by column chromatography on silica gel ( $n$-hexane/EtOAc: $1 / 1$ ) yielded 173ma (170.7 mg, 56\%) as a white solid. M.p.: $154-155^{\circ} \mathrm{C} .{ }^{1} \mathrm{H}-\mathrm{NMR}\left(400 \mathrm{MHz}, \mathrm{CDCl}_{3}\right) \delta=8.64$ (ddd, $J=$ 4.8, 1.8, 0.9 Hz, 1H), 8.11-7.89 (m, 4H), 7.67-7.54 (m, 2H), 7.52-7.46 (m, 4H), 7.44$7.35(\mathrm{~m}, 5 \mathrm{H}), 7.29-7.24(\mathrm{~m}, 2 \mathrm{H}), 7.14(\mathrm{ddd}, J=7.6,4.8,1.1 \mathrm{~Hz}, 1 \mathrm{H}), 6.86(\mathrm{dd}, J=8.0$, $1.1 \mathrm{~Hz}, 1 \mathrm{H}), 6.05(\mathrm{~d}, J=7.6 \mathrm{~Hz}, 1 \mathrm{H}), 1.91(\mathrm{~s}, 6 \mathrm{H}) .{ }^{13} \mathrm{C}-\mathrm{NMR}\left(100 \mathrm{MHz}, \mathrm{CDCl}_{3}\right) \delta=158.3$ $\left(C_{q}\right), 153.5\left(C_{q}\right), 153.0\left(C_{q}\right), 152.0\left(C_{q}\right), 149.4(C H), 143.7(C H), 139.5\left(C_{q}\right), 135.8(C H)$, 133.7 (CH), $132.8\left(\mathrm{C}_{\mathrm{q}}\right), 131.3\left(\mathrm{C}_{\mathrm{q}}\right), 129.3(\mathrm{CH}), 129.1(\mathrm{CH}), 129.0(\mathrm{CH}), 128.9(\mathrm{CH}), 128.6$ (CH), $125.7(\mathrm{CH}), 122.9(\mathrm{CH}), 121.8\left(\mathrm{C}_{\mathrm{q}}\right), 98.5(\mathrm{CH}), 76.0\left(\mathrm{C}_{\mathrm{q}}\right), 20.9\left(\mathrm{CH}_{3}\right)$. IR (ATR): 1661, 1599, 1537, 1448, 1375, 1354, 1170, 1084, 891, $551 \mathrm{~cm}^{-1}$. MS (ESI) $\mathrm{m} / z$ (relative intensity): 610 (100) $[\mathrm{M}+\mathrm{H}]^{+}$. HR-MS (ESI) $\mathrm{m} / \mathrm{z}$ calcd for $\mathrm{C}_{33} \mathrm{H}_{28} \mathrm{~N}_{3} \mathrm{O}_{5} \mathrm{~S}_{2}[\mathrm{M}+\mathrm{H}]^{+} 610.1465$, found 610.1475 .

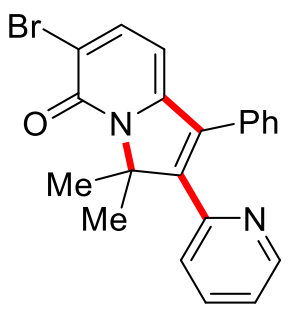

6-Bromo-3,3-dimethyl-1-phenyl-2-(pyridin-2-yl)indolizin-5(3H)-one (173na): The general procedure $A$ was followed using 3-bromo-2H-[1,2'-bipyridin]-2-one (172n) (125.6 mg, $0.50 \mathrm{mmol}$ ) and methyl (2-methyl-4-phenylbut-3-yn-2-yl)carbonate (88a) (328mg, $1.50 \mathrm{mmol}$ ). Purification by column chromatography on silica gel ( $n$ hexane/EtOAc: $1 / 1$ ) yielded 173 na (129.8 mg, 66\%) as a white solid. M.p.: $206-207^{\circ} \mathrm{C}$. ${ }^{1} \mathrm{H}-\mathrm{NMR}\left(400 \mathrm{MHz}, \mathrm{CDCl}_{3}\right) \delta=8.63(\mathrm{ddd}, J=4.9,1.9,1.0 \mathrm{~Hz}, 1 \mathrm{H}), 7.69(\mathrm{~d}, J=7.5 \mathrm{~Hz}$, 1H), 7.46-7.30 (m, 4H), 7.26-7.20 (m, 2H), 7.12 (ddd, J = 7.6, 4.9, 1.0 Hz, 1H), 6.86 (dd, $J=8.0,1.0 \mathrm{~Hz}, 1 \mathrm{H}), 5.97(\mathrm{~d}, J=7.6 \mathrm{~Hz}, 1 \mathrm{H}), 2.06(\mathrm{~s}, 6 \mathrm{H}) .{ }^{13} \mathrm{C}-\mathrm{NMR}\left(100 \mathrm{MHz}, \mathrm{CDCl}_{3}\right) \delta=$ $157.8\left(\mathrm{C}_{\mathrm{q}}\right), 152.1\left(\mathrm{C}_{\mathrm{q}}\right), 150.9\left(\mathrm{C}_{\mathrm{q}}\right), 150.2\left(\mathrm{C}_{\mathrm{q}}\right), 149.3(\mathrm{CH}), 140.9(\mathrm{CH}), 135.7(\mathrm{CH}), 132.9$ $\left(\mathrm{C}_{\mathrm{q}}\right), 131.4\left(\mathrm{C}_{\mathrm{q}}\right), 129.2(\mathrm{CH}), 129.0(\mathrm{CH}), 128.8(\mathrm{CH}), 125.7(\mathrm{CH}), 122.7(\mathrm{CH}), 114.7\left(\mathrm{C}_{\mathrm{q}}\right)$, 
$99.9(\mathrm{CH}), 76.3\left(\mathrm{C}_{\mathrm{q}}\right), 21.0\left(\mathrm{CH}_{3}\right)$. IR (ATR): 1642, 1586, 1563, 1518, 1337, 1075, 1060, 796, 739, $698 \mathrm{~cm}^{-1}$. MS (ESI) $\mathrm{m} / z$ (relative intensity): 415 (10) $[\mathrm{M}+\mathrm{Na}]^{+}, 393$ (100) $[\mathrm{M}+\mathrm{H}]^{+}$. HR-MS (ESI) $\mathrm{m} / z$ calcd for $\mathrm{C}_{21} \mathrm{H}_{18} \mathrm{~N}_{2} \mathrm{OBr}[\mathrm{M}+\mathrm{H}]^{+} 393.0597$, found 393.0604 .

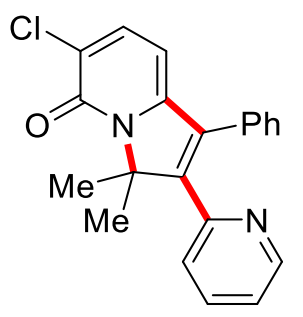

6-Chloro-3,3-dimethyl-1-phenyl-2-(pyridin-2-yl)indolizin-5(3H)-one (1730a): The general procedure A was followed using 3-chloro-2H-[1,2'-bipyridin]-2-one (1720) (103.3 mg, $0.50 \mathrm{mmol}$ ) and methyl (2-methyl-4-phenylbut-3-yn-2-yl)carbonate (88a) (328mg, $1.50 \mathrm{mmol})$. Purification by column chromatography on silica gel $(n$ hexane/EtOAc: $1 / 1$ ) yielded $1730 a(121.9 \mathrm{mg}, 70 \%)$ as a white solid. M.p.: 208-209 ${ }^{\circ} \mathrm{C}$. ${ }^{1} \mathrm{H}-\mathrm{NMR}\left(400 \mathrm{MHz}, \mathrm{CDCl}_{3}\right) \delta=8.62(\mathrm{ddd}, J=4.8,1.9,1.0 \mathrm{~Hz}, 1 \mathrm{H}), 7.48(\mathrm{~d}, J=7.6 \mathrm{~Hz}$, 1H), 7.41-7.32 (m, 4H), 7.26-7.21 (m, 2H), 7.11 (ddd, J = 7.6, 4.8, 1.1 Hz, 1H), 6.86 (dt, $J=8.0,1.0 \mathrm{~Hz}, 1 \mathrm{H}), 6.02(\mathrm{~d}, J=7.6 \mathrm{~Hz}, 1 \mathrm{H}), 2.06(\mathrm{~s}, 6 \mathrm{H}) .{ }^{13} \mathrm{C}-\mathrm{NMR}\left(100 \mathrm{MHz}, \mathrm{CDCl}_{3}\right) \delta=$ 157.7 $\left(\mathrm{C}_{q}\right), 152.1\left(\mathrm{C}_{q}\right), 150.9\left(\mathrm{C}_{\mathrm{q}}\right), 149.3(\mathrm{CH}), 149.2\left(\mathrm{C}_{\mathrm{q}}\right), 137.1(\mathrm{CH}), 135.6(\mathrm{CH}), 132.8$ $\left(\mathrm{C}_{\mathrm{q}}\right), 131.4\left(\mathrm{C}_{\mathrm{q}}\right), 129.2(\mathrm{CH}), 129.0(\mathrm{CH}), 128.8(\mathrm{CH}), 125.7(\mathrm{CH}), 124.1\left(\mathrm{C}_{\mathrm{q}}\right), 122.7(\mathrm{CH})$, $99.0(\mathrm{CH}), 76.1\left(\mathrm{C}_{\mathrm{q}}\right), 21.0\left(\mathrm{CH}_{3}\right)$. IR (ATR): 1647, 1588, 1564, 1524, 1339, 1173, 1089, 789, 764, $699 \mathrm{~cm}^{-1}$. MS (ESI) $\mathrm{m} / \mathrm{z}$ (relative intensity): 719 (6) [2M+Na], 371 (25) $[\mathrm{M}+\mathrm{Na}]^{+}, 349(100)[\mathrm{M}+\mathrm{H}]^{+}$. HR-MS (ESI) $\mathrm{m} / z$ calcd for $\mathrm{C}_{21} \mathrm{H}_{18} \mathrm{~N}_{2} \mathrm{OCl}[\mathrm{M}+\mathrm{H}]^{+}$349.1102, found 349.1109 .

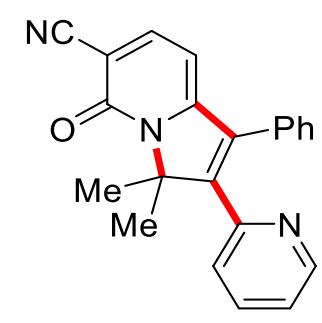

3,3-Dimethyl-5-oxo-1-phenyl-2-(pyridin-2-yl)-3,5-dihydroindolizine-6-carbonitrile 
(173pa): The general procedure A was followed using 3-chloro-2H-[1,2'-bipyridin]-2one (172p) (98.6 mg, $0.50 \mathrm{mmol}$ ) and methyl (2-methyl-4-phenylbut-3-yn-2yl)carbonate (88a) (328mg, $1.50 \mathrm{mmol}$ ). Purification by column chromatography on silica gel ( $n$-hexane/EtOAc: $1 / 1)$ yielded $1730 a(127.3 \mathrm{mg}, 75 \%)$ as a white solid. M.p.: 219-220 ${ }^{\circ} \mathrm{C} .{ }^{1} \mathrm{H}-\mathrm{NMR}\left(400 \mathrm{MHz}, \mathrm{CDCl}_{3}\right) \delta=8.64$ (ddd, $\left.J=4.8,1.8,0.9 \mathrm{~Hz}, 1 \mathrm{H}\right), 8.14-$ $7.96(m, 4 H), 7.64-7.56(m, 2 H), 7.53-7.46(m, 4 H), 7.44-7.34(m, 5 H), 7.31-7.24(m$, 2H), 7.14 (ddd, $J=7.6,4.8,1.1 \mathrm{~Hz}, 1 \mathrm{H}), 6.86$ (ddd, $J=8.0,1.1,1.1 \mathrm{~Hz}, 1 \mathrm{H}), 6.05(\mathrm{~d}, J=$ $7.6 \mathrm{~Hz}, 1 \mathrm{H}), 1.91(\mathrm{~s}, 6 \mathrm{H}) .{ }^{13} \mathrm{C}-\mathrm{NMR}\left(100 \mathrm{MHz}, \mathrm{CDCl}_{3}\right) \delta=159.0\left(\mathrm{C}_{\mathrm{q}}\right), 155.2\left(\mathrm{C}_{\mathrm{q}}\right), 155.2$ $\left(\mathrm{C}_{\mathrm{q}}\right), 151.3\left(\mathrm{C}_{\mathrm{q}}\right), 149.5(\mathrm{CH}), 146.4(\mathrm{CH}), 135.9(\mathrm{CH}), 132.8\left(\mathrm{C}_{\mathrm{q}}\right), 130.8\left(\mathrm{C}_{\mathrm{q}}\right), 129.3(\mathrm{CH})$, $129.2(\mathrm{CH}), 129.1(\mathrm{CH}), 125.8(\mathrm{CH}), 123.3(\mathrm{CH}), 116.5\left(\mathrm{C}_{q}\right), 102.3\left(\mathrm{C}_{q}\right), 99.8(\mathrm{CH}), 76.8$ (C $\mathrm{q}), 21.0\left(\mathrm{CH}_{3}\right)$. IR (ATR): 2219, 1650, 1583, 1536, 1460, 1432, 1179, 776, 728, $699 \mathrm{~cm}^{-}$ 1. MS (ESI) $m / z$ (relative intensity): 340 (100) $[\mathrm{M}+\mathrm{H}]^{+}$. HR-MS (ESI) $\mathrm{m} / \mathrm{z}$ calcd for $\mathrm{C}_{22} \mathrm{H}_{18} \mathrm{~N}_{3} \mathrm{O}[\mathrm{M}+\mathrm{H}]^{+} 340.1444$, found 340.1453 .

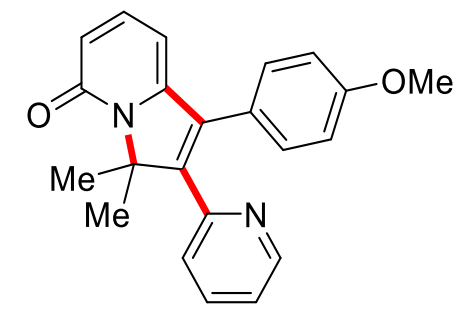

1-(4-Methoxyphenyl)-3,3-dimethyl-2-(pyridin-2-yl)indolizin-5(3H)-one (173ac): The general procedure A was followed using $2 \mathrm{H}$-[1,2'-bipyridin]-2-one (172a) $(86.1 \mathrm{mg}$, $0.50 \mathrm{mmol}$ ) and 4-(4-methoxyphenyl)-2-methylbut-3-yn-2-yl methyl carbonate (88c) (373 mg, $1.50 \mathrm{mmol}$ ). Purification by column chromatography on silica gel ( $n$ hexane/EtOAc: $1 / 1)$ yielded $173 a c(115 \mathrm{mg}, 67 \%)$ as a white solid. M.p.: $161-162{ }^{\circ} \mathrm{C}$. ${ }^{1} \mathrm{H}-\mathrm{NMR}\left(400 \mathrm{MHz}, \mathrm{CDCl}_{3}\right) \delta=8.64(\mathrm{ddd}, J=4.8,1.8,0.8 \mathrm{~Hz}, 1 \mathrm{H}), 7.40(\mathrm{dd}, J=7.6,1.8$ $\mathrm{Hz}, 1 \mathrm{H}$ ), $7.31(\mathrm{~d}, J=6.5 \mathrm{~Hz}, 1 \mathrm{H}), 7.17(\mathrm{~d}, J=8.7 \mathrm{~Hz}, 2 \mathrm{H}), 7.12$ (ddd, $J=7.6,4.8,1.0 \mathrm{~Hz}$, 1H), 6.92-6.84 (m, 3H), $6.33(\mathrm{~s}, 1 \mathrm{H}), 6.04(\mathrm{~d}, J=6.8 \mathrm{~Hz}, 1 \mathrm{H}), 3.80(\mathrm{~s}, 3 \mathrm{H}), 2.05(\mathrm{~s}, 6 \mathrm{H})$. ${ }^{13} \mathrm{C}-\mathrm{NMR}\left(100 \mathrm{MHz}, \mathrm{CDCl}_{3}\right) \delta=162.0\left(\mathrm{C}_{\mathrm{q}}\right), 159.7\left(\mathrm{C}_{\mathrm{q}}\right), 152.8\left(\mathrm{C}_{\mathrm{q}}\right), 150.8\left(\mathrm{C}_{\mathrm{q}}\right), 150.2\left(\mathrm{C}_{\mathrm{q}}\right)$, $149.3(\mathrm{CH}), 138.7(\mathrm{CH}), 135.6(\mathrm{CH}), 132.9\left(\mathrm{C}_{\mathrm{q}}\right), 130.6(\mathrm{CH}), 125.7(\mathrm{CH}), 123.9\left(\mathrm{C}_{\mathrm{q}}\right), 122.4$ 
(CH), $119.2(\mathrm{CH}), 114.3(\mathrm{CH}), 100.2(\mathrm{CH}), 75.0\left(\mathrm{C}_{\mathrm{q}}\right), 55.2\left(\mathrm{CH}_{3}\right), 21.2\left(\mathrm{CH}_{3}\right)$. IR $(\mathrm{ATR})$ : 1654, 1583, 1532, 1511, 1463, 1251, 1177, 1029, 845, $793 \mathrm{~cm}^{-1}$. MS (ESI) $\mathrm{m} / z$ (relative intensity): 345 (100) $[\mathrm{M}+\mathrm{H}]^{+}$. HR-MS (ESI) $\mathrm{m} / \mathrm{z}$ calcd for $\mathrm{C}_{22} \mathrm{H}_{21} \mathrm{~N}_{2} \mathrm{O}_{2}[\mathrm{M}+\mathrm{H}]^{+} 345.1598$, found 345.1600 .

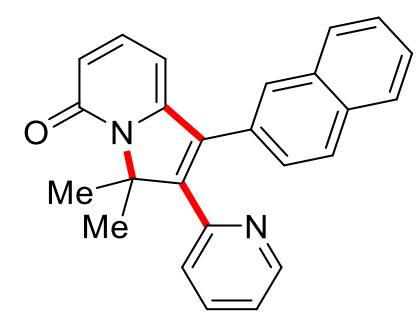

3,3-Dimethyl-1-(naphthalen-2-yl)-2-(pyridin-2-yl)indolizin-5(3H)-one (173ad): The general procedure A was followed using $2 \mathrm{H}$-[1,2'-bipyridin]-2-one (172a) $(86.1 \mathrm{mg}$, $0.50 \mathrm{mmol}$ ) and methyl (2-methyl-4-(naphthalen-2-yl)but-3-yn-2-yl) carbonate (88d) (403 mg, $1.50 \mathrm{mmol}$ ). Purification by column chromatography on silica gel ( $n$ hexane/EtOAc: $1 / 1$ ) yielded 3ad (106 mg, 58\%) as a white solid. M.p.: $185-186{ }^{\circ} \mathrm{C} .{ }^{1} \mathbf{H}-$ NMR $\left(400 \mathrm{MHz}, \mathrm{CDCl}_{3}\right) \delta=8.66(\mathrm{ddd}, J=4.8,1.9,1.0 \mathrm{~Hz}, 1 \mathrm{H}), 7.92-7.70(\mathrm{~m}, 4 \mathrm{H}), 7.58-$ $7.43(\mathrm{~m}, 2 \mathrm{H}), 7.35-7.26$ (m, 3H), 7.10 (ddd, $J=7.6,4.8,1.1 \mathrm{~Hz}, 1 \mathrm{H}), 6.89$ (ddd, J = 7.9, 1.1, $1.1 \mathrm{~Hz}, 1 \mathrm{H}), 6.40(\mathrm{dd}, J=9.0,1.1 \mathrm{~Hz}, 1 \mathrm{H}), 6.13(\mathrm{dd}, J=6.9,1.1 \mathrm{~Hz}, 1 \mathrm{H}), 2.12(\mathrm{~s}, 6 \mathrm{H})$. ${ }^{13} \mathrm{C}-\mathrm{NMR}\left(100 \mathrm{MHz}, \mathrm{CDCl}_{3}\right) \delta=162.3\left(\mathrm{C}_{\mathrm{q}}\right), 152.5\left(\mathrm{C}_{\mathrm{q}}\right), 151.1\left(\mathrm{C}_{\mathrm{q}}\right), 150.6\left(\mathrm{C}_{\mathrm{q}}\right), 149.3(\mathrm{CH})$, $138.9(\mathrm{CH}), 135.7(\mathrm{CH}), 133.3\left(\mathrm{C}_{\mathrm{q}}\right), 133.2\left(\mathrm{C}_{\mathrm{q}}\right), 133.0\left(\mathrm{C}_{\mathrm{q}}\right), 129.4\left(\mathrm{C}_{\mathrm{q}}\right), 128.8(\mathrm{CH}), 128.7$ (CH), $128.0(\mathrm{CH}), 127.8(\mathrm{CH}), 126.9(\mathrm{CH}), 126.7(\mathrm{CH}), 126.5(\mathrm{CH}), 125.8(\mathrm{CH}), 122.6(\mathrm{CH})$, $119.0(\mathrm{CH}), 100.2(\mathrm{CH}), 75.3\left(\mathrm{C}_{\mathrm{q}}\right), 21.2\left(\mathrm{CH}_{3}\right)$. IR (ATR): 1653, 1582, 1531, 1460, 1433, 1153, 787, 746, $479 \mathrm{~cm}^{-1}$. MS (ESI) $\mathrm{m} / \mathrm{z}$ (relative intensity): 365 (100) [M+H] $]^{+}$. HR-MS (ESI) $\mathrm{m} / z$ calcd for $\mathrm{C}_{25} \mathrm{H}_{21} \mathrm{~N}_{2} \mathrm{O}[\mathrm{M}+\mathrm{H}]^{+} 365.1648$, found 365.1658 . 


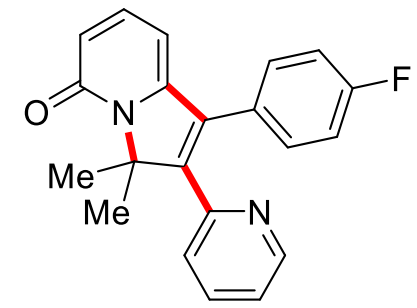

1-(4-Fluorophenyl)-3,3-dimethyl-2-(pyridin-2-yl)indolizin-5(3H)-one (173ae): The general procedure A was followed using $2 \mathrm{H}$-[1,2'-bipyridin]-2-one (172a) $(86.1 \mathrm{mg}$, $0.50 \mathrm{mmol}$ ) and 4-(4-fluorophenyl)-2-methylbut-3-yn-2-yl methyl carbonate (88e) (354 $\mathrm{mg}, 1.50 \mathrm{mmol}$ ). Purification by column chromatography on silica gel ( $n$-hexane/EtOAc: 1/1) yielded 3ae (140 mg, 84\%) as a white solid. M.p.: $148-149{ }^{\circ} \mathrm{C} .{ }^{1} \mathrm{H}-\mathrm{NMR}(400 \mathrm{MHz}$, $\left.\mathrm{CDCl}_{3}\right) \delta=8.63(\mathrm{ddd}, J=4.8,1.9,0.9 \mathrm{~Hz}, 1 \mathrm{H}), 7.42(\mathrm{dd}, J=7.6,1.9 \mathrm{~Hz}, 1 \mathrm{H}), 7.28(\mathrm{dd}, J$ = 9.0, 7.0 Hz, 1H), 7.25-7.18 (m, 2H), $7.13(\mathrm{ddd}, J=7.6,4.8,1.1 \mathrm{~Hz}, 1 \mathrm{H}), 7.06-6.97(\mathrm{~m}$, $2 \mathrm{H}), 6.85(\mathrm{dd}, J=8.0,1.1 \mathrm{~Hz}, 1 \mathrm{H}), 6.36(\mathrm{dd}, J=9.0,1.1 \mathrm{~Hz}, 1 \mathrm{H}), 6.06(\mathrm{dd}, J=7.0,1.1 \mathrm{~Hz}$, 1H), $2.02(\mathrm{~s}, 6 \mathrm{H}) .{ }^{13} \mathrm{C}-\mathrm{NMR}\left(100 \mathrm{MHz}, \mathrm{CDCl}_{3}\right) \delta=162.65\left(\mathrm{~d},{ }^{1} \mathrm{~J}_{\mathrm{C}-\mathrm{F}}=249.0 \mathrm{~Hz}, \mathrm{C}_{\mathrm{q}}\right), 162.3$ $\left(\mathrm{C}_{\mathrm{q}}\right), 152.2\left(\mathrm{C}_{\mathrm{q}}\right), 151.2\left(\mathrm{C}_{\mathrm{q}}\right), 150.2\left(\mathrm{C}_{\mathrm{q}}\right), 149.4(\mathrm{CH}), 139.0(\mathrm{CH}), 135.8(\mathrm{CH}), 132.1\left(\mathrm{C}_{\mathrm{q}}\right)$, $131.1\left(\mathrm{~d},{ }^{3} J_{\mathrm{C}-\mathrm{F}}=8.1 \mathrm{~Hz}, \mathrm{CH}\right), 127.6\left(\mathrm{~d},{ }^{4} J_{\mathrm{C}-\mathrm{F}}=3.5 \mathrm{~Hz}, \mathrm{C}_{\mathrm{q}}\right), 125.6(\mathrm{CH}), 122.7(\mathrm{CH}), 118.9$ (CH), $116.0\left(\mathrm{~d},{ }^{2} \mathrm{~J}_{\mathrm{C}-\mathrm{F}}=21.6 \mathrm{~Hz}, \mathrm{CH}\right), 100.1(\mathrm{CH}), 75.2\left(\mathrm{C}_{\mathrm{q}}\right), 21.0\left(\mathrm{CH}_{3}\right) .{ }^{19} \mathrm{~F}-\mathrm{NMR}(376 \mathrm{MHz}$, $\left.\mathrm{CDCl}_{3}\right) \delta=-112.01$ (s). IR (ATR): 1651, 1581, 1531, 1508, 1462, 1433, 1348, 1224, 1157, 851, $796 \mathrm{~cm}^{-1}$. MS (ESI) $\mathrm{m} / z$ (relative intensity): $687(32)[2 \mathrm{M}+\mathrm{Na}]^{+}, 355(10)[\mathrm{M}+\mathrm{Na}]^{+}$, $333(100)[\mathrm{M}+\mathrm{H}]^{+}$. HR-MS (ESI) $\mathrm{m} / \mathrm{z}$ calcd for $\mathrm{C}_{21} \mathrm{H}_{18} \mathrm{~N}_{2} \mathrm{OF}[\mathrm{M}+\mathrm{H}]^{+} 333.1398$, found 333.1399.

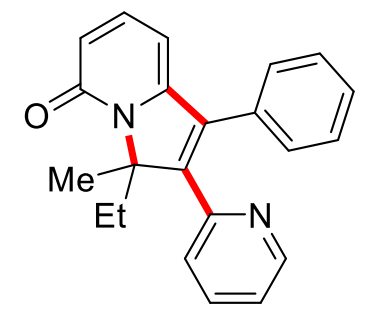

3-Ethyl-3-methyl-1-phenyl-2-(pyridin-2-yl)indolizin-5(3H)-one (173af): The general procedure A was followed using $2 \mathrm{H}$-[1,2'-bipyridin]-2-one (172a) (86.1 mg, $0.50 \mathrm{mmol}$ ) and methyl (3-methyl-1-phenylpent-1-yn-3-yl) carbonate (88f) (349 mg, $1.50 \mathrm{mmol}$ ). 
Purification by column chromatography on silica gel ( $n$-hexane/EtOAc: $1 / 1$ ) yielded 173af (136 mg, 83\%) as a white solid. M.p.: $117-118^{\circ} \mathrm{C} .{ }^{1} \mathbf{H}-\mathrm{NMR}\left(400 \mathrm{MHz}, \mathrm{CDCl}_{3}\right) \delta$ $=8.64(\mathrm{ddd}, J=4.8,1.9,0.9 \mathrm{~Hz}, 1 \mathrm{H}), 7.40-7.33(\mathrm{~m}, 4 \mathrm{H}), 7.30(\mathrm{dd}, J=9.0,6.9 \mathrm{~Hz}, 1 \mathrm{H})$, 7.27-7.22 (m, 2H), 7.11 (ddd, J = 7.6, 4.8, 1.1 Hz, 1H), 6.85 (dt, J = 7.9, $1.1 \mathrm{~Hz}, 1 \mathrm{H}), 6.38$ (dd, $J=9.0,1.1 \mathrm{~Hz}, 1 \mathrm{H}), 6.07(\mathrm{dd}, J=6.9,1.1 \mathrm{~Hz}, 1 \mathrm{H}), 3.18(\mathrm{dq}, J=14.6,7.4 \mathrm{~Hz}, 1 \mathrm{H}$ ), $2.34(\mathrm{dq}, J=13.8,7.4 \mathrm{~Hz}, 1 \mathrm{H}), 2.05(\mathrm{~s}, 3 \mathrm{H}), 0.61(\mathrm{t}, J=7.4 \mathrm{~Hz}, 3 \mathrm{H}) .{ }^{13} \mathrm{C}-\mathrm{NMR}(100 \mathrm{MHz}$, $\left.\mathrm{CDCl}_{3}\right) \delta=162.2\left(\mathrm{C}_{\mathrm{q}}\right), 152.6\left(\mathrm{C}_{\mathrm{q}}\right), 151.4\left(\mathrm{C}_{\mathrm{q}}\right), 149.4(\mathrm{CH}), 148.6\left(\mathrm{C}_{\mathrm{q}}\right), 139.0(\mathrm{CH}), 135.6$ $(\mathrm{CH}), 134.9\left(\mathrm{C}_{\mathrm{q}}\right), 132.0\left(\mathrm{C}_{\mathrm{q}}\right), 129.4(\mathrm{CH}), 128.9(\mathrm{CH}), 128.6(\mathrm{CH}), 125.6(\mathrm{CH}), 122.5(\mathrm{CH})$, $118.8(\mathrm{CH}), 99.8(\mathrm{CH}), 79.0\left(\mathrm{C}_{\mathrm{q}}\right), 25.5\left(\mathrm{CH}_{2}\right), 21.0\left(\mathrm{CH}_{3}\right), 8.0\left(\mathrm{CH}_{3}\right)$. IR (ATR): 1653, 1582, $1530,1463,1445,1433,1352,1155,795,701 \mathrm{~cm}^{-1}$. MS (ESI) $\mathrm{m} / z$ (relative intensity): 351 (8) $[\mathrm{M}+\mathrm{Na}]^{+}, 329(100)[\mathrm{M}+\mathrm{H}]^{+}$. HR-MS (ESI) $\mathrm{m} / z$ calcd for $\mathrm{C}_{22} \mathrm{H}_{21} \mathrm{~N}_{2} \mathrm{O}[\mathrm{M}+\mathrm{H}]^{+}$ 329.1648 , found 329.1655 .

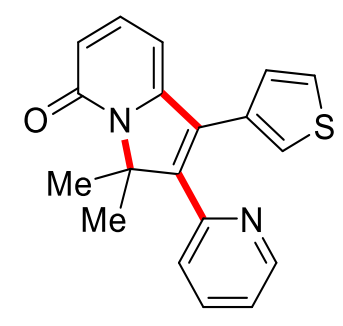

3,3-Dimethyl-2-(pyridin-2-yl)-1-(thiophen-3-yl)indolizin-5(3H)-one (173ag): The general procedure A was followed using $2 \mathrm{H}$-[1,2'-bipyridin]-2-one (172a) $(86.1 \mathrm{mg}$, $0.50 \mathrm{mmol}$ ) and methyl (2-methyl-4-(thiophen-2-yl)but-3-yn-2-yl) carbonate (88g) (337 mg, $1.50 \mathrm{mmol}$ ). Purification by column chromatography on silica gel ( $n$ hexane/EtOAc: $1 / 1$ ) yielded 173ag (106 mg, 62\%) as a white solid. M.p.: $142-143{ }^{\circ} \mathrm{C}$. ${ }^{1} \mathrm{H}-\mathrm{NMR}\left(400 \mathrm{MHz}, \mathrm{CDCl}_{3}\right) \delta=8.65(\mathrm{~d}, J=4.3 \mathrm{~Hz}, 1 \mathrm{H}), 7.57-7.11(\mathrm{~m}, 5 \mathrm{H}), 6.94(\mathrm{~d}, J=$ $7.5 \mathrm{~Hz}, 1 \mathrm{H}), 6.88(\mathrm{~d}, J=4.3 \mathrm{~Hz}, 1 \mathrm{H}), 6.32(\mathrm{~s}, 1 \mathrm{H}), 6.21-6.03(\mathrm{~m}, 1 \mathrm{H}), 2.02(\mathrm{~s}, 6 \mathrm{H})$. ${ }^{13} \mathrm{C}-\mathrm{NMR}\left(100 \mathrm{MHz}, \mathrm{CDCl}_{3}\right) \delta=162.5\left(\mathrm{C}_{\mathrm{q}}\right), 152.5\left(\mathrm{C}_{\mathrm{q}}\right), 150.7\left(\mathrm{C}_{\mathrm{q}}\right), 150.1\left(\mathrm{C}_{\mathrm{q}}\right), 149.3(\mathrm{CH})$, $138.6(\mathrm{CH}), 135.7(\mathrm{CH}), 131.5\left(\mathrm{C}_{q}\right), 128.1\left(\mathrm{C}_{q}\right), 127.9(\mathrm{CH}), 126.3(\mathrm{CH}), 125.3(\mathrm{CH}), 125.1$ (CH), $122.6(\mathrm{CH}), 119.4(\mathrm{CH}), 100.0(\mathrm{CH}), 74.7\left(\mathrm{C}_{\mathrm{q}}\right), 21.1\left(\mathrm{CH}_{3}\right)$. IR (ATR): 1650, 1578, 1461, 1433, 1151, 842, 792, 735, $672 \mathrm{~cm}^{-1}$. MS (ESI) $m / z$ (relative intensity): 663 (10) 
$[2 \mathrm{M}+\mathrm{Na}]^{+}, 321(100)[\mathrm{M}+\mathrm{H}]^{+}$. HR-MS (ESI) $\mathrm{m} / \mathrm{z}$ calcd for $\mathrm{C}_{19} \mathrm{H}_{17} \mathrm{~N}_{2} \mathrm{OS}[\mathrm{M}+\mathrm{H}]^{+}$321.1056, found 321.1057 .

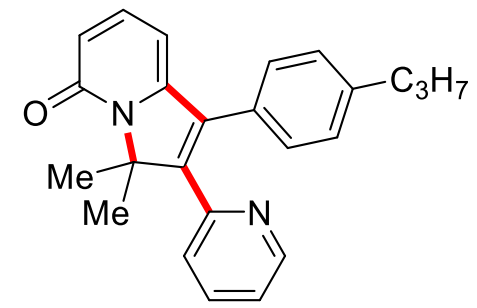

3,3-Dimethyl-1-(4-propylphenyl)-2-(pyridin-2-yl)indolizin-5(3H)-one (173ah): The general procedure A was followed using $2 H$-[1,2'-bipyridin]-2-one (172a) $(86.1 \mathrm{mg}$, $0.50 \mathrm{mmol}$ ) and methyl (2-methyl-4-(4-propylphenyl)but-3-yn-2-yl) carbonate (88h) (391 mg, $1.50 \mathrm{mmol}$ ). Purification by column chromatography on silica gel ( $n$ hexane/EtOAc: $1 / 1$ ) yielded $173 a g(102 \mathrm{mg}, 57 \%)$ as a white solid. M.p.: $137-138^{\circ} \mathrm{C}$. ${ }^{1} \mathrm{H}-\mathrm{NMR}\left(400 \mathrm{MHz}, \mathrm{CDCl}_{3}\right) \delta=8.62(\mathrm{ddd}, J=4.8,1.9,0.9 \mathrm{~Hz}, 1 \mathrm{H}), 7.36(\mathrm{dd}, J=7.7,1.9$ $\mathrm{Hz}, 1 \mathrm{H}), 7.25(\mathrm{dd}, J=9.0,6.9 \mathrm{~Hz}, 1 \mathrm{H}), 7.13(\mathrm{~s}, 4 \mathrm{H}), 7.09$ (ddd, J = 7.5, 4.8, $1.1 \mathrm{~Hz}, 1 \mathrm{H})$, $6.86(\mathrm{dd}, J=8.0,1.1 \mathrm{~Hz}, 1 \mathrm{H}), 6.34(\mathrm{dd}, J=9.0,1.1 \mathrm{~Hz}, 1 \mathrm{H}), 6.08(\mathrm{dd}, J=6.9,1.1 \mathrm{~Hz}, 1 \mathrm{H})$, 2.66-2.41 (m, 2H), $2.04(\mathrm{~s}, 6 \mathrm{H}), 1.70-1.50(\mathrm{~m}, 2 \mathrm{H}), 0.90(\mathrm{t}, J=7.3 \mathrm{~Hz}, 3 \mathrm{H}) .{ }^{13} \mathrm{C}-\mathrm{NMR}$ $\left(100 \mathrm{MHz}, \mathrm{CDCl}_{3}\right) \delta=162.2\left(\mathrm{C}_{\mathrm{q}}\right), 152.6\left(\mathrm{C}_{\mathrm{q}}\right), 150.6\left(\mathrm{C}_{\mathrm{q}}\right), 150.4\left(\mathrm{C}_{\mathrm{q}}\right), 149.2(\mathrm{CH}), 143.2$ $\left(\mathrm{C}_{\mathrm{q}}\right), 138.8(\mathrm{CH}), 135.5(\mathrm{CH}), 133.2\left(\mathrm{C}_{\mathrm{q}}\right), 129.1(\mathrm{CH}), 129.0\left(\mathrm{C}_{\mathrm{q}}\right), 128.9(\mathrm{CH}), 125.7(\mathrm{CH})$, 122.4 (CH), $118.7(\mathrm{CH}), 100.1(\mathrm{CH}), 75.0\left(\mathrm{C}_{\mathrm{q}}\right), 37.7\left(\mathrm{CH}_{2}\right), 24.2\left(\mathrm{CH}_{2}\right), 21.1\left(\mathrm{CH}_{3}\right), 13.7$ $\left(\mathrm{CH}_{3}\right)$. IR (ATR): 1656, 1585, 1531, 1463, 1154, 795, 744, $640 \mathrm{~cm}^{-1}$. MS (ESI) $\mathrm{m} / \mathrm{z}$ (relative intensity): 379 (12) [M+Na] $]^{+}, 357(100)[\mathrm{M}+\mathrm{H}]^{+}$. HR-MS (ESI) $\mathrm{m} / z$ calcd for $\mathrm{C}_{24} \mathrm{H}_{24} \mathrm{~N}_{2} \mathrm{O}[\mathrm{M}+\mathrm{H}]^{+}$357.1961, found 357.1964.

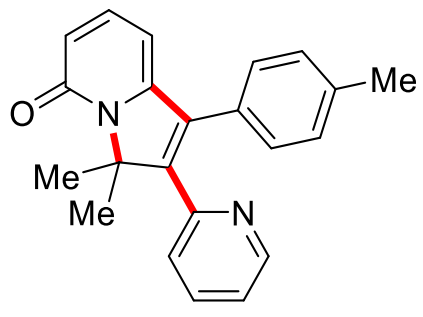

3,3-Dimethyl-2-(pyridin-2-yl)-1-(p-tolyl)indolizin-5(3H)-one (173al): The general 
procedure A was followed using $2 \mathrm{H}$-[1,2'-bipyridin]-2-one (172a) $(86.1 \mathrm{mg}, 0.50 \mathrm{mmol})$ and 2,2- Dimethyl-4-p-tolylbut-3-yn-2-yl carbonate (88I) (349 mg, $1.50 \mathrm{mmol}$ ). Purification by column chromatography on silica gel ( $n$-hexane/EtOAc: $1 / 1$ ) yielded 173al (100 mg, 61\%) as a white solid. M.p.: $156-158{ }^{\circ} \mathrm{C} .{ }^{1} \mathrm{H}-\mathrm{NMR}\left(400 \mathrm{MHz}, \mathrm{CDCl}_{3}\right) \delta=$ 8.65 (ddd, $J=4.8,1.8,0.9 \mathrm{~Hz}, 1 \mathrm{H}), 7.40$ (dd, $J=7.8,1.8 \mathrm{~Hz}, 1 \mathrm{H}$ ), $7.28(\mathrm{~s}, 1 \mathrm{H}), 7.18-7.08$ $(\mathrm{m}, 5 \mathrm{H}), 6.89(\mathrm{dd}, J=8.0,1.1 \mathrm{~Hz}, 1 \mathrm{H}), 6.36(\mathrm{~d}, J=9.0 \mathrm{~Hz}, 1 \mathrm{H}), 6.08(\mathrm{~d}, J=6.9 \mathrm{~Hz}, 1 \mathrm{H})$, $2.35(\mathrm{~s}, 3 \mathrm{H}), 2.06(\mathrm{~s}, 6 \mathrm{H}) .{ }^{13} \mathrm{C}-\mathrm{NMR}\left(100 \mathrm{MHz}, \mathrm{CDCl}_{3}\right) \delta=162.3\left(\mathrm{C}_{\mathrm{q}}\right), 152.7\left(\mathrm{C}_{\mathrm{q}}\right), 150.7$ $\left(C_{q}\right), 150.5\left(C_{q}\right), 149.3(C H), 138.9(C H), 138.5\left(C_{q}\right), 135.7(C H), 133.3\left(C_{q}\right), 129.7(C H)$, $129.2(\mathrm{CH}), 128.9\left(\mathrm{C}_{\mathrm{q}}\right), 125.8(\mathrm{CH}), 122.5(\mathrm{CH}), 118.9(\mathrm{CH}), 100.1(\mathrm{CH}), 75.1\left(\mathrm{C}_{\mathrm{q}}\right), 21.3$ $\left(\mathrm{CH}_{3}\right), 21.2\left(\mathrm{CH}_{3}\right) . \mathrm{IR}$ (ATR): 1653, 1584, 1531, 1462, 1348, 840, 1177, 1154, 795, 743 $\mathrm{cm}^{-1}$. MS (ESI) m/z (relative intensity): $679(35)[2 \mathrm{M}+\mathrm{Na}]^{+}, 329(100)[\mathrm{M}+\mathrm{H}]^{+}$. HR-MS (ESI) $\mathrm{m} / \mathrm{z}$ calcd for $\mathrm{C}_{22} \mathrm{H}_{20} \mathrm{~N}_{2} \mathrm{O}[\mathrm{M}+\mathrm{H}]^{+} 329.1648$, found 329.1652 .

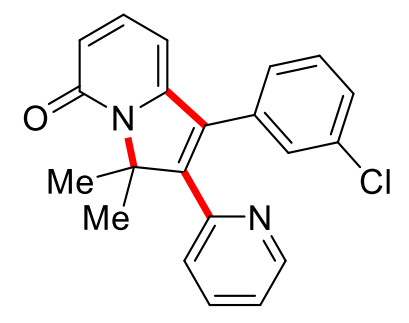

1-(3-Chlorophenyl)-3,3-dimethyl-2-(pyridin-2-yl)indolizin-5(3H)-one (173aj): The general procedure A was followed using $2 \mathrm{H}$-[1,2'-bipyridin]-2-one (172a) $(86.1 \mathrm{mg}$, $0.50 \mathrm{mmol}$ ) and 4-(3-chlorophenyl)-2-methylbut-3-yn-2-yl methyl carbonate (88j) (379 $\mathrm{mg}, 1.50 \mathrm{mmol}$ ). Purification by column chromatography on silica gel ( $n$-hexane/EtOAc: 1/1) yielded 173ag (95.9 mg, 55\%) as a white solid. M.p.: $126-127{ }^{\circ} \mathrm{C} .{ }^{1} \mathrm{H}-\mathrm{NMR}$ (400 $\left.\mathrm{MHz}, \mathrm{CDCl}_{3}\right) \delta=8.63(\mathrm{ddd}, J=4.8,1.9,0.9 \mathrm{~Hz}, 1 \mathrm{H}), 7.41$ (dd, $\left.J=7.8,1.9 \mathrm{~Hz}, 1 \mathrm{H}\right), 7.32-$ $7.20(\mathrm{~m}, 4 \mathrm{H}), 7.15-7.06(\mathrm{~m}, 2 \mathrm{H}), 6.86(\mathrm{dd}, J=7.8,1.1 \mathrm{~Hz}, 1 \mathrm{H}), 6.35$ (dd, $J=9.0,1.1 \mathrm{~Hz}$, 1H), $6.02(\mathrm{dd}, J=6.9,1.1 \mathrm{~Hz}, 1 \mathrm{H}), 2.02(\mathrm{~s}, 6 \mathrm{H}) .{ }^{13} \mathrm{C}-\mathrm{NMR}\left(100 \mathrm{MHz}, \mathrm{CDCl}_{3}\right) \delta=162.1$ $\left(C_{q}\right), 152.0\left(C_{q}\right), 151.6\left(C_{q}\right), 149.8\left(C_{q}\right), 149.5(C H), 138.9(C H), 135.8(C H), 134.8\left(C_{q}\right)$, $133.6\left(\mathrm{C}_{\mathrm{q}}\right), 131.8\left(\mathrm{C}_{\mathrm{q}}\right), 130.2(\mathrm{CH}), 129.2(\mathrm{CH}), 128.8(\mathrm{CH}), 127.6(\mathrm{CH}), 125.6(\mathrm{CH}), 122.8$ (CH), $119.2(\mathrm{CH}), 99.9(\mathrm{CH}), 75.2\left(\mathrm{C}_{\mathrm{q}}\right), 21.0\left(\mathrm{CH}_{3}\right)$. IR (ATR): 1711, 1651, 1582, 1529, 
1461, 1432, 1347, 1178, 1155, $793 \mathrm{~cm}^{-1}$. MS (ESI) m/z (relative intensity): 719 (15) $[2 \mathrm{M}+\mathrm{Na}]^{+}, 371(12)[\mathrm{M}+\mathrm{Na}]^{+}, 349(100)[\mathrm{M}+\mathrm{H}]^{+}$. HR-MS (ESI) $\mathrm{m} / z$ calcd for $\mathrm{C}_{21} \mathrm{H}_{18} \mathrm{~N}_{2} \mathrm{OCl}$ $[\mathrm{M}+\mathrm{H}]^{+}$349.1102, found 349.1103.

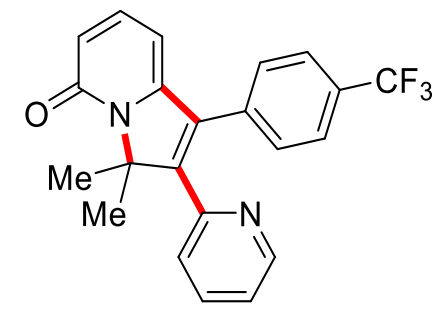

\section{3,3-Dimethyl-2-(pyridin-2-yl)-1-(4-(trifluoromethyl)phenyl)indolizin-5(3H)-one}

(173ak): The general procedure A was followed using $2 H$-[1,2'-bipyridin]-2-one (172a) (86.1 mg, $0.50 \mathrm{mmol}$ ) and methyl (2-methyl-4-(4-(trifluoromethyl)phenyl)but-3-yn-2yl) carbonate (88k) (430 mg, $1.50 \mathrm{mmol})$. Purification by column chromatography on silica gel ( $n$-hexane/EtOAc: $1 / 1)$ yielded 173ak (105 mg, 55\%) as a white solid. M.p.: 138-139 ${ }^{\circ} \mathrm{C} .{ }^{1} \mathrm{H}-\mathrm{NMR}\left(400 \mathrm{MHz}, \mathrm{CDCl}_{3}\right) \delta=8.7$ (ddd, $\left.J=4.8,1.8,1.0 \mathrm{~Hz}, 1 \mathrm{H}\right), 7.65-7.59$ (m, 2H), $7.47(\mathrm{dd}, J=7.8,1.8 \mathrm{~Hz}, 1 \mathrm{H}), 7.41(\mathrm{dd}, J=7.9,0.8 \mathrm{~Hz}, 1 \mathrm{H}), 7.31(\mathrm{dd}, J=9.1,6.9$ $\mathrm{Hz}, 1 \mathrm{H}), 7.19(\mathrm{ddd}, J=7.6,4.8,1.1 \mathrm{~Hz}, 1 \mathrm{H}), 6.86(\mathrm{dt}, J=7.8,1.0 \mathrm{~Hz}, 1 \mathrm{H}), 6.41(\mathrm{dd}, J=$ 9.1, $1.1 \mathrm{~Hz}, 1 \mathrm{H}), 6.05$ (dd, J = 6.9, $1.1 \mathrm{~Hz}, 1 \mathrm{H}), 2.07(\mathrm{~s}, 6 \mathrm{H}) .{ }^{13} \mathrm{C}-\mathrm{NMR}\left(100 \mathrm{MHz}, \mathrm{CDCl}_{3}\right)$ $\delta=162.2\left(\mathrm{C}_{\mathrm{q}}\right), 152.2\left(\mathrm{C}_{\mathrm{q}}\right), 152.0\left(\mathrm{C}_{\mathrm{q}}\right), 149.7\left(\mathrm{C}_{\mathrm{q}}\right), 149.6(\mathrm{CH}), 138.9(\mathrm{CH}), 136.0(\mathrm{CH})$, $135.7\left(C_{q}\right), 131.9\left(C_{q}\right), 130.7\left(q,{ }^{2} J_{C-F}=32.7 \mathrm{~Hz}, C_{q}\right), 129.8(C H), 125.9\left(q,{ }^{3} J_{C-F}=3.8 \mathrm{~Hz}\right.$, $\mathrm{CH}), 125.5(\mathrm{CH}), 123.8\left(\mathrm{q},{ }^{1} J_{\mathrm{C}-\mathrm{F}}=272.2 \mathrm{~Hz}, \mathrm{C}_{\mathrm{q}}\right), 122.9(\mathrm{CH}), 119.4(\mathrm{CH}), 99.8(\mathrm{CH}), 75.3$ $\left(\mathrm{C}_{\mathrm{q}}\right), 21.1\left(\mathrm{CH}_{3}\right) .{ }^{19} \mathrm{~F}-\mathrm{NMR}\left(376 \mathrm{MHz}, \mathrm{CDCl}_{3}\right) \delta=-62.74$ (s). IR (ATR): 1655, 1584, 1531, 1463, 1321, 1164, 1123, 1068, $1018 \mathrm{~cm}^{-1}$. MS (ESI) m/z (relative intensity): 787 (45) $[2 \mathrm{M}+\mathrm{Na}]^{+}, 383(100)[\mathrm{M}+\mathrm{H}]^{+}$. HR-MS (ESI) $\mathrm{m} / z$ calcd for $\mathrm{C}_{22} \mathrm{H}_{17} \mathrm{~N}_{2} \mathrm{OF}{ }_{3}[\mathrm{M}+\mathrm{H}]^{+} 383.1366$, found 383.1367 .

\subsubsection{Mechanistic Studies}

Intermolecular competition experiments 
<smiles>CC(F)(F)c1ccc(=O)n(-c2ccccn2)c1</smiles>

$172 \mathrm{~g} / 172 \mathrm{f}$

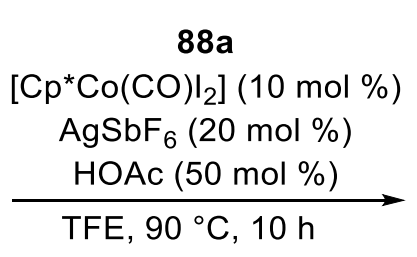

TFE, $90^{\circ} \mathrm{C}, 10 \mathrm{~h}$

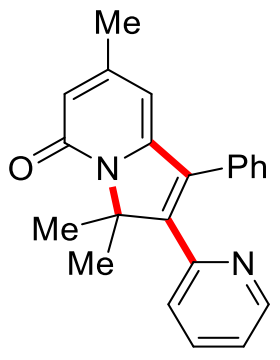

173ga: $26 \%$

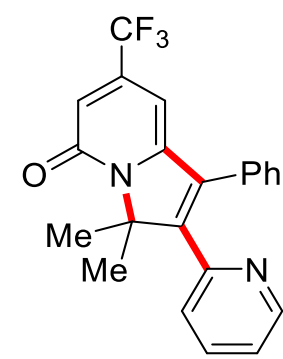

173fa: trace

4-Methyl-2H-[1,2'-bipyridin]-2-one (172g) $(93.1 \mathrm{mg}, 0.50 \mathrm{mmol})$, 4-(trifluoromethyl)2H-[1,2'-bipyridin]-2-one (172f) $(120 \mathrm{mg}, 0.50 \mathrm{mmol})$, methyl (2-methyl-4-phenylbut3-yn-2-yl)carbonate (88a) (328 mg, $1.50 \mathrm{mmol}), \mathrm{Cp} * \mathrm{Co}(\mathrm{CO}) \mathrm{I}_{2}(24.0 \mathrm{mg}, 10 \mathrm{~mol} \%)$, $\mathrm{AgSbF}_{6}(34.4 \mathrm{mg}, 20 \mathrm{~mol} \%), \mathrm{HOAc}(15.0 \mathrm{mg}, 50 \mathrm{~mol} \%)$, and TFE $(2.0 \mathrm{~mL})$ were placed in a $25 \mathrm{~mL}$ Schlenk pressure tube under $\mathrm{N}_{2}$ atmosphere, and stirred at $90^{\circ} \mathrm{C}$ for $10 \mathrm{~h}$. After cooling to ambient temperature, the mixture was transferred into a round bottom flask with $\mathrm{CH}_{2} \mathrm{Cl}_{2}(20 \mathrm{~mL})$ and concentrated in vacuo. Purification by column chromatography on silica gel ( $n$-hexane/EtOAc: $6 / 1 \rightarrow 1 / 1$ ) afforded 173ga (42.7 mg, $26 \%)$ and trace of $\mathbf{1 7 3 f a}$.<smiles>CC(F)(F)c1ccc(-n2ccccc2=O)nc1</smiles>

172i/172k

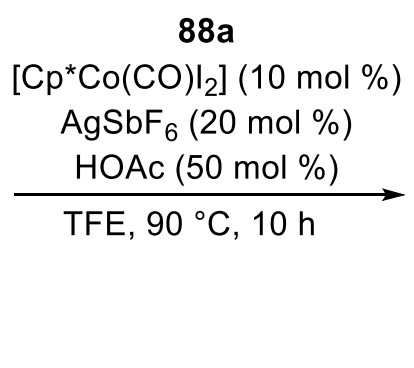

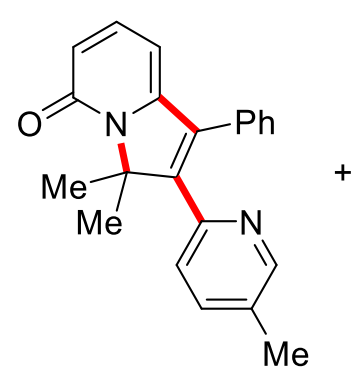

173ia: $37 \%$

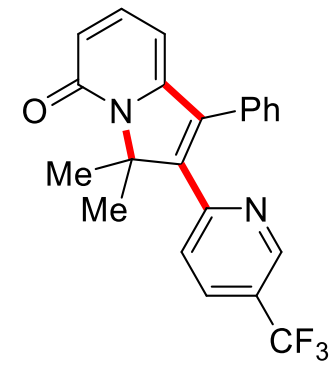

173ka: $12 \%$

5'-Methyl-2H-[1,2'-bipyridin]-2-one (172i) $(93.1 \mathrm{mg}, 0.50 \mathrm{mmol}), 5^{\prime}$-(trifluoromethyl)2H-[1,2'-bipyridin]-2-one (172k) (103 mg, $0.50 \mathrm{mmol}$ ), methyl (2-methyl-4-phenylbut3-yn-2-yl)carbonate (88a) (328 mg, $1.50 \mathrm{mmol}), \mathrm{Cp} * \mathrm{Co}(\mathrm{CO}) \mathrm{I}_{2}(24.0 \mathrm{mg}, 10 \mathrm{~mol} \%)$, $\mathrm{AgSbF}_{6}(34.4 \mathrm{mg}, 20 \mathrm{~mol} \%), \mathrm{HOAc}(15.0 \mathrm{mg}, 50 \mathrm{~mol} \%)$, and TFE $(2.0 \mathrm{~mL})$ were placed in a $25 \mathrm{~mL}$ Schlenk pressure tube under $\mathrm{N}_{2}$ atmosphere, and stirred at $90{ }^{\circ} \mathrm{C}$ for $10 \mathrm{~h}$. After cooling to ambient temperature, the mixture was transferred into a round 
bottom flask with $\mathrm{CH}_{2} \mathrm{Cl}_{2}(20 \mathrm{~mL})$ and concentrated in vacuo. Purification by column chromatography on silica gel ( $n$-hexane/EtOAc: 6/1 $\rightarrow 1 / 1$ ) afforded 173ia (60.8 mg, $37 \%)$ and 173ka (22.9 mg, 12\%).

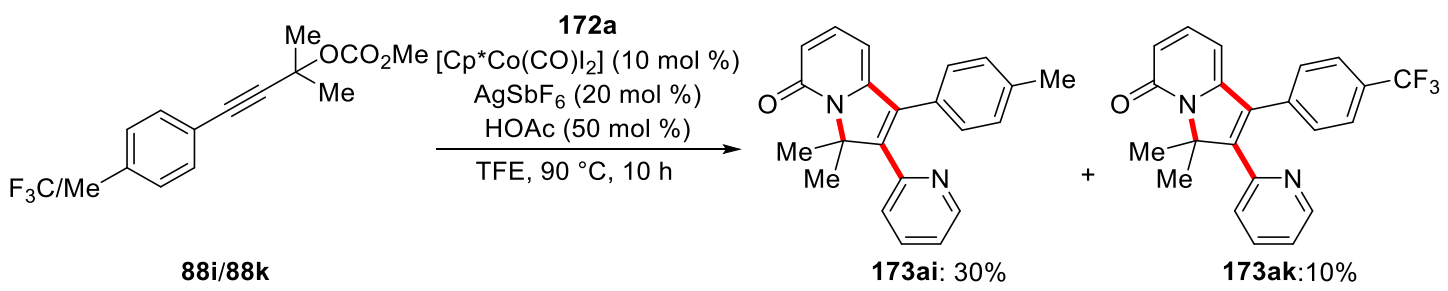

2H-[1,2'-Bipyridin]-2-one (172a) $(86.1 \mathrm{mg}, 0.50 \mathrm{mmol})$, methyl (2-methyl-4-(ptolyl)but-3-yn-2-yl) carbonate (88i), methyl (2-methyl-4-(4(trifluoromethyl)phenyl)but-3-yn-2-yl) carbonate (88k) (430 mg, $1.50 \mathrm{mmol}$ ), $\mathrm{Cp}^{*} \mathrm{Co}(\mathrm{CO}) \mathrm{I}_{2}(24.0 \mathrm{mg}, 10 \mathrm{~mol} \%), \mathrm{AgSbF}_{6}(34.4 \mathrm{mg}, 20 \mathrm{~mol} \%), \mathrm{HOAc}(15.0 \mathrm{mg}, 50$ $\mathrm{mol} \%)$, and TFE $\left(2.0 \mathrm{~mL}\right.$ ) were placed in a $25 \mathrm{~mL}$ Schlenk pressure tube under $\mathrm{N}_{2}$ atmosphere, and stirred at $90{ }^{\circ} \mathrm{C}$ for $10 \mathrm{~h}$. After cooling to ambient temperature, the mixture was transferred into a round bottom flask with $\mathrm{CH}_{2} \mathrm{Cl}_{2}(20 \mathrm{~mL})$ and concentrated in vacuo. Purification by column chromatography on silica gel ( $n$ hexane/EtOAc: $6 / 1 \rightarrow 1 / 1$ ) afforded 173ai (49.3 mg, 30\%) and 173ak (19.1 mg, 10\%).

\section{H/D Exchange Experiments}<smiles>O=c1ccccn1-c1ccccn1</smiles>

$172 a$
$88 a$ $\left[\mathrm{Cp}{ }^{\star} \mathrm{Co}(\mathrm{CO}) \mathrm{I}_{2}\right](10 \mathrm{~mol} \%)$ $\mathrm{AgSbF}_{6}(20 \mathrm{~mol} \%)$ $\underset{\mathrm{D}_{3} \text {-TFE }}{\stackrel{\mathrm{CD}_{3} \mathrm{CO}_{2} \mathrm{D}(50 \mathrm{~mol} \%)}{\longrightarrow}}$ $90^{\circ} \mathrm{C}, 10 \mathrm{~h}$<smiles>O=c1cccc([18OH])n1-c1ccccn1</smiles>

$[D]_{1}-172 a: 10 \%$

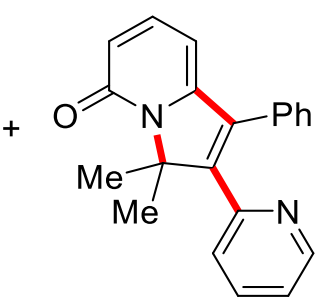

173aa: $73 \%$

2H-[1,2'-Bipyridin]-2-one (172a) $(86.1 \mathrm{mg}, 0.50 \mathrm{mmol})$, methyl (2-methyl-4-phenylbut3-yn-2-yl)carbonate (88a) (328 mg, $1.50 \mathrm{mmol}), \mathrm{Cp} * \mathrm{Co}(\mathrm{CO}) \mathrm{I}_{2}(24.0 \mathrm{mg}, 10 \mathrm{~mol} \%)$, $\mathrm{AgSbF}_{6}$ (34.4 mg, $\left.20 \mathrm{~mol} \%\right), \mathrm{CD}_{3} \mathrm{CO}_{2} \mathrm{D}$ (16.0 mg, $50 \mathrm{~mol} \%$ ), and $\mathrm{D}_{3}$-TFE (2.0 mL) were placed in a $25 \mathrm{~mL}$ Schlenk pressure tube under $\mathrm{N}_{2}$ atmosphere, and stirred at $90{ }^{\circ} \mathrm{C}$ for $10 \mathrm{~h}$. After cooling to ambient temperature, the mixture was transferred into a round 
bottom flask with $\mathrm{CH}_{2} \mathrm{Cl}_{2}(20 \mathrm{~mL})$ and concentrated in vacuo. Purification by column chromatography on silica gel ( $n$-hexane/EtOAc: $3 / 1 \rightarrow 1 / 1$ ) afforded afforded [D] $]_{1}-172 a$ (8.7 mg, 10\%) and 173aa (115 mg, 73\%). The $\mathrm{D}$ incorporation was determined by ${ }^{1} \mathrm{H}-$ NMR spectroscopy.
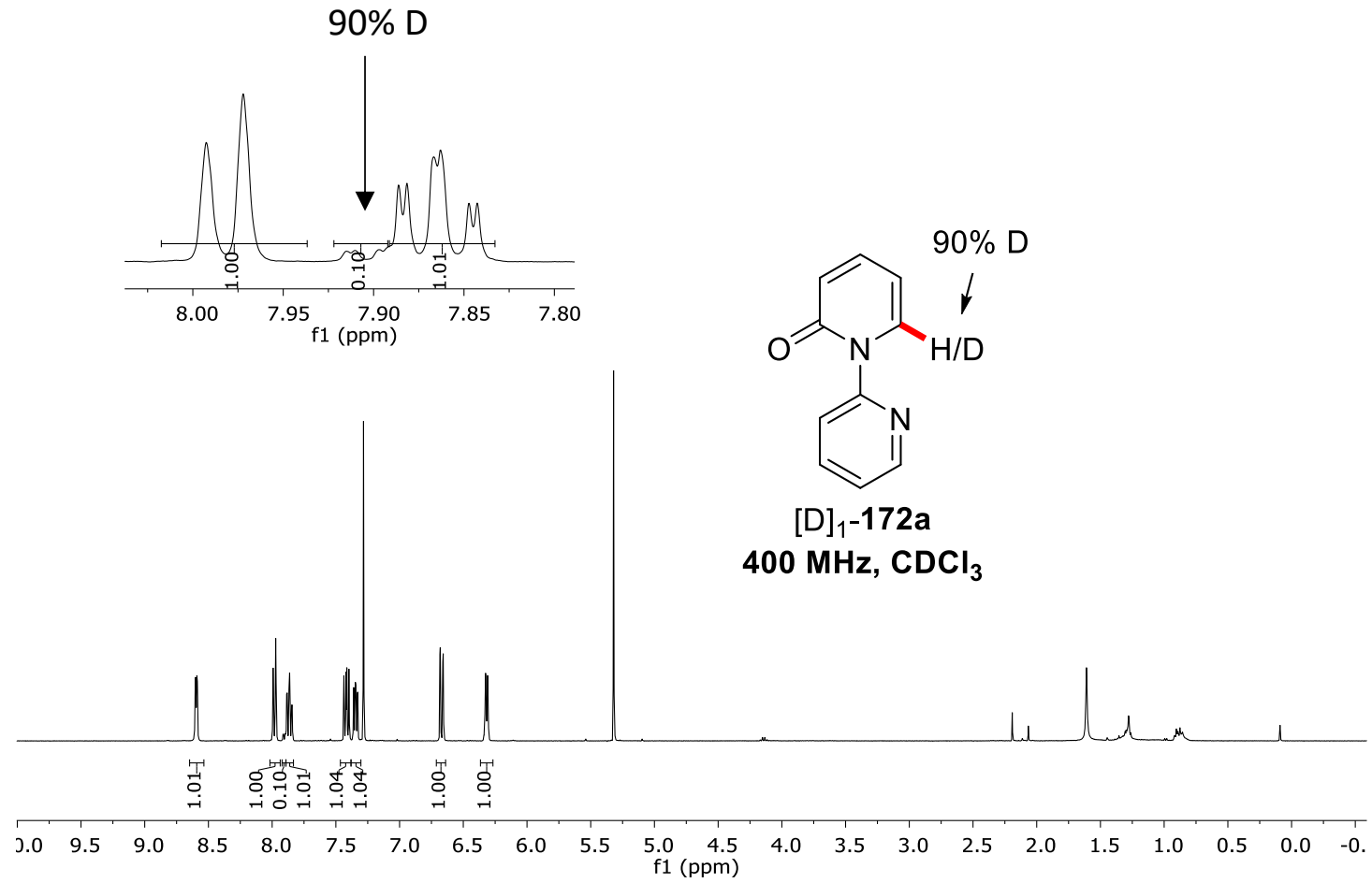

Kinetic Isotope Effect Study

$88 a$<smiles>O=c1cccc([18OH])n1-c1ccccn1</smiles>

172a or $[D]_{1}-172 a$<smiles>O=c1cccc(-n2cccc2[18OH])n1-c1ccccn1</smiles>

$[D]_{1}-172 a$

$400 \mathrm{MHz}^{\mathrm{CDCl}_{3}}$ $\left[\mathrm{Cp}{ }^{*} \mathrm{Co}(\mathrm{CO}) \mathrm{I}_{2}\right](10 \mathrm{~mol} \%)$ $\mathrm{AgSbF}_{6}(20 \mathrm{~mol} \%)$ $\mathrm{HOAC}(50 \mathrm{~mol} \%)$ TFE, $90^{\circ} \mathrm{C}, \mathrm{t} \mathrm{h}$

$$
k_{\mathrm{H}} / k_{\mathrm{D}}=1.3
$$

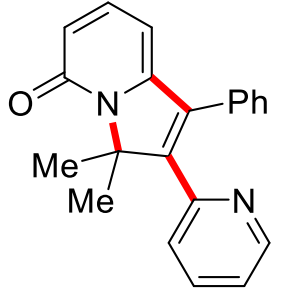

173aa

Five independent reactions of $172 a$ or $[D]_{1}-172 a$ with $88 a$ were performed to determine the KIE. $172 \mathrm{a}(86.2 \mathrm{mg}, 0.50 \mathrm{mmol})$ or [D] ${ }_{1}-172 \mathrm{a}(86.6 \mathrm{mg}, 0.50 \mathrm{mmol}), 88 \mathrm{a}$ (328mg, $1.50 \mathrm{mmol}), \mathrm{Cp}^{*} \mathrm{Co}(\mathrm{CO}) \mathrm{I}_{2}(24.0 \mathrm{mg}, 10 \mathrm{~mol} \%), \mathrm{AgSbF}_{6}(34.4 \mathrm{mg}, 20 \mathrm{~mol} \%)$, 
HOAc (15.0 mg, $50 \mathrm{~mol} \%)$, and TFE $(2.0 \mathrm{~mL})$ were placed in a $25 \mathrm{~mL}$ Schlenk pressure tube under $\mathrm{N}_{2}$ atmosphere, and stirred at $90^{\circ} \mathrm{C}$. After cooling to ambient temperature, the mixture was transferred into a round bottom flask with $\mathrm{CH}_{2} \mathrm{Cl}_{2}(20 \mathrm{~mL})$ and concentrated in vacuo. Purification by column chromatography on silica gel ( $n$-hexane/EtOAc: $1 / 1$ ) yielded 173aa or $[D]_{n}$-173aa.

\begin{tabular}{|l|l|l|l|l|l|}
\hline$t(\min )$ & 60 & 80 & 100 & 120 & 140 \\
\hline 173aa (\%) & 3 & 10 & 15 & 20 & 25 \\
\hline$[D]_{n}-173 a a(\%)$ & 2 & 8 & 10 & 15 & 19 \\
\hline
\end{tabular}

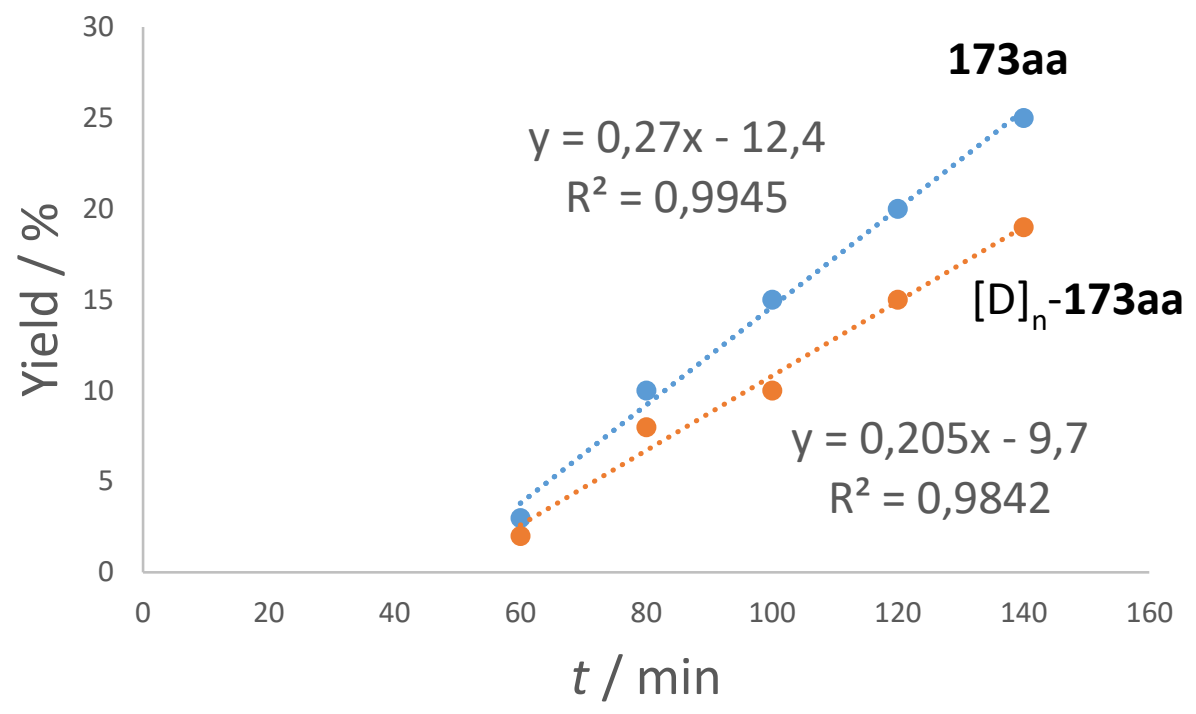

Late-Stage Modifications

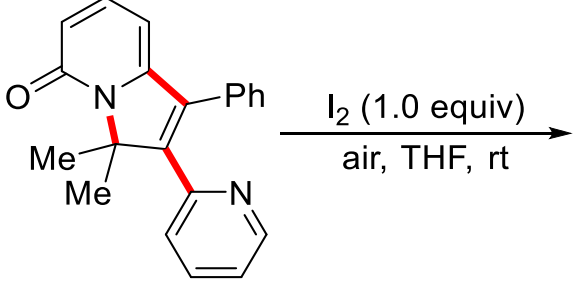

173aa

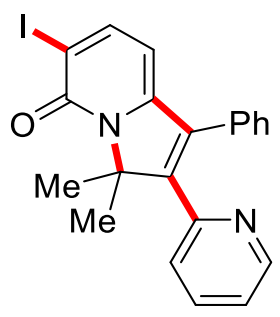

174: $58 \%$

173aa (57.4 mg, $0.2 \mathrm{mmol})$ and $\mathrm{I}_{2}(50.8 \mathrm{mg}, 0.2 \mathrm{mmol})$ were dissolved in THF $(1.0 \mathrm{~mL})$. 
The resulting solution was stirred for $24 \mathrm{~h}$ at $23^{\circ} \mathrm{C}$. The mixture was transferred into a round bottom flask with $\mathrm{CH}_{2} \mathrm{Cl}_{2}(20 \mathrm{~mL})$ and concentrated in vacuo. Purification by column chromatography on silica gel ( $n$-hexane/EtOAc: $1 / 1$ ) afforded the desired product 174 (51.1 mg, 58\%).

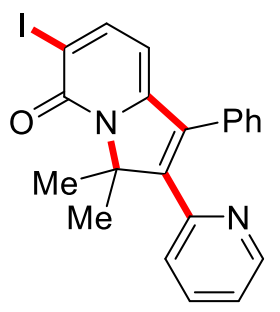

6-lodo-3,3-dimethyl-1-phenyl-2-(pyridin-2-yl)indolizin-5(3H)-one (174): White solid. M.p.: $212-213{ }^{\circ} \mathrm{C} .{ }^{1} \mathrm{H}-\mathrm{NMR}\left(400 \mathrm{MHz}, \mathrm{CDCl}_{3}\right) \delta=8.64$ (ddd, $\left.J=4.8,1.8,1.0 \mathrm{~Hz}, 1 \mathrm{H}\right)$, $7.93(\mathrm{~d}, J=7.5 \mathrm{~Hz}, 1 \mathrm{H}), 7.43-7.33(\mathrm{~m}, 4 \mathrm{H}), 7.27-7.21(\mathrm{~m}, 2 \mathrm{H}), 7.13$ (ddd, J = 7.5, 4.8, $1.0 \mathrm{~Hz}, 1 \mathrm{H}), 6.87(\mathrm{dd}, J=7.9,1.0 \mathrm{~Hz}, 1 \mathrm{H}), 5.88(\mathrm{~d}, J=7.5 \mathrm{~Hz}, 1 \mathrm{H}), 2.06(\mathrm{~s}, 6 \mathrm{H}) .{ }^{13} \mathrm{C}-\mathbf{N M R}$ $\left(100 \mathrm{MHz}, \mathrm{CDCl}_{3}\right) \delta=158.7\left(\mathrm{C}_{\mathrm{q}}\right), 152.2\left(\mathrm{C}_{\mathrm{q}}\right), 151.4\left(\mathrm{C}_{\mathrm{q}}\right), 150.8\left(\mathrm{C}_{\mathrm{q}}\right), 149.4(\mathrm{CH}), 147.9$ $(\mathrm{CH}), 135.7(\mathrm{CH}), 133.0\left(\mathrm{C}_{\mathrm{q}}\right), 131.5\left(\mathrm{C}_{\mathrm{q}}\right), 129.3(\mathrm{CH}), 129.1(\mathrm{CH}), 128.8(\mathrm{CH}), 125.8(\mathrm{CH})$, 122.7 (CH), 101.3 (CH), $91.4\left(\mathrm{C}_{\mathrm{q}}\right), 76.5\left(\mathrm{C}_{\mathrm{q}}\right), 21.1\left(\mathrm{CH}_{3}\right)$. IR (ATR): 1645, 1591, 1510, 1462, 1337, 1076, 1053, 791, $701 \mathrm{~cm}^{-1}$. MS (ESI) m/z (relative intensity): 903 (5) [2M+Na] ${ }^{+}$, $463(10)[\mathrm{M}+\mathrm{Na}]^{+}, 441(100)[\mathrm{M}+\mathrm{H}]^{+}$. HR-MS (ESI) $\mathrm{m} / \mathrm{z}$ calcd for $\mathrm{C}_{21} \mathrm{H}_{18} \mathrm{~N}_{2} \mathrm{Ol}[\mathrm{M}+\mathrm{H}]^{+}$ 441.0458 , found 441.0462 .

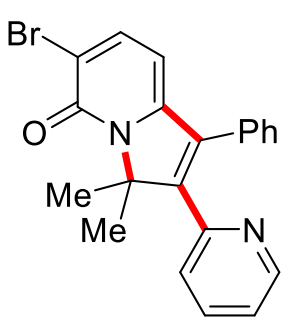

173na

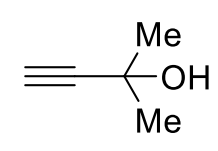

88ah

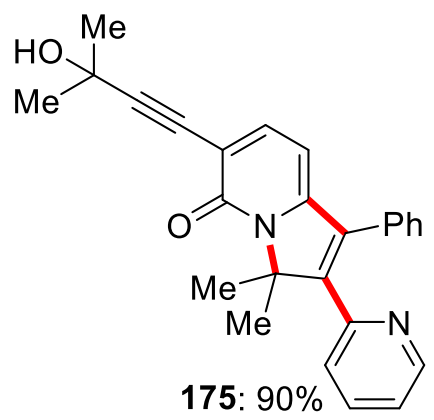

173na (78.7 mg, $0.20 \mathrm{mmol}), 2$-methylbut-3-yn-2-ol (33.6 mg, $0.40 \mathrm{mmol}),\left[\mathrm{Pd}\left(\mathrm{PPh}_{3}\right)\right.$ $\mathrm{Cl}_{2}$ ] (14.0 mg, $\left.10 \mathrm{~mol} \%\right)$, Cul (3.8 mg, $\left.10 \mathrm{~mol} \%\right)$, and $\mathrm{Et}_{3} \mathrm{~N}(0.4 \mathrm{~mL}) \mathrm{DMF}(0.8 \mathrm{~mL})$ were placed in a $25 \mathrm{~mL}$ Schlenk pressure tube under $\mathrm{N}_{2}$ atmosphere, and stirred at $50^{\circ} \mathrm{C}$ for 
$24 \mathrm{~h}$. After cooling to ambient temperature, the mixture was transferred into a round bottom flask with $\mathrm{CH}_{2} \mathrm{Cl}_{2}(20 \mathrm{~mL})$ and concentrated in vacuo. Purification by column chromatography on silica gel ( $n$-hexane/EtOAc: $3 / 1 \rightarrow 1 / 1$ ) afforded 175 (71.4 mg, 90\%). as a white solid. M.p.: $162-163{ }^{\circ} \mathrm{C} .{ }^{1} \mathrm{H}-\mathrm{NMR}\left(400 \mathrm{MHz}, \mathrm{CDCl}_{3}\right) \delta=8.63$ (ddd, $J=$ 4.8, 1.9, 1.0 Hz, 1H), 7.48 (d, J = 7.4 Hz, 1H), 7.42-7.32 (m, 4H), 7.27-7.19 (m, 2H), 7.12 (ddd, $J=7.6,4.8,1.1 \mathrm{~Hz}, 1 \mathrm{H}), 6.86(\mathrm{dd}, J=8.0,1.1 \mathrm{~Hz}, 1 \mathrm{H}), 6.07(\mathrm{~d}, J=7.4 \mathrm{~Hz}, 1 \mathrm{H}), 2.06$ (s, 6H), $1.61(\mathrm{~s}, 6 \mathrm{H}) .{ }^{13} \mathrm{C}-\mathrm{NMR}\left(100 \mathrm{MHz}, \mathrm{CDCl}_{3}\right) \delta=161.2\left(\mathrm{C}_{\mathrm{q}}\right), 152.2\left(\mathrm{C}_{\mathrm{q}}\right), 151.8\left(\mathrm{C}_{\mathrm{q}}\right)$, $150.3\left(\mathrm{C}_{\mathrm{q}}\right), 149.3(\mathrm{CH}), 142.2(\mathrm{CH}), 135.7(\mathrm{CH}), 133.1\left(\mathrm{C}_{\mathrm{q}}\right), 131.5\left(\mathrm{C}_{\mathrm{q}}\right), 129.3(\mathrm{CH}), 129.0$ $(\mathrm{CH}), 128.8(\mathrm{CH}), 125.7(\mathrm{CH}), 122.7(\mathrm{CH}), 113.3\left(\mathrm{C}_{\mathrm{q}}\right), 100.1(\mathrm{CH}), 99.8\left(\mathrm{C}_{\mathrm{q}}\right), 78.3\left(\mathrm{C}_{\mathrm{q}}\right)$, $75.9\left(\mathrm{C}_{\mathrm{q}}\right), 65.4\left(\mathrm{C}_{\mathrm{q}}\right), 31.4\left(\mathrm{CH}_{3}\right), 21.2\left(\mathrm{CH}_{3}\right)$. IR (ATR): 2979, 1637, 1583, 1539, 1463, 1339, 1270, 1166, 780, $702 \mathrm{~cm}^{-1} . \mathrm{MS}$ (ESI) $\mathrm{m} / \mathrm{z}$ (relative intensity): 815 (12) [2M+Na] $]^{+}, 419$ (100) $[\mathrm{M}+\mathrm{Na}]^{+}, 397(65)[\mathrm{M}+\mathrm{H}]^{+}$. HR-MS (ESI) $\mathrm{m} / \mathrm{z}$ calcd for $\mathrm{C}_{26} \mathrm{H}_{25} \mathrm{~N}_{2} \mathrm{O}_{2}[\mathrm{M}+\mathrm{H}]^{+}$ 397.1911, found 397.1917. 


\subsection{Manganese(I)-Catalyzed C-H Activation Domino Alkyne Annulation}

\section{by Transformable Pyridines}

\subsubsection{Characterization Data}

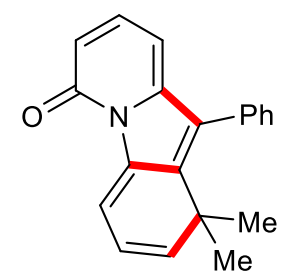

1,1-Dimethyl-10-phenylpyrido[1,2-a]indol-6(1H)-one (180aa): The general procedure B was followed using $2 \mathrm{H}$-[1,2'-bipyridin]-2-one (172a) $(43.1 \mathrm{mg}, 0.25 \mathrm{mmol}$ ) and methyl (2-methyl-4-phenylbut-3-yn-2-yl)carbonate (88a) $(83.0 \mathrm{mg}, 0.38 \mathrm{mmol}$ ). Purification by column chromatography on silica gel ( $n$-hexane/EtOAc: $10 / 1$ ) yielded 180aa (51.0 mg, 71\%) as an orange solid. M.p.: $160-161^{\circ} \mathrm{C} .{ }^{1} \mathbf{H}-\mathbf{N M R}\left(400 \mathrm{MHz}, \mathrm{CDCl}_{3}\right)$ $\delta=7.98(\mathrm{~d}, J=6.5 \mathrm{~Hz}, 1 \mathrm{H}), 7.52-7.40(\mathrm{~m}, 3 \mathrm{H}), 7.37-7.32(\mathrm{~m}, 2 \mathrm{H}), 7.28(\mathrm{dd}, J=9.0,7.1$ $\mathrm{Hz}, 1 \mathrm{H}), 6.50-6.40(\mathrm{~m}, 1 \mathrm{H}), 6.28(\mathrm{dd}, J=9.5,6.5 \mathrm{~Hz}, 1 \mathrm{H}), 5.95-5.72(\mathrm{~m}, 2 \mathrm{H}), 1.21(\mathrm{~s}$, 6H). ${ }^{13} \mathrm{C}-\mathrm{NMR}\left(100 \mathrm{MHz}, \mathrm{CDCl}_{3}\right) \delta=161.5\left(\mathrm{C}_{\mathrm{q}}\right), 148.3\left(\mathrm{C}_{\mathrm{q}}\right), 142.7\left(\mathrm{C}_{\mathrm{q}}\right), 142.5(\mathrm{CH}), 138.0$ $\left(\mathrm{C}_{q}\right), 137.4(\mathrm{CH}), 132.8\left(\mathrm{C}_{q}\right), 131.8\left(\mathrm{C}_{\mathrm{q}}\right), 130.6(\mathrm{CH}), 128.3(\mathrm{CH}), 128.1(\mathrm{CH}), 119.9(\mathrm{CH})$, $115.8(\mathrm{CH}), 115.7(\mathrm{CH}), 99.6(\mathrm{CH}), 38.7\left(\mathrm{C}_{\mathrm{q}}\right), 28.3\left(\mathrm{CH}_{3}\right)$. IR (ATR): 3036, 2969, 2161, 1653, 1585, 1218, 1151, 790, $702 \mathrm{~cm}^{-1}$. MS (ESI) $\mathrm{m} / \mathrm{z}$ (relative intensity): 597 (25) $[2 \mathrm{M}+\mathrm{Na}]^{+}, 310(52)[\mathrm{M}+\mathrm{Na}]^{+}, 288(100)[\mathrm{M}+\mathrm{H}]^{+}$. HR-MS (ESI) $\mathrm{m} / z$ calcd for $\mathrm{C}_{20} \mathrm{H}_{18} \mathrm{NO}$ $[\mathrm{M}+\mathrm{H}]^{+} 288.1383$, found 288.1380 . The compound 180 aa was also unambiguously characterized by X-ray crystallographic diffraction analysis (vide infra).

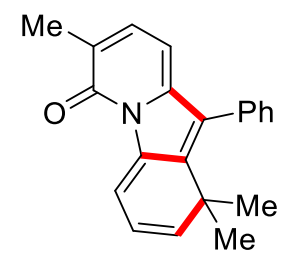

1,1,7-Trimethyl-10-phenylpyrido[1,2-a]indol-6(1H)-one (180ba): The general procedure B was followed using 3-methyl-2H-[1,2'-bipyridin]-2-one (172b) (46.6 mg, 
$0.25 \mathrm{mmol}$ ) and methyl (2-methyl-4-phenylbut-3-yn-2-yl)carbonate (88a) $(83.0 \mathrm{mg}$, $0.38 \mathrm{mmol}$ ). Purification by column chromatography on silica gel ( $n$-hexane/EtOAc: 10/1) yielded 180 ba $\left(51.2 \mathrm{mg}, 68 \%\right.$ ) as an orange solid. M.p.: $188-189{ }^{\circ} \mathrm{C} .{ }^{1} \mathbf{H}-\mathbf{N M R}$ $\left(400 \mathrm{MHz}, \mathrm{CDCl}_{3}\right) \delta=8.00(\mathrm{~d}, J=6.5 \mathrm{~Hz}, 1 \mathrm{H}), 7.46-7.34(\mathrm{~m}, 3 \mathrm{H}), 7.35-7.26(\mathrm{~m}, 2 \mathrm{H})$, $7.06(\mathrm{dd}, J=9.1,0.5 \mathrm{~Hz}, 1 \mathrm{H}), 6.39(\mathrm{~d}, J=9.1 \mathrm{~Hz}, 1 \mathrm{H}), 6.23(\mathrm{dd}, J=9.4,6.5 \mathrm{~Hz}, 1 \mathrm{H}), 5.77$ (d, J = 9.4 Hz, 1H), $1.50(\mathrm{~s}, 3 \mathrm{H}), 1.12(\mathrm{~s}, 6 \mathrm{H}) \cdot{ }^{13} \mathrm{C}-\mathrm{NMR}\left(100 \mathrm{MHz}, \mathrm{CDCl}_{3}\right) \delta=161.2\left(\mathrm{C}_{\mathrm{q}}\right)$, 142.6 $\left(\mathrm{C}_{\mathrm{q}}\right), 142.5\left(\mathrm{C}_{\mathrm{q}}\right), 142.4(\mathrm{CH}), 142.2(\mathrm{CH}), 137.7\left(\mathrm{C}_{\mathrm{q}}\right), 134.9\left(\mathrm{C}_{\mathrm{q}}\right), 132.5\left(\mathrm{C}_{\mathrm{q}}\right), 130.9$ $(\mathrm{CH}), 128.2(\mathrm{CH}), 127.8(\mathrm{CH}), 120.0(\mathrm{CH}), 115.6(\mathrm{CH}), 114.9(\mathrm{CH}), 110.7\left(\mathrm{C}_{\mathrm{q}}\right), 38.6\left(\mathrm{C}_{\mathrm{q}}\right)$, $28.1\left(\mathrm{CH}_{3}\right), 16.4\left(\mathrm{CH}_{3}\right)$. IR (ATR): 3032, 2959, 2922, 1652, 1590, 1513, 802, $738 \mathrm{~cm}^{-1}$. MS (ESI) $m / z$ (relative intensity): 625 (14) $[2 \mathrm{M}+\mathrm{Na}]^{+}, 324(10)[\mathrm{M}+\mathrm{Na}]^{+}, 302(100)$ $[\mathrm{M}+\mathrm{H}]^{+}$. HR-MS (ESI) $\mathrm{m} / z$ calcd for $\mathrm{C}_{21} \mathrm{H}_{20} \mathrm{NO}[\mathrm{M}+\mathrm{H}]^{+} 302.1539$, found 302.1539 .

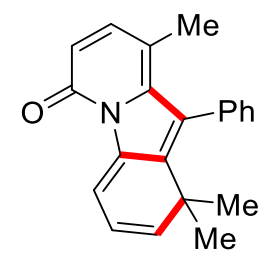

1,1,9-Trimethyl-10-phenylpyrido[1,2-a]indol-6(1H)-one (180 ca): The general procedure B was followed using 5-methyl-2H-[1,2'-bipyridin]-2-one (172c) (46.6 mg, $0.25 \mathrm{mmol}$ ) and methyl (2-methyl-4-phenylbut-3-yn-2-yl)carbonate (88a) $(83.0 \mathrm{mg}$, $0.38 \mathrm{mmol}$ ). Purification by column chromatography on silica gel ( $n$-hexane/EtOAc: 10/1) yielded $180 \mathrm{ca}(40.0 \mathrm{mg}, 53 \%)$ as an orange solid. M.p.: $225-226^{\circ} \mathrm{C} .{ }^{1}$ H-NMR (400 $\left.\mathrm{MHz}_{\mathrm{CDCl}}\right) \delta=8.02(\mathrm{~d}, J=6.5 \mathrm{~Hz}, 1 \mathrm{H}), 7.42(\mathrm{dd}, J=4.9,2.0 \mathrm{~Hz}, 3 \mathrm{H}), 7.36-7.30(\mathrm{~m}, 2 \mathrm{H})$, $7.08(\mathrm{~d}, J=9.0 \mathrm{~Hz}, 1 \mathrm{H}), 6.40(\mathrm{~d}, J=9.0 \mathrm{~Hz}, 1 \mathrm{H}), 6.25(\mathrm{dd}, J=9.4,6.5 \mathrm{~Hz}, 1 \mathrm{H}), 5.79(\mathrm{~d}, J$ $=9.4 \mathrm{~Hz}, 1 \mathrm{H}), 1.52(\mathrm{~s}, 3 \mathrm{H}), 1.14(\mathrm{~s}, 6 \mathrm{H}) .{ }^{13} \mathrm{C}-\mathrm{NMR}\left(100 \mathrm{MHz}, \mathrm{CDCl}_{3}\right) \delta=161.2\left(\mathrm{C}_{\mathrm{q}}\right), 142.5$ $\left(\mathrm{C}_{q}\right), 142.4(\mathrm{CH}), 142.2\left(\mathrm{C}_{\mathrm{q}}\right), 142.1(\mathrm{CH}), 137.7\left(\mathrm{C}_{\mathrm{q}}\right), 134.9\left(\mathrm{C}_{\mathrm{q}}\right), 132.5\left(\mathrm{C}_{\mathrm{q}}\right), 130.9(\mathrm{CH})$, $128.2(\mathrm{CH}), 127.8(\mathrm{CH}), 120.0(\mathrm{CH}), 115.6(\mathrm{CH}), 114.9(\mathrm{CH}), 110.6\left(\mathrm{C}_{q}\right), 38.6\left(\mathrm{C}_{q}\right), 28.1$ $\left(\mathrm{CH}_{3}\right), 16.4\left(\mathrm{CH}_{3}\right)$. IR (ATR): 3031, 2960, 2923, 1652, 1590, 1513, 1020, $801 \mathrm{~cm}^{-1}$. MS (ESI) $m / z$ (relative intensity): $625(22)[2 \mathrm{M}+\mathrm{Na}]^{+}, 324(52)[\mathrm{M}+\mathrm{Na}]^{+}, 302(100)[\mathrm{M}+\mathrm{H}]^{+}$. HR-MS (ESI) $m / z$ calcd for $\mathrm{C}_{21} \mathrm{H}_{20} \mathrm{NO}[\mathrm{M}+\mathrm{H}]^{+} 302.1539$, found 302.1543. 


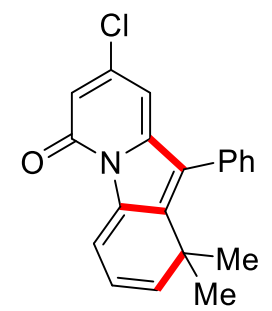

8-Chloro-1,1-dimethyl-10-phenylpyrido[1,2-a]indol-6(1H)-one (180da): The general procedure B was followed using 4-chloro-2H-[1,2'-bipyridin]-2-one (172d) (51.7 mg, $0.25 \mathrm{mmol}$ ) and methyl (2-methyl-4-phenylbut-3-yn-2-yl)carbonate (88a) $(83.0 \mathrm{mg}$, $0.38 \mathrm{mmol}$ ). Purification by column chromatography on silica gel ( $n$-hexane/EtOAc: 10/1) yielded $180 \mathrm{da}$ (44.2 $\mathrm{mg}, 55 \%)$ as an orange solid. M.p.: $190-191{ }^{\circ} \mathrm{C} .{ }^{1} \mathrm{H}-\mathrm{NMR}$ $\left(300 \mathrm{MHz}, \mathrm{CDCl}_{3}\right) \delta=7.96(\mathrm{~d}, J=6.6 \mathrm{~Hz}, 1 \mathrm{H}), 7.51-7.39(\mathrm{~m}, 3 \mathrm{H}), 7.35-7.25(\mathrm{~m}, 2 \mathrm{H})$, $6.45(\mathrm{~d}, J=1.9 \mathrm{~Hz}, 1 \mathrm{H}), 6.27(\mathrm{dd}, J=9.5,6.6 \mathrm{~Hz}, 1 \mathrm{H}), 5.94-5.78(\mathrm{~m}, 2 \mathrm{H}), 1.19(\mathrm{~s}, 6 \mathrm{H})$. ${ }^{13} \mathrm{C}-\mathrm{NMR}\left(125 \mathrm{MHz}, \mathrm{CDCl}_{3}\right) \delta=159.9\left(\mathrm{C}_{\mathrm{q}}\right), 148.1\left(\mathrm{C}_{\mathrm{q}}\right), 145.1\left(\mathrm{C}_{\mathrm{q}}\right), 144.5\left(\mathrm{C}_{\mathrm{q}}\right), 143.4(\mathrm{CH})$, $137.4\left(\mathrm{C}_{\mathrm{q}}\right), 131.9\left(\mathrm{C}_{\mathrm{q}}\right), 131.2\left(\mathrm{C}_{\mathrm{q}}\right), 130.5(\mathrm{CH}), 128.5(\mathrm{CH}), 128.2(\mathrm{CH}), 119.7(\mathrm{CH}), 116.9$ (CH), $113.9(\mathrm{CH}), 100.9(\mathrm{CH}), 39.0\left(\mathrm{C}_{\mathrm{q}}\right), 28.1\left(\mathrm{CH}_{3}\right)$. IR (ATR): 3142, 2963, 2926, 1653, 1584, 1488, 1082, $753 \mathrm{~cm}^{-1}$. MS (ESI) $\mathrm{m} / \mathrm{z}$ (relative intensity): $322(100)[\mathrm{M}+\mathrm{H}]^{+}\left({ }^{35} \mathrm{Cl}\right)$. HR-MS (ESI) $\mathrm{m} / \mathrm{z}$ calcd for $\mathrm{C}_{20} \mathrm{H}_{17}{ }^{35} \mathrm{CINO}[\mathrm{M}+\mathrm{H}]^{+} 322.0993$, found 322.0997. The compound 3da was also unambiguously characterized by X-ray crystallographic diffraction analysis (vide infra).

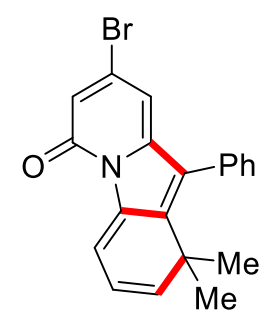

8-Bromo-1,1-dimethyl-10-phenylpyrido[1,2-a]indol-6(1H)-one (180ea): The general procedure B was followed using 4-bromo-2H-[1,2'-bipyridin]-2-one (172e) (62.8 mg, $0.25 \mathrm{mmol})$, methyl (2-methyl-4-phenylbut-3-yn-2-yl)carbonate (88a) $(83.0 \mathrm{mg}, 0.38$ $\mathrm{mmol})$, and $\mathrm{MnBr}(\mathrm{CO})_{5}(13.8 \mathrm{mg}, 20 \mathrm{~mol} \%)$. Purification by column chromatography on silica gel ( $n$-hexane/EtOAc: $10 / 1$ ) yielded 180 ea $(58.6 \mathrm{mg}, 64 \%)$ as an orange solid. 
M. p. $=200-201{ }^{\circ} \mathrm{C} .{ }^{1} \mathrm{H}-\mathrm{NMR}\left(300 \mathrm{MHz}, \mathrm{CDCl}_{3}\right) \delta=7.96(\mathrm{~d}, J=6.5 \mathrm{~Hz}, 1 \mathrm{H}), 7.54-7.36$ (m, 3H), 7.36-7.26 (m, 2H), $6.65(\mathrm{~d}, J=1.8 \mathrm{~Hz}, 1 \mathrm{H}), 6.28(\mathrm{dd}, J=9.5,6.5 \mathrm{~Hz}, 1 \mathrm{H}), 6.04-$ $5.83(\mathrm{~m}, 2 \mathrm{H}), 1.19(\mathrm{~s}, 6 \mathrm{H}) .{ }^{13} \mathrm{C}-\mathrm{NMR}\left(125 \mathrm{MHz}, \mathrm{CDCl}_{3}\right) \delta=159.7\left(\mathrm{C}_{\mathrm{q}}\right), 147.9\left(\mathrm{C}_{\mathrm{q}}\right), 144.4$ $\left(\mathrm{C}_{\mathrm{q}}\right), 143.4(\mathrm{CH}), 137.4\left(\mathrm{C}_{\mathrm{q}}\right), 133.8\left(\mathrm{C}_{\mathrm{q}}\right), 131.9\left(\mathrm{C}_{\mathrm{q}}\right), 131.1\left(\mathrm{C}_{\mathrm{q}}\right), 130.5(\mathrm{CH}), 128.5(\mathrm{CH})$, $128.2(\mathrm{CH}), 119.8(\mathrm{CH}), 117.3(\mathrm{CH}), 117.0(\mathrm{CH}), 103.4(\mathrm{CH}), 39.0\left(\mathrm{C}_{\mathrm{q}}\right), 28.1\left(\mathrm{CH}_{3}\right)$. IR (ATR): 2988, 2927, 1751, 1581, 1488, 1264, 1128, $755 \mathrm{~cm}^{-1}$. MS (ESI) $\mathrm{m} / \mathrm{z}$ (relative intensity): $755(10)[2 \mathrm{M}+\mathrm{Na}]^{+}\left({ }^{81} \mathrm{Br}\right), 388(12)[\mathrm{M}+\mathrm{Na}]^{+}\left({ }^{79} \mathrm{Br}\right), 366(100)[\mathrm{M}+\mathrm{H}]^{+}\left({ }^{79} \mathrm{Br}\right)$. HR-MS (ESI) $\mathrm{m} / \mathrm{z}$ calcd for $\mathrm{C}_{20} \mathrm{H}_{17}{ }^{79} \mathrm{BrNO}[\mathrm{M}+\mathrm{H}]^{+} 366.0488$, found 366.0489; calcd for $\mathrm{C}_{20} \mathrm{H}_{17}{ }^{81} \mathrm{BrNO}[\mathrm{M}+\mathrm{H}]^{+} 368.0468$, found 368.0474 . The compound 180 ea was also unambiguously characterized by X-ray crystallographic diffraction analysis (vide infra).

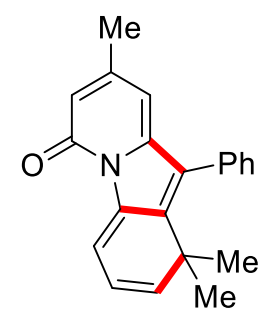

1,1,8-Trimethyl-10-phenylpyrido[1,2-a]indol-6(1H)-one (180fa): The general procedure B was followed using 4-methyl-2H-[1,2'-bipyridin]-2-one (172f) (46.6 mg, $0.25 \mathrm{mmol}$ ) and methyl (2-methyl-4-phenylbut-3-yn-2-yl)carbonate (88a) $(83.0 \mathrm{mg}$, $0.38 \mathrm{mmol}$ ). Purification by column chromatography on silica gel ( $n$-hexane/EtOAc: 10/1) yielded $180 \mathrm{fa}(56.5 \mathrm{mg}, 75 \%)$ as an orange solid. M.p.: $225-226^{\circ} \mathrm{C} .{ }^{1} \mathbf{H}-\mathbf{N M R}(400$ $\left.\mathrm{MHz}, \mathrm{CDCl}_{3}\right) \delta=7.86(\mathrm{~d}, J=6.4 \mathrm{~Hz}, 1 \mathrm{H}), 7.51-7.39(\mathrm{~m}, 3 \mathrm{H}), 7.36-7.28(\mathrm{~m}, 2 \mathrm{H}), 6.30-$ $6.15(\mathrm{~m}, 2 \mathrm{H}), 5.80(\mathrm{~d}, J=9.4 \mathrm{~Hz}, 1 \mathrm{H}), 5.65(\mathrm{~d}, J=1.3 \mathrm{~Hz}, 1 \mathrm{H}), 2.14(\mathrm{~s}, 3 \mathrm{H}), 1.17(\mathrm{~s}, 6 \mathrm{H})$. ${ }^{13} \mathrm{C}-\mathrm{NMR}\left(100 \mathrm{MHz}, \mathrm{CDCl}_{3}\right) \delta=161.3\left(\mathrm{C}_{\mathrm{q}}\right), 149.3\left(\mathrm{C}_{\mathrm{q}}\right), 147.5\left(\mathrm{C}_{\mathrm{q}}\right), 143.0\left(\mathrm{C}_{\mathrm{q}}\right), 142.0(\mathrm{CH})$, $137.9\left(\mathrm{C}_{\mathrm{q}}\right), 132.9\left(\mathrm{C}_{\mathrm{q}}\right), 131.6\left(\mathrm{C}_{\mathrm{q}}\right), 130.6(\mathrm{CH}), 128.2(\mathrm{CH}), 128.1(\mathrm{CH}), 119.9(\mathrm{CH}), 114.8$ (CH), $114.7(\mathrm{CH}), 101.9(\mathrm{CH}), 38.6\left(\mathrm{C}_{\mathrm{q}}\right), 28.3\left(\mathrm{CH}_{3}\right), 21.5\left(\mathrm{CH}_{3}\right)$. IR (ATR): 3057, 2972, 1661, 1592, 1513, 1394, $808 \mathrm{~cm}^{-1}$. MS (ESI) m/z (relative intensity): 625 (20) [2M+Na] , $324(18)[\mathrm{M}+\mathrm{Na}]^{+}, 302(100)[\mathrm{M}+\mathrm{H}]^{+}$. HR-MS (ESI) $\mathrm{m} / \mathrm{z}$ calcd for $\mathrm{C}_{21} \mathrm{H}_{20} \mathrm{NO}[\mathrm{M}+\mathrm{H}]^{+}$ 302.1539 , found 302.1539 . 


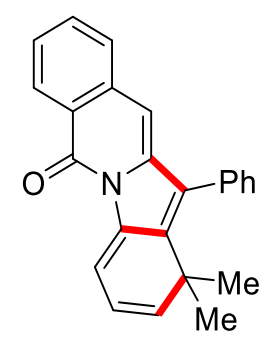

1,1-Dimethyl-12-phenylindolo[1,2-b]isoquinolin-6(1H)-one (180ga): The general procedure B was followed using 2-(pyridin-2-yl)isoquinolin-1(2H)-one (172g) (55.6 mg, $0.25 \mathrm{mmol}$ ) and methyl (2-methyl-4-phenylbut-3-yn-2-yl)carbonate (88a) $(83.0 \mathrm{mg}$, $0.38 \mathrm{mmol}$ ). Purification by column chromatography on silica gel ( $n$-hexane/EtOAc: 10/1) yielded 180ga (51.5 mg, 61\%) as an orange solid. M.p.: $210-211{ }^{\circ} \mathrm{C} .{ }^{\mathbf{1}} \mathbf{H}-\mathbf{N M R}$ $\left(400 \mathrm{MHz}, \mathrm{CDCl}_{3}\right) \delta=8.51(\mathrm{ddd}, J=8.1,1.5,0.7 \mathrm{~Hz}, 1 \mathrm{H}), 7.68(\mathrm{dd}, J=6.5,0.7 \mathrm{~Hz}, 1 \mathrm{H})$, 7.56 (ddd, $J=7.8,7.2,1.5 \mathrm{~Hz}, 1 \mathrm{H}), 7.51-7.46(\mathrm{~m}, 3 \mathrm{H}), 7.44-7.37(\mathrm{~m}, 4 \mathrm{H}), 6.24$ (dd, $J=$ 9.5, $6.5 \mathrm{~Hz}, 1 \mathrm{H}), 6.07(\mathrm{~s}, 1 \mathrm{H}), 5.76-5.59(\mathrm{~m}, 1 \mathrm{H}), 1.21(\mathrm{~s}, 6 \mathrm{H}) .{ }^{13} \mathrm{C}-\mathrm{NMR}\left(100 \mathrm{MHz}, \mathrm{CDCl}_{3}\right)$ $\delta=160.6\left(C_{q}\right), 144.1\left(C_{q}\right), 143.0\left(C_{q}\right), 139.4(C H), 138.2\left(C_{q}\right), 136.3\left(C_{q}\right), 133.1\left(C_{q}\right), 132.3$ $\left(\mathrm{C}_{\mathrm{q}}\right), 132.0(\mathrm{CH}), 130.7(\mathrm{CH}), 128.2(\mathrm{CH}), 128.1(\mathrm{CH}), 127.9(\mathrm{CH}), 126.4(\mathrm{CH}), 125.8(\mathrm{CH})$, $123.9\left(\mathrm{C}_{\mathrm{q}}\right), 120.0(\mathrm{CH}), 111.0(\mathrm{CH}), 99.4(\mathrm{CH}), 38.4\left(\mathrm{C}_{\mathrm{q}}\right), 28.8\left(\mathrm{CH}_{3}\right) . \mathrm{MS}(\mathrm{ESI}) \mathrm{m} / \mathrm{z}$ (relative intensity): $697(20)[2 \mathrm{M}+\mathrm{Na}]^{+}, 338(100)[\mathrm{M}+\mathrm{H}]^{+}$. HR-MS (ESI) $\mathrm{m} / z$ calcd for $\mathrm{C}_{24} \mathrm{H}_{20} \mathrm{NO}[\mathrm{M}+\mathrm{H}]^{+} 338.1539$, found 338.1541. The compound 180ga was also unambiguously characterized by X-ray crystallographic diffraction analysis (vide infra).<smiles>CC1=CC(C)(C)c2c(-c3ccccc3)c3cccc(=O)n3c2=C1</smiles>

1,1,3-Trimethyl-10-phenylpyrido[1,2-a]indol-6(1H)-one (180ha): The general procedure B was followed using 4'-methyl-2H-[1,2'-bipyridin]-2-one (172h) (46.5 mg, $0.25 \mathrm{mmol}$ ) and methyl (2-methyl-4-phenylbut-3-yn-2-yl)carbonate (88a) $(83.0 \mathrm{mg}$, $0.38 \mathrm{mmol}$ ). Purification by column chromatography on silica gel ( $n$-hexane/EtOAc: 10/1) yielded $\mathbf{1 8 0 h a}(46.7 \mathrm{mg}, 63 \%)$ as an orange solid. M.p.: $210-211^{\circ} \mathrm{C} .{ }^{\mathbf{1}} \mathbf{H}-\mathbf{N M R}$ 
$\left(400 \mathrm{MHz} \mathrm{CDCl}_{3}\right) \delta=7.90(\mathrm{~d}, J=1.0 \mathrm{~Hz}, 1 \mathrm{H}), 7.51-7.39(\mathrm{~m}, 3 \mathrm{H}), 7.37-7.31(\mathrm{~m}, 2 \mathrm{H})$, $7.28(\mathrm{dd}, J=9.0,7.0 \mathrm{~Hz}, 1 \mathrm{H}), 6.44(\mathrm{dd}, J=9.0,1.0 \mathrm{~Hz}, 1 \mathrm{H}), 5.85(\mathrm{dd}, J=7.0,1.0 \mathrm{~Hz}, 1 \mathrm{H})$, $5.62-5.50(\mathrm{~m}, 1 \mathrm{H}), 2.02(\mathrm{~d}, J=1.6 \mathrm{~Hz}, 3 \mathrm{H}), 1.17(\mathrm{~s}, 6 \mathrm{H}) .{ }^{13} \mathrm{C}-\mathrm{NMR}\left(100 \mathrm{MHz}, \mathrm{CDCl}_{3}\right) \delta=$ $161.5\left(\mathrm{C}_{\mathrm{q}}\right), 148.6\left(\mathrm{C}_{\mathrm{q}}\right), 142.8\left(\mathrm{C}_{\mathrm{q}}\right), 138.2\left(\mathrm{C}_{\mathrm{q}}\right), 137.7(\mathrm{CH}), 137.4(\mathrm{CH}), 132.8\left(\mathrm{C}_{\mathrm{q}}\right), 131.3$ $\left(\mathrm{C}_{q}\right), 130.6(\mathrm{CH}), 128.2(\mathrm{CH}), 128.1(\mathrm{CH}), 127.6\left(\mathrm{C}_{\mathrm{q}}\right), 119.6(\mathrm{CH}), 115.7(\mathrm{CH}), 99.6(\mathrm{CH})$, $38.2\left(\mathrm{C}_{\mathrm{q}}\right), 28.5\left(\mathrm{CH}_{3}\right), 21.6\left(\mathrm{CH}_{3}\right)$. IR (ATR): 3046, 2973, 2917, 1653, 1584, 1515, 1156, $701 \mathrm{~cm}^{-1}$. MS (ESI) m/z (relative intensity): $302(100)[\mathrm{M}+\mathrm{H}]^{+}$. HR-MS (ESI) $\mathrm{m} / z$ calcd for $\mathrm{C}_{21} \mathrm{H}_{20} \mathrm{NO}[\mathrm{M}+\mathrm{H}]^{+} 302.1539$, found 302.1540 .

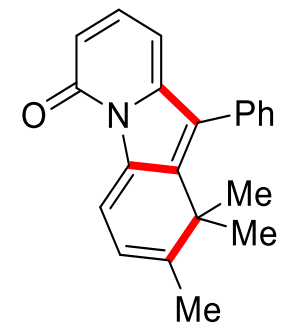

1,1,2-Trimethyl-10-phenylpyrido[1,2-a]indol-6(1H)-one (180ia): The general procedure B was followed using 5'-methyl-2H-[1,2'-bipyridin]-2-one (172i) (46.5 mg, $0.25 \mathrm{mmol}$ ) and methyl (2-methyl-4-phenylbut-3-yn-2-yl)carbonate (88a) $(83.0 \mathrm{mg}$, $0.38 \mathrm{mmol}$ ). Purification by column chromatography on silica gel ( $n$-hexane/EtOAc: 10/1) yielded 180ia (57.3 mg, 76\%) as an orange solid. M. p. $=190-191{ }^{\circ} \mathrm{C} .{ }^{\mathbf{1}} \mathbf{H}-\mathbf{N M R}$ $\left(400 \mathrm{MHz}, \mathrm{CDCl}_{3}\right) \delta=7.90(\mathrm{dd}, J=6.8,1.0 \mathrm{~Hz}, 1 \mathrm{H}), 7.42(\mathrm{dd}, J=5.0,1.9 \mathrm{~Hz}, 3 \mathrm{H}), 7.34-$ $7.26(\mathrm{~m}, 2 \mathrm{H}), 7.26-7.21(\mathrm{~m}, 1 \mathrm{H}), 6.39(\mathrm{dd}, J=9.0,1.0 \mathrm{~Hz}, 1 \mathrm{H}), 6.12(\mathrm{dd}, J=6.8,1.5 \mathrm{~Hz}$, 1H), 5.77 (dd, $J=7.1,1.0 \mathrm{~Hz}, 1 \mathrm{H}), 1.92(\mathrm{~s}, 3 \mathrm{H}), 1.24(\mathrm{~s}, 6 \mathrm{H}) .{ }^{13} \mathrm{C}-\mathrm{NMR}\left(100 \mathrm{MHz}, \mathrm{CDCl}_{3}\right)$ $\delta=161.3\left(C_{q}\right), 149.3\left(C_{q}\right), 148.4\left(C_{q}\right), 144.2\left(C_{q}\right), 137.1(C H), 136.9\left(C_{q}\right), 133.1\left(C_{q}\right), 130.6$ $\left(\mathrm{C}_{\mathrm{q}}\right), 130.5(\mathrm{CH}), 128.1(\mathrm{CH}), 128.0(\mathrm{CH}), 119.5(\mathrm{CH}), 116.8(\mathrm{CH}), 115.0(\mathrm{CH}), 99.1(\mathrm{CH})$, $41.5\left(\mathrm{C}_{\mathrm{q}}\right), 27.2\left(\mathrm{CH}_{3}\right), 18.7\left(\mathrm{CH}_{3}\right)$. IR (ATR): 3037, 2972, 1651, 1583, 1514, 818, $707 \mathrm{~cm}^{-}$ 1. MS (ESI) $m / z$ (relative intensity): $625(18)[2 \mathrm{M}+\mathrm{Na}]^{+}, 324(16)[\mathrm{M}+\mathrm{Na}]^{+}, 302(100)$ $[\mathrm{M}+\mathrm{H}]^{+}$. HR-MS (ESI) $\mathrm{m} / z$ calcd for $\mathrm{C}_{21} \mathrm{H}_{20} \mathrm{NO}[\mathrm{M}+\mathrm{H}]^{+} 302.1539$, found 302.1541 . 
<smiles></smiles>

1,1-Dimethyl-10-phenyl-2-(trifluoromethyl)pyrido[1,2-a]indol-6(1H)-one

(180ja):

The general procedure B was followed using 5'-(trifluoromethyl)-2H-[1,2'-bipyridin]-2one (172j) (60.1 mg, $0.25 \mathrm{mmol}$ ) and methyl (2-methyl-4-phenylbut-3-yn-2yl)carbonate (88a) $(83.0 \mathrm{mg}, 0.38 \mathrm{mmol})$. Purification by column chromatography on silica gel ( $n$-hexane/EtOAc: $10 / 1$ ) yielded 180 ja $(49.8 \mathrm{mg}, 56 \%)$ as an orange solid. $\mathbf{M}$. p. $=195-196{ }^{\circ} \mathrm{C} .{ }^{1} \mathrm{H}-\mathrm{NMR}\left(400 \mathrm{MHz}, \mathrm{CDCl}_{3}\right) \delta=7.87(\mathrm{dd}, J=7.0,1.4 \mathrm{~Hz}, 1 \mathrm{H}), 7.50-7.43$ (m, 3H), 7.36-7.30 (m, 2H), 7.27 (dd, J = 9.2, 2.2 Hz, 1H), $6.93(\mathrm{dd}, J=7.0,1.6 \mathrm{~Hz}, 1 \mathrm{H})$, $6.47(\mathrm{dd}, J=9.2,1.0 \mathrm{~Hz}, 1 \mathrm{H}), 5.81(\mathrm{~d}, J=7.0 \mathrm{~Hz}, 1 \mathrm{H}), 1.41(\mathrm{q}, J=1.0 \mathrm{~Hz}, 6 \mathrm{H}) .{ }^{13} \mathrm{C}-\mathbf{N M R}$ $\left(100 \mathrm{MHz}, \mathrm{CDCl}_{3}\right) \delta=161.2\left(\mathrm{C}_{\mathrm{q}}\right), 148.5\left(\mathrm{C}_{\mathrm{q}}\right), 142.4\left(\mathrm{C}_{\mathrm{q}}\right), 140.6\left(\mathrm{C}_{\mathrm{q}}\right), 137.9(\mathrm{CH}), 135.4(\mathrm{q}$, $\left.{ }^{2} J_{\mathrm{C}-\mathrm{F}}=26.5 \mathrm{~Hz}, \mathrm{C}_{\mathrm{q}}\right), 132.8\left(\mathrm{C}_{\mathrm{q}}\right), 132.1\left(\mathrm{C}_{\mathrm{q}}\right), 130.3(\mathrm{CH}), 128.6(\mathrm{CH}), 128.3(\mathrm{CH}), 126.2(\mathrm{q}$, $\left.{ }^{3} \mathrm{~J}_{\mathrm{C}-\mathrm{F}}=7.7 \mathrm{~Hz}, \mathrm{CH}\right), 124.4\left(\mathrm{q},{ }^{1} \mathrm{~J}_{\mathrm{C}-\mathrm{F}}=273.9 \mathrm{~Hz}, \mathrm{C}_{\mathrm{q}}\right), 117.6(\mathrm{CH}), 111.1(\mathrm{CH}), 101.2(\mathrm{CH})$, $39.8\left(\mathrm{C}_{\mathrm{q}}\right), 27.6\left(\mathrm{CH}_{3}\right) .{ }^{19} \mathrm{~F} \mathrm{NMR}\left(375 \mathrm{MHz}, \mathrm{CDCl}_{3}\right) \delta=-58.89$ (s). IR (ATR): 2995, 2940, 1659, 1596, 1283, 1163, 1107, $998 \mathrm{~cm}^{-1}$. MS (ESI) m/z (relative intensity): 733 (65) $[2 \mathrm{M}+\mathrm{Na}]^{+}, 378(50)[\mathrm{M}+\mathrm{Na}]^{+}, 356(100)[\mathrm{M}+\mathrm{H}]^{+}$. HR-MS (ESI) $\mathrm{m} / z$ calcd for $\mathrm{C}_{21} \mathrm{H}_{17} \mathrm{~F}_{3} \mathrm{NO}$ $[\mathrm{M}+\mathrm{H}]^{+}$356.1257, found 356.1259.

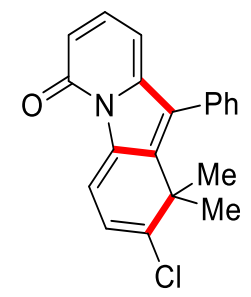

2-Chloro-1,1-dimethyl-10-phenylpyrido[1,2-a]indol-6(1H)-one (180ka): The general procedure B was followed using 5'-chloro-2H-[1,2'-bipyridin]-2-one (172k) (51.7 mg, $0.25 \mathrm{mmol}$ ) and methyl (2-methyl-4-phenylbut-3-yn-2-yl)carbonate (88a) $(83.0 \mathrm{mg}$, $0.38 \mathrm{mmol}$ ). Purification by column chromatography on silica gel ( $n$-hexane/EtOAc: 
10/1) yielded $180 \mathrm{ka}(42.6 \mathrm{mg}, 53 \%)$ as an orange solid. $\mathbf{M}$. p. $=168-169{ }^{\circ} \mathrm{C} .{ }^{1} \mathbf{H}-\mathbf{N M R}$ $\left(400 \mathrm{MHz}, \mathrm{CDCl}_{3}\right) \delta=7.83(\mathrm{~d}, J=7.2 \mathrm{~Hz}, 1 \mathrm{H}), 7.56-7.39(\mathrm{~m}, 3 \mathrm{H}), 7.33-7.27(\mathrm{~m}, 2 \mathrm{H})$, $7.25(\mathrm{dd}, J=9.1,2.0 \mathrm{~Hz}, 1 \mathrm{H}), 6.51-6.25(\mathrm{~m}, 2 \mathrm{H}), 5.81$ (dd, $J=7.0,0.7 \mathrm{~Hz}, 1 \mathrm{H}), 1.36(\mathrm{~s}$, 6H). ${ }^{13} \mathrm{C}-\mathrm{NMR}\left(100 \mathrm{MHz}, \mathrm{CDCl}_{3}\right) \delta=161.2\left(\mathrm{C}_{\mathrm{q}}\right), 148.3\left(\mathrm{C}_{\mathrm{q}}\right), 145.6\left(\mathrm{C}_{\mathrm{q}}\right), 142.5\left(\mathrm{C}_{\mathrm{q}}\right), 137.5$ $(\mathrm{CH}), 137.3\left(\mathrm{C}_{\mathrm{q}}\right), 132.4\left(\mathrm{C}_{\mathrm{q}}\right), 132.3\left(\mathrm{C}_{\mathrm{q}}\right), 130.5(\mathrm{CH}), 128.5(\mathrm{CH}), 128.3(\mathrm{CH}), 121.3(\mathrm{CH})$, $116.3(\mathrm{CH}), 114.5(\mathrm{CH}), 100.2(\mathrm{CH}), 43.5\left(\mathrm{C}_{\mathrm{q}}\right), 27.5\left(\mathrm{CH}_{3}\right)$. IR (ATR): 2969, 1684, 1584, $1508,1487,1156,837,795 \mathrm{~cm}^{-1}$. MS (ESI) $\mathrm{m} / z$ (relative intensity): 665 (18) [2M+Na] ${ }^{+}$ $\left({ }^{35} \mathrm{Cl}\right), 344(30)[\mathrm{M}+\mathrm{Na}]^{+}\left({ }^{35} \mathrm{Cl}\right), 322(100)[\mathrm{M}+\mathrm{H}]^{+}\left({ }^{35} \mathrm{Cl}\right)$. HR-MS (ESI) $\mathrm{m} / \mathrm{z}$ calcd for $\mathrm{C}_{20} \mathrm{H}_{17}{ }^{35} \mathrm{CINO}[\mathrm{M}+\mathrm{H}]^{+}$322.0993, found 322.0999.

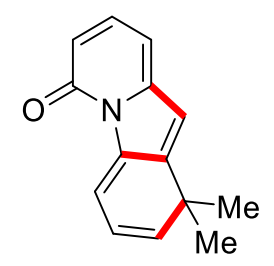

1,1-Dimethylpyrido[1,2-a]indol-6(1H)-one (180ab): The general procedure B was followed using $2 \mathrm{H}$-[1,2'-bipyridin]-2-one (172a) $(43.1 \mathrm{mg}, 0.25 \mathrm{mmol})$ and methyl (2methylbut-3-yn-2-yl)carbonate (88b) $(54.0 \mathrm{mg}, 0.38 \mathrm{mmol})$. Purification by column chromatography on silica gel ( $n$-hexane/EtOAc: $10 / 1$ ) yielded $180 \mathrm{ab}(31.7 \mathrm{mg}, 60 \%)$ as an orange solid. M. p. $=120-121^{\circ} \mathrm{C} .{ }^{1} \mathbf{H}-\mathbf{N M R}\left(400 \mathrm{MHz}, \mathrm{CDCl}_{3}\right) \delta=7.83$ (ddd, $J=6.5$, 1.8, 0.5 Hz, 1H), 7.35 (dd, $J=9.0,7.0 \mathrm{~Hz}, 1 \mathrm{H}$ ), 6.57 (d, $J=1.8 \mathrm{~Hz}, 1 \mathrm{H}), 6.43(\mathrm{dd}, J=9.0$, $0.9 \mathrm{~Hz}, 1 \mathrm{H}), 6.37-6.25(\mathrm{~m}, 2 \mathrm{H}), 6.01(\mathrm{~d}, J=9.5 \mathrm{~Hz}, 1 \mathrm{H}), 1.33(\mathrm{~s}, 6 \mathrm{H}) .{ }^{13} \mathrm{C}-\mathrm{NMR}(100 \mathrm{MHz}$, $\left.\mathrm{CDCl}_{3}\right) \delta=161.7\left(\mathrm{C}_{\mathrm{q}}\right), 149.1\left(\mathrm{C}_{\mathrm{q}}\right), 146.5\left(\mathrm{C}_{\mathrm{q}}\right), 141.2(\mathrm{CH}), 138.2\left(\mathrm{C}_{\mathrm{q}}\right), 137.7(\mathrm{CH}), 120.7$ (CH), $115.9(\mathrm{CH}), 115.8(\mathrm{CH}), 115.5(\mathrm{CH}), 100.1(\mathrm{CH}), 37.4\left(\mathrm{C}_{\mathrm{q}}\right), 29.9\left(\mathrm{CH}_{3}\right) . \mathrm{MS}(\mathrm{ESI}) \mathrm{m} / \mathrm{z}$ (relative intensity): $445(22)[2 \mathrm{M}+\mathrm{Na}]^{+}, 234(52)[\mathrm{M}+\mathrm{Na}]^{+}, 212(100)[\mathrm{M}+\mathrm{H}]^{+}$. HR-MS (ESI) $m / z$ calcd for $\mathrm{C}_{14} \mathrm{H}_{14} \mathrm{NO}[\mathrm{M}+\mathrm{H}]^{+} 212.1070$, found 212.1072 .

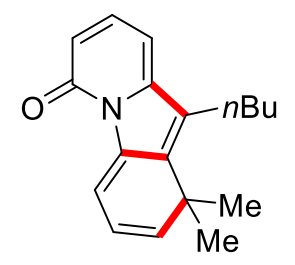


10-Butyl-1,1-dimethylpyrido[1,2-a]indol-6(1H)-one (180ac): The general procedure B was followed using $2 \mathrm{H}$-[1,2'-bipyridin]-2-one (172a) $(43.1 \mathrm{mg}, 0.25 \mathrm{mmol}$ ) and methyl (2-methyloct-3-yn-2-yl)carbonate (88c) $(75.4 \mathrm{mg}, 0.38 \mathrm{mmol})$. Purification by column chromatography on silica gel ( $n$-hexane/EtOAc: $10 / 1)$ yielded $180 \mathrm{ac}(46.8 \mathrm{mg}, 70 \%)$ as an orange solid. M. p. $=142-143{ }^{\circ} \mathrm{C} .{ }^{1} \mathrm{H}-\mathrm{NMR}\left(400 \mathrm{MHz}, \mathrm{CDCl}_{3}\right) \delta=7.83$ (d, $J=6.5 \mathrm{~Hz}$, 1H), 7.36 (dd, J = 9.0, 7.1 Hz, 1H), 6.42 (dd, $J=9.0,0.9 \mathrm{~Hz}, 1 \mathrm{H}$ ), 6.30 (dd, $J=7.1,0.9 \mathrm{~Hz}$, $1 \mathrm{H}), 6.21(\mathrm{dd}, J=9.5,6.5 \mathrm{~Hz}, 1 \mathrm{H}), 5.83(\mathrm{dd}, J=9.5,0.5 \mathrm{~Hz}, 1 \mathrm{H}), 2.84-2.64(\mathrm{~m}, 2 \mathrm{H}), 1.64-$ $1.55(\mathrm{~m}, 2 \mathrm{H}), 1.53-1.43(\mathrm{~m}, 2 \mathrm{H}), 1.40(\mathrm{~s}, 6 \mathrm{H}), 0.98(\mathrm{t}, J=7.3 \mathrm{~Hz}, 3 \mathrm{H}) .{ }^{13} \mathrm{C}-\mathrm{NMR}(100$ $\left.\mathrm{MHz}, \mathrm{CDCl}_{3}\right) \delta=161.6\left(\mathrm{C}_{\mathrm{q}}\right), 147.3\left(\mathrm{C}_{\mathrm{q}}\right), 141.5(\mathrm{CH}), 140.7\left(\mathrm{C}_{\mathrm{q}}\right), 138.2\left(\mathrm{C}_{\mathrm{q}}\right), 137.2(\mathrm{CH})$, 131.4 $\left(\mathrm{C}_{q}\right), 119.9(\mathrm{CH}), 115.7(\mathrm{CH}), 114.4(\mathrm{CH}), 98.1(\mathrm{CH}), 37.9\left(\mathrm{C}_{q}\right), 32.9\left(\mathrm{CH}_{2}\right), 27.7$ $\left(\mathrm{CH}_{3}\right), 25.6\left(\mathrm{CH}_{2}\right), 23.3\left(\mathrm{CH}_{2}\right), 13.8\left(\mathrm{CH}_{3}\right)$. IR (ATR): 2959, 2928, 2869, 1750, 1652, 1578, 1261, $792 \mathrm{~cm}^{-1}$. MS (ESI) m/z (relative intensity): 557 (10) [2M+Na], $290(20)[\mathrm{M}+\mathrm{Na}]^{+}$, $268(100)[\mathrm{M}+\mathrm{H}]^{+}$. HR-MS (ESI) $\mathrm{m} / z$ calcd for $\mathrm{C}_{18} \mathrm{H}_{22} \mathrm{NO}[\mathrm{M}+\mathrm{H}]^{+} 268.1696$, found 268.1703.

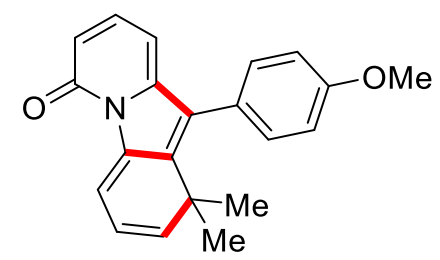

10-(4-Methoxyphenyl)-1,1-dimethylpyrido[1,2-a]indol-6(1H)-one $\quad$ (180ad): The general procedure B was followed using $2 H$-[1,2'-bipyridin]-2-one (172a) $(43.1 \mathrm{mg}$, $0.25 \mathrm{mmol}$ ) and 4-(4-methoxyphenyl)-2-methylbut-3-yn-2-yl methyl carbonate (88d) (94.4 mg, $0.38 \mathrm{mmol}$ ). Purification by column chromatography on silica gel (n-hexane/EtOAc: $10 / 1$ ) yielded 180 ad $(57.1 \mathrm{mg}, 72 \%$ ) as an orange solid. M. p. = 192$193^{\circ} \mathrm{C} .{ }^{1} \mathrm{H}-\mathrm{NMR}\left(400 \mathrm{MHz}, \mathrm{CDCl}_{3}\right) \delta=7.93(\mathrm{dd}, J=6.5,0.5 \mathrm{~Hz}, 1 \mathrm{H}), 7.36-7.23(\mathrm{~m}, 1 \mathrm{H})$, 7.22 (d, J = 8.8 Hz, 2H), 6.95 (d, J=8.8 Hz, 2H), 6.41 (dd, J = 9.0, $0.9 \mathrm{~Hz}, 1 \mathrm{H}$ ), 6.25 (dd, $J=9.5,6.5 \mathrm{~Hz}, 1 \mathrm{H}), 5.91-5.77(\mathrm{~m}, 2 \mathrm{H}), 3.85(\mathrm{~s}, 3 \mathrm{H}), 1.19(\mathrm{~s}, 6 \mathrm{H}) .{ }^{13} \mathrm{C}-\mathbf{N M R}(100 \mathrm{MHz}$, $\left.\mathrm{CDCl}_{3}\right) \delta=161.5\left(\mathrm{C}_{\mathrm{q}}\right), 159.5\left(\mathrm{C}_{\mathrm{q}}\right), 148.5\left(\mathrm{C}_{\mathrm{q}}\right), 142.8\left(\mathrm{C}_{\mathrm{q}}\right), 142.4(\mathrm{CH}), 138.0\left(\mathrm{C}_{\mathrm{q}}\right), 137.4$ 
(CH), $131.7(\mathrm{CH}), 131.6\left(\mathrm{C}_{q}\right), 124.6\left(\mathrm{C}_{q}\right), 119.9(\mathrm{CH}), 115.7(\mathrm{CH}), 115.5(\mathrm{CH}), 113.5(\mathrm{CH})$, $99.5(\mathrm{CH}), 55.3\left(\mathrm{CH}_{3}\right), 38.6\left(\mathrm{C}_{\mathrm{q}}\right), 28.3\left(\mathrm{CH}_{3}\right)$. IR (ATR): 3034, 2962, 1657, 1547, 1502, 1284, 1245, $791 \mathrm{~cm}^{-1}$. MS (ESI) $\mathrm{m} / \mathrm{z}$ (relative intensity): 657 (20) [2M+Na] ${ }^{+}, 340$ (25) $[\mathrm{M}+\mathrm{Na}]^{+}, 318(100)[\mathrm{M}+\mathrm{H}]^{+}$. HR-MS (ESI) $\mathrm{m} / z$ calcd for $\mathrm{C}_{21} \mathrm{H}_{20} \mathrm{NO}_{2}[\mathrm{M}+\mathrm{H}]^{+}$318.1489, found 318.1489 .

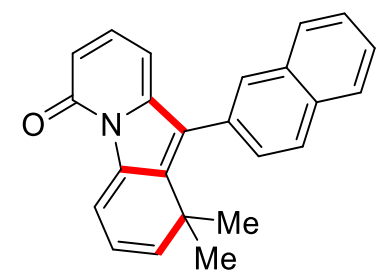

1,1-Dimethyl-10-(naphthalen-2-yl)pyrido[1,2-a]indol-6(1H)-one (180ae): The general procedure B was followed using $2 \mathrm{H}$-[1,2'-bipyridin]-2-one (148a) (43.1 mg, $0.25 \mathrm{mmol}$ ) and methyl [2-methyl-4-(naphthalen-2-yl)but-3-yn-2-yl]carbonate (88e) (102.0 mg, $0.38 \mathrm{mmol}$ ). Purification by column chromatography on silica gel ( $n$-hexane/EtOAc: 10/1) yielded 180ae (62.4 mg, 74\%) as an orange solid. M. p. $=204-205^{\circ} \mathrm{C} .{ }^{1} \mathbf{H}-\mathbf{N M R}$ $\left(300 \mathrm{MHz}, \mathrm{CDCl}_{3}\right) \delta=8.02(\mathrm{dd}, J=6.5,0.5 \mathrm{~Hz}, 1 \mathrm{H}), 7.97-7.78(\mathrm{~m}, 4 \mathrm{H}), 7.64-7.51(\mathrm{~m}$, 2H), 7.44 (dd, $J=8.4,1.7 \mathrm{~Hz}, 1 \mathrm{H}), 7.27(\mathrm{dd}, J=9.0,7.0 \mathrm{~Hz}, 1 \mathrm{H}$ ), 6.46 (ddd, $J=9.0,1.0$, $0.5 \mathrm{~Hz}, 1 \mathrm{H}), 6.30(\mathrm{dd}, J=9.5,6.5 \mathrm{~Hz}, 1 \mathrm{H}), 5.92-5.80(\mathrm{~m}, 2 \mathrm{H}), 1.44-0.93(\mathrm{~m}, 6 \mathrm{H}) .{ }^{13} \mathrm{C}-$ $\operatorname{NMR}\left(125 \mathrm{MHz}, \mathrm{CDCl}_{3}\right) \delta=161.3\left(\mathrm{C}_{\mathrm{q}}\right), 148.2\left(\mathrm{C}_{\mathrm{q}}\right), 143.0\left(\mathrm{C}_{\mathrm{q}}\right), 142.4(\mathrm{CH}), 138.0\left(\mathrm{C}_{\mathrm{q}}\right)$, $137.3(\mathrm{CH}), 132.8\left(\mathrm{C}_{q}\right), 132.6\left(\mathrm{C}_{q}\right), 131.6\left(\mathrm{C}_{q}\right), 130.1\left(\mathrm{C}_{q}\right), 129.7(\mathrm{CH}), 128.2(\mathrm{CH}), 127.9$ (CH), $127.7(\mathrm{CH}), 127.6(\mathrm{CH}), 126.6(\mathrm{CH}), 126.5(\mathrm{CH}), 119.9(\mathrm{CH}), 115.8(\mathrm{CH}), 115.7(\mathrm{CH})$, $99.6(\mathrm{CH}), 38.8\left(\mathrm{C}_{\mathrm{q}}\right), 28.8\left(\mathrm{CH}_{3}\right), 28.1\left(\mathrm{CH}_{3}\right)$. IR (ATR): 3066, 2965, 2925, 1655, 1585, 1514, 1151, 798, $752 \mathrm{~cm}^{-1}$. MS (ESI) $\mathrm{m} / z$ (relative intensity): 697 (12) [2M+Na] $]^{+}, 360$ (15) $[\mathrm{M}+\mathrm{Na}]^{+}, 338(100)[\mathrm{M}+\mathrm{H}]^{+}$. HR-MS (ESI) $\mathrm{m} / z$ calcd for $\mathrm{C}_{24} \mathrm{H}_{20} \mathrm{NO}[\mathrm{M}+\mathrm{H}]^{+} 338.1539$, found 338.1541 .

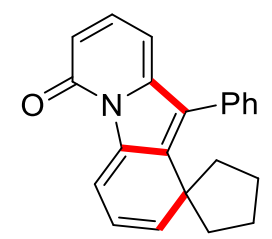


10'-Phenyl-6' H-spiro[cyclopentane-1,1'-pyrido[1,2-a]indol]-6'-one (180af): The general procedure B was followed using $2 H$-[1,2'-bipyridin]-2-one (172a) $(43.1 \mathrm{mg}$, $0.25 \mathrm{mmol}$ ) and methyl [1-(phenylethynyl)cyclopentyl]carbonate (88f) (92.8 mg, 0.38 mmol). Purification by column chromatography on silica gel ( $n$-hexane/EtOAc: 10/1) yielded 180af (45.4 mg, 58\%) as an orange solid. M. p. = $175-176{ }^{\circ} \mathrm{C} .{ }^{1} \mathbf{H}-\mathbf{N M R}(400$ $\left.\mathrm{MHz}, \mathrm{CDCl}_{3}\right) \delta=7.98(\mathrm{~d}, J=6.5 \mathrm{~Hz}, 1 \mathrm{H}), 7.48-7.37(\mathrm{~m}, 3 \mathrm{H}), 7.35-7.28(\mathrm{~m}, 2 \mathrm{H}), 7.28-$ $7.20(\mathrm{~m}, 1 \mathrm{H}), 6.40(\mathrm{dd}, J=9.0,1.0 \mathrm{~Hz}, 1 \mathrm{H}), 6.22(\mathrm{dd}, J=9.5,6.5 \mathrm{~Hz}, 1 \mathrm{H}), 6.06(\mathrm{dd}, J=$ 9.5, $0.9 \mathrm{~Hz}, 1 \mathrm{H}), 5.80(\mathrm{dd}, J=7.0,0.9 \mathrm{~Hz}, 1 \mathrm{H}), 2.04-1.90(\mathrm{~m}, 2 \mathrm{H}), 1.85-1.73(\mathrm{~m}, 2 \mathrm{H})$, 1.70-1.58 (m, 2H), 1.42-1.28 (m, 2H). ${ }^{13} \mathrm{C}-\mathrm{NMR}\left(100 \mathrm{MHz}, \mathrm{CDCl}_{3}\right) \delta=161.4\left(\mathrm{C}_{\mathrm{q}}\right), 148.4$ $\left(C_{q}\right), 143.2\left(C_{q}\right), 141.2(C H), 138.5\left(C_{q}\right), 137.3(C H), 132.7\left(C_{q}\right), 130.9\left(C_{q}\right), 130.61(C H)$, $128.3(\mathrm{CH}), 128.2(\mathrm{CH}), 118.2(\mathrm{CH}), 115.9(\mathrm{CH}) 115.6(\mathrm{CH}), 99.4(\mathrm{CH}), 48.6\left(\mathrm{C}_{\mathrm{q}}\right), 42.0$ $\left(\mathrm{CH}_{2}\right), 26.0\left(\mathrm{CH}_{2}\right)$. IR (ATR): 3037, 2953, 2870, 1655, 1583, 1513, 1282, $791 \mathrm{~cm}^{-1}$. MS (ESI) $m / z$ (relative intensity): $649(15)[2 \mathrm{M}+\mathrm{Na}]^{+}, 336(11)[\mathrm{M}+\mathrm{Na}]^{+}, 314(100)[\mathrm{M}+\mathrm{H}]^{+}$. HR-MS (ESI) $m / z$ calcd for $\mathrm{C}_{22} \mathrm{H}_{20} \mathrm{NO}[\mathrm{M}+\mathrm{H}]^{+} 314.1539$, found 314.1545 . The compound 180af was also unambiguously characterized by X-ray crystallographic diffraction analysis (vide infra).

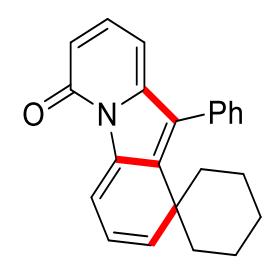

10'-Phenyl-6' H-spiro\{cyclohexane-1,1'-pyrido[1,2-a]indol\}-6'-one (180ag): The general procedure B was followed using $2 H$-[1,2'-bipyridin]-2-one (172a) $(43.1 \mathrm{mg}$, $0.25 \mathrm{mmol}$ ) and methyl [1-(phenylethynyl)cyclohexyl]carbonate $(\mathbf{8 8 g})(98.2 \mathrm{mg}, 0.38$ mmol). Purification by column chromatography on silica gel ( $n$-hexane/EtOAc: 10/1) yielded 180ag (53.2 mg, 65\%) as an orange solid. M. p. = 230-231 ${ }^{\circ} \mathrm{C} .{ }^{1} \mathbf{H}-\mathbf{N M R}(400$ $\left.\mathrm{MHz}, \mathrm{CDCl}_{3}\right) \delta=7.96(\mathrm{~d}, J=6.4 \mathrm{~Hz}, 1 \mathrm{H}), 7.48-7.37(\mathrm{~m}, 3 \mathrm{H}), 7.34-7.27(\mathrm{~m}, 2 \mathrm{H}), 7.27-$ $7.19(\mathrm{~m}, 1 \mathrm{H}), 6.61(\mathrm{~d}, J=9.7 \mathrm{~Hz}, 1 \mathrm{H}), 6.44-6.30(\mathrm{~m}, 2 \mathrm{H}), 5.75(\mathrm{dd}, J=7.0,0.9 \mathrm{~Hz}, 1 \mathrm{H})$, 
$1.76(\mathrm{td}, J=13.6,4.7 \mathrm{~Hz}, 2 \mathrm{H}), 1.68-1.36(\mathrm{~m}, 7 \mathrm{H}), 0.98-0.75(\mathrm{~m}, 1 \mathrm{H}) .{ }^{13} \mathrm{C}-\mathrm{NMR}(100$ $\left.\mathrm{MHz}, \mathrm{CDCl}_{3}\right) \delta=161.4\left(\mathrm{C}_{\mathrm{q}}\right), 148.6\left(\mathrm{C}_{\mathrm{q}}\right), 143.5\left(\mathrm{C}_{\mathrm{q}}\right), 138.6\left(\mathrm{C}_{\mathrm{q}}\right), 137.7(\mathrm{CH}), 137.4(\mathrm{CH})$, $133.1\left(\mathrm{C}_{q}\right), 131.5\left(\mathrm{C}_{\mathrm{q}}\right), 130.7(\mathrm{CH}), 128.2(\mathrm{CH}), 128.0(\mathrm{CH}), 120.9(\mathrm{CH}), 115.6(\mathrm{CH}), 115.3$ (CH), $99.5(\mathrm{CH}), 42.6\left(\mathrm{C}_{\mathrm{q}}\right), 37.0\left(\mathrm{CH}_{2}\right), 25.5\left(\mathrm{CH}_{2}\right), 21.6\left(\mathrm{CH}_{2}\right)$. IR (ATR): 2935, 2856, 1650, 1581, 1510, 1140, 792, $699 \mathrm{~cm}^{-1}$. MS (ESI) m/z (relative intensity): 677 (32) [2M+Na] , $350(10)[\mathrm{M}+\mathrm{Na}]^{+}, 328(100)[\mathrm{M}+\mathrm{H}]^{+}$. HR-MS (ESI) $\mathrm{m} / z$ calcd for $\mathrm{C}_{23} \mathrm{H}_{22} \mathrm{NO}[\mathrm{M}+\mathrm{H}]^{+}$ 328.1696, found 328.1690 .

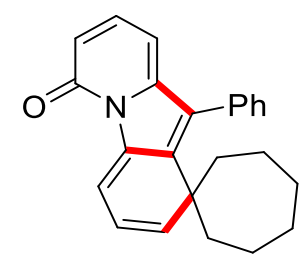

10'-Phenyl-6' H-spiro\{cycloheptane-1,1'-pyrido[1,2-a]indol\}-6'-one (180ah): The general procedure B was followed using 2H-[1,2'-bipyridin]-2-one (172a) $(43.1 \mathrm{mg}$, $0.25 \mathrm{mmol}$ ) and methyl [1-(phenylethynyl)cycloheptyl]carbonate $(\mathbf{8 8 h})(103.5 \mathrm{mg}$, $0.38 \mathrm{mmol}$ ). Purification by column chromatography on silica gel ( $n$-hexane/EtOAc: 10/1) yielded $180 \mathrm{ah}(52.9 \mathrm{mg}, 62 \%)$ as an orange solid. $\mathbf{M}$. p. $=210-211^{\circ} \mathrm{C} .{ }^{1} \mathbf{H}-\mathbf{N M R}$ $\left(400 \mathrm{MHz} \mathrm{CDCl}_{3}\right) \delta=7.94(\mathrm{~d}, J=6.4 \mathrm{~Hz}, 1 \mathrm{H}), 7.51-7.37(\mathrm{~m}, 3 \mathrm{H}), 7.36-7.30(\mathrm{~m}, 2 \mathrm{H})$, 7.29-7.20 (m, 1H), 6.51-6.10 (m, 3H), 5.77 (dd, J = 7.0, 0.9 Hz, 1H), 1.91 (ddd, J = 14.0, 11.0, $2.5 \mathrm{~Hz}, 2 \mathrm{H}), 1.72-1.59(\mathrm{~m}, 2 \mathrm{H}), 1.56-1.43(\mathrm{~m}, 4 \mathrm{H}), 1.41-1.17(\mathrm{~m}, 4 \mathrm{H}) .{ }^{13} \mathrm{C}-\mathrm{NMR}$ $\left(100 \mathrm{MHz}, \mathrm{CDCl}_{3}\right) \delta=161.4\left(\mathrm{C}_{\mathrm{q}}\right), 148.6\left(\mathrm{C}_{\mathrm{q}}\right), 145.0\left(\mathrm{C}_{\mathrm{q}}\right), 140.3(\mathrm{CH}), 138.0\left(\mathrm{C}_{\mathrm{q}}\right), 137.4$ $(\mathrm{CH}), 133.2\left(\mathrm{C}_{\mathrm{q}}\right), 131.4\left(\mathrm{C}_{\mathrm{q}}\right), 130.8(\mathrm{CH}), 128.2(\mathrm{CH}), 128.1(\mathrm{CH}), 120.4(\mathrm{CH}), 115.7(\mathrm{CH})$, 115.3 (CH), 99.6 (CH), $45.7\left(\mathrm{C}_{\mathrm{q}}\right), 40.5\left(\mathrm{CH}_{2}\right), 28.6\left(\mathrm{CH}_{2}\right), 23.9\left(\mathrm{CH}_{2}\right)$. IR (ATR): 3037, 2916, 2847, 1658, 1584, 1511, 1159, $701 \mathrm{~cm}^{-1}$. MS (ESI) m/z (relative intensity): 705 (20) $[2 \mathrm{M}+\mathrm{Na}]^{+}, 364(13)[\mathrm{M}+\mathrm{Na}]^{+}, 342(100)[\mathrm{M}+\mathrm{H}]^{+} . \mathbf{H R}-\mathrm{MS}(\mathrm{ESI}) \mathrm{m} / z$ calcd for $\mathrm{C}_{24} \mathrm{H}_{24} \mathrm{NO}$ $[\mathrm{M}+\mathrm{H}]^{+} 342.1852$, found 342.1848 . 


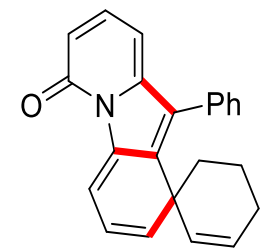

10'-Phenyl-6' H-spiro\{cyclohexane-1,1'-pyrido[1,2-a]indol\}-2-en-6'-one (180ai): The general procedure B was followed using $2 \mathrm{H}$-[1,2'-bipyridin]-2-one (172a) $(43.1 \mathrm{mg}$, $0.25 \mathrm{mmol}$ ) and methyl [1-(phenylethynyl)cyclohex-2-en-1-yl]carbonate (88i) $(97.4 \mathrm{mg}$, $0.38 \mathrm{mmol}$ ). Purification by column chromatography on silica gel ( $n$-hexane/EtOAc: 10/1) yielded 180 ai $(40.7 \mathrm{mg}, 50 \%)$ as an orange solid. $\mathbf{M}$. p. $=205-206{ }^{\circ} \mathrm{C} .{ }^{\mathbf{1}} \mathbf{H}-\mathbf{N M R}$ $\left(400 \mathrm{MHz}, \mathrm{CDCl}_{3}\right) \delta=7.94(\mathrm{~d}, J=6.5 \mathrm{~Hz}, 1 \mathrm{H}), 7.36-7.37(\mathrm{~m}, 4 \mathrm{H}), 7.29(\mathrm{dd}, J=9.0,7.0$ $\mathrm{Hz}, 1 \mathrm{H}), 6.44(\mathrm{~d}, J=9.0 \mathrm{~Hz}, 1 \mathrm{H}), 6.26(\mathrm{dd}, J=9.5,6.5 \mathrm{~Hz}, 1 \mathrm{H}), 6.09(\mathrm{~d}, J=9.5 \mathrm{~Hz}, 1 \mathrm{H})$, $5.99(\mathrm{~d}, J=7.0 \mathrm{~Hz}, 1 \mathrm{H}), 5.77-5.60(\mathrm{~m}, 1 \mathrm{H}), 5.36-5.33(\mathrm{~m}, 1 \mathrm{H}), 1.97-1.86(\mathrm{~m}, 1 \mathrm{H}), 1.84-$ $1.73(\mathrm{~m}, 1 \mathrm{H}), 1.72-1.63(\mathrm{~m}, 1 \mathrm{H}), 1.63-1.54(\mathrm{~m}, 2 \mathrm{H}), 1.57-1.47(\mathrm{~m}, 2 \mathrm{H}) .{ }^{13} \mathrm{C}-\mathrm{NMR}(100$ $\left.\mathrm{MHz} \mathrm{CDCl}_{3}\right) \delta=147.9\left(\mathrm{C}_{\mathrm{q}}\right), 141.6\left(\mathrm{C}_{\mathrm{q}}\right), 138.3\left(\mathrm{C}_{\mathrm{q}}\right), 138.2(\mathrm{CH}), 137.4(\mathrm{CH}), 133.0\left(\mathrm{C}_{\mathrm{q}}\right)$, $132.5\left(\mathrm{C}_{\mathrm{q}}\right), 132.3\left(\mathrm{C}_{\mathrm{q}}\right), 130.5(\mathrm{CH}), 129.4(\mathrm{CH}), 128.1(\mathrm{CH}), 128.0(\mathrm{CH}), 127.8(\mathrm{CH}), 119.9$ (CH), $115.9(\mathrm{CH}), 115.4(\mathrm{CH}), 99.8(\mathrm{CH}), 42.7\left(\mathrm{C}_{\mathrm{q}}\right), 33.4\left(\mathrm{CH}_{2}\right), 24.0\left(\mathrm{CH}_{2}\right), 18.4\left(\mathrm{CH}_{2}\right) . \mathbf{I R}$ (ATR): 3017, 2928, 1657, 1585, 1515, 1442, 821, $702 \mathrm{~cm}^{-1}$. MS (ESI) $\mathrm{m} / \mathrm{z}$ (relative intensity): 326 (34) $[\mathrm{M}+\mathrm{H}]^{+}$. HR-MS (ESI) $\mathrm{m} / z$ calcd for $\mathrm{C}_{23} \mathrm{H}_{20} \mathrm{NO}[\mathrm{M}+\mathrm{H}]^{+} 326.1539$, found 326.1541 .

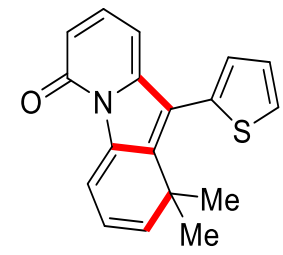

1,1-Dimethyl-10-(thiophen-2-yl)pyrido[1,2-a]indol-6(1H)-one (180aj): The general procedure B was followed using $2 \mathrm{H}$-[1,2'-bipyridin]-2-one (172a) (43.1 mg, $0.25 \mathrm{mmol}$ ) and methyl [2-methyl-4-(thiophen-2-yl)but-3-yn-2-yl] carbonate (88j) $(85.2 \mathrm{mg}, 0.38$ mmol). Purification by column chromatography on silica gel ( $n$-hexane/EtOAc: 10/1) yielded 180aj (44.7 mg, 61\%) as an orange solid. M. p. $=174-175{ }^{\circ} \mathrm{C} .{ }^{1} \mathbf{H}-\mathbf{N M R}(400$ 
$\left.\mathrm{MHz}, \mathrm{CDCl}_{3}\right) \delta=7.94(\mathrm{dd}, J=6.5,0.5 \mathrm{~Hz}, 1 \mathrm{H}), 7.42(\mathrm{dd}, J=4.9,2.9 \mathrm{~Hz}, 1 \mathrm{H}), 7.32-7.26$ (m, 2H), $7.08(\mathrm{dd}, J=4.9,1.3 \mathrm{~Hz}, 1 \mathrm{H}), 6.42(\mathrm{dd}, J=9.0,1.0 \mathrm{~Hz}, 1 \mathrm{H}), 6.26(\mathrm{dd}, J=9.4,6.5$ $\mathrm{Hz}, 1 \mathrm{H}$ ), 5.94 (ddd, $J=7.1,1.0,0.5 \mathrm{~Hz}, 1 \mathrm{H}), 5.86(\mathrm{dd}, J=9.4,0.5 \mathrm{~Hz}, 1 \mathrm{H}), 1.22(\mathrm{~s}, 6 \mathrm{H})$. ${ }^{13} \mathrm{C}-\mathrm{NMR}\left(100 \mathrm{MHz}, \mathrm{CDCl}_{3}\right) \delta=161.4\left(\mathrm{C}_{\mathrm{q}}\right), 148.0\left(\mathrm{C}_{\mathrm{q}}\right), 143.7\left(\mathrm{C}_{\mathrm{q}}\right), 142.5(\mathrm{CH}), 138.0\left(\mathrm{C}_{\mathrm{q}}\right)$, $137.5(\mathrm{CH}), 132.2\left(\mathrm{C}_{\mathrm{q}}\right), 129.9(\mathrm{CH}), 126.7\left(\mathrm{C}_{\mathrm{q}}\right), 125.8(\mathrm{CH}), 125.6(\mathrm{CH}), 119.9(\mathrm{CH}), 115.9$ (CH), $115.8(\mathrm{CH}), 99.4(\mathrm{CH}), 38.6\left(\mathrm{C}_{q}\right), 28.1\left(\mathrm{CH}_{3}\right)$. IR (ATR): 3022,, 1653, 1632, 1541, 1438, 1309, 1048, $802 \mathrm{~cm}^{-1}$. MS (ESI) m/z (relative intensity): 609 (14) [2M+Na] ${ }^{+}, 316$ (27) $[\mathrm{M}+\mathrm{Na}]^{+}, 294(100)[\mathrm{M}+\mathrm{H}]^{+}$. HR-MS (ESI) $\mathrm{m} / z$ calcd for $\mathrm{C}_{18} \mathrm{H}_{16} \mathrm{NOS}[\mathrm{M}+\mathrm{H}]^{+}$ 294.0947, found 294.0955. The compound 180aj was also unambiguously characterized by X-ray crystallographic diffraction analysis (vide infra).

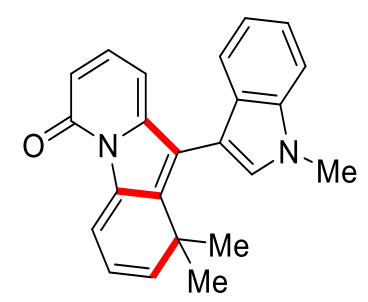

1,1-Dimethyl-10-(1-methyl-1H-indol-3-yl)pyrido[1,2-a]indol-6(1H)-one (180ak): The general procedure B was followed using $2 \mathrm{H}$-[1,2'-bipyridin]-2-one (172a) $(43.1 \mathrm{mg}$, $0.25 \mathrm{mmol}$ ) and methyl [2-methyl-4-(1-methyl-1H-indol-3-yl)but-3-yn-2-yl] carbonate (88k) (103.1 mg, $0.38 \mathrm{mmol}$ ). Purification by column chromatography on silica gel (n-hexane/EtOAc: $10 / 1$ ) yielded $\mathbf{1 8 0 a k}$ (51.1 mg, 60\%) as an orange solid. ${ }^{1} \mathbf{H}$-NMR (300 $\left.\mathrm{MHz}, \mathrm{CDCl}_{3}\right) \delta=8.01(\mathrm{~d}, J=6.4 \mathrm{~Hz}, 1 \mathrm{H}), 7.51-7.28(\mathrm{~m}, 4 \mathrm{H}), 7.19-7.07(\mathrm{~m}, 2 \mathrm{H}), 6.45(\mathrm{~d}$, $J=9.0 \mathrm{~Hz}, 1 \mathrm{H}), 6.33(\mathrm{dd}, J=9.5,5.8 \mathrm{~Hz}, 1 \mathrm{H}), 5.95-5.82(\mathrm{~m}, 2 \mathrm{H}), 3.93(\mathrm{~s}, 3 \mathrm{H}), 1.43(\mathrm{~s}$, 3H), $1.11(\mathrm{~s}, 3 \mathrm{H}) .{ }^{13} \mathrm{C}-\mathrm{NMR}\left(125 \mathrm{MHz}, \mathrm{CDCl}_{3}\right) \delta=148.4\left(\mathrm{C}_{\mathrm{q}}\right), 144.7\left(\mathrm{C}_{\mathrm{q}}\right), 142.5(\mathrm{CH}), 138.3$ $\left(\mathrm{C}_{\mathrm{q}}\right), 137.8\left(\mathrm{C}_{\mathrm{q}}\right), 137.4(\mathrm{CH}), 136.5\left(\mathrm{C}_{\mathrm{q}}\right), 129.2(\mathrm{CH}), 128.9\left(\mathrm{C}_{\mathrm{q}}\right), 124.6\left(\mathrm{C}_{\mathrm{q}}\right), 122.1(\mathrm{CH})$, $120.1(\mathrm{CH}), 119.8(\mathrm{CH}), 119.7(\mathrm{CH}), 115.7(\mathrm{CH}), 115.4(\mathrm{CH}), 109.3(\mathrm{CH}), 105.9\left(\mathrm{C}_{\mathrm{q}}\right), 99.7$ (CH), $38.7\left(\mathrm{C}_{q}\right), 33.1\left(\mathrm{CH}_{3}\right), 29.9\left(\mathrm{CH}_{3}\right), 26.7\left(\mathrm{CH}_{3}\right)$. IR (ATR): 2963, 2925, 1653, 1584, 1511, 1243, 1134, $741 \mathrm{~cm}^{-1}$. MS (ESI) $\mathrm{m} / z$ (relative intensity): 363 (10) [M+Na] ${ }^{+}, 341$ (100) $[\mathrm{M}+\mathrm{H}]^{+}$. HR-MS (ESI) $m / z$ calcd for $\mathrm{C}_{23} \mathrm{H}_{21} \mathrm{~N}_{2} \mathrm{O}[\mathrm{M}+\mathrm{H}]^{+} 341.1648$, found 341.1655. 


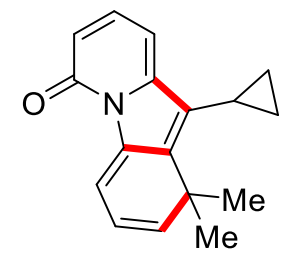

10'-Phenyl-6' H-spiro\{cyclopropane-1,1'-pyrido[1,2-a]indol\}-6'-one (180al): The general procedure B was followed using $2 \mathrm{H}$-[1,2'-bipyridin]-2-one (172a) $(43.1 \mathrm{mg}$, $0.25 \mathrm{mmol}$ ) and 4-cyclopropyl-2-methylbut-3-yn-2-yl methyl carbonate (88I) $(69.2 \mathrm{mg}$, $0.38 \mathrm{mmol}$ ). Purification by column chromatography on silica gel ( $n$-hexane/EtOAc: 10/1) yielded $180 \mathrm{al}$ (38.3 mg, 61\%) as an orange oil. ${ }^{1} \mathbf{H}-\mathbf{N M R}\left(400 \mathrm{MHz}, \mathrm{CDCl}_{3}\right) \delta=7.85$ (d, $J=6.6 \mathrm{~Hz}, 1 \mathrm{H}), 7.32(\mathrm{dd}, J=9.0,7.2 \mathrm{~Hz}, 1 \mathrm{H}), 6.47(\mathrm{~d}, J=7.2 \mathrm{~Hz}, 1 \mathrm{H}), 6.39$ (dd, $J=$ 9.0, $0.9 \mathrm{~Hz}, 1 \mathrm{H}), 6.18(\mathrm{dd}, J=9.5,6.6 \mathrm{~Hz}, 1 \mathrm{H}), 5.85(\mathrm{~d}, J=9.5 \mathrm{~Hz}, 1 \mathrm{H}), 1.95-1.83(\mathrm{~m}$, 1H), $1.50(\mathrm{~s}, 6 \mathrm{H}), 1.10-1.01(\mathrm{~m}, 2 \mathrm{H}), 0.98-0.89(\mathrm{~m}, 2 \mathrm{H}) .{ }^{13} \mathrm{C}-\mathrm{NMR}\left(100 \mathrm{MHz}, \mathrm{CDCl}_{3}\right) \delta=$ $161.7\left(C_{q}\right), 146.8\left(C_{q}\right), 144.1\left(C_{q}\right), 142.4(C H), 138.0\left(C_{q}\right), 137.2(C H), 130.8\left(C_{q}\right), 119.8$ (CH), $115.6(\mathrm{CH}), 114.4(\mathrm{CH}), 99.5(\mathrm{CH}), 38.5\left(\mathrm{C}_{\mathrm{q}}\right), 26.7\left(\mathrm{CH}_{3}\right), 7.5(\mathrm{CH}), 7.4\left(\mathrm{CH}_{2}\right)$. IR (ATR): 2967, 2928, 1711, 1655, 1516, 1361, $803 \mathrm{~cm}^{-1}$. MS (ESI) $\mathrm{m} / \mathrm{z}$ (relative intensity): $525(30)[2 \mathrm{M}+\mathrm{Na}]^{+}, 274(20)[\mathrm{M}+\mathrm{Na}]^{+}, 252(100)[\mathrm{M}+\mathrm{H}]^{+}$. HR-MS (ESI) m/z calcd for $\mathrm{C}_{17} \mathrm{H}_{18} \mathrm{NO}[\mathrm{M}+\mathrm{H}]^{+} 252.1383$, found 252.1388 .

\subsubsection{Mechanistic Studies}

H/D Exchange Experiments

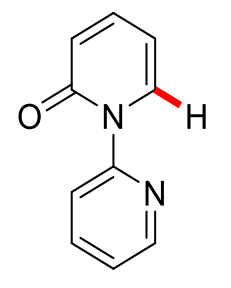

$172 a$

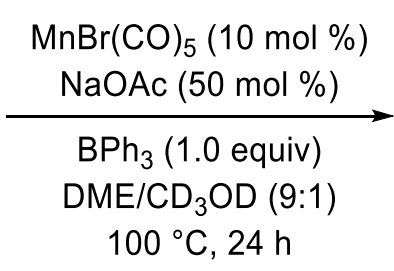

$100{ }^{\circ} \mathrm{C}, 24 \mathrm{~h}$

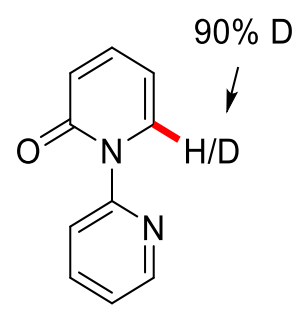

$[D]_{n}-172 a: 94 \%$

172a (43.1 mg, $0.25 \mathrm{mmol}), \operatorname{MnBr}(\mathrm{CO})_{5}(6.9 \mathrm{mg}, 10 \mathrm{~mol} \%), \mathrm{NaOAc}(10 \mathrm{mg}, 50 \mathrm{~mol} \%)$, $\mathrm{BPh}_{3}\left(60 \mathrm{mg}, 1.0\right.$ equiv), $\mathrm{DME}(0.9 \mathrm{~mL})$ and $\mathrm{CD}_{3} \mathrm{OD}(0.1 \mathrm{~mL})$ were placed in a $25 \mathrm{~mL}$ Schlenk pressure tube under $\mathrm{N}_{2}$ atmosphere and stirred at $100{ }^{\circ} \mathrm{C}$ for $24 \mathrm{~h}$. After cooling to ambient temperature, the mixture was transferred into a round bottom flask 
with $\mathrm{CH}_{2} \mathrm{Cl}_{2}(20 \mathrm{~mL})$ and concentrated in vacuo. Purification by column chromatography on silica gel ( $n$-hexane/EtOAc: 10/1) afforded [D $]_{n}-172 a(40.9 \mathrm{mg}$, 94\%). The $D$ incorporation was determined by ${ }^{1} \mathrm{H}-\mathrm{NMR}$ spectroscopy.
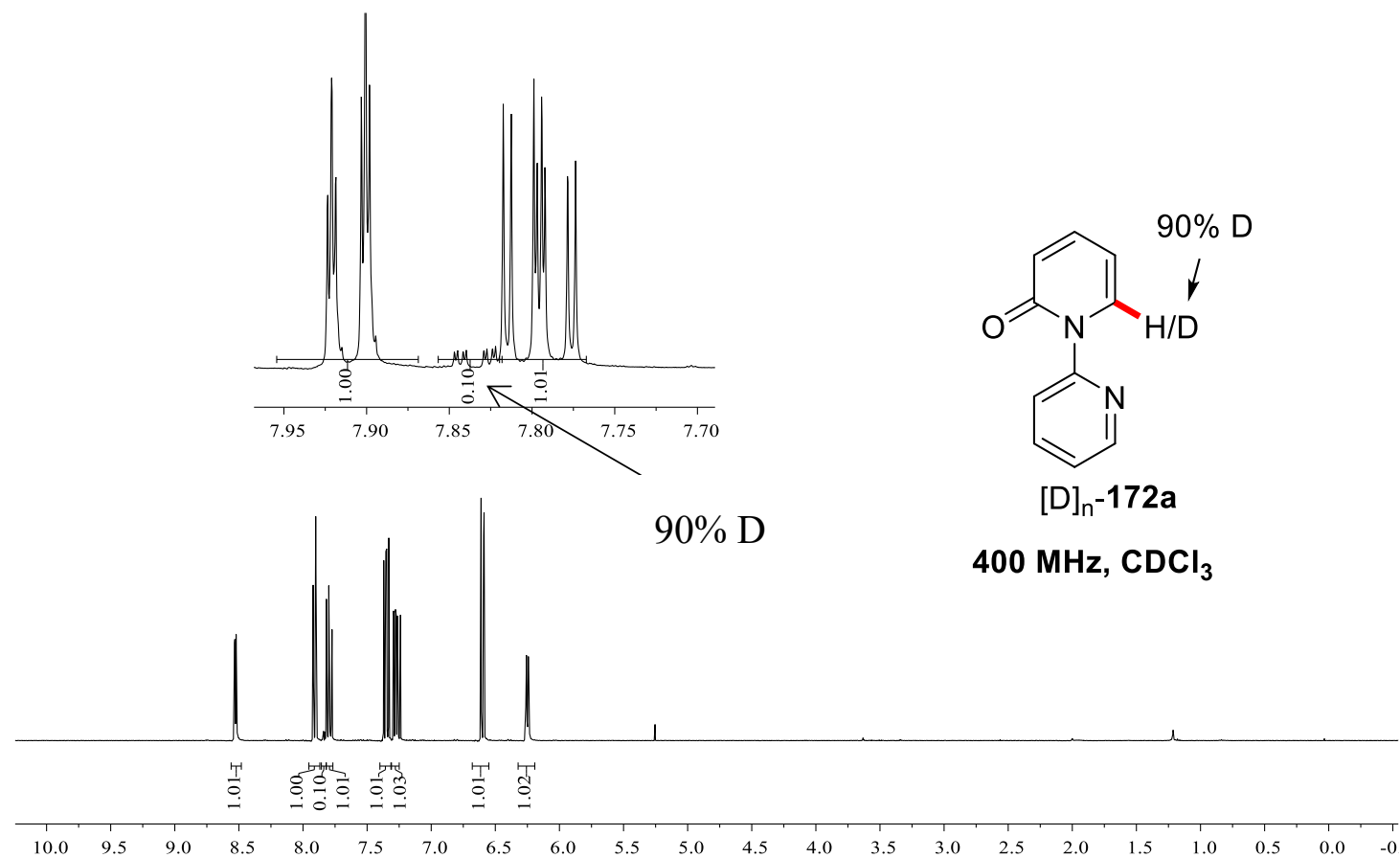<smiles>[2H]c1cccn1-c1cccc(=O)n1-c1ccccn1</smiles>

$[D]_{n}-172 a$
$00 \mathrm{MHz}, \mathrm{CDCl}_{3}$<smiles>O=c1ccccn1-c1ccccn1</smiles>

$172 a$

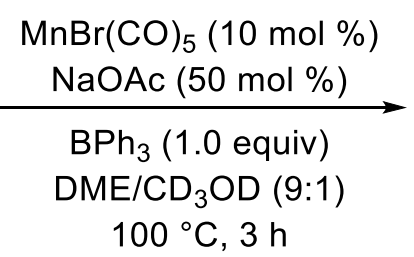

$100{ }^{\circ} \mathrm{C}, 3 \mathrm{~h}$

$53 \%$ D<smiles>CC1(C)C=CC=c2c1c(-c1ccccc1)c1ccc([Hg]O)c(=O)n21</smiles>

$[D]_{n}-180$ aa: $20 \%$

172a (43.1 mg, $0.25 \mathrm{mmol}), 88 \mathrm{a}(83.0 \mathrm{mg}, 0.38 \mathrm{mmol}), \operatorname{MnBr}(\mathrm{CO})_{5}(6.9 \mathrm{mg}, 10 \mathrm{~mol} \%)$, $\mathrm{NaOAc}\left(10 \mathrm{mg}, 50 \mathrm{~mol} \%\right.$ ) and $\mathrm{BPh}_{3}\left(60 \mathrm{mg}, 1.0\right.$ equiv) in $\mathrm{DME}(0.9 \mathrm{~mL})$ and $\mathrm{CD}_{3} \mathrm{OD}(0.1$ $\mathrm{mL}$ ) were placed in a $25 \mathrm{~mL}$ Schlenk pressure tube under $\mathrm{N}_{2}$ and stirred at $100{ }^{\circ} \mathrm{C}$ for 3 h. After cooling to ambient temperature, the mixture was transferred into a round bottom flask with $\mathrm{CH}_{2} \mathrm{Cl}_{2}(20 \mathrm{~mL})$ and concentrated in vacuo. Purification by column chromatography on silica gel ( $n$-hexane/EtOAc: $10 / 1$ ) yielded [D] ${ }_{n}$-180aa (14.4 mg, $20 \%)$ and $[D]_{n}-172 a(33.9 \mathrm{mg}, 78 \%)$, The $\mathrm{D}$ incorporation was determined by ${ }^{1} \mathrm{H}-\mathrm{NMR}$ 
spectroscopy.

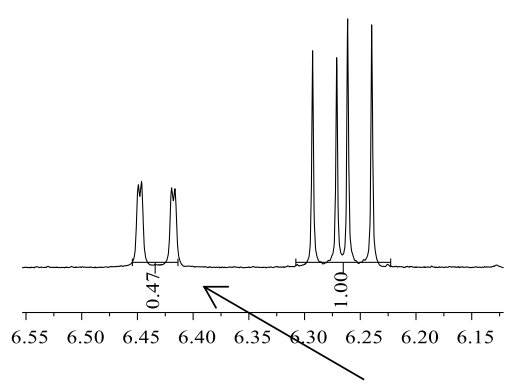

$53 \%$ D

$53 \% \mathrm{D}$

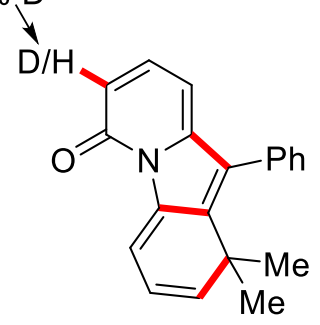

$[D]_{n}-180$ aa

$300 \mathrm{MHz}, \mathrm{CDCl}_{3}$

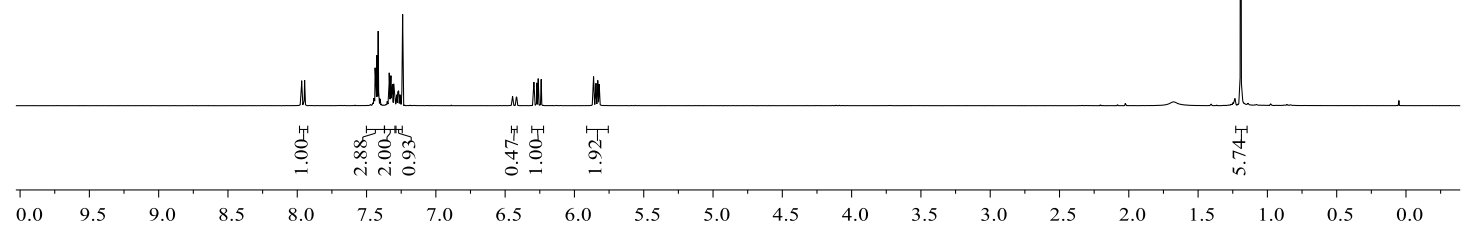

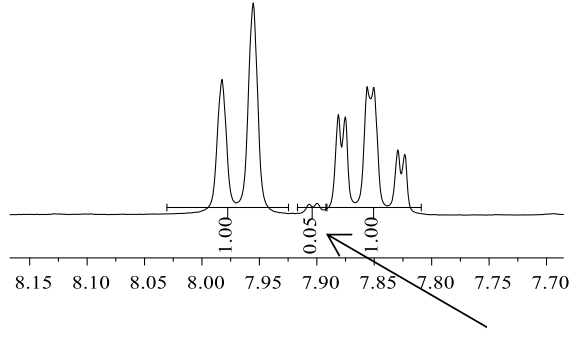

$95 \% \mathrm{D}$

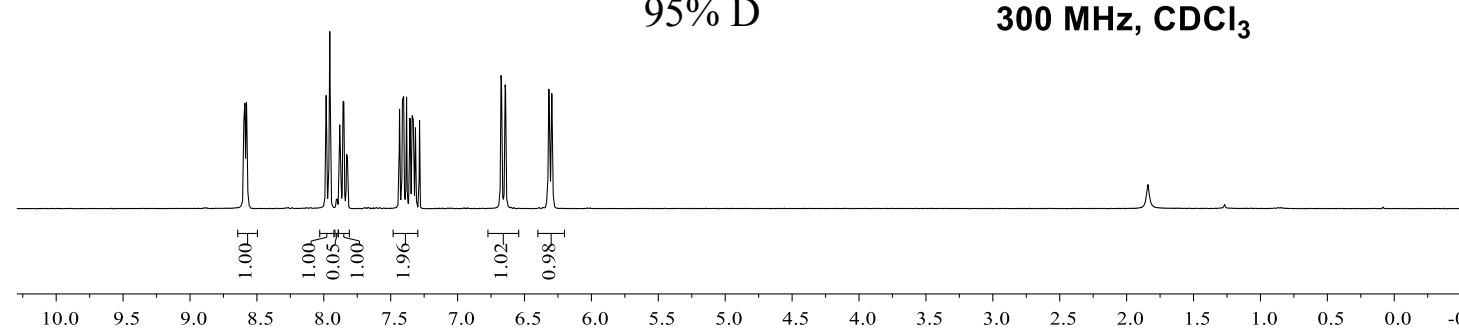

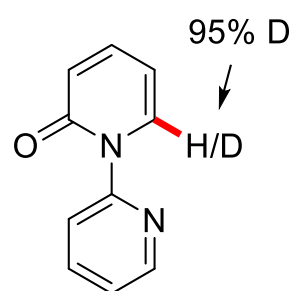

$[D]_{n}-172 a$

$300 \mathrm{MHz}, \mathrm{CDCl}_{3}$ 
Kinetic Isotope Effect Study

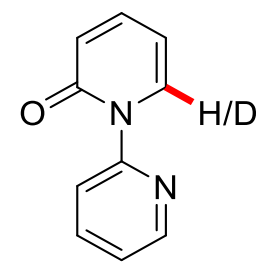

$172 \mathrm{a}$ or $[\mathrm{D}]_{1}-172 \mathrm{a}$
$88 a$

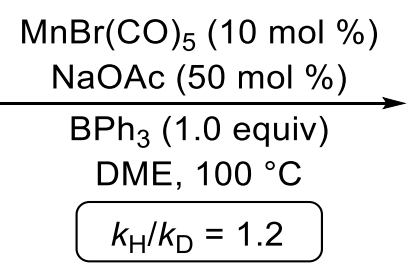

$k_{\mathrm{H}} / k_{\mathrm{D}}=1.2$

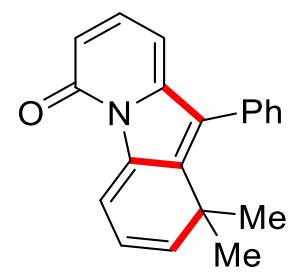

180aa

Five independent reactions of $172 a$ or $[D]_{1}-172 a$ with $88 a$ were performed to determine the KIE. 172a (43.1 mg, $0.25 \mathrm{mmol}$ ) or [D]1-172a (43.3 mg, $0.25 \mathrm{mmol}), 88 \mathrm{a}$ (83.0 mg, $0.38 \mathrm{mmol}), \mathrm{MnBr}(\mathrm{CO})_{5}(6.9 \mathrm{mg}, 10 \mathrm{~mol} \%), \mathrm{NaOAc}(10 \mathrm{mg}, 50 \mathrm{~mol} \%), \mathrm{BPh}_{3}$ (60 mg, 1.0 equiv), and DME (1.0 mL) were placed in a $25 \mathrm{~mL}$ Schlenk pressure tube under $\mathrm{N}_{2}$ and stirred at $100{ }^{\circ} \mathrm{C}$. After cooling to ambient temperature, the mixture was transferred into a round bottom flask with $\mathrm{CH}_{2} \mathrm{Cl}_{2}(20 \mathrm{~mL})$ and concentrated in vacuo. Purification by column chromatography on silica gel ( $n$-hexane/EtOAc: $10 / 1$ ) yielded 180aa or $[D]_{n}-180 a a$.

\begin{tabular}{|l|l|l|l|l|l|}
\hline$t(\min )$ & 10 & 20 & 40 & 60 & 80 \\
\hline 180aa (\%) & 5 & 13 & 27 & 43 & 55 \\
\hline$[D]_{n}-180 a a(\%)$ & 2 & 8 & 18 & 32 & 45 \\
\hline
\end{tabular}

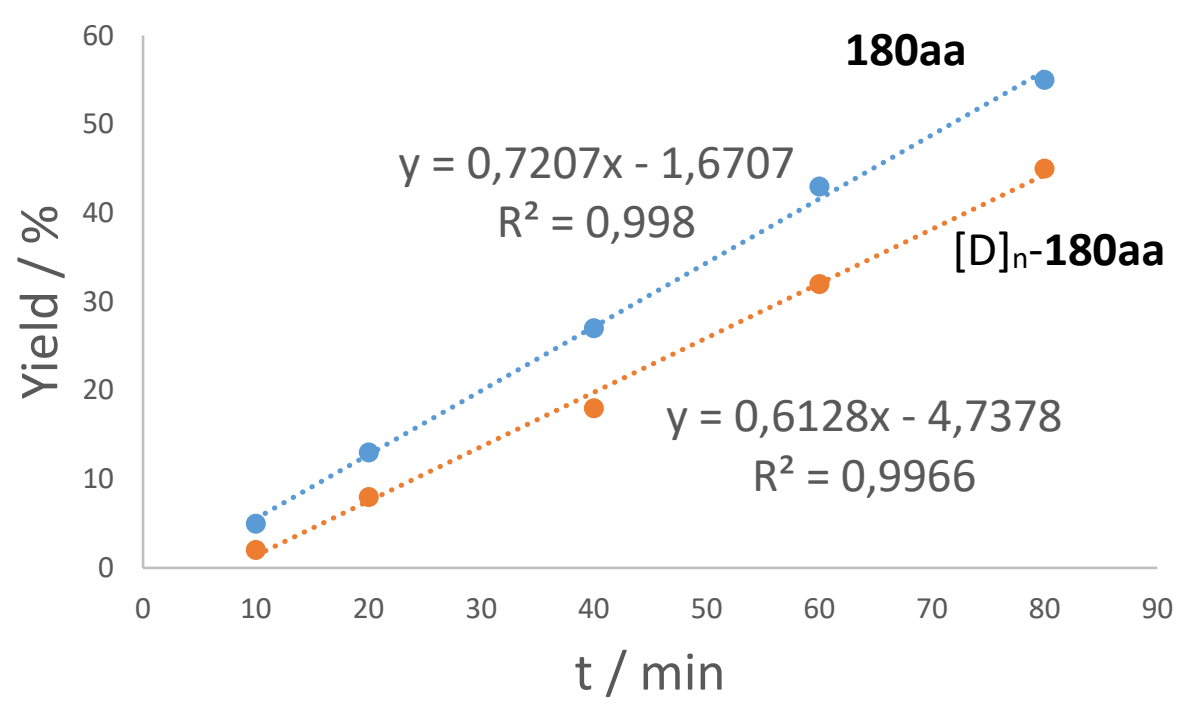




\section{Late-Stage Modifications}

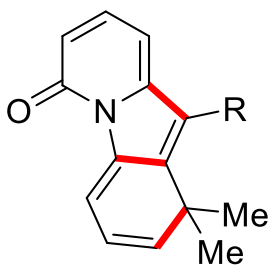

$\mathrm{R}=\mathrm{Ph}(180 \mathrm{aa})$

$\mathrm{R}=n \mathrm{Bu}(180 \mathrm{ac})$

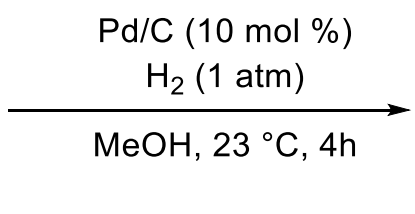

$\mathrm{R}=\mathrm{Ph}(181 \mathrm{a}): \quad 75 \%$

$\mathrm{R}=n \mathrm{Bu}(181 \mathrm{~b}): 68 \%$

180aa (57.4 mg, $0.2 \mathrm{mmol}$ ) or $180 \mathrm{ac}(53.5 \mathrm{mg}, 0.2 \mathrm{mmol}), \mathrm{Pd} / \mathrm{C}(20 \mathrm{mg}, 10 \mathrm{~mol} \%, 10$ wt. \% of palladium on activated carbon) were dissolved in $\mathrm{MeOH}(2.0 \mathrm{~mL})$ and refilled with $\mathrm{H}_{2}(1 \mathrm{~atm})$. The resulting solution was stirred for $4 \mathrm{~h}$ at $23^{\circ} \mathrm{C}$. The mixture was transferred into a round bottom flask with $\mathrm{CH}_{2} \mathrm{Cl}_{2}(20 \mathrm{~mL})$ and concentrated in vacuo. Purification by column chromatography on silica gel ( $n$-hexane/EtOAc: $1 / 1$ ) afforded the desired products $181 \mathrm{a}(43.7 \mathrm{mg}, 75 \%)$ and $181 \mathrm{~b}(36.9 \mathrm{mg}, 68 \%)$, respectively.

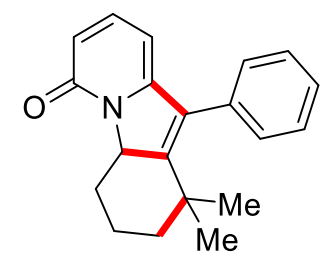

\section{1,1-Dimethyl-10-phenyl-2,3,4,4a-tetrahydropyrido[1,2-a]indol-6(1H)-one (181a):}

Colourless oil. ${ }^{1} \mathrm{H}-\mathrm{NMR}\left(400 \mathrm{MHz}, \mathrm{CDCl}_{3}\right) \delta=7.41-7.34(\mathrm{~m}, 3 \mathrm{H}), 7.31-7.23(\mathrm{~m}, 2 \mathrm{H})$, 7.23-7.17 (m, 1H), 6.30 (dd, J = 9.1, 1.0 Hz, 1H), $5.64(\mathrm{dd}, J=7.0,1.0 \mathrm{~Hz}, 1 \mathrm{H}), 4.96$ (dd, $J=11.6,5.3 \mathrm{~Hz}, 1 \mathrm{H}), 3.51-3.46(\mathrm{~m}, 1 \mathrm{H}), 1.88-1.69(\mathrm{~m}, 2 \mathrm{H}), 1.62-1.57(\mathrm{~m}, 1 \mathrm{H}), 1.35(\mathrm{td}$, $J=13.3,4.6 \mathrm{~Hz}, 1 \mathrm{H}), 1.25(\mathrm{~s}, 3 \mathrm{H}), 1.13-0.96(\mathrm{~m}, 1 \mathrm{H}), 0.83(\mathrm{~s}, 3 \mathrm{H}) .{ }^{13} \mathrm{C}-\mathrm{NMR}(100 \mathrm{MHz}$, $\left.\mathrm{CDCl}_{3}\right) \delta=162.0\left(\mathrm{C}_{\mathrm{q}}\right), 154.9\left(\mathrm{C}_{\mathrm{q}}\right), 153.9\left(\mathrm{C}_{\mathrm{q}}\right), 139.8(\mathrm{CH}), 133.4\left(\mathrm{C}_{\mathrm{q}}\right), 130.5(\mathrm{CH}), 129.6$ $(\mathrm{CH}), 128.6\left(\mathrm{C}_{q}\right), 128.1(\mathrm{CH}), 115.4(\mathrm{CH}), 98.9(\mathrm{CH}), 65.5(\mathrm{CH}), 42.4\left(\mathrm{CH}_{2}\right), 37.1\left(\mathrm{C}_{\mathrm{q}}\right), 31.4$ $\left(\mathrm{CH}_{2}\right), 30.2\left(\mathrm{CH}_{3}\right), 28.3\left(\mathrm{CH}_{3}\right), 20.1\left(\mathrm{CH}_{2}\right)$. IR (ATR): 2963, 2932, 2866, 1712, 1650, 1579, 1358, $792 \mathrm{~cm}^{-1}$. MS (ESI) $\mathrm{m} / \mathrm{z}$ (relative intensity): $605(34)[2 \mathrm{M}+\mathrm{Na}]^{+}, 314(17)[\mathrm{M}+\mathrm{Na}]^{+}$, $292(100)[\mathrm{M}+\mathrm{H}]^{+}$. HR-MS (ESI) $\mathrm{m} / z$ calcd for $\mathrm{C}_{20} \mathrm{H}_{22} \mathrm{NO}[\mathrm{M}+\mathrm{H}]^{+} 292.1696$, found 292.1694. 


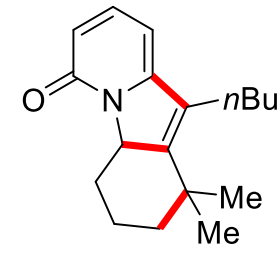

10-Butyl-1,1-dimethyl-2,3,4,4a-tetrahydropyrido[1,2-a]indol-6(1H)-one (181b):

Colourless oil. ${ }^{1} \mathrm{H}-\mathrm{NMR}\left(400 \mathrm{MHz}, \mathrm{CDCl}_{3}\right) \delta=7.37(\mathrm{dd}, J=9.0,7.0 \mathrm{~Hz}, 1 \mathrm{H}), 6.29$ (dd, $J=$ 9.0, $1.0 \mathrm{~Hz}, 1 \mathrm{H}), 6.13(\mathrm{dd}, J=7.0,1.0 \mathrm{~Hz}, 1 \mathrm{H}), 4.77(\mathrm{dd}, J=11.6,5.2 \mathrm{~Hz}, 1 \mathrm{H}), 3.52-3.22$ (m, 1H), 2.65-2.38 (m, 2H), 1.92-1.63 (m, 2H), 1.65-1.55 (m, 2H), 1.52-1.30 (m, 7H), $1.21(\mathrm{~s}, 3 \mathrm{H}), 0.93(\mathrm{t}, J=7.0 \mathrm{~Hz}, 3 \mathrm{H}), 0.88-0.77(\mathrm{~m}, 1 \mathrm{H}) .{ }^{13} \mathrm{C}-\mathrm{NMR}\left(100 \mathrm{MHz}, \mathrm{CDCl}_{3}\right) \delta=$ $162.2\left(\mathrm{C}_{\mathrm{q}}\right), 153.6\left(\mathrm{C}_{\mathrm{q}}\right), 152.5\left(\mathrm{C}_{\mathrm{q}}\right), 139.8(\mathrm{CH}), 126.9\left(\mathrm{C}_{\mathrm{q}}\right), 115.0(\mathrm{CH}), 97.1(\mathrm{CH}), 65.3$ (CH), $42.4\left(\mathrm{CH}_{2}\right), 37.5\left(\mathrm{C}_{\mathrm{q}}\right), 32.7\left(\mathrm{CH}_{2}\right), 31.2\left(\mathrm{CH}_{2}\right), 29.3\left(\mathrm{CH}_{3}\right), 28.2\left(\mathrm{CH}_{3}\right), 24.6\left(\mathrm{CH}_{2}\right)$, $23.0\left(\mathrm{CH}_{2}\right), 20.1\left(\mathrm{CH}_{2}\right), 13.9\left(\mathrm{CH}_{3}\right)$. IR (ATR): 2955, 2928, 2868, 1652, 1578, 1530, 1456, $1164 \mathrm{~cm}^{-1}$. MS (ESI) m/z (relative intensity): 565 (48) [2M+Na] ${ }^{+}, 294(32)[\mathrm{M}+\mathrm{Na}]^{+}, 272$ (100) $[\mathrm{M}+\mathrm{H}]^{+}$. HR-MS (ESI) $\mathrm{m} / z$ calcd for $\mathrm{C}_{18} \mathrm{H}_{26} \mathrm{NO}[\mathrm{M}+\mathrm{H}]^{+} 272.2009$, found 272.2008.

\section{Catalytic and Stoichiometric Reactions with Cyclometalated Complex 182}<smiles>O=c1ccccn1-c1ccccn1</smiles>

$172 a$

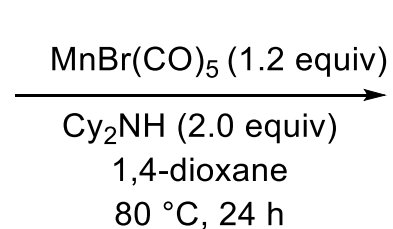

$80^{\circ} \mathrm{C}, 24 \mathrm{~h}$

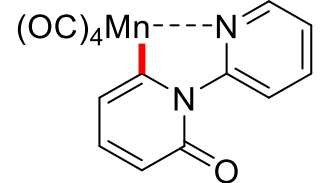

182: $76 \%$

$\operatorname{MnBr}(\mathrm{CO})_{5}$ (274 mg, $\left.1.0 \mathrm{mmol}\right), 2 \mathrm{H}$-[1,2'-bipyridin]-2-one 172a (174 mg, $1.0 \mathrm{mmol}$ ), dicyclohexylamine $(362 \mathrm{mg}, 2.0 \mathrm{mmol})$ and 1,4-dioxane $(2.0 \mathrm{~mL})$ were placed in a 25 $\mathrm{mL}$ Schlenk tube under $\mathrm{N}_{2}$ and then stirred at $100 \stackrel{\circ}{ } \mathrm{C}$ for $14 \mathrm{~h}$. At ambient temperature, the mixture was diluted with EtOAc $(20 \mathrm{~mL})$ and filtered through a short pad of celite. The solvent was removed and the residue was purified by column chromatography on silica gel ( $n$-hexane/EtOAc: $10 / 1)$ to afford $182(257 \mathrm{mg}, 76 \%)$ as a pale yellow solid. 


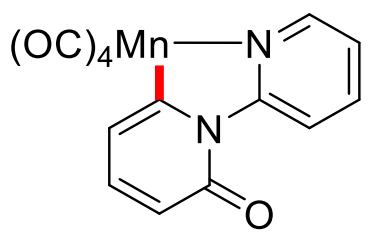

M. p. $=120-122{ }^{\circ} \mathrm{C} .{ }^{1} \mathrm{H}-\mathrm{NMR}\left(400 \mathrm{MHz}, \mathrm{CDCl}_{3}\right) \delta=9.54(\mathrm{~d}, J=9.0 \mathrm{~Hz}, 1 \mathrm{H}), 8.54(\mathrm{~d}, J=$ $3.9 \mathrm{~Hz}, 1 \mathrm{H}), 7.91(\mathrm{dd}, J=7.2,7.2 \mathrm{~Hz}, 1 \mathrm{H}), 7.19-7.06(\mathrm{~m}, 2 \mathrm{H}), 6.69(\mathrm{~d}, J=6.6 \mathrm{~Hz}, 1 \mathrm{H})$, $6.29(\mathrm{~d}, J=9.0 \mathrm{~Hz}, 1 \mathrm{H}) .{ }^{13} \mathrm{C}-\mathrm{NMR}\left(100 \mathrm{MHz}, \mathrm{CDCl}_{3}\right) \delta=217.4\left(\mathrm{C}_{\mathrm{q}}\right), 212.6\left(\mathrm{C}_{\mathrm{q}}\right), 210.2\left(\mathrm{C}_{\mathrm{q}}\right)$, $183.6\left(\mathrm{C}_{q}\right), 167.6\left(\mathrm{C}_{\mathrm{q}}\right), 160.4\left(\mathrm{C}_{\mathrm{q}}\right), 152.5(\mathrm{CH}), 140.2(\mathrm{CH}), 138.1(\mathrm{CH}), 122.1(\mathrm{CH}), 120.4$ (CH), 119.7 (CH), 115.9 (CH). MS (ESI) m/z (relative intensity): 361 (76) [M+Na] $]^{+}, 339$ (85) $[\mathrm{M}+\mathrm{H}]^{+}$. HR-MS (ESI) $\mathrm{m} / z$ calcd for $\mathrm{C}_{14} \mathrm{H}_{8} \mathrm{MnN}_{2} \mathrm{O}_{5}[\mathrm{M}+\mathrm{H}]^{+} 338.9808$, found 338.9809.<smiles></smiles>

$172 \mathrm{a}$

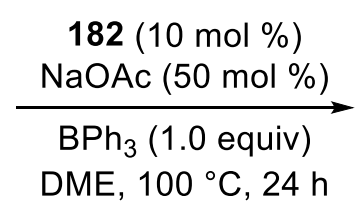

DME, $100^{\circ} \mathrm{C}, 24 \mathrm{~h}$

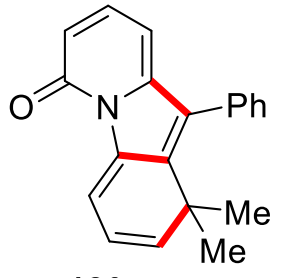

180aa: $75 \%$

172a (43.1 mg, $0.25 \mathrm{mmol}), 88 \mathrm{a}$ ( $83.0 \mathrm{mg}, 0.38 \mathrm{mmol}), 182$ (8.5 mg, $10 \mathrm{~mol} \%), \mathrm{NaOAc}$ (10 mg, $50 \mathrm{~mol} \%), \mathrm{BPh}_{3}$ (60 mg, 1.0 equiv) and DME (1.0 mL) were placed in a $25 \mathrm{~mL}$ Schlenk pressure tube under $\mathrm{N}_{2}$ atomosphere and stirred at $100{ }^{\circ} \mathrm{C}$ for $24 \mathrm{~h}$. After cooling to ambient temperature, the mixture was transferred into a round bottom flask with $\mathrm{CH}_{2} \mathrm{Cl}_{2}(20 \mathrm{~mL})$ and concentrated in vacuo. Purification by column chromatography on silica gel ( $n$-hexane/EtOAc: 10/1) yielded 180aa (53.8 mg, 75\%).<smiles>O=c1oc2cccc(=O)n2c2ccccc12</smiles>

182

$$
\text { 88a } \underset{\mathrm{NaOAc}(50 \mathrm{~mol} \%)}{\stackrel{\mathrm{NPh}}{\mathrm{B}(1.0 \text { equiv })}}
$$

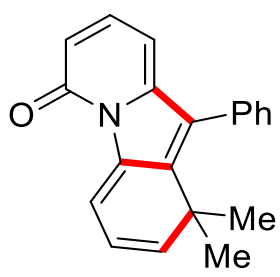

180aa: $65 \%$

182 (84.6 mg, $0.25 \mathrm{mmol}$ ), 88a (83.0 mg, $0.38 \mathrm{mmol}$ ), NaOAc (10 mg, $50 \mathrm{~mol} \%), \mathrm{BPh}_{3}$ 
(60 mg, 1.0 equiv) and DME $(1.0 \mathrm{~mL})$ were placed in a $25 \mathrm{~mL}$ Schlenk pressure tube under $\mathrm{N}_{2}$ atomosphere and stirred at $100{ }^{\circ} \mathrm{C}$ for $24 \mathrm{~h}$. After cooling to ambient temperature, the mixture was transferred into a round bottom flask with $\mathrm{CH}_{2} \mathrm{Cl}_{2}$ (20 $\mathrm{mL}$ ) and concentrated in vacuo. Purification by column chromatography on silica gel ( $n$-hexane/EtOAc: $10 / 1$ ) yielded 180aa (46.6 mg, 65\%).

\section{Domino C-H activation/Diels-Alder/retro-Diels-Alder with allene}<smiles>O=c1cc(Br)ccn1-c1ccccn1</smiles>

$172 \mathrm{e}$

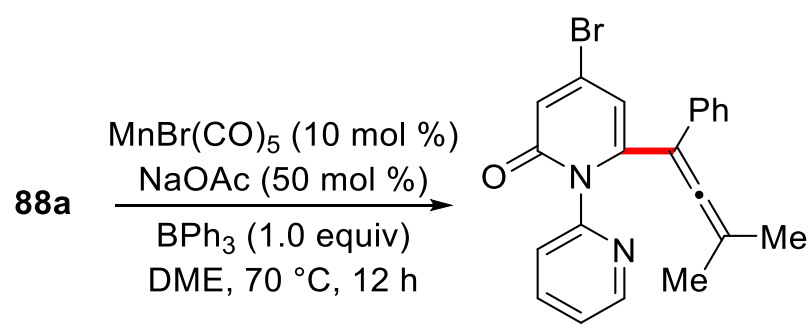

183: $20 \%$

172e (62.8 mg, $0.25 \mathrm{mmol}), 88 \mathrm{a}(83.0 \mathrm{mg}, 0.38 \mathrm{mmol}), \operatorname{MnBr}(\mathrm{CO})_{5}(6.9 \mathrm{mg}, 10 \mathrm{~mol} \%)$, $\mathrm{NaOAc}(10 \mathrm{mg}, 50 \mathrm{~mol} \%), \mathrm{BPh}_{3}(60 \mathrm{mg}, 1.0$ equiv) and $\mathrm{DME}(1.0 \mathrm{~mL})$ were placed in a $25 \mathrm{~mL}$ Schlenk pressure tube under $\mathrm{N}_{2}$ atomosphere and stirred at $70^{\circ} \mathrm{C}$ for $12 \mathrm{~h}$. After cooling to ambient temperature, the mixture was transferred into a round bottom flask with $\mathrm{CH}_{2} \mathrm{Cl}_{2}(20 \mathrm{~mL})$ and concentrated in vacuo. Purification by column chromatography on silica gel ( $n$-hexane/EtOAc: 5/1) yielded 183 (19.7 mg, 20\%).<smiles>CC(C)=CC(=Cc1ccccn1)c1cc(Br)cc(=O)n1-c1ccccc1</smiles>

4-Bromo-6-(3-methyl-1-phenylbuta-1,2-dien-1-yl)-2H-[1,2'-bipyridin]-2-one (183):

${ }^{1} \mathrm{H}-\mathrm{NMR}\left(400 \mathrm{MHz}, \mathrm{CDCl}_{3}\right) \delta=8.40(\mathrm{ddd}, J=4.9,1.9,0.8 \mathrm{~Hz}, 1 \mathrm{H}), 7.48(\mathrm{dd}, J=7.7,1.9$ $\mathrm{Hz}, 1 \mathrm{H}), 7.19-7.08(\mathrm{~m}, 4 \mathrm{H}), 6.94(\mathrm{ddd}, J=6.9,4.7,1.3 \mathrm{~Hz}, 3 \mathrm{H}), 6.86(\mathrm{~d}, J=2.1 \mathrm{~Hz}, 1 \mathrm{H})$, $6.43(\mathrm{~d}, J=2.1 \mathrm{~Hz}, 1 \mathrm{H}), 1.67(\mathrm{~s}, 6 \mathrm{H}) .{ }^{13} \mathrm{C}-\mathrm{NMR}\left(100 \mathrm{MHz}, \mathrm{CDCl}_{3}\right) \delta=203.6\left(\mathrm{C}_{\mathrm{q}}\right), 162.1$ $\left(\mathrm{C}_{\mathrm{q}}\right), 151.1\left(\mathrm{C}_{\mathrm{q}}\right), 149.0(\mathrm{CH}), 145.7\left(\mathrm{C}_{\mathrm{q}}\right), 137.0(\mathrm{CH}), 136.4\left(\mathrm{C}_{\mathrm{q}}\right), 135.7\left(\mathrm{C}_{\mathrm{q}}\right), 128.3(\mathrm{CH})$, 127.2 (CH), 126.7 (CH), 124.3 (CH), 123.4 (CH), $122.0(\mathrm{CH}), 112.5(\mathrm{CH}), 101.6\left(\mathrm{C}_{\mathrm{q}}\right), 101.2$ $\left(\mathrm{C}_{\mathrm{q}}\right), 19.8\left(\mathrm{CH}_{3}\right)$. MS (ESI) $m / z$ (relative intensity): 393 (100) [M+H] $]^{+}$. HR-MS (ESI) $m / z$ 
calcd for $\mathrm{C}_{21} \mathrm{H}_{18} \mathrm{BrN}_{2} \mathrm{O}[\mathrm{M}+\mathrm{H}]^{+}$393.0597, found 393.0596.<smiles>CC(C)=C=C(c1ccccc1)c1cc(Br)cc(=O)n1-c1ccccn1</smiles>

183

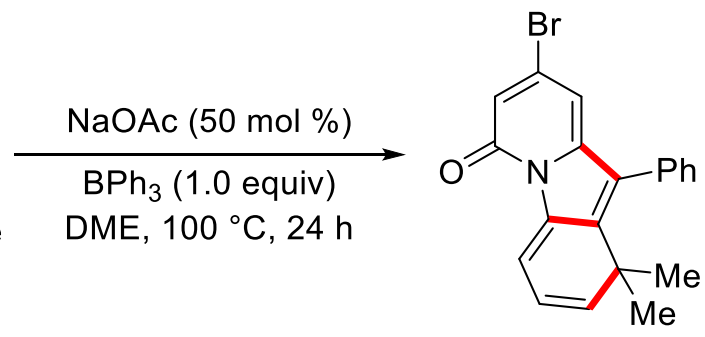

180ea: $64 \%$

183 (98.0 mg, $0.25 \mathrm{mmol}$ ), 88a (83.0 mg, $0.38 \mathrm{mmol}$ ), NaOAc (10 mg, $50 \mathrm{~mol} \%), \mathrm{BPh}_{3}$

(60 mg, 1.0 equiv) and DME $(1.0 \mathrm{~mL}$ ) were placed in a $25 \mathrm{~mL}$ Schlenk pressure tube under $\mathrm{N}_{2}$ atomosphere and stirred at $100{ }^{\circ} \mathrm{C}$ for $24 \mathrm{~h}$. After cooling to ambient temperature, the mixture was transferred into a round bottom flask with $\mathrm{CH}_{2} \mathrm{Cl}_{2}(20$ $\mathrm{mL}$ ) and concentrated in vacuo. Purification by column chromatography on silica gel ( $n$-hexane/EtOAc: 10/1) yielded 180ea (58.4 mg, 64\%). 


\subsection{Manganese(II/III/I)-Catalyzed C-H Arylations in Continuous Flow}

\subsubsection{Characterization Data}<smiles>CCCCNC(=O)c1ncccc1-c1ccc(OC)cc1</smiles>

$\mathbf{N}$ - $n$-Butyl-3-(4-methoxyphenyl)picolinamide (188aa). The general procedure C was followed using 112a (44.5 mg, $0.25 \mathrm{mmol}$ ) and 151a (0.40 mL, $1.0 \mathrm{mmol}, 2.5 \mathrm{~m}$ in THF). Isolation by column chromatography ( $n$-hexane/EtOAc: $2: 1 \rightarrow 1: 1$ ) yielded 188aa (52.6 mg, 74\%) as a white solid. M. p. $=96-97{ }^{\circ} \mathrm{C} .{ }^{1} \mathbf{H}-\mathbf{N M R}\left(300 \mathrm{MHz}, \mathrm{CDCl}_{3}\right) \delta=8.48(\mathrm{dd}, \mathrm{J}$ $=4.6,1.7 \mathrm{~Hz}, 1 \mathrm{H}), 7.66-7.62(\mathrm{~m}, 2 \mathrm{H}), 7.38(\mathrm{dd}, J=7.8,4.6 \mathrm{~Hz}, 1 \mathrm{H}), 7.25(\mathrm{~d}, J=8.8 \mathrm{~Hz}$, $2 \mathrm{H}), 6.92(\mathrm{~d}, J=8.8 \mathrm{~Hz}, 2 \mathrm{H}), 3.81(\mathrm{~s}, 3 \mathrm{H}), 3.34(\mathrm{td}, J=7.2,6.0 \mathrm{~Hz}, 2 \mathrm{H}), 1.60-1.44(\mathrm{~m}$, $2 \mathrm{H}), 1.42-1.23(\mathrm{~m}, 2 \mathrm{H}), 0.91(\mathrm{t}, J=7.2 \mathrm{~Hz}, 3 \mathrm{H}) .{ }^{13} \mathrm{C}-\mathrm{NMR}\left(75 \mathrm{MHz}^{\mathrm{C}} \mathrm{CDCl}_{3}\right) \delta=165.2\left(\mathrm{C}_{\mathrm{q}}\right)$, $159.0\left(C_{q}\right), 148.2\left(C_{q}\right), 146.4(C H), 139.9(C H), 137.7\left(C_{q}\right), 131.6\left(C_{q}\right), 129.5(C H), 124.9$ (CH), $113.4(\mathrm{CH}), 55.2\left(\mathrm{CH}_{3}\right), 39.2\left(\mathrm{CH}_{2}\right), 31.7\left(\mathrm{CH}_{2}\right), 20.2\left(\mathrm{CH}_{2}\right), 13.8\left(\mathrm{CH}_{3}\right)$. IR (ATR): 3330, 2324, 2181, 2032, 514, 478, 455, $432 \mathrm{~cm}^{-1}$. MS (EI) m/z (relative intensity): 284 (55) [M] ${ }^{+}, 242$ (20), 227 (70), 213 (50), 185 (100), 169 (32). HR-MS (ESI) m/z calcd for $\mathrm{C}_{17} \mathrm{H}_{21} \mathrm{~N}_{2} \mathrm{O}_{2}[\mathrm{M}+\mathrm{H}]^{+}$285.1598, found 285.1597.<smiles>COc1ccc(-c2cccnc2C(=O)NCc2ccccc2)cc1</smiles>

$\mathbf{N}$-Benzyl-3-(4-methoxyphenyl)picolinamide (188ba). The general procedure C was followed using $112 b$ (53.1 mg, $0.25 \mathrm{mmol})$ and 151a $(0.40 \mathrm{~mL}, 1.0 \mathrm{mmol}, 2.5 \mathrm{~m}$ in THF). Isolation by column chromatography ( $n$-hexane/EtOAc: $2: 1 \rightarrow 1: 1$ ) yielded 188ba (51.7 mg, 65\%) as a white solid. M. p. $=138-140{ }^{\circ} \mathrm{C} .{ }^{1} \mathbf{H}-\mathbf{N M R}\left(300 \mathrm{MHz}, \mathrm{CDCl}_{3}\right) \delta=8.45(\mathrm{dd}$, $J=4.6,1.7 \mathrm{~Hz}, 1 \mathrm{H}), 7.96(\mathrm{sbr}, 1 \mathrm{H}), 7.63(\mathrm{dd}, J=7.8,1.7 \mathrm{~Hz}, 1 \mathrm{H}), 7.36(\mathrm{dd}, J=7.8,4.6 \mathrm{~Hz}$, 1H), 7.29-7.14 (m, 7H), $6.90(\mathrm{~d}, J=8.8 \mathrm{~Hz}, 2 \mathrm{H}), 4.51(\mathrm{~d}, J=6.0 \mathrm{~Hz}, 2 \mathrm{H}), 3.80(\mathrm{~s}, 3 \mathrm{H}) .{ }^{13} \mathrm{C}-$ 
NMR $\left(125 \mathrm{MHz}, \mathrm{CDCl}_{3}\right) \delta=165.2\left(\mathrm{C}_{\mathrm{q}}\right), 159.1\left(\mathrm{C}_{\mathrm{q}}\right), 147.9\left(\mathrm{C}_{\mathrm{q}}\right), 146.6(\mathrm{CH}), 140.1(\mathrm{CH})$, $138.4\left(\mathrm{C}_{\mathrm{q}}\right), 138.0\left(\mathrm{C}_{\mathrm{q}}\right), 131.5\left(\mathrm{C}_{\mathrm{q}}\right), 129.7(\mathrm{CH}), 128.6(\mathrm{CH}), 127.9(\mathrm{CH}), 127.3(\mathrm{CH}), 125.2$ (CH), $113.5(\mathrm{CH}), 55.2\left(\mathrm{CH}_{3}\right), 43.4\left(\mathrm{CH}_{2}\right)$. IR (ATR): 3330, 3066, 2995, 2913, 1655, 1607, 1250, $600 \mathrm{~cm}^{-1}$. MS (EI) m/z (relative intensity): 318 (40) [M] ${ }^{+}, 275$ (15), 213 (25), 185 (67), 106 (100), 91 (26). HR-MS (ESI) $m / z$ calcd for $\mathrm{C}_{20} \mathrm{H}_{19} \mathrm{~N}_{2} \mathrm{O}_{2}[\mathrm{M}+\mathrm{H}]^{+} 319.1441$, found 319.1440.<smiles>COc1ccc(-c2cccnc2C(=O)NC2CCCCC2)cc1</smiles>

$\mathbf{N}$-Cyclohexyl-3-(4-methoxyphenyl)picolinamide (188ca). The general procedure C was followed using $112 \mathrm{c}(51.1 \mathrm{mg}, 0.25 \mathrm{mmol})$ and $151 \mathrm{a}(0.40 \mathrm{~mL}, 1.0 \mathrm{mmol}, 2.5 \mathrm{~m}$ in THF). Isolation by column chromatography ( $n$-hexane/EtOAc: $2: 1 \rightarrow 1: 1)$ yielded $188 \mathrm{ca}$ (54.3 mg, 70\%) as a white solid. M. p. $=95-96{ }^{\circ} \mathrm{C} .{ }^{1} \mathbf{H}-\mathbf{N M R}\left(400 \mathrm{MHz}, \mathrm{CDCl}_{3}\right) \delta=8.48$ (dd, $J=4.7,1.7 \mathrm{~Hz}, 1 \mathrm{H}), 7.63(\mathrm{dd}, J=7.8,1.7 \mathrm{~Hz}, 1 \mathrm{H}$ ), 7.52 (d, J=8.6 Hz, 1H), 7.37 (dd, $J=7.8,4.7 \mathrm{~Hz}, 1 \mathrm{H}), 7.24(\mathrm{~d}, J=8.8 \mathrm{~Hz}, 2 \mathrm{H}), 6.91(\mathrm{~d}, J=8.8 \mathrm{~Hz}, 2 \mathrm{H}), 3.88-3.78(\mathrm{~m}, 4 \mathrm{H})$, 1.95-1.90 (m, 2H), 1.71-1.66 (m, 2H), 1.61-1.54 (m, 1H), 1.40-1.08 (m, 5H). ${ }^{13} \mathrm{C}-\mathbf{N M R}$ $\left(100 \mathrm{MHz}, \mathrm{CDCl}_{3}\right) \delta=164.4\left(\mathrm{C}_{\mathrm{q}}\right), 159.0\left(\mathrm{C}_{\mathrm{q}}\right), 148.4\left(\mathrm{C}_{\mathrm{q}}\right), 146.5(\mathrm{CH}), 139.9(\mathrm{CH}), 137.7$ $\left(\mathrm{C}_{\mathrm{q}}\right), 131.6\left(\mathrm{C}_{\mathrm{q}}\right), 129.5(\mathrm{CH}), 124.8(\mathrm{CH}), 113.4(\mathrm{CH}), 55.1\left(\mathrm{CH}_{3}\right), 48.0(\mathrm{CH}), 32.9\left(\mathrm{CH}_{2}\right)$, $25.5\left(\mathrm{CH}_{2}\right), 24.8\left(\mathrm{CH}_{2}\right)$. IR (ATR): 3250, 2929, 2850, 1641, 1511, 1289, 836, $580 \mathrm{~cm}^{-1}$. MS (EI) m/z (relative intensity): 310 (65) [M]+, 227 (94), 212 (42), 184 (99), 169 (36), 98 (100). HR-MS (EI) $m / z$ calcd for $\mathrm{C}_{19} \mathrm{H}_{22} \mathrm{~N}_{2} \mathrm{O}_{2}[\mathrm{M}]^{+} 310.1676$, found 310.1689. 
OMe

$N$-(4-Methoxybenzyl)-3-(4-methoxyphenyl)picolinamide (188da). The general procedure $\mathbf{C}$ was followed using $112 \mathrm{~d}(60.6 \mathrm{mg}, 0.25 \mathrm{mmol})$ and $151 \mathrm{a}(0.40 \mathrm{~mL}, 1.0$ mmol, $2.5 \mathrm{~m}$ in THF). Isolation by column chromatography ( $n$-hexane/EtOAc: $2: 1 \rightarrow 1: 1$ ) yielded $188 \mathrm{da}(53.1 \mathrm{mg}, 61 \%)$ as a white solid. M. p. $=92-93{ }^{\circ} \mathrm{C} .{ }^{1} \mathbf{H}-\mathbf{N M R}(500 \mathrm{MHz}$, $\left.\mathrm{CDCl}_{3}\right) \delta=8.49(\mathrm{dd}, J=4.6,1.7 \mathrm{~Hz}, 1 \mathrm{H}), 7.92\left(\mathrm{~s}_{\mathrm{br}}, 1 \mathrm{H}\right), 7.67(\mathrm{dd}, J=7.8,1.7 \mathrm{~Hz}, 1 \mathrm{H}), 7.41$ (dd, $J=7.8,4.6 \mathrm{~Hz}, 1 \mathrm{H}), 7.28(\mathrm{~d}, J=8.7 \mathrm{~Hz}, 2 \mathrm{H}), 7.24(\mathrm{~d}, J=8.7 \mathrm{~Hz}, 2 \mathrm{H}), 6.95(\mathrm{~d}, J=8.7$ $\mathrm{Hz}, 2 \mathrm{H}), 6.86(\mathrm{~d}, J=8.7 \mathrm{~Hz}, 2 \mathrm{H}), 4.49(\mathrm{~d}, J=5.9 \mathrm{~Hz}, 2 \mathrm{H}), 3.85(\mathrm{~s}, 3 \mathrm{H}), 3.79(\mathrm{~s}, 3 \mathrm{H})$. ${ }^{13} \mathrm{C}-\mathrm{NMR}\left(125 \mathrm{MHz}, \mathrm{CDCl}_{3}\right) \delta=165.1\left(\mathrm{C}_{\mathrm{q}}\right), 159.1\left(\mathrm{C}_{\mathrm{q}}\right), 158.9\left(\mathrm{C}_{\mathrm{q}}\right), 148.0\left(\mathrm{C}_{\mathrm{q}}\right), 146.6(\mathrm{CH})$, $140.1(\mathrm{CH}), 137.9\left(\mathrm{C}_{\mathrm{q}}\right), 131.5\left(\mathrm{C}_{\mathrm{q}}\right), 130.5\left(\mathrm{C}_{\mathrm{q}}\right), 129.7(\mathrm{CH}), 129.2(\mathrm{CH}), 125.1(\mathrm{CH}), 114.0$ (CH), $113.4(\mathrm{CH}), 55.3\left(\mathrm{CH}_{3}\right), 55.2\left(\mathrm{CH}_{3}\right), 42.9\left(\mathrm{CH}_{2}\right)$. IR (ATR): 3330, 3000, 2936, 2835, 1641, 1242, 1033, $795 \mathrm{~cm}^{-1}$. MS (EI) m/z (relative intensity): 348 (15) [M] $]^{+}, 185$ (15), 136 (100), 121 (14), 109 (8), 43 (10). HR-MS (EI) m/z calcd for $\mathrm{C}_{21} \mathrm{H}_{20} \mathrm{~N}_{2} \mathrm{O}_{3}$ [M] 348.1468, found 348.1473 .<smiles>COc1ccc(-c2cccnc2C(=O)NCc2ccc(F)cc2)cc1</smiles>

N-(4-Fluorobenzyl)-3-(4-methoxyphenyl)picolinamide (188ea). The general procedure $\mathrm{C}$ was followed using $112 \mathrm{e}(57.6 \mathrm{mg}, 0.25 \mathrm{mmol})$ and 151a $(0.40 \mathrm{~mL}, 1.0$ $\mathrm{mmol}, 2.5 \mathrm{~m}$ in THF). Isolation by column chromatography ( $n$-hexane/EtOAc: $2: 1 \rightarrow 1: 1$ ) yielded $188 \mathrm{ea}(63.0 \mathrm{mg}, 75 \%)$ as a white solid. M. p. $=129-130{ }^{\circ} \mathrm{C} .{ }^{1} \mathrm{H}-\mathrm{NMR}(500 \mathrm{MHz}$, 
$\left.\mathrm{CDCl}_{3}\right) \quad \delta=8.48(\mathrm{dd}, J=4.7,1.7 \mathrm{~Hz}, 1 \mathrm{H}), 8.03(\mathrm{sbr}, 1 \mathrm{H}), 7.67(\mathrm{dd}, J=7.8,1.7 \mathrm{~Hz}, 1 \mathrm{H})$, $7.41(\mathrm{dd}, J=7.8,4.7 \mathrm{~Hz}, 1 \mathrm{H}), 7.33-7.19(\mathrm{~m}, 4 \mathrm{H}), 7.06-6.88(\mathrm{~m}, 4 \mathrm{H}), 4.60-4.39(\mathrm{~m}, 2 \mathrm{H})$, $3.84(\mathrm{~s}, 3 \mathrm{H}) .{ }^{13} \mathrm{C}-\mathrm{NMR}\left(125 \mathrm{MHz}, \mathrm{CDCl}_{3}\right) \delta=165.2\left(\mathrm{C}_{\mathrm{q}}\right), 162.0\left(\mathrm{~d},{ }^{1} \mathrm{~J}_{\mathrm{C}-\mathrm{F}}=245.4 \mathrm{~Hz}, \mathrm{C}_{\mathrm{q}}\right)$, $159.1\left(C_{q}\right), 147.8\left(C_{q}\right), 146.6(C H), 140.1(C H), 137.9\left(C_{q}\right), 134.2\left(d,{ }^{4} J_{C-F}=3.1 \mathrm{~Hz}, C_{q}\right)$, $131.4\left(C_{q}\right), 129.6(C H), 129.4\left(d,{ }^{3} J_{C-F}=8.1 \mathrm{~Hz}, C H\right), 125.2(C H), 115.3\left(d,{ }^{2} J_{C-F}=21.6 \mathrm{~Hz}\right.$, $\mathrm{CH}), 113.4(\mathrm{CH}), 55.1\left(\mathrm{CH}_{3}\right), 42.6\left(\mathrm{CH}_{2}\right) .{ }^{19} \mathrm{~F}-\mathrm{NMR}\left(471 \mathrm{MHz}, \mathrm{CDCl}_{3}\right) \delta=-115.3$. IR (ATR): 3330, 3064, 2911, 1657, 1508, 1221, 735, $651 \mathrm{~cm}^{-1}$. MS (ESI) $\mathrm{m} / \mathrm{z}$ (relative intensity): $695(100)[2 \mathrm{M}+\mathrm{Na}]^{+}, 359(26)[\mathrm{M}+\mathrm{Na}]^{+}, 337(22)[\mathrm{M}+\mathrm{H}]^{+}$. HR-MS (ESI) $\mathrm{m} / \mathrm{z}$ calcd for $\mathrm{C}_{20} \mathrm{H}_{18} \mathrm{FN}_{2} \mathrm{O}_{2}[\mathrm{M}+\mathrm{H}]^{+} 337.1347$, found 337.1344.<smiles>COc1ccc(-c2cccnc2C(=O)NCc2ccccc2F)cc1</smiles>

$N$-(2-Fluorobenzyl)-3-(4-methoxyphenyl)picolinamide (188fa). The general procedure $\mathbf{C}$ was followed using $112 \mathrm{f}(57.6 \mathrm{mg}, 0.25 \mathrm{mmol})$ and $151 \mathrm{a}(0.40 \mathrm{~mL}, 1.0$ mmol, $2.5 \mathrm{~m}$ in THF). Isolation by column chromatography ( $n$-hexane/EtOAc: $2: 1 \rightarrow 1: 1$ ) yielded $188 \mathrm{fa}$ (55.4 mg, 66\%) as a white solid. M. p. $=115-116^{\circ} \mathrm{C} .{ }^{1} \mathrm{H}-\mathrm{NMR}(500 \mathrm{MHz}$, $\left.\mathrm{CDCl}_{3}\right) \quad \delta=8.51(\mathrm{dd}, J=4.6,1.6 \mathrm{~Hz}, 1 \mathrm{H}), 8.07(\mathrm{sbr}, 1 \mathrm{H}), 7.67(\mathrm{dd}, J=7.8,1.6 \mathrm{~Hz}, 1 \mathrm{H})$, $7.42(\mathrm{dd}, J=7.8,4.6 \mathrm{~Hz}, 1 \mathrm{H}), 7.36-7.34(\mathrm{~m}, 1 \mathrm{H}), 7.30-7.20(\mathrm{~m}, 3 \mathrm{H}), 7.12-7.00(\mathrm{~m}, 2 \mathrm{H})$, $6.93(\mathrm{~d}, J=8.7 \mathrm{~Hz}, 2 \mathrm{H}), 4.75-4.57(\mathrm{~m}, 2 \mathrm{H}), 3.84(\mathrm{~s}, 3 \mathrm{H}) .{ }^{13} \mathrm{C}-\mathrm{NMR}\left(126 \mathrm{MHz}, \mathrm{CDCl}_{3}\right) \delta=$ $165.2\left(C_{q}\right), 160.9\left(d,{ }^{1} J_{C-F}=246.2 \mathrm{~Hz}, C_{q}\right), 159.1\left(C_{q}\right), 147.8\left(C_{q}\right), 146.6(C H), 140.0(C H)$, $137.9\left(C_{q}\right), 131.3\left(C_{q}\right), 130.1\left(d,{ }^{3} J_{C-F}=4.5 \mathrm{~Hz}, C H\right), 129.6(C H), 129.0\left(d,{ }^{3} J_{C-F}=8.1 \mathrm{~Hz}\right.$, $\mathrm{CH}), 125.3\left(\mathrm{~d},{ }^{2} J_{\mathrm{C}-\mathrm{F}}=15.0 \mathrm{~Hz}, \mathrm{C}_{\mathrm{q}}\right), 125.2(\mathrm{CH}), 124.1\left(\mathrm{~d},{ }^{4} \mathrm{~J}_{\mathrm{C}-\mathrm{F}}=3.6 \mathrm{~Hz}, \mathrm{CH}\right), 115.2\left(\mathrm{~d},{ }^{2} \mathrm{~J}_{\mathrm{C}-\mathrm{F}}\right.$ $=21.4 \mathrm{~Hz}, \mathrm{CH}), 113.4(\mathrm{CH}), 55.1\left(\mathrm{CH}_{3}\right), 37.2\left(\mathrm{~d},{ }^{3} \mathrm{~J}_{\mathrm{C}-\mathrm{F}}=4.1 \mathrm{~Hz}, \mathrm{CH}_{2}\right) \cdot{ }^{19} \mathrm{~F}-\mathrm{NMR}(471 \mathrm{MHz}$, $\left.\mathrm{CDCl}_{3}\right) \delta=-118.8$. IR (ATR): 3300, 3067, 2992, 1656, 1455, 1228, 824, $683 \mathrm{~cm}^{-1}$. MS (ESI) $m / z$ (relative intensity): $695(100)[2 \mathrm{M}+\mathrm{Na}]^{+}, 359(26)[\mathrm{M}+\mathrm{Na}]^{+}$. HR-MS (ESI) $\mathrm{m} / z$ calcd for $\mathrm{C}_{20} \mathrm{H}_{18} \mathrm{FN}_{2} \mathrm{O}_{2}[\mathrm{M}+\mathrm{H}]^{+} 337.1347$, found 337.1343. 
(N)

3-(4-Methoxyphenyl)-N-(1,2,3,4-tetrahydronaphthalen-1-yl)picolinamide (188ga). The general procedure $\mathbf{C}$ was followed using $112 \mathrm{~g}(63.1 \mathrm{mg}, 0.25 \mathrm{mmol})$ and $151 \mathrm{a}(0.40$ $\mathrm{mL}, 1.0 \mathrm{mmol}, 2.5 \mathrm{~m}$ in THF). Isolation by column chromatography ( $n$-hexane/EtOAc: 2:1 $\rightarrow 1: 1$ ) yielded $188 \mathrm{ga}\left(70.7 \mathrm{mg}, 79 \%\right.$ ) as a white solid. M. p. $=125-126^{\circ} \mathrm{C} .{ }^{1} \mathbf{H}-\mathbf{N M R}$ $\left(400 \mathrm{MHz}, \mathrm{CDCl}_{3}\right) \delta=8.49(\mathrm{dd}, J=4.7,1.6 \mathrm{~Hz}, 1 \mathrm{H}), 7.85(\mathrm{sbr}, 1 \mathrm{H}), 7.68(\mathrm{dd}, J=7.8,1.6$ $\mathrm{Hz}, 1 \mathrm{H}), 7.41(\mathrm{dd}, J=7.8,4.7 \mathrm{~Hz}, 1 \mathrm{H}), 7.34(\mathrm{~d}, J=8.7 \mathrm{~Hz}, 2 \mathrm{H}), 7.28-7.24(\mathrm{~m}, 1 \mathrm{H}), 7.21-$ $7.08(\mathrm{~m}, 3 \mathrm{H}), 6.99(\mathrm{~d}, J=8.7 \mathrm{~Hz}, 2 \mathrm{H}), 5.30-5.25(\mathrm{~m}, 1 \mathrm{H}), 3.87(\mathrm{~s}, 3 \mathrm{H}), 2.88-2.74(\mathrm{~m}, 2 \mathrm{H})$, 2.16-2.01 (m, 1H), 1.97-1.75 (m, 3H). ${ }^{13} \mathrm{C}-\mathrm{NMR}\left(100 \mathrm{MHz}, \mathrm{CDCl}_{3}\right) \delta=164.7\left(\mathrm{C}_{\mathrm{q}}\right), 159.2$ $\left(\mathrm{C}_{\mathrm{q}}\right), 148.3\left(\mathrm{C}_{\mathrm{q}}\right), 146.7(\mathrm{CH}), 139.9(\mathrm{CH}), 137.7\left(\mathrm{C}_{\mathrm{q}}\right), 137.5\left(\mathrm{C}_{\mathrm{q}}\right), 136.7\left(\mathrm{C}_{\mathrm{q}}\right), 131.5\left(\mathrm{C}_{\mathrm{q}}\right)$, 129.7 (CH), $129.0(\mathrm{CH}), 128.8(\mathrm{CH}), 127.1(\mathrm{CH}), 126.1(\mathrm{CH}), 125.0(\mathrm{CH}), 113.5(\mathrm{CH}), 55.2$ $\left(\mathrm{CH}_{3}\right), 47.3(\mathrm{CH}), 30.1\left(\mathrm{CH}_{2}\right), 29.2\left(\mathrm{CH}_{2}\right), 20.0\left(\mathrm{CH}_{2}\right)$. IR (ATR): 2932, 2835, 1668, 1610, 1499, 1445, 1287, $834 \mathrm{~cm}^{-1}$. MS (EI) m/z (relative intensity): 358 (8) [M] ${ }^{+}, 307$ (5), 229 (10), 184 (15), 146 (100), 130 (15). HR-MS (EI) m/z calcd for $\mathrm{C}_{23} \mathrm{H}_{22} \mathrm{~N}_{2} \mathrm{O}_{2}$ [M] ${ }^{+} 358.1676$, found 358.1681 .<smiles>COc1ccc(-c2cccnc2C(=O)NCCc2ccccc2)cc1</smiles>

3-(4-Methoxyphenyl)-N-phenethylpicolinamide (188ha). The general procedure C was followed using $112 \mathrm{~h}(56.6 \mathrm{mg}, 0.25 \mathrm{mmol})$ and $151 \mathrm{a}(0.40 \mathrm{~mL}, 1.0 \mathrm{mmol}, 2.5 \mathrm{~m}$ in THF). Isolation by column chromatography ( $n$-hexane/EtOAc: $2: 1 \rightarrow 1: 1$ ) yielded $188 \mathrm{ha}$ (61.4 mg, 74\%) as a white solid. M. p. $=102-103{ }^{\circ} \mathrm{C} .{ }^{1} \mathbf{H}-\mathbf{N M R}\left(500 \mathrm{MHz}, \mathrm{CDCl}_{3}\right) \delta=8.49$ 
(dd, $J=4.6,1.7 \mathrm{~Hz}, 1 \mathrm{H}), 7.79(\mathrm{sbr}, 1 \mathrm{H}), 7.67(\mathrm{dd}, J=7.8,1.7 \mathrm{~Hz}, 1 \mathrm{H}), 7.40(\mathrm{dd}, J=7.8$, $4.6 \mathrm{~Hz}, 1 \mathrm{H}), 7.34-7.29(\mathrm{~m}, 2 \mathrm{H}), 7.29-7.20(\mathrm{~m}, 5 \mathrm{H}), 6.97(\mathrm{~d}, J=8.8 \mathrm{~Hz}, 2 \mathrm{H}), 3.86(\mathrm{~s}, 3 \mathrm{H})$, $3.65(\mathrm{td}, J=7.2,6.2 \mathrm{~Hz}, 2 \mathrm{H}), 2.89(\mathrm{t}, J=7.2 \mathrm{~Hz}, 2 \mathrm{H}) .{ }^{13} \mathrm{C}-\mathrm{NMR}\left(125 \mathrm{MHz}, \mathrm{CDCl}_{3}\right) \delta=$ $165.3\left(\mathrm{C}_{\mathrm{q}}\right), 159.0\left(\mathrm{C}_{\mathrm{q}}\right), 148.1\left(\mathrm{C}_{\mathrm{q}}\right), 146.5(\mathrm{CH}), 139.9(\mathrm{CH}), 139.0\left(\mathrm{C}_{\mathrm{q}}\right), 137.6\left(\mathrm{C}_{\mathrm{q}}\right), 131.4$ $\left(\mathrm{C}_{q}\right), 129.5(\mathrm{CH}), 128.7(\mathrm{CH}), 128.4(\mathrm{CH}), 126.2(\mathrm{CH}), 125.0(\mathrm{CH}), 113.4(\mathrm{CH}), 55.1\left(\mathrm{CH}_{3}\right)$, $40.5\left(\mathrm{CH}_{2}\right), 35.7\left(\mathrm{CH}_{2}\right)$. IR (ATR): 3325, 3026, 2922, 1647, 1514, 1288, 803, $699 \mathrm{~cm}^{-1}$. MS (ESI) $m / z$ (relative intensity): $687(100)[2 \mathrm{M}+\mathrm{Na}]^{+}, 355(26)[\mathrm{M}+\mathrm{Na}]^{+}, 333(10)$ $[\mathrm{M}+\mathrm{H}]^{+}$. HR-MS (ESI) $m / z$ calcd for $\mathrm{C}_{21} \mathrm{H}_{21} \mathrm{~N}_{2} \mathrm{O}_{2}[\mathrm{M}+\mathrm{H}]^{+} 333.1598$, found 333.1598 .<smiles>CCCCNC(=O)c1ncc(/C=C/c2ccccc2)cc1-c1ccc(OC)cc1</smiles>

(E)-N-n-Butyl-3-(4-methoxyphenyl)-5-styrylpicolinamide (188ia). The general procedure $\mathrm{C}$ was followed using $112 \mathrm{i}(70.1 \mathrm{mg}, 0.25 \mathrm{mmol})$ and $151 \mathrm{a}(0.40 \mathrm{~mL}, 1.0$ mmol, $2.5 \mathrm{~m}$ in THF). Isolation by column chromatography ( $n$-hexane/EtOAc: $2: 1 \rightarrow 1: 1$ ) yielded 188ia (57.9 mg, 60\%) as a white solid. M. p. $=77-78{ }^{\circ} \mathrm{C} .{ }^{1} \mathbf{H}-\mathbf{N M R}(400 \mathrm{MHz}$, $\left.\mathrm{CDCl}_{3}\right) \delta=8.60(\mathrm{~d}, J=2.2 \mathrm{~Hz}, 1 \mathrm{H}), 7.77(\mathrm{~d}, J=2.2 \mathrm{~Hz}, 1 \mathrm{H}), 7.75-7.72(\mathrm{sbr}, 1 \mathrm{H}), 7.55-7.52$ (m, 2H), 7.42-7.36 (m, 2H), 7.35-7.28 (m, 3H), 7.27-7.23 (d, J=16.4 Hz, 1H), 7.11 (d, $J=16.4 \mathrm{~Hz}, 1 \mathrm{H}), 6.97(\mathrm{~d}, J=8.8 \mathrm{~Hz}, 2 \mathrm{H}), 3.86(\mathrm{~s}, 3 \mathrm{H}), 3.37(\mathrm{td}, J=7.2,6.0 \mathrm{~Hz}, 2 \mathrm{H}), 1.63-$ $1.46(\mathrm{~m}, 2 \mathrm{H}), 1.45-1.31(\mathrm{~m}, 2 \mathrm{H}), 0.93(\mathrm{t}, J=7.2 \mathrm{~Hz}, 3 \mathrm{H}) .{ }^{13} \mathrm{C}-\mathrm{NMR}\left(100 \mathrm{MHz}, \mathrm{CDCl}_{3}\right) \delta=$ $164.9\left(C_{q}\right), 159.1\left(C_{q}\right), 146.5\left(C_{q}\right), 145.1(C H), 137.9\left(C_{q}\right), 136.6(C H), 136.3\left(C_{q}\right), 134.4$ $\left(\mathrm{C}_{\mathrm{q}}\right), 132.5(\mathrm{CH}), 131.8\left(\mathrm{C}_{\mathrm{q}}\right), 129.6(\mathrm{CH}), 128.8(\mathrm{CH}), 128.6(\mathrm{CH}), 126.8(\mathrm{CH}), 123.8(\mathrm{CH})$, $113.4(\mathrm{CH}), 55.2\left(\mathrm{CH}_{3}\right), 39.1\left(\mathrm{CH}_{2}\right), 31.7\left(\mathrm{CH}_{2}\right), 20.2\left(\mathrm{CH}_{2}\right), 13.8\left(\mathrm{CH}_{3}\right)$. IR (ATR): 3323, 2959, 2928, 1646, 1512, 1249, 831, $690 \mathrm{~cm}^{-1}$. MS (ESI) m/z (relative intensity): 795 (100) $[2 \mathrm{M}+\mathrm{Na}]^{+}, 409(28)[\mathrm{M}+\mathrm{Na}]^{+}, 387(14)[\mathrm{M}+\mathrm{H}]^{+}$. HR-MS (ESI) m/z calcd for 
$\mathrm{C}_{25} \mathrm{H}_{27} \mathrm{~N}_{2} \mathrm{O}_{2}[\mathrm{M}+\mathrm{H}]^{+}$387.2067, found 387.2064.<smiles>COc1ccc(-c2cccnc2C(=O)NC(C)c2ccccc2)cc1</smiles>

(S)-3-(4-Methoxyphenyl)-N-(1-phenylethyl)picolinamide (188ja). The general procedure $\mathrm{C}$ was followed using $(S)-112 \mathrm{j}(56.6 \mathrm{mg}, 0.25 \mathrm{mmol})$ and $151 \mathrm{a}(0.40 \mathrm{~mL}, 1.0$ $\mathrm{mmol}, 2.5 \mathrm{~m}$ in THF). Isolation by column chromatography ( $n$-hexane/EtOAc: $2: 1 \rightarrow 1: 1$ ) yielded (S)- 188 ja (56.4 mg, 68\%) as a white solid. M. p. $=110-111^{\circ} \mathrm{C} .{ }^{1} \mathbf{H}-\mathbf{N M R}(400$ $\left.\mathrm{MHz}, \mathrm{CDCl}_{3}\right) \delta=8.50(\mathrm{dd}, J=4.6,1.6 \mathrm{~Hz}, 1 \mathrm{H}), 7.92(\mathrm{~d}, J=8.5 \mathrm{~Hz}, 1 \mathrm{H}), 7.64(\mathrm{dd}, J=7.8$, $1.6 \mathrm{~Hz}, 1 \mathrm{H}), 7.39$ (dd, $J=7.8,4.6 \mathrm{~Hz}, 1 \mathrm{H}), 7.36-7.28(\mathrm{~m}, 4 \mathrm{H}), 7.27-7.20(\mathrm{~m}, 3 \mathrm{H}), 6.91$ (d, $J=8.8 \mathrm{~Hz}, 2 \mathrm{H}), 5.22(\mathrm{dq}, J=8.5,6.9 \mathrm{~Hz}, 1 \mathrm{H}), 3.82(\mathrm{~s}, 3 \mathrm{H}), 1.54(\mathrm{~d}, J=6.9 \mathrm{~Hz}, 3 \mathrm{H})$. ${ }^{13} \mathrm{C}-\mathrm{NMR}\left(100 \mathrm{MHz}, \mathrm{CDCl}_{3}\right) \delta=164.4\left(\mathrm{C}_{\mathrm{q}}\right), 159.1\left(\mathrm{C}_{\mathrm{q}}\right), 148.1\left(\mathrm{C}_{\mathrm{q}}\right), 146.5(\mathrm{CH}), 143.3\left(\mathrm{C}_{\mathrm{q}}\right)$, $140.0(\mathrm{CH}), 137.8\left(\mathrm{C}_{\mathrm{q}}\right), 131.4\left(\mathrm{C}_{\mathrm{q}}\right), 129.6(\mathrm{CH}), 128.5(\mathrm{CH}), 127.1(\mathrm{CH}), 126.2(\mathrm{CH}), 125.0$ (CH), $113.4(\mathrm{CH}), 55.1\left(\mathrm{CH}_{3}\right), 48.5(\mathrm{CH}), 21.9\left(\mathrm{CH}_{3}\right)$. IR (ATR): 3200, 3026, 1647, 1514, 1251, 818, 694, $572 \mathrm{~cm}^{-1}$. MS (EI) m/z (relative intensity): 332 (10) [M] ${ }^{+}, 227$ (6), 212 (8), 184 (25), 120 (100), 105 (10). HR-MS (EI) m/z calcd for $\mathrm{C}_{21} \mathrm{H}_{20} \mathrm{~N}_{2} \mathrm{O}_{2}$ [M] 332.1519, found 332.1529. HPLC analysis (Chiralcel IA-3, $i \mathrm{PrOH} / n$-hexane 40:60, flow rate $=1.0$ $\mathrm{mL} / \min , \lambda=250 \mathrm{~nm}): t_{r}$ (minor) $=6.1 \mathrm{~min}, t_{\mathrm{r}}($ major $)=7.0 \mathrm{~min}$.

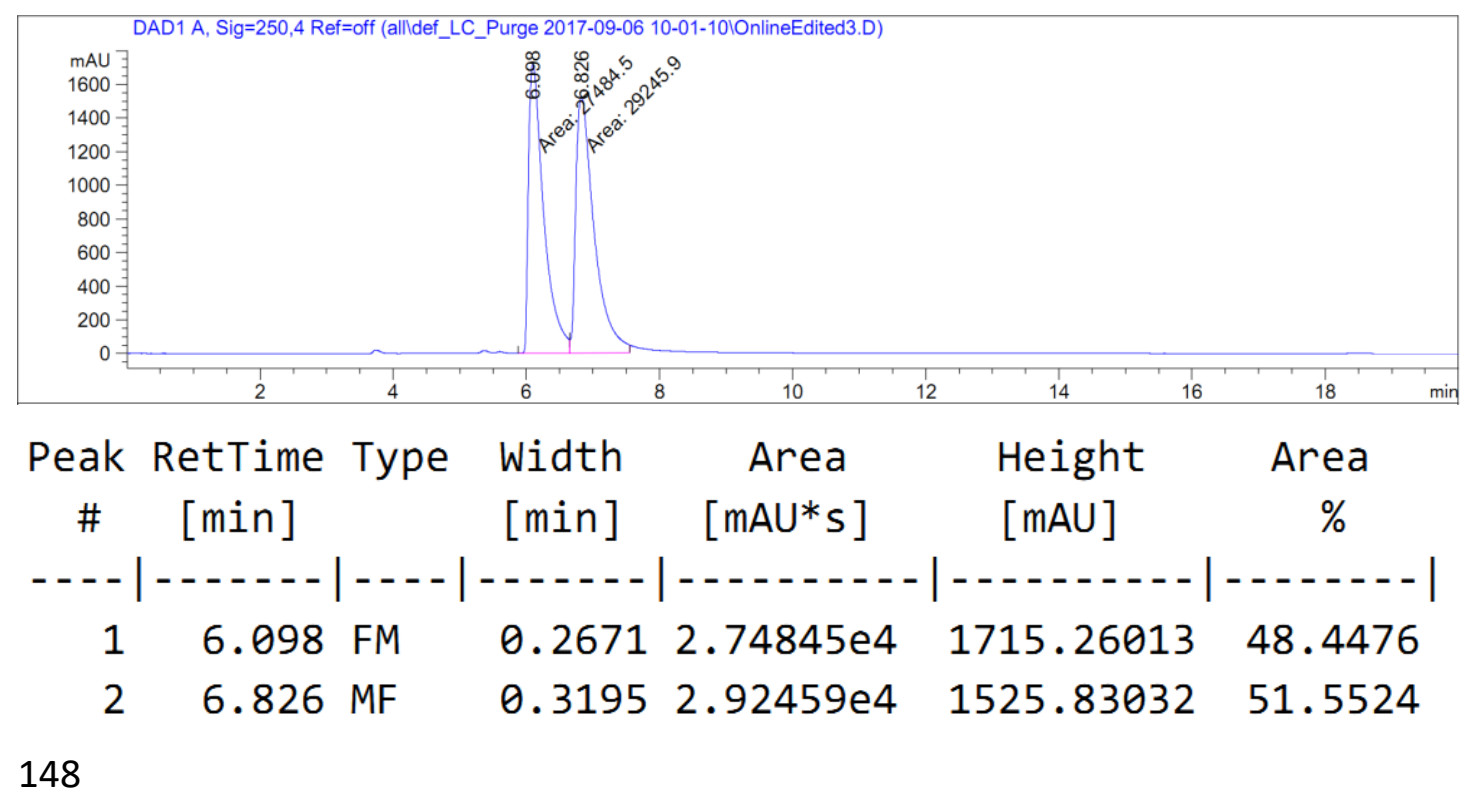




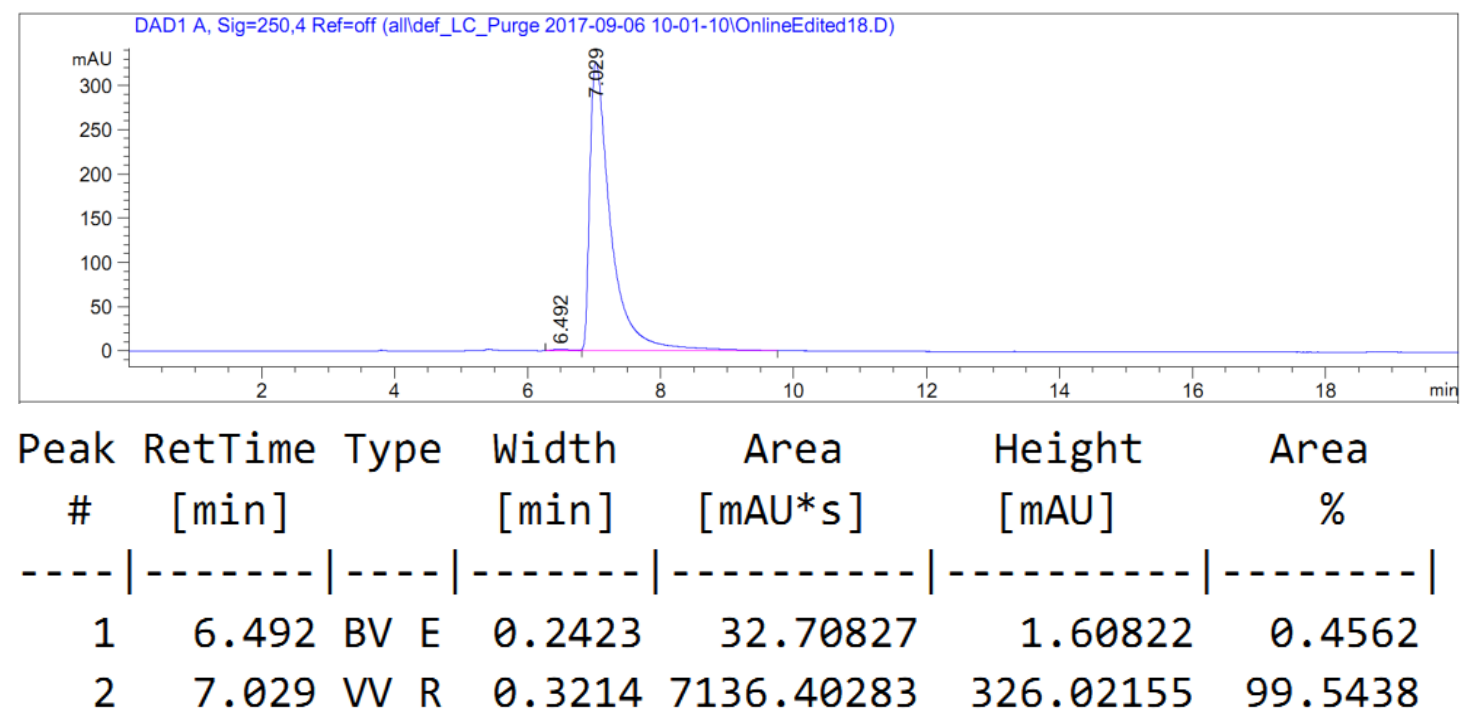

(N)

N-n-Butyl-3-(4-methoxyphenyl)-5-phenylpicolinamide (188ka). The general procedure $\mathbf{C}$ was followed using $112 \mathrm{k}(63.6 \mathrm{mg}, 0.25 \mathrm{mmol})$ and $151 \mathrm{a}(0.40 \mathrm{~mL}, 1.0$ mmol, $2.5 \mathrm{~m}$ in THF). Isolation by column chromatography ( $n$-hexane/EtOAc: $2: 1 \rightarrow 1: 1$ ) yielded 188ka (48.6 mg, 54\%) as a white solid. M. p. $=91-92{ }^{\circ} \mathrm{C} .{ }^{1} \mathrm{H}-\mathrm{NMR}(300 \mathrm{MHz}$, $\left.\mathrm{CDCl}_{3}\right) \delta=8.74(\mathrm{~d}, J=2.2 \mathrm{~Hz}, 1 \mathrm{H}), 7.85(\mathrm{~d}, J=2.2 \mathrm{~Hz}, 1 \mathrm{H}), 7.77(\mathrm{sbr}, 1 \mathrm{H}), 7.68-7.58(\mathrm{~m}$, $2 \mathrm{H}), 7.56-7.39(\mathrm{~m}, 3 \mathrm{H}), 7.33(\mathrm{~d}, J=8.8 \mathrm{~Hz}, 2 \mathrm{H}), 6.97(\mathrm{~d}, J=8.8 \mathrm{~Hz}, 2 \mathrm{H}), 3.86(\mathrm{~s}, 3 \mathrm{H})$, $3.39(\mathrm{td}, J=7.1,6.0 \mathrm{~Hz}, 2 \mathrm{H}), 1.68-1.50(\mathrm{~m}, 2 \mathrm{H}), 1.45-1.27(\mathrm{~m}, 2 \mathrm{H}), 0.94(\mathrm{t}, J=7.1 \mathrm{~Hz}$, 3H). ${ }^{13} \mathrm{C}-\mathrm{NMR}\left(100 \mathrm{MHz}, \mathrm{CDCl}_{3}\right) \delta=164.9\left(\mathrm{C}_{\mathrm{q}}\right), 159.1\left(\mathrm{C}_{\mathrm{q}}\right), 146.6\left(\mathrm{C}_{\mathrm{q}}\right), 144.8(\mathrm{CH}), 138.2$ $(\mathrm{CH}), 137.9\left(\mathrm{C}_{\mathrm{q}}\right), 137.8\left(\mathrm{C}_{\mathrm{q}}\right), 136.6\left(\mathrm{C}_{\mathrm{q}}\right), 131.6\left(\mathrm{C}_{\mathrm{q}}\right), 129.6(\mathrm{CH}), 129.1(\mathrm{CH}), 128.6(\mathrm{CH})$, $127.1(\mathrm{CH}), 113.4(\mathrm{CH}), 55.2\left(\mathrm{CH}_{3}\right), 39.2\left(\mathrm{CH}_{2}\right), 31.7\left(\mathrm{CH}_{2}\right), 20.2\left(\mathrm{CH}_{2}\right), 13.9\left(\mathrm{CH}_{3}\right)$. IR (ATR): 3300, 2956, 2931, 1659, 1510, 1244, 832, $762 \mathrm{~cm}^{-1}$. MS (EI) $\mathrm{m} / \mathrm{z}$ (relative intensity): 360 (44) [M]+, 303 (55), 261 (100), 245 (18), 217 (32), 130 (15). HR-MS (ESI) $m / z$ calcd for $\mathrm{C}_{21} \mathrm{H}_{25} \mathrm{~N}_{2} \mathrm{O}_{2}[\mathrm{M}+\mathrm{H}]^{+} 361.1911$, found 361.1909 . 
(N)

N-n-Butyl-4-(4-methoxyphenyl)nicotinamide (188la). The general procedure C was followed using 112l (44.6 mg, $0.25 \mathrm{mmol})$ and 151a (0.40 mL, $1.0 \mathrm{mmol}, 2.5 \mathrm{~m}$ in THF). Isolation by column chromatography ( $n$-hexane/EtOAc: $2: 1 \rightarrow 1: 1$ ) yielded 188la $(54.7$ mg, 77\%) as a white solid. M. p. $=104-105{ }^{\circ} \mathrm{C} .{ }^{1} \mathrm{H}-\mathrm{NMR}\left(400 \mathrm{MHz}, \mathrm{CDCl}_{3}\right) \delta=8.79$ (d, $J=0.7 \mathrm{~Hz}, 1 \mathrm{H}), 8.60(\mathrm{~d}, J=5.2 \mathrm{~Hz}, 1 \mathrm{H}), 7.37(\mathrm{~d}, J=8.8 \mathrm{~Hz}, 2 \mathrm{H}), 7.25(\mathrm{dd}, J=5.2,0.7 \mathrm{~Hz}$, $1 \mathrm{H}), 6.97(\mathrm{~d}, J=8.8 \mathrm{~Hz}, 2 \mathrm{H}), 5.48\left(\mathrm{~s}_{\mathrm{br}}, 1 \mathrm{H}\right), 3.85(\mathrm{~s}, 3 \mathrm{H}), 3.23(\mathrm{td}, J=7.0,5.8 \mathrm{~Hz}, 2 \mathrm{H})$, 1.35-1.21 (m, 2H), 1.13-1.01 (m, 2H), $0.81(\mathrm{t}, J=7.0 \mathrm{~Hz}, 3 \mathrm{H}) .{ }^{13} \mathrm{C}-\mathrm{NMR}\left(100 \mathrm{MHz}, \mathrm{CDCl}_{3}\right)$ $\delta=167.4\left(\mathrm{C}_{\mathrm{q}}\right), 160.4\left(\mathrm{C}_{\mathrm{q}}\right), 150.7(\mathrm{CH}), 149.6(\mathrm{CH}), 146.5\left(\mathrm{C}_{\mathrm{q}}\right), 131.1\left(\mathrm{C}_{\mathrm{q}}\right), 129.7(\mathrm{CH})$, $129.5\left(\mathrm{C}_{q}\right), 124.0(\mathrm{CH}), 114.4(\mathrm{CH}), 55.4\left(\mathrm{CH}_{3}\right), 39.6\left(\mathrm{CH}_{2}\right), 31.1\left(\mathrm{CH}_{2}\right), 19.9\left(\mathrm{CH}_{2}\right), 13.6$ $\left(\mathrm{CH}_{3}\right)$. IR (ATR): 3200, 2957, 2870, 1637, 1515, 1247, 828, $577 \mathrm{~cm}^{-1}$. MS (EI) m/z (relative intensity): $284(40)\left[\mathrm{M}^{+}, 227\right.$ (38), 212 (100), 184 (10), 169 (24), 141 (15). HRMS (EI) $m / z$ calcd for $\mathrm{C}_{17} \mathrm{H}_{20} \mathrm{~N}_{2} \mathrm{O}_{2}[\mathrm{M}]^{+} 284.1519$, found 284.1533 .<smiles>CCCCNC(=O)c1cncc(C)c1-c1ccc(OC)cc1</smiles>

N-n-Butyl-4-(4-methoxyphenyl)-5-methylnicotinamide (188ma). The general procedure $\mathbf{C}$ was followed using $112 \mathrm{~m}(48.1 \mathrm{mg}, 0.25 \mathrm{mmol})$ and $151 \mathrm{a}(0.40 \mathrm{~mL}, 1.0$ mmol, $2.5 \mathrm{~m}$ in THF). Isolation by column chromatography ( $n$-hexane/EtOAc: $2: 1 \rightarrow 1: 1$ ) yielded 188ma (52.9 mg, 71\%) as a white solid. M. p. $=111-112{ }^{\circ} \mathrm{C} .{ }^{1} \mathrm{H}-\mathbf{N M R}(400 \mathrm{MHz}$, $\left.\mathrm{CDCl}_{3}\right) \delta=8.70(\mathrm{~s}, 1 \mathrm{H}), 8.48(\mathrm{~s}, 1 \mathrm{H}), 7.15(\mathrm{~d}, J=8.8 \mathrm{~Hz}, 2 \mathrm{H}), 6.98(\mathrm{~d}, J=8.8 \mathrm{~Hz}, 2 \mathrm{H}), 5.39$ (sbr, $1 \mathrm{H}), 3.84(\mathrm{~s}, 3 \mathrm{H}), 3.11(\mathrm{td}, J=7.0,5.8 \mathrm{~Hz}, 2 \mathrm{H}), 2.12(\mathrm{~s}, 3 \mathrm{H}), 1.25-0.89(\mathrm{~m}, 4 \mathrm{H}), 0.78$ 
$(\mathrm{t}, J=7.0 \mathrm{~Hz}, 3 \mathrm{H}) .{ }^{13} \mathrm{C}-\mathrm{NMR}\left(125 \mathrm{MHz}, \mathrm{CDCl}_{3}\right) \delta=166.8\left(\mathrm{C}_{\mathrm{q}}\right), 159.6\left(\mathrm{C}_{\mathrm{q}}\right), 151.7(\mathrm{CH})$, $147.1(\mathrm{CH}), 146.0\left(\mathrm{C}_{\mathrm{q}}\right), 131.6\left(\mathrm{C}_{\mathrm{q}}\right), 131.5\left(\mathrm{C}_{\mathrm{q}}\right), 129.4(\mathrm{CH}), 128.5\left(\mathrm{C}_{\mathrm{q}}\right), 114.3(\mathrm{CH}), 55.3$ $\left(\mathrm{CH}_{3}\right), 39.5\left(\mathrm{CH}_{2}\right), 31.2\left(\mathrm{CH}_{2}\right), 19.9\left(\mathrm{CH}_{2}\right), 17.4\left(\mathrm{CH}_{3}\right), 13.7\left(\mathrm{CH}_{3}\right)$. IR (ATR): 3330, 2956, 2930, 2870, 1638, 1515, 1246, $833 \mathrm{~cm}^{-1}$. MS (ESI) m/z (relative intensity): 619 (85) $[2 \mathrm{M}+\mathrm{Na}]^{+}, 321(55)[\mathrm{M}+\mathrm{Na}]^{+}, 299(100)[\mathrm{M}+\mathrm{H}]^{+} . \mathbf{H R}-\mathrm{MS}(\mathrm{ESI}) \mathrm{m} / \mathrm{z}$ calcd for $\mathrm{C}_{18} \mathrm{H}_{23} \mathrm{~N}_{2} \mathrm{O}_{2}$ $[\mathrm{M}+\mathrm{H}]^{+} 299.1754$, found 299.1754 .<smiles>CCCCNC(=O)c1ccncc1-c1ccc(OC)cc1</smiles>

N-n-Butyl-3-(4-methoxyphenyl)isonicotinamide (188na). The general procedure C was followed using $112 \mathrm{n}(44.6 \mathrm{mg}, 0.25 \mathrm{mmol})$ and $151 \mathrm{a}(0.40 \mathrm{~mL}, 1.0 \mathrm{mmol}, 2.5 \mathrm{~m}$ in THF). Isolation by column chromatography ( $n$-hexane/EtOAc: $2: 1 \rightarrow 1: 1$ ) yielded 188 na (35.5 mg, 50\%) as a white solid. M. p. $=121-122{ }^{\circ} \mathrm{C} .{ }^{1} \mathrm{H}-\mathrm{NMR}\left(400 \mathrm{MHz}, \mathrm{CDCl}_{3}\right) \delta=$ 8.62-8.60 (m, 2H), $7.53(\mathrm{~d}, J=4.9 \mathrm{~Hz}, 1 \mathrm{H}), 7.34(\mathrm{~d}, J=8.7 \mathrm{~Hz}, 2 \mathrm{H}), 6.98(\mathrm{~d}, J=8.7 \mathrm{~Hz}$, 2H), $5.42(\mathrm{sbr}, 1 \mathrm{H}), 3.85(\mathrm{~s}, 3 \mathrm{H}), 3.20(\mathrm{td}, J=7.0,5.8 \mathrm{~Hz}, 2 \mathrm{H}), 1.30-1.13(\mathrm{~m}, 2 \mathrm{H}), 1.11-$ $0.94(\mathrm{~m}, 2 \mathrm{H}), 0.80(\mathrm{t}, J=7.3 \mathrm{~Hz}, 3 \mathrm{H}) .{ }^{13} \mathrm{C}-\mathrm{NMR}\left(100 \mathrm{MHz}, \mathrm{CDCl}_{3}\right) \delta=167.2\left(\mathrm{C}_{\mathrm{q}}\right), 160.0$ $\left(\mathrm{C}_{q}\right), 150.9(\mathrm{CH}), 148.7(\mathrm{CH}), 142.2\left(\mathrm{C}_{\mathrm{q}}\right), 133.5\left(\mathrm{C}_{\mathrm{q}}\right), 130.1(\mathrm{CH}), 128.5\left(\mathrm{C}_{\mathrm{q}}\right), 122.2(\mathrm{CH})$, $114.4(\mathrm{CH}), 55.4\left(\mathrm{CH}_{3}\right), 39.6\left(\mathrm{CH}_{2}\right), 31.0\left(\mathrm{CH}_{2}\right), 19.8\left(\mathrm{CH}_{2}\right), 13.6\left(\mathrm{CH}_{3}\right)$. IR (ATR): 3200, $3037,2931,1641,1540,1247,831,670 \mathrm{~cm}^{-1}$. MS (EI) $\mathrm{m} / \mathrm{z}$ (relative intensity): 284 (62) $\left[\mathrm{M}^{+}, 227\right.$ (45), 212 (100), 184 (8), 169 (24), 141 (15). HR-MS (EI) m/z calcd for $\mathrm{C}_{17} \mathrm{H}_{20} \mathrm{~N}_{2} \mathrm{O}_{2}[\mathrm{M}]^{+} 284.1525$, found 284.1536. 
<smiles>COc1ccc(-c2cnccc2C(=O)NCc2ccccc2)cc1</smiles>

$\boldsymbol{N}$-n-Benzyl-3-(4-methoxyphenyl)isonicotinamide (1880a). The general procedure C was followed using 1120 (53.1 mg, $0.25 \mathrm{mmol}$ ) and 151a (0.40 mL, $1.0 \mathrm{mmol}, 2.5 \mathrm{~m}$ in THF). Isolation by column chromatography ( $n$-hexane/EtOAc: $2: 1 \rightarrow 1: 1$ ) yielded $1880 a$ (41.3 mg, 52\%) as a white solid. M. p. $=150-151{ }^{\circ} \mathrm{C} .{ }^{1} \mathbf{H}-\mathbf{N M R}\left(400 \mathrm{MHz}, \mathrm{CDCl}_{3}\right) \quad \delta=$ 8.62-8.48 (m, 2H), $7.53(\mathrm{~d}, J=4.9 \mathrm{~Hz}, 1 \mathrm{H}), 7.31-7.25(\mathrm{~m}, 2 \mathrm{H}), 7.22-7.21(\mathrm{~m}, 3 \mathrm{H}), 6.95-$ $6.92(\mathrm{~m}, 2 \mathrm{H}), 6.89(\mathrm{~d}, J=8.7 \mathrm{~Hz}, 2 \mathrm{H}), 5.83(\mathrm{sbr}, 1 \mathrm{H}), 4.37(\mathrm{~d}, J=5.6 \mathrm{~Hz}, 2 \mathrm{H}), 3.83(\mathrm{~s}, 3 \mathrm{H})$. ${ }^{13} \mathrm{C}-\mathrm{NMR}\left(100 \mathrm{MHz}, \mathrm{CDCl}_{3}\right) \delta=167.1\left(\mathrm{C}_{\mathrm{q}}\right), 159.9\left(\mathrm{C}_{\mathrm{q}}\right), 150.9(\mathrm{CH}), 148.6(\mathrm{CH}), 142.0\left(\mathrm{C}_{\mathrm{q}}\right)$, $137.0\left(\mathrm{C}_{\mathrm{q}}\right), 133.6\left(\mathrm{C}_{\mathrm{q}}\right), 130.1(\mathrm{CH}), 128.6(\mathrm{CH}), 128.3\left(\mathrm{C}_{\mathrm{q}}\right), 127.8(\mathrm{CH}), 127.5(\mathrm{CH}), 122.2$ (CH), $114.4(\mathrm{CH}), 55.3\left(\mathrm{CH}_{3}\right), 44.0\left(\mathrm{CH}_{2}\right)$. IR (ATR): 3200, 3060, 2962, 1635, 1550, 1248, 830, $695 \mathrm{~cm}^{-1}$. MS (EI) m/z (relative intensity): 318 (100) [M] $]^{+}, 212$ (40), 185 (35), 170 (24), 106 (38). HR-MS (EI) $m / z$ calcd for $\mathrm{C}_{20} \mathrm{H}_{18} \mathrm{~N}_{2} \mathrm{O}_{2}$ [M] ${ }^{+} 318.1363$, found 318.1363.<smiles>CCCCNC(=O)c1ncncc1-c1ccc(OC)cc1</smiles>

$N$-n-Butyl-5-(4-methoxyphenyl)pyrimidine-4-carboxamide (188pa). The general procedure $\mathrm{C}$ was followed using $112 \mathrm{p}(44.8 \mathrm{mg}, 0.25 \mathrm{mmol})$ and $151 \mathrm{a}(0.40 \mathrm{~mL}, 1.0$ mmol, $2.5 \mathrm{~m}$ in THF). Isolation by column chromatography ( $n$-hexane/EtOAc: $2: 1 \rightarrow 1: 1$ ) yielded 188pa (37.8 mg, 53\%) as a white solid. M. p. = 51-52 ${ }^{\circ} \mathrm{C} .{ }^{1} \mathbf{H}-\mathbf{N M R}(400 \mathrm{MHz}$, $\left.\mathrm{CDCl}_{3}\right) \delta=9.15(\mathrm{~d}, J=1.3 \mathrm{~Hz}, 1 \mathrm{H}), 8.46(\mathrm{~d}, J=1.3 \mathrm{~Hz}, 1 \mathrm{H}), 8.17(\mathrm{~d}, J=8.9 \mathrm{~Hz}, 2 \mathrm{H}), 8.05$ (sbr, $1 \mathrm{H}), 7.03(\mathrm{~d}, J=8.9 \mathrm{~Hz}, 2 \mathrm{H}), 3.89(\mathrm{~s}, 3 \mathrm{H}), 3.50(\mathrm{td}, J=7.1,6.0 \mathrm{~Hz}, 2 \mathrm{H}), 1.68-1.61$ $(\mathrm{m}, 2 \mathrm{H}), 1.51-1.34(\mathrm{~m}, 2 \mathrm{H}), 0.97(\mathrm{t}, J=7.1 \mathrm{~Hz}, 3 \mathrm{H}) .{ }^{13} \mathrm{C}-\mathrm{NMR}\left(100 \mathrm{MHz}, \mathrm{CDCl}_{3}\right) \delta=165.7$ $\left(\mathrm{C}_{q}\right), 163.0\left(\mathrm{C}_{\mathrm{q}}\right), 162.6\left(\mathrm{C}_{\mathrm{q}}\right), 157.7(\mathrm{CH}), 156.7\left(\mathrm{C}_{\mathrm{q}}\right), 129.1(\mathrm{CH}), 128.5\left(\mathrm{C}_{\mathrm{q}}\right), 114.5(\mathrm{CH})$, 
$113.1(\mathrm{CH}), 55.5\left(\mathrm{CH}_{3}\right), 39.3\left(\mathrm{CH}_{2}\right), 31.6\left(\mathrm{CH}_{2}\right), 20.1\left(\mathrm{CH}_{2}\right), 13.7\left(\mathrm{CH}_{3}\right)$. IR (ATR): 3400, 3047, 2962, 1672, 1510, 1251, 836, $574 \mathrm{~cm}^{-1}$. MS (ESI) m/z (relative intensity): 593 (25) $[2 \mathrm{M}+\mathrm{Na}]^{+}, 308(100)[\mathrm{M}+\mathrm{Na}]^{+}, 286(12)[\mathrm{M}+\mathrm{H}]^{+} . \mathrm{HR}-\mathrm{MS}(\mathrm{ESI}) \mathrm{m} / z$ calcd for $\mathrm{C}_{16} \mathrm{H}_{20} \mathrm{~N}_{3} \mathrm{O}_{2}$ $[\mathrm{M}+\mathrm{H}]^{+}$286.1550, found 286.1547 .<smiles>CCCCn1cc(C(C)(C)NC(=O)c2ccccc2-c2ccc(OC)cc2)nn1</smiles>

N-(2-(1--n-Butyl-1H-1,2,3-triazol-4-yl)propan-2-yl)-4'-methoxy-[1,1'-biphenyl]-2carboxamide (156). The general procedure $C$ was followed using 159a (71.6 mg, 0.25 $\mathrm{mmol}$ ) and 151a $(0.70 \mathrm{~mL}, 1.75 \mathrm{mmol}, 2.5 \mathrm{~m}$ in THF). Isolation by column chromatography ( $n$-hexane/EtOAc: 3:1 $\rightarrow 1: 1$ ) yielded $156(52.0 \mathrm{mg}, 53 \%$ ) as a white solid. M. p. $=115-116^{\circ} \mathrm{C}^{1}{ }^{1} \mathrm{H}-\mathrm{NMR}\left(400 \mathrm{MHz}, \mathrm{CDCl}_{3}\right) \delta=7.64-7.61(\mathrm{~m}, 1 \mathrm{H}), 7.44-7.40$ (m, 1H), 7.38-7.28 (m, 5H), $6.91(\mathrm{~d}, J=8.8 \mathrm{~Hz}, 2 \mathrm{H}), 5.89(\mathrm{sbr}, 1 \mathrm{H}), 4.27(\mathrm{t}, J=7.3 \mathrm{~Hz}$, $2 \mathrm{H}), 3.84(\mathrm{~s}, 3 \mathrm{H}), 1.93-1.79(\mathrm{~m}, 2 \mathrm{H}), 1.60(\mathrm{~s}, 6 \mathrm{H}), 1.41-1.28(\mathrm{~m}, 2 \mathrm{H}), 0.95(\mathrm{t}, \mathrm{J}=7.4 \mathrm{~Hz}$, 3H). ${ }^{13} \mathrm{C}-\mathrm{NMR}\left(100 \mathrm{MHz}, \mathrm{CDCl}_{3}\right) \delta=168.5\left(\mathrm{C}_{\mathrm{q}}\right), 159.3\left(\mathrm{C}_{\mathrm{q}}\right), 152.7\left(\mathrm{C}_{\mathrm{q}}\right), 139.3\left(\mathrm{C}_{\mathrm{q}}\right), 136.2$ $\left(\mathrm{C}_{\mathrm{q}}\right), 132.7\left(\mathrm{C}_{\mathrm{q}}\right), 130.2(\mathrm{CH}), 130.1(\mathrm{CH}), 129.9(\mathrm{CH}), 128.6(\mathrm{CH}), 127.1(\mathrm{CH}), 120.4(\mathrm{CH})$, $113.9(\mathrm{CH}), 55.4\left(\mathrm{CH}_{3}\right), 51.6\left(\mathrm{CH}_{2}\right), 50.0\left(\mathrm{CH}_{2}\right), 32.2\left(\mathrm{CH}_{2}\right), 27.5\left(\mathrm{CH}_{3}\right), 19.8\left(\mathrm{CH}_{2}\right), 13.5$ $\left(\mathrm{CH}_{3}\right)$. IR (ATR): 3292, 2959, 2928, 1632, 1541, 1438, 1309, $1048 \mathrm{~cm}^{-1}$. MS (ESI) m/z (relative intensity): $807(12)[2 \mathrm{M}+\mathrm{Na}]^{+}, 415(52)[\mathrm{M}+\mathrm{Na}]^{+}, 393(34)[\mathrm{M}+\mathrm{H}]^{+}$. HR-MS (ESI) $m / z$ calcd for $\mathrm{C}_{23} \mathrm{H}_{29} \mathrm{~N}_{4} \mathrm{O}_{2}[\mathrm{M}+\mathrm{H}]^{+} 393.2285$, found 393.2284 .<smiles>CCCCNC(=O)c1ncccc1-c1ccccc1</smiles>

N-n-Butyl-3-phenylpicolinamide (188ab). The general procedure $\mathbf{C}$ was followed using 
112a (44.5 mg, $0.25 \mathrm{mmol})$ and $151 \mathrm{~b}(0.38 \mathrm{~mL}, 1.0 \mathrm{mmol}, 2.6 \mathrm{~m}$ in THF). Isolation by column chromatography ( $n$-hexane/EtOAc: $2: 1 \rightarrow 1: 1$ ) yielded 188ab $(50.8 \mathrm{mg}, 80 \%$ ) as a white solid. M. p. $=55-56{ }^{\circ} \mathrm{C} .{ }^{1} \mathbf{H}-\mathbf{N M R}\left(400 \mathrm{MHz}, \mathrm{CDCl}_{3}\right) \delta=8.54$ (dd, $J=4.7,1.7 \mathrm{~Hz}$, 1H), $7.71(\mathrm{sbr}, 1 \mathrm{H}), 7.67(\mathrm{dd}, J=7.8,1.7 \mathrm{~Hz}, 1 \mathrm{H}), 7.48-7.29(\mathrm{~m}, 6 \mathrm{H}), 3.35(\mathrm{td}, J=7.2,6.0$ $\mathrm{Hz}, 2 \mathrm{H}), 1.62-1.49(\mathrm{~m}, 2 \mathrm{H}), 1.43-1.28(\mathrm{~m}, 2 \mathrm{H}), 0.92(\mathrm{t}, J=7.2 \mathrm{~Hz}, 3 \mathrm{H}) .{ }^{13} \mathrm{C}-\mathrm{NMR}(100$ $\left.\mathrm{MHz}_{1} \mathrm{CDCl}_{3}\right) \delta=165.0\left(\mathrm{C}_{\mathrm{q}}\right), 148.1\left(\mathrm{C}_{\mathrm{q}}\right), 146.8(\mathrm{CH}), 139.9(\mathrm{CH}), 139.5\left(\mathrm{C}_{\mathrm{q}}\right), 138.1\left(\mathrm{C}_{\mathrm{q}}\right)$, $128.3(\mathrm{CH}), 127.8(\mathrm{CH}), 127.4(\mathrm{CH}), 124.9(\mathrm{CH}), 39.1\left(\mathrm{CH}_{2}\right), 31.6\left(\mathrm{CH}_{2}\right), 20.1\left(\mathrm{CH}_{2}\right), 13.7$ $\left(\mathrm{CH}_{3}\right)$. IR (ATR): 3250, 3060, 2955, 1648, 1541, 1316, 758, $666 \mathrm{~cm}^{-1}$. MS (ESI) m/z (relative intensity): $531(100)[2 \mathrm{M}+\mathrm{Na}]^{+}, 277(18)[\mathrm{M}+\mathrm{Na}]^{+}, 255(12)[\mathrm{M}+\mathrm{H}]^{+}$. HR-MS (ESI) $\mathrm{m} / z$ calcd for $\mathrm{C}_{16} \mathrm{H}_{19} \mathrm{~N}_{2} \mathrm{O}[\mathrm{M}+\mathrm{H}]^{+} 255.1492$, found 255.1490 .<smiles>CCCCNC(=O)c1ncccc1-c1ccc(C)cc1</smiles>

$\boldsymbol{N}$ - $\boldsymbol{n}$-Butyl-3-( $\boldsymbol{p}$-tolyl)picolinamide (188ac). The general procedure C was followed using 112a (44.5 mg, $0.25 \mathrm{mmol}$ ) and $151 \mathrm{c}(0.42 \mathrm{~mL}, 1.0 \mathrm{mmol}, 2.4 \mathrm{~m}$ in THF). Isolation by column chromatography ( $n$-hexane/EtOAc: $2: 1 \rightarrow 1: 1)$ yielded 188 ac $(50.9 \mathrm{mg}, 76 \%)$ as a white solid. M. p. $=110-111^{\circ} \mathrm{C} .{ }^{1} \mathrm{H}-\mathrm{NMR}\left(400 \mathrm{MHz}, \mathrm{CDCl}_{3}\right) \delta=8.52(\mathrm{dd}, \mathrm{J}=4.7$, $1.7 \mathrm{~Hz}, 1 \mathrm{H}), 7.68-7.65(\mathrm{~m}, 2 \mathrm{H}), 7.41(\mathrm{dd}, J=7.8,4.7 \mathrm{~Hz}, 1 \mathrm{H}), 7.22(\mathrm{~m}, 4 \mathrm{H}), 3.36(\mathrm{td}, J=$ 7.1, $6.0 \mathrm{~Hz}, 2 \mathrm{H}), 2.39(\mathrm{~s}, 3 \mathrm{H}), 1.61-1.48(\mathrm{~m}, 2 \mathrm{H}), 1.44-1.27(\mathrm{~m}, 2 \mathrm{H}), 0.92(\mathrm{t}, \quad J=7.1 \mathrm{~Hz}$, 3H). ${ }^{13} \mathrm{C}-\mathrm{NMR}\left(100 \mathrm{MHz}, \mathrm{CDCl}_{3}\right) \delta=165.1\left(\mathrm{C}_{\mathrm{q}}\right), 148.3\left(\mathrm{C}_{\mathrm{q}}\right), 146.6(\mathrm{CH}), 139.9(\mathrm{CH}), 138.1$ $\left(\mathrm{C}_{\mathrm{q}}\right), 137.1\left(\mathrm{C}_{\mathrm{q}}\right), 136.5\left(\mathrm{C}_{\mathrm{q}}\right), 128.6(\mathrm{CH}), 128.2(\mathrm{CH}), 124.9(\mathrm{CH}), 39.1\left(\mathrm{CH}_{2}\right), 31.6\left(\mathrm{CH}_{2}\right)$, $21.2\left(\mathrm{CH}_{3}\right), 20.1\left(\mathrm{CH}_{2}\right), 13.7\left(\mathrm{CH}_{3}\right)$. IR (ATR): 3250, 2956, 2922, 1665, 1550, 1306, 801, $696 \mathrm{~cm}^{-1}$. MS (EI) $\mathrm{m} / \mathrm{z}$ (relative intensity): $268(28)[\mathrm{M}]^{+}, 211$ (42), 168 (70), 154 (13), 43 (100). HR-MS (ESI) $m / z$ calcd for $\mathrm{C}_{17} \mathrm{H}_{21} \mathrm{~N}_{2} \mathrm{O}[\mathrm{M}+\mathrm{H}]^{+} 269.1648$, found 269.1650. 
<smiles>CCCCNC(=O)c1ncccc1-c1ccc(C(C)(C)C)cc1</smiles>

N-n-Butyl-3-[4-(tert-butyl)phenyl]picolinamide (188ad). The general procedure $\mathbf{C}$ was followed using 112a (44.5 mg, $0.25 \mathrm{mmol}$ ) and 151d (0.40 mL, $1.0 \mathrm{mmol}, 2.5 \mathrm{~m}$ in THF). Isolation by column chromatography ( $n$-hexane/EtOAc: $2: 1 \rightarrow 1: 1$ ) yielded 188ad (56.6 mg, 73\%) as a white solid. M. p. $=108-109^{\circ} \mathrm{C} .{ }^{1} \mathrm{H}-\mathrm{NMR}\left(400 \mathrm{MHz}, \mathrm{CDCl}_{3}\right) \delta=8.52$ (dd, $J=4.6,1.7 \mathrm{~Hz}, 1 \mathrm{H}), 7.68-7.65(\mathrm{~m}, 2 \mathrm{H}), 7.48-7.37(\mathrm{~m}, 3 \mathrm{H}), 7.32-7.25(\mathrm{~m}, 2 \mathrm{H}), 3.36(\mathrm{td}$, $J=7.2,6.0 \mathrm{~Hz}, 2 \mathrm{H}), 1.59-1.48(\mathrm{~m}, 2 \mathrm{H}), 1.41-1.31(\mathrm{~m}, 11 \mathrm{H}), 0.92(\mathrm{t}, J=7.2 \mathrm{~Hz}, 3 \mathrm{H}) .{ }^{13} \mathrm{C}-$ $\operatorname{NMR}\left(100 \mathrm{MHz}, \mathrm{CDCl}_{3}\right) \delta=165.2\left(\mathrm{C}_{\mathrm{q}}\right), 150.1\left(\mathrm{C}_{\mathrm{q}}\right), 148.2\left(\mathrm{C}_{\mathrm{q}}\right), 146.6(\mathrm{CH}), 140.1(\mathrm{CH})$, $137.9\left(\mathrm{C}_{q}\right), 136.3\left(\mathrm{C}_{\mathrm{q}}\right), 128.1(\mathrm{CH}), 124.9(\mathrm{CH}), 124.8(\mathrm{CH}), 39.1\left(\mathrm{CH}_{2}\right), 34.5\left(\mathrm{C}_{\mathrm{q}}\right), 31.5$ $\left(\mathrm{CH}_{2}\right), 31.3\left(\mathrm{CH}_{3}\right), 20.1\left(\mathrm{CH}_{2}\right), 13.7\left(\mathrm{CH}_{3}\right)$. IR (ATR): 3280, 2957, 2869, 1638, 1547, 1432, 841, $584 \mathrm{~cm}^{-1}$. MS (EI) m/z (relative intensity): 310 (88) [M] $]^{+}, 253$ (85), 211 (80), 194 (70), 182 (100). HR-MS (ESI) $m / z$ calcd for $\mathrm{C}_{20} \mathrm{H}_{27} \mathrm{~N}_{2} \mathrm{O}[\mathrm{M}+\mathrm{H}]^{+} 311.2118$, found 311.2117.<smiles>CCCCNC(=O)c1ncccc1-c1ccc(-c2ccccc2)cc1</smiles>

3- [(1,1'-Biphenyl)-4-yl]-N-n-butylpicolinamide (188ae). The general procedure $\mathbf{C}$ was followed using $112 \mathrm{a}(44.5 \mathrm{mg}, 0.25 \mathrm{mmol})$ and $151 \mathrm{e}(0.44 \mathrm{~mL}, 1.0 \mathrm{mmol}, 2.3 \mathrm{~m}$ in THF). Isolation by column chromatography ( $n$-hexane/EtOAc: $2: 1 \rightarrow 1: 1$ ) yielded 188ae (41.3 mg, 50\%) as a white solid. M. p. $=118-119^{\circ} \mathrm{C} .{ }^{1} \mathrm{H}-\mathrm{NMR}\left(400 \mathrm{MHz}, \mathrm{CDCl}_{3}\right) \delta=8.56(\mathrm{dd}$, $J=4.7,1.7 \mathrm{~Hz}, 1 \mathrm{H}), 7.78\left(\mathrm{~s}_{\mathrm{br}}, 1 \mathrm{H}\right), 7.72(\mathrm{dd}, J=7.8,1.7 \mathrm{~Hz}, 1 \mathrm{H}), 7.68-7.60(\mathrm{~m}, 4 \mathrm{H}), 7.49$ $7.39(\mathrm{~m}, 5 \mathrm{H}), 7.38-7.31(\mathrm{~m}, 1 \mathrm{H}), 3.39(\mathrm{td}, J=7.2,6.0 \mathrm{~Hz}, 2 \mathrm{H}), 1.62-1.51(\mathrm{~m}, 2 \mathrm{H}), 1.46-$ $1.30(\mathrm{~m}, 2 \mathrm{H}), 0.93(\mathrm{t}, J=7.2 \mathrm{~Hz}, 3 \mathrm{H}) .{ }^{13} \mathrm{C}-\mathrm{NMR}\left(100 \mathrm{MHz}, \mathrm{CDCl}_{3}\right) \delta=165.0\left(\mathrm{C}_{\mathrm{q}}\right), 148.1$ $\left(\mathrm{C}_{\mathrm{q}}\right), 146.9(\mathrm{CH}), 140.8\left(\mathrm{C}_{\mathrm{q}}\right), 140.2\left(\mathrm{C}_{\mathrm{q}}\right), 140.1(\mathrm{CH}), 138.5\left(\mathrm{C}_{\mathrm{q}}\right), 137.9\left(\mathrm{C}_{\mathrm{q}}\right), 128.9(\mathrm{CH})$, 
$128.7(\mathrm{CH}), 127.2(\mathrm{CH}), 127.1(\mathrm{CH}), 126.6(\mathrm{CH}), 125.1(\mathrm{CH}), 39.2\left(\mathrm{CH}_{2}\right), 31.6\left(\mathrm{CH}_{2}\right), 20.2$ $\left(\mathrm{CH}_{2}\right), 13.8\left(\mathrm{CH}_{3}\right)$. IR (ATR): 3220, 2958, 2931, 1643, 1548, 766, 696, $580 \mathrm{~cm}^{-1}$. MS (ESI) $\mathrm{m} / \mathrm{z}$ (relative intensity): $683(100)[2 \mathrm{M}+\mathrm{Na}]^{+}, 353(54)[\mathrm{M}+\mathrm{Na}]^{+}, 331(17)[\mathrm{M}+\mathrm{H}]^{+} . \mathbf{H R}-$ MS (ESI) $m / z$ calcd for $\mathrm{C}_{22} \mathrm{H}_{23} \mathrm{~N}_{2} \mathrm{O}[\mathrm{M}+\mathrm{H}]^{+} 331.1805$, found 331.1802 .<smiles>CCCCNC(=O)c1ncccc1-c1ccc(F)cc1</smiles>

$\boldsymbol{N}$-n-Butyl-3-(4-fluorophenyl)picolinamide (188af). The general procedure C was followed using 112a (44.5 mg, $0.25 \mathrm{mmol}$ ) and $151 \mathrm{f}(0.38 \mathrm{~mL}, 1.0 \mathrm{mmol}, 2.6 \mathrm{~m}$ in THF). Isolation by column chromatography ( $n$-hexane/EtOAc: $2: 1 \rightarrow 1: 1$ ) yielded 188af $(44.2$ mg, 65\%) as a white solid. M. p. $=81-82{ }^{\circ} \mathrm{C} .{ }^{1} \mathrm{H}-\mathrm{NMR}\left(300 \mathrm{MHz}, \mathrm{CDCl}_{3}\right) \delta=8.52(\mathrm{dd}, \mathrm{J}$ $=4.7,1.7 \mathrm{~Hz}, 1 \mathrm{H}), 7.82(\mathrm{sbr}, 1 \mathrm{H}), 7.62(\mathrm{dd}, J=7.8,1.7 \mathrm{~Hz}, 1 \mathrm{H}), 7.41(\mathrm{dd}, J=7.8,4.7 \mathrm{~Hz}$, 1H), 7.33-7.19 (m, 2H), 7.15-6.95 (m, 2H), $3.33(\mathrm{td}, J=7.1,6.0 \mathrm{~Hz}, 2 \mathrm{H}), 1.62-1.46(\mathrm{~m}$, 2H), $1.43-1.25(\mathrm{~m}, 2 \mathrm{H}), 0.90(\mathrm{t}, J=7.1 \mathrm{~Hz}, 3 \mathrm{H}) .{ }^{13} \mathrm{C}-\mathrm{NMR}\left(125 \mathrm{MHz}, \mathrm{CDCl}_{3}\right) \delta=164.7$ $\left(C_{q}\right), 162.2\left(d,{ }^{1} J_{C-F}=246.0 \mathrm{~Hz}, C_{q}\right), 147.8\left(C_{q}\right), 146.8(C H), 139.9(C H), 137.2\left(C_{q}\right), 135.4$ $\left(d,{ }^{4} J_{C-F}=3.4 \mathrm{~Hz}, C_{q}\right), 129.9\left(d,{ }^{3} J_{C-F}=8.2 \mathrm{~Hz}, C H\right), 125.0(C H), 114.7\left(d,{ }^{2} J_{C-F}=21.6 \mathrm{~Hz}\right.$, $\mathrm{CH}), 39.1\left(\mathrm{CH}_{2}\right), 31.7\left(\mathrm{CH}_{2}\right), 20.2\left(\mathrm{CH}_{2}\right), 13.8\left(\mathrm{CH}_{3}\right) .{ }^{19} \mathrm{~F}-\mathrm{NMR}\left(282 \mathrm{MHz}, \mathrm{CDCl}_{3}\right) \delta=-$ 115.18. IR (ATR): 3330, 2956, 2859, 1648, 1512, 1223, 649, $632 \mathrm{~cm}^{-1}$. MS (EI) m/z (relative intensity): $272(30)\left[\mathrm{M}^{+}, 215\right.$ (50), 172 (100), 145 (32), 72 (28). HR-MS (EI) $\mathrm{m} / \mathrm{z}$ calcd for $\mathrm{C}_{16} \mathrm{H}_{17} \mathrm{FN}_{2} \mathrm{O}[\mathrm{M}]^{+} 272.1319$, found 272.1324 .<smiles>CCCCNC(=O)c1ncccc1-c1ccc(N(C)C)cc1</smiles>

N-n-Butyl-3-[4-(dimethylamino)phenyl]picolinamide (188ag). The general procedure 
C was followed using $112 \mathrm{a}(44.5 \mathrm{mg}, 0.25 \mathrm{mmol})$ and $151 \mathrm{~g}(0.36 \mathrm{~mL}, 1.0 \mathrm{mmol}, 2.8 \mathrm{~m}$ in THF). Isolation by column chromatography ( $n$-hexane/EtOAc: $2: 1 \rightarrow 1: 1$ ) yielded 188ag (40.8 mg, 55\%) as a white solid. M. p. $=77-78^{\circ} \mathrm{C} .{ }^{1} \mathbf{H}-\mathbf{N M R}\left(400 \mathrm{MHz}, \mathrm{CDCl}_{3}\right) \delta$ $=8.47(\mathrm{dd}, J=4.6,1.7 \mathrm{~Hz}, 1 \mathrm{H}), 7.68(\mathrm{dd}, J=7.8,1.7 \mathrm{~Hz}, 1 \mathrm{H}), 7.43\left(\mathrm{~s}_{\mathrm{br}}, 1 \mathrm{H}\right), 7.37(\mathrm{dd}, \quad J$ $=7.8,4.6 \mathrm{~Hz}, 1 \mathrm{H}), 7.24(\mathrm{~d}, J=8.9 \mathrm{~Hz}, 2 \mathrm{H}), 6.76(\mathrm{~d}, J=8.9 \mathrm{~Hz}, 2 \mathrm{H}), 3.37(\mathrm{td}, J=7.1,6.0$ $\mathrm{Hz}, 2 \mathrm{H}), 2.98(\mathrm{~s}, 6 \mathrm{H}), 1.61-1.46(\mathrm{~m}, 2 \mathrm{H}), 1.42-1.27(\mathrm{~m}, 2 \mathrm{H}), 0.91(\mathrm{t}, J=7.1 \mathrm{~Hz}, 3 \mathrm{H}) .{ }^{13} \mathrm{C}-$ NMR $\left(101 \mathrm{MHz} \mathrm{CDCl}_{3}\right) \delta=165.9\left(\mathrm{C}_{\mathrm{q}}\right), 150.0\left(\mathrm{C}_{\mathrm{q}}\right), 148.7\left(\mathrm{C}_{\mathrm{q}}\right), 146.0(\mathrm{CH}), 139.7(\mathrm{CH})$, $138.0\left(\mathrm{C}_{\mathrm{q}}\right), 129.3(\mathrm{CH}), 126.7\left(\mathrm{C}_{\mathrm{q}}\right), 124.8(\mathrm{CH}), 111.9(\mathrm{CH}), 40.4\left(\mathrm{CH}_{3}\right), 39.2\left(\mathrm{CH}_{2}\right), 31.6$ $\left(\mathrm{CH}_{2}\right), 20.1\left(\mathrm{CH}_{2}\right), 13.8\left(\mathrm{CH}_{3}\right)$. IR (ATR): 3250, 2955, 2929, 2869, 1647, 1523, 821, 633 $\mathrm{cm}^{-1}$. MS (EI) m/z (relative intensity): 297 (100) [M] ${ }^{+}, 240$ (30), 198 (65), 182 (18), 154 (25). HR-MS (EI) $m / z$ calcd for $\mathrm{C}_{18} \mathrm{H}_{23} \mathrm{~N}_{3} \mathrm{O}[\mathrm{M}]^{+} 297.1836$, found 297.1830.<smiles>CCCCNC(=O)c1ncccc1-c1cccc(OC)c1</smiles>

N-n-Butyl-3-(3-methoxyphenyl)picolinamide (188ah). The general procedure C was followed using 112a (44.5 mg, $0.25 \mathrm{mmol}$ ) and $151 \mathrm{~h}(0.40 \mathrm{~mL}, 1.0 \mathrm{mmol}, 2.5 \mathrm{~m}$ in THF). Isolation by column chromatography ( $n$-hexane/EtOAc: $2: 1 \rightarrow 1: 1$ ) yielded 188ah (47.6 mg, 67\%) as a white solid. M. p. $=99-100{ }^{\circ} \mathrm{C} .{ }^{1} \mathbf{H}-\mathrm{NMR}\left(400 \mathrm{MHz}, \mathrm{CDCl}_{3}\right) \delta=8.53$ (dd, $J=4.7,1.7 \mathrm{~Hz}, 1 \mathrm{H}), 7.67(\mathrm{dd}, J=7.8,1.7 \mathrm{~Hz}, 1 \mathrm{H}), 7.62\left(\mathrm{sbr}_{1} 1 \mathrm{H}\right), 7.41(\mathrm{dd}, J=7.8,4.7 \mathrm{~Hz}$, $1 \mathrm{H}), 7.33-7.29(\mathrm{~m}, 1 \mathrm{H}), 6.99-6.80(\mathrm{~m}, 3 \mathrm{H}), 3.81(\mathrm{~s}, 3 \mathrm{H}), 3.35(\mathrm{td}, J=7.2,6.0 \mathrm{~Hz}, 2 \mathrm{H})$, 1.60-1.48 (m, 2H), 1.41-1.30 (m, 2H), $0.91(\mathrm{t}, J=7.2 \mathrm{~Hz}, 3 \mathrm{H}) .{ }^{13} \mathrm{C}-\mathrm{NMR}\left(100 \mathrm{MHz}, \mathrm{CDCl}_{3}\right)$ $\delta=165.0\left(\mathrm{C}_{\mathrm{q}}\right), 159.1\left(\mathrm{C}_{\mathrm{q}}\right), 148.5\left(\mathrm{C}_{\mathrm{q}}\right), 146.9(\mathrm{CH}), 140.8\left(\mathrm{C}_{\mathrm{q}}\right), 139.7(\mathrm{CH}), 137.8\left(\mathrm{C}_{\mathrm{q}}\right)$, $128.8(\mathrm{CH}), 124.8(\mathrm{CH}), 120.9(\mathrm{CH}), 114.1(\mathrm{CH}), 112.8(\mathrm{CH}), 55.1\left(\mathrm{CH}_{3}\right), 39.1\left(\mathrm{CH}_{2}\right), 31.6$ $\left(\mathrm{CH}_{2}\right), 20.1\left(\mathrm{CH}_{2}\right), 13.7\left(\mathrm{CH}_{3}\right)$. IR (ATR): 3300, 2955, 2870, 1656, 1516, 1117, 782, 670 $\mathrm{cm}^{-1}$. MS (ESI) $\mathrm{m} / z$ (relative intensity): $591(100)[2 \mathrm{M}+\mathrm{Na}]^{+}, 307(42)[\mathrm{M}+\mathrm{Na}]^{+}, 285(21)$ $[\mathrm{M}+\mathrm{H}]^{+}$. HR-MS (ESI) $m / z$ calcd for $\mathrm{C}_{17} \mathrm{H}_{21} \mathrm{~N}_{2} \mathrm{O}_{2}[\mathrm{M}+\mathrm{H}]^{+}$285.1598, found 285.1597. 
<smiles>CCCCNC(=O)c1ncccc1-c1cccc(F)c1</smiles>

$\boldsymbol{N}$-n-Butyl-3-(3-fluorophenyl)picolinamide (188ai). The general procedure C was followed using 112a (44.5 mg, $0.25 \mathrm{mmol}$ ) and $151 \mathrm{i}(0.44 \mathrm{~mL}, 1.0 \mathrm{mmol}, 2.3 \mathrm{~m}$ in THF). Isolation by column chromatography ( $n$-hexane/EtOAc: $2: 1 \rightarrow 1: 1$ ) yielded 188ai (40.8 mg, 60\%) as a white solid. M. p. $=81-82{ }^{\circ} \mathrm{C} .{ }^{1} \mathrm{H}-\mathrm{NMR}\left(400 \mathrm{MHz}, \mathrm{CDCl}_{3}\right) \delta=8.56(\mathrm{~d}, \mathrm{~J}=$ $4.6 \mathrm{~Hz}, 1 \mathrm{H}), 7.82\left(\mathrm{sbr}_{1} 1 \mathrm{H}\right), 7.64(\mathrm{dd}, J=7.7,1.2 \mathrm{~Hz}, 1 \mathrm{H}), 7.44(\mathrm{dd}, J=7.7,4.6 \mathrm{~Hz}, 1 \mathrm{H})$, $7.35(\mathrm{~m}, 1 \mathrm{H}), 7.14-6.95(\mathrm{~m}, 3 \mathrm{H}), 3.35(\mathrm{td}, \mathrm{J}=7.3,6.3 \mathrm{~Hz}, 2 \mathrm{H}) 1.60-1.53(\mathrm{~m}, 2 \mathrm{H}), 1.44-$ $1.31(\mathrm{~m}, 2 \mathrm{H}), 0.92(\mathrm{t}, J=7.3 \mathrm{~Hz}, 3 \mathrm{H}) .{ }^{13} \mathrm{C}-\mathrm{NMR}\left(100 \mathrm{MHz}, \mathrm{CDCl}_{3}\right) \delta=164.6\left(\mathrm{C}_{\mathrm{q}}\right), 162.2$ $\left(\mathrm{d},{ }^{1} \mathrm{~J}_{\mathrm{C}-\mathrm{F}}=245.6 \mathrm{~Hz}, \mathrm{C}_{\mathrm{q}}\right), 147.9\left(\mathrm{C}_{\mathrm{q}}\right), 147.2(\mathrm{CH}), 141.8\left(\mathrm{~d},{ }^{3} \mathrm{~J}_{\mathrm{C}-\mathrm{F}}=8.1 \mathrm{~Hz}, \mathrm{C}_{\mathrm{q}}\right), 139.9(\mathrm{CH})$, $137.0\left(\mathrm{C}_{\mathrm{q}}\right), 129.3\left(\mathrm{~d},{ }^{3} J_{\mathrm{C}-\mathrm{F}}=8.4 \mathrm{~Hz}, \mathrm{CH}\right), 125.1(\mathrm{CH}), 124.2\left(\mathrm{~d},{ }^{4} \mathrm{~J}_{\mathrm{C}-\mathrm{F}}=3.0 \mathrm{~Hz}, \mathrm{CH}\right), 115.5$ $\left(d,{ }^{2} J_{C-F}=22.4 \mathrm{~Hz}, \mathrm{CH}\right), 114.3\left(\mathrm{~d},{ }^{2} J_{\mathrm{C}-\mathrm{F}}=21.1 \mathrm{~Hz}, \mathrm{CH}\right), 39.1\left(\mathrm{CH}_{2}\right), 31.6\left(\mathrm{CH}_{2}\right), 20.1\left(\mathrm{CH}_{2}\right)$, 13.7 $\left(\mathrm{CH}_{3}\right) .{ }^{19} \mathrm{~F}-\mathrm{NMR}\left(282 \mathrm{MHz}, \mathrm{CDCl}_{3}\right) \delta=-115.17$. IR (ATR): 3330, 3058, 2958, 2871, 1656, 1585, 809, $692 \mathrm{~cm}^{-1}$. MS (ESI) m/z (relative intensity): 567 (100) [2M+Na] $]^{+}, 295$ (63) $[\mathrm{M}+\mathrm{Na}]^{+}, 273(35)[\mathrm{M}+\mathrm{H}]^{+}$. HR-MS (ESI) $m / z$ calcd for $\mathrm{C}_{16} \mathrm{H}_{18} \mathrm{~N}_{2} \mathrm{OF}[\mathrm{M}+\mathrm{H}]^{+} 273.1398$, found 273.1398 .<smiles>CCCCNC(=O)c1ncccc1-c1ccc2ccccc2c1</smiles>

N-n-Butyl-3-(naphthalen-2-yl)picolinamide (188aj). The general procedure C was followed using 112a (44.5 mg, $0.25 \mathrm{mmol}$ ) and $151 \mathrm{j}(0.45 \mathrm{~mL}, 1.0 \mathrm{mmol}, 2.2 \mathrm{~m}$ in THF). Isolation by column chromatography ( $n$-hexane/EtOAc: $2: 1 \rightarrow 1: 1$ ) yielded 188aj (44.8 mg, 59\%) as a white solid. M. p. $=81-82{ }^{\circ} \mathrm{C} .{ }^{1} \mathbf{H}-\mathbf{N M R}\left(400 \mathrm{MHz}, \mathrm{CDCl}_{3}\right) \delta=8.59$ (dd, $J$ $=4.7,1.6 \mathrm{~Hz}, 1 \mathrm{H}), 7.89-7.70(\mathrm{~m}, 6 \mathrm{H}), 7.51-7.41(\mathrm{~m}, 4 \mathrm{H}), 3.35(\mathrm{td}, J=7.2,6.1 \mathrm{~Hz}, 2 \mathrm{H})$, 
1.60-1.49 (m, 2H), 1.41-1.28 (m, 2H), $0.90(\mathrm{t}, J=7.2 \mathrm{~Hz}, 3 \mathrm{H}) .{ }^{13} \mathrm{C}-\mathrm{NMR}\left(100 \mathrm{MHz}, \mathrm{CDCl}_{3}\right)$ $\delta=165.0\left(\mathrm{C}_{\mathrm{q}}\right), 148.2\left(\mathrm{C}_{\mathrm{q}}\right), 147.0(\mathrm{CH}), 140.4(\mathrm{CH}), 138.2\left(\mathrm{C}_{\mathrm{q}}\right), 137.4\left(\mathrm{C}_{\mathrm{q}}\right), 133.2\left(\mathrm{C}_{\mathrm{q}}\right)$, $132.7\left(\mathrm{C}_{\mathrm{q}}\right), 128.1(\mathrm{CH}), 127.7(\mathrm{CH}), 127.3(\mathrm{CH}), 127.0(\mathrm{CH}), 126.6(\mathrm{CH}), 126.1(\mathrm{CH}), 126.0$ (CH), $125.1(\mathrm{CH}), 39.1\left(\mathrm{CH}_{2}\right), 31.6\left(\mathrm{CH}_{2}\right), 20.1\left(\mathrm{CH}_{2}\right), 13.7\left(\mathrm{CH}_{3}\right)$. IR (ATR): 3300, 3050, 2927, 1651, 1519, 1302, 809, $481 \mathrm{~cm}^{-1}$. MS (ESI) $\mathrm{m} / \mathrm{z}$ (relative intensity): 631 (100) $[2 \mathrm{M}+\mathrm{Na}]^{+}, 327(38)[\mathrm{M}+\mathrm{Na}]^{+}, 305(22)[\mathrm{M}+\mathrm{H}]^{+}$. HR-MS (ESI) $\mathrm{m} / z$ calcd for $\mathrm{C}_{20} \mathrm{H}_{21} \mathrm{~N}_{2} \mathrm{O}$ $[\mathrm{M}+\mathrm{H}]^{+}$305.1648, found 305.1647.<smiles>CCCCNC(=O)c1ncccc1-c1ccsc1</smiles>

N-n-Butyl-3-(thiophen-3-yl)picolinamide (188ak). The general procedure C was followed using 112a (44.5 mg, $0.25 \mathrm{mmol}$ ) and 151k (0.44 mL, $1.0 \mathrm{mmol}, 2.3 \mathrm{~m}$ in THF). Isolation by column chromatography ( $n$-hexane/EtOAc: $2: 1 \rightarrow 1: 1$ ) yielded 188ak (33.2 mg, 51\%) as a white solid. M. p. $=62-63{ }^{\circ} \mathrm{C} .{ }^{1} \mathrm{H}-\mathrm{NMR}\left(300 \mathrm{MHz}, \mathrm{CDCl}_{3}\right) \delta=8.52$ (dd, $\mathrm{J}$

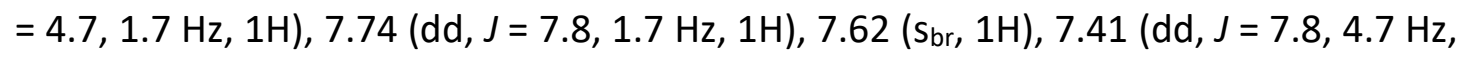
$1 \mathrm{H}), 7.34(\mathrm{dd}, J=4.9,3.0 \mathrm{~Hz}, 1 \mathrm{H}), 7.30$ (dd, $J=3.0,1.4 \mathrm{~Hz}, 1 \mathrm{H}), 7.17$ (dd, $J=4.9,1.4 \mathrm{~Hz}$, $1 \mathrm{H}), 3.38(\mathrm{td}, J=7.1,6.0 \mathrm{~Hz}, 2 \mathrm{H}), 1.65-1.47(\mathrm{~m}, 2 \mathrm{H}), 1.44-1.29(\mathrm{~m}, 2 \mathrm{H}), 0.93(\mathrm{t}, J=7.1$ $\mathrm{Hz}, 3 \mathrm{H}) .{ }^{13} \mathrm{C}-\mathrm{NMR}\left(126 \mathrm{MHz}, \mathrm{CDCl}_{3}\right) \delta=165.1\left(\mathrm{C}_{\mathrm{q}}\right), 148.3\left(\mathrm{C}_{\mathrm{q}}\right), 146.8(\mathrm{CH}), 139.9(\mathrm{CH})$, $139.3\left(\mathrm{C}_{\mathrm{q}}\right), 132.8\left(\mathrm{C}_{\mathrm{q}}\right), 128.9(\mathrm{CH}), 125.0(\mathrm{CH}), 124.5(\mathrm{CH}), 122.8(\mathrm{CH}), 39.3\left(\mathrm{CH}_{2}\right), 31.7$ $\left(\mathrm{CH}_{2}\right), 20.3\left(\mathrm{CH}_{2}\right), 13.9\left(\mathrm{CH}_{3}\right)$. IR (ATR): 3300, 3082, 2956, 2869, 1652, 1517, 859, 706 $\mathrm{cm}^{-1}$. MS (ESI) $\mathrm{m} / \mathrm{z}$ (relative intensity): $543(100)[2 \mathrm{M}+\mathrm{Na}]^{+}, 283(78)[\mathrm{M}+\mathrm{Na}]^{+}, 261(32)$ $[\mathrm{M}+\mathrm{H}]^{+}$. HR-MS (ESI) $m / z$ calcd for $\mathrm{C}_{14} \mathrm{H}_{17} \mathrm{~N}_{2} \mathrm{OS}[\mathrm{M}+\mathrm{H}]^{+}$261.1056, found 261.1055. 
<smiles>Cc1cc(C)c(NC(=O)c2cccnc2C)c(C(=O)NC(C)c2ccccc2)c1</smiles>

3-Mesityl-N-(1-phenylethyl)picolinamide (188jl). The general procedure C was followed using 112j (56.5 mg, $0.25 \mathrm{mmol}$ ) $\mathrm{MnCl}_{2}$ (6.2 mg, $20 \mathrm{~mol} \%$ ), TMEDA (74 $\mu \mathrm{L}$, 2.0 equiv) in THF ( $0.25 \mathrm{~mL}), 151 \mathrm{l}(0.70 \mathrm{~mL}, 1.0 \mathrm{mmol}, 1.4 \mathrm{~m}$ in THF), $n B u B r(81 \mu \mathrm{L}, 3.0$ equiv). Isolation by column chromatography ( $n$-hexane/EtOAc: $2: 1 \rightarrow 1: 1$ ) yielded $18 \mathbf{j}$ l (46.5 mg, 54\%) as a white solid. M. p. $=121-122{ }^{\circ} \mathrm{C} .{ }^{1} \mathbf{H}-\mathbf{N M R}\left(400 \mathrm{MHz}, \mathrm{CDCl}_{3}\right) \delta=8.58$ (dd, $J=4.5,1.8 \mathrm{~Hz}, 1 \mathrm{H}), 8.20(\mathrm{~d}, J=8.7,1 \mathrm{H}), 7.53(\mathrm{dd}, J=7.7,1.8 \mathrm{~Hz}, 1 \mathrm{H}), 7.48(\mathrm{dd}, J=$ 7.7, $4.5 \mathrm{~Hz}, 1 \mathrm{H}), 7.37-7.29(\mathrm{~m}, 4 \mathrm{H}), 7.28-7.21(\mathrm{~m}, 1 \mathrm{H}), 6.97-6.89(\mathrm{~m}, 2 \mathrm{H}), 5.22(\mathrm{dq}, J=$ 8.7, $6.9 \mathrm{~Hz}, 1 \mathrm{H}), 2.33(\mathrm{~s}, 3 \mathrm{H}), 1.94(\mathrm{~s}, 3 \mathrm{H}), 1.87(\mathrm{~s}, 3 \mathrm{H}), 1.54$ (d, J = 6.9 Hz, 3H). ${ }^{13} \mathrm{C}-\mathbf{N M R}$ $\left(100 \mathrm{MHz} \mathrm{CDCl}_{3}\right) \delta=163.3\left(\mathrm{C}_{\mathrm{q}}\right), 147.8\left(\mathrm{C}_{\mathrm{q}}\right), 146.8(\mathrm{CH}), 143.5\left(\mathrm{C}_{\mathrm{q}}\right), 140.4(\mathrm{CH}), 137.2$ $\left(C_{q}\right), 136.5\left(C_{q}\right), 136.3\left(C_{q}\right), 134.4\left(C_{q}\right), 134.4\left(C_{q}\right), 128.5(C H), 128.0(C H), 127.1(C H)$, 126.2 (CH), $125.7(\mathrm{CH}), 48.2\left(\mathrm{CH}_{3}\right), 22.1(\mathrm{CH}), 21.2\left(\mathrm{CH}_{3}\right), 20.7\left(\mathrm{CH}_{3}\right), 20.7\left(\mathrm{CH}_{3}\right)$. IR (ATR): $3250,2972,1648,1529,1212,1000,850,705 \mathrm{~cm}^{-1}$. MS (ESI) $\mathrm{m} / z$ (relative intensity): $711(100)[2 \mathrm{M}+\mathrm{Na}]^{+}, 367(33)[\mathrm{M}+\mathrm{Na}]^{+}, 345(15)[\mathrm{M}+\mathrm{H}]^{+}$. HR-MS (ESI) $\mathrm{m} / z$ calcd for $\mathrm{C}_{23} \mathrm{H}_{25} \mathrm{~N}_{2} \mathrm{O}[\mathrm{M}+\mathrm{H}]^{+}$345.1961, found 345.1959.

\subsubsection{Mechanistic Studies}

\section{Intermolecular competition experiment}

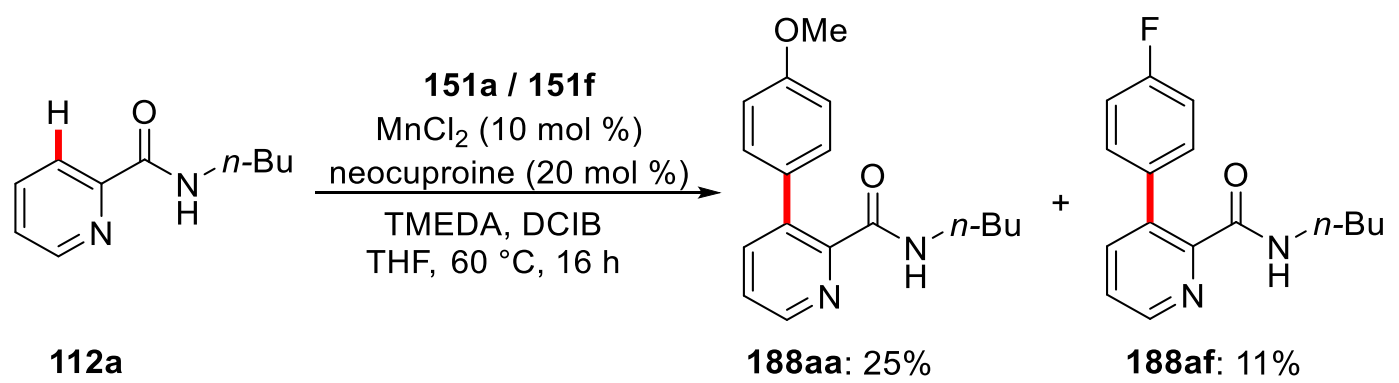

To a stirred solution of $112 \mathrm{a}(44.5 \mathrm{mg}, 0.25 \mathrm{mmol}), \mathrm{MnCl}_{2}(3.1 \mathrm{mg}, 10 \mathrm{~mol} \%$ ), neocuproine (10.4 mg, $20 \mathrm{~mol} \%$ ) and TMEDA (74 $\mu \mathrm{L}, 0.5 \mathrm{mmol})$ in THF $(0.40 \mathrm{~mL}), 151 \mathrm{a}$ 160 
(0.40 mL, $1.0 \mathrm{mmol}, 2.5 \mathrm{~m}$ in THF) and $151 \mathrm{f}(0.38 \mathrm{~mL}, 1.0 \mathrm{mmol}, 2.6 \mathrm{~m}$ in THF) (0.38 $\mathrm{mL}, 4.0$ equiv) were added dropwise over $30 \mathrm{~s}$. After the mixture was further stirred for $1 \mathrm{~min}$ at ambient temperature, a solution of 1,2-dichloro-2-methylpropane (DCIB) ( $88 \mu \mathrm{L}, 3.0$ equiv) in THF ( $0.1 \mathrm{~mL}$ ) was added to the reaction mixture. Then, the mixture was placed in a pre-heated oil bath at $60^{\circ} \mathrm{C}$. After stirring for $16 \mathrm{~h}$, a saturated aqueous $\mathrm{NH}_{4} \mathrm{Cl}(15 \mathrm{~mL})$ was added and the reaction mixture was extracted with EtOAc $(3 \times 15$ $\mathrm{mL}$ ). The combined organic layers were dried over $\mathrm{Na}_{2} \mathrm{SO}_{4}$, filtered and concentrated in vacuo. The crude product was purified by column chromatography ( $n$-hexane/EtOAc: $2: 1 \rightarrow 1: 1)$ to yield $188 \mathrm{aa}(17.8 \mathrm{mg}, 25 \%)$ and $188 \mathrm{af}(7.5 \mathrm{mg}, 11 \%)$.<smiles>CCCCNC(=O)c1ccccn1</smiles>

$112 a$<smiles>CCCCNC(=O)c1cccnc1</smiles>

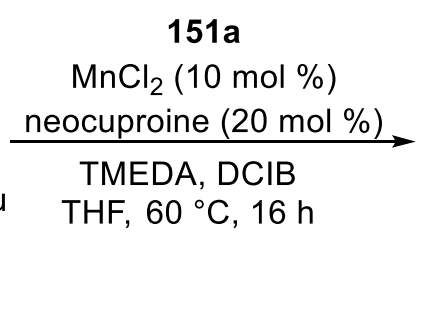

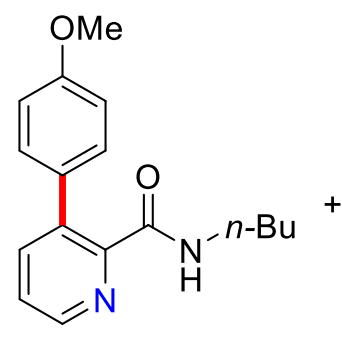

188aa: $33 \%$<smiles>CCCCNC(=O)c1cnccc1-c1ccc(OC)cc1</smiles>

188Ia: $52 \%$

To a stirred solution of $112 \mathrm{a}(44.5 \mathrm{mg}, 0.25 \mathrm{mmol})$ and $112 \mathrm{l}(44.5 \mathrm{mg}, 0.25 \mathrm{mmol})$, $\mathrm{MnCl}_{2}$ (3.1 mg, $\left.10 \mathrm{~mol} \%\right)$, neocuproine (10.4 mg, $20 \mathrm{~mol} \%$ ) and TMEDA (74 $\mu \mathrm{L}$, $0.5 \mathrm{mmol})$ in THF $(0.40 \mathrm{~mL}), 151 \mathrm{a}(0.40 \mathrm{~mL}, 1.0 \mathrm{mmol}, 2.5 \mathrm{~m}$ in THF) was added dropwise over $30 \mathrm{~s}$. After the mixture was further stirred for $1 \mathrm{~min}$ at ambient temperature, a solution of 1,2-dichloro-2-methylpropane (DCIB) $(88 \mu \mathrm{L}, 0.75 \mathrm{mmol})$ in THF $(0.10 \mathrm{~mL})$ was added to the reaction mixture. Then, the mixture was placed in a pre-heated oil bath at $60^{\circ} \mathrm{C}$. After stirring for $16 \mathrm{~h}$, a saturated aqueous $\mathrm{NH}_{4} \mathrm{Cl}(15 \mathrm{~mL})$ was added and the reaction mixture was extracted with EtOAc $(3 \times 15 \mathrm{~mL})$. The combined organic layers were dried over $\mathrm{Na}_{2} \mathrm{SO}_{4}$, filtered and concentrated in vacuo. The crude product was purified by column chromatography ( $n$-hexane/EtOAc: $2: 1 \rightarrow 1: 1$ ) to yield $188 \mathrm{aa}$ ( $23.4 \mathrm{mg}, 33 \%$ ) and $188 \mathrm{la}$ (36.9 $\mathrm{mg}, 52 \%)$. 


\section{Kinetic Isotope Effect Study}

KIE study by independent experiments

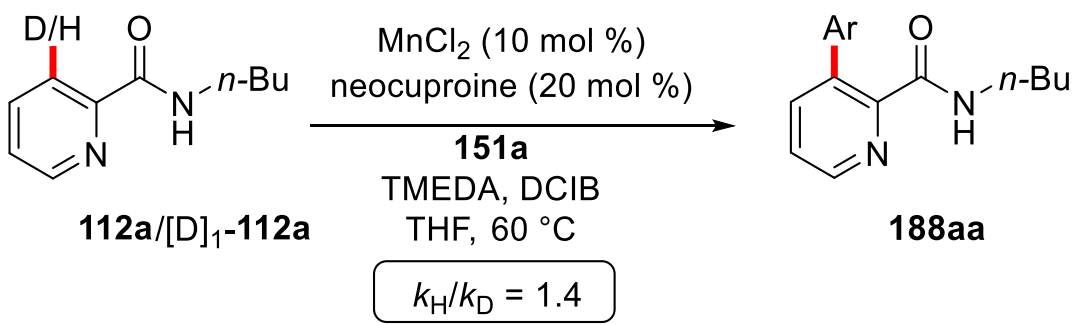

Five parallel independent reactions with $112 a$ or $[D]_{1}-112 a$ with $151 a$ were performed to determine the KIE.

To a stirred solution of $112 \mathrm{a}(44.5 \mathrm{mg}, 0.25 \mathrm{mmol})$ or $[\mathrm{D}]_{1}-112 \mathrm{a}(44.5 \mathrm{mg}, 0.25 \mathrm{mmol})$, $\mathrm{MnCl}_{2}$ (3.1 mg, $10 \mathrm{~mol} \%$ ), neocuproine (10.4 mg, $20 \mathrm{~mol} \%$ ) and TMEDA (74 $\mu \mathrm{L}, 0.5$ $\mathrm{mmol})$ in THF (0.40 mL), 151a (0.40 mL, $1.0 \mathrm{mmol}, 2.5 \mathrm{~m}$ in THF) was added dropwise over $30 \mathrm{~s}$. After the mixture was further stirred for $1 \mathrm{~min}$ at ambient temperature, a solution of 1,2-dichloro-2-methylpropane (DCIB) $(88 \mu \mathrm{L}, 0.75 \mathrm{mmol})$ in THF $(0.10 \mathrm{~mL})$ was added to the reaction mixture. Afterwards, the mixture was placed in a pre-heated oil bath at $60^{\circ} \mathrm{C}$. Then a saturated aqueous $\mathrm{NH}_{4} \mathrm{Cl}(15 \mathrm{~mL})$ was added and the reaction mixture was extracted with EtOAc $(3 \times 15 \mathrm{~mL})$. The combined organic layers were dried over $\mathrm{Na}_{2} \mathrm{SO}_{4}$, filtered and concentrated in vacuo. The crude product was purified by column chromatography ( $n$-hexane/EtOAc: $2: 1 \rightarrow 1: 1$ ) to yield 188aa and [D] ${ }_{1}$-188aa.

\begin{tabular}{|l|l|l|l|l|l|}
\hline $\mathrm{t}$ & $0.5 \mathrm{~h}$ & $1.5 \mathrm{~h}$ & $2.5 \mathrm{~h}$ & $3.5 \mathrm{~h}$ & $4.5 \mathrm{~h}$ \\
\hline $188 \mathrm{aa}$ & $7 \%$ & $20 \%$ & $32 \%$ & $43 \%$ & $56 \%$ \\
\hline$[\mathrm{D}]_{1}-188 \mathrm{aa}$ & $7 \%$ & $12 \%$ & $20 \%$ & $31 \%$ & $40 \%$ \\
\hline
\end{tabular}




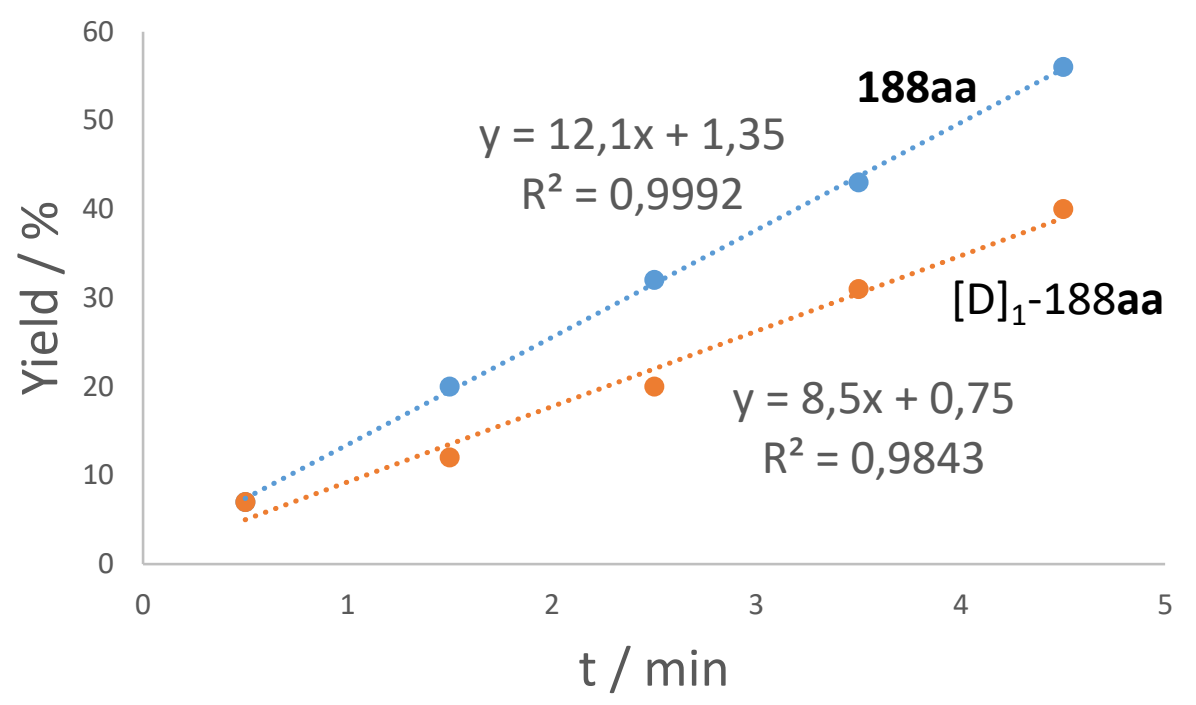

Well-defined Complex 189 as catalyst

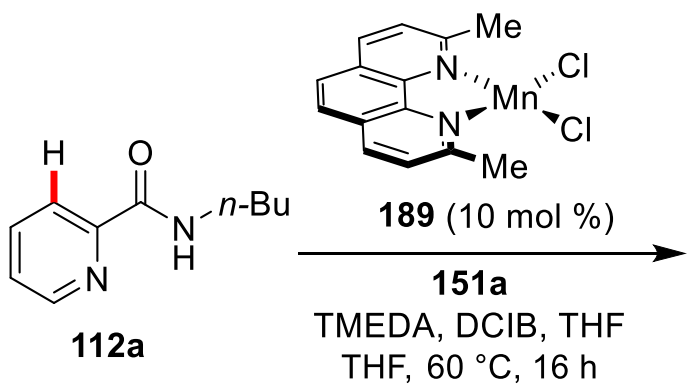<smiles>CCCCNC(=O)c1ncccc1-c1ccc(C(C)(C)C)cc1</smiles>

To a stirred solution of $112 \mathrm{a}$ (44.5 mg, $0.25 \mathrm{mmol}$ ), complex 189 (8.3 mg, $10 \mathrm{~mol} \%$ ) and TMEDA (74 $\mu \mathrm{L}, 0.5 \mathrm{mmol})$ in THF $(0.40 \mathrm{~mL}), 151 \mathrm{a}(0.40 \mathrm{~mL}, 1.0 \mathrm{mmol}, 2.5 \mathrm{~m}$ in THF) was added dropwise over $30 \mathrm{~s}$. After the mixture was further stirred for $1 \mathrm{~min}$ at ambient temperature, a solution of 1,2-dichloro-2-methylpropane (DCIB) (88 $\mu \mathrm{L}, 0.75$ $\mathrm{mmol})$ in THF $(0.10 \mathrm{~mL})$ was added to the reaction mixture. Then, the mixture was placed in a pre-heated oil bath at $60^{\circ} \mathrm{C}$. After stirring for $16 \mathrm{~h}$, a saturated aqueous $\mathrm{NH}_{4} \mathrm{Cl}(15 \mathrm{~mL})$ was added and the reaction mixture was extracted with EtOAc $(3 \times 15$ $\mathrm{mL}$ ). The combined organic layers were dried over $\mathrm{Na}_{2} \mathrm{SO}_{4}$, filtered and concentrated in vacuo. The crude product was purified by column chromatography ( $n$-hexane/EtOAc: $2: 1 \rightarrow 1: 1)$ to yield $188 \mathrm{aa}(61.1 \mathrm{mg}, 86 \%)$. 


\section{Gram scale $\mathrm{C}-\mathrm{H}$ arylation in flow}

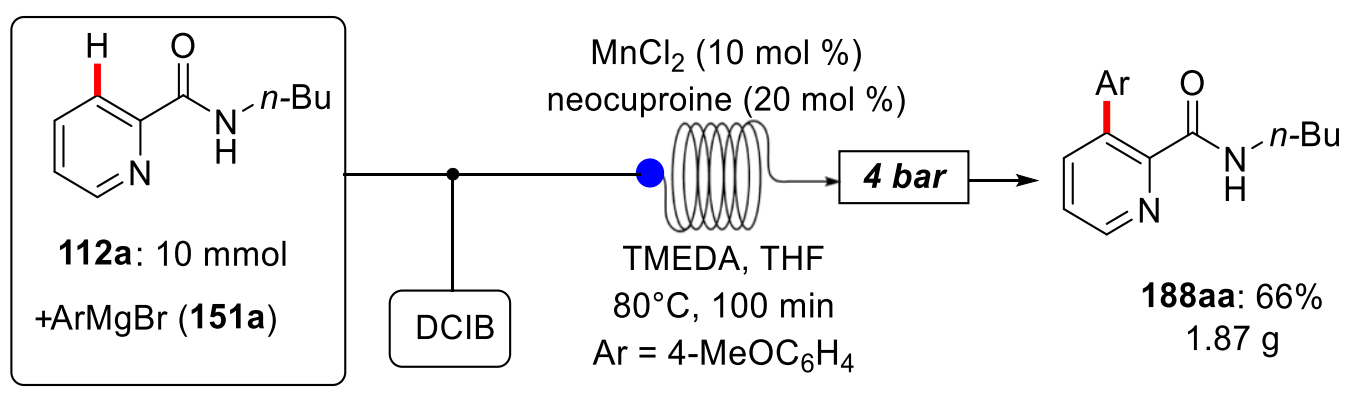

A $100 \mathrm{~mL}$ oven-dried round-bottom Schlenk flask was charged with amide 112a (1.78 g, $10 \mathrm{mmol}), \mathrm{MnCl}_{2}(0.124 \mathrm{~g}, 10 \mathrm{~mol} \%)$, neocuproine $(0.416 \mathrm{~g}, 20 \mathrm{~mol} \%)$ and TMEDA (3.0 mL, $20 \mathrm{mmol})$ in THF (1.0 mL) and 151a (16 mL, $1.0 \mathrm{mmol}, 2.5 \mathrm{~m}$ in THF) under $\mathrm{N}_{2}$ atmosphere and brought to a volume of $20 \mathrm{~mL}$. A solution of 1,2-dichloro-2methylpropane (DCIB) $(3.52 \mathrm{~mL}, 30 \mathrm{mmol})$ in THF was prepared in a vial and brought to a volume of $20 \mathrm{~mL}$. The solutions were charged in separate syringes pumps (Vapourtec V-3) operating at a flow rate of $100 \mu \mathrm{L} / \mathrm{min}$. The two solutions were mixed with a T-joint connection. Subsequently, the solution was pumped into the $10 \mathrm{~mL}$ standard heated reactor with 100 min residence time. The back pressure was set to 4.0 bar and the temperature of the reactor was set to $80^{\circ} \mathrm{C}$. Using the Flow Wizard system, the solution was collected automatically. Then, a saturated aqueous $\mathrm{NH}_{4} \mathrm{Cl}(45$ $\mathrm{mL})$ was added and the reaction mixture was extracted with EtOAc $(3 \times 45 \mathrm{~mL})$. The combined organic layers were dried over $\mathrm{Na}_{2} \mathrm{SO}_{4}$, filtered and concentrated in vacuo. The crude product was purified by column chromatography ( $n$-hexane/EtOAc: $2: 1 \rightarrow 1: 1$ ) yielding the desired product $188 \mathrm{aa}$ ( $1.87 \mathrm{~g}, 66 \%)$.

\section{Late-stage modification}




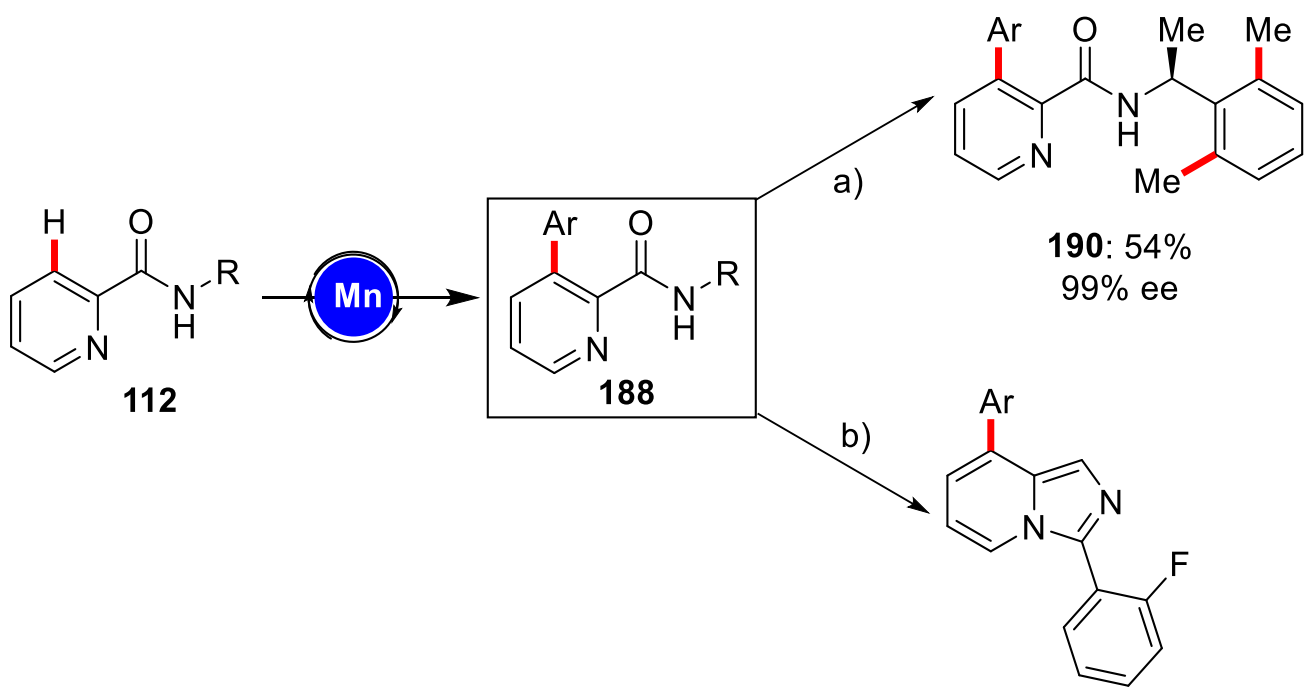

191: $53 \%$

Reaction a): ${ }^{[137 a]}$ To a Schlenk tube charged with $188 \mathrm{ja}(66.5 \mathrm{mg}, 0.20 \mathrm{mmol}$ ), $\mathrm{ZnCl}_{2} \bullet$ TMEDA (152 mg, $\left.0.60 \mathrm{mmol}\right)$ and THF (1.0 ml), MeMgBr $(457 \mu \mathrm{l}, 1.40 \mathrm{mmol}, 3$ m) was added dropwise at ambient temperature under $\mathrm{N}_{2}$ atmosphere. After stirring for $5 \mathrm{~min}$, dppen (11.9 mg, $0.03 \mathrm{mmol}, 15 \mathrm{~mol} \%$ ) and $\mathrm{FeCl}_{3}(4.9 \mathrm{mg}, 0.03 \mathrm{mmol}, 15$ mol \%) were added successively. After stirring at ambient temperature for further 5 min, 2,3-dichlorobutane $(70 \mu \mathrm{l}, 0.60 \mathrm{mmol})$ was added and the reaction mixture stirred at $60{ }^{\circ} \mathrm{C}$ for $16 \mathrm{~h}$. Then, a saturated aqueous $\mathrm{NH}_{4} \mathrm{Cl}(15 \mathrm{~mL})$ was added and the reaction mixture was extracted with EtOAc $(3 \times 15 \mathrm{~mL})$. The combined organic layers were dried over $\mathrm{Na}_{2} \mathrm{SO}_{4}$, filtered and concentrated in vacuo. The crude product was purified by column chromatography ( $n$-hexane/EtOAc: 3:1) yielding the desired product 190 (38.9 $\mathrm{mg}, 54 \%)$ as a white solid.<smiles>COc1ccc(-c2cccnc2C(=O)NC(C)c2c(C)cccc2C)cc1</smiles>

(S)-N-[1-(2,6-Dimethylphenyl)ethyl]-3-(4-methoxyphenyl)picolinamide (190).

${ }^{1} \mathrm{H}-\mathrm{NMR}\left(400 \mathrm{MHz}, \mathrm{CDCl}_{3}\right) \delta=8.50(\mathrm{dd}, J=4.7,1.7 \mathrm{~Hz}, 1 \mathrm{H}), 8.26(\mathrm{sbr}, 1 \mathrm{H}), 7.63(\mathrm{dd}, J=$ 
7.8, 1.7 Hz, 1H), 7.38 (dd, J = 7.8, 4.7 Hz, 1H), 7.22 (d, J= 8.9 Hz, 2H), 7.07-6.93 (m, $3 \mathrm{H}), 6.88(\mathrm{~d}, J=8.8 \mathrm{~Hz}, 2 \mathrm{H}), 5.63(\mathrm{dq}, J=8.2,7.2 \mathrm{~Hz}, 1 \mathrm{H}), 3.82(\mathrm{~s}, 3 \mathrm{H}), 2.47(\mathrm{~s}, 6 \mathrm{H}), 1.55$ $(\mathrm{d}, J=7.2 \mathrm{~Hz}, 3 \mathrm{H}) .{ }^{13} \mathrm{C}-\mathrm{NMR}\left(101 \mathrm{MHz}, \mathrm{CDCl}_{3}\right) \delta=164.2\left(\mathrm{C}_{\mathrm{q}}\right), 159.1\left(\mathrm{C}_{\mathrm{q}}\right), 148.3\left(\mathrm{C}_{\mathrm{q}}\right)$, $146.5(\mathrm{CH}), 140.0(\mathrm{CH}), 139.2\left(\mathrm{C}_{\mathrm{q}}\right), 137.6\left(\mathrm{C}_{\mathrm{q}}\right), 135.6\left(\mathrm{C}_{\mathrm{q}}\right), 131.4\left(\mathrm{C}_{\mathrm{q}}\right), 129.7(\mathrm{CH}), 129.4$ (CH), $126.7(\mathrm{CH}), 124.9(\mathrm{CH}), 113.4(\mathrm{CH}), 55.1\left(\mathrm{CH}_{3}\right), 45.4\left(\mathrm{CH}_{3}\right), 21.1(\mathrm{CH}), 19.8\left(\mathrm{CH}_{3}\right)$. IR (ATR): 3400, 2957, 2837, 1677, 1447, 1016, 766, $560 \mathrm{~cm}^{-1}$. MS (ESI) $\mathrm{m} / \mathrm{z}$ (relative intensity): $743(32)[2 \mathrm{M}+\mathrm{Na}]^{+}, 383(42)[\mathrm{M}+\mathrm{Na}]^{+}, 360$ (100) $[\mathrm{M}+\mathrm{H}]^{+}$. HR-MS (ESI) m/z calcd for $\mathrm{C}_{23} \mathrm{H}_{25} \mathrm{~N}_{2} \mathrm{O}_{2}[\mathrm{M}+\mathrm{H}]^{+}$361.1911, found 361.1907. HPLC analysis (Chiralcel IB-3, $i \mathrm{PrOH} / n$-hexane 30:70, flow rate $=1.0 \mathrm{~mL} / \mathrm{min}, \lambda=250 \mathrm{~nm}): t_{r}(\operatorname{minor})=7.3 \mathrm{~min}, t_{\mathrm{r}}$ $($ major $)=9.6 \mathrm{~min}$.
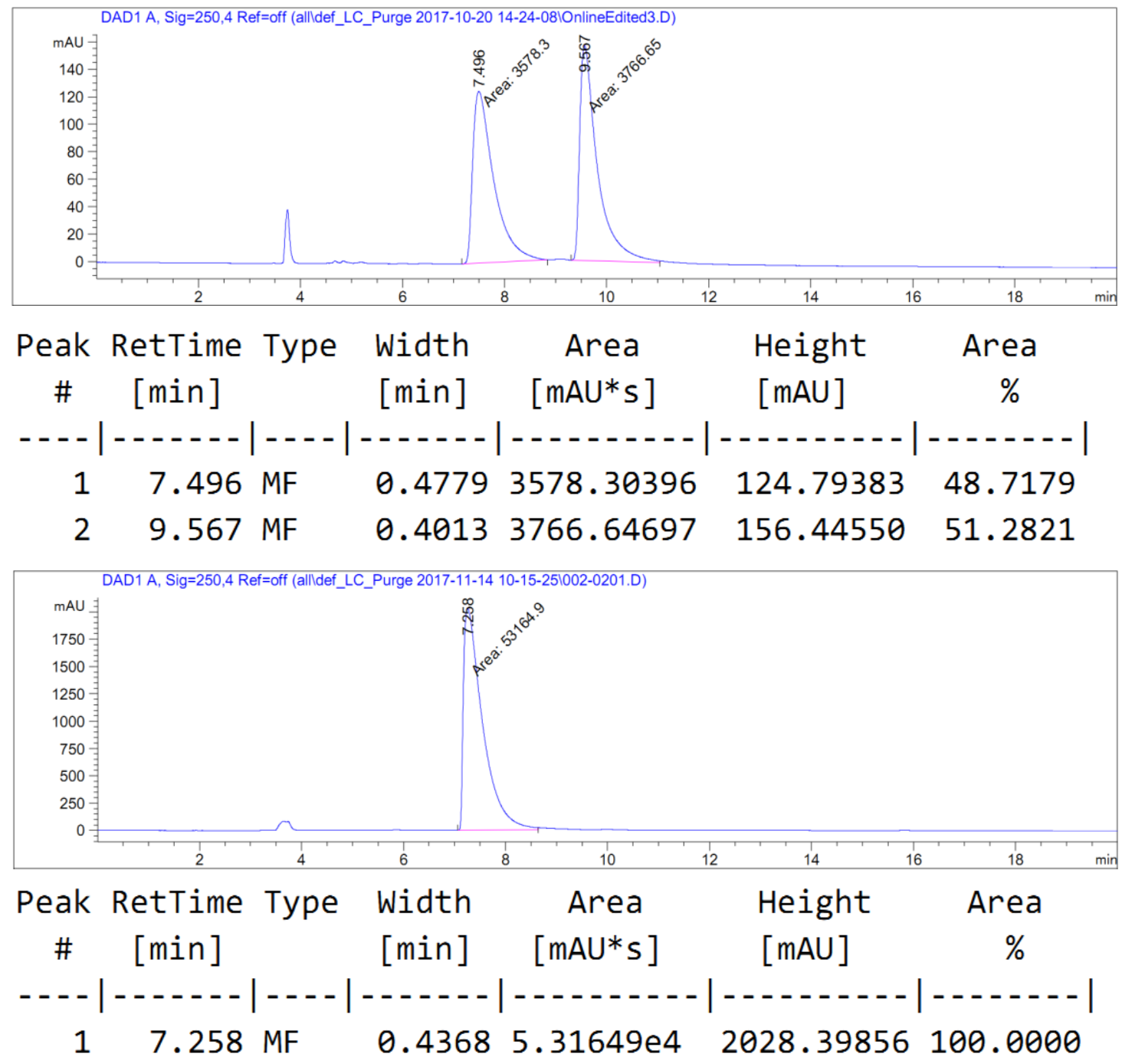

Reaction b): ${ }^{[137 \mathrm{~b}]}$ A mixture of $\mathbf{1 8 8 \mathrm { fa }}(67.3 \mathrm{mg}, 0.2 \mathrm{mmol})$ and $\mathrm{POCl}_{3}(1 \mathrm{~mL}, 10.7 \mathrm{mmol})$ 166 
was heated with stirring at $150{ }^{\circ} \mathrm{C}$ for $45 \mathrm{~min}$ in a microwave reactor. After cooling to ambient temperature, the mixture was concentrated in vacuo and $\mathrm{H}_{2} \mathrm{O}(10 \mathrm{~mL})$ was added to the residue. The $\mathrm{pH}$ of the resulting solution was adjusted to $7-8$ with concentrated $\mathrm{NH}_{4} \mathrm{OH}$ and the mixture was extracted with EtOAc $(3 \times 15 \mathrm{~mL})$. The combined organic layers were washed with brine $(10 \mathrm{~mL})$, dried over $\mathrm{Na}_{2} \mathrm{SO}_{4}$ and concentrated in vacuo. The residue was purified by column chromatography ( $n$-hexane/EtOAc: 6:1) to yield 191 (33.8 mg, 53\%) as white solid.<smiles>COc1ccc(-c2cccn3c(-c4ccccc4F)ncc23)cc1</smiles>

3-(2-Fluorophenyl)-8-(4-methoxyphenyl)imidazo[1,5-a]pyridine (191). ${ }^{1} \mathrm{H}-\mathrm{NMR}$ (400 $\left.\mathrm{MHz}, \mathrm{CDCl}_{3}\right) \delta=7.79-7.73(\mathrm{~m}, 2 \mathrm{H}), 7.72(\mathrm{~d}, J=1.0 \mathrm{~Hz}, 1 \mathrm{H}), 7.67(\mathrm{~d}, J=8.8 \mathrm{~Hz}, 2 \mathrm{H}), 7.48$ (m, 1H), $7.33(\mathrm{~m}, 1 \mathrm{H}), 7.29-7.21(\mathrm{~m}, 1 \mathrm{H}), 7.05(\mathrm{~d}, J=8.8 \mathrm{~Hz}, 2 \mathrm{H}), 6.77(\mathrm{dd}, J=6.7,0.9$ $\mathrm{Hz}, 1 \mathrm{H}), 6.72-6.65(\mathrm{~m}, 1 \mathrm{H}), 3.89(\mathrm{~s}, 3 \mathrm{H}) .{ }^{13} \mathrm{C}-\mathrm{NMR}\left(101 \mathrm{MHz}, \mathrm{CDCl}_{3}\right) \delta=160.0\left(\mathrm{~d},{ }^{1} \mathrm{~J}_{\mathrm{C}-\mathrm{F}}\right.$ $\left.=249.5 \mathrm{~Hz}, \mathrm{C}_{\mathrm{q}}\right), 159.9\left(\mathrm{C}_{\mathrm{q}}\right), 134.2\left(\mathrm{C}_{\mathrm{q}}\right), 132.5\left(\mathrm{C}_{\mathrm{q}}\right), 132.3\left(\mathrm{~d},{ }^{3} \mathrm{~J}_{\mathrm{C}-\mathrm{F}}=3.2 \mathrm{~Hz}, \mathrm{CH}\right), 131.5\left(\mathrm{C}_{\mathrm{q}}\right)$, $130.9\left(\mathrm{~d},{ }^{3} J_{\mathrm{C}-\mathrm{F}}=8.2 \mathrm{~Hz}, \mathrm{CH}\right), 130.1\left(\mathrm{C}_{\mathrm{q}}\right), 129.1(\mathrm{CH}), 124.9\left(\mathrm{~d},{ }^{4} J_{\mathrm{C}-\mathrm{F}}=3.4 \mathrm{~Hz}, \mathrm{CH}\right), 121.4$ (CH), $120.7(d, J=6.6 \mathrm{~Hz}, \mathrm{CH}), 118.4\left(\mathrm{~d},{ }^{2} \mathrm{~J}_{\mathrm{C}-\mathrm{F}}=14.4 \mathrm{~Hz}, \mathrm{C}_{\mathrm{q}}\right), 117.5(\mathrm{CH}), 116.2\left(\mathrm{~d},{ }^{2} J_{\mathrm{C}-\mathrm{F}}=\right.$ $21.5 \mathrm{~Hz}, \mathrm{CH}), 114.3(\mathrm{CH}), 113.2(\mathrm{CH}), 55.4\left(\mathrm{CH}_{3}\right) .{ }^{19} \mathrm{~F}-\mathrm{NMR}\left(376 \mathrm{MHz}, \mathrm{CDCl}_{3}\right) \delta=-111.14$. IR (ATR): 2933, 2836, 1608, 1507, 1246, 1029, 758, $725 \mathrm{~cm}^{-1}$. MS (ESI) $\mathrm{m} / z$ (relative intensity): 659 (8) [2M+Na] $]^{+}, 319(100)[\mathrm{M}+\mathrm{H}]^{+}$. HR-MS (ESI) $m / z$ calcd for $\mathrm{C}_{20} \mathrm{H}_{16} \mathrm{FN}_{2} \mathrm{O}$ $[\mathrm{M}+\mathrm{H}]^{+}$319.1241, found 319.1236. 
5.6 Metallaelectrocatalyses: Electricity for Resource-Economic Iron- and Manganese-Catalyzed C-H Activation

\subsubsection{Characterization Data}<smiles>CCCCn1cc(C(C)(C)NC(=O)c2ccccc2-c2ccc(OC)cc2)nn1</smiles>

$N$-[2-(1-n-Butyl-1H-1,2,3-triazol-4-yl)propan-2-yl]-4'-methoxy-[1,1'-biphenyl]-2-carboxamide (192). The general procedure E was followed using 159a (71.6 mg, 0.25 mmol) and 151a (0.88 mL, $1.75 \mathrm{mmol}, 2.0 \mathrm{~m}$ in THF). Purification by column chromatography on silica gel ( $n$-hexane/EtOAc: 3:1 $\rightarrow 1: 1)$ yielded 192 (93.2 mg, 95\%) as a white solid. M. p. $=112-113^{\circ} \mathrm{C} .{ }^{1} \mathrm{H}-\mathrm{NMR}\left(400 \mathrm{MHz}, \mathrm{CDCl}_{3}\right) \delta=7.63(\mathrm{dd}, \mathrm{J}=\mathbf{7 . 5}$, $1.5 \mathrm{~Hz}, 1 \mathrm{H}), 7.42$ (ddd, $J=7.5,7.5,1.5 \mathrm{~Hz}, 1 \mathrm{H}), 7.38-7.28(\mathrm{~m}, 5 \mathrm{H}), 6.91(\mathrm{~d}, J=8.8 \mathrm{~Hz}$, $2 \mathrm{H}), 5.89\left(\mathrm{~s}_{\mathrm{br}}, 1 \mathrm{H}\right), 4.27(\mathrm{t}, J=7.3 \mathrm{~Hz}, 2 \mathrm{H}), 3.84(\mathrm{~s}, 3 \mathrm{H}), 1.93-1.79(\mathrm{~m}, 2 \mathrm{H}), 1.60(\mathrm{~s}, 6 \mathrm{H})$, 1.41-1.28 (m, 2H), $0.95(\mathrm{t}, J=7.4 \mathrm{~Hz}, 3 \mathrm{H}) .{ }^{13} \mathrm{C}-\mathrm{NMR}\left(100 \mathrm{MHz}, \mathrm{CDCl}_{3}\right) \delta=168.5\left(\mathrm{C}_{\mathrm{q}}\right)$, $159.3\left(C_{q}\right), 152.7\left(C_{q}\right), 139.3\left(C_{q}\right), 136.2\left(C_{q}\right), 132.7\left(C_{q}\right), 130.2(C H), 130.1(C H), 129.9$ $(\mathrm{CH}), 128.6(\mathrm{CH}), 127.1(\mathrm{CH}), 120.4(\mathrm{CH}), 113.9(\mathrm{CH}), 55.4\left(\mathrm{CH}_{3}\right), 51.6\left(\mathrm{C}_{q}\right), 50.0\left(\mathrm{CH}_{2}\right)$, $32.2\left(\mathrm{CH}_{2}\right), 27.5\left(\mathrm{CH}_{3}\right), 19.8\left(\mathrm{CH}_{2}\right), 13.5\left(\mathrm{CH}_{3}\right)$. IR (ATR): 3243, 3142, 2954, 1664, 1515, 1300, 1242, $831 \mathrm{~cm}^{-1}$. MS (ESI) $\mathrm{m} / \mathrm{z}$ (relative intensity): 807 (12) [2M+Na] ${ }^{+}, 415$ (52) $[\mathrm{M}+\mathrm{Na}]^{+}, 393$ (34) $[\mathrm{M}+\mathrm{H}]^{+}$. HR-MS (ESI) $\mathrm{m} / \mathrm{z}$ calcd for $\mathrm{C}_{23} \mathrm{H}_{29} \mathrm{~N}_{4} \mathrm{O}_{2}[\mathrm{M}+\mathrm{H}]^{+} 393.2285$, found 393.2284. The analytical data are in accordance to those reported in the literature. 


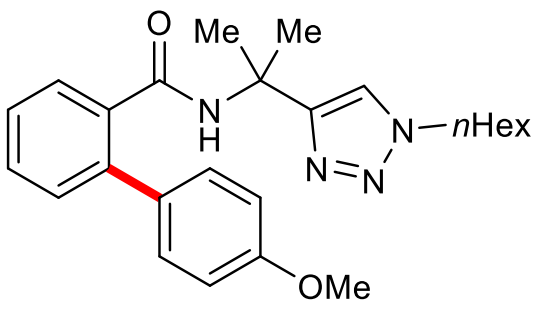

$N$-[2-(1-n-Hexyl-1H-1,2,3-triazol-4-yl)propan-2-yl]-4'-methoxy-[1,1'-biphenyl]-2-

carboxamide (193). The general procedure E was followed using 159b (78.6 mg, 0.25 $\mathrm{mmol}$ ) and 151a $(0.88 \mathrm{~mL}, 1.75 \mathrm{mmol}, 2.0 \mathrm{~m}$ in THF). Purification by column chromatography on silica gel ( $n$-hexane/EtOAc: 3:1 $\rightarrow 1: 1)$ yielded 193 (103.0 mg, 98\%) as a white solid. M. p. $=86-87^{\circ} \mathrm{C} .{ }^{1} \mathbf{H}-\mathbf{N M R}\left(400 \mathrm{MHz}, \mathrm{CDCl}_{3}\right) \delta=7.61(\mathrm{dd}, \mathrm{J}=7.5,1.5$ $\mathrm{Hz}, 1 \mathrm{H}), 7.41$ (ddd, $J=7.5,7.5,1.5 \mathrm{~Hz}, 1 \mathrm{H}), 7.36-7.28(\mathrm{~m}, 5 \mathrm{H}), 6.90(\mathrm{~d}, J=8.8 \mathrm{~Hz}, 2 \mathrm{H})$, $5.91(\mathrm{sbr}, 1 \mathrm{H}), 4.28(\mathrm{t}, J=7.3 \mathrm{~Hz}, 2 \mathrm{H}), 3.83(\mathrm{~s}, 3 \mathrm{H}), 1.95-1.80(\mathrm{~m}, 2 \mathrm{H}), 1.59(\mathrm{~s}, 6 \mathrm{H}), 1.37-$ $1.27(\mathrm{~m}, 6 \mathrm{H}), 0.87(\mathrm{t}, J=7.0 \mathrm{~Hz}, 3 \mathrm{H}) .{ }^{13} \mathrm{C}-\mathrm{NMR}\left(100 \mathrm{MHz}, \mathrm{CDCl}_{3}\right) \delta=168.5\left(\mathrm{C}_{\mathrm{q}}\right), 159.3$ $\left(C_{q}\right), 152.7\left(C_{q}\right), 139.2\left(C_{q}\right), 136.2\left(C_{q}\right), 132.6\left(C_{q}\right), 130.1(C H), 130.0(C H), 129.8(C H)$, $128.5(\mathrm{CH}), 127.1(\mathrm{CH}), 120.4(\mathrm{CH}), 113.9(\mathrm{CH}), 55.3\left(\mathrm{CH}_{3}\right), 51.6\left(\mathrm{C}_{\mathrm{q}}\right), 50.2\left(\mathrm{CH}_{2}\right), 31.1$ $\left(\mathrm{CH}_{2}\right), 30.2\left(\mathrm{CH}_{2}\right), 27.4\left(\mathrm{CH}_{3}\right), 26.1\left(\mathrm{CH}_{2}\right), 22.4\left(\mathrm{CH}_{2}\right), 13.9\left(\mathrm{CH}_{3}\right)$. IR (ATR): 3293, 2927, 2858, 1637, 1544, 1514, 1240, $831 \mathrm{~cm}^{-1}$. MS (ESI) m/z (relative intensity): 863 (18) $[2 \mathrm{M}+\mathrm{Na}]^{+}, 443(60)[\mathrm{M}+\mathrm{Na}]^{+}, 421(100)[\mathrm{M}+\mathrm{H}]^{+}$. HR-MS (ESI) $\mathrm{m} / z$ calcd for $\mathrm{C}_{25} \mathrm{H}_{33} \mathrm{~N}_{4} \mathrm{O}_{2}$ $[\mathrm{M}+\mathrm{H}]^{+}$421.2598, found 421.2599.<smiles>COc1ccc(-c2ccccc2C(=O)NC(C)(C)c2cn(Cc3ccccc3)nn2)cc1</smiles>

N-[2-(1-Benzyl-1H-1,2,3-triazol-4-yl)propan-2-yl]-4'-methoxy-[1,1'-biphenyl]-2carboxamide (194). The general procedure $\mathbf{E}$ was followed using 159c (80.1 mg, 0.25 $\mathrm{mmol}$ ) and $151 \mathrm{a}(0.88 \mathrm{~mL}, 1.75 \mathrm{mmol}, 2.0 \mathrm{~m}$ in THF). Purification by column chromatography on silica gel ( $n$-hexane/EtOAc: 3:1 $\rightarrow 1: 1$ ) yielded 194 (90.6 mg, 85\%)

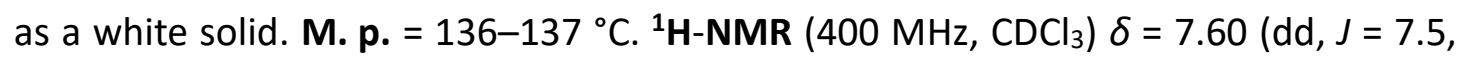


1.5 Hz, 1H), 7.40 (ddd, J = 7.5, 7.5, 1.5 Hz, 1H), 7.39-7.19 (m, 10H), 6.85 (d, J = 8.7 Hz, 2H), $5.87\left(\mathrm{sbr}_{\mathrm{br}} 1 \mathrm{H}\right), 5.45(\mathrm{~s}, 2 \mathrm{H}), 3.79(\mathrm{~s}, 3 \mathrm{H}), 1.56(\mathrm{~s}, 6 \mathrm{H}) .{ }^{13} \mathrm{C}-\mathrm{NMR}\left(100 \mathrm{MHz}, \mathrm{CDCl}_{3}\right) \delta$ $=168.5\left(C_{q}\right), 159.2\left(C_{q}\right), 153.2\left(C_{q}\right), 139.2\left(C_{q}\right), 136.1\left(C_{q}\right), 134.8\left(C_{q}\right), 132.6\left(C_{q}\right), 130.1$ (CH), $130.0(\mathrm{CH}), 129.8(\mathrm{CH}), 129.0(\mathrm{CH}), 128.5(\mathrm{CH}), 127.9(\mathrm{CH}), 127.1(\mathrm{CH}), 120.5(\mathrm{CH})$, $113.9(\mathrm{CH}), 55.3\left(\mathrm{CH}_{3}\right), 53.9\left(\mathrm{C}_{\mathrm{q}}\right), 51.6\left(\mathrm{CH}_{2}\right), 27.4\left(\mathrm{CH}_{3}\right)$. IR (ATR): 3300, 1639, 1516, 1251, 1180, 836, 732, $578 \mathrm{~cm}^{-1}$. MS (ESI) $\mathrm{m} / \mathrm{z}$ (relative intensity): 875 (26) [2M+Na] $]^{+}$, $449(65)[\mathrm{M}+\mathrm{Na}]^{+}, 427(100)[\mathrm{M}+\mathrm{H}]^{+}$. HR-MS (ESI) $\mathrm{m} / \mathrm{z}$ calcd for $\mathrm{C}_{26} \mathrm{H}_{27} \mathrm{~N}_{4} \mathrm{O}_{2}[\mathrm{M}+\mathrm{H}]^{+}$ 427.2129, found 427.2127.<smiles>CCCCn1cc(C(C)(C)NC(=O)c2ccc(OC)cc2-c2ccc(OC)cc2)nn1</smiles>

N-[2-(1-n-Butyl-1H-1,2,3-triazol-4-yl)propan-2-yl]-4',5-dimethoxy-[1,1'-biphenyl]-2carboxamide (195). The general procedure E was followed using 159d (79.1 mg, 0.25 $\mathrm{mmol}$ ) and 151a $(0.88 \mathrm{~mL}, 1.75 \mathrm{mmol}, 2.0 \mathrm{~m}$ in THF). Purification by column chromatography on silica gel ( $n$-hexane/EtOAc: 3:1 $\rightarrow 1: 1$ ) yielded 195 (101.4 mg, 96\%) as a white solid. M. p. $=91-92{ }^{\circ} \mathrm{C} .{ }^{1} \mathbf{H}-\mathbf{N M R}\left(400 \mathrm{MHz}, \mathrm{CDCl}_{3}\right) \delta=7.59$ (d, J = 8.6 Hz, 1H), $7.32(\mathrm{~s}, 1 \mathrm{H}), 7.25(\mathrm{~d}, J=8.7 \mathrm{~Hz}, 2 \mathrm{H}), 6.87(\mathrm{~d}, J=8.7 \mathrm{~Hz}, 2 \mathrm{H}), 6.82(\mathrm{dd}, J=8.6,2.6$ $\mathrm{Hz}, 1 \mathrm{H}), 6.74(\mathrm{~d}, J=2.6 \mathrm{~Hz}, 1 \mathrm{H}), 5.79\left(\mathrm{~s}_{\mathrm{br}}, 1 \mathrm{H}\right), 4.22(\mathrm{t}, J=7.3 \mathrm{~Hz}, 2 \mathrm{H}), 3.79(\mathrm{~s}, 3 \mathrm{H}), 3.77$ (s, 3H) 1.89-1.74 (m, 2H), $1.52(\mathrm{~s}, 6 \mathrm{H}), 1.34-1.23(\mathrm{~m}, 2 \mathrm{H}), 0.90(\mathrm{t}, J=7.4 \mathrm{~Hz}, 3 \mathrm{H}) .{ }^{13} \mathrm{C}-$ $\operatorname{NMR}\left(100 \mathrm{MHz}, \mathrm{CDCl}_{3}\right) \delta=167.8\left(\mathrm{C}_{\mathrm{q}}\right), 160.4\left(\mathrm{C}_{\mathrm{q}}\right), 159.3\left(\mathrm{C}_{\mathrm{q}}\right), 152.7\left(\mathrm{C}_{\mathrm{q}}\right), 141.1\left(\mathrm{C}_{\mathrm{q}}\right)$, $132.6\left(\mathrm{C}_{q}\right), 130.6(\mathrm{CH}), 129.9(\mathrm{CH}), 128.5\left(\mathrm{C}_{\mathrm{q}}\right), 120.3(\mathrm{CH}), 115.4(\mathrm{CH}), 113.8(\mathrm{CH}), 112.4$ (CH), $55.3\left(\mathrm{CH}_{3}\right), 55.2\left(\mathrm{CH}_{3}\right), 51.3\left(\mathrm{C}_{\mathrm{q}}\right), 49.8\left(\mathrm{CH}_{2}\right), 32.1\left(\mathrm{CH}_{2}\right), 27.4\left(\mathrm{CH}_{3}\right), 19.6\left(\mathrm{CH}_{2}\right)$, $13.3\left(\mathrm{CH}_{3}\right)$. IR (ATR): 3301, 2961, 1627, 1600, 1317, 1031, $838 \mathrm{~cm}^{-1}$. MS (ESI) $\mathrm{m} / \mathrm{z}$ (relative intensity): $867(13)[2 \mathrm{M}+\mathrm{Na}]^{+}, 445(52)[\mathrm{M}+\mathrm{Na}]^{+}, 423(100)[\mathrm{M}+\mathrm{H}]^{+}$. HR-MS (ESI) $m / z$ calcd for $\mathrm{C}_{24} \mathrm{H}_{31} \mathrm{~N}_{4} \mathrm{O}_{3}[\mathrm{M}+\mathrm{H}]^{+} 423.2391$, found 423.2389 . 
<smiles>CCCCn1cc(C(C)(C)NC(=O)c2ccc(C(C)(C)C)cc2-c2ccc(OC)cc2)nn1</smiles>

5-(tert-Butyl)-N-[2-(1-n-butyl-1H-1,2,3-triazol-4-yl)propan-2-yl]-4'-methoxy-[1,1'biphenyl]-2-carboxamide (196). The general procedure E was followed using 159e (85.6 mg, $0.25 \mathrm{mmol}$ ) and 151a $(0.88 \mathrm{~mL}, 1.75 \mathrm{mmol}, 2.0 \mathrm{~m}$ in THF). Purification by column chromatography on silica gel ( $n$-hexane/EtOAc: 3:1 $\rightarrow 1: 1)$ yielded 196 (109.9 mg, 98\%) as a white solid. M. p. $=100-101{ }^{\circ} \mathrm{C} .{ }^{1} \mathrm{H}-\mathrm{NMR}\left(400 \mathrm{MHz}, \mathrm{CDCl}_{3}\right) \delta=7.58(\mathrm{~d}$, $J=8.2 \mathrm{~Hz}, 1 \mathrm{H}), 7.37(\mathrm{dd}, J=8.2,2.0 \mathrm{~Hz}, 1 \mathrm{H}), 7.34-7.27(\mathrm{~m}, 4 \mathrm{H}), 6.92(\mathrm{~d}, J=8.8 \mathrm{~Hz}, 2 \mathrm{H})$, $5.86(\mathrm{sbr}, 1 \mathrm{H}), 4.26(\mathrm{t}, J=7.3 \mathrm{~Hz}, 2 \mathrm{H}), 3.83(\mathrm{~s}, 3 \mathrm{H}), 1.89-1.77(\mathrm{~m}, 2 \mathrm{H}), 1.58(\mathrm{~s}, 6 \mathrm{H}), 1.32$ $(\mathrm{s}, 11 \mathrm{H}), 0.94(\mathrm{t}, J=7.4 \mathrm{~Hz}, 3 \mathrm{H}) \cdot{ }^{13} \mathrm{C}-\mathrm{NMR}\left(100 \mathrm{MHz}, \mathrm{CDCl}_{3}\right) \delta=168.4\left(\mathrm{C}_{\mathrm{q}}\right), 159.2\left(\mathrm{C}_{\mathrm{q}}\right)$, $153.1\left(C_{q}\right), 152.7\left(C_{q}\right), 138.9\left(C_{q}\right), 133.3\left(C_{q}\right), 133.2\left(C_{q}\right), 130.1(C H), 128.4(C H), 127.2$ $(\mathrm{CH}), 124.2(\mathrm{CH}), 120.4(\mathrm{CH}), 113.8(\mathrm{CH}), 55.3\left(\mathrm{CH}_{3}\right), 51.5\left(\mathrm{C}_{\mathrm{q}}\right), 49.8\left(\mathrm{CH}_{2}\right), 34.7\left(\mathrm{C}_{\mathrm{q}}\right)$, $32.1\left(\mathrm{CH}_{2}\right), 31.1\left(\mathrm{CH}_{3}\right), 27.4\left(\mathrm{CH}_{3}\right), 19.7\left(\mathrm{CH}_{2}\right), 13.4\left(\mathrm{CH}_{3}\right)$. IR (ATR): 3281, 2961, 1634, 1514, 1240, 1044, $834 \mathrm{~cm}^{-1}$. MS (ESI) $\mathrm{m} / \mathrm{z}$ (relative intensity): 919 (10) [2M+Na], 471 (30) $[\mathrm{M}+\mathrm{Na}]^{+}, 449(100)[\mathrm{M}+\mathrm{H}]^{+}$. HR-MS (ESI) $\mathrm{m} / \mathrm{z}$ calcd for $\mathrm{C}_{27} \mathrm{H}_{37} \mathrm{~N}_{4} \mathrm{O}_{2}[\mathrm{M}+\mathrm{H}]^{+}$ 449.2911, found 449.2907 .<smiles>CCCCn1cc(C(C)(C)NC(=O)c2ccc(S(C)(=O)=O)cc2-c2ccc(OC)cc2)nn1</smiles>

N-[2-(1-n-Butyl-1H-1,2,3-triazol-4-yl)propan-2-yl]-4'-methoxy-5-(methylthio)-[1,1'biphenyl]-2-carboxamide (197). The general procedure E was followed using $\mathbf{1 5 9 f}$ ( $83.1 \mathrm{mg}, 0.25 \mathrm{mmol}$ ) and $151 \mathrm{a}(0.88 \mathrm{~mL}, 1.75 \mathrm{mmol}, 2.0 \mathrm{~m}$ in THF). Purification by column chromatography on silica gel ( $n$-hexane/EtOAc: 3:1 $\rightarrow 1: 1)$ yielded 197 (102.0 mg, 93\%) as a white solid. M. p. $=94-95^{\circ} \mathrm{C} .{ }^{1} \mathrm{H}-\mathbf{N M R}\left(400 \mathrm{MHz}, \mathrm{CDCl}_{3}\right) \delta=7.55(\mathrm{~d}, \mathrm{~J}=$ 
$8.1 \mathrm{~Hz}, 1 \mathrm{H}), 7.31(\mathrm{~s}, 1 \mathrm{H}), 7.25(\mathrm{~d}, J=8.7 \mathrm{~Hz}, 2 \mathrm{H}), 7.16(\mathrm{dd}, J=8.2,2.0 \mathrm{~Hz}, 1 \mathrm{H}), 7.08(\mathrm{~d}, J$ $=1.9 \mathrm{~Hz}, 1 \mathrm{H}), 6.88(\mathrm{~d}, J=8.7 \mathrm{~Hz}, 2 \mathrm{H}), 5.85\left(\mathrm{~s}_{\mathrm{br}}, 1 \mathrm{H}\right), 4.23(\mathrm{t}, J=7.3 \mathrm{~Hz}, 2 \mathrm{H}), 3.80(\mathrm{~s}, 3 \mathrm{H})$, $2.45(\mathrm{~s}, 3 \mathrm{H}), 1.90-1.75(\mathrm{~m}, 2 \mathrm{H}), 1.54(\mathrm{~s}, 6 \mathrm{H}), 1.35-1.26(\mathrm{~m}, 2 \mathrm{H}), 0.91(\mathrm{t}, J=7.4 \mathrm{~Hz}, 3 \mathrm{H})$. ${ }^{13} \mathrm{C}-\mathrm{NMR}\left(100 \mathrm{MHz}, \mathrm{CDCl}_{3}\right) \delta=167.8\left(\mathrm{C}_{\mathrm{q}}\right), 159.4\left(\mathrm{C}_{\mathrm{q}}\right), 152.6\left(\mathrm{C}_{\mathrm{q}}\right), 141.2\left(\mathrm{C}_{\mathrm{q}}\right), 139.8\left(\mathrm{C}_{\mathrm{q}}\right)$, $132.5\left(\mathrm{C}_{q}\right), 132.2\left(\mathrm{C}_{q}\right), 130.0(\mathrm{CH}), 129.2(\mathrm{CH}), 127.2(\mathrm{CH}), 124.3(\mathrm{CH}), 120.4(\mathrm{CH}), 113.9$ (CH), $55.3\left(\mathrm{CH}_{3}\right), 51.5\left(\mathrm{C}_{\mathrm{q}}\right), 49.9\left(\mathrm{CH}_{2}\right), 32.1\left(\mathrm{CH}_{2}\right), 27.4\left(\mathrm{CH}_{3}\right), 19.7\left(\mathrm{CH}_{2}\right), 15.2\left(\mathrm{CH}_{3}\right)$, $13.4\left(\mathrm{CH}_{3}\right)$. IR (ATR): 3274, 2869, 1633, 1513, 1239, 1025, $831 \mathrm{~cm}^{-1}$. MS (ESI) $\mathrm{m} / \mathrm{z}$ (relative intensity): $899(10)[2 \mathrm{M}+\mathrm{Na}]^{+}, 461(35)[\mathrm{M}+\mathrm{Na}]^{+}, 439(100)[\mathrm{M}+\mathrm{H}]^{+}$. HR-MS (ESI) $m / z$ calcd for $\mathrm{C}_{24} \mathrm{H}_{31} \mathrm{~N}_{4} \mathrm{O}_{2} \mathrm{~S}[\mathrm{M}+\mathrm{H}]^{+} 439.2162$, found 439.2159 .<smiles>CCCCn1cc(C(C)(C)NC(=O)c2ccc(F)cc2-c2ccc(OC)cc2)nn1</smiles>

$N$-[2-(1-n-Butyl-1H-1,2,3-triazol-4-yl)propan-2-yl]-5-fluoro-4'-methoxy-[1,1'-biphenyl]-2-carboxamide (198). The general procedure E was followed using 159g (76.1 $\mathrm{mg}, 0.25 \mathrm{mmol}$ ) and $151 \mathrm{a}(0.88 \mathrm{~mL}, 1.75 \mathrm{mmol}, 2.0 \mathrm{~m}$ in THF). Purification by column chromatography on silica gel ( $n$-hexane/EtOAc: 3:1 $\rightarrow 1: 1$ ) yielded 198 (95.4 mg, 93\%) as a white solid. M. p. $=109-110{ }^{\circ} \mathrm{C} .{ }^{1} \mathrm{H}-\mathrm{NMR}\left(400 \mathrm{MHz}, \mathrm{CDCl}_{3}\right) \delta=7.58(\mathrm{dd}, \mathrm{J}=8.5$, $6.1 \mathrm{~Hz}, 1 \mathrm{H}), 7.32(\mathrm{~s}, 1 \mathrm{H}), 7.25(\mathrm{~d}, J=8.8 \mathrm{~Hz}, 2 \mathrm{H}), 7.04-6.92(\mathrm{~m}, 2 \mathrm{H}), 6.87(\mathrm{~d}, J=8.8 \mathrm{~Hz}$, $2 \mathrm{H}), 5.92\left(\mathrm{~s}_{\mathrm{br}}, 1 \mathrm{H}\right), 4.24(\mathrm{t}, J=7.4 \mathrm{~Hz}, 2 \mathrm{H}), 3.79(\mathrm{~s}, 3 \mathrm{H}), 1.91-1.73(\mathrm{~m}, 2 \mathrm{H}), 1.55(\mathrm{~s}, 6 \mathrm{H})$, 1.41-1.21 (m, 2H), $0.91(\mathrm{t}, J=7.4 \mathrm{~Hz}, 3 \mathrm{H}) .{ }^{13} \mathrm{C}-\mathrm{NMR}\left(100 \mathrm{MHz}, \mathrm{CDCl}_{3}\right) \delta=167.5\left(\mathrm{C}_{\mathrm{q}}\right)$, $163.0\left(\mathrm{~d},{ }^{1} J_{C-F}=250.3 \mathrm{~Hz}, C_{q}\right), 159.6\left(C_{q}\right), 152.6\left(C_{q}\right), 141.8\left(d,{ }^{3} J_{C-F}=8.3 \mathrm{~Hz}, C_{q}\right), 132.3$ $\left(d,{ }^{4} J_{C-F}=3.4 \mathrm{~Hz}, C_{q}\right), 131.4\left(d,{ }^{4} J_{C-F}=1.8 \mathrm{~Hz}, C_{q}\right), 130.8\left(d,{ }^{3} J_{C-F}=9.0 \mathrm{~Hz}, C H\right), 129.9(C H)$, $120.3(\mathrm{CH}), 116.9\left(\mathrm{~d},{ }^{2} \mathrm{~J}_{\mathrm{C}-\mathrm{F}}=21.9 \mathrm{~Hz}, \mathrm{CH}\right), 114.0(\mathrm{CH}), 113.9\left(\mathrm{~d},{ }^{2} \mathrm{~J}_{\mathrm{C}-\mathrm{F}}=21.3 \mathrm{~Hz}, \mathrm{CH}\right), 55.3$ $\left(\mathrm{CH}_{3}\right), 51.6\left(\mathrm{C}_{\mathrm{q}}\right), 49.9\left(\mathrm{CH}_{2}\right), 32.1\left(\mathrm{CH}_{2}\right), 27.3\left(\mathrm{CH}_{3}\right), 19.7\left(\mathrm{CH}_{2}\right), 13.4\left(\mathrm{CH}_{3}\right) .{ }^{19} \mathrm{~F}-\mathrm{NMR}(376$ $\mathrm{MHz}_{\mathrm{CDCl}}$ ) $\delta=-110.69$ (ddd, $J=8.7,8.7,5.8 \mathrm{~Hz}$ ). IR (ATR): 3274, 2963, 2873, 1630, $1608,1517,1026,835 \mathrm{~cm}^{-1}$. MS (ESI) $\mathrm{m} / \mathrm{z}$ (relative intensity): 843 (40) [2M+Na] $]^{+}, 433$ 
(75) $[\mathrm{M}+\mathrm{Na}]^{+}, 411(100)[\mathrm{M}+\mathrm{H}]^{+}$. HR-MS (ESI) $\mathrm{m} / \mathrm{z}$ calcd for $\mathrm{C}_{23} \mathrm{H}_{28} \mathrm{FN}_{4} \mathrm{O}_{2}[\mathrm{M}+\mathrm{H}]^{+}$ 411.2191, found 411.2188.<smiles>CCCCn1cc(C(C)(C)NC(=O)c2ccc(Cl)cc2-c2ccc(OC)cc2)nn1</smiles>

N-[2-(1-n-Butyl-1H-1,2,3-triazol-4-yl)propan-2-yl]-5-chloro-4'-methoxy-[1,1'biphenyl]-2-carboxamide (199). The general procedure E was followed using $159 \mathrm{~h}$ (80.2 mg, $0.25 \mathrm{mmol}$ ) and 151a (0.88 mL, $1.75 \mathrm{mmol}, 2.0 \mathrm{~m}$ in THF). Purification by column chromatography on silica gel ( $n$-hexane/EtOAc: $3: 1 \rightarrow 1: 1$ ) yielded 199 (55.5 mg, $52 \%)$ as a white solid. M. p. $=106-107^{\circ} \mathrm{C} .{ }^{1} \mathrm{H}-\mathrm{NMR}\left(400 \mathrm{MHz}, \mathrm{CDCl}_{3}\right) \delta=7.53(\mathrm{~d}, \mathrm{~J}=$ $8.8 \mathrm{~Hz}, 1 \mathrm{H}), 7.32(\mathrm{~s}, 1 \mathrm{H}), 7.29-7.23(\mathrm{~m}, 4 \mathrm{H}), 6.88(\mathrm{~d}, J=8.8 \mathrm{~Hz}, 2 \mathrm{H}), 5.94(\mathrm{sbr}, 1 \mathrm{H}), 4.24$ $(\mathrm{t}, J=7.3 \mathrm{~Hz}, 2 \mathrm{H}), 3.80(\mathrm{~s}, 3 \mathrm{H}), 1.87-1.78(\mathrm{~m}, 2 \mathrm{H}), 1.55(\mathrm{~s}, 6 \mathrm{H}), 1.37-1.22(\mathrm{~m}, 2 \mathrm{H}), 0.92$ $(\mathrm{t}, J=7.4 \mathrm{~Hz}, 3 \mathrm{H}) .{ }^{13} \mathrm{C}-\mathrm{NMR}\left(100 \mathrm{MHz}, \mathrm{CDCl}_{3}\right) \delta=167.4\left(\mathrm{C}_{\mathrm{q}}\right), 159.6\left(\mathrm{C}_{\mathrm{q}}\right), 152.5\left(\mathrm{C}_{\mathrm{q}}\right)$, $141.0\left(\mathrm{C}_{\mathrm{q}}\right), 135.6\left(\mathrm{C}_{\mathrm{q}}\right), 134.5\left(\mathrm{C}_{\mathrm{q}}\right), 131.2\left(\mathrm{C}_{\mathrm{q}}\right), 130.1(\mathrm{CH}), 130.0(\mathrm{CH}), 129.9(\mathrm{CH}), 127.1$ $(\mathrm{CH}), 120.3(\mathrm{CH}), 114.0(\mathrm{CH}), 55.3\left(\mathrm{CH}_{3}\right), 51.6\left(\mathrm{C}_{\mathrm{q}}\right), 49.9\left(\mathrm{CH}_{2}\right), 32.1\left(\mathrm{CH}_{2}\right), 27.4\left(\mathrm{CH}_{3}\right)$, $19.7\left(\mathrm{CH}_{2}\right), 13.4\left(\mathrm{CH}_{3}\right)$. IR (ATR): 3272, 2958, 2089, 1631, 1549, 1257, 1023, $837 \mathrm{~cm}^{-1}$. MS (ESI) $m / z$ (relative intensity): $875(10)[2 \mathrm{M}+\mathrm{Na}]{ }^{+}\left({ }^{35} \mathrm{Cl}\right), 449(90)[\mathrm{M}+\mathrm{Na}]{ }^{+}\left({ }^{35} \mathrm{Cl}\right), 427$ (100) $[\mathrm{M}+\mathrm{H}]^{+}\left({ }^{35} \mathrm{Cl}\right)$. HR-MS (ESI) $\mathrm{m} / \mathrm{z}$ calcd for $\mathrm{C}_{27} \mathrm{H}_{28}{ }^{35} \mathrm{ClN}_{4} \mathrm{O}_{2}[\mathrm{M}+\mathrm{H}]^{+} 427.1895$, found 427.1890.<smiles>COc1ccc(-c2cc(C)ccc2C(=O)NC(C)(C)c2cn(Cc3ccccc3)nn2)cc1</smiles>

N-[2-(1-Benzyl-1H-1,2,3-triazol-4-yl)propan-2-yl]-4'-methoxy-5-methyl-[1,1'biphenyl]-2-carboxamide (200). The general procedure E was followed using 159i 
(83.6 mg, $0.25 \mathrm{mmol}$ ) and $151 \mathrm{a}(0.88 \mathrm{~mL}, 1.75 \mathrm{mmol}, 2.0 \mathrm{~m}$ in THF). Purification by column chromatography on silica gel ( $n$-hexane/EtOAc: 3:1 $\rightarrow 1: 1$ ) yielded 200 (87.0 mg, 79\%) as a white solid. M. p. $=89-90{ }^{\circ} \mathrm{C} .{ }^{1} \mathbf{H}-\mathbf{N M R}\left(300 \mathrm{MHz}, \mathrm{CDCl}_{3}\right) \delta=7.51(\mathrm{~d}, \mathrm{~J}=7.8$ $\mathrm{Hz}, 1 \mathrm{H}), 7.39-7.28(\mathrm{~m}, 4 \mathrm{H}), 7.26-7.19(\mathrm{~m}, 4 \mathrm{H}), 7.13(\mathrm{dd}, J=7.8,1.8 \mathrm{~Hz}, 1 \mathrm{H}), 7.07(\mathrm{~d}, J$ $=1.8 \mathrm{~Hz}, 1 \mathrm{H}), 6.83(\mathrm{~d}, J=8.7 \mathrm{~Hz}, 2 \mathrm{H}), 5.79(\mathrm{sbr}, 1 \mathrm{H}), 5.43(\mathrm{~s}, 2 \mathrm{H}), 3.78(\mathrm{~s}, 3 \mathrm{H}), 2.35(\mathrm{~s}$, 3H), $1.53(\mathrm{~s}, 6 \mathrm{H}) .{ }^{13} \mathrm{C}-\mathrm{NMR}\left(125 \mathrm{MHz}, \mathrm{CDCl}_{3}\right) \delta=168.2\left(\mathrm{C}_{\mathrm{q}}\right), 159.1\left(\mathrm{C}_{\mathrm{q}}\right), 153.1\left(\mathrm{C}_{\mathrm{q}}\right), 139.9$ $\left(C_{q}\right), 139.1\left(C_{q}\right), 134.7\left(C_{q}\right), 133.2\left(C_{q}\right), 132.7\left(C_{q}\right), 130.7(C H), 129.9(C H), 128.9(C H)$, 128.7 (CH), $128.4(\mathrm{CH}), 127.8(\mathrm{CH}), 127.7(\mathrm{CH}), 120.5(\mathrm{CH}), 113.8(\mathrm{CH}), 55.3\left(\mathrm{CH}_{3}\right), 53.9$ $\left(\mathrm{CH}_{2}\right), 51.5\left(\mathrm{C}_{\mathrm{q}}\right), 27.5\left(\mathrm{CH}_{3}\right), 21.3\left(\mathrm{CH}_{3}\right)$. IR (ATR): 3272, 2954, 1628, 1514, 1244, 1030, $582 \mathrm{~cm}^{-1}$. MS (ESI) $\mathrm{m} / \mathrm{z}$ (relative intensity): $903(10)[2 \mathrm{M}+\mathrm{Na}]^{+}, 463(45)[\mathrm{M}+\mathrm{Na}]^{+}, 441$ (100) $[\mathrm{M}+\mathrm{H}]^{+}$. HR-MS (ESI) $m / z$ calcd for $\mathrm{C}_{27} \mathrm{H}_{29} \mathrm{~N}_{4} \mathrm{O}_{2}[\mathrm{M}+\mathrm{H}]^{+} 441.2285$, found 441.2287.<smiles>COc1ccc(-c2cc(C(F)(F)F)ccc2C(=O)NC(C)(C)c2cn(Cc3ccccc3)nn2)cc1</smiles>

N-[2-(1-Benzyl-1H-1,2,3-triazol-4-yl)propan-2-yl]-4'-methoxy-5-(trifluoromethyl)-

[1,1'-biphenyl]-2-carboxamide (201). The general procedure E was followed using 159j (97.1 mg, $0.25 \mathrm{mmol}$ ) and 151a (0.88 mL, $1.75 \mathrm{mmol}, 2.0 \mathrm{~m}$ in THF). Purification by column chromatography on silica gel ( $n$-hexane/EtOAc: 3:1 $\rightarrow 1: 1)$ yielded 201 (66.8 mg, 54\%) as a white solid. M. p. $=100-101^{\circ} \mathrm{C} .{ }^{1} \mathrm{H}-\mathrm{NMR}\left(400 \mathrm{MHz}, \mathrm{CDCl}_{3}\right) \delta=7.68(\mathrm{dd}$, $J=7.9,0.8 \mathrm{~Hz}, 1 \mathrm{H}), 7.59-7.52(\mathrm{~m}, 2 \mathrm{H}), 7.39-7.30(\mathrm{~m}, 3 \mathrm{H}), 7.31-7.26(\mathrm{~m}, 3 \mathrm{H}), 7.24-$ $7.19(\mathrm{~m}, 2 \mathrm{H}), 6.86(\mathrm{~d}, J=8.7 \mathrm{~Hz}, 2 \mathrm{H}), 6.00(\mathrm{sbr}, 1 \mathrm{H}), 5.44(\mathrm{~s}, 2 \mathrm{H}), 3.79(\mathrm{~s}, 3 \mathrm{H}), 1.56(\mathrm{~s}$, 6H). ${ }^{13}$ C-NMR $\left(125 \mathrm{MHz}, \mathrm{CDCl}_{3}\right) \delta=167.3\left(\mathrm{C}_{\mathrm{q}}\right), 159.7\left(\mathrm{C}_{\mathrm{q}}\right), 153.0\left(\mathrm{C}_{\mathrm{q}}\right), 140.0\left(\mathrm{C}_{\mathrm{q}}\right), 139.3$ $\left(C_{q}\right), 134.7\left(C_{q}\right), 131.8\left(q, \quad{ }^{2} J_{C-F}=32.6 \mathrm{~Hz}, C_{q}\right), 131.0\left(C_{q}\right), 130.0(C H), 129.1(C H)$, $129.0(\mathrm{CH}), 128.7(\mathrm{CH}), 128.0(\mathrm{CH}), 127.0\left(\mathrm{q},{ }^{3} \mathrm{~J}_{\mathrm{C}-\mathrm{F}}=3.8 \mathrm{~Hz}, \mathrm{CH}\right), 123.8\left(\mathrm{q},{ }^{3} \mathrm{~J}_{\mathrm{C}-\mathrm{F}}=3.7 \mathrm{~Hz}\right.$, $\mathrm{CH}), 123.7\left(\mathrm{q},{ }^{1} J_{\mathrm{C}-\mathrm{F}}=272.5 \mathrm{~Hz}, \mathrm{C}_{\mathrm{q}}\right), 120.4(\mathrm{CH}), 114.1(\mathrm{CH}), 55.4\left(\mathrm{CH}_{3}\right), 54.0\left(\mathrm{CH}_{2}\right), 51.8$ $\left(\mathrm{C}_{\mathrm{q}}\right), 27.3\left(\mathrm{CH}_{3}\right) .{ }^{19} \mathrm{~F}-\mathrm{NMR}\left(376 \mathrm{MHz}, \mathrm{CDCl}_{3}\right) \delta=-62.80$ (s). IR (ATR): 3270, 2935, 1635, 
$1518,1257,1116,837 \mathrm{~cm}^{-1}$. MS (ESI) $\mathrm{m} / z$ (relative intensity): $1011(10)[2 \mathrm{M}+\mathrm{Na}]^{+}, 517$ (60) $[\mathrm{M}+\mathrm{Na}]^{+}, 495(100)[\mathrm{M}+\mathrm{H}]^{+}$. HR-MS (ESI) $\mathrm{m} / \mathrm{z}$ calcd for $\mathrm{C}_{27} \mathrm{H}_{26} \mathrm{~F}_{3} \mathrm{~N}_{4} \mathrm{O}_{2}[\mathrm{M}+\mathrm{H}]^{+}$ 495.2002, found 495.2002 .<smiles>CCCCn1cc(C(C)(C)NC(=O)c2cccc(F)c2-c2ccc(OC)cc2)nn1</smiles>

\section{N-[2-(1-n-Butyl-1H-1,2,3-triazol-4-yl)propan-2-yl]-4-fluoro-4'-methoxy-[1,1'-}

biphenyl]-2-carboxamide (202). The general procedure E was followed using 159k (76.1 mg, $0.25 \mathrm{mmol}$ ) and 151a (0.88 mL, $1.75 \mathrm{mmol}, 2.0 \mathrm{~m}$ in THF). Purification by column chromatography on silica gel ( $n$-hexane/EtOAc: 3:1 $\rightarrow 1: 1$ ) yielded 202 (54.4 mg, $53 \%)$ as a white solid. M. p. $=116-117{ }^{\circ} \mathrm{C} .{ }^{1} \mathrm{H}-\mathrm{NMR}\left(400 \mathrm{MHz}, \mathrm{CDCl}_{3}\right) \delta=7.41(\mathrm{dd}, \mathrm{J}=$ 7.6, $1.3 \mathrm{~Hz}, 1 \mathrm{H}), 7.32-7.20(\mathrm{~m}, 4 \mathrm{H}), 7.15$ (ddd, $J=9.4,8.2,1.3 \mathrm{~Hz}, 1 \mathrm{H}), 6.91(\mathrm{~d}, J=8.8$ $\mathrm{Hz}, 2 \mathrm{H}), 5.90(\mathrm{sbr}, 1 \mathrm{H}), 4.24(\mathrm{t}, J=7.3 \mathrm{~Hz}, 2 \mathrm{H}), 3.81(\mathrm{~s}, 3 \mathrm{H}), 1.91-1.73(\mathrm{~m}, 2 \mathrm{H}), 1.52(\mathrm{~s}$, $6 \mathrm{H}), 1.37-1.27(\mathrm{~m}, 2 \mathrm{H}), 0.93(\mathrm{t}, J=7.4 \mathrm{~Hz}, 3 \mathrm{H}) .{ }^{13} \mathrm{C}-\mathrm{NMR}\left(100 \mathrm{MHz}, \mathrm{CDCl}_{3}\right) \delta=166.9$ (d, $\left.{ }^{4} J_{C-F}=3.2 \mathrm{~Hz}, C_{q}\right), 159.7\left(d,{ }^{1} J_{C-F}=246.5 \mathrm{~Hz}, C_{q}\right), 159.6\left(C_{q}\right), 152.6\left(C_{q}\right), 138.8\left(d,{ }^{3} J_{C-F}=\right.$ $\left.1.8 \mathrm{~Hz}, \mathrm{C}_{\mathrm{q}}\right), 131.0\left(\mathrm{~d},{ }^{4} J_{\mathrm{C}-\mathrm{F}}=1.5 \mathrm{~Hz}, \mathrm{CH}\right), 128.8\left(\mathrm{~d},{ }^{3} J_{\mathrm{C}-\mathrm{F}}=8.6 \mathrm{~Hz}, \mathrm{CH}\right), 126.9\left(\mathrm{~d},{ }^{2} J_{\mathrm{C}-\mathrm{F}}=\right.$ $\left.17.1 \mathrm{~Hz}, \mathrm{C}_{\mathrm{q}}\right), 125.3\left(\mathrm{C}_{\mathrm{q}}\right), 124.1\left(\mathrm{~d},{ }^{4} \mathrm{~J}_{\mathrm{C}-\mathrm{F}}=3.6 \mathrm{~Hz}, \mathrm{CH}\right), 120.3(\mathrm{CH}), 117.2\left(\mathrm{~d},{ }^{2} \mathrm{~J}_{\mathrm{C}-\mathrm{F}}=23.5\right.$ $\mathrm{Hz}, \mathrm{CH}), 113.9(\mathrm{CH}), 55.3\left(\mathrm{CH}_{3}\right), 51.7\left(\mathrm{C}_{\mathrm{q}}\right), 49.9\left(\mathrm{CH}_{2}\right), 32.2\left(\mathrm{CH}_{2}\right), 27.4\left(\mathrm{CH}_{3}\right), 19.7\left(\mathrm{CH}_{2}\right)$, $13.4\left(\mathrm{CH}_{3}\right) .{ }^{19} \mathrm{~F}-\mathrm{NMR}\left(376 \mathrm{MHz}, \mathrm{CDCl}_{3}\right) \delta=-115.10$ (dd, $\left.J=9.4,5.1 \mathrm{~Hz}\right)$. IR (ATR): 3285 , 2954, 1638, 1454, 1240, 838, $568 \mathrm{~cm}^{-1}$. MS (ESI) $\mathrm{m} / \mathrm{z}$ (relative intensity): 843 (12) $[2 \mathrm{M}+\mathrm{Na}]^{+}, 433(96)[\mathrm{M}+\mathrm{Na}]^{+}, 411(100)[\mathrm{M}+\mathrm{H}]^{+}$. HR-MS (ESI) $\mathrm{m} / \mathrm{z}$ calcd for $\mathrm{C}_{23} \mathrm{H}_{28} \mathrm{FN}_{4} \mathrm{O}_{2}$ $[\mathrm{M}+\mathrm{H}]^{+}$411.2191, found 411.2192 . 
<smiles>COc1ccc(-c2ccc(OC)cc2C(=O)NC(C)(C)c2cn(Cc3ccccc3)nn2)cc1</smiles>

N-[2-(1-Benzyl-1H-1,2,3-triazol-4-yl)propan-2-yl]-4,4'-dimethoxy-[1,1'-biphenyl]-2carboxamide (203). The general procedure E was followed using 159l (87.6 mg, 0.25 mmol) and 151a $(0.88 \mathrm{~mL}, 1.75 \mathrm{mmol}, 2.0 \mathrm{~m}$ in THF). Purification by column chromatography on silica gel ( $n$-hexane/EtOAc: 3:1 $\rightarrow 1: 1)$ yielded 203 (77.6 mg, 68\%) as a white solid. M. p. $=120-121{ }^{\circ} \mathrm{C} .{ }^{1} \mathbf{H}-\mathbf{N M R}\left(300 \mathrm{MHz}, \mathrm{CDCl}_{3}\right) \delta=7.42-7.30(\mathrm{~m}, 3 \mathrm{H})$, $7.30(\mathrm{~s}, 1 \mathrm{H}), 7.30-7.13(\mathrm{~m}, 6 \mathrm{H}), 6.97(\mathrm{dd}, J=8.5,2.8 \mathrm{~Hz}, 1 \mathrm{H}), 6.84(\mathrm{~d}, J=8.7 \mathrm{~Hz}, 2 \mathrm{H})$, $5.81(\mathrm{sbr}, 1 \mathrm{H}), 5.46(\mathrm{~s}, 2 \mathrm{H}), 3.84(\mathrm{~s}, 3 \mathrm{H}), 3.80(\mathrm{~s}, 3 \mathrm{H}), 1.54(\mathrm{~s}, 6 \mathrm{H}) .{ }^{13} \mathrm{C}-\mathrm{NMR}(100 \mathrm{MHz}$, $\left.\mathrm{CDCl}_{3}\right) \delta=167.9\left(\mathrm{C}_{\mathrm{q}}\right), 158.9\left(\mathrm{C}_{\mathrm{q}}\right), 158.6\left(\mathrm{C}_{\mathrm{q}}\right), 153.1\left(\mathrm{C}_{\mathrm{q}}\right), 136.8\left(\mathrm{C}_{\mathrm{q}}\right), 134.7\left(\mathrm{C}_{\mathrm{q}}\right), 132.3\left(\mathrm{C}_{\mathrm{q}}\right)$, $131.7\left(\mathrm{C}_{q}\right), 131.4(\mathrm{CH}), 130.1(\mathrm{CH}), 129.0(\mathrm{CH}), 128.5(\mathrm{CH}), 127.9(\mathrm{CH}), 120.5(\mathrm{CH}), 116.5$ (CH), $113.9(\mathrm{CH}), 113.0(\mathrm{CH}), 55.5\left(\mathrm{CH}_{3}\right), 55.4\left(\mathrm{CH}_{3}\right), 54.0\left(\mathrm{CH}_{2}\right), 51.6\left(\mathrm{C}_{\mathrm{q}}\right), 27.4\left(\mathrm{CH}_{3}\right) . \mathrm{IR}$ (ATR): 3290, 1634, 1548, 1465, 1271, $1045 \mathrm{~cm}^{-1}$. MS (ESI) m/z (relative intensity): 935 (10) $[2 \mathrm{M}+\mathrm{Na}]^{+}, 479(100)[\mathrm{M}+\mathrm{Na}]^{+}, 457(100)[\mathrm{M}+\mathrm{H}]^{+}$. HR-MS (ESI) $\mathrm{m} / \mathrm{z}$ calcd for $\mathrm{C}_{27} \mathrm{H}_{29} \mathrm{~N}_{4} \mathrm{O}_{3}[\mathrm{M}+\mathrm{H}]^{+} 457.2234$, found 457.2236 .<smiles>COc1ccc(-c2cc3ccccc3cc2C(=O)NC(C)(C)c2cn(Cc3ccccc3)nn2)cc1</smiles>

N-[2-(1-Benzyl-1H-1,2,3-triazol-4-yl)propan-2-yl]-3-(4-methoxyphenyl)-2naphthamide (204). The general procedure E was followed using 159m (92.6 mg, 0.25 $\mathrm{mmol}$ ) and $151 \mathrm{a}(0.88 \mathrm{~mL}, 1.75 \mathrm{mmol}, 2.0 \mathrm{~m}$ in THF). Purification by column chromatography on silica gel ( $n$-hexane/EtOAc: 3:1 $\rightarrow 1: 1$ ) yielded 204 (85.8 mg, 72\%) as a white solid. M. p. $=161-162{ }^{\circ} \mathrm{C} .{ }^{1} \mathrm{H}-\mathrm{NMR}\left(400 \mathrm{MHz}, \mathrm{CDCl}_{3}\right) \delta=8.12(\mathrm{~s}, 1 \mathrm{H}), 7.86-$ $7.83(\mathrm{dd}, J=7.8,2.1 \mathrm{~Hz}, 1 \mathrm{H}), 7.81-7.78(\mathrm{dd}, J=7.8,2.1 \mathrm{~Hz}, 1 \mathrm{H}), 7.73(\mathrm{~s}, 1 \mathrm{H}), 7.53-7.44$ 
(m, 2H), 7.38-7.31 (m, 6H), 7.26-7.21 (m, 2H), $6.87(\mathrm{~d}, J=8.8 \mathrm{~Hz}, 2 \mathrm{H}), 6.07\left(\mathrm{~s}_{\mathrm{br}}, 1 \mathrm{H}\right)$, $5.45(\mathrm{~s}, 2 \mathrm{H}), 3.80(\mathrm{~s}, 3 \mathrm{H}), 1.61(\mathrm{~s}, 6 \mathrm{H}) .{ }^{13} \mathrm{C}-\mathrm{NMR}\left(100 \mathrm{MHz}, \mathrm{CDCl}_{3}\right) \delta=168.3\left(\mathrm{C}_{\mathrm{q}}\right), 159.2$ $\left(C_{q}\right), 153.2\left(C_{q}\right), 136.6\left(C_{q}\right), 134.8\left(C_{q}\right), 134.5\left(C_{q}\right), 133.7\left(C_{q}\right), 132.7\left(C_{q}\right), 131.7\left(C_{q}\right)$, $130.2(\mathrm{CH}), 129.1(\mathrm{CH}), 129.0(\mathrm{CH}), 128.7(\mathrm{CH}), 128.6(\mathrm{CH}), 128.2(\mathrm{CH}), 128.0(\mathrm{CH})$, $127.6(\mathrm{CH}), 127.4(\mathrm{CH}), 126.4(\mathrm{CH}), 120.6(\mathrm{CH}), 113.9(\mathrm{CH}), 55.3\left(\mathrm{CH}_{3}\right), 54.0\left(\mathrm{CH}_{2}\right), 51.6$ $\left(\mathrm{C}_{\mathrm{q}}\right), 27.5\left(\mathrm{CH}_{3}\right)$. IR (ATR): 3269, 2024, 1966, 1634, 1543, 1455, 1241, $720 \mathrm{~cm}^{-1}$. MS (ESI) $m / z$ (relative intensity): $975(12)[2 \mathrm{M}+\mathrm{Na}]^{+}, 499(70)[\mathrm{M}+\mathrm{Na}]^{+}, 477(100)[\mathrm{M}+\mathrm{H}]^{+}$. HR-MS (ESI) $m / z$ calcd for $\mathrm{C}_{30} \mathrm{H}_{29} \mathrm{~N}_{4} \mathrm{O}_{2}[\mathrm{M}+\mathrm{H}]^{+} 477.2285$, found 477.2285. The analytical data are in accordance to those reported in the literature.<smiles>CCCCn1cc(C(C)(C)NC(=O)c2ccsc2-c2ccc(OC)cc2)nn1</smiles>

N-[2-(1-n-Butyl-1H-1,2,3-triazol-4-yl)propan-2-yl]-2-(4-methoxyphenyl)thiophene3-carboxamide (205). The general procedure E was followed using 159n (73.1 mg, 0.25 mmol) 151a (0.88 mL, $1.75 \mathrm{mmol}, 2.0 \mathrm{~m}$ in THF). Purification by column chromatography on silica gel ( $n$-hexane/EtOAc: 3:1 $\rightarrow 1: 1)$ yielded 205 (77.7 mg, 78\%) as a white solid. M. p. $=98-99{ }^{\circ} \mathrm{C} .{ }^{1} \mathbf{H}-\mathbf{N M R}\left(400 \mathrm{MHz}, \mathrm{CDCl}_{3}\right) \delta=7.43-7.35(\mathrm{~m}, 3 \mathrm{H})$, $7.32(\mathrm{~d}, J=5.3 \mathrm{~Hz}, 1 \mathrm{H}), 7.14(\mathrm{~d}, J=5.3 \mathrm{~Hz}, 1 \mathrm{H}), 6.91(\mathrm{~d}, J=8.8 \mathrm{~Hz}, 2 \mathrm{H}), 6.00\left(\mathrm{~s}_{\mathrm{br}}, 1 \mathrm{H}\right)$, $4.24(\mathrm{t}, J=7.3 \mathrm{~Hz}, 2 \mathrm{H}), 3.81(\mathrm{~s}, 3 \mathrm{H}), 1.83(\mathrm{~m}, 2 \mathrm{H}), 1.59(\mathrm{~s}, 6 \mathrm{H}), 1.39-1.17(\mathrm{~m}, 2 \mathrm{H}), 0.91$ $(t, J=7.4 \mathrm{~Hz}, 3 \mathrm{H}) .{ }^{13} \mathrm{C}-\mathrm{NMR}\left(100 \mathrm{MHz}, \mathrm{CDCl}_{3}\right) \delta=163.2\left(\mathrm{C}_{\mathrm{q}}\right), 160.2\left(\mathrm{C}_{\mathrm{q}}\right), 152.6\left(\mathrm{C}_{\mathrm{q}}\right), 143.7$ $\left(\mathrm{C}_{\mathrm{q}}\right), 133.8\left(\mathrm{C}_{\mathrm{q}}\right), 131.0(\mathrm{CH}), 129.2(\mathrm{CH}), 124.8\left(\mathrm{C}_{\mathrm{q}}\right), 123.7(\mathrm{CH}), 120.5(\mathrm{CH}), 114.2(\mathrm{CH})$, 55.3 $\left(\mathrm{CH}_{3}\right), 51.3\left(\mathrm{C}_{\mathrm{q}}\right), 49.9\left(\mathrm{CH}_{2}\right), 32.1\left(\mathrm{CH}_{2}\right), 27.6\left(\mathrm{CH}_{3}\right), 19.7\left(\mathrm{CH}_{2}\right), 13.4\left(\mathrm{CH}_{3}\right)$. IR (ATR): $3278,2957,2142,1656,1634,1291,1178,829 \mathrm{~cm}^{-1}$. MS (ESI) $\mathrm{m} / z$ (relative intensity): $819(12)[2 \mathrm{M}+\mathrm{Na}]^{+}, 421(60)[\mathrm{M}+\mathrm{Na}]^{+}, 399(100)[\mathrm{M}+\mathrm{H}]^{+}$. HR-MS (ESI) $\mathrm{m} / z$ calcd for $\mathrm{C}_{21} \mathrm{H}_{27} \mathrm{~N}_{4} \mathrm{O}_{2} \mathrm{~S}[\mathrm{M}+\mathrm{H}]^{+} 399.1849$, found 399.1851. 


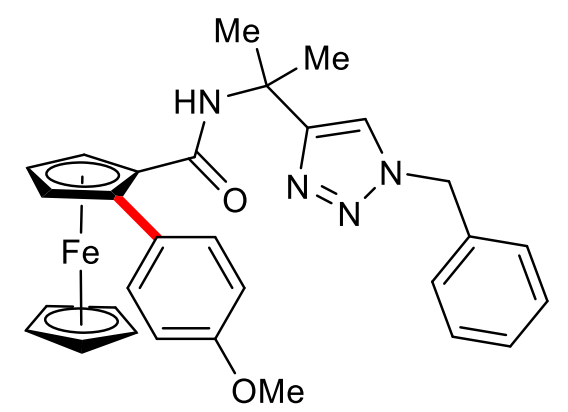

N-[2-(1-Benzyl-1H-1,2,3-triazol-4-yl)-propan-2-yl]-2-(4-methoxyphenyl)-

ferrocenoylamide (206). The general procedure E was followed using 1590 (107.1 mg, $0.25 \mathrm{mmol})$ 151a $(0.88 \mathrm{~mL}, 1.75 \mathrm{mmol}, 2.0 \mathrm{~m}$ in THF). Purification by column chromatography on silica gel ( $n$-hexane/EtOAc: 3:1 $\rightarrow 1: 1$ ) yielded 206 (93.5 mg, 70\%) as a white solid. M. p. $=137-138{ }^{\circ} \mathrm{C} .{ }^{1} \mathrm{H}-\mathbf{N M R}\left(300 \mathrm{MHz}, \mathrm{CDCl}_{3}\right) \delta=7.49$ (d, $J=8.7 \mathrm{~Hz}$, 2H), $7.41(\mathrm{~s}, 1 \mathrm{H}), 7.33(\mathrm{~m}, 3 \mathrm{H}), 7.25(\mathrm{dd}, J=5.6,2.2 \mathrm{~Hz}, 2 \mathrm{H}), 6.86(\mathrm{~d}, J=8.7 \mathrm{~Hz}, 2 \mathrm{H})$, $6.15\left(\mathrm{~s}_{\mathrm{br}}, 1 \mathrm{H}\right), 5.47(\mathrm{~s}, 2 \mathrm{H}), 4.79(\mathrm{dd}, J=2.5,1.6 \mathrm{~Hz}, 1 \mathrm{H}), 4.36(\mathrm{dd}, J=2.5,1.6 \mathrm{~Hz}, 1 \mathrm{H})$, $4.31(\mathrm{dd}, J=2.5,2.5 \mathrm{~Hz}, 1 \mathrm{H}), 4.15(\mathrm{~s}, 5 \mathrm{H}), 3.81(\mathrm{~s}, 3 \mathrm{H}), 1.63(\mathrm{~s}, 3 \mathrm{H}), 1.57(\mathrm{~s}, 3 \mathrm{H}) .{ }^{13} \mathrm{C}-$ $\operatorname{NMR}\left(125 \mathrm{MHz}, \mathrm{CDCl}_{3}\right) \delta=168.9\left(\mathrm{C}_{\mathrm{q}}\right), 158.9\left(\mathrm{C}_{\mathrm{q}}\right), 153.2\left(\mathrm{C}_{\mathrm{q}}\right), 134.8\left(\mathrm{C}_{\mathrm{q}}\right), 131.6(\mathrm{CH})$, $128.9(\mathrm{CH}), 128.5(\mathrm{CH}), 128.2\left(\mathrm{C}_{\mathrm{q}}\right), 127.9(\mathrm{CH}), 120.6(\mathrm{CH}), 113.5(\mathrm{CH}), 88.3\left(\mathrm{C}_{\mathrm{q}}\right), 76.3$ $\left(\mathrm{C}_{\mathrm{q}}\right), 72.6(\mathrm{CH}), 70.8(\mathrm{CH}), 70.2(\mathrm{CH}), 68.4(\mathrm{CH}), 55.4\left(\mathrm{CH}_{3}\right), 54.0\left(\mathrm{C}_{\mathrm{q}}\right), 51.1\left(\mathrm{CH}_{2}\right), 28.2$ $\left(\mathrm{CH}_{3}\right), 27.7\left(\mathrm{CH}_{3}\right)$. IR (ATR): 3337, 2956, 1638, 1517, 1294, 1048, $822 \mathrm{~cm}^{-1}$. MS (ESI) m/z (relative intensity): $1091(5)[2 \mathrm{M}+\mathrm{Na}]^{+}, 557(75)[\mathrm{M}+\mathrm{Na}]^{+}, 535(100)[\mathrm{M}+\mathrm{H}]^{+}$. HR-MS (ESI) $m / z$ calcd for $\mathrm{C}_{30} \mathrm{H}_{31} \mathrm{FeN}_{4} \mathrm{O}_{2}[\mathrm{M}+\mathrm{H}]^{+} 535.1791$, found 535.1794 . The analytical data are in accordance to those reported in the literature.<smiles>COc1ccc(-c2cc(OC)ccc2C(=O)NC(C)(C)c2ccccn2)cc1</smiles>

4',5-Dimethoxy-N-[2-(pyridin-2-yl)propan-2-yl]-[1,1'-biphenyl]-2-carboxamide (207). The general procedure $\mathrm{E}$ was followed using $159 \mathrm{p}$ (67.6 mg, $0.25 \mathrm{mmol}) 151 \mathrm{a}(0.88 \mathrm{~mL}$, $1.75 \mathrm{mmol}, 2.0 \mathrm{~m}$ in THF). Purification by column chromatography on silica gel 
( $n$-hexane/EtOAc: 3:1 $\rightarrow 1: 1$ ) yielded 207 (61.2 mg, 65\%) as a white solid. M. p. = 88$89{ }^{\circ} \mathrm{C} .{ }^{1} \mathrm{H}-\mathrm{NMR}\left(300 \mathrm{MHz}, \mathrm{CDCl}_{3}\right) \delta=8.30(\mathrm{dd}, J=4.9,1.8 \mathrm{~Hz}, 1 \mathrm{H}), 7.70(\mathrm{~d}, J=8.5,1 \mathrm{H})$, 7.60 (ddd, $J=8.1,7.5,1.8 \mathrm{~Hz}, 1 \mathrm{H}), 7.36(\mathrm{~d}, J=8.8 \mathrm{~Hz}, 2 \mathrm{H}), 7.29-7.18(\mathrm{~m}, 2 \mathrm{H}), 7.07$ (dd, $J=7.5,4.9 \mathrm{~Hz}, 1 \mathrm{H}), 6.95-6.82(\mathrm{~m}, 3 \mathrm{H}), 6.81(\mathrm{~d}, J=2.6 \mathrm{~Hz}, 1 \mathrm{H}), 3.83(\mathrm{~s}, 3 \mathrm{H}), 3.74(\mathrm{~s}, 3 \mathrm{H})$, $1.59(\mathrm{~s}, 6 \mathrm{H}) .{ }^{13} \mathrm{C}-\mathrm{NMR}\left(100 \mathrm{MHz}, \mathrm{CDCl}_{3}\right) \delta=167.8\left(\mathrm{C}_{\mathrm{q}}\right), 164.2\left(\mathrm{C}_{\mathrm{q}}\right), 160.3\left(\mathrm{C}_{\mathrm{q}}\right), 159.2\left(\mathrm{C}_{\mathrm{q}}\right)$, 147.3 (CH), $141.2\left(\mathrm{C}_{\mathrm{q}}\right), 136.7(\mathrm{CH}), 132.9\left(\mathrm{C}_{\mathrm{q}}\right), 130.7(\mathrm{CH}), 130.1(\mathrm{CH}), 129.3\left(\mathrm{C}_{\mathrm{q}}\right), 121.4$ $(\mathrm{CH}), 119.1(\mathrm{CH}), 115.4(\mathrm{CH}), 113.7(\mathrm{CH}), 112.4(\mathrm{CH}), 56.9\left(\mathrm{C}_{\mathrm{q}}\right), 55.4\left(\mathrm{CH}_{3}\right), 55.3\left(\mathrm{CH}_{3}\right)$, $27.1\left(\mathrm{CH}_{3}\right)$. IR (ATR): 3290, 2959, 2956, 2108, 1990, 1637, 1540, $831 \mathrm{~cm}^{-1}$. MS (ESI) m/z (relative intensity): $775(10)[2 \mathrm{M}+\mathrm{Na}]^{+}, 399(14)[\mathrm{M}+\mathrm{Na}]^{+}, 377(100)[\mathrm{M}+\mathrm{H}]^{+}$. HR-MS (ESI) $m / z$ calcd for $\mathrm{C}_{23} \mathrm{H}_{25} \mathrm{~N}_{2} \mathrm{O}_{3}[\mathrm{M}+\mathrm{H}]^{+} 377.1860$, found 377.1861 . The analytical data are in accordance to those reported in the literature. ${ }^{[147]}$<smiles>COc1ccc(-c2ccccc2C(=O)NC(C)(C)c2ccccn2)cc1</smiles>

4'-Methoxy-N-[2-(pyridin-2-yl)propan-2-yl]-[1,1'-biphenyl]-2-carboxamide (208). The general procedure $\mathbf{E}$ was followed using $159 q(60.1 \mathrm{mg}, 0.25 \mathrm{mmol}) 151 \mathrm{a}(0.88 \mathrm{~mL}$, $1.75 \mathrm{mmol}, 2.0 \mathrm{~m}$ in THF). Purification by column chromatography on silica gel ( $n$-hexane/EtOAc: 3:1 $\rightarrow 1: 1$ ) yielded 208 (50.2 mg, 58\%) as a white solid. M. p. = 106$107{ }^{\circ} \mathrm{C} .{ }^{1} \mathrm{H}-\mathrm{NMR}\left(300 \mathrm{MHz}, \mathrm{CDCl}_{3}\right) \delta=8.31(\mathrm{dd}, J=4.9,1.8 \mathrm{~Hz}, 1 \mathrm{H}), 7.69$ (dd, $J=7.4$, $1.8 \mathrm{~Hz}, 1 \mathrm{H}), 7.61$ (ddd, $J=8.1,7.4,1.8 \mathrm{~Hz}, 1 \mathrm{H}), 7.49-7.30(\mathrm{~m}, 6 \mathrm{H}), 7.27-7.21(\mathrm{~m}, 1 \mathrm{H})$, 7.09 (ddd, $J=7.4,4.9 \mathrm{~Hz}, 1 \mathrm{H}), 6.86(\mathrm{~d}, J=8.6 \mathrm{~Hz}, 2 \mathrm{H}), 3.75(\mathrm{~s}, 3 \mathrm{H}), 1.62(\mathrm{~s}, 6 \mathrm{H}) .{ }^{13} \mathrm{C}-$ $\operatorname{NMR}\left(125 \mathrm{MHz}, \mathrm{CDCl}_{3}\right) \delta=168.3\left(\mathrm{C}_{\mathrm{q}}\right), 164.1\left(\mathrm{C}_{\mathrm{q}}\right), 159.0\left(\mathrm{C}_{\mathrm{q}}\right), 147.3(\mathrm{CH}), 139.3\left(\mathrm{C}_{\mathrm{q}}\right)$, $137.0\left(\mathrm{C}_{\mathrm{q}}\right), 136.7(\mathrm{CH}), 132.9\left(\mathrm{C}_{\mathrm{q}}\right), 130.2(\mathrm{CH}), 130.1(\mathrm{CH}), 129.5(\mathrm{CH}), 128.6(\mathrm{CH}), 127.0$ (CH), 121.5 (CH), $119.1(\mathrm{CH}), 113.7(\mathrm{CH}), 57.0\left(\mathrm{C}_{q}\right), 55.3\left(\mathrm{CH}_{3}\right), 27.1\left(\mathrm{CH}_{3}\right)$. IR (ATR): 3293, 2988, 1640, 1542, 1474, 1240, $835 \mathrm{~cm}^{-1}$. MS (ESI) $\mathrm{m} / \mathrm{z}$ (relative intensity): 715 (5) $[2 \mathrm{M}+\mathrm{Na}]^{+}, 369(4)[\mathrm{M}+\mathrm{Na}]^{+}, 347(100)[\mathrm{M}+\mathrm{H}]^{+} . \mathbf{H R}-\mathrm{MS}(\mathrm{ESI}) \mathrm{m} / z$ calcd for $\mathrm{C}_{22} \mathrm{H}_{23} \mathrm{~N}_{2} \mathrm{O}_{2}$ 
$[\mathrm{M}+\mathrm{H}]^{+} 347.1754$, found 347.1756 . The analytical data are in accordance to those reported in the literature. ${ }^{[147]}$<smiles>CCCCn1cc(C(C)(C)NC(=O)c2ccccc2-c2ccc(C)cc2)nn1</smiles>

N-[2-(1-n-Butyl-1H-1,2,3-triazol-4-yl)propan-2-yl]-4'-methyl-[1,1'-biphenyl]-2-

carboxamide (209). The general procedure E was followed using 159a (76.1 mg, 0.25 $\mathrm{mmol}$ ) and $151 \mathrm{c}(0.83 \mathrm{~mL}, 1.75 \mathrm{mmol}, 2.1 \mathrm{~m}$ in THF). Purification by column chromatography on silica gel ( $n$-hexane/EtOAc: 3:1 $\rightarrow 1: 1)$ yielded 209 (102.0 mg, 77\%) as a white solid. M. p. $=106-107^{\circ} \mathrm{C} .{ }^{1} \mathrm{H}-\mathrm{NMR}\left(400 \mathrm{MHz}, \mathrm{CDCl}_{3}\right) \delta=7.61$ (dd, J = 7.5, $1.5 \mathrm{~Hz}, 1 \mathrm{H}$ ), 7.40 (ddd, J = 7.5, 7.5, $1.5 \mathrm{~Hz}, 1 \mathrm{H}), 7.35-7.22(\mathrm{~m}, 5 \mathrm{H}), 7.16$ (d, J = 7.6 Hz, 2H), $5.86(\mathrm{sbr}, 1 \mathrm{H}), 4.24(\mathrm{t}, J=7.3 \mathrm{~Hz}, 2 \mathrm{H}), 2.36(\mathrm{~s}, 3 \mathrm{H}), 1.92-1.76(\mathrm{~m}, 2 \mathrm{H}), 1.55(\mathrm{~s}, 6 \mathrm{H})$, 1.87-1.79 (m, 2H), $0.92(\mathrm{t}, J=7.4 \mathrm{~Hz}, 3 \mathrm{H}) .{ }^{13} \mathrm{C}-\mathrm{NMR}\left(100 \mathrm{MHz}, \mathrm{CDCl}_{3}\right) \delta=168.4\left(\mathrm{C}_{\mathrm{q}}\right)$, $152.7\left(C_{q}\right), 139.6\left(C_{q}\right), 137.4\left(C_{q}\right), 137.3\left(C_{q}\right), 136.2\left(C_{q}\right), 130.1(C H), 129.8(C H), 129.1$ $(\mathrm{CH}), 128.8(\mathrm{CH}), 128.5(\mathrm{CH}), 127.2(\mathrm{CH}), 120.4(\mathrm{CH}), 51.6\left(\mathrm{C}_{\mathrm{q}}\right), 49.9\left(\mathrm{CH}_{2}\right), 32.2\left(\mathrm{CH}_{2}\right)$, $27.3\left(\mathrm{CH}_{3}\right), 21.1\left(\mathrm{CH}_{3}\right), 19.7\left(\mathrm{CH}_{2}\right), 13.4\left(\mathrm{CH}_{3}\right)$. IR (ATR): 3262, 3146, 2959, 1668, 1532, 1469, 1306, $756 \mathrm{~cm}^{-1}$. MS (ESI) $\mathrm{m} / \mathrm{z}$ (relative intensity): 775 (16) [2M+Na] ${ }^{+}, 399$ (60) $[\mathrm{M}+\mathrm{Na}]^{+}, 377(100)[\mathrm{M}+\mathrm{H}]^{+}$. HR-MS (ESI) $\mathrm{m} / \mathrm{z}$ calcd for $\mathrm{C}_{23} \mathrm{H}_{29} \mathrm{~N}_{4} \mathrm{O}[\mathrm{M}+\mathrm{H}]^{+}$377.2336, found 377.2332 .<smiles>CCCCn1cc(C(C)(C)NC(=O)c2ccccc2-c2ccc(C(C)(C)C)cc2)nn1</smiles>

4'-(tert-Butyl)-N-[2-(1-n-butyl-1H-1,2,3-triazol-4-yl)propan-2-yl]-[1,1'-biphenyl]-2carboxamide (210). The general procedure E was followed using 159a (76.1 mg, 0.25 
$\mathrm{mmol})$ and $151 \mathrm{~d}(0.88 \mathrm{~mL}, 1.75 \mathrm{mmol}, 2.0 \mathrm{~m}$ in THF). Purification by column chromatography on silica gel ( $n$-hexane/EtOAc: 3:1 $\rightarrow 1: 1)$ yielded 210 (102.0 mg, 76\%) as a white solid. M. p. $=136-137^{\circ} \mathrm{C} .{ }^{1} \mathrm{H}-\mathrm{NMR}\left(400 \mathrm{MHz}, \mathrm{CDCl}_{3}\right) \delta=7.66$ (dd, J = 7.6, $1.5 \mathrm{~Hz}, 1 \mathrm{H}), 7.46-7.38(\mathrm{~m}, 4 \mathrm{H}), 7.38-7.29(\mathrm{~m}, 4 \mathrm{H}), 5.76\left(\mathrm{~s}_{\mathrm{br}}, 1 \mathrm{H}\right), 4.26(\mathrm{t}, J=7.3 \mathrm{~Hz}, 2 \mathrm{H})$, 1.93-1.73 (m, 2H), $1.49(\mathrm{~s}, 6 \mathrm{H}), 1.38-1.28(\mathrm{~m}, 11 \mathrm{H}), 0.94(\mathrm{t}, J=7.4 \mathrm{~Hz}, 3 \mathrm{H}) .{ }^{13} \mathrm{C}-\mathbf{N M R}$ $\left(100 \mathrm{MHz}, \mathrm{CDCl}_{3}\right) \delta=168.2\left(\mathrm{C}_{\mathrm{q}}\right), 152.6\left(\mathrm{C}_{\mathrm{q}}\right), 150.7\left(\mathrm{C}_{\mathrm{q}}\right), 139.5\left(\mathrm{C}_{\mathrm{q}}\right), 137.3\left(\mathrm{C}_{\mathrm{q}}\right), 136.1\left(\mathrm{C}_{\mathrm{q}}\right)$, $130.0(\mathrm{CH}), 129.9(\mathrm{CH}), 128.7(\mathrm{CH}), 128.6(\mathrm{CH}), 127.3(\mathrm{CH}), 125.4(\mathrm{CH}), 120.4(\mathrm{CH}), 51.4$ $\left(\mathrm{C}_{\mathrm{q}}\right), 49.9\left(\mathrm{CH}_{2}\right), 34.5\left(\mathrm{C}_{\mathrm{q}}\right), 32.2\left(\mathrm{CH}_{2}\right), 31.3\left(\mathrm{CH}_{3}\right), 27.2\left(\mathrm{CH}_{3}\right), 19.7\left(\mathrm{CH}_{2}\right), 13.4\left(\mathrm{CH}_{3}\right)$. IR (ATR): 3314, 2963, 2867, 1635, 1541, 1318, 1046, $581 \mathrm{~cm}^{-1}$. MS (ESI) m/z (relative intensity): 859 (20) $[2 \mathrm{M}+\mathrm{Na}]^{+}, 441(52)[\mathrm{M}+\mathrm{Na}]^{+}, 419(100)[\mathrm{M}+\mathrm{H}]^{+}$. HR-MS (ESI) m/z calcd for $\mathrm{C}_{26} \mathrm{H}_{35} \mathrm{~N}_{4} \mathrm{O}[\mathrm{M}+\mathrm{H}]^{+} 419.2805$, found 419.2801 .<smiles>CCCCn1cc(C(C)(C)NC(=O)c2ccccc2-c2cccc(OC)c2)nn1</smiles>

N-[2-(1-Butyl-1H-1,2,3-triazol-4-yl)propan-2-yl]-3'-methoxy-[1,1'-biphenyl]-2-

carboxamide (211). The general procedure E was followed using 159a (76.1 mg, 0.25 $\mathrm{mmol}$ ) and $151 \mathrm{~h}(0.88 \mathrm{~mL}, 1.75 \mathrm{mmol}, 2.0 \mathrm{~m}$ in THF). Purification by column chromatography on silica gel ( $n$-hexane/EtOAc: 3:1 $\rightarrow 1: 1$ ) yielded 211 (102.0 mg, 98\%) as a white solid. M. p. $=111-112{ }^{\circ} \mathrm{C} .{ }^{1} \mathrm{H}-\mathrm{NMR}\left(300 \mathrm{MHz}, \mathrm{CDCl}_{3}\right) \delta=7.62(\mathrm{dd}, \mathrm{J}=7.3$, $1.7 \mathrm{~Hz}, 1 \mathrm{H}), 7.46-7.33(\mathrm{~m}, 2 \mathrm{H}), 7.33-7.23(\mathrm{~m}, 3 \mathrm{H}), 6.99-6.81(\mathrm{~m}, 3 \mathrm{H}), 5.85\left(\mathrm{~s}_{b r}, 1 \mathrm{H}\right)$, $4.24(\mathrm{t}, J=7.3 \mathrm{~Hz}, 2 \mathrm{H}), 3.77(\mathrm{~s}, 3 \mathrm{H}), 1.91-1.71(\mathrm{~m}, 2 \mathrm{H}), 1.54(\mathrm{~s}, 6 \mathrm{H}), 1.39-1.14(\mathrm{~m}, 2 \mathrm{H})$, $0.93(\mathrm{t}, J=7.4 \mathrm{~Hz}, 3 \mathrm{H}) .{ }^{13} \mathrm{C}-\mathrm{NMR}\left(100 \mathrm{~Hz}, \mathrm{CDCl}_{3}\right) \delta=168.0\left(\mathrm{C}_{\mathrm{q}}\right), 159.4\left(\mathrm{C}_{\mathrm{q}}\right), 152.6\left(\mathrm{C}_{\mathrm{q}}\right)$, $141.7\left(\mathrm{C}_{\mathrm{q}}\right), 139.4\left(\mathrm{C}_{\mathrm{q}}\right), 136.2\left(\mathrm{C}_{\mathrm{q}}\right), 129.8(\mathrm{CH}), 129.7(\mathrm{CH}), 129.4(\mathrm{CH}), 128.5(\mathrm{CH}), 127.5$ $(\mathrm{CH}), 121.1(\mathrm{CH}), 120.2(\mathrm{CH}), 114.1(\mathrm{CH}), 113.5(\mathrm{CH}), 55.3\left(\mathrm{CH}_{3}\right), 51.6\left(\mathrm{C}_{\mathrm{q}}\right), 49.9\left(\mathrm{CH}_{2}\right)$, $32.2\left(\mathrm{CH}_{2}\right), 27.4\left(\mathrm{CH}_{3}\right), 19.8\left(\mathrm{CH}_{2}\right), 13.5\left(\mathrm{CH}_{3}\right)$. IR (ATR): 2960, 2873, 1653, 1511, 1467, 
$1210,759 \mathrm{~cm}^{-1} . \mathrm{MS}(\mathrm{ESI}) \mathrm{m} / \mathrm{z}$ (relative intensity): $807(20)[2 \mathrm{M}+\mathrm{Na}]^{+}, 415(50)[\mathrm{M}+\mathrm{Na}]^{+}$, $393(100)[\mathrm{M}+\mathrm{H}]^{+}$. HR-MS (ESI) $\mathrm{m} / \mathrm{z}$ calcd for $\mathrm{C}_{23} \mathrm{H}_{29} \mathrm{~N}_{4} \mathrm{O}_{2}[\mathrm{M}+\mathrm{H}]^{+} 393.2285$, found 393.2282.<smiles>CCCCn1cc(C(C)(C)NC(=O)c2ccccc2-c2cc(C)cc(C)c2)nn1</smiles>

$N$-[2-(1-n-Butyl-1H-1,2,3-triazol-4-yl)propan-2-yl]-3',5'-dimethyl-[1,1'-biphenyl]-2carboxamide (212). The general procedure $\mathbf{E}$ was followed using 159a (76.1 mg, 0.25 $\mathrm{mmol})$ and $151 \mathrm{~m}(0.76 \mathrm{~mL}, 1.75 \mathrm{mmol}, 2.3 \mathrm{~m}$ in THF). Purification by column chromatography on silica gel ( $n$-hexane/EtOAc: 3:1 $\rightarrow 1: 1$ ) yielded 212 (102.0 mg, 84\%) as a white solid. M. p. $=112-113{ }^{\circ} \mathrm{C} .{ }^{1} \mathrm{H}-\mathrm{NMR}\left(400 \mathrm{MHz}, \mathrm{CDCl}_{3}\right) \delta=7.65$ (dd, $J=7.4$, $1.5 \mathrm{~Hz}, 1 \mathrm{H}$ ), 7.41 (ddd, $J=7.4,7.4,1.5 \mathrm{~Hz}, 1 \mathrm{H}), 7.37-7.28(\mathrm{~m}, 3 \mathrm{H}), 7.01(\mathrm{~d}, J=0.7 \mathrm{~Hz}$, $2 \mathrm{H}), 7.00(\mathrm{~s}, 1 \mathrm{H}), 5.86\left(\mathrm{~s}_{\mathrm{br}}, 1 \mathrm{H}\right), 4.26(\mathrm{t}, J=7.3 \mathrm{~Hz}, 2 \mathrm{H}), 2.32(\mathrm{~s}, 6 \mathrm{H}), 1.99-1.75(\mathrm{~m}, 2 \mathrm{H})$, $1.53(\mathrm{~s}, 6 \mathrm{H}), 1.40-1.21(\mathrm{~m}, 2 \mathrm{H}), 0.94(\mathrm{t}, J=7.4 \mathrm{~Hz}, 3 \mathrm{H}) .{ }^{13} \mathrm{C}-\mathrm{NMR}\left(100 \mathrm{MHz}, \mathrm{CDCl}_{3}\right) \delta=$ $168.2\left(C_{q}\right), 152.7\left(C_{q}\right), 140.3\left(C_{q}\right), 139.9\left(C_{q}\right), 138.0\left(C_{q}\right), 136.0\left(C_{q}\right), 130.0(C H), 129.8$ (CH), $129.1(\mathrm{CH}), 128.6(\mathrm{CH}), 127.3(\mathrm{CH}), 126.7(\mathrm{CH}), 120.3(\mathrm{CH}), 51.5\left(\mathrm{C}_{\mathrm{q}}\right), 49.9\left(\mathrm{CH}_{2}\right)$, 32.2 $\left(\mathrm{CH}_{2}\right), 27.3\left(\mathrm{CH}_{3}\right), 21.2\left(\mathrm{CH}_{3}\right), 19.7\left(\mathrm{CH}_{2}\right), 13.4\left(\mathrm{CH}_{3}\right)$. IR (ATR): 3243, 2951, 2975, $1659,1525,1300,1194,1056 \mathrm{~cm}^{-1}$. MS (ESI) $\mathrm{m} / \mathrm{z}$ (relative intensity): 803 (15) [2M+Na] ${ }^{+}$, $413(28)[\mathrm{M}+\mathrm{Na}]^{+}, 391(100)[\mathrm{M}+\mathrm{H}]^{+}$. HR-MS (ESI) $\mathrm{m} / z$ calcd for $\mathrm{C}_{24} \mathrm{H}_{31} \mathrm{~N}_{4} \mathrm{O}[\mathrm{M}+\mathrm{H}]^{+}$ 391.2492 , found 391.2492 . 
<smiles>CCCCn1cc(C(C)(C)NC(=O)c2ccccc2-c2ccc3ccccc3c2)nn1</smiles>

N-[2-(1-n-Butyl-1H-1,2,3-triazol-4-yl)propan-2-yl]-2-(naphthalen-2-yl)benzamide (213). The general procedure $\mathbf{E}$ was followed using 159a (76.1 $\mathrm{mg}, 0.25 \mathrm{mmol}$ ) and 151j ( $0.80 \mathrm{~mL}, 1.75 \mathrm{mmol}, 2.2 \mathrm{~m}$ in THF). Purification by column chromatography on silica gel ( $n$-hexane/EtOAc: 3:1 $\rightarrow 1: 1$ ) yielded $\mathbf{2 1 3}(102.0 \mathrm{mg}, 88 \%)$ as a white solid. $\mathbf{M}$. p. $=140-141^{\circ} \mathrm{C} .{ }^{1} \mathbf{H}-\mathrm{NMR}\left(400 \mathrm{MHz}, \mathrm{CDCl}_{3}\right) \delta=7.89-7.77(\mathrm{~m}, 4 \mathrm{H}), 7.65(\mathrm{dd}, \mathrm{J}=7.6,1.5$ $\mathrm{Hz}, 1 \mathrm{H}), 7.51-7.43(\mathrm{~m}, 4 \mathrm{H}), 7.4-7.35(\mathrm{~m}, 2 \mathrm{H}), 6.97(\mathrm{~s}, 1 \mathrm{H}), 5.94\left(\mathrm{~s}_{\mathrm{br}}, 1 \mathrm{H}\right), 4.0(\mathrm{t}, J=7.3$ $\mathrm{Hz}, 2 \mathrm{H}), 1.71-1.60(\mathrm{~m}, 2 \mathrm{H}), 1.50(\mathrm{~s}, 6 \mathrm{H}), 1.33-1.14(\mathrm{~m}, 2 \mathrm{H}), 0.88(\mathrm{t}, J=7.4 \mathrm{~Hz}, 3 \mathrm{H}) .{ }^{13} \mathrm{C}-$ NMR $\left(100 \mathrm{MHz}, \mathrm{CDCl}_{3}\right) \delta=168.3\left(\mathrm{C}_{\mathrm{q}}\right), 152.6\left(\mathrm{C}_{\mathrm{q}}\right), 139.5\left(\mathrm{C}_{\mathrm{q}}\right), 137.9\left(\mathrm{C}_{\mathrm{q}}\right), 136.5\left(\mathrm{C}_{\mathrm{q}}\right)$, $133.1\left(\mathrm{C}_{\mathrm{q}}\right), 132.4\left(\mathrm{C}_{\mathrm{q}}\right), 130.4(\mathrm{CH}), 129.9(\mathrm{CH}), 128.5(\mathrm{CH}), 128.0(\mathrm{CH}), 127.9(\mathrm{CH}), 127.5$ $(\mathrm{CH}), 127.5(\mathrm{CH}), 127.5(\mathrm{CH}), 126.3(\mathrm{CH}), 126.1(\mathrm{CH}), 120.0(\mathrm{CH}), 51.7\left(\mathrm{C}_{\mathrm{q}}\right), 49.7\left(\mathrm{CH}_{2}\right)$, $32.0\left(\mathrm{CH}_{2}\right), 27.1\left(\mathrm{CH}_{3}\right), 19.6\left(\mathrm{CH}_{2}\right), 13.4\left(\mathrm{CH}_{3}\right)$. IR (ATR): 3247, 3055, 2966, 1634, 1558, 1322, 1051, $754 \mathrm{~cm}^{-1}$. MS (ESI) $\mathrm{m} / \mathrm{z}$ (relative intensity): 847 (15) [2M+Na] ${ }^{+}, 435$ (52) $[\mathrm{M}+\mathrm{Na}]^{+}, 413(100)[\mathrm{M}+\mathrm{H}]^{+}$. HR-MS (ESI) $\mathrm{m} / \mathrm{z}$ calcd for $\mathrm{C}_{26} \mathrm{H}_{29} \mathrm{~N}_{4} \mathrm{O}[\mathrm{M}+\mathrm{H}]^{+}$413.2336, found 413.2333 .<smiles>CCCCn1cc(C(C)(C)NC(=O)c2ccccc2-c2ccsc2)nn1</smiles>

$N$-[2-(1-n-Butyl-1H-1,2,3-triazol-4-yl)propan-2-yl]-2-(thiophen-3-yl)benzamide (214). The general procedure $\mathbf{E}$ was followed using 159a $(76.1 \mathrm{mg}, 0.25 \mathrm{mmol})$ and $151 \mathrm{k}$ ( $0.88 \mathrm{~mL}, 1.75 \mathrm{mmol}, 2.0 \mathrm{~m}$ in THF). Purification by column chromatography on silica gel ( $n$-hexane/EtOAc: 3:1 $\rightarrow 1: 1)$ yielded $214(102.0 \mathrm{mg}, 63 \%)$ as a white solid. M. p. = 
116-117 ${ }^{\circ} \mathrm{C} .{ }^{1} \mathrm{H}-\mathrm{NMR}\left(400 \mathrm{MHz}, \mathrm{CDCl}_{3}\right) \delta=7.63(\mathrm{dd}, J=6.6,1.6 \mathrm{~Hz}, 1 \mathrm{H}), 7.51-7.31(\mathrm{~m}$, $6 \mathrm{H}), 7.16(\mathrm{dd}, J=4.6,1.6 \mathrm{~Hz}, 1 \mathrm{H}), 6.06\left(\mathrm{~s}_{\mathrm{br}}, 1 \mathrm{H}\right), 4.32(\mathrm{t}, J=7.3 \mathrm{~Hz}, 2 \mathrm{H}), 2.01-1.80(\mathrm{~m}$, 2H), $1.68(\mathrm{~s}, 6 \mathrm{H}), 1.36(\mathrm{dt}, J=14.7,7.4 \mathrm{~Hz}, 2 \mathrm{H}), 0.98(\mathrm{t}, J=7.4 \mathrm{~Hz}, 3 \mathrm{H}) .{ }^{13} \mathrm{C}-\mathrm{NMR}(100$ $\left.\mathrm{MHz}, \mathrm{CDCl}_{3}\right) \delta=168.4\left(\mathrm{C}_{\mathrm{q}}\right), 152.6\left(\mathrm{C}_{\mathrm{q}}\right), 140.5\left(\mathrm{C}_{\mathrm{q}}\right), 136.3\left(\mathrm{C}_{\mathrm{q}}\right), 134.0\left(\mathrm{C}_{\mathrm{q}}\right), 129.8(\mathrm{CH})$, $129.7(\mathrm{CH}), 128.7(\mathrm{CH}), 128.3(\mathrm{CH}), 127.5(\mathrm{CH}), 125.6(\mathrm{CH}), 123.0(\mathrm{CH}), 120.4(\mathrm{CH}), 51.6$ $\left(\mathrm{C}_{\mathrm{q}}\right), 49.9\left(\mathrm{CH}_{2}\right), 32.1\left(\mathrm{CH}_{2}\right), 27.4\left(\mathrm{CH}_{3}\right), 19.7\left(\mathrm{CH}_{2}\right), 13.4\left(\mathrm{CH}_{3}\right)$. IR (ATR): 3297, 3149, 2929, 2874, 1633, 1543, 1195, 751, $627 \mathrm{~cm}^{-1}$. MS (ESI) m/z (relative intensity): 759 (22) $[2 \mathrm{M}+\mathrm{Na}]^{+}, 391(52)[\mathrm{M}+\mathrm{Na}]^{+}, 369(100)[\mathrm{M}+\mathrm{H}]^{+}$. HR-MS (ESI) $\mathrm{m} / z$ calcd for $\mathrm{C}_{20} \mathrm{H}_{25} \mathrm{~N}_{4} \mathrm{OS}$ $[\mathrm{M}+\mathrm{H}]^{+}$369.1744, found 369.1742 .

\subsubsection{Mechanistic Studies}

\section{Comparision of Electrochemical Oxidation versus Chemical Oxidation}

General procedure for chemical oxidation $\mathrm{C}-\mathrm{H}$ arylation: A solution of $\mathrm{ArMgBr}$ ( $2.10 \mathrm{~mL}, 7.0$ equiv, $1.0 \mathrm{~m}$ in THF) was slowly added to a mixture of amide $\mathbf{1 5 9}$ (0.3 mmol) and $\mathrm{ZnBr}_{2} \bullet$ TMEDA (308 mg, 3.00 equiv) under $\mathrm{N}_{2}$. The resulting mixture was stirred at ambient temperature for $10 \mathrm{~min}$, then a solution of $\mathrm{FeCl}_{3}(4.9 \mathrm{mg}$, $10 \mathrm{~mol} \%)$ and dppe $(11.9 \mathrm{mg}, 10 \mathrm{~mol} \%)$ in THF $(1.5 \mathrm{~mL})$ was added. The reaction mixture was stirred at ambient temperature for $10 \mathrm{~min}$ and then DCIB $(76.2 \mathrm{mg}$, 2.0 equiv) was added. The mixture was stirred at $55{ }^{\circ} \mathrm{C}(t=0 \mathrm{~min})$. At ambient temperature, saturated aqueous $\mathrm{NH}_{4} \mathrm{Cl}$ solution $(10 \mathrm{~mL})$ was added, the reaction mixture was extracted with EtOAc $(3 \times 10 \mathrm{~mL})$ and dried over $\mathrm{Na}_{2} \mathrm{SO}_{4}$. Evaporation of the solvents and purification by column chromatography on silica gel ( $n$-Hexane/EtOAc $3: 1 \rightarrow 1: 1)$ the desired product 192, 194, 196.

\section{Kinetic Studies by ${ }^{19} \mathrm{~F}-\mathrm{NMR}$}

General procedure for chemical oxidation $\mathrm{C}-\mathrm{H}$ arylation: A solution of $\mathrm{ArMgBr}$ (2.10 mL, 7.0 equiv, $1.0 \mathrm{~m}$ in THF) was slowly added to a mixture of amide $\mathbf{1 5 9}$ 
(0.3 mmol) and $\mathrm{ZnBr}_{2} \bullet$ TMEDA (308 mg, 3.00 equiv) under $\mathrm{N}_{2}$. The resulting mixture was stirred at ambient temperature for $10 \mathrm{~min}$, then a solution of $\mathrm{FeCl}_{3}(4.9 \mathrm{mg}$, $10 \mathrm{~mol} \%)$ and dppe (11.9 mg, $10 \mathrm{~mol} \%)$ in THF (1.5 mL) was added. The reaction mixture was stirred at ambient temperature for $10 \mathrm{~min}$ and then DCIB $(76.2 \mathrm{mg}$, 2.0 equiv) was added. The mixture was stirred at $55^{\circ} \mathrm{C}(t=0 \mathrm{~min})$. Aliquots (100 $\left.\mu \mathrm{L}\right)$ were removed via a syringe periodically every 5 and $10 \mathrm{~min}$. The conversion was determined by ${ }^{19} \mathrm{~F}$-NMR using $n$-nonyl fluoride $(54 \mu \mathrm{L}, 0.3 \mathrm{mmol}$ ) as the internal standard.

General procedure for electrochemical oxidation $\mathrm{C}-\mathrm{H}$ arylation: The electrocatalysis was carried out in an undivided cell with a RVC anode $(10 \mathrm{~mm} \times 15 \mathrm{~mm} \times 6 \mathrm{~mm})$ and a platinum cathode $(10 \mathrm{~mm} \times 15 \mathrm{~mm} \times 0.25 \mathrm{~mm})$. A solution of $\operatorname{ArMgBr}(0.88 \mathrm{~mL}, 7.0$ equiv, $2.0 \mathrm{~m}$ in THF) was slowly added to a mixture of amide $159(0.25 \mathrm{mmol}$, 1.00 equiv), $\mathrm{Fe}(\mathrm{acac})_{3}(8.8 \mathrm{mg}, 10 \mathrm{~mol} \%)$, dppe (10.0 mg, $\left.10 \mathrm{~mol} \%\right)$ and $\mathrm{ZnCl}_{2} \cdot \mathrm{TMEDA}$ (189 mg, 3.00 equiv) were placed in a $10 \mathrm{~mL}$ cell and dissolved in THF $(5 \mathrm{~mL})$. Electrolysis was performed at $40{ }^{\circ} \mathrm{C}$ with a constant current of $5 \mathrm{~mA}(t=0 \mathrm{~min})$. Aliquots $(300 \mu \mathrm{L})$ were removed periodically every 5 and $10 \mathrm{~min}$. The conversion was determined by ${ }^{19} \mathrm{~F}-\mathrm{NMR}$ using $n$-nonyl fluoride $(45 \mu \mathrm{L}, 0.25 \mathrm{mmol})$ as the internal standard.

Each reaction was performed three times, the measured conversions were averaged and the error corresponds to the standard deviation.

Chemical oxidant

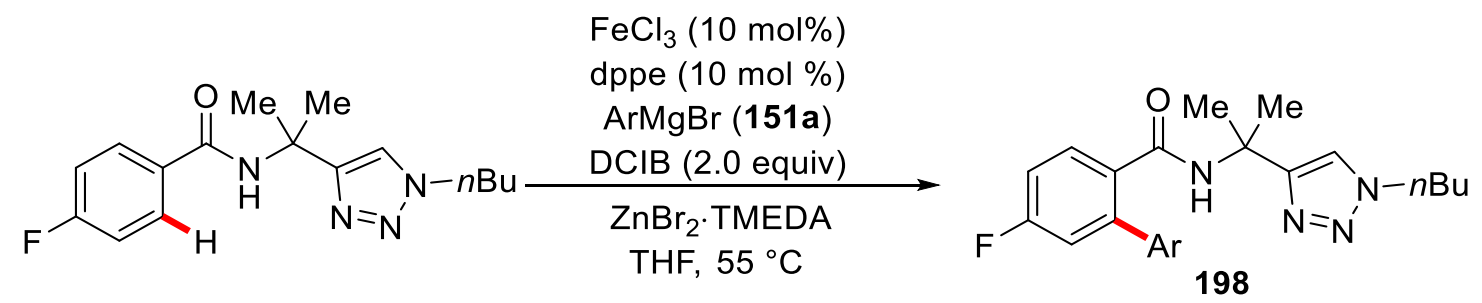

Electrochemical reaction 


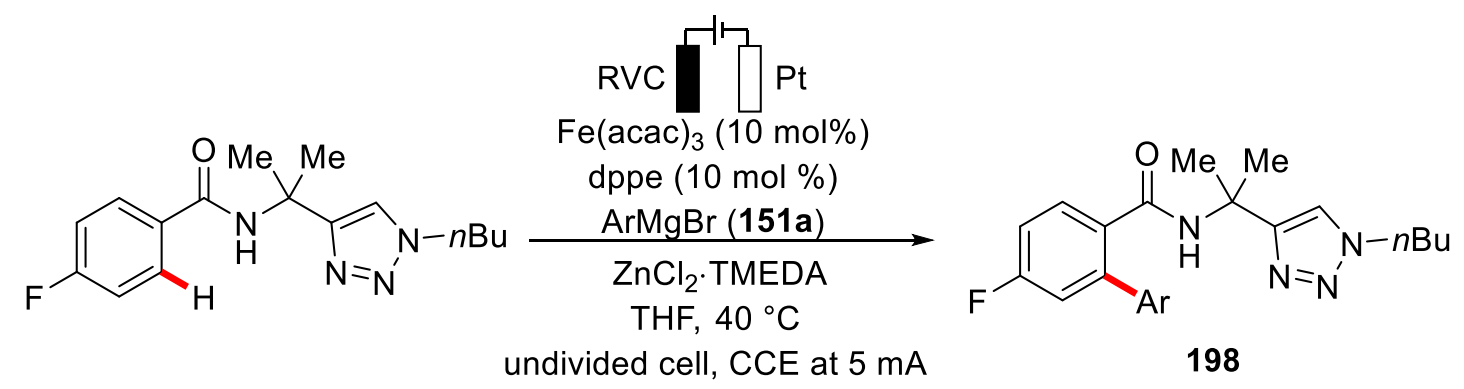

\begin{tabular}{cc|cccccccc}
\hline NMR conv. (\%) & $t(\min )$ & 5 & 10 & 20 & 30 & 40 & 50 & 60 \\
\hline Reaction & $1^{\text {st }}$ & 3 & 4 & 11 & 12 & 19 & 21 & 25 \\
\hline \multirow{2}{*}{ Chemical oxidation } & $2^{\text {nd }}$ & 2 & 3 & 11 & 14 & 18 & 20 & 25 \\
& $3^{\text {rd }}$ & 4 & 5 & 8 & 10 & 16 & 20 & 24 \\
\multirow{2}{*}{ Electrochemical } & $1^{\text {st }}$ & 10 & 12 & 23 & 35 & 40 & 45 & 59 \\
oxidation & $2^{\text {nd }}$ & 15 & 17 & 22 & 30 & 39 & 45 & 56 \\
& $3^{\text {rd }}$ & 14 & 16 & 25 & 30 & 37 & 41 & 51 \\
\hline
\end{tabular}

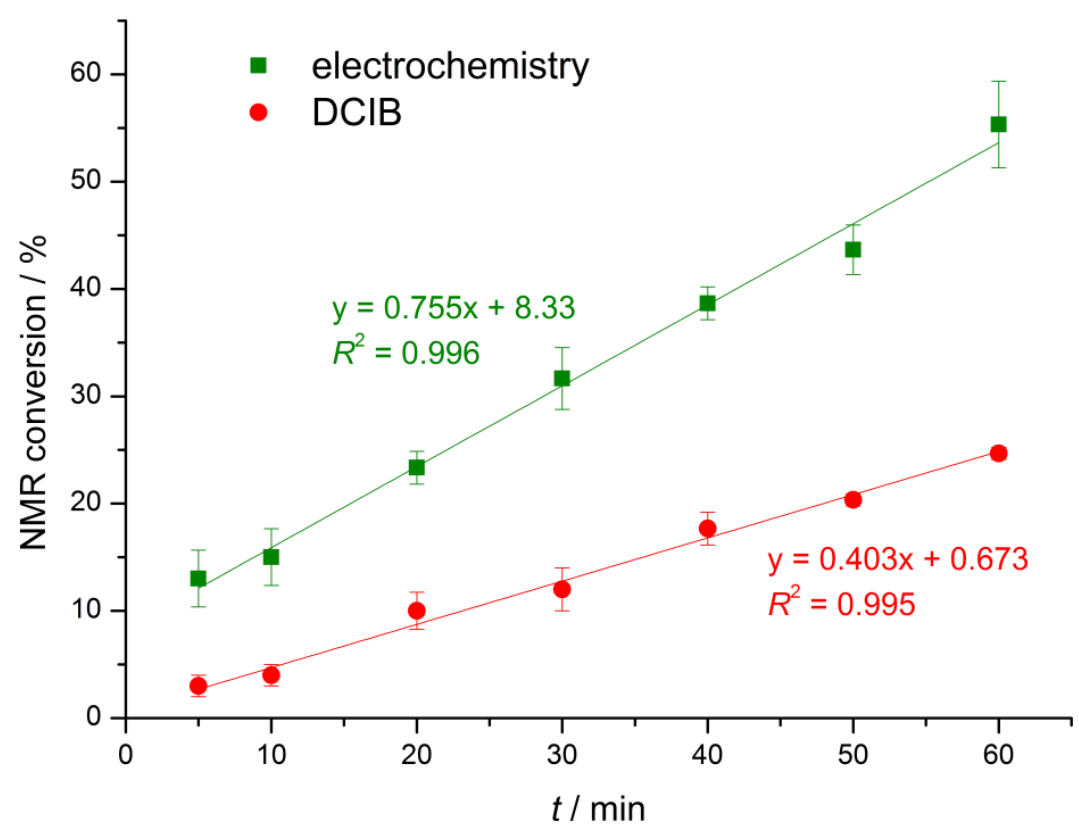

Figure 5.1. Comparision of electrochemical versus chemical oxidation reaction of 198.

Chemical oxidant 


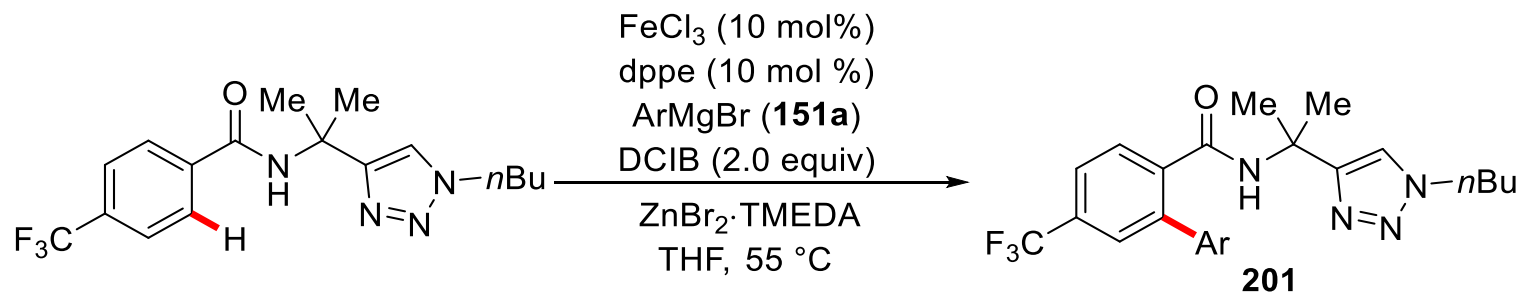

Electrochemical reaction

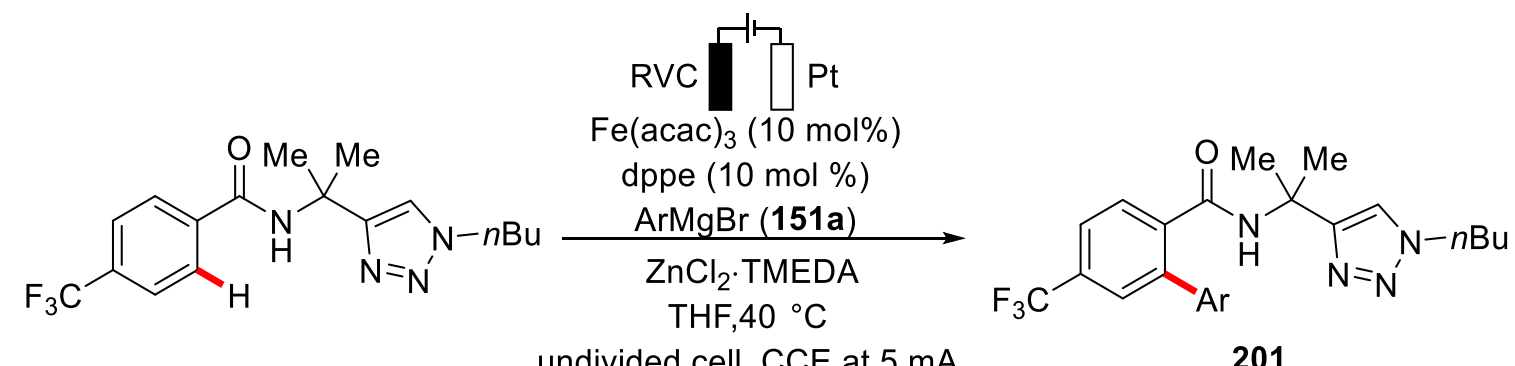
undivided cell, CCE at $5 \mathrm{~mA}$

201

\begin{tabular}{cc|cccccccc}
\hline NMR conv. (\%) & $t(\mathrm{~min})$ & 5 & 10 & 20 & 30 & 40 & 50 & 60 \\
\hline Reaction & $1^{\text {st }}$ & 5 & 8 & 12 & 13 & 16 & 16 & 16 \\
\hline \multirow{3}{*}{ Chemical oxidation } & $2^{\text {nd }}$ & 5 & 8 & 12 & 14 & 18 & 18 & 19 \\
& $3^{\text {rd }}$ & 6 & 6 & 13 & 16 & 20 & 21 & 22 \\
\multirow{2}{*}{$\begin{array}{c}\text { Electrochemical } \\
\text { oxidation }\end{array}$} & $1^{\text {st }}$ & 11 & 18 & 21 & 24 & 32 & 37 & 43 \\
& $2^{\text {nd }}$ & 14 & 22 & 30 & 32 & 37 & 39 & 41 \\
& $3^{\text {rd }}$ & 16 & 25 & 22 & 29 & 33 & 39 & 40 \\
\hline
\end{tabular}




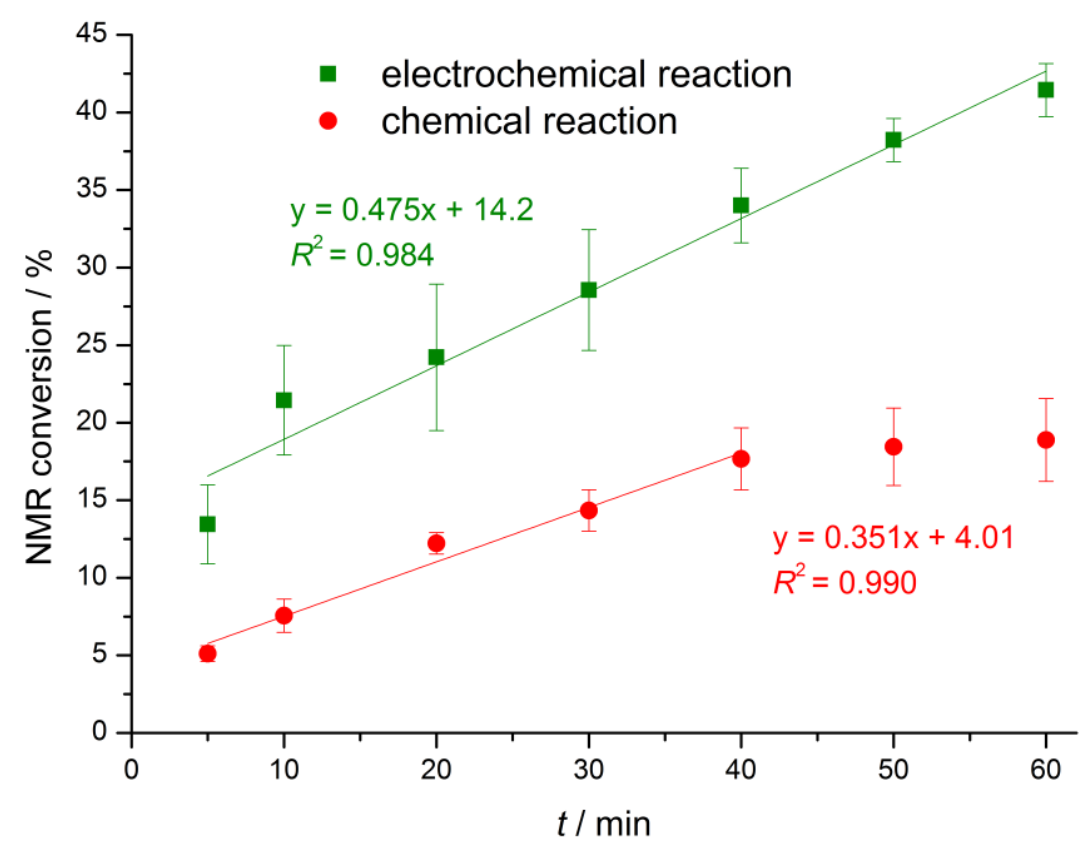

Figure 5.2. Comparision of electrochemical versus chemical oxidation reaction rate of 201.

Intermolecular Competition Experiment

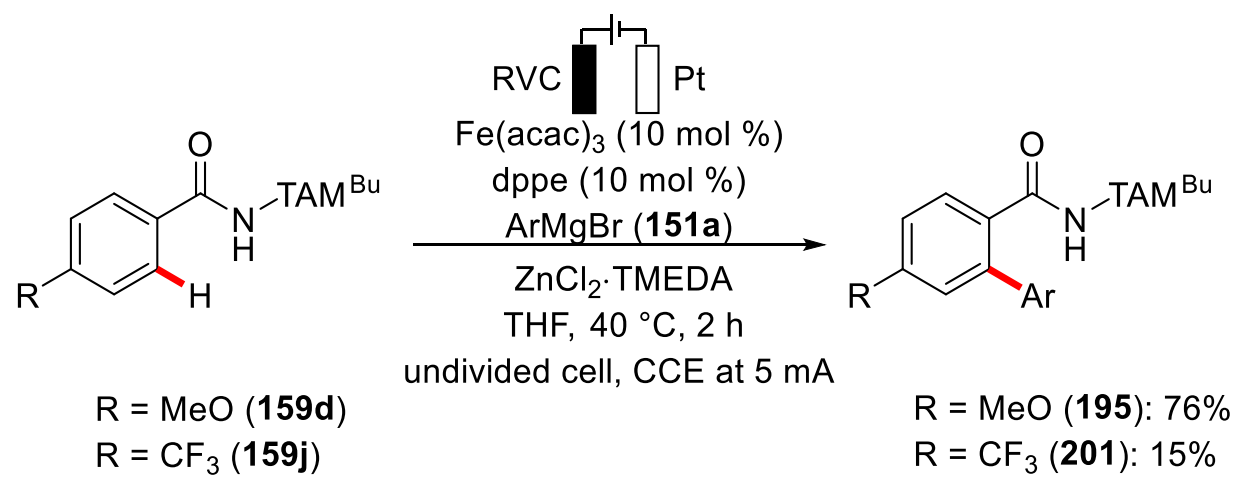

A solution of $\operatorname{ArMgBr}(0.88 \mathrm{~mL}, 7.0$ equiv, $2.0 \mathrm{~m}$ in THF) was slowly added to a mixture of amide 159d (79.1 mg, $0.25 \mathrm{mmol}$ ) and 159j (88.6 mg, $0.25 \mathrm{mmol}), \mathrm{Fe}(\mathrm{acac})_{3}(8.8 \mathrm{mg}$, $10 \mathrm{~mol} \%)$, dppe (10.0 mg, $10 \mathrm{~mol} \%$ ) and $\mathrm{ZnCl}_{2} \cdot \operatorname{TMEDA}(189 \mathrm{mg}, 3.00$ equiv) were placed in a $10 \mathrm{~mL}$ cell and dissolved in THF (5 mL). Electrolysis was performed at $40{ }^{\circ} \mathrm{C}$ with a constant current of $5 \mathrm{~mA}$ maintained for $2 \mathrm{~h}$. At ambient temperature, a saturated aqueous $\mathrm{NH}_{4} \mathrm{Cl}$ solution $(10 \mathrm{~mL}$ ) was added and the $\mathrm{RVC}$ anode was washed with EtOAc $(3 \times 2 \mathrm{~mL})$ in an ultrasonic bath. The combined phases were extracted with 
EtOAc $(3 \times 10 \mathrm{~mL})$ and then dried over $\mathrm{Na}_{2} \mathrm{SO}_{4}$. Evaporation of the solvents and purification by column chromatography on silica gel ( $n$-hexane/EtOAc $3: 1 \rightarrow 1: 1$ ) yielded 195 (80.3 mg, 76\%) and 201 (17.3 mg, 15\%).

\section{Kinetic Isotope Effect Studies}

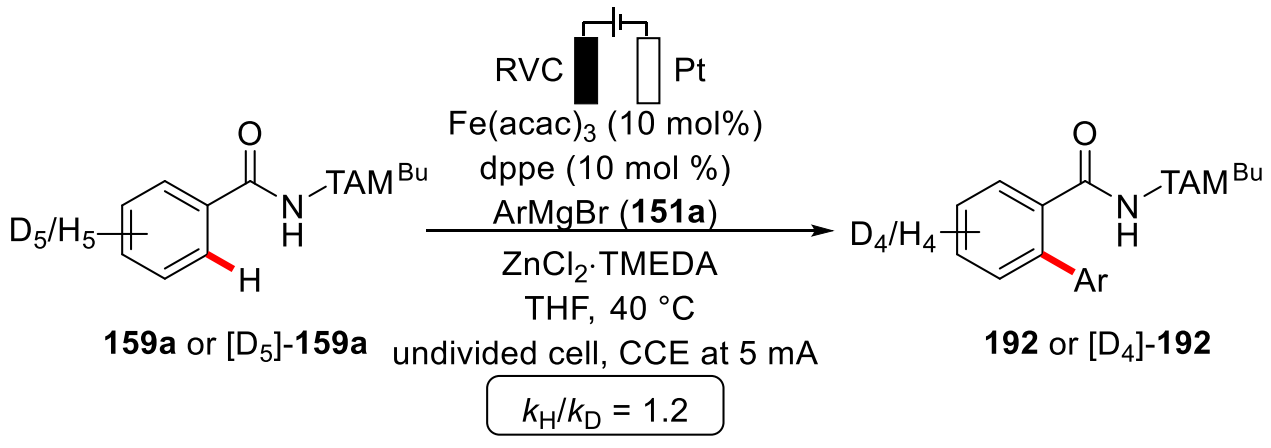

Five parallel independent reactions of 159a or $\left[D_{5}\right]-159 a$ with 151a were performed to determine the KIE. A solution of $\operatorname{ArMgBr}(0.88 \mathrm{~mL}, 7.0$ equiv, $2.0 \mathrm{~m}$ in THF) was slowly added to a mixture of amide $159 \mathrm{a}(76.1 \mathrm{mg}, 0.25 \mathrm{mmol})$ and $\left[\mathrm{D}_{5}\right]-159 \mathrm{a}(72.9$ $\mathrm{mg}, 0.25 \mathrm{mmol}), \mathrm{Fe}(\mathrm{acac})_{3}(8.8 \mathrm{mg}, 10 \mathrm{~mol} \%)$, dppe $(10.0 \mathrm{mg}, 10 \mathrm{~mol} \%)$ and $\mathrm{ZnCl}_{2} \cdot$ TMEDA (189 mg, 3.00 equiv) were placed in a $10 \mathrm{~mL}$ cell and dissolved in THF $(5 \mathrm{~mL})$. Electrolysis was performed at $40{ }^{\circ} \mathrm{C}$ with a constant current of $5 \mathrm{~mA}$. At ambient temperature, a saturated aqueous $\mathrm{NH}_{4} \mathrm{Cl}$ solution $(10 \mathrm{~mL})$ was added and the RVC anode was washed with EtOAc $(3 \times 2 \mathrm{~mL})$ in an ultrasonic bath. The combined phases were extracted with EtOAc $(3 \times 10 \mathrm{~mL})$ and then dried over $\mathrm{Na}_{2} \mathrm{SO}_{4}$. Evaporation of the solvents and purification by column chromatography on silica gel ( $n$-hexane/EtOAc 3:1 $\rightarrow 1: 1$ ), Then ${ }^{1} \mathrm{H}-\mathrm{NMR}$ conversions were obtained by the use of $\mathrm{CH}_{2} \mathrm{Br}_{2}(17 \mu \mathrm{L}, 0.25 \mathrm{mmol})$ as the standard.

\begin{tabular}{|l|l|l|l|l|l|l|}
\hline$t(\min )$ & 15 & 30 & 45 & 60 & 75 & 90 \\
\hline $192(\%)$ & 9 & 19 & 25 & 32 & 38 & 45 \\
\hline$\left[\mathrm{D}_{4}\right]-192(\%)$ & 5 & 12 & 19 & 24 & 28 & 36 \\
\hline
\end{tabular}




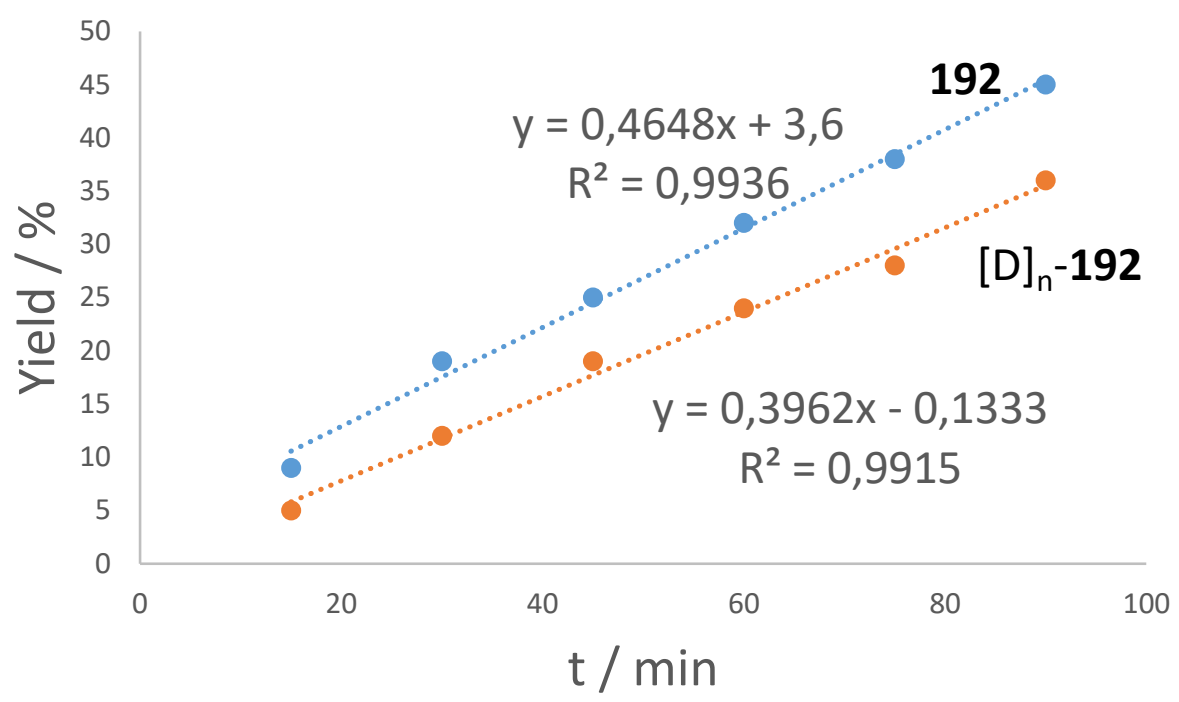

Figure 5.3. Kinetic profile with substrates $192 \mathrm{a}$ or $\left[D_{5}\right]-192 a$.

\section{Gram-Scale Synthesis of 192}

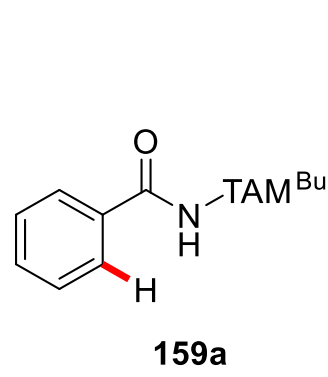

$159 a$

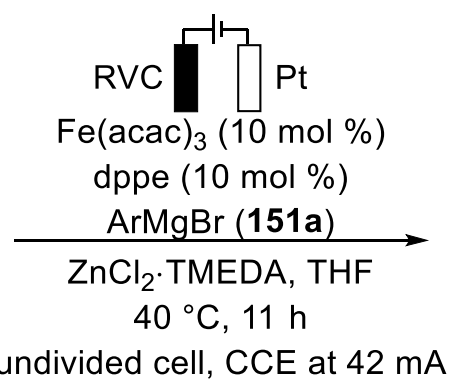

undivided cell, CCE at $42 \mathrm{~mA}$<smiles>O=C(N[Te])c1ccccc1Br</smiles>

192: $89 \%(1.40 \mathrm{~g})$

Benzamide 159a (1.15 g, $4.00 \mathrm{mmol}, 1.00$ equiv), Fe(acac) 3 (141 mg, $10 \mathrm{~mol} \%$ ), dppe (160 mg, $10 \mathrm{~mol} \%$ ), ZnCl 2 TMEDA (3.02 g, 3.00 equiv) and 151a (14.0 mL, 7.0 equiv, $2.0 \mathrm{~m}$ in THF) were placed in an undivided cell $(100 \mathrm{~mL})$ with a RVC anode $(25 \mathrm{~mm} \times$ $50 \mathrm{~mm} \times 6 \mathrm{~mm})$ and a platinum cathode $(25 \mathrm{~mm} \times 50 \mathrm{~mm} \times 0.25 \mathrm{~mm})$ and dissolved in THF (50 mL). Electrocatalysis was performed at $40^{\circ} \mathrm{C}$ with a constant current of $41.7 \mathrm{~mA}$ maintained for $11.6 \mathrm{~h}(4.51 \mathrm{~F} / \mathrm{mol})$. At ambient temperature, saturated aqueous $\mathrm{NH}_{4} \mathrm{Cl}(10 \mathrm{~mL})$ was added, and the RVC anode was washed with EtOAc $(3 \times 10$ $\mathrm{mL})$ in an ultrasonic bath. The combined phases were extracted with EtOAc $(3 \times 30 \mathrm{~mL})$ and then dried over $\mathrm{Na}_{2} \mathrm{SO}_{4}$. Evaporation of the solvents and purification by column chromatography ( $n$-hexane/EtOAc $=3: 1 \rightarrow 1: 1)$ yielded $192(1.40 \mathrm{~g}, 89 \%)$ as a white solid. 


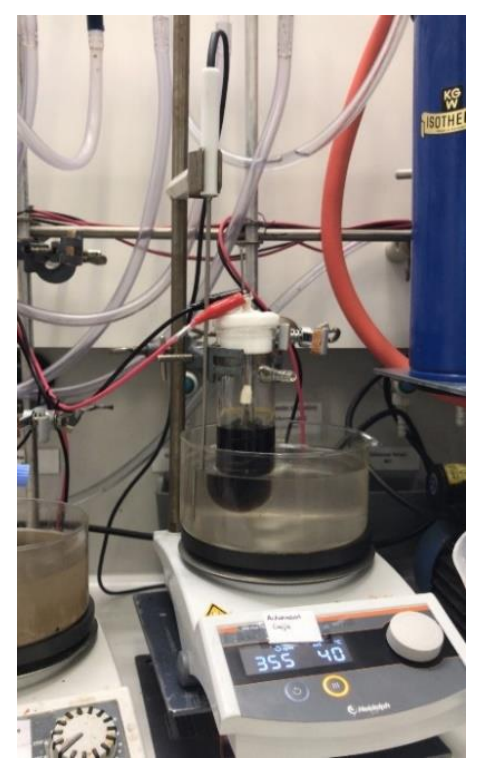

Figure 5.4. Electrolysis setup for gram-scale. 


\subsection{Crystallographic Data}

The crystal structures of 173,180 and 188 aa were measured and solved by Dr. Christopher Golz (Alcarazo research group).

The crystal was kept at $99.93 \mathrm{~K}$ during data collection. Using Olex2, ${ }^{[148]}$ the structure was solved with the $\mathrm{XT}^{[149]}$ structure solution program using Intrinsic Phasing and refined with the $\mathrm{XL}^{[150]}$ refinement package using Least Squares minimisation.

Table 5.1. Crystal data and structure refinement 173aa.

\begin{tabular}{|c|c|}
\hline Compound & 173aa \\
\hline Empirical formula & $\mathrm{C}_{21} \mathrm{H}_{18} \mathrm{~N}_{2} \mathrm{O}$ \\
\hline Formula weight & 314.37 \\
\hline Temperature/K & 99.93 \\
\hline Crystal system & monoclinic \\
\hline Space group & $\mathrm{P} 2{ }_{1} / \mathrm{c}$ \\
\hline $\mathrm{a} / \AA ̊$ & $10.2077(4)$ \\
\hline $\mathrm{b} / \AA ̊$ & $19.7705(7)$ \\
\hline$c / A ̊$ & $8.1575(3)$ \\
\hline$\alpha /^{\circ}$ & 90 \\
\hline$\beta /^{\circ}$ & $97.3950(10)$ \\
\hline$\gamma /{ }^{\circ}$ & 90 \\
\hline Volume $/ \AA^{3}$ & $1632.58(11)$ \\
\hline z & 4 \\
\hline$\rho_{\text {calc }} \mathrm{g} / \mathrm{cm}^{3}$ & 1.279 \\
\hline$\mu / \mathrm{mm}^{-1}$ & 0.079 \\
\hline$F(000)$ & 664.0 \\
\hline Crystal size $/ \mathrm{mm}^{3}$ & $0.475 \times 0.36 \times 0.242$ \\
\hline Radiation & $\operatorname{MoK} \alpha(\lambda=0.71073)$ \\
\hline $2 \Theta$ range for data collection $/^{\circ}$ & 5.76 to 59.326 \\
\hline
\end{tabular}




\begin{tabular}{|c|c|}
\hline Index ranges & $-14 \leq h \leq 14,0 \leq k \leq 27,0 \leq \mathrm{I} \leq 11$ \\
\hline Reflections collected & 4532 \\
\hline Independent reflections & $4532\left[\mathrm{R}_{\text {int }}=?, \mathrm{R}_{\text {sigma }}=0.0160\right]$ \\
\hline Data/restraints/parameters & $4532 / 0 / 220$ \\
\hline Goodness-of-fit on $F^{2}$ & 1.071 \\
\hline Final $R$ indexes $[1>=2 \sigma(I)]$ & $R_{1}=0.0364, w R_{2}=0.0939$ \\
\hline Final $R$ indexes [all data] & $R_{1}=0.0380, w R_{2}=0.0953$ \\
\hline Largest diff. peak/hole / e $\AA^{-3}$ & $0.35 /-0.21$ \\
\hline
\end{tabular}

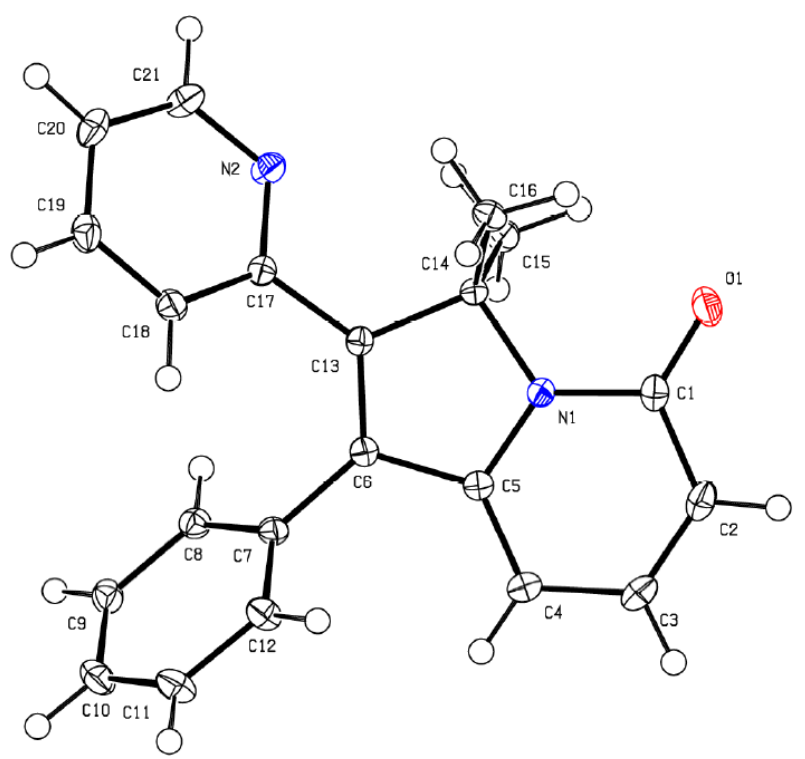

Figure 5.5. Molecular structure of 173aa with thermal ellipoids at 50\% probablitiy level. The hydrogen atoms are omitted for clarity.

Crystal Data for $\mathrm{C}_{21} \mathrm{H}_{18} \mathrm{~N}_{2} \mathrm{O}\left(\mathrm{M}=314.37 \mathrm{~g} / \mathrm{mol}\right.$ ): monoclinic, space group $\mathrm{P} 2{ }_{1} / \mathrm{c}$ (no. 14), $a=10.2077(4) \AA, \quad b=19.7705(7) \AA, \quad c=8.1575(3) \AA, \quad b=97.3950(10)^{\circ}, \quad V=$ 1632.58(11) $\AA^{3}, Z=4, T=99.93 \mathrm{~K}, \mu($ MoK $\alpha)=0.079 \mathrm{~mm}^{-1}$, Dcalc $=1.279 \mathrm{~g} / \mathrm{cm}^{3}, 4532$ reflections measured $\left(5.76^{\circ} \leq 2 \Theta \leq 59.326^{\circ}\right), 4532$ unique $\left(R_{\text {int }}=\right.$ ?, $\left.R_{\text {sigma }}=0.0160\right)$ which were used in all calculations. The final $R_{1}$ was $0.0364(I>2 \sigma(I))$ and $w R_{2}$ was 0.0953 (all data). 
Table 5.2. Bond Lengths [ $\AA$ ] for 173aa.

\begin{tabular}{|c|c|c|}
\hline Atom & Atom & Length/Å \\
\hline $\mathrm{O} 1$ & $\mathrm{C} 1$ & $1.2373(12)$ \\
\hline N1 & $\mathrm{C} 1$ & $1.3934(11)$ \\
\hline N1 & C5 & $1.3734(11)$ \\
\hline N1 & C14 & $1.4892(11)$ \\
\hline N2 & C17 & $1.3504(12)$ \\
\hline N2 & $\mathrm{C} 21$ & $1.3377(12)$ \\
\hline $\mathrm{C} 1$ & $\mathrm{C} 2$ & $1.4426(14)$ \\
\hline $\mathrm{C} 2$ & C3 & $1.3595(15)$ \\
\hline C3 & $\mathrm{C} 4$ & $1.4182(14)$ \\
\hline $\mathrm{C} 4$ & C5 & $1.3674(13)$ \\
\hline C5 & $\mathrm{C} 6$ & $1.4609(12)$ \\
\hline C6 & $\mathrm{C} 7$ & $1.4775(12)$ \\
\hline C6 & C13 & $1.3554(12)$ \\
\hline $\mathrm{C} 7$ & $\mathrm{C} 8$ & $1.3980(12)$ \\
\hline $\mathrm{C} 7$ & C12 & $1.3969(13)$ \\
\hline $\mathrm{C} 8$ & C9 & $1.3903(13)$ \\
\hline C9 & C10 & $1.3889(15)$ \\
\hline C10 & C11 & $1.3891(15)$ \\
\hline C11 & C12 & $1.3922(13)$ \\
\hline C13 & C14 & $1.5253(12)$ \\
\hline C13 & C17 & $1.4775(12)$ \\
\hline C14 & C15 & $1.5377(12)$ \\
\hline C14 & C16 & $1.5318(12)$ \\
\hline C17 & C18 & $1.3995(12)$ \\
\hline C18 & C19 & $1.3896(13)$ \\
\hline
\end{tabular}




\begin{tabular}{|l|l|l|}
\hline C19 & C20 & $1.3857(15)$ \\
\hline C20 & C21 & $1.3881(14)$ \\
\hline
\end{tabular}

Table 5.3. Bond angles $\left[^{\circ}\right]$ for $173 a a$

\begin{tabular}{|c|c|c|c|}
\hline Atom & Atom & Atom & Angle/ ${ }^{\circ}$ \\
\hline C1 & N1 & C14 & $124.13(8)$ \\
\hline C5 & N1 & $\mathrm{C} 1$ & $124.01(8)$ \\
\hline C5 & N1 & C14 & $111.80(7)$ \\
\hline C21 & N2 & C17 & $117.57(9)$ \\
\hline $\mathrm{O} 1$ & $\mathrm{C} 1$ & N1 & $121.11(9)$ \\
\hline 01 & $\mathrm{C} 1$ & $\mathrm{C} 2$ & $125.04(9)$ \\
\hline N1 & $\mathrm{C} 1$ & $\mathrm{C} 2$ & $113.84(8)$ \\
\hline C3 & $\mathrm{C} 2$ & $\mathrm{C} 1$ & $122.27(9)$ \\
\hline $\mathrm{C} 2$ & C3 & $\mathrm{C} 4$ & 121.15(9) \\
\hline C5 & $\mathrm{C} 4$ & $\mathrm{C} 3$ & 117.38(9) \\
\hline N1 & $\mathrm{C} 5$ & C6 & $107.74(7)$ \\
\hline C4 & $\mathrm{C} 5$ & N1 & $121.30(8)$ \\
\hline C4 & $\mathrm{C} 5$ & C6 & $130.93(8)$ \\
\hline C5 & C6 & $\mathrm{C} 5$ & $122.42(8)$ \\
\hline C13 & C6 & $\mathrm{C} 5$ & $108.82(8)$ \\
\hline C13 & C6 & $\mathrm{C7}$ & $128.75(8)$ \\
\hline $\mathrm{C} 8$ & $\mathrm{C7}$ & C6 & $120.16(8)$ \\
\hline $\mathrm{C} 12$ & $\mathrm{C7}$ & C6 & $120.72(8)$ \\
\hline C12 & $\mathrm{C7}$ & $\mathrm{C} 8$ & $119.12(8)$ \\
\hline C9 & $\mathrm{C} 8$ & $\mathrm{C7}$ & $120.43(9)$ \\
\hline C10 & C9 & $\mathrm{C} 8$ & $120.16(9)$ \\
\hline C9 & C10 & C11 & 119.77(9) \\
\hline C10 & C11 & C12 & $120.34(9)$ \\
\hline
\end{tabular}




\begin{tabular}{|l|l|l|l|}
\hline C11 & C12 & C7 & $120.17(9)$ \\
\hline C6 & C13 & C14 & $110.84(8)$ \\
\hline C6 & C13 & C17 & $127.92(8)$ \\
\hline C17 & C13 & C14 & $120.76(8)$ \\
\hline N1 & C14 & C13 & $100.45(7)$ \\
\hline N1 & C14 & C15 & $109.05(7)$ \\
\hline N1 & C14 & C16 & $110.85(7)$ \\
\hline C13 & C14 & C15 & $112.40(7)$ \\
\hline C13 & C14 & C16 & $111.10(7)$ \\
\hline C16 & C14 & C15 & $112.37(7)$ \\
\hline N2 & C17 & C13 & $116.92(8)$ \\
\hline N2 & C17 & C18 & $121.84(8)$ \\
\hline C18 & C17 & C13 & $120.98(8)$ \\
\hline C19 & C18 & C17 & $119.38(9)$ \\
\hline C20 & C19 & C18 & $118.93(9)$ \\
\hline C19 & C20 & C21 & $117.92(9)$ \\
\hline N1 & C21 & C20 & $124.36(9)$ \\
\hline
\end{tabular}

Table 5.4. Crystal data and structure refinement $\mathbf{1 7 3 c a .}$

\begin{tabular}{|l|l|}
\hline Compound & $173 \mathrm{ca}$ \\
\hline Empirical formula & $\mathrm{C}_{25} \mathrm{H}_{20} \mathrm{~N}_{2} \mathrm{O}$ \\
\hline Formula weight & 364.43 \\
\hline Temperature/K & 100.01 \\
\hline Crystal system & triclinic \\
\hline Space group & P-1 \\
\hline a/Å & $8.7963(9)$ \\
\hline b/Å & $10.3540(12)$ \\
\hline
\end{tabular}




\begin{tabular}{|c|c|}
\hline$c / \AA ̊$ & $11.5419(14)$ \\
\hline$\alpha /^{\circ}$ & $110.430(3)$ \\
\hline$\beta /^{\circ}$ & $100.373(3)$ \\
\hline$\gamma /{ }^{\circ}$ & $101.270(4)$ \\
\hline Volume $/ \AA^{3}$ & $930.16(18)$ \\
\hline Z & 2 \\
\hline$\rho_{\text {calc }} \mathrm{g} / \mathrm{cm}^{3}$ & 1.301 \\
\hline$\mu / \mathrm{mm}^{-1}$ & 0.080 \\
\hline$F(000)$ & 384.0 \\
\hline Crystal size $/ \mathrm{mm}^{3}$ & $0.348 \times 0.281 \times 0.191$ \\
\hline Radiation & $\operatorname{MoK} \alpha(\lambda=0.71073)$ \\
\hline $2 \Theta$ range for data collection $/^{\circ}$ & 4.904 to 59.224 \\
\hline Index ranges & $-12 \leq h \leq 11,-14 \leq k \leq 14,-15 \leq \mathrm{I} \leq 15$ \\
\hline Reflections collected & 17309 \\
\hline Independent reflections & $5094\left[R_{\text {int }}=0.0229, R_{\text {sigma }}=0.0231\right]$ \\
\hline Data/restraints/parameters & $5094 / 0 / 255$ \\
\hline Goodness-of-fit on $\mathrm{F}^{2}$ & 1.048 \\
\hline Final $R$ indexes $[I>=2 \sigma(I)]$ & $R_{1}=0.0410, w R_{2}=0.1026$ \\
\hline Final $R$ indexes [all data] & $\mathrm{R}_{1}=0.0469, \mathrm{wR}_{2}=0.1081$ \\
\hline Largest diff. peak/hole / e $\AA^{-3}$ & $0.38 /-0.21$ \\
\hline
\end{tabular}




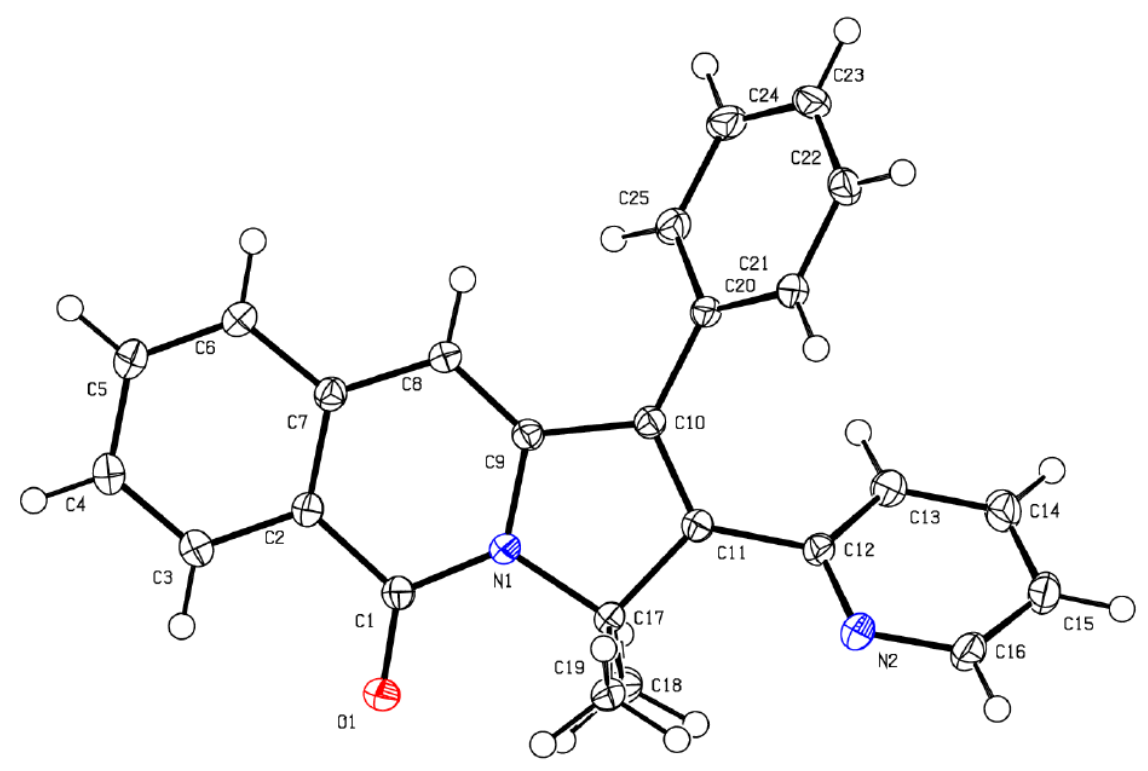

Figure 5.6. Molecular structure of $\mathbf{1 7 3}$ ca with thermal ellipoids at $50 \%$ probablitiy level. The hydrogen atoms are omitted for clarity.

Crystal Data for $\mathrm{C}_{25} \mathrm{H}_{20} \mathrm{~N}_{2} \mathrm{O}(M=364.43 \mathrm{~g} / \mathrm{mol})$ : triclinic, space group P-1 (no. 2), $a=$ 8.7963(9) $\AA, b=10.3540(12) \AA, c=11.5419(14) \AA, \alpha=110.430(3)^{\circ}, b=100.373(3)^{\circ}, y=$ 101.270(4) $)^{\circ}, V=930.16(18) \AA^{3}, Z=2, T=100.01 \mathrm{~K}, \mu($ MoK $\alpha)=0.080 \mathrm{~mm}^{-1}$, Dcalc $=$ $1.301 \mathrm{~g} / \mathrm{cm}^{3}, 17309$ reflections measured $\left(4.904^{\circ} \leq 2 \Theta \leq 59.224^{\circ}\right), 5094$ unique $\left(R_{\text {int }}=\right.$ $\left.0.0229, R_{\text {sigma }}=0.0231\right)$ which were used in all calculations. The final $R_{1}$ was $0.0410(I>$ $2 \sigma(\mathrm{I}))$ and $w R_{2}$ was 0.1081 (all data).

Table 5.5. Bond Lengths $[\AA]$ for $173 \mathrm{ca}$.

\begin{tabular}{|l|l|l|}
\hline Atom & Atom & Length/Å \\
\hline $\mathrm{O} 1$ & $\mathrm{C} 1$ & $1.2327(13)$ \\
\hline $\mathrm{N} 1$ & $\mathrm{C} 1$ & $1.3789(13)$ \\
\hline $\mathrm{N} 1$ & $\mathrm{C} 9$ & $1.3903(13)$ \\
\hline $\mathrm{N} 1$ & $\mathrm{C} 17$ & $1.4948(12)$ \\
\hline $\mathrm{N} 2$ & $\mathrm{C} 12$ & $1.3460(13)$ \\
\hline $\mathrm{N} 2$ & $\mathrm{C} 16$ & $1.3422(14)$ \\
\hline $\mathrm{C} 1$ & $\mathrm{C} 2$ & $1.4741(14)$ \\
\hline $\mathrm{C} 2$ & $\mathrm{C} 3$ & $1.4044(14)$ \\
\hline
\end{tabular}




\begin{tabular}{|l|l|l|}
\hline C2 & C7 & $1.4116(14)$ \\
\hline C3 & C4 & $1.3780(15)$ \\
\hline C4 & C5 & $1.4032(16)$ \\
\hline C5 & C6 & $1.3816(15)$ \\
\hline C6 & C7 & $1.4129(14)$ \\
\hline C7 & C8 & $1.4351(14)$ \\
\hline C8 & C9 & $1.3572(14)$ \\
\hline C9 & C10 & $1.4625(14)$ \\
\hline C10 & C11 & $1.3541(14)$ \\
\hline C10 & C20 & $1.4775(14)$ \\
\hline C11 & C12 & $1.4793(14)$ \\
\hline C11 & C17 & $1.5207(14)$ \\
\hline C12 & C13 & $1.4000(15)$ \\
\hline C13 & C14 & $1.3855(15)$ \\
\hline C14 & C15 & $1.3883(18)$ \\
\hline C15 & C16 & $1.3849(18)$ \\
\hline C17 & C18 & $1.5314(15)$ \\
\hline C17 & C19 & $1.5339(14)$ \\
\hline C20 & C21 & $1.3983(14)$ \\
\hline C20 & C25 & $1.3986(14)$ \\
\hline C21 & C22 & $1.3909(15)$ \\
\hline C22 & C23 & $1.3912(17)$ \\
\hline C23 & C24 & $1.3882(18)$ \\
\hline C25 & $1.3882(16)$ \\
\hline
\end{tabular}


Table 5.6. Bond angles $\left[^{\circ}\right]$ for $\mathbf{1 7 3 c a}$

\begin{tabular}{|c|c|c|c|}
\hline Atom & Atom & Atom & Angle/ ${ }^{\circ}$ \\
\hline C1 & N1 & $\mathrm{C} 9$ & $124.06(9)$ \\
\hline C1 & N1 & C17 & $124.06(8)$ \\
\hline C9 & N1 & C17 & $111.77(8)$ \\
\hline C16 & N2 & C12 & $117.36(10)$ \\
\hline $\mathrm{O} 1$ & $\mathrm{C} 1$ & N1 & 122.02(9) \\
\hline 01 & $\mathrm{C} 1$ & $\mathrm{C} 2$ & $123.40(9)$ \\
\hline N1 & $\mathrm{C} 1$ & $\mathrm{C} 2$ & $114.58(9)$ \\
\hline C3 & $\mathrm{C} 2$ & $\mathrm{C} 1$ & 117.99(9) \\
\hline $\mathrm{C} 2$ & C3 & $\mathrm{C} 4$ & $120.53(9)$ \\
\hline C3 & $\mathrm{C} 2$ & $\mathrm{C7}$ & $121.46(9)$ \\
\hline $\mathrm{C7}$ & $\mathrm{C} 2$ & $\mathrm{C} 1$ & $120.15(10)$ \\
\hline $\mathrm{C} 4$ & C3 & $\mathrm{C} 2$ & 119.85(10) \\
\hline C3 & $\mathrm{C} 4$ & $\mathrm{C} 5$ & $120.76(10)$ \\
\hline C6 & $\mathrm{C} 5$ & $\mathrm{C} 4$ & $120.38(10)$ \\
\hline C5 & C6 & $\mathrm{C7}$ & 118.32(9) \\
\hline C2 & $\mathrm{C7}$ & C6 & 119.16(9) \\
\hline C6 & $\mathrm{C7}$ & $\mathrm{C} 8$ & $122.50(9)$ \\
\hline C9 & $\mathrm{C} 8$ & $\mathrm{C7}$ & $118.80(9)$ \\
\hline N1 & $\mathrm{C9}$ & C10 & $107.24(8)$ \\
\hline $\mathrm{C} 8$ & $\mathrm{CO}$ & N1 & $121.92(9)$ \\
\hline $\mathrm{C} 8$ & $\mathrm{C} 9$ & C10 & $130.82(9)$ \\
\hline C9 & C10 & $\mathrm{C} 20$ & $122.63(9)$ \\
\hline C11 & C10 & C9 & 108.94(9) \\
\hline C11 & C10 & $\mathrm{C} 20$ & $128.43(9)$ \\
\hline C10 & C11 & C12 & 125.89(9) \\
\hline
\end{tabular}




\begin{tabular}{|l|l|l|l|}
\hline C10 & C11 & C17 & $111.62(9)$ \\
\hline C12 & C11 & C17 & $122.34(9)$ \\
\hline N2 & C12 & C11 & $117.10(9)$ \\
\hline N2 & C12 & C13 & $122.52(9)$ \\
\hline C13 & C12 & C11 & $120.38(9)$ \\
\hline C14 & C13 & C12 & $118.93(10)$ \\
\hline C13 & C14 & C15 & $118.85(11)$ \\
\hline C16 & C15 & C14 & $118.41(10)$ \\
\hline N2 & C16 & C15 & $123.86(11)$ \\
\hline N1 & C17 & C11 & $100.31(8)$ \\
\hline N1 & C17 & C18 & $110.87(8)$ \\
\hline N1 & C17 & C19 & $109.89(8)$ \\
\hline C11 & C17 & C18 & $110.49(9)$ \\
\hline C11 & C17 & C19 & $113.37(8)$ \\
\hline C18 & C17 & C19 & $111.42(9)$ \\
\hline C21 & C20 & C10 & $121.26(9)$ \\
\hline C21 & C20 & C25 & $118.79(9)$ \\
\hline C25 & C20 & C10 & $119.95(9)$ \\
\hline C22 & C21 & C20 & $120.51(10)$ \\
\hline C21 & C22 & C23 & $120.28(10)$ \\
\hline C24 & C23 & C22 & $119.43(10)$ \\
\hline C25 & C24 & C23 & $120.58(10)$ \\
\hline C24 & C25 & C20 & $120.40(10)$ \\
\hline
\end{tabular}

Table 5.7. Crystal data and structure refinement 173ga.

\begin{tabular}{|l|l|}
\hline Compound & 173ga \\
\hline Empirical formula & $\mathrm{C}_{22} \mathrm{H}_{20} \mathrm{~N}_{2} \mathrm{O}$ \\
\hline
\end{tabular}




\begin{tabular}{|c|c|}
\hline Formula weight & 328.40 \\
\hline Temperature/K & 100.0 \\
\hline Crystal system & triclinic \\
\hline Space group & P-1 \\
\hline $\mathrm{a} / \AA ̊$ & $9.0581(12)$ \\
\hline $\mathrm{b} / \AA ̊ \AA$ & $9.9273(12)$ \\
\hline$c / \AA ̊$ & $10.2645(12)$ \\
\hline$\alpha /^{\circ}$ & $105.947(4)$ \\
\hline$\beta /^{\circ}$ & $96.819(4)$ \\
\hline$\gamma /{ }^{\circ}$ & $97.151(4)$ \\
\hline Volume $/ \AA^{3}$ & $869.20(19)$ \\
\hline Z & 2 \\
\hline$\rho_{\text {calc }} \mathrm{g} / \mathrm{cm}^{3}$ & 1.255 \\
\hline$\mu / \mathrm{mm}^{-1}$ & 0.078 \\
\hline$F(000)$ & 348.0 \\
\hline Crystal size $/ \mathrm{mm}^{3}$ & $0.346 \times 0.235 \times 0.178$ \\
\hline Radiation & $\operatorname{MoK} \alpha(\lambda=0.71073)$ \\
\hline $2 \Theta$ range for data collection $/^{\circ}$ & 4.592 to 57.512 \\
\hline Index ranges & $-12 \leq h \leq 12,-13 \leq k \leq 13,-13 \leq \mathrm{I} \leq 13$ \\
\hline Reflections collected & 24237 \\
\hline Independent reflections & $4505\left[R_{\text {int }}=0.0217, R_{\text {sigma }}=0.0172\right]$ \\
\hline Data/restraints/parameters & $4505 / 0 / 229$ \\
\hline Goodness-of-fit on $F^{2}$ & 1.036 \\
\hline Final $R$ indexes $[I>=2 \sigma(I)]$ & $R_{1}=0.0409, w R_{2}=0.1051$ \\
\hline Final $R$ indexes [all data] & $R_{1}=0.0437, w R_{2}=0.1077$ \\
\hline Largest diff. peak/hole / e $\AA^{-3}$ & $0.43 /-0.19$ \\
\hline
\end{tabular}




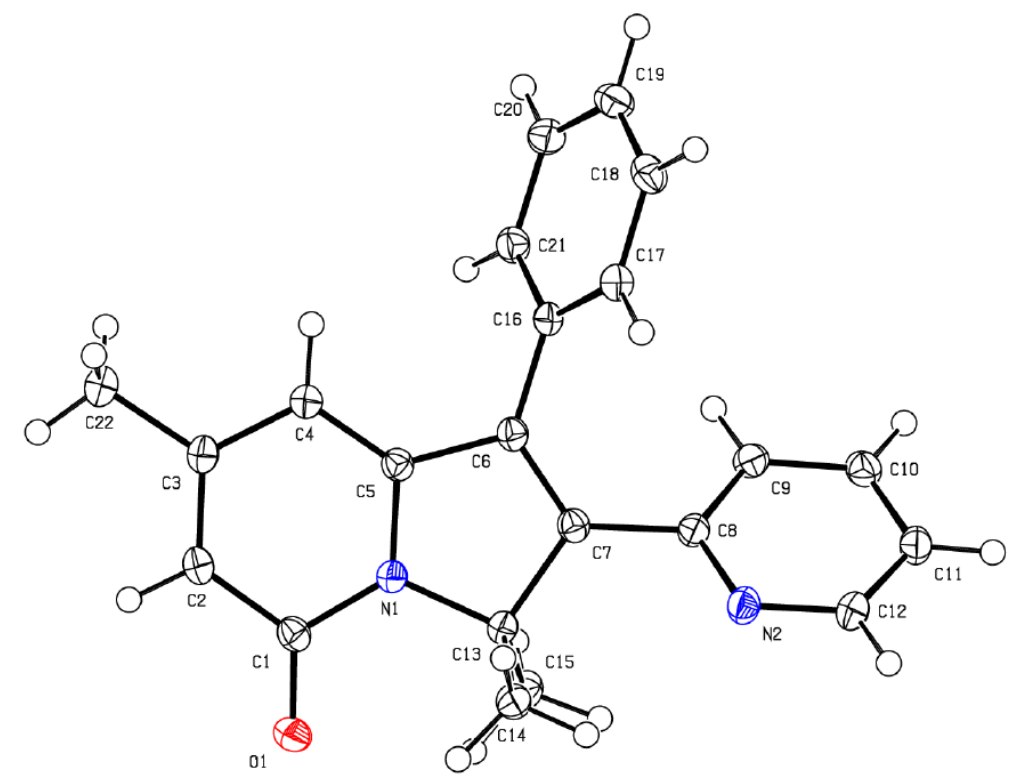

Figure 5.7. Molecular structure of 173ga with thermal ellipoids at 50\% probablitiy level. The hydrogen atoms are omitted for clarity.

Crystal Data for $\mathrm{C}_{22} \mathrm{H}_{20} \mathrm{~N}_{2} \mathrm{O}(M=328.40 \mathrm{~g} / \mathrm{mol})$ : triclinic, space group P-1 (no. 2), $a=$ 9.0581(12) $\AA, b=9.9273(12) \AA, c=10.2645(12) \AA, \alpha=105.947(4)^{\circ}, b=96.819(4)^{\circ}, y=$ 97.151(4) $)^{\circ}, V=869.20(19) \AA^{3}, Z=2, T=100.0 \mathrm{~K}, \mu(\mathrm{MoK} \alpha)=0.078 \mathrm{~mm}^{-1}$, Dcalc $=$ $1.255 \mathrm{~g} / \mathrm{cm}^{3}, 24237$ reflections measured $\left(4.592^{\circ} \leq 2 \Theta \leq 57.512^{\circ}\right), 4505$ unique $\left(R_{\text {int }}=\right.$ $\left.0.0217, R_{\text {sigma }}=0.0172\right)$ which were used in all calculations. The final $R_{1}$ was $0.0409(I>$ $2 \sigma(I))$ and $w R_{2}$ was 0.1077 (all data).

Table 5.8. Bond Lengths [ $\AA$ ] for 173ga.

\begin{tabular}{|l|l|l|}
\hline Atom & Atom & Length/Å \\
\hline $\mathrm{O} 1$ & $\mathrm{C} 1$ & $1.2364(12)$ \\
\hline $\mathrm{N} 1$ & $\mathrm{C} 1$ & $1.3934(13)$ \\
\hline $\mathrm{N} 1$ & $\mathrm{C} 5$ & $1.3747(12)$ \\
\hline $\mathrm{N} 1$ & $\mathrm{C} 13$ & $1.4938(12)$ \\
\hline $\mathrm{N} 2$ & $\mathrm{C} 8$ & $1.3432(13)$ \\
\hline $\mathrm{N} 2$ & $\mathrm{C} 12$ & $1.3407(13)$ \\
\hline $\mathrm{C} 1$ & $\mathrm{C} 2$ & $1.4437(14)$ \\
\hline $\mathrm{C} 2$ & $\mathrm{C} 3$ & $1.3664(14)$ \\
\hline
\end{tabular}




\begin{tabular}{|l|l|l|}
\hline C3 & C4 & $1.4228(14)$ \\
\hline C3 & C22 & $1.5027(14)$ \\
\hline C4 & C5 & $1.3620(14)$ \\
\hline C5 & C6 & $1.4607(13)$ \\
\hline C6 & C7 & $1.3470(14)$ \\
\hline C6 & C16 & $1.4776(13)$ \\
\hline C7 & C8 & $1.4773(13)$ \\
\hline C7 & C13 & $1.5227(14)$ \\
\hline C8 & C9 & $1.3990(14)$ \\
\hline C9 & C10 & $1.3833(15)$ \\
\hline C10 & C11 & $1.3886(15)$ \\
\hline C11 & C12 & $1.3839(15)$ \\
\hline C13 & C14 & $1.5329(14)$ \\
\hline C13 & C15 & $1.5330(14)$ \\
\hline C16 & C17 & $1.3959(14)$ \\
\hline C16 & C21 & $1.3951(14)$ \\
\hline C17 & C18 & $1.3890(14)$ \\
\hline C18 & C19 & $1.3874(15)$ \\
\hline C19 & C20 & $1.3913(16)$ \\
\hline C20 & C21 & $1.3895(14)$ \\
\hline
\end{tabular}

Table 5.9. Bond angles $\left[^{\circ}\right]$ for $\mathbf{1 7 3 c a}$

\begin{tabular}{|l|l|l|l|}
\hline Atom & Atom & Atom & Angle/ $^{\circ}$ \\
\hline C1 & N1 & C9 & $125.09(8)$ \\
\hline C5 & N1 & C17 & $123.29(9)$ \\
\hline C5 & N1 & C17 & $111.60(8)$ \\
\hline C12 & N2 & C12 & $117.65(9)$ \\
\hline
\end{tabular}




\begin{tabular}{|c|c|c|c|}
\hline $\mathrm{O} 1$ & $\mathrm{C} 1$ & N1 & 121.33(9) \\
\hline O1 & $\mathrm{C} 1$ & $\mathrm{C} 2$ & 124.71(9) \\
\hline N1 & $\mathrm{C} 1$ & $\mathrm{C} 2$ & 113.95(9) \\
\hline C3 & $\mathrm{C} 2$ & $\mathrm{C} 1$ & 123.28(9) \\
\hline $\mathrm{C} 2$ & $\mathrm{C} 3$ & $\mathrm{C} 4$ & 119.32(9) \\
\hline $\mathrm{C} 2$ & $\mathrm{C} 3$ & $\mathrm{C7}$ & 121.47(9) \\
\hline C4 & C3 & $\mathrm{C} 1$ & 119.20(9) \\
\hline C5 & $\mathrm{C} 4$ & $\mathrm{C} 2$ & $118.40(9)$ \\
\hline N1 & C5 & C5 & $107.79(8)$ \\
\hline $\mathrm{C} 4$ & $\mathrm{C} 5$ & $\mathrm{C} 4$ & $121.72(9)$ \\
\hline $\mathrm{C} 4$ & $\mathrm{C} 5$ & $\mathrm{C7}$ & $130.49(9)$ \\
\hline C5 & C6 & C6 & 122.11(9) \\
\hline $\mathrm{C7}$ & C6 & $\mathrm{C} 8$ & 108.88(9) \\
\hline C7 & C6 & $\mathrm{C7}$ & 129.01(9) \\
\hline C6 & $\mathrm{C7}$ & C10 & $126.08(9)$ \\
\hline C6 & $\mathrm{C7}$ & N1 & $111.32(9)$ \\
\hline C8 & $\mathrm{C7}$ & C10 & $122.38(8)$ \\
\hline N2 & $\mathrm{C} 8$ & $\mathrm{C} 20$ & $116.91(9)$ \\
\hline N2 & $\mathrm{C} 8$ & C9 & $122.27(9)$ \\
\hline C9 & $\mathrm{C} 8$ & $\mathrm{C} 20$ & $120.81(9)$ \\
\hline C10 & $\mathrm{C} 9$ & $\mathrm{C} 12$ & 119.18(9) \\
\hline C9 & C10 & C17 & $118.74(10)$ \\
\hline C12 & C11 & C17 & $118.41(10)$ \\
\hline N2 & C12 & C11 & $123.75(10)$ \\
\hline N1 & C13 & C13 & $100.37(7)$ \\
\hline N1 & C13 & C11 & $109.92(8)$ \\
\hline N1 & C13 & C12 & $110.88(8)$ \\
\hline
\end{tabular}




\begin{tabular}{|l|l|l|l|}
\hline C7 & C13 & C15 & $113.59(8)$ \\
\hline C7 & C13 & C14 & $110.30(8)$ \\
\hline C14 & C13 & C15 & $111.31(8)$ \\
\hline C17 & C16 & C11 & $120.90(9)$ \\
\hline C21 & C16 & C18 & $119.84(9)$ \\
\hline C21 & C16 & C19 & $119.25(9)$ \\
\hline C18 & C17 & C18 & $120.13(9)$ \\
\hline C19 & C18 & C19 & $120.30(10)$ \\
\hline C18 & C19 & C19 & $119.98(10)$ \\
\hline C21 & C20 & C19 & $119.79(10)$ \\
\hline C20 & C21 & C16 & $120.55(10)$ \\
\hline
\end{tabular}

Table 5.10. Crystal data and structure refinement 180aa.

\begin{tabular}{|c|c|}
\hline Compound & 180aa \\
\hline Empirical formula & $\mathrm{C}_{20} \mathrm{H}_{17} \mathrm{NO}$ \\
\hline Formula weight & 287.35 \\
\hline Temperature/K & 99.99 \\
\hline Crystal system & triclinic \\
\hline Space group & P-1 \\
\hline$a / \AA ̊$ & $8.3674(7)$ \\
\hline $\mathrm{b} / \AA ̊ \AA$ & $9.9101(8)$ \\
\hline$c / \AA$ & $10.4597(7)$ \\
\hline$\alpha /^{\circ}$ & $104.876(3)$ \\
\hline$\beta /^{\circ}$ & $113.305(3)$ \\
\hline$\gamma /{ }^{\circ}$ & $99.676(3)$ \\
\hline Volume $/ \AA^{3}$ & $733.49(10)$ \\
\hline Z & 2 \\
\hline
\end{tabular}




\begin{tabular}{|c|c|}
\hline$\rho_{\text {calc }} / \mathrm{cm}^{3}$ & 1.301 \\
\hline$\mu / \mathrm{mm}^{-1}$ & 0.080 \\
\hline$F(000)$ & 304.0 \\
\hline Crystal size $/ \mathrm{mm}^{3}$ & $0.306 \times 0.259 \times 0.24$ \\
\hline Radiation & $\operatorname{MoK} \alpha(\lambda=0.71073)$ \\
\hline $2 \Theta$ range for data collection $/^{\circ}$ & 4.464 to 63.028 \\
\hline Index ranges & $-11 \leq h \leq 12,-14 \leq k \leq 11,-14 \leq \mathrm{I} \leq 15$ \\
\hline Reflections collected & 10987 \\
\hline Independent reflections & $4872\left[R_{\text {int }}=0.0224, R_{\text {sigma }}=0.0309\right]$ \\
\hline Data/restraints/parameters & $4872 / 0 / 201$ \\
\hline Goodness-of-fit on $\mathrm{F}^{2}$ & 1.021 \\
\hline Final $R$ indexes $[I>=2 \sigma(I)]$ & $\mathrm{R}_{1}=0.0452, \mathrm{wR}_{2}=0.1216$ \\
\hline Final $\mathrm{R}$ indexes [all data] & $\mathrm{R}_{1}=0.0517, \mathrm{wR}_{2}=0.1276$ \\
\hline Largest diff. peak/hole / e $\AA^{-3}$ & $0.48 /-0.27$ \\
\hline
\end{tabular}

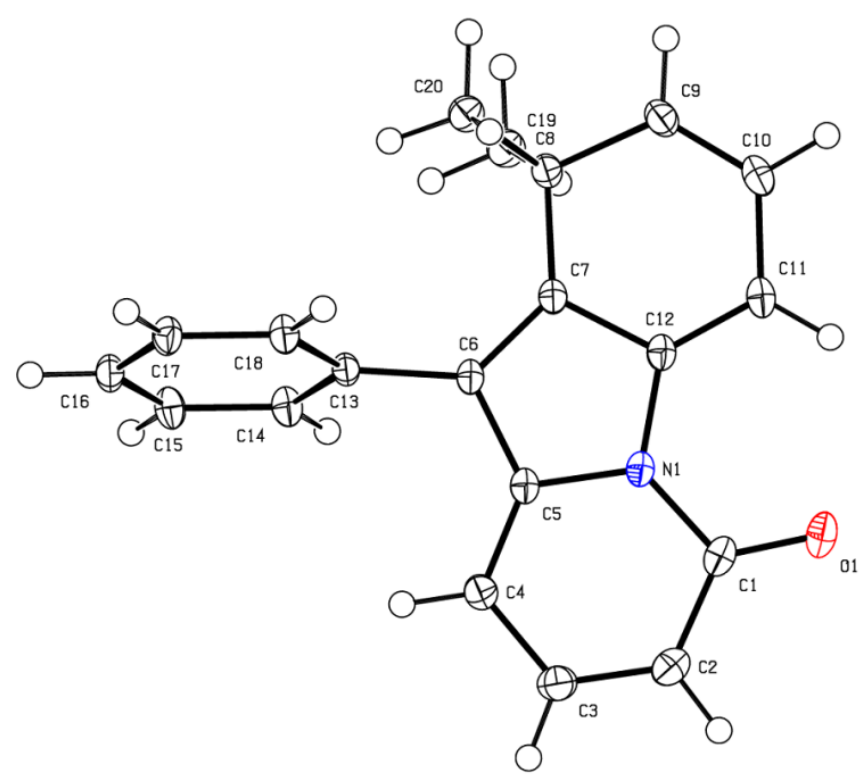

Figure 5.8. Molecular structure of 180aa with thermal ellipoids at 50\% probablitiy level. The hydrogen atoms are omitted for clarity.

Crystal Data for $\mathrm{C}_{20} \mathrm{H}_{17} \mathrm{NO}(\mathrm{M}=287.35 \mathrm{~g} / \mathrm{mol}$ ): triclinic, space group P-1 (no. 2), $a=$ 
$8.3674(7) \AA, b=9.9101(8) \AA, c=10.4597(7) \AA, \alpha=104.876(3)^{\circ}, b=113.305(3)^{\circ}, y=$ 99.676(3) $, V=733.49(10) \AA^{3}, Z=2, T=99.99 \mathrm{~K}, \mu(\mathrm{MoK} \alpha)=0.080 \mathrm{~mm}^{-1}$, Dcalc $=$ $1.301 \mathrm{~g} / \mathrm{cm}^{3}, 10987$ reflections measured $\left(4.464^{\circ} \leq 2 \Theta \leq 63.028^{\circ}\right), 4872$ unique $\left(R_{\text {int }}=\right.$ $\left.0.0224, R_{\text {sigma }}=0.0309\right)$ which were used in all calculations. The final $R_{1}$ was 0.0452 (I > $2 \sigma(\mathrm{I}))$ and $w R_{2}$ was 0.1276 (all data).

Table 5.11. Bond Lengths $[\AA ̊]$ for 180 aa.

\begin{tabular}{|l|l|l|}
\hline Atom & Atom & Length/A \\
\hline O1 & C1 & $1.2359(12)$ \\
\hline N1 & C1 & $1.4049(12)$ \\
\hline N1 & C5 & $1.3897(11)$ \\
\hline N1 & C12 & $1.4114(12)$ \\
\hline C1 & C2 & $1.4409(15)$ \\
\hline C2 & C3 & $1.3656(15)$ \\
\hline C3 & C4 & $1.4150(14)$ \\
\hline C4 & C5 & $1.3669(13)$ \\
\hline C5 & C6 & $1.4521(13)$ \\
\hline C6 & C7 & $1.3711(12)$ \\
\hline C6 & C13 & $1.4831(12)$ \\
\hline C7 & C8 & $1.5098(13)$ \\
\hline C7 & C12 & $1.4537(13)$ \\
\hline C8 & C9 & $1.5100(13)$ \\
\hline C8 & C19 & $1.5533(14)$ \\
\hline C8 & C20 & $1.5404(14)$ \\
\hline C9 & C10 & $1.3409(14)$ \\
\hline C10 & C11 & $1.4495(14)$ \\
\hline C11 & C12 & $1.3555(12)$ \\
\hline C13 & C14 & $1.4011(13)$ \\
\hline
\end{tabular}




\begin{tabular}{|l|l|l|}
\hline C13 & C18 & $1.3987(13)$ \\
\hline C14 & C15 & $1.3917(13)$ \\
\hline C15 & C16 & $1.3923(14)$ \\
\hline C16 & C17 & $1.3899(13)$ \\
\hline C17 & C18 & $1.3939(13)$ \\
\hline
\end{tabular}

Table 5.12. Bond angles $\left[^{\circ}\right]$ for $180 a a$

\begin{tabular}{|l|l|l|l|}
\hline Atom & Atom & Atom & Angle $^{\circ}$ \\
\hline C1 & N1 & C12 & $127.38(8)$ \\
\hline C5 & N1 & C1 & $124.07(8)$ \\
\hline C5 & N1 & C12 & $108.52(7)$ \\
\hline O1 & C1 & N1 & $120.43(9)$ \\
\hline O1 & C1 & C2 & $125.91(9)$ \\
\hline N1 & C1 & C2 & $113.65(8)$ \\
\hline C3 & C2 & C1 & $122.27(9)$ \\
\hline C2 & C3 & C4 & $121.52(9)$ \\
\hline C5 & C4 & C3 & $117.80(9)$ \\
\hline N1 & C5 & C6 & $108.17(8)$ \\
\hline C4 & C5 & N1 & $120.70(9)$ \\
\hline C4 & C5 & C6 & $131.10(9)$ \\
\hline C5 & C6 & C13 & $119.92(8)$ \\
\hline C7 & C6 & C5 & $107.80(8)$ \\
\hline C7 & C6 & C13 & $132.27(9)$ \\
\hline C6 & C7 & C8 & $131.32(8)$ \\
\hline C6 & C7 & C12 & $108.39(8)$ \\
\hline C12 & C7 & C8 & $119.95(8)$ \\
\hline C7 & C8 & C9 & $110.97(8)$ \\
\hline
\end{tabular}




\begin{tabular}{|l|l|l|l|}
\hline C7 & C8 & C19 & $107.64(8)$ \\
\hline C7 & C8 & C20 & $112.69(8)$ \\
\hline C9 & C8 & C19 & $107.68(8)$ \\
\hline C9 & C8 & C20 & $108.33(8)$ \\
\hline C20 & C8 & C19 & $109.40(8)$ \\
\hline C10 & C9 & C8 & $124.66(9)$ \\
\hline C9 & C10 & C11 & $122.16(9)$ \\
\hline C12 & C11 & C10 & $117.56(9)$ \\
\hline N1 & C12 & C7 & $107.10(7)$ \\
\hline C11 & C12 & N1 & $129.13(9)$ \\
\hline C11 & C12 & C7 & $123.76(9)$ \\
\hline C14 & C13 & C6 & $119.73(8)$ \\
\hline C18 & C13 & C6 & $121.49(8)$ \\
\hline C18 & C13 & C14 & $118.58(8)$ \\
\hline C15 & C14 & C13 & $120.71(9)$ \\
\hline C14 & C15 & C16 & $120.11(9)$ \\
\hline C17 & C16 & C15 & $119.76(8)$ \\
\hline C16 & C17 & C18 & $120.15(9)$ \\
\hline C17 & C18 & C13 & $120.68(8)$ \\
\hline
\end{tabular}

Table 5.13. Crystal data and structure refinement $180 \mathrm{da}$.

\begin{tabular}{|l|l|}
\hline Compound & $\mathbf{1 8 0 d a}$ \\
\hline Empirical formula & $\mathrm{C}_{20} \mathrm{H}_{16} \mathrm{ClNO}$ \\
\hline Formula weight & 321.79 \\
\hline Temperature/K & 214.99 \\
\hline Crystal system & monoclinic \\
\hline Space group & $\mathrm{P} 21 / \mathrm{n}$ \\
\hline
\end{tabular}




\begin{tabular}{|c|c|}
\hline $\mathrm{a} / \AA ̊$ & $9.1784(8)$ \\
\hline $\mathrm{b} / \AA ̊$ & $9.7854(7)$ \\
\hline$c / \AA ̊$ & $17.6525(16)$ \\
\hline$\alpha /^{\circ}$ & 90 \\
\hline$\beta /^{\circ}$ & $102.112(3)$ \\
\hline$\gamma / /^{\circ}$ & 90 \\
\hline Volume $/ \AA^{3}$ & $1550.2(2)$ \\
\hline Z & 4 \\
\hline$\rho_{\text {calc }} g / \mathrm{cm}^{3}$ & 1.379 \\
\hline$\mu / \mathrm{mm}^{-1}$ & 0.250 \\
\hline$F(000)$ & 672.0 \\
\hline Crystal size $/ \mathrm{mm}^{3}$ & $0.342 \times 0.142 \times 0.074$ \\
\hline Radiation & $\operatorname{MoK} \alpha(\lambda=0.71073)$ \\
\hline $2 \Theta$ range for data collection $/^{\circ}$ & 4.786 to 57.464 \\
\hline Index ranges & $-12 \leq h \leq 12,-13 \leq k \leq 13,-23 \leq \mathrm{I} \leq 23$ \\
\hline Reflections collected & 23026 \\
\hline Independent reflections & $4004\left[R_{\text {int }}=0.0273, R_{\text {sigma }}=0.0184\right]$ \\
\hline Data/restraints/parameters & $4004 / 0 / 210$ \\
\hline Goodness-of-fit on $\mathrm{F}^{2}$ & 1.058 \\
\hline Final $R$ indexes $[I>=2 \sigma(I)]$ & $R_{1}=0.0376, w R_{2}=0.0948$ \\
\hline Final $R$ indexes [all data] & $R_{1}=0.0440, w R_{2}=0.0998$ \\
\hline Largest diff. peak/hole / e $\AA^{-3}$ & $0.30 /-0.39$ \\
\hline
\end{tabular}




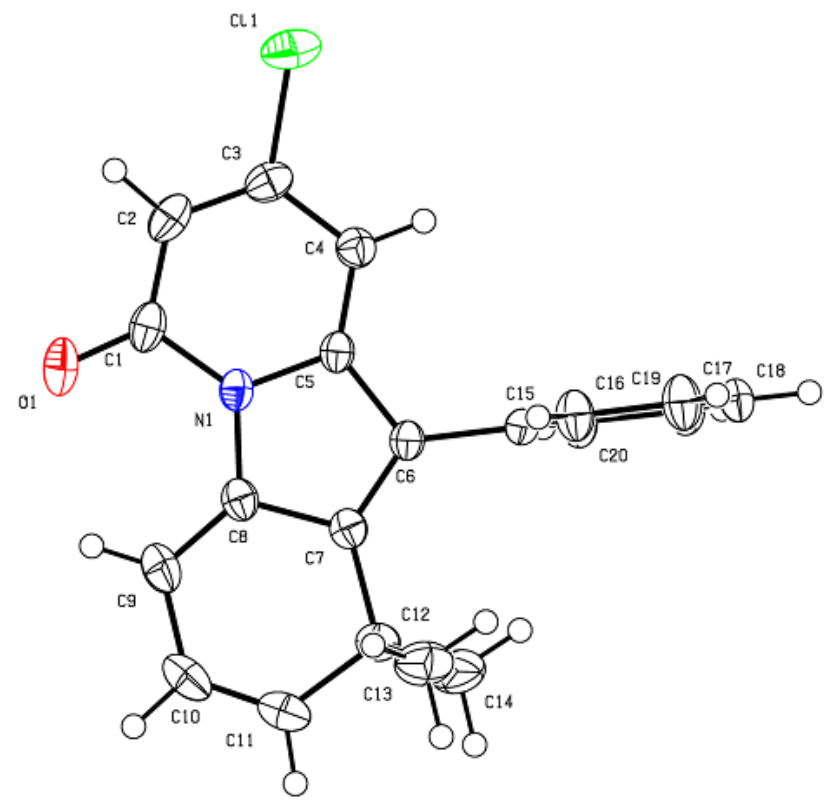

Figure 5.9. Molecular structure of $\mathbf{1 8 0 d a}$ with thermal ellipoids at $50 \%$ probablitiy level. The hydrogen atoms are omitted for clarity.

Crystal Data for $\mathrm{C}_{20} \mathrm{H}_{16} \mathrm{CINO}(M=321.79 \mathrm{~g} / \mathrm{mol})$ : monoclinic, space group $\mathrm{P} 21 / \mathrm{n}$ (no. 14), $a=9.1784(8) \AA, b=9.7854(7) \AA, c=17.6525(16) \AA, b=102.112(3)^{\circ}, V=$ 1550.2(2) $\AA^{3}, Z=4, T=214.99 \mathrm{~K}, \mu($ MoK $\alpha)=0.250 \mathrm{~mm}^{-1}$, Dcalc $=1.379 \mathrm{~g} / \mathrm{cm}^{3}, 23026$ reflections measured $\left(4.786^{\circ} \leq 2 \Theta \leq 57.464^{\circ}\right), 4004$ unique $\left(R_{\text {int }}=0.0273, R_{\text {sigma }}=\right.$ $0.0184)$ which were used in all calculations. The final $R_{1}$ was $0.0376(I>2 \sigma(I))$ and $w R_{2}$ was 0.0998 (all data).

Table 5.14. Bond Lengths [ $[\AA]$ for $180 \mathrm{da}$.

\begin{tabular}{|l|l|l|}
\hline Atom & Atom & Length/A \\
\hline Cl1 & C3 & $1.7336(14)$ \\
\hline O1 & C1 & $1.2305(16)$ \\
\hline N1 & C1 & $1.4057(16)$ \\
\hline N1 & C5 & $1.3886(14)$ \\
\hline N1 & C8 & $1.4081(16)$ \\
\hline C1 & C2 & $1.429(2)$ \\
\hline C2 & C3 & $1.359(2)$ \\
\hline C3 & C4 & $1.4088(18)$ \\
\hline
\end{tabular}




\begin{tabular}{|l|l|l|}
\hline C4 & C5 & $1.3620(17)$ \\
\hline C5 & C6 & $1.4513(16)$ \\
\hline C6 & C7 & $1.3639(16)$ \\
\hline C6 & C15 & $1.4888(15)$ \\
\hline C7 & C8 & $1.4473(16)$ \\
\hline C7 & C12 & $1.5100(17)$ \\
\hline C8 & C9 & $1.3506(17)$ \\
\hline C9 & C10 & $1.444(2)$ \\
\hline C10 & C11 & $1.330(2)$ \\
\hline C11 & C12 & $1.5099(19)$ \\
\hline C12 & C13 & $1.544(2)$ \\
\hline C12 & C14 & $1.5337(19)$ \\
\hline C15 & C16 & $1.3903(17)$ \\
\hline C15 & C20 & $1.3889(16)$ \\
\hline C16 & C17 & $1.3911(18)$ \\
\hline C17 & C18 & $1.3789(19)$ \\
\hline C18 & C19 & $1.3807(19)$ \\
\hline C19 & C20 & $1.3871(18)$ \\
\hline
\end{tabular}

Table 5.15. Bond angles $\left[^{\circ}\right.$ ] for $180 \mathrm{da}$

\begin{tabular}{|l|l|l|l|}
\hline Atom & Atom & Atom & Angle/ $^{\circ}$ \\
\hline C1 & N1 & C8 & $127.17(10)$ \\
\hline C5 & N1 & C1 & $124.09(11)$ \\
\hline C5 & N1 & C8 & $108.71(10)$ \\
\hline O1 & C1 & N1 & $120.28(13)$ \\
\hline O1 & C1 & C2 & $125.93(13)$ \\
\hline N1 & C1 & C2 & $113.78(11)$ \\
\hline
\end{tabular}




\begin{tabular}{|c|c|c|c|}
\hline C3 & $\mathrm{C} 2$ & $\mathrm{C} 1$ & $121.55(12)$ \\
\hline $\mathrm{C} 2$ & C3 & $\mathrm{Cl} 1$ & $119.41(10)$ \\
\hline $\mathrm{C} 2$ & C3 & C4 & $122.92(12)$ \\
\hline C4 & C3 & $\mathrm{Cl} 1$ & $117.66(11)$ \\
\hline C5 & $\mathrm{C} 4$ & C3 & $116.90(12)$ \\
\hline N1 & C5 & $\mathrm{C} 6$ & $107.83(10)$ \\
\hline C4 & C5 & N1 & $120.73(11)$ \\
\hline C4 & C5 & C6 & $131.40(11)$ \\
\hline C5 & C6 & C15 & $121.63(10)$ \\
\hline $\mathrm{C7}$ & C6 & $\mathrm{C} 5$ & $107.81(10)$ \\
\hline $\mathrm{C7}$ & C6 & C15 & $130.55(11)$ \\
\hline C6 & $\mathrm{C7}$ & $\mathrm{C} 8$ & $108.72(11)$ \\
\hline C6 & $\mathrm{C7}$ & C12 & $131.50(11)$ \\
\hline C8 & $\mathrm{C7}$ & C12 & $119.73(11)$ \\
\hline N1 & $\mathrm{C} 8$ & $\mathrm{C7}$ & $106.88(10)$ \\
\hline C9 & $\mathrm{C} 8$ & N1 & $129.06(12)$ \\
\hline C9 & $\mathrm{C} 8$ & $\mathrm{C7}$ & $124.01(12)$ \\
\hline C8 & C9 & C10 & $117.58(13)$ \\
\hline C11 & C10 & C9 & $122.36(13)$ \\
\hline C10 & C11 & C12 & $124.66(13)$ \\
\hline $\mathrm{C7}$ & C12 & C13 & $108.99(11)$ \\
\hline $\mathrm{C7}$ & C12 & C14 & $111.29(11)$ \\
\hline C11 & C12 & C7 & $111.09(11)$ \\
\hline C11 & C12 & C13 & $107.23(12)$ \\
\hline C11 & C12 & C14 & $108.45(12)$ \\
\hline C14 & C12 & C13 & $109.70(13)$ \\
\hline C16 & C15 & C6 & $120.68(10)$ \\
\hline
\end{tabular}




\begin{tabular}{|l|l|l|l|}
\hline C20 & C15 & C6 & $120.87(11)$ \\
\hline C20 & C15 & C16 & $118.43(11)$ \\
\hline C15 & C16 & C17 & $120.74(12)$ \\
\hline C18 & C17 & C16 & $120.14(12)$ \\
\hline C17 & C18 & C19 & $119.60(12)$ \\
\hline C18 & C19 & C20 & $120.36(12)$ \\
\hline C19 & C20 & C15 & $120.70(12)$ \\
\hline
\end{tabular}

Table 5.16. Crystal data and structure refinement 180 ea.

\begin{tabular}{|c|c|}
\hline Compound & 180ea \\
\hline Empirical formula & $\mathrm{C}_{20} \mathrm{H}_{16} \mathrm{BrNO}$ \\
\hline Formula weight & 366.25 \\
\hline Temperature/K & 99.99 \\
\hline Crystal system & monoclinic \\
\hline Space group & $\mathrm{P} 2{ }_{1} / \mathrm{n}$ \\
\hline$a / \AA ̊$ & $9.2403(5)$ \\
\hline $\mathrm{b} / \AA ̊ \AA$ & $9.7366(6)$ \\
\hline$c / \AA ̊$ & $17.5839(12)$ \\
\hline$\alpha /^{\circ}$ & 90 \\
\hline$\beta /^{\circ}$ & $102.074(2)$ \\
\hline$\gamma /{ }^{\circ}$ & 90 \\
\hline Volume $/ \AA^{3}$ & $1547.01(17)$ \\
\hline Z & 4 \\
\hline$\rho_{\text {calc }} \mathrm{g} / \mathrm{cm}^{3}$ & 1.572 \\
\hline$\mu / \mathrm{mm}^{-1}$ & 2.661 \\
\hline$F(000)$ & 744.0 \\
\hline Crystal size $/ \mathrm{mm}^{3}$ & $0.398 \times 0.328 \times 0.128$ \\
\hline
\end{tabular}




\begin{tabular}{|c|c|}
\hline Radiation & $\operatorname{MoK} \alpha(\lambda=0.71073)$ \\
\hline $2 \Theta$ range for data collection $/^{\circ}$ & 4.738 to 63.28 \\
\hline Index ranges & $-13 \leq h \leq 13,-14 \leq k \leq 14,-25 \leq \mathrm{I} \leq 25$ \\
\hline Reflections collected & 54741 \\
\hline Independent reflections & $5186\left[R_{\text {int }}=0.0212, R_{\text {sigma }}=0.0128\right]$ \\
\hline Data/restraints/parameters & $5186 / 0 / 210$ \\
\hline Goodness-of-fit on $\mathrm{F}^{2}$ & 1.043 \\
\hline Final $R$ indexes $[I>=2 \sigma(I)]$ & $R_{1}=0.0236, w R_{2}=0.0736$ \\
\hline Final $R$ indexes [all data] & $\mathrm{R}_{1}=0.0244, w \mathrm{R}_{2}=0.0741$ \\
\hline Largest diff. peak/hole / e $\AA^{-3}$ & $0.59 /-0.43$ \\
\hline
\end{tabular}

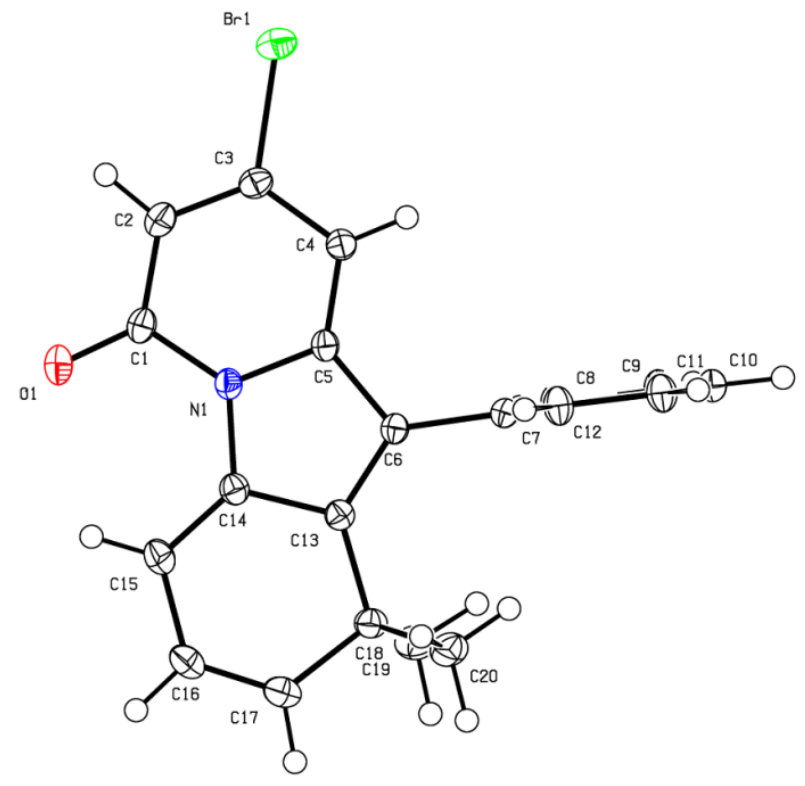

Figure 5.10. Molecular structure of $\mathbf{1 8 0 e a}$ with thermal ellipoids at $50 \%$ probablitiy level. The hydrogen atoms are omitted for clarity.

Crystal Data for $\mathrm{C}_{20} \mathrm{H}_{16} \mathrm{BrNO}\left(\mathrm{M}=366.25 \mathrm{~g} / \mathrm{mol}\right.$ ): monoclinic, space group $\mathrm{P} 2{ }_{1} / \mathrm{n}$ (no. 14), $a=9.2403(5) \AA, b=9.7366(6) \AA, c=17.5839(12) \AA, b=102.074(2)^{\circ}, V=$ 1547.01(17) $\AA^{3}, Z=4, T=99.99 \mathrm{~K}, \mu($ MoK $\alpha)=2.661 \mathrm{~mm}^{-1}$, Dcalc $=1.572 \mathrm{~g} / \mathrm{cm}^{3}, 54741$ reflections measured $\left(4.738^{\circ} \leq 2 \Theta \leq 63.28^{\circ}\right), 5186$ unique $\left(R_{\text {int }}=0.0212, R_{\text {sigma }}=0.0128\right)$ which were used in all calculations. The final $R_{1}$ was $0.0236(I>2 \sigma(I))$ and $w R_{2}$ was 0.0741 (all data). 
Table 5.17. Bond Lengths $[\AA ̊]$ for 180 ea.

\begin{tabular}{|c|c|c|}
\hline Atom & Atom & Length/Å \\
\hline $\mathrm{Br} 1$ & C3 & $1.8858(11)$ \\
\hline 01 & $\mathrm{C} 1$ & $1.2315(14)$ \\
\hline N1 & $\mathrm{C} 1$ & $1.4035(13)$ \\
\hline N1 & $\mathrm{C} 5$ & $1.3897(12)$ \\
\hline N1 & C14 & $1.4094(14)$ \\
\hline C1 & $\mathrm{C} 2$ & $1.4382(16)$ \\
\hline $\mathrm{C} 2$ & C3 & $1.3673(16)$ \\
\hline C3 & $\mathrm{C} 4$ & $1.4110(15)$ \\
\hline C4 & C5 & $1.3673(14)$ \\
\hline C5 & C6 & $1.4527(14)$ \\
\hline C6 & $\mathrm{C7}$ & $1.4837(14)$ \\
\hline C6 & C13 & $1.3695(14)$ \\
\hline $\mathrm{C7}$ & $\mathrm{C} 8$ & $1.3967(14)$ \\
\hline $\mathrm{C7}$ & C12 & $1.3953(14)$ \\
\hline C8 & $\mathrm{C9}$ & $1.3917(15)$ \\
\hline C9 & C10 & $1.3897(15)$ \\
\hline C10 & C11 & $1.3887(15)$ \\
\hline C11 & C12 & $1.3961(15)$ \\
\hline C13 & C14 & $1.4490(14)$ \\
\hline C13 & C18 & $1.5106(15)$ \\
\hline C14 & C15 & $1.3551(14)$ \\
\hline C15 & C16 & $1.4503(17)$ \\
\hline C16 & C17 & $1.3401(17)$ \\
\hline C17 & C18 & $1.5096(16)$ \\
\hline
\end{tabular}




\begin{tabular}{|l|l|l|}
\hline C18 & C19 & $1.5498(16)$ \\
\hline C18 & C20 & $1.5392(16)$ \\
\hline
\end{tabular}

Table 5.18. Bond angles $\left[{ }^{\circ}\right]$ for 180 ea

\begin{tabular}{|l|l|l|l|}
\hline Atom & Atom & Atom & Angle/ $^{\circ}$ \\
\hline C1 & N1 & C14 & $127.07(9)$ \\
\hline C5 & N1 & C1 & $124.37(9)$ \\
\hline C5 & N1 & C14 & $108.51(8)$ \\
\hline O1 & C1 & N1 & $120.75(11)$ \\
\hline O1 & C1 & C2 & $125.36(10)$ \\
\hline N1 & C1 & C2 & $113.88(9)$ \\
\hline C3 & C2 & C1 & $121.10(10)$ \\
\hline C2 & C3 & Br1 & $119.47(8)$ \\
\hline C2 & C3 & C4 & $123.08(10)$ \\
\hline C4 & C3 & Br1 & $117.44(8)$ \\
\hline C5 & C4 & C3 & $116.81(9)$ \\
\hline N1 & C5 & C6 & $108.16(9)$ \\
\hline C4 & C5 & N1 & $120.73(9)$ \\
\hline C4 & C5 & C6 & $131.06(9)$ \\
\hline C5 & C6 & C7 & $121.76(9)$ \\
\hline C13 & C6 & C5 & $107.54(9)$ \\
\hline C13 & C6 & C7 & $130.67(9)$ \\
\hline C8 & C7 & C6 & $120.55(9)$ \\
\hline C12 & C7 & C6 & $120.74(9)$ \\
\hline C12 & C7 & C8 & $118.70(9)$ \\
\hline C9 $10 ~$ & C9 & C8 & $120.58(10)$ \\
\hline
\end{tabular}




\begin{tabular}{|l|l|l|l|}
\hline C11 & C10 & C9 & $119.66(10)$ \\
\hline C10 & C11 & C12 & $120.03(10)$ \\
\hline C7 & C12 & C11 & $120.70(10)$ \\
\hline C6 & C13 & C14 & $108.68(9)$ \\
\hline C6 & C13 & C18 & $131.31(9)$ \\
\hline C14 & C13 & C18 & $119.96(9)$ \\
\hline N1 & C14 & C13 & $107.06(8)$ \\
\hline C15 & C14 & N1 & $128.91(10)$ \\
\hline C15 & C14 & C13 & $123.99(10)$ \\
\hline C14 & C15 & C16 & $117.44(10)$ \\
\hline C17 & C16 & C15 & $122.24(10)$ \\
\hline C16 & C17 & C18 & $124.56(10)$ \\
\hline C13 & C18 & C19 & $108.95(9)$ \\
\hline C13 & C18 & C20 & $111.27(9)$ \\
\hline C17 & C18 & C13 & $111.18(9)$ \\
\hline C17 & C18 & C19 & $107.34(9)$ \\
\hline C17 & C18 & C20 & $108.51(9)$ \\
\hline C20 & C18 & C19 & $109.50(10)$ \\
\hline
\end{tabular}

Table 5.19. Crystal data and structure refinement 180ga.

\begin{tabular}{|l|l|}
\hline Compound & $\mathbf{1 8 0 g a}$ \\
\hline Empirical formula & $\mathrm{C}_{24} \mathrm{H}_{19} \mathrm{NO}$ \\
\hline Formula weight & 337.40 \\
\hline Temperature/K & 149.98 \\
\hline Crystal system & triclinic \\
\hline Space group & $\mathrm{P}-1$ \\
\hline a/A & $8.6794(10)$ \\
\hline
\end{tabular}




\begin{tabular}{|c|c|}
\hline $\mathrm{b} / \AA ̊ \AA$ & $10.1657(11)$ \\
\hline$c / \AA ̊$ & $11.5718(12)$ \\
\hline$\alpha /^{\circ}$ & $107.780(4)$ \\
\hline$\beta /^{\circ}$ & $108.770(4)$ \\
\hline$\gamma /{ }^{\circ}$ & $103.334(5)$ \\
\hline Volume $/ \AA^{3}$ & $857.10(17)$ \\
\hline Z & 2 \\
\hline$\rho_{\text {calc }} \mathrm{g} / \mathrm{cm}^{3}$ & 1.307 \\
\hline$\mu / \mathrm{mm}^{-1}$ & 0.079 \\
\hline$F(000)$ & 356.0 \\
\hline Crystal size $/ \mathrm{mm}^{3}$ & $0.407 \times 0.288 \times 0.178$ \\
\hline Radiation & $\operatorname{MoK} \alpha(\lambda=0.71073)$ \\
\hline $2 \Theta$ range for data collection $/^{\circ}$ & 5.158 to 61.104 \\
\hline Index ranges & $-12 \leq h \leq 12,-14 \leq k \leq 14,-16 \leq \mathrm{I} \leq 16$ \\
\hline Reflections collected & 32730 \\
\hline Independent reflections & $5231\left[R_{\text {int }}=0.0229, R_{\text {sigma }}=0.0176\right]$ \\
\hline Data/restraints/parameters & $5231 / 0 / 237$ \\
\hline Goodness-of-fit on $\mathrm{F}^{2}$ & 1.027 \\
\hline Final $R$ indexes $[I>=2 \sigma(I)]$ & $\mathrm{R}_{1}=0.0411, w \mathrm{R}_{2}=0.1168$ \\
\hline Final $R$ indexes [all data] & $\mathrm{R}_{1}=0.0425, w \mathrm{R}_{2}=0.1183$ \\
\hline Largest diff. peak/hole / e $\AA^{-3}$ & $0.41 /-0.19$ \\
\hline
\end{tabular}




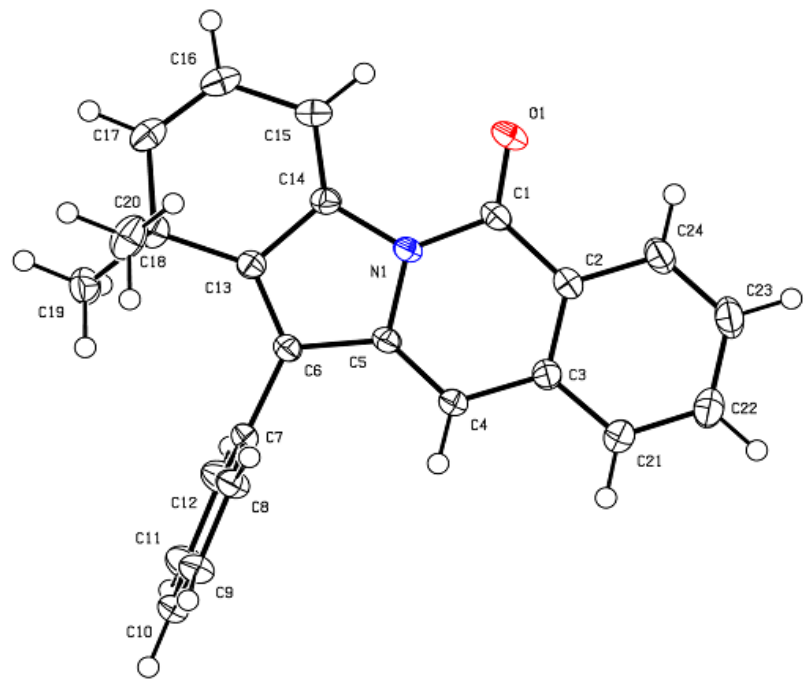

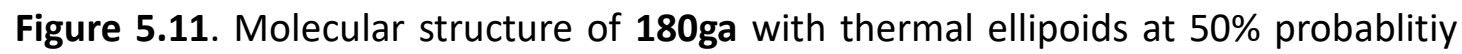
level. The hydrogen atoms are omitted for clarity.

Crystal Data for $\mathrm{C}_{24} \mathrm{H}_{19} \mathrm{NO}(M=337.40 \mathrm{~g} / \mathrm{mol}$ ): triclinic, space group P-1 (no. 2), $a=$ $8.6794(10) \AA, b=\quad 10.1657(11) \AA, c=11.5718(12) \AA, \alpha=\quad 107.780(4)^{\circ}, b=$ $108.770(4)^{\circ}, \gamma=103.334(5)^{\circ}, V=857.10(17) \AA^{3}, Z=2, T=149.98 \mathrm{~K}, \mu(\mathrm{MoK} \alpha)=0.079$ $\mathrm{mm}^{-1}$, Dcalc $=1.307 \mathrm{~g} / \mathrm{cm}^{3}, 32730$ reflections measured $\left(5.158^{\circ} \leq 2 \Theta \leq 61.104^{\circ}\right), 5231$ unique $\left(R_{\text {int }}=0.0229, R_{\text {sigma }}=0.0176\right)$ which were used in all calculations. The final $R_{1}$ was $0.0411(\mathrm{I}>2 \sigma(\mathrm{I}))$ and $w R_{2}$ was 0.1183 (all data).

Table 5.20. Bond Lengths $[\AA ̊]$ for 180ga.

\begin{tabular}{|l|l|l|}
\hline Atom & Atom & Length/Å \\
\hline O1 & C1 & $1.2313(10)$ \\
\hline N1 & C1 & $1.3888(10)$ \\
\hline N1 & C5 & $1.3995(9)$ \\
\hline N1 & C14 & $1.4101(10)$ \\
\hline C1 & C2 & $1.4648(12)$ \\
\hline C2 & C3 & $1.4127(11)$ \\
\hline C2 & C24 & $1.4038(11)$ \\
\hline C3 & C4 & $1.4340(11)$ \\
\hline
\end{tabular}




\begin{tabular}{|l|l|l|}
\hline C3 & C21 & $1.4093(11)$ \\
\hline C4 & C5 & $1.3554(10)$ \\
\hline C5 & C6 & $1.4535(10)$ \\
\hline C6 & C7 & $1.4830(10)$ \\
\hline C6 & C13 & $1.3660(10)$ \\
\hline C7 & C8 & $1.3943(11)$ \\
\hline C7 & C12 & $1.3939(12)$ \\
\hline C8 & C9 & $1.3936(11)$ \\
\hline C9 & C10 & $1.3885(14)$ \\
\hline C10 & C11 & $1.3842(16)$ \\
\hline C11 & C12 & $1.3924(13)$ \\
\hline C13 & C14 & $1.4540(11)$ \\
\hline C13 & C18 & $1.5109(11)$ \\
\hline C14 & C15 & $1.3531(11)$ \\
\hline C15 & C16 & $1.4506(13)$ \\
\hline C16 & C17 & $1.3393(14)$ \\
\hline C17 & C18 & $1.5127(12)$ \\
\hline C18 & C19 & $1.5327(13)$ \\
\hline C18 & C20 & $1.5528(12)$ \\
\hline C21 & C22 & $1.3790(13)$ \\
\hline C22 & C23 & $1.4013(15)$ \\
\hline C23 & C24 & $1.3802(14)$ \\
\hline
\end{tabular}

Table 5.21. Bond angles $\left[{ }^{\circ}\right]$ for 180 ga

\begin{tabular}{|l|l|l|l|}
\hline Atom & Atom & Atom & Angle $^{\circ}$ \\
\hline C1 & N1 & C5 & $124.20(7)$ \\
\hline C1 & N1 & C14 & $127.13(7)$ \\
\hline
\end{tabular}




\begin{tabular}{|c|c|c|c|}
\hline C5 & N1 & C14 & $108.67(6)$ \\
\hline 01 & $\mathrm{C} 1$ & N1 & $120.71(8)$ \\
\hline 01 & $\mathrm{C} 1$ & $\mathrm{C} 2$ & $124.68(8)$ \\
\hline N1 & $\mathrm{C} 1$ & $\mathrm{C} 2$ & $114.60(7)$ \\
\hline C3 & $\mathrm{C} 2$ & $\mathrm{C} 1$ & $121.12(7)$ \\
\hline $\mathrm{C} 24$ & $\mathrm{C} 2$ & $\mathrm{C} 1$ & $118.88(8)$ \\
\hline $\mathrm{C} 24$ & $\mathrm{C} 2$ & C3 & $120.00(8)$ \\
\hline $\mathrm{C} 2$ & C3 & $\mathrm{C} 4$ & $119.79(7)$ \\
\hline $\mathrm{C} 21$ & $\mathrm{C} 3$ & $\mathrm{C} 2$ & $118.65(8)$ \\
\hline C21 & $\mathrm{C} 3$ & C4 & $121.55(8)$ \\
\hline $\mathrm{C} 5$ & $\mathrm{C} 4$ & C3 & $118.93(7)$ \\
\hline N1 & C5 & C6 & $107.55(6)$ \\
\hline $\mathrm{C} 4$ & $\mathrm{C} 5$ & N1 & $121.23(7)$ \\
\hline $\mathrm{C} 4$ & $\mathrm{C} 5$ & C6 & $131.21(7)$ \\
\hline C5 & C6 & $\mathrm{C7}$ & $119.83(7)$ \\
\hline C13 & C6 & C5 & $108.15(7)$ \\
\hline C13 & C6 & $\mathrm{C7}$ & $132.02(7)$ \\
\hline $\mathrm{C} 8$ & $\mathrm{C7}$ & C6 & $120.68(7)$ \\
\hline C12 & $\mathrm{C7}$ & C6 & $120.31(7)$ \\
\hline C12 & $\mathrm{C7}$ & $\mathrm{C} 8$ & $118.88(8)$ \\
\hline C9 & C8 & $\mathrm{C} 7$ & $120.67(8)$ \\
\hline C10 & $\mathrm{C9}$ & $\mathrm{C} 8$ & $120.09(9)$ \\
\hline C11 & C10 & C9 & $119.42(8)$ \\
\hline C10 & C11 & $\mathrm{C} 12$ & $120.76(9)$ \\
\hline C11 & C12 & $\mathrm{C} 7$ & $120.17(9)$ \\
\hline $\mathrm{C} 6$ & C13 & C14 & $108.58(7)$ \\
\hline $\mathrm{C} 6$ & C13 & C18 & $131.96(7)$ \\
\hline
\end{tabular}




\begin{tabular}{|l|l|l|l|}
\hline C14 & C13 & C18 & $119.19(7)$ \\
\hline N1 & C14 & C13 & $106.93(6)$ \\
\hline C15 & C14 & N1 & $129.14(8)$ \\
\hline C15 & C14 & C13 & $123.72(8)$ \\
\hline C14 & C15 & C16 & $117.33(8)$ \\
\hline C17 & C16 & C15 & $122.42(8)$ \\
\hline C16 & C17 & C18 & $123.91(8)$ \\
\hline C13 & C18 & C17 & $110.58(7)$ \\
\hline C13 & C18 & C19 & $113.37(7)$ \\
\hline C13 & C18 & C20 & $107.24(7)$ \\
\hline C17 & C18 & C19 & $110.00(7)$ \\
\hline C17 & C18 & C20 & $106.63(7)$ \\
\hline C19 & C18 & C20 & $108.74(8)$ \\
\hline C22 & C21 & C3 & $120.56(9)$ \\
\hline C21 & C22 & C23 & $120.46(9)$ \\
\hline C24 & C23 & C22 & $120.02(8)$ \\
\hline C23 & C24 & C2 & $120.26(9)$ \\
\hline
\end{tabular}

Table 5.22. Crystal data and structure refinement 180af.

\begin{tabular}{|l|l|}
\hline Compound & 180af \\
\hline Empirical formula & $\mathrm{C}_{22} \mathrm{H}_{19} \mathrm{NO}$ \\
\hline Formula weight & 313.38 \\
\hline Temperature/K & 215.12 \\
\hline Crystal system & triclinic \\
\hline Space group & $\mathrm{P}-1$ \\
\hline a/Å & $9.875(2)$ \\
\hline b/Å & $10.011(2)$ \\
\hline
\end{tabular}




\begin{tabular}{|c|c|}
\hline$c / \AA$ & $10.0121(19)$ \\
\hline$\alpha /^{\circ}$ & $67.728(6)$ \\
\hline$\beta /^{\circ}$ & $77.189(8)$ \\
\hline$\gamma /{ }^{\circ}$ & $61.053(9)$ \\
\hline Volume $/ \AA^{3}$ & $800.7(3)$ \\
\hline Z & 2 \\
\hline$\rho_{\text {calc }} \mathrm{g} / \mathrm{cm}^{3}$ & 1.300 \\
\hline$\mu / \mathrm{mm}^{-1}$ & 0.079 \\
\hline$F(000)$ & 332.0 \\
\hline Crystal size $/ \mathrm{mm}^{3}$ & $0.324 \times 0.125 \times 0.11$ \\
\hline Radiation & $\operatorname{MoK} \alpha(\lambda=0.71073)$ \\
\hline $2 \Theta$ range for data collection $/^{\circ}$ & 5.428 to 59.342 \\
\hline Index ranges & $-13 \leq h \leq 13,-13 \leq k \leq 13,-13 \leq \mathrm{I} \leq 13$ \\
\hline Reflections collected & 16703 \\
\hline Independent reflections & $4492\left[R_{\text {int }}=0.0209, R_{\text {sigma }}=0.0190\right]$ \\
\hline Data/restraints/parameters & $4492 / 0 / 217$ \\
\hline Goodness-of-fit on $F^{2}$ & 1.076 \\
\hline Final $R$ indexes $[\mid>=2 \sigma(I)]$ & $R_{1}=0.0464, w R_{2}=0.1306$ \\
\hline Final $R$ indexes [all data] & $R_{1}=0.0505, w R_{2}=0.1340$ \\
\hline Largest diff. peak/hole / e $\AA^{-3}$ & $0.27 /-0.19$ \\
\hline
\end{tabular}




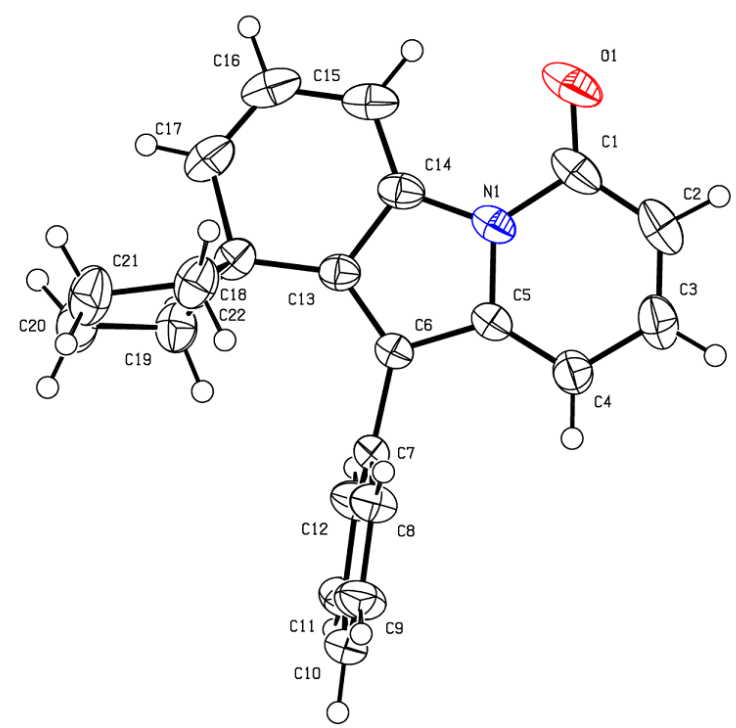

Figure 5.12. Molecular structure of 180 af with thermal ellipoids at $50 \%$ probablitiy level. The hydrogen atoms are omitted for clarity.

Crystal Data for $\mathrm{C}_{22} \mathrm{H}_{19} \mathrm{NO}(M=313.38 \mathrm{~g} / \mathrm{mol}$ ): triclinic, space group P-1 (no. 2), $a=$ 9.875(2) $\AA, b=10.011(2) \AA, c=10.0121(19) \AA, \alpha=67.728(6)^{\circ}, b=77.189(8)^{\circ}, y=$ 61.053(9) $, V=800.7(3) \AA^{3}, Z=2, T=215.12 \mathrm{~K}, \mu($ MoK $\alpha)=0.079 \mathrm{~mm}^{-1}$, Dcalc $=$ $1.300 \mathrm{~g} / \mathrm{cm}^{3}, 16703$ reflections measured $\left(5.428^{\circ} \leq 2 \Theta \leq 59.342^{\circ}\right), 4492$ unique $\left(R_{\text {int }}=\right.$ $\left.0.0209, R_{\text {sigma }}=0.0190\right)$ which were used in all calculations. The final $R_{1}$ was $0.0464(I>$ $2 \sigma(\mathrm{I}))$ and $w R_{2}$ was 0.1340 (all data).

Table 5.23. Bond Lengths $[\AA ̊]$ for 180af.

\begin{tabular}{|l|l|l|}
\hline Atom & Atom & Length/A \\
\hline O1 & C1 & $1.2324(17)$ \\
\hline N1 & C1 & $1.4053(15)$ \\
\hline N1 & C5 & $1.3844(14)$ \\
\hline N1 & C14 & $1.4067(16)$ \\
\hline C1 & C2 & $1.434(2)$ \\
\hline C2 & C3 & $1.355(2)$ \\
\hline C3 & C4 & $1.4126(17)$ \\
\hline C4 & C5 & $1.3622(17)$ \\
\hline
\end{tabular}




\begin{tabular}{|l|l|l|}
\hline C5 & C6 & $1.4521(15)$ \\
\hline C6 & C7 & $1.4828(14)$ \\
\hline C6 & C13 & $1.3639(15)$ \\
\hline C7 & C8 & $1.3870(16)$ \\
\hline C7 & C12 & $1.3895(16)$ \\
\hline C8 & C9 & $1.3911(17)$ \\
\hline C9 & C10 & $1.375(2)$ \\
\hline C10 & C11 & $1.374(2)$ \\
\hline C11 & C12 & $1.3895(17)$ \\
\hline C13 & C14 & $1.4542(15)$ \\
\hline C13 & C18 & $1.5032(16)$ \\
\hline C14 & C15 & $1.3514(17)$ \\
\hline C15 & C16 & $1.441(2)$ \\
\hline C16 & C17 & $1.334(2)$ \\
\hline C17 & C18 & $1.5099(18)$ \\
\hline C18 & C19 & $1.5440(18)$ \\
\hline C18 & C22 & $1.5584(18)$ \\
\hline C19 & C20 & $1.5361(19)$ \\
\hline C20 & C21 & $1.538(2)$ \\
\hline C21 & C22 & $1.532(2)$ \\
\hline
\end{tabular}

Table 5.24. Bond angles $\left[{ }^{\circ}\right]$ for 180 af

\begin{tabular}{|l|l|l|l|}
\hline Atom & Atom & Atom & Angle/ $^{\circ}$ \\
\hline C1 & N1 & C14 & $127.56(11)$ \\
\hline C5 & N1 & C1 & $123.83(11)$ \\
\hline C5 & N1 & C14 & $108.60(9)$ \\
\hline O1 & C1 & N1 & $119.99(14)$ \\
\hline
\end{tabular}




\begin{tabular}{|c|c|c|c|}
\hline 01 & $\mathrm{C} 1$ & $\mathrm{C} 2$ & $126.21(13)$ \\
\hline N1 & $\mathrm{C} 1$ & $\mathrm{C} 2$ & $113.79(12)$ \\
\hline C3 & $\mathrm{C} 2$ & $\mathrm{C} 1$ & $122.14(12)$ \\
\hline $\mathrm{C} 2$ & C3 & $\mathrm{C} 4$ & $121.81(13)$ \\
\hline C5 & C4 & $\mathrm{C} 3$ & $117.69(12)$ \\
\hline N1 & C5 & C6 & 107.90(9) \\
\hline $\mathrm{C} 4$ & C5 & N1 & $120.68(10)$ \\
\hline $\mathrm{C} 4$ & $\mathrm{C} 5$ & C6 & $131.42(10)$ \\
\hline C5 & $\mathrm{C} 6$ & $\mathrm{C} 7$ & 119.20(9) \\
\hline C13 & $\mathrm{C} 6$ & C5 & 108.18(9) \\
\hline C13 & C6 & $\mathrm{C7}$ & $132.61(10)$ \\
\hline $\mathrm{C} 8$ & $\mathrm{C7}$ & C6 & $120.41(10)$ \\
\hline $\mathrm{C} 8$ & $\mathrm{C} 7$ & C12 & $118.63(10)$ \\
\hline C12 & $\mathrm{C} 7$ & C6 & $120.72(10)$ \\
\hline $\mathrm{C} 7$ & $\mathrm{C} 8$ & C9 & $120.45(11)$ \\
\hline C10 & C9 & $\mathrm{C} 8$ & $120.26(12)$ \\
\hline C11 & C10 & $\mathrm{C} 9$ & $119.90(11)$ \\
\hline C10 & C11 & C12 & $120.17(12)$ \\
\hline $\mathrm{C} 7$ & C12 & C11 & $120.58(12)$ \\
\hline $\mathrm{C} 6$ & C13 & C14 & $108.02(10)$ \\
\hline $\mathrm{C} 6$ & C13 & C18 & $131.94(10)$ \\
\hline C14 & C13 & C18 & $119.81(10)$ \\
\hline N1 & C14 & C13 & 107.23(9) \\
\hline C15 & C14 & N1 & $129.24(12)$ \\
\hline C15 & C14 & C13 & $123.44(12)$ \\
\hline C14 & C15 & C16 & $117.51(12)$ \\
\hline C17 & C16 & C15 & $122.51(12)$ \\
\hline
\end{tabular}




\begin{tabular}{|l|l|l|l|}
\hline C16 & C17 & C18 & $124.25(13)$ \\
\hline C13 & C18 & C17 & $110.59(11)$ \\
\hline C13 & C18 & C19 & $116.33(10)$ \\
\hline C13 & C18 & C22 & $110.17(10)$ \\
\hline C17 & C18 & C19 & $110.64(11)$ \\
\hline C17 & C18 & C22 & $108.27(10)$ \\
\hline C19 & C18 & C22 & $100.16(10)$ \\
\hline C20 & C19 & C18 & $105.27(11)$ \\
\hline C19 & C20 & C21 & $105.73(12)$ \\
\hline C22 & C21 & C20 & $106.13(11)$ \\
\hline C21 & C22 & C18 & $104.78(11)$ \\
\hline
\end{tabular}

Table 5.25. Crystal data and structure refinement 180aj.

\begin{tabular}{|c|c|}
\hline Compound & 180aj \\
\hline Empirical formula & $\mathrm{C}_{18} \mathrm{H}_{15} \mathrm{NOS}$ \\
\hline Formula weight & 293.37 \\
\hline Temperature/K & 150.0 \\
\hline Crystal system & orthorhombic \\
\hline Space group & Pbca \\
\hline $\mathrm{a} / \AA ̊$ & $11.8017(9)$ \\
\hline $\mathrm{b} / \AA ̊$ & $15.4593(10)$ \\
\hline$c / \AA$ & $15.6870(11)$ \\
\hline$\alpha /^{\circ}$ & 90 \\
\hline$\beta /^{\circ}$ & 90 \\
\hline$\gamma /{ }^{\circ}$ & 90 \\
\hline Volume/ $/ \AA^{3}$ & $2862.0(3)$ \\
\hline Z & 8 \\
\hline
\end{tabular}




\begin{tabular}{|c|c|}
\hline$\rho_{\text {calc }} / \mathrm{cm}^{3}$ & 1.362 \\
\hline$\mu / \mathrm{mm}^{-1}$ & 0.224 \\
\hline$F(000)$ & 1232.0 \\
\hline Crystal size $/ \mathrm{mm}^{3}$ & $0.429 \times 0.429 \times 0.34$ \\
\hline Radiation & $\operatorname{MoK} \alpha(\lambda=0.71073)$ \\
\hline $2 \Theta$ range for data collection $/^{\circ}$ & 5.06 to 59.188 \\
\hline Index ranges & $-16 \leq h \leq 15,-21 \leq k \leq 21,-21 \leq \mathrm{I} \leq 21$ \\
\hline Reflections collected & 26519 \\
\hline Independent reflections & $4013\left[R_{\text {int }}=0.0236, R_{\text {sigma }}=0.0158\right]$ \\
\hline Data/restraints/parameters & 4013/51/199 \\
\hline Goodness-of-fit on $F^{2}$ & 1.058 \\
\hline Final $R$ indexes $[I>=2 \sigma(I)]$ & $R_{1}=0.0365, w R_{2}=0.0969$ \\
\hline Final $\mathrm{R}$ indexes [all data] & $\mathrm{R}_{1}=0.0397, \mathrm{wR}_{2}=0.0996$ \\
\hline Largest diff. peak/hole / e $\AA^{-3}$ & $0.37 /-0.29$ \\
\hline
\end{tabular}

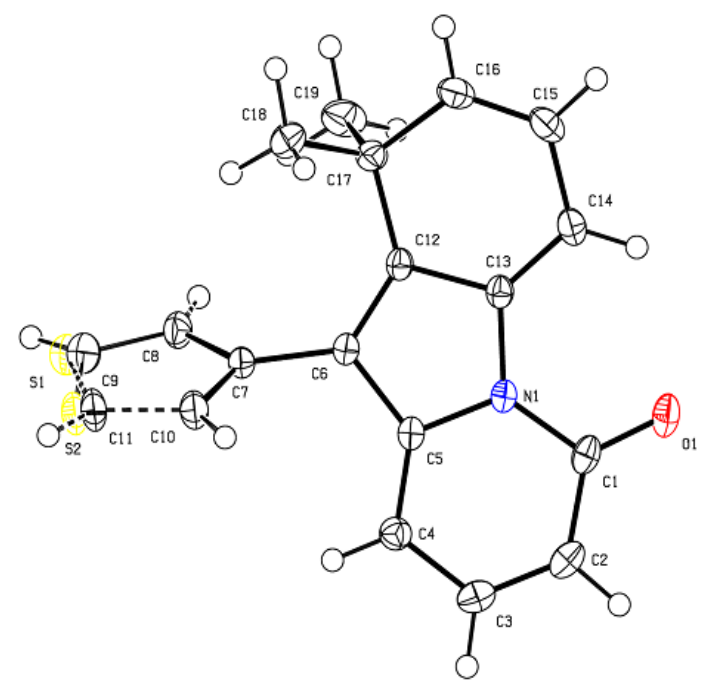

Figure 5.13. Molecular structure of 180 aj with thermal ellipoids at $50 \%$ probablitiy level. The hydrogen atoms are omitted for clarity.

Crystal Data for $\mathrm{C}_{18} \mathrm{H}_{15} \mathrm{NOS}(M=293.37 \mathrm{~g} / \mathrm{mol}$ ): orthorhombic, space group Pbca (no. 61), $a=11.8017(9) \AA, b=15.4593(10) \AA, c=15.6870(11) \AA, V=2862.0(3) \AA^{3}, Z=8, T=$ 
$150.0 \mathrm{~K}, \mu(\mathrm{MoK} \alpha)=0.224 \mathrm{~mm}^{-1}$, Dcalc $=1.362 \mathrm{~g} / \mathrm{cm}^{3}, 26519$ reflections measured $\left(5.06^{\circ} \leq 2 \Theta \leq 59.188^{\circ}\right), 4013$ unique $\left(R_{\text {int }}=0.0236, R_{\text {sigma }}=0.0158\right)$ which were used in all calculations. The final $R_{1}$ was $0.0365(I>2 \sigma(I))$ and $w R_{2}$ was 0.0996 (all data).

Table 5.26. Bond Lengths $[\AA ̊]$ for 180aj.

\begin{tabular}{|l|l|l|}
\hline Atom & Atom & Length/A \\
\hline S1 & C8 & $1.622(6)$ \\
\hline S1 & C11 & $1.781(17)$ \\
\hline S2 & C9 & $1.702(13)$ \\
\hline S2 & C10 & $1.6952(12)$ \\
\hline O1 & C1 & $1.2363(13)$ \\
\hline N1 & C1 & $1.3996(12)$ \\
\hline N1 & C5 & $1.3902(12)$ \\
\hline N1 & C13 & $1.4094(13)$ \\
\hline C1 & C2 & $1.4376(15)$ \\
\hline C2 & C3 & $1.3657(16)$ \\
\hline C3 & C4 & $1.4138(14)$ \\
\hline C4 & C5 & $1.3658(14)$ \\
\hline C5 & C6 & $1.4556(13)$ \\
\hline C6 & C7 & $1.4734(13)$ \\
\hline C6 & C12 & $1.3673(13)$ \\
\hline C7 & C8 & $1.4260(14)$ \\
\hline C7 & C10 & $1.3813(14)$ \\
\hline C8 & C9 & $1.389(8)$ \\
\hline C10 & C11 & $1.417(10)$ \\
\hline C12 & C13 & $1.4497(13)$ \\
\hline C12 & C17 & $1.5109(14)$ \\
\hline C13 & C14 & $1.3536(14)$ \\
\hline
\end{tabular}




\begin{tabular}{|l|l|l|}
\hline C14 & C15 & $1.4486(16)$ \\
\hline C15 & C16 & $1.3413(15)$ \\
\hline C16 & C17 & $1.5127(14)$ \\
\hline C17 & C18 & $1.5355(15)$ \\
\hline C17 & C19 & $1.5499(15)$ \\
\hline
\end{tabular}

Table 5.27. Bond angles $\left[^{\circ}\right]$ for $180 a j$

\begin{tabular}{|l|l|l|l|}
\hline Atom & Atom & Atom & Angle $^{\circ}$ \\
\hline C8 & S1 & C11 & $92.8(5)$ \\
\hline C10 & S2 & C9 & $92.4(3)$ \\
\hline C1 & N1 & C13 & $126.75(8)$ \\
\hline C5 & N1 & C1 & $124.38(9)$ \\
\hline C5 & N1 & C13 & $108.85(8)$ \\
\hline O1 & C1 & N1 & $120.34(10)$ \\
\hline O1 & C1 & C2 & $125.93(9)$ \\
\hline N1 & C1 & C2 & $113.73(9)$ \\
\hline C3 & C2 & C1 & $122.01(9)$ \\
\hline C2 & C3 & C4 & $121.75(10)$ \\
\hline C5 & C4 & C3 & $117.73(9)$ \\
\hline N1 & C5 & C6 & $107.53(8)$ \\
\hline C4 & C5 & N1 & $120.38(9)$ \\
\hline C4 & C5 & C6 & $132.09(9)$ \\
\hline C5 & C6 & C7 & $121.64(9)$ \\
\hline C12 & C6 & C5 & $108.08(8)$ \\
\hline C12 & C6 & C7 & $130.26(9)$ \\
\hline C8 & C7 & C6 & $125.03(9)$ \\
\hline C10 & C7 & C6 & $122.96(9)$ \\
\hline
\end{tabular}




\begin{tabular}{|l|l|l|l|}
\hline C10 & C7 & C8 & $112.00(9)$ \\
\hline C7 & C8 & S1 & $113.7(4)$ \\
\hline C9 & C8 & C7 & $111.5(5)$ \\
\hline C8 & C9 & S2 & $111.9(7)$ \\
\hline C7 & C10 & S2 & $112.16(8)$ \\
\hline C7 & C10 & C11 & $112.8(5)$ \\
\hline C10 & C11 & S1 & $108.5(8)$ \\
\hline C6 & C12 & C13 & $108.42(8)$ \\
\hline C6 & C12 & C17 & $131.80(9)$ \\
\hline C13 & C12 & C17 & $119.78(8)$ \\
\hline N1 & C13 & C12 & $107.03(8)$ \\
\hline C14 & C13 & N1 & $128.92(9)$ \\
\hline C14 & C13 & C12 & $123.67(9)$ \\
\hline C13 & C14 & C15 & $117.77(9)$ \\
\hline C16 & C15 & C14 & $121.97(10)$ \\
\hline C15 & C16 & C17 & $124.24(10)$ \\
\hline C12 & C17 & C16 & $110.63(8)$ \\
\hline C12 & C17 & C18 & $111.39(9)$ \\
\hline C12 & C17 & C19 & $109.15(9)$ \\
\hline C16 & C17 & C18 & $109.71(9)$ \\
\hline C16 & C17 & C19 & $106.09(9)$ \\
\hline C18 & C17 & C19 & $109.72(9)$ \\
\hline
\end{tabular}

Table 5.28. Crystal data and structure refinement 188aa.

\begin{tabular}{|l|l|}
\hline Compound & $188 \mathrm{aa}$ \\
\hline Empirical formula & $\mathrm{C}_{17} \mathrm{H}_{20} \mathrm{~N}_{2} \mathrm{O}_{2}$ \\
\hline
\end{tabular}




\begin{tabular}{|c|c|}
\hline Formula weight & 284.35 \\
\hline Temperature/K & 100.01 \\
\hline Crystal system & orthorhombic \\
\hline Space group & Pbca \\
\hline$a / \AA$ & $10.6389(4)$ \\
\hline $\mathrm{b} / \AA ̊ \AA$ & $9.3991(3)$ \\
\hline$c / \AA ̊$ & $31.0555(13)$ \\
\hline$\alpha /^{\circ}$ & 90 \\
\hline$\beta /^{\circ}$ & 90 \\
\hline$\gamma /{ }^{\circ}$ & 90 \\
\hline Volume $/ \AA^{3}$ & $3105.4(2)$ \\
\hline Z & 8 \\
\hline$\rho_{\text {calc }} / \mathrm{cm}^{3}$ & 1.216 \\
\hline$\mu / \mathrm{mm}^{-1}$ & 0.080 \\
\hline$F(000)$ & 1216.0 \\
\hline Crystal size $/ \mathrm{mm}^{3}$ & $0.458 \times 0.402 \times 0.146$ \\
\hline Radiation & $\operatorname{MoK} \alpha(\lambda=0.71073)$ \\
\hline $2 \Theta$ range for data collection $/^{\circ}$ & 4.642 to 59.22 \\
\hline Index ranges & $-14 \leq h \leq 14,-11 \leq k \leq 13,-43 \leq \mathrm{I} \leq 42$ \\
\hline Reflections collected & 22335 \\
\hline Independent reflections & $4350\left[R_{\text {int }}=0.0257, R_{\text {sigma }}=0.0200\right]$ \\
\hline Data/restraints/parameters & $4350 / 0 / 192$ \\
\hline Goodness-of-fit on $\mathrm{F}^{2}$ & 1.084 \\
\hline Final $R$ indexes $[I>=2 \sigma(I)]$ & $\mathrm{R}_{1}=0.0467, \mathrm{wR}_{2}=0.1142$ \\
\hline Final $R$ indexes [all data] & $\mathrm{R}_{1}=0.0498, \mathrm{wR}_{2}=0.1161$ \\
\hline Largest diff. peak/hole / e $\AA^{-3}$ & $0.38 /-0.22$ \\
\hline
\end{tabular}




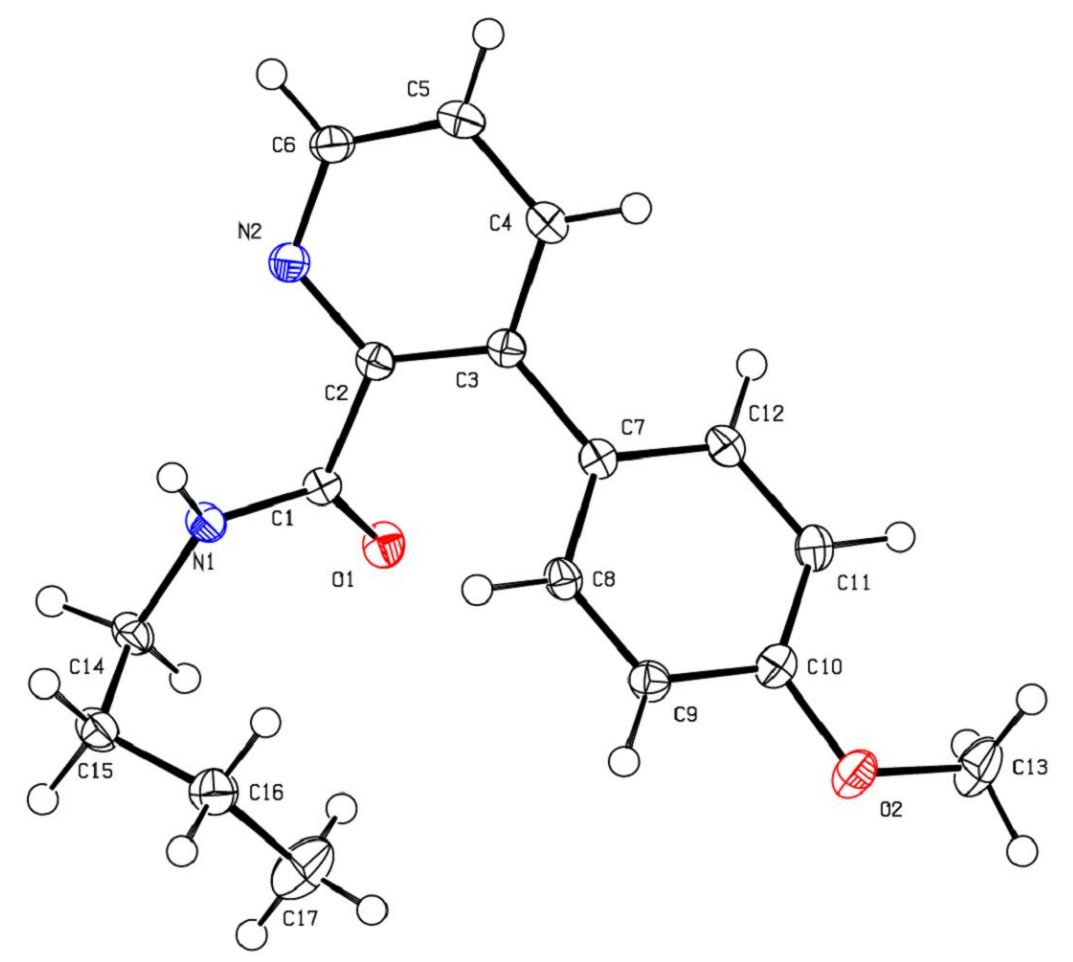

Figure 5.14. Molecular structure of 188aa with thermal ellipoids at 50\% probablitiy level. The hydrogen atoms are omitted for clarity.

Crystal Data for $\mathrm{C}_{17} \mathrm{H}_{20} \mathrm{~N}_{2} \mathrm{O}_{2}(M=284.35 \mathrm{~g} / \mathrm{mol})$ : orthorhombic, space group Pbca (no. 61), $a=10.6389(4) \AA, b=9.3991(3) \AA, c=31.0555(13) \AA, V=3105.4(2) \AA^{3}, Z=$ $8, T=100.01 \mathrm{~K}, \mu($ MoK $\alpha)=0.080 \mathrm{~mm}-1$, Dcalc $=1.216 \mathrm{~g} / \mathrm{cm}^{3}, 22335$ reflections measured $\left(4.642^{\circ} \leq 2 \Theta \leq 59.22^{\circ}\right), 4350$ unique $\left(R_{\text {int }}=0.0257, R_{\text {sigma }}=0.0200\right)$ which were used in all calculations. The final $R_{1}$ was $0.0467(I>2 \sigma(I))$ and $w R_{2}$ was 0.1161 (all data).

Table 5.29. Bond Lengths [Å] for 188aa.

\begin{tabular}{|l|l|l|}
\hline Atom & Atom & Length/Å \\
\hline $\mathrm{O} 1$ & $\mathrm{C} 1$ & $1.2345(14)$ \\
\hline $\mathrm{O} 2$ & $\mathrm{C} 10$ & $1.3661(14)$ \\
\hline $\mathrm{O} 2$ & $\mathrm{C} 13$ & $1.4256(16)$ \\
\hline $\mathrm{N} 1$ & $\mathrm{C} 1$ & $1.3311(14)$ \\
\hline
\end{tabular}




\begin{tabular}{|l|l|l|}
\hline N1 & C14 & $1.4584(14)$ \\
\hline N2 & C2 & $1.3413(14)$ \\
\hline N2 & C6 & $1.3392(15)$ \\
\hline C1 & C2 & $1.5099(15)$ \\
\hline C2 & C3 & $1.4068(15)$ \\
\hline C3 & C4 & $1.3963(15)$ \\
\hline C3 & C7 & $1.4812(15)$ \\
\hline C4 & C5 & $1.3834(17)$ \\
\hline C5 & C6 & $1.3870(17)$ \\
\hline C7 & C8 & $1.4033(15)$ \\
\hline C7 & C12 & $1.3918(15)$ \\
\hline C8 & C9 & $1.3791(16)$ \\
\hline C9 & C10 & $1.3988(16)$ \\
\hline C10 & C11 & $1.3913(16)$ \\
\hline C11 & C12 & $1.3913(16)$ \\
\hline C14 & C15 & $1.5229(17)$ \\
\hline C15 & C16 & $1.5248(18)$ \\
\hline C16 & C17 & $1.521(2)$ \\
\hline
\end{tabular}

Table 5.30. Bond angles $\left[{ }^{\circ}\right]$ for $188 a a$

\begin{tabular}{|l|l|l|l|}
\hline Atom & Atom & Atom $^{\text {Angle/ }}$ \\
\hline C10 & O2 & C13 & $116.83(10)$ \\
\hline C1 & N1 & C14 & $123.64(10)$ \\
\hline C6 & N2 & C2 & $118.15(10)$ \\
\hline O1 & C1 & N1 & $124.98(10)$ \\
\hline O1 & C1 & C2 & $119.89(10)$ \\
\hline
\end{tabular}




\begin{tabular}{|l|l|l|l|}
\hline N1 & C1 & C2 & $115.10(9)$ \\
\hline N2 & C2 & C1 & $114.19(10)$ \\
\hline N2 & C2 & C3 & $123.46(10)$ \\
\hline C3 & C2 & C1 & $122.14(10)$ \\
\hline C2 & C3 & C7 & $123.25(10)$ \\
\hline C4 & C3 & C2 & $116.51(10)$ \\
\hline C4 & C3 & C7 & $120.23(10)$ \\
\hline C5 & C4 & C3 & $120.55(11)$ \\
\hline C4 & C5 & C6 & $118.22(11)$ \\
\hline N2 & C6 & C5 & $123.05(11)$ \\
\hline C8 & C7 & C3 & $121.65(10)$ \\
\hline C12 & C7 & C3 & $120.48(10)$ \\
\hline C12 & C7 & C8 & $117.85(10)$ \\
\hline C9 & C8 & C7 & $121.21(10)$ \\
\hline C8 & C9 & C10 & $119.94(11)$ \\
\hline O2 & C10 & C9 & $115.43(10)$ \\
\hline O2 & C10 & C11 & $124.62(11)$ \\
\hline C11 & C10 & C9 & $119.95(11)$ \\
\hline C12 & C11 & C10 & $119.22(11)$ \\
\hline C11 & C12 & C7 & $121.82(10)$ \\
\hline N1 & C14 & C15 & $111.72(10)$ \\
\hline C14 & C15 & C16 & $114.58(10)$ \\
\hline C17 & C16 & C15 & $113.93(12)$ \\
\hline
\end{tabular}




\section{References}

[1] a) E. B. Pinxterhuis, M. Giannerini, V. Hornillos, B. L. Feringa, Nat. Commun. 2016, 7, 11698; b) B. H. Lipshutz, N. A. Isley, J. C. Fennewald, E. D. Slack, Angew. Chem. Int. Ed. 2013, 52, 10952-10958; c) B. H. Lipshutz, A. R. Abela, Ž. V. Bošković, T. Nishikata, C. Duplais, A. Krasovskiy, Top. Catal. 2010, 53, 985-990.

[2] a) B. Trost, Science 1991, 254, 1471-1477; b) B. M. Trost, Angew. Chem. Int. Ed. 1995, 34, 259-281.

[3] a) P. T. Anastas, M. M. Kirchhoff, Acc. Chem. Res. 2002, 35, 686-694; b) P. Anastas, Oxford University Press, Oxford, 1998.

[4] T. H. Meyer, L. H. Finger, P. Gandeepan, L. Ackermann, Trends Chem. 2019, 1, 63-76.

[5] C. Glaser, Chem. Ber. 1869, 2, 422-424.

[6] F. Ullmann, J. Bielecki, Chem. Ber. 1901, 34, 2174-2185.

[7] J. Hassan, M. Sévignon, C. Gozzi, E. Schulz, M. Lemaire, Chem. Rev. 2002, 102, 1359-1470.

[8] a) N. Miyaura, A. Suzuki, Chem. Rev. 1995, 95, 2457-2483; b) P. Lloyd-Williams, E. Giralt, Chem. Soc. Rev. 2001, 30, 145-157.

[9] D. Milstein, J. K. Stille, J. Am. Chem. Soc. 1978, 100, 3636-3638.

[10] K. Tamao, Y. Kiso, K. Sumitani, M. Kumada, J. Am. Chem. Soc. 1972, 94, 92689269.

[11] Y. Hatanaka, T. Hiyama, J. Org. Chem. 1988, 53, 918-920.

[12] a) S. Baba, E. Negishi, J. Am. Chem. Soc. 1976, 98, 6729-6731; b) E.-i. Negishi, S. Baba, J. Chem. Soc. 1976, 596b-597b.

[13] L. Ackermann, "Arylation Reactions: A Historical Perspective", in Modern Arylation Methods (Ed.: L. Ackermann), Wiley-VCH, Weinheim, 2009, 1-24.

[14] a) D. Balcells, E. Clot, O. Eisenstein, Chem. Rev. 2010, 110, 749-823; b) D. L. Davies, S. A. Macgregor, C. L. McMullin, Chem. Rev. 2017, 117, 8649-8709.

[15] L. Ackermann, Chem. Rev. 2011, 111, 1315-1345.

[16] J. A. Labinger, J. E. Bercaw, Nature 2002, 417, 507-514.

[17] J. Oxgaard, W. J. Tenn, R. J. Nielsen, R. A. Periana, W. A. Goddard, Organometallics 2007, 26, 1565-1567.

[18] a) S. I. Gorelsky, D. Lapointe, K. Fagnou, J. Am. Chem. Soc. 2008, 130, 1084810849; b) D. García-Cuadrado, A. A. C. Braga, F. Maseras, A. M. Echavarren, J. Am. Chem. Soc. 2006, 128, 1066-1067; c) L.-C. Campeau, M. Parisien, A. Jean, K. Fagnou, J. Am. Chem. Soc. 2006, 128, 581-590; d) L.-C. Campeau, M. Parisien, M. Leblanc, K. Fagnou, J. Am. Chem. Soc. 2004, 126, 9186-9187.

[19] a) Y. Boutadla, D. L. Davies, S. A. Macgregor, A. I. Poblador-Bahamonde, Dalton Trans. 2009, 5820-5831; b) Y. Boutadla, D. L. Davies, S. A. Macgregor, A. I. Poblador-Bahamonde, Dalton Trans. 2009, 5887-5893.

[20] a) K. Naksomboon, J. Poater, F. M. Bickelhaupt, M. Á. Fernández-lbáñez, J. Am. Chem. Soc. 2019, 141, 6719-6725; b) E. Tan, O. Quinonero, M. Elena de Orbe, 
A. M. Echavarren, ACS Catal. 2018, 8, 2166-2172; c) D. Zell, M. Bursch, V. Müller, S. Grimme, L. Ackermann, Angew. Chem. Int. Ed. 2017, 56, 10378-10382; d) H. Wang, M. Moselage, M. J. González, L. Ackermann, ACS Catal. 2016, 6, 27052709; e) D. Santrač, S. Cella, W. Wang, L. Ackermann, Eur. J. Org. Chem. 2016, 2016, 5429-5436; f) R. Mei, J. Loup, L. Ackermann, ACS Catal. 2016, 6, 793-797; g) W. Ma, R. Mei, G. Tenti, L. Ackermann, Chem. Eur. J. 2014, 20, 15248-15251.

[21] a) P. Y. Choy, S. M. Wong, A. Kapdi, F. Y. Kwong, Org. Chem. Front. 2018, 5, 288321; b) O. Baudoin, Acc. Chem. Res. 2017, 50, 1114-1123; c) N. Della Ca', M. Fontana, E. Motti, M. Catellani, Acc. Chem. Res. 2016, 49, 1389-1400; d) J. Le Bras, J. Muzart, Eur. J. Org. Chem. 2018, 2018, 1176-1203; e) C.-L. Sun, B.-J. Li, Z.-J. Shi, Chem. Commun. 2010, 46, 677-685; f) X. Chen, K. M. Engle, D.-H. Wang, J.-Q. Yu, Angew. Chem. Int. Ed. 2009, 48, 5094-5115; g) S. R. Neufeldt, M. S. Sanford, Acc. Chem. Res. 2012, 45, 936-946; h) J. Ye, M. Lautens, Nat. Chem. 2015, 7, 863; i) M. Catellani, E. Motti, N. Della Ca', Acc. Chem. Res. 2008, 41, 1512-1522.

[22] a) M. Nagamoto, T. Nishimura, ACS Catal. 2017, 7, 833-847; b) S. Pan, T. Shibata, ACS Catal. 2013, 3, 704-712; c) T. Suzuki, Chem. Rev. 2011, 111, 1825-1845; d) J. Choi, A. S. Goldman, in Iridium Catalysis (Ed.: P. G. Andersson), Springer Berlin Heidelberg, Berlin, Heidelberg, 2011, 139-167; e) J. Kim, S. Chang, Angew. Chem. Int. Ed. 2014, 53, 2203-2207.

[23] a) D. A. Colby, R. G. Bergman, J. A. Ellman, Chem. Rev. 2010, 110, 624-655; b) T. Piou, T. Rovis, Acc. Chem. Res. 2018, 51, 170-180; c) Y. Yang, K. Li, Y. Cheng, D. Wan, M. Li, J. You, Chem. Commun. 2016, 52, 2872-2884; d) B. Ye, N. Cramer, Acc. Chem. Res. 2015, 48, 1308-1318; e) G. Song, F. Wang, X. Li, Chem. Soc. Rev. 2012, 41, 3651-3678; f) D. A. Colby, A. S. Tsai, R. G. Bergman, J. A. Ellman, Acc. Chem. Res. 2012, 45, 814-825; g) T. Satoh, M. Miura, Chem. Eur. J. 2010, 16, 11212-11222; h) J. Wencel-Delord, F. Glorius, Nat. Chem. 2013, 5, 369-375.

[24] a) P. Nareddy, F. Jordan, M. Szostak, ACS Catal. 2017, 7, 5721-5745; b) J. A. Leitch, C. G. Frost, Chem. Soc. Rev. 2017, 46, 7145-7153; c) S. Ruiz, P. Villuendas, E. P. Urriolabeitia, Tetrahedron Lett. 2016, 57, 3413-3432; d) V. S. Thirunavukkarasu, S. I. Kozhushkov, L. Ackermann, Chem. Commun. 2014, 50, 29-39; e) P. B. Arockiam, C. Bruneau, P. H. Dixneuf, Chem. Rev. 2012, 112, 58795918; f) L. Ackermann, A. Althammer, R. Born, Synlett 2007, 2833-2836; g) L. Ackermann, R. Vicente, in C-H Activation (Eds.: J.-Q. Yu, Z. Shi), Springer Berlin Heidelberg, Berlin, Heidelberg, 2010, 211-229.

[25] P. Gandeepan, T. Müller, D. Zell, G. Cera, S. Warratz, L. Ackermann, Chem. Rev. 2019, 119, 2192-2452.

[26] J. R. Rumble, D. R. Lide, T. J. Bruno, CRC handbook of chemistry and physics : a ready-reference book of chemical and physical data, 2018.

[27] a) B. Sun, T. Yoshino, S. Matsunaga, M. Kanai, Adv. Synth. Catal. 2014, 356, 1491-1495; b) M. Moselage, J. Li, L. Ackermann, ACS Catal. 2015, 6, 498-525; c) 
D. Wei, X. Zhu, J. L. Niu, M. P. Song, ChemCatChem 2016, 8, 1242-1263; d) T. Yoshino, S. Matsunaga, Adv. Synth. Catal. 2017, 359, 1245-1262; e) S. Wang, S.Y. Chen, X.-Q. Yu, Chem. Commun. 2017, 53, 3165-3180; f) L. Ackermann, J. Org. Chem. 2014, 79, 8948-8954.

[28] G. Song, X. Li, Acc. Chem. Res. 2015, 48, 1007-1020.

[29] M. Moselage, J. Li, L. Ackermann, ACS Catal. 2016, 6, 498-525.

[30] H. Ikemoto, T. Yoshino, K. Sakata, S. Matsunaga, M. Kanai, J.Am.Chem.Soc. 2014, 136, 5424-5431.

[31] M. S. Kharasch, E. K. Fields, J. Am. Chem. Soc. 1941, 63, 2316-2320.

[32] a) S. Murahashi, J. Am. Chem. Soc. 1955, 77, 6403-6404; b) S. Murahashi, S. Horiie, J. Am. Chem. Soc. 1956, 78, 4816-4817.

[33] F. Hebrard, P. Kalck, Chem. Rev. 2009, 109, 4272-4282.

[34] a) J. Blanco-Urgoiti, L. Añorbe, L. Pérez-Serrano, G. Domínguez, J. Pérez-Castells, Chem. Soc. Rev. 2004, 33, 32-42; b) D. Tilly, G. Dayaker, P. Bachu, Catal. Sci. Technol. 2014, 4, 2756-2777; c) I. U. Khand, G. R. Knox, P. L. Pauson, W. E. Watts, J. Chem. Soc. D 1971, 36a.

[35] J. K. Kochi, R. T. Tang, T. Bernath, J. Am. Chem. Soc. 1973, 95, 7114-7123.

[36] H.-F. Klein, M. Helwig, U. Koch, U. Flörke, H.-J. Haupt, in Zeitschrift für Naturforschung B, Vol. 48, 1993, 778-784.

[37] S. Camadanli, R. Beck, U. Flörke, H.-F. Klein, Dalton Trans. 2008, 5701-5704.

[38] H. F. Klein, S. Camadanli, R. Beck, D. Leukel, U. Flörke, Angew. Chem. Int. Ed. 2005, 44, 975-977.

[39] R. Beck, H. Sun, X. Li, S. Camadanli, H. F. Klein, Eur. J. Inorg. Chem. 2008, 32533257.

[40] a) H.-F. Klein, S. Schneider, M. He, U. Floerke, H.-J. Haupt, Eur. J. Inorg.Chem. 2000, 2295-2301; b) H.-F. Klein, R. Beck, U. Flörke, H.-J. Haupt, Eur. J. Inorg. Chem. 2003, 1380-1387.

[41] R. Beck, M. Frey, S. Camadanli, H.-F. Klein, Dalton Trans. 2008, 4981-4983.

[42] G. Halbritter, F. Knoch, A. Wolski, H. Kisch, Angew. Chem. Int. Ed. 1994, 33, 1603-1605.

[43] a) P. S. Lee, T. Fujita, N. Yoshikai, J. Am. Chem. Soc. 2011, 133, 17283-17295; b) B. H. Tan, J. Dong, N. Yoshikai, Angew. Chem. Int. Ed. 2012, 51, 9610-9614; c) Z. Ding, N. Yoshikai, Angew. Chem. Int. Ed. 2013, 52, 8574-8578; d) K. Gao, N. Yoshikai, Acc. Chem. Res. 2014, 47, 1208-1219; e) N. Yoshikai, Bull. Chem. Soc. Jpn. 2014, 87, 843-857

[44] a) Q. Chen, L. Ilies, E. Nakamura, J. Am. Chem. Soc. 2011, 133, 428-429; b) Q. Chen, L. Ilies, N. Yoshikai, E. Nakamura, Org. Lett. 2011, 13, 3232-3234; c) L. Ilies, Q. Chen, X. Zeng, E. Nakamura, J. Am. Chem. Soc. 2011, 133, 5221-5223.

[45] a) W. Song, L. Ackermann, Angew. Chem. Int. Ed. 2012, 51, 8251-8254; b) B. Punji, W. Song, G. A. Shevchenko, L. Ackermann, Chem. Eur. J. 2013, 19, 1060510610; c) J. Li, L. Ackermann, Chem. Eur. J. 2015, 21, 5718-5722; d) M. Moselage, N. Sauermann, S. C. Richter, L. Ackermann, Angew. Chem. Int. Ed. 2015, 54, 
6352-6355.

[46] a) J. V. Obligacion, S. P. Semproni, P. J. Chirik, J. Am. Chem. Soc. 2014, 136, $4133-$ 4136; b) B. J. Fallon, E. Derat, M. Amatore, C. Aubert, F. Chemla, F. Ferreira, A. Perez-Luna, M. Petit, J. Am. Chem. Soc. 2015, 137, 2448-2451; c) L. Zhang, Z. Huang, J. Am. Chem. Soc. 2015, 137, 15600-15603.

[47] T. Yoshino, H. Ikemoto, S. Matsunaga, M. Kanai, Angew. Chem. Int. Ed. 2013, 52, 2207-2211.

[48] U. Koelle, B. Fuss, M. V. Rajasekharan, B. L. Ramakrishna, J. H. Ammeter, M. C. Boehm, J. Am. Chem. Soc. 1984, 106, 4152-4160.

[49] T. Yoshino, H. Ikemoto, S. Matsunaga, M. Kanai, Chem. Eur. J. 2013, 19, 91429146.

[50] R. Tanaka, H. Ikemoto, M. Kanai, T. Yoshino, S. Matsunaga, Org. Lett. 2016, 18, 5732-5735.

[51] H. Ikemoto, R. Tanaka, K. Sakata, M. Kanai, T. Yoshino, S. Matsunaga, Angew. Chem. Int. Ed. 2017, 56, 7156-7160.

[52] a) T. Yoshino, S. Matsunaga, Synlett 2019, 30, 1384-1400; b) K. Sakata, M. Eda, Y. Kitaoka, T. Yoshino, S. Matsunaga, J. Org. Chem. 2017, 82, 7379-7387.

[53] a) D.-G. Yu, T. Gensch, F. de Azambuja, S. Vásquez-Céspedes, F. Glorius, J. Am. Chem. Soc. 2014, 136, 17722-17725; b) M. Moselage, N. Sauermann, J. Koeller, W. Liu, D. Gelman, L. Ackermann, Synlett 2015, 26, 1596-1600.

[54] Y. Suzuki, B. Sun, K. Sakata, T. Yoshino, S. Matsunaga, M. Kanai, Angew. Chem. Int. Ed. 2015, 54, 9944-9947.

[55] a) Y. Bunno, N. Murakami, Y. Suzuki, M. Kanai, T. Yoshino, S. Matsunaga, Org. Lett. 2016, 18, 2216-2219; b) H. Wang, M. M. Lorion, L. Ackermann, ACS Catal. 2017, 7, 3430-3433.

[56] S. Wu, X. Huang, W. Wu, P. Li, C. Fu, S. Ma, Nat. Commun. 2015, 6, 7946.

[57] M. Sen, P. Dahiya, J. R. Premkumar, B. Sundararaju, Org. Lett. 2017, 19, 36993702.

[58] M. Sen, B. Emayavaramban, N. Barsu, J. R. Premkumar, B. Sundararaju, ACS Catal. 2016, 6, 2792-2796.

[59] N. Barsu, M. A. Rahman, M. Sen, B. Sundararaju, Chem. Eur. J. 2016, 22, 91359138.

[60] Pesciaioli, U. Dhawa, J. C. A. Oliveira, R. Yin, M. John, L. Ackermann, Angew. Chem. Int. Ed. 2018, 57, 15425-15429.

[61] J. W. Morgan, E. Anders, Proc. Natl. Acad. Sci. 1980, 77, 6973-6977.

[62] a) P. B. Tchounwou, C. G. Yedjou, A. K. Patlolla, D. J. Sutton, in Molecular, clinical and environmental toxicology, Springer, 2012, 133-164; b) S. H. Gilani, Y. Alibhai, J. Toxicol. Environ. Health 1990, 30, 23-31.

[63] M. I. Bruce, M. Z. Iqbal, F. G. A. Stone, J. Chem. Soc. 1970, 3204-3209.

[64] a) G. J. Depree, L. Main, B. K. Nicholson, J. Organomet. Chem. 1998, 551, 281291; b) W. Tully, L. Main, B. K. Nicholson, J. Organomet. Chem. 1995, 503, 75- 
92; c) N. P. Robinson, L. Main, B. K. Nicholson, J. Organomet. Chem. 1989, 364, C37-C39; d) L. H. P. Gommans, L. Main, B. K. Nicholson, J. Chem. Soc. 1987, 761762.

[65] a) R. C. Cambie, M. R. Metzler, P. S. Rutledge, P. D. Woodgate, J. Organomet. Chem. 1992, 429, 41-57; b) R. C. Cambie, M. R. Metzler, P. S. Rutledge, P. D. Woodgate, J. Organomet. Chem. 1990, 398, C22-C24; c) R. C. Cambie, M. R. Metzler, P. S. Rutledge, P. D. Woodgate, J. Organomet. Chem. 1990, 381, C26C30.

[66] L. S. Liebeskind, J. R. Gasdaska, J. S. McCallum, S. J. Tremont, J. Org. Chem. 1989, 54, 669-677.

[67] a) J.-P. Djukic, A. Maisse, M. Pfeffer, J. Organomet. Chem. 1998, 567, 65-74; b) C. Morton, D. J. Duncalf, J. P. Rourke, J. Organomet. Chem. 1997, 530, 19-25; c) J.-P. Djukic, A. Maisse, M. Pfeffer, A. de Cian, J. Fischer, Organometallics 1997, 16, 657-667; d) G. J. Depree, N. D. Childerhouse, B. K. Nicholson, J. Organomet. Chem. 1997, 533, 143-151.

[68] a) J. Albert, J. M. Cadena, J. Granell, X. Solans, M. Font-Bardia, J. Organomet. Chem. 2004, 689, 4889-4896; b) D. Lafrance, J. L. Davis, R. Dhawan, B. A. Arndtsen, Organometallics 2001, 20, 1128-1136.

[69] G. J. Depree, L. Main, B. K. Nicholson, N. P. Robinson, G. B. Jameson, J. Organomet. Chem. 2006, 691, 667-679.

[70] M. A. Leeson, B. K. Nicholson, M. R. Olsen, J. Organomet. Chem. 1999, 579, 243-251.

[71] Y. Kuninobu, Y. Nishina, T. Takeuchi, K. Takai, Angew. Chem. Int. Ed. 2007, 46, 6518-6520.

[72] B. Zhou, Y. Hu, C. Wang, Angew. Chem. Int. Ed. 2015, 54, 13659-13663.

[73] Q. Lu, S. Greßies, F. J. R. Klauck, F. Glorius, Angew. Chem. Int. Ed. 2017, 56, 66606664.

[74] H. Wang, F. Pesciaioli, J. C. A. Oliveira, S. Warratz, L. Ackermann, Angew. Chem. Int. Ed. 2017, 56, 15063-15067.

[75] Q. Lu, S. Greßies, S. Cembellín, F. J. Klauck, C. G. Daniliuc, F. Glorius, Angew. Chem. Int. Ed. 2017, 56, 12778-12782.

[76] Modern Heterocyclic Chemistry, Wiley-VCH, Weinheim, 2011.

[77] Y.-F. Liang, V. Müller, W. Liu, A. Münch, D. Stalke, L. Ackermann, Angew. Chem. Int. Ed. 2017, 56, 9415-9419.

[78] a) C. Wang, A. Wang, M. Rueping, Angew. Chem. Int. Ed. 2017, 56, 9935-9938; b) S.-Y. Chen, X.-L. Han, J.-Q. Wu, Q. Li, Y. Chen, H. Wang, Angew. Chem. Int. Ed. 2017, 56, 9939-9943.

[79] Y.-F. Liang, R. Steinbock, A. Münch, D. Stalke, L. Ackermann, Angew. Chem. Int. Ed. 2018, 57, 5384-5388.

[80] Q. Gu, H. H. Al Mamari, K. Graczyk, E. Diers, L. Ackermann, Angew. Chem. Int. Ed. 2014, 53, 3868-3871.

[81] W. Liu, G. Cera, J. C. A. Oliveira, Z. Shen, L. Ackermann, Chem. Eur. J. 2017, 23, 
11524-11528.

[82] T. Sato, T. Yoshida, H. H. Al Mamari, L. Ilies, E. Nakamura, Org. Lett. 2017, 19, 5458-5461.

[83] Z. Shen, H. Huang, C. Zhu, S. Warratz, L. Ackermann, Org. Lett. 2019, 21, $571-$ 574.

[84] a) R. Francke, R. D. Little, Chem. Soc. Rev. 2014, 43, 2492-2521; b) J. B. Sperry, D. L. Wright, Chem. Soc. Rev. 2006, 35, 605-621; c) A. Wiebe, T. Gieshoff, S. Möhle, E. Rodrigo, M. Zirbes, S. R. Waldvogel, Angew. Chem. Int. Ed. 2018, 57, 5594-5619; d) J.-i. Yoshida, K. Kataoka, R. Horcajada, A. Nagaki, Chem. Rev. 2008, 108, 2265-2299; e) N. Sauermann, T. H. Meyer, Y. Qiu, L. Ackermann, ACS Catal. 2018, 8, 7086-7103.

[85] N. Sauermann, T. H. Meyer, L. Ackermann, Chem. Eur. J. 2018, 24, 16209-16217.

[86] C. Amatore, C. Cammoun, A. Jutand, Adv. Synth. Catal. 2007, 349, 292-296.

[87] F. Kakiuchi, T. Kochi, H. Mutsutani, N. Kobayashi, S. Urano, M. Sato, S. Nishiyama, T. Tanabe, J. Am. Chem. Soc. 2009, 131, 11310-11311.

[88] F. Saito, H. Aiso, T. Kochi, F. Kakiuchi, Organometallics 2014, 33, 6704-6707.

[89] Q.-L. Yang, Y.-Q. Li, C. Ma, P. Fang, X.-J. Zhang, T.-S. Mei, J. Am. Chem. Soc. 2017, 139, 3293-3298.

[90] C. Ma, C.-Q. Zhao, Y.-Q. Li, L.-P. Zhang, X.-T. Xu, K. Zhang, T.-S. Mei, Chem. Commun. 2017, 53, 12189-12192.

[91] a) P. Gomes, C. Gosmini, J. Périchon, J. Org. Chem. 2003, 68, 1142-1145; b) P. Gomes, C. Gosmini, J. Périchon, Tetrahedron 2003, 59, 2999-3002.

[92] N. Sauermann, T. H. Meyer, C. Tian, L. Ackermann, J. Am. Chem. Soc. 2017, 139, 18452-18455.

[93] C. Tian, L. Massignan, T. H. Meyer, L. Ackermann, Angew. Chem. Int. Ed. 2018, 57, 2383-2387.

[94] N. Sauermann, R. Mei, L. Ackermann, Angew. Chem. Int. Ed. 2018, 57, 50905094.

[95] X. Gao, P. Wang, L. Zeng, S. Tang, A. Lei, J. Am. Chem. Soc. 2018, 140, 4195-4199.

[96] R. Mei, N. Sauermann, J. C. A. Oliveira, L. Ackermann, J. Am. Chem. Soc. 2018, 140, 7913-7921.

[97] T. H. Meyer, J. C. A. Oliveira, S. C. Sau, N. W. J. Ang, L. Ackermann, ACS Catal. 2018, 8, 9140-9147.

[98] Y. Qiu, W.-J. Kong, J. Struwe, N. Sauermann, T. Rogge, A. Scheremetjew, L. Ackermann, Angew. Chem. Int. Ed. 2018, 57, 5828-5832.

[99] W.-J. Kong, L. H. Finger, J. C. A. Oliveira, L. Ackermann, Angew. Chem. Int. Ed. 2019, 58, 6342-6346.

[100] a) F. Xu, Y.-J. Li, C. Huang, H.-C. Xu, ACS Catal. 2018, 8, 3820-3824; b) L. Ackermann, A. V. Lygin, N. Hofmann, Org. Lett. 2011, 13, 3278-3281.

[101] Y. Qiu, C. Tian, L. Massignan, T. Rogge, L. Ackermann, Angew. Chem. Int. Ed. 2018, 57, 5818-5822. 
[102] S.-K. Zhang, R. C. Samanta, N. Sauermann, L. Ackermann, Chem. Eur. J. 2018, 24, 19166-19170.

[103] P. Enghag, Encyclopedia of the elements, Wiley-VCH, Weinheim, 2004.

[104] a) A. Fürstner, ACS Cent. Sci. 2016, 2, 778-789; b) S. Enthaler, K. Junge, M. Beller, Angew. Chem. Int. Ed. 2008, 47, 3317-3321.

[105] O. M. Kuzmina, A. K. Steib, A. Moyeux, G. Cahiez, P. Knochel, Synthesis 2015, 47, 1696-1705.

[106] a) G. Cera, L. Ackermann, Top. Curr. Chem. 2016, 374, 57; b) N. Yoshikai, Isr. J. Chem. 2017, 57, 1117-1130; c) R. Shang, L. Ilies, E. Nakamura, Chem. Rev. 2017.

[107] a) M. Tamura, J. K. Kochi, J. Am. Chem. Soc. 1971, 93, 1487-1489; b) S. M. Neumann, J. K. Kochi, J. Org. Chem. 1975, 40, 599-606.

[108] J. Norinder, A. Matsumoto, N. Yoshikai, E. Nakamura, J. Am. Chem. Soc. 2008, 130, 5858-5859.

[109] N. Yoshikai, A. Matsumoto, J. Norinder, E. Nakamura, Angew. Chem. Int. Ed. 2009, 48, 2925-2928.

[110] L. Ilies, E. Konno, Q. Chen, E. Nakamura, Asian J. Org. Chem. 2012, 1, 142-145.

[111] V. G. Zaitsev, D. Shabashov, O. Daugulis, J. Am. Chem. Soc. 2005, 127, 1315413155.

[112] R. Shang, L. Ilies, A. Matsumoto, E. Nakamura, J. Am. Chem. Soc. 2013, 135, 6030-6032.

[113] H. H. Al Mamari, E. Diers, L. Ackermann, Chem. Eur. J. 2014, 20, 9739-9743.

[114] G. Cera, T. Haven, L. Ackermann, Angew. Chem. Int. Ed. 2016, 55, 1484-1488.

[115] G. Cera, T. Haven, L. Ackermann, Chem. Eur. J. 2017, 23, 3577-3582.

[116] G. Cera, T. Haven, L. Ackermann, Chem. Commun. 2017, 53, 6460-6463.

[117] a) A. Dey, S. K. Sinha, T. K. Achar, D. Maiti, Angew. Chem. Int. Ed. 2019, 58, 10820-10843; b) C. Sambiagio, D. Schönbauer, R. Blieck, T. Dao-Huy, G. Pototschnig, P. Schaaf, T. Wiesinger, M. F. Zia, J. Wencel-Delord, T. Besset, B. U. W. Maes, M. Schnürch, Chem. Soc. Rev. 2018, 47, 6603-6743; c) Y. Park, Y. Kim, S. Chang, Chem. Rev. 2017, 117, 9247-9301.

[118] a) J. Yamaguchi, K. Muto, K. Itami, Eur. J. Org. Chem. 2013, 2013, 19-30; b) W. Liu, L. Ackermann, ACS Catal. 2016, 6, 3743-3752; c) Y. Nakao, Chem. Rec. 2011, 11, 242-251; d) R. Shang, L. Ilies, E. Nakamura, Chem. Rev. 2017, 117, 90869139; e) L. C. M. Castro, N. Chatani, Chem. Lett. 2015, 44, 410-421; f) K. Hirano, M. Miura, Chem. Lett. 2015, 44, 868-873.

[119] a) D. Zell, U. Dhawa, V. Müller, M. Bursch, S. Grimme, L. Ackermann, ACS Catal. 2017, 7, 4209-4213; b) H. Wang, M. M. Lorion, L. Ackermann, Angew. Chem. Int. Ed. 2017, 56, 6339-6342; c) Z. Ruan, N. Sauermann, E. Manoni, L. Ackermann, Angew. Chem. Int. Ed. 2017, 56, 3172-3176; d) Q. Lu, F. J. Klauck, F. Glorius, Chem. Sci. 2017, 8, 3379-3383; e) B. Zhou, H. Chen, C. Wang, J. Am. Chem. Soc. 2013, 135, 1264-1267.

[120] a) W. Liu, S. C. Richter, R. Mei, M. Feldt, L. Ackermann, Chem. Eur. J. 2016, 22, 17958-17961; b) W. Liu, J. Bang, Y. Zhang, L. Ackermann, Angew. Chem. Int. Ed. 
2015, 54, 14137-14140; c) J. Li, L. Ackermann, Angew. Chem. Int. Ed. 2015, 54, 3635-3638.

[121] a) S. Ma, Chem. Rev. 2005, 105, 2829-2872; b) J. Le Bras, J. Muzart, Chem. Soc. Rev. 2014, 43, 3003-3040.

[122] K. Hirano, M. Miura, Chem. Sci. 2018, 9, 22-32.

[123] a) J.-R. m. Pouliot, F. o. Grenier, J. T. Blaskovits, S. Beaupré, M. Leclerc, Chem. Rev. 2016, 116, 14225-14274; b) L. Ackermann, R. Vicente, A. R. Kapdi, Angew. Chem. Int. Ed. 2009, 48, 9792-9826.

[124] a) W. Liu, L. Ackermann, ACS Catal. 2016, 6, 3743-3752; b) C. Wang, Synlett 2013, 24, 1606-1613; c) G. Cahiez, A. Moyeux, Chem. Rev. 2010, 110, 14351462; d) Y. Hu, B. Zhou, C. Wang, Acc. Chem. Res. 2018, 51, 816-827.

[125] a) S. R. Waldvogel, S. Lips, M. Selt, B. Riehl, C. J. Kampf, Chem. Rev. 2018, 118, 6706-6765; b) C. Ma, P. Fang, T.-S. Mei, ACS Catal. 2018, 8, 7179-7189; c) S. Tang, Y. C. Liu, A. W. Lei, Chem 2018, 4, 27-45; d) M. Yan, Y. Kawamata, P. S. Baran, Chem. Rev. 2017, 117, 13230-13319; e) E. J. Horn, B. R. Rosen, P. S. Baran, ACS Central Science 2016, 2, 302-308; f) A. Jutand, Chem. Rev. 2008, 108, 2300 2347.

[126] a) M. S. Frei, M. K. Bilyard, T. A. Alanine, W. R. J. D. Galloway, J. E. Stokes, D. R. Spring, Bioorg. Med. Chem. 2015, 23, 2666-2679; b) E. M. Mmutlane, J. M. Harris, A. Padwa, J. Org. Chem. 2005, 70, 8055-8063; c) M. Toyota, C. Komori, M. Ihara, J. Org. Chem. 2000, 65, 7110-7113; d) A. Padwa, S. M. Sheehan, C. S. Straub, J. Org. Chem. 1999, 64, 8648-8659; e) H. Josien, S.-B. Ko, D. Bom, D. P. Curran, Chem. Eur. J. 1998, 4, 67-83.

[127] a) C. Zhu, R. Kuniyil, L. Ackermann, Angew. Chem. Int. Ed. 2019, 58, 5338-5342;

b) G. Zheng, J. Sun, Y. Xu, S. Zhai, X. Li, Angew. Chem. Int. Ed. 2019, 58, 50905094.

[128] P. Gandeepan, T. Muller, D. Zell, G. Cera, S. Warratz, L. Ackermann, Chem. Rev. 2019, 119, 2192-2452.

[129] W. Liu, S. C. Richter, Y. Zhang, L. Ackermann, Angew. Chem. Int. Ed. 2016, 55, 7747-7750.

[130] a) L. F. Tietze, Chem. Rev. 1996, 96, 115-136; b) L. F. Tietze, B. Waldecker, D. Ganapathy, C. Eichhorst, T. Lenzer, K. Oum, S. O. Reichmann, D. Stalke, Angew. Chem. Int. Ed. 2015, 54, 10317-10321; c) F. Lotz, K. Kahle, M. Kangani, S. Senthilkumar, L. F. Tietze, Eur. J. Org. Chem. 2018, 2018, 5562-5569; d) L. F. Tietze, Domino Reactions: Concepts for Efficient Organic Synthesis, Wiley, Weinheim, 2013.

[131] L. Ackermann, Acc. Chem. Res. 2014, 47, 281-295.

[132] a) J. He, M. Wasa, K. S. L. Chan, Q. Shao, J.-Q. Yu, Chem. Rev. 2017, 117, 87548786; b) H. Yi, G. Zhang, H. Wang, Z. Huang, J. Wang, A. K. Singh, A. Lei, Chem. Rev. 2017, 117, 9016-9085; c) W. Ma, P. Gandeepan, J. Li, L. Ackermann, Org. Chem. Front. 2017, 4, 1435-1467; d) Y. Wei, P. Hu, M. Zhang, W. Su, Chem. Rev. 
2017, 117, 8864-8907; e) Q.-Z. Zheng, N. Jiao, Chem. Soc. Rev. 2016, 45, 45904627; f) C. Borie, L. Ackermann, M. Nechab, Chem. Soc. Rev. 2016, 45, 13681386; g) B. Ye, N. Cramer, Acc. Chem. Res. 2015, 48, 1308-1318; h) J. WencelDelord, F. Glorius, Nature Chem. 2013, 5, 369-375; i) G. Rouquet, N. Chatani, Angew. Chem. Int. Ed. 2013, 52, 11726-11743; j) A. J. Hickman, M. S. Sanford, Nature 2012, 484, 177-185; k) T. Satoh, M. Miura, Chem. Eur. J. 2010, 16, 11212 11222; I) O. Daugulis, H.-Q. Do, D. Shabashov, Acc. Chem. Res. 2009, 42, 10741086.

[133] a) Z. Dong, Z. Ren, S. J. Thompson, Y. Xu, G. Dong, Chem. Rev. 2017, 117, 93339403; b) T. Yoshino, S. Matsunaga, Adv. Synth. Catal. 2017, 117, 9333-9403; c) K. Hirano, M. Miura, Chem. Lett. 2015, 44, 868-873; d) K. Gao, N. Yoshikai, Acc. Chem. Res 2014, 47, 1208-1219; e) L. Ackermann, J. Org. Chem 2014, 79, 89488954; f) J. Yamaguchi, K. Muto, K. Itami, Eur. J. Org. Chem. 2013, 2013, 19-30; g) Y. Nakao, Chem. Rec. 2011, 11, 242-251; h) A. A. Kulkarni, O. Daugulis, Synthesis 2009, 4087-4109.

[134] a) R. Porta, M. Benaglia, A. Puglisi, Org. Process Res. Dev. 2016, 20, 2-25; b) S. G. Newman, K. F. Jensen, Green Chem. 2013, 15, 1456; c) D. T. McQuade, P. H. Seeberger, J. Org. Chem. 2013, 78, 6384-6389; d) T. N. Glasnov, C. O. Kappe, Chem. Eur. J. 2011, 17, 11956-11968; e) H. P. Gemoets, Y. Su, M. Shang, V. Hessel, R. Luque, T. Noel, Chem. Soc. Rev. 2016, 45, 83-117; f) J. Zakrzewski, A. P. Smalley, M. A. Kabeshov, M. J. Gaunt, A. A. Lapkin, Angew. Chem. Int. Ed. 2016, 55, 8878-8883; g) H. P. Gemoets, V. Hessel, T. Noël, Org. Lett. 2014, 16, 5800-5803.

[135] C. Zhu, J. C. A. Oliveira, Z. Shen, H. Huang, L. Ackermann, ACS Catal. 2018, 8, $4402-4407$.

[136] A. Majumder, M. Westerhausen, A. N. Kneifel, J.-P. Sutter, N. Daro, S. Mitra, Inorg. Chim. Acta 2006, 359, 3841-3846.

[137] a) Z. Shen, G. Cera, T. Haven, L. Ackermann, Org. Lett. 2017, 19, 3795-3798; b) V. S. Arvapalli, G. Chen, S. Kosarev, M. E. Tan, D. Xie, L. Yet, Tetrahedron Lett. 2010, 51, 284-286.

[138] a) M. Bauer, W. Wang, M. M. Lorion, C. Dong, L. Ackermann, Angew. Chem. Int. Ed. 2018, 57, 203-207; b) X. Tian, F. Yang, D. Rasina, M. Bauer, S. Warratz, F. Ferlin, L. Vaccaro, L. Ackermann, Chem. Commun. 2016, 52, 9777-9780; c) H. C. Kolb, K. B. Sharpless, Drug Discov. Today 2003, 8, 1128-1137.

[139] S. Santoro, F. Ferlin, L. Luciani, L. Ackermann, L. Vaccaro, Green Chem. 2017, 19, 1601-1612.

[140] S.-Y. Yan, Y.-Q. Han, Q.-J. Yao, X.-L. Nie, L. Liu, B.-F. Shi, Angew. Chem. Int. Ed. 2018, 57, 9093-9097.

[141] L. Wang, B. P. Carrow, ACS Catal. 2019, 9, 6821-6836.

[142] G. Lefèvre, A. Jutand, Chem. Eur. J. 2014, 20, 4796-4805.

[143] A. Krasovskiy, P. Knochel, Synthesis 2006, 890-891.

[144] R. Odani, K. Hirano, T. Satoh, M. Miura, Angew. Chem. Int. Ed. 2014, 53, 10784- 
10788.

[145] T. S. N. Zhao, Y. Yang, T. Lessing, K. J. Szabó, J. Am. Chem. Soc. 2014, 136, $7563-$ 7566.

[146] S. Cai, C. Chen, P. Shao, C. Xi, Org. Lett. 2014, 16, 3142-3145.

[147] S. Zhao, B. Liu, B.-B. Zhan, W.-D. Zhang, B.-F. Shi, Org. Lett. 2016, 18, 4586-4589.

[148] O. V. Dolomanov, L. J. Bourhis, R. J. Gildea, J. A. K. Howard, H. Puschmann, J. Appl. Cryst. 2009, 42, 339-341.

[149] G. Sheldrick, Acta Cryst. A 2015, 71, 3-8.

[150] G. Sheldrick, Acta Cryst. A 2008, 64, 112-122. 


\section{NMR Spectra}

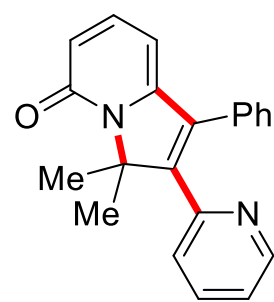

173aa

$400 \mathrm{MHz}^{\mathrm{CDCl}} \mathrm{CDC}_{3}$
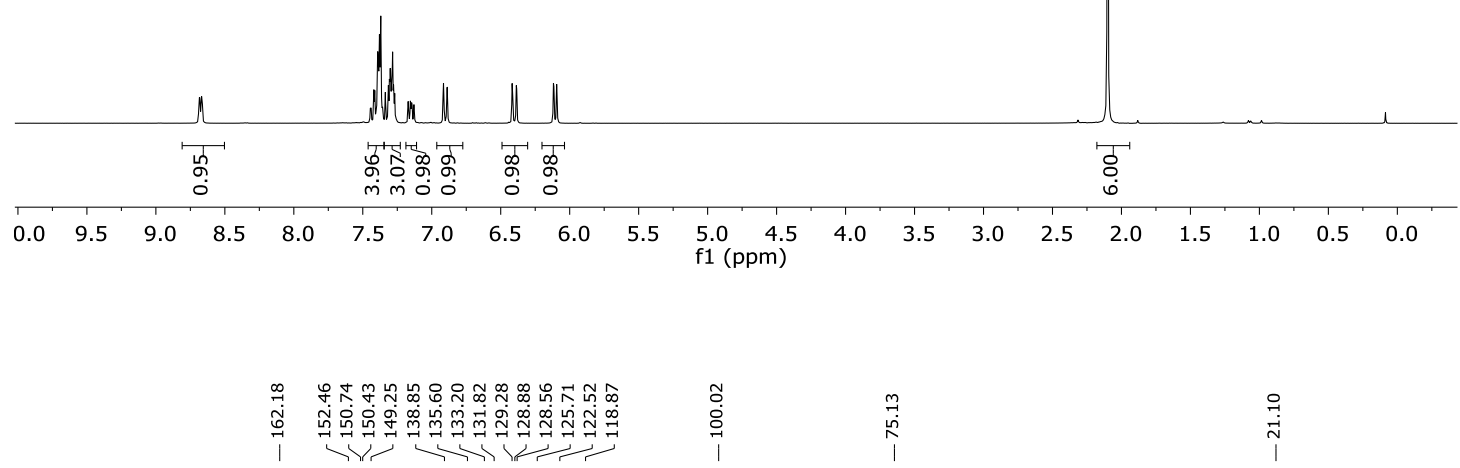

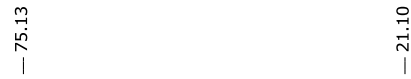
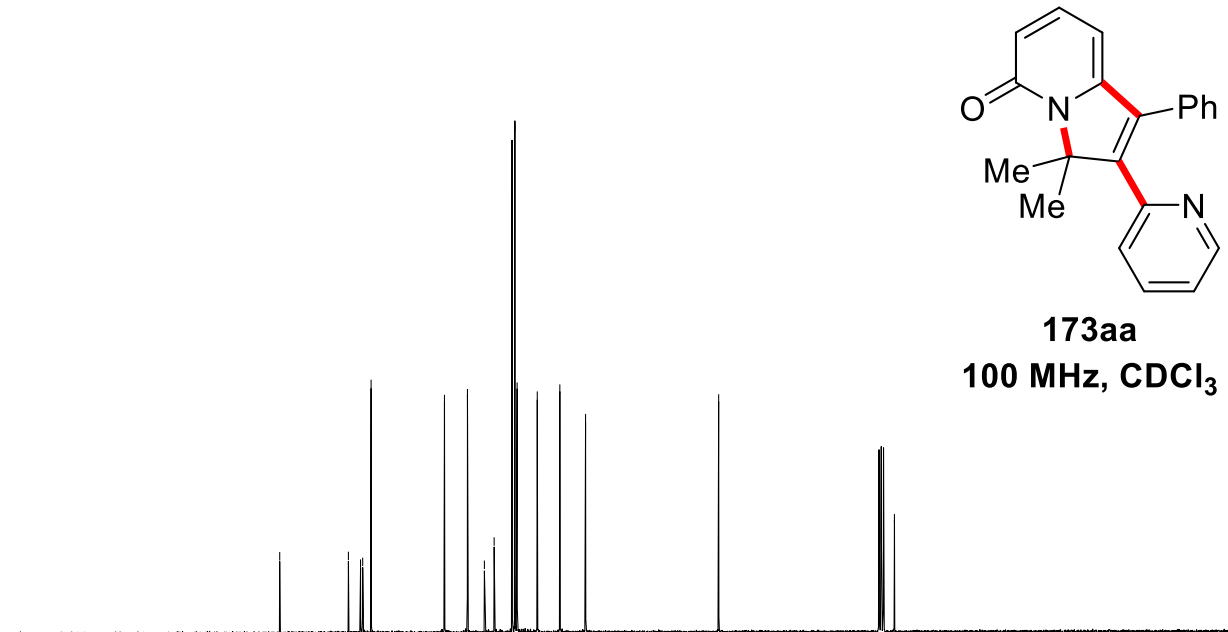

173aa

$100 \mathrm{MHz}^{\mathrm{CDCl}}{ }_{3}$

$\begin{array}{llllllllllllllllllll}190 & 180 & 170 & 160 & 150 & 140 & 130 & 120 & 110 & \begin{array}{c}100 \\ \mathrm{f} 1(\mathrm{ppm})\end{array} & 90 & 80 & 70 & 60 & 50 & 40 & 30 & 20 & 10 & 0\end{array}$ 


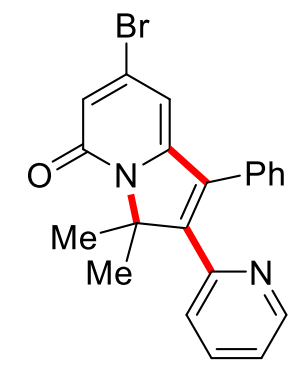

173ba

$400 \mathrm{MHz}, \mathrm{CDCl}_{3}$

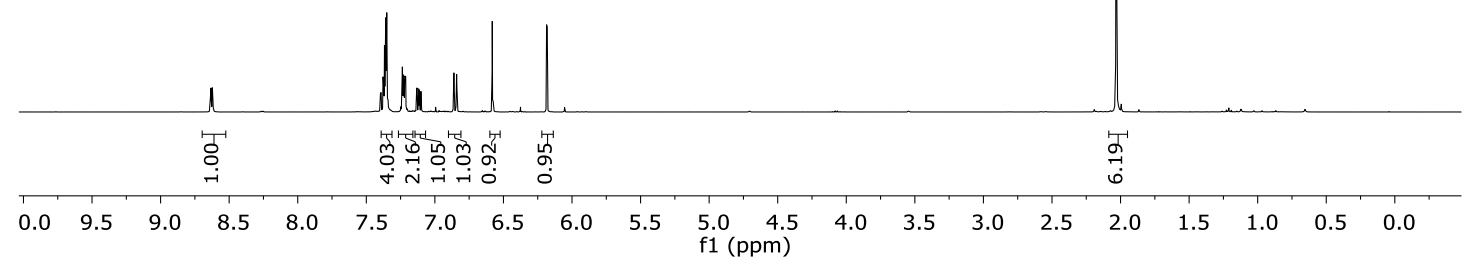

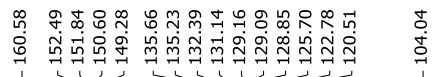

$\stackrel{\vec{m}}{n}$

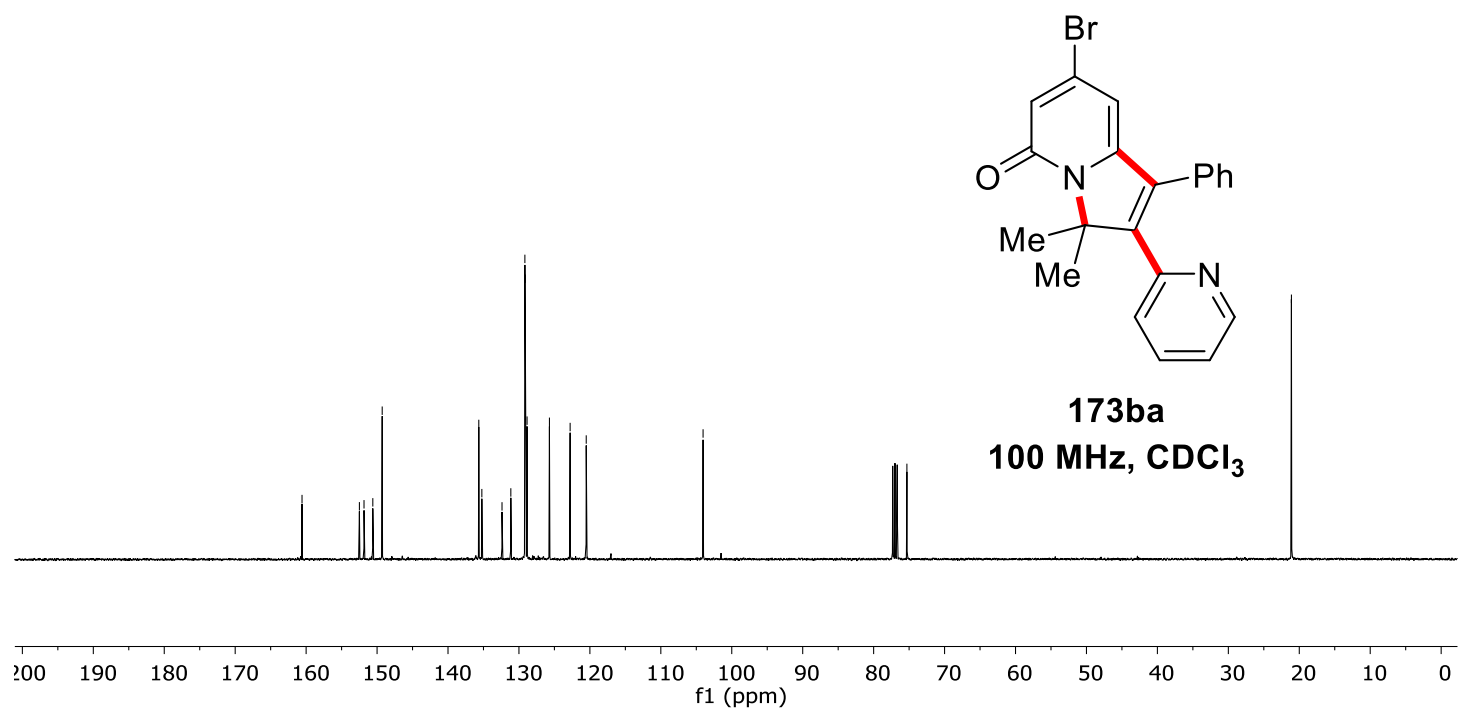




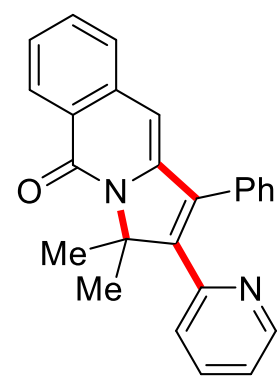

173ca

$400 \mathrm{MHz}^{\mathrm{CDCl}_{3}}$

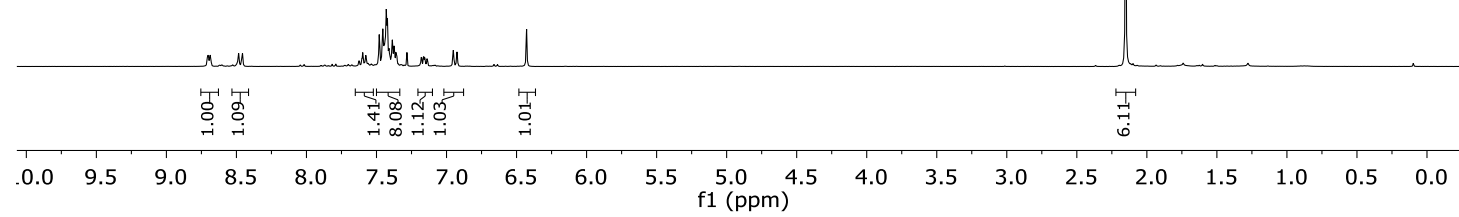

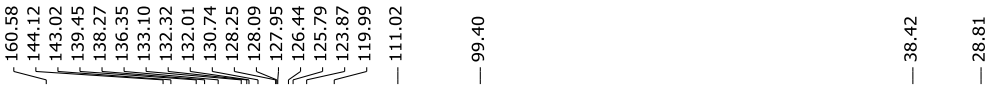

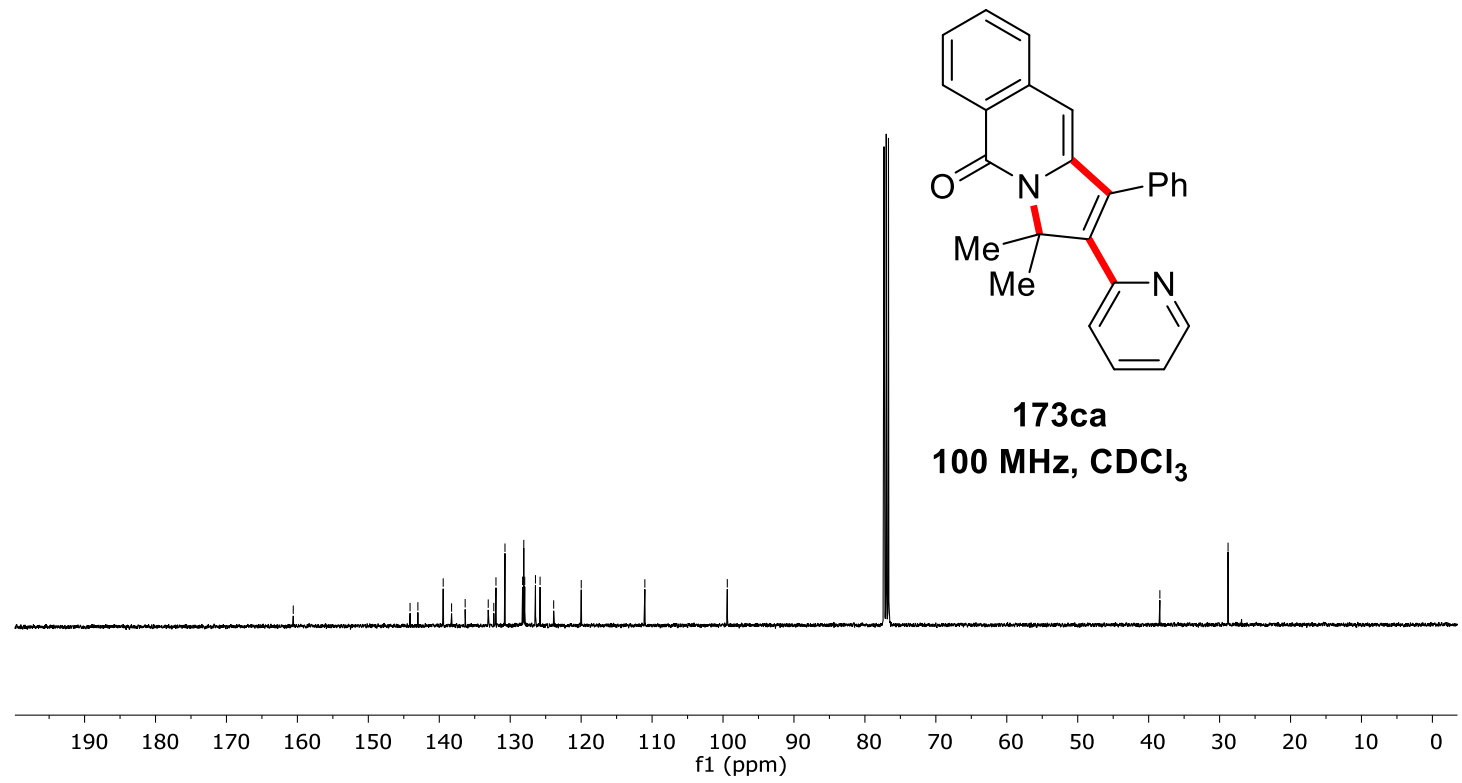




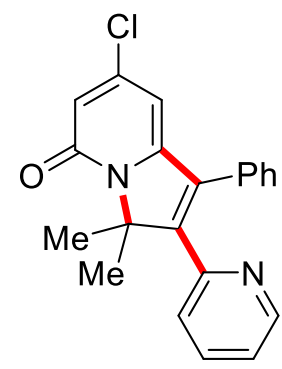

173da

$400 \mathrm{MHz}^{\mathrm{CDCl}_{3}}$

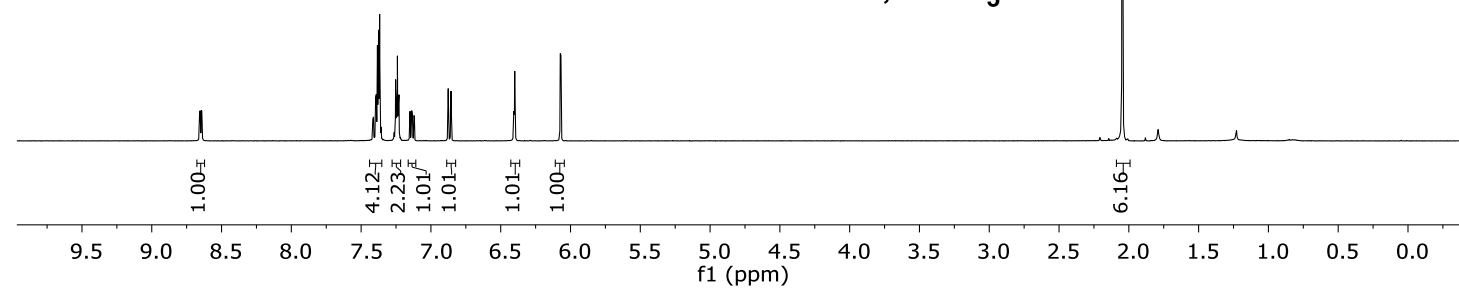

क

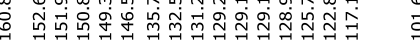

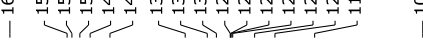

$\stackrel{\substack{m\\}}{i}$

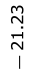

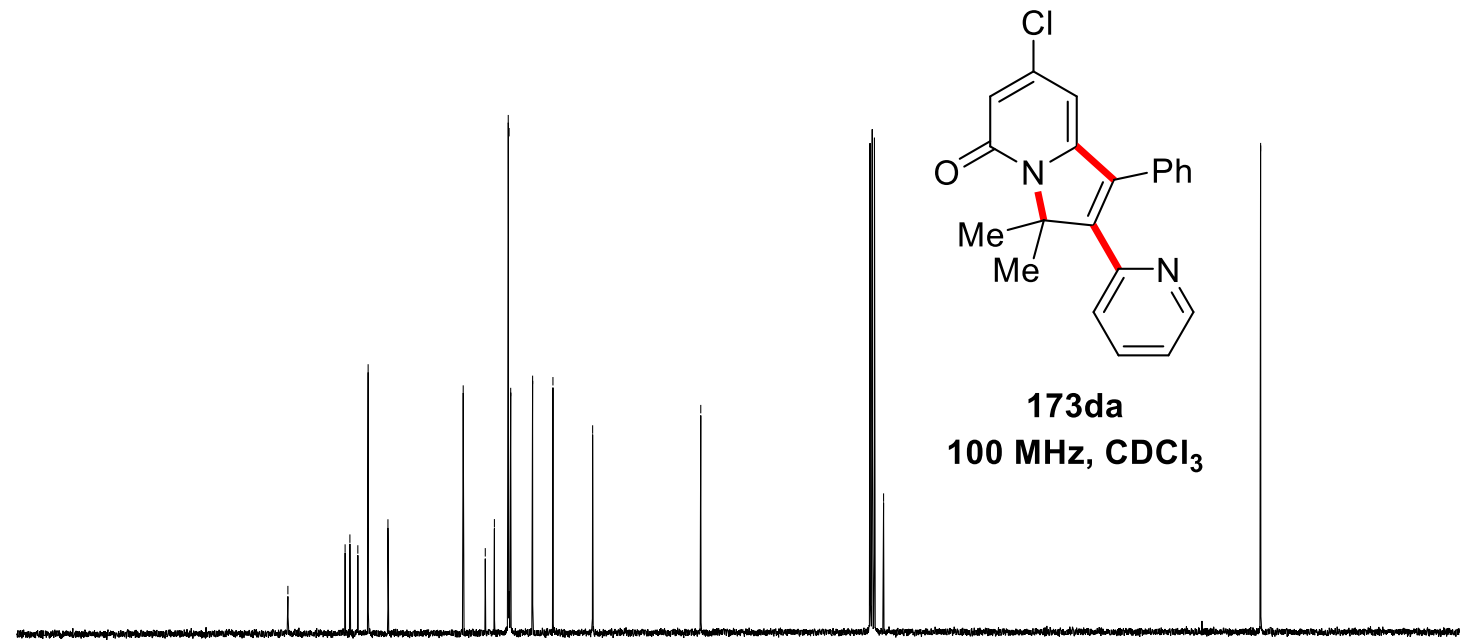

$\begin{array}{llllllllllllllllllll}190 & 180 & 170 & 160 & 150 & 140 & 130 & 120 & 110 & 100 & 90 & 80 & 70 & 60 & 50 & 40 & 30 & 20 & 10 & 0\end{array}$ 


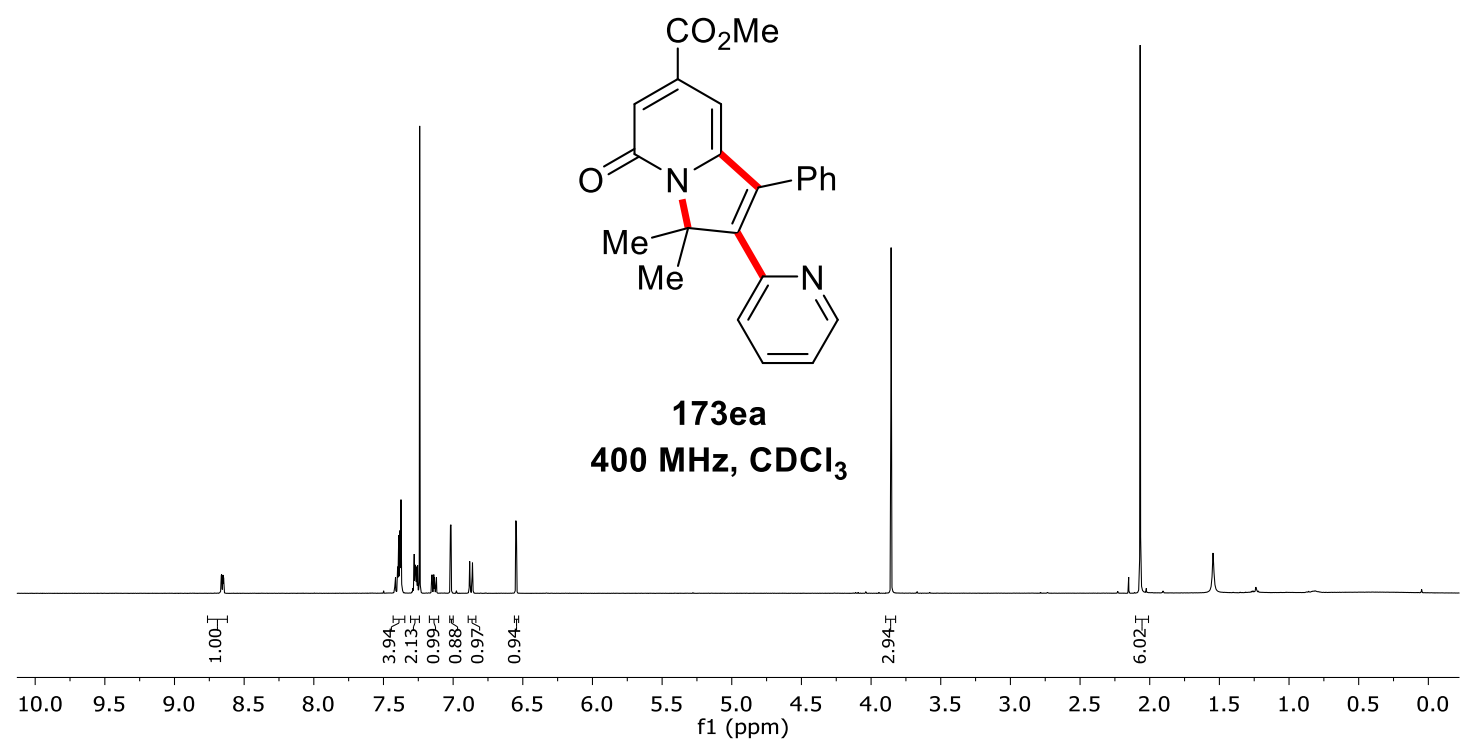

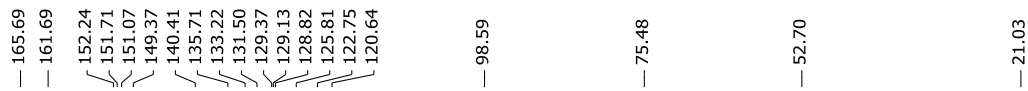

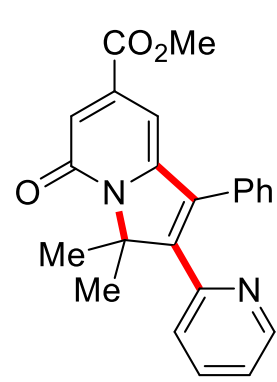

173ea

$100 \mathrm{MHz}, \mathrm{CDCl}_{3}$

$\begin{array}{llllllllll}190 & 180 & 170 & 160 & 150 & 140 & 130 & 120 & 110 & 100 \\ \mathrm{f} 1(\mathrm{ppm})\end{array}$

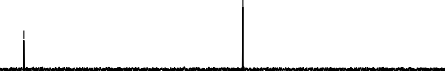




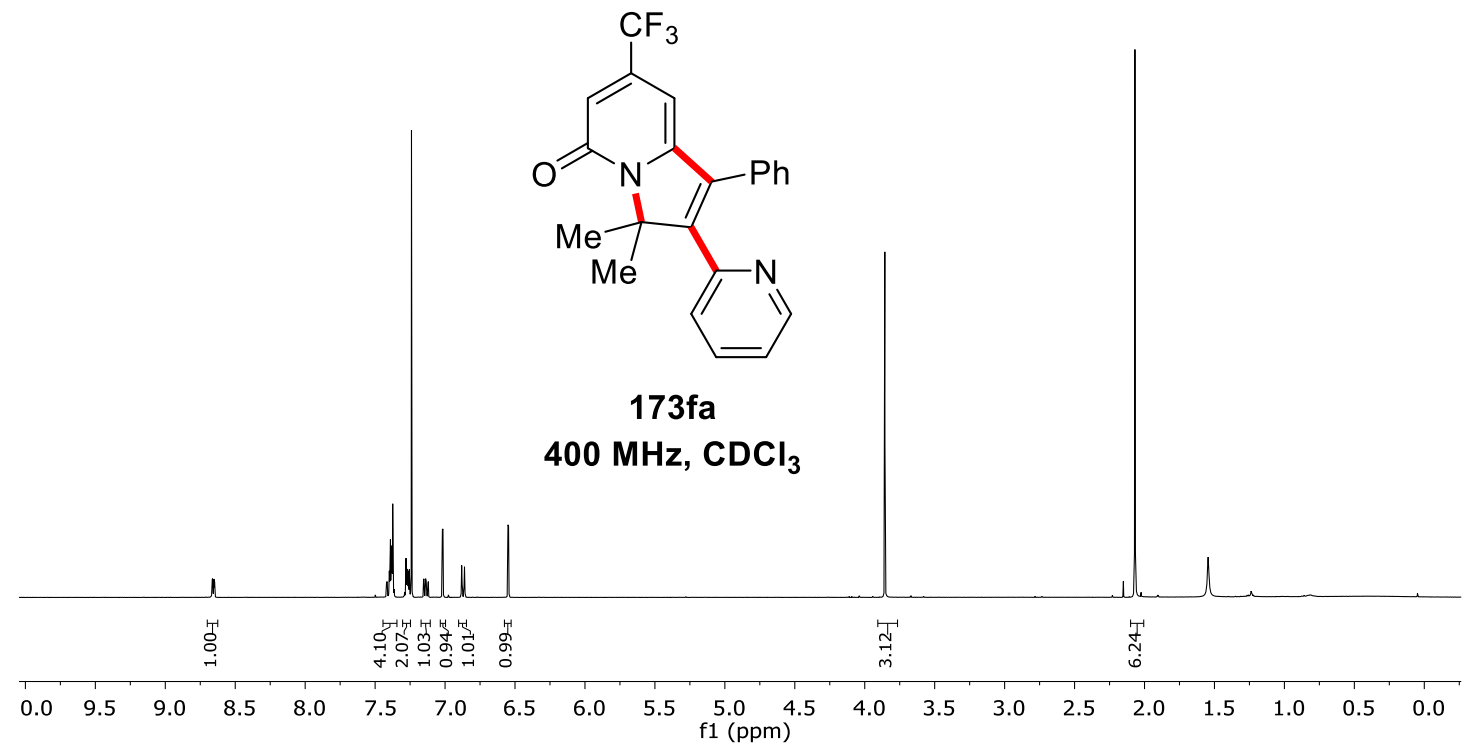

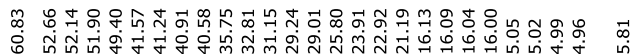
至

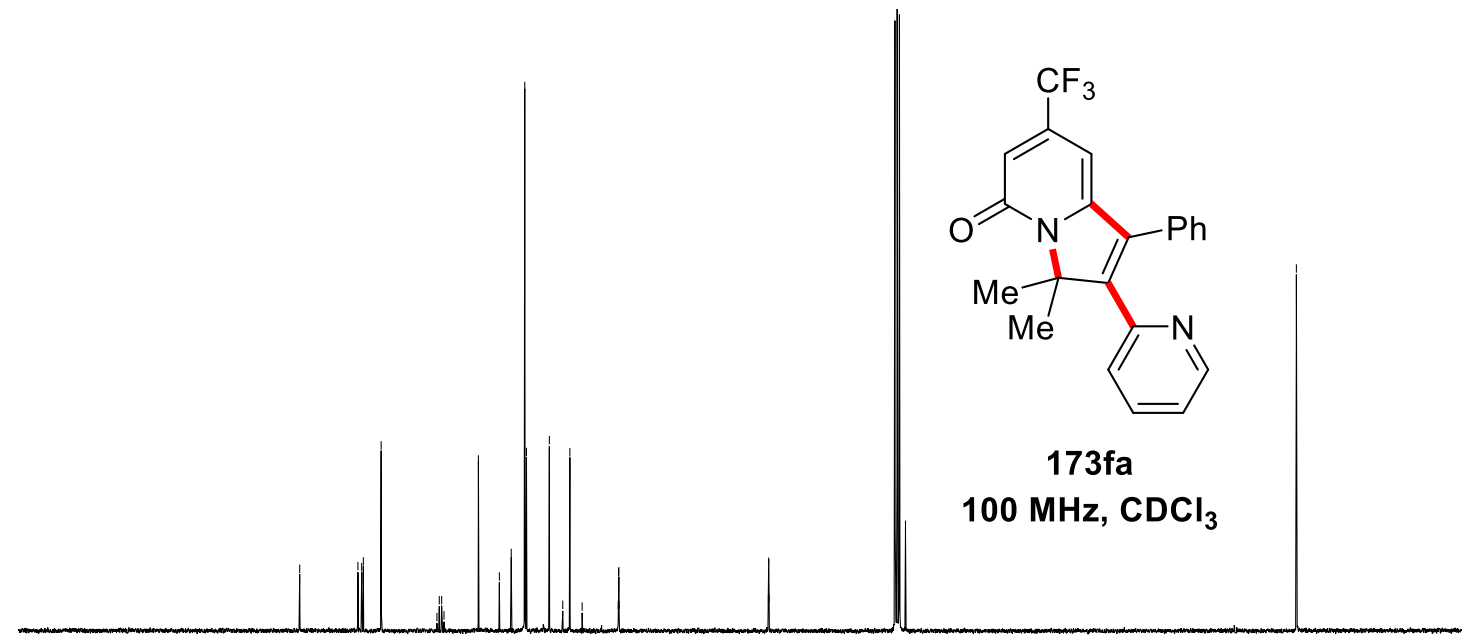

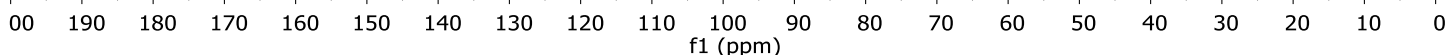




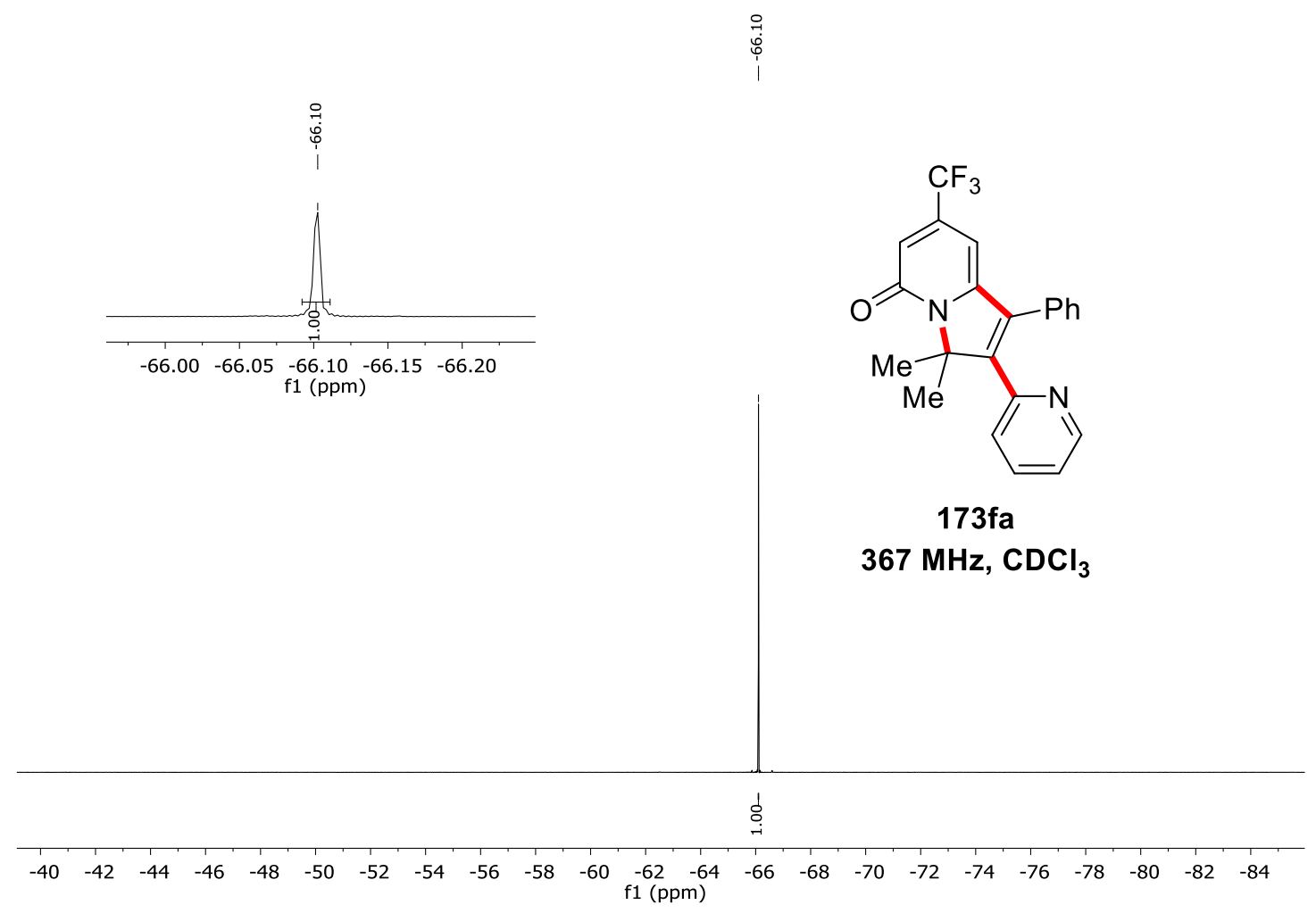




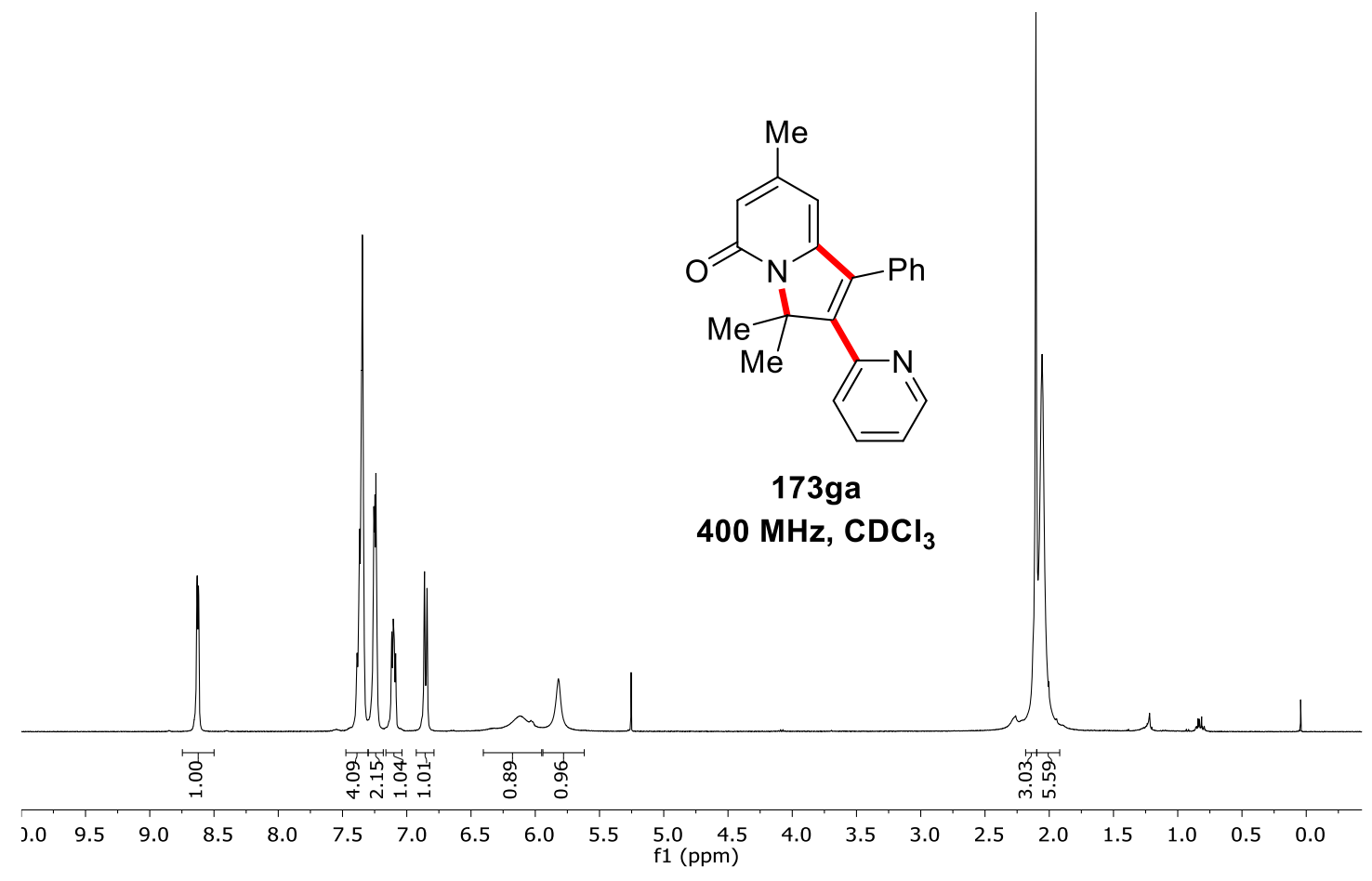

ํํำ กู่

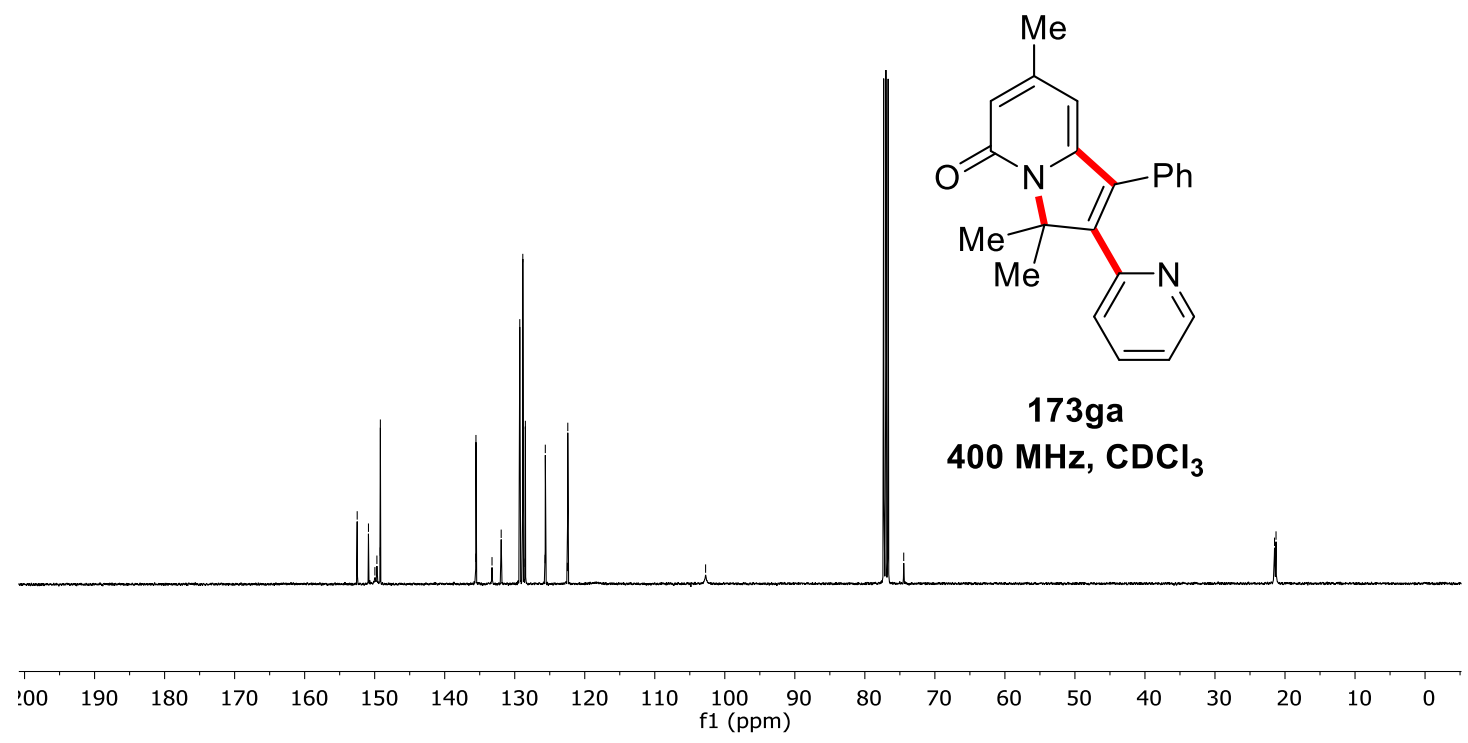




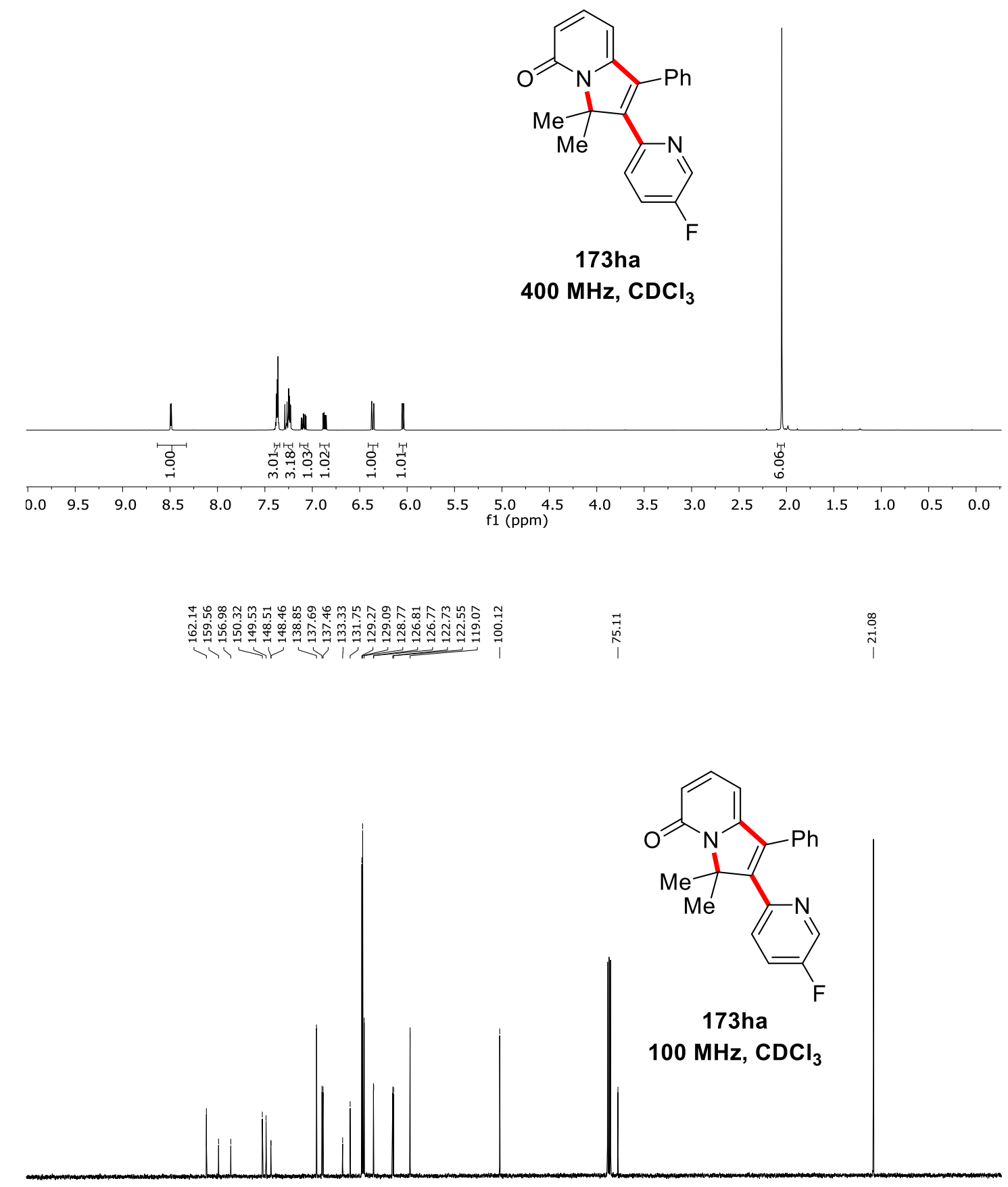

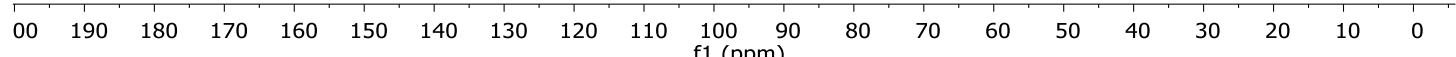




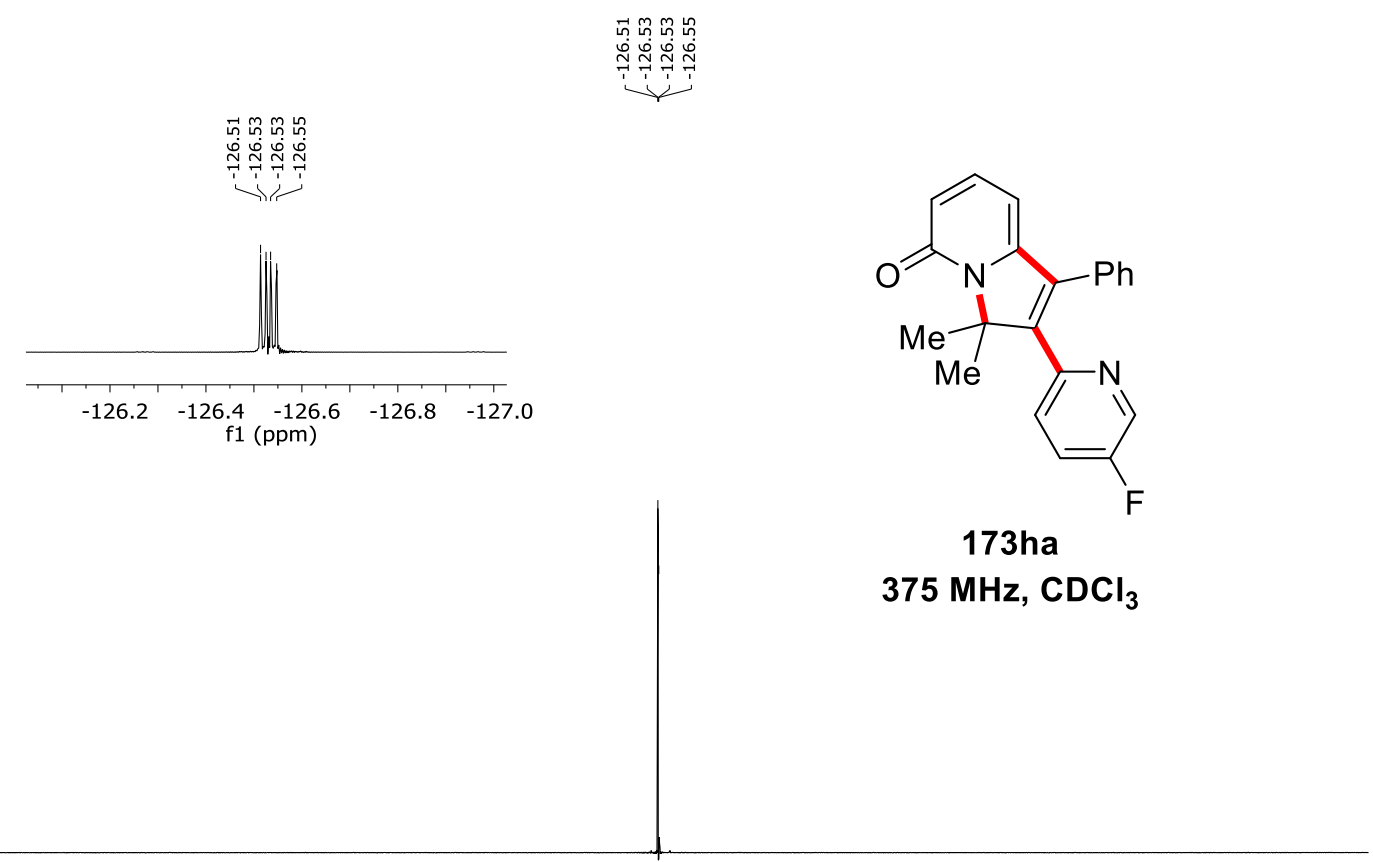

$-100-102-104-106-108-110-112-114-116-118-120-122-124-126-128-130-132-134-136-138-140-142-144-146-148-150-152$ f1 (ppm) 

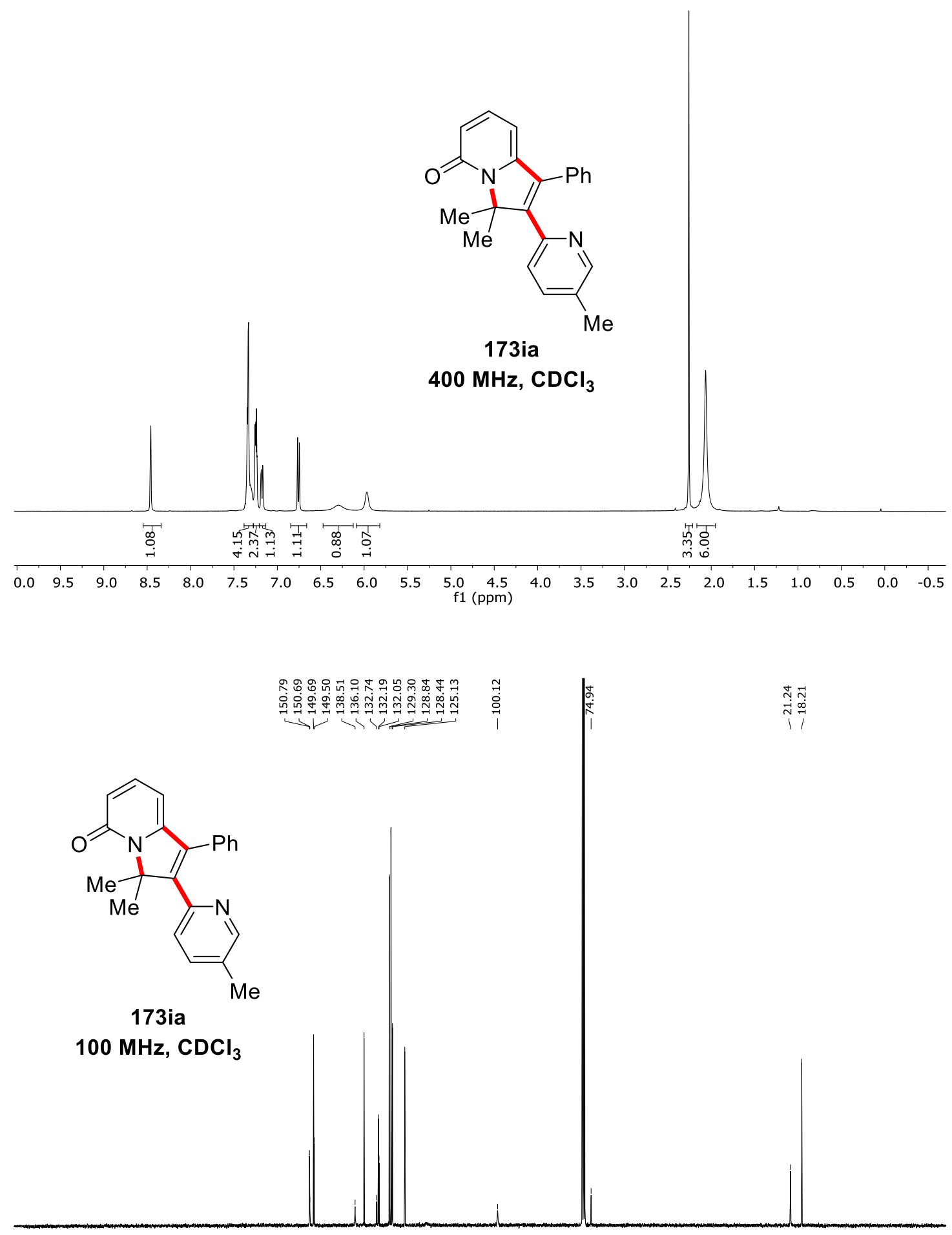

\begin{tabular}{llllllllllllllllllllllllllllll}
\hline 30 & 220 & 210 & 200 & 190 & 180 & 170 & 160 & 150 & 140 & 130 & 120 & 110 & 100 & 90 & 80 & 70 & 60 & 50 & 40 & 30 & 20 & 10 & 0 & -10 & -2
\end{tabular} 


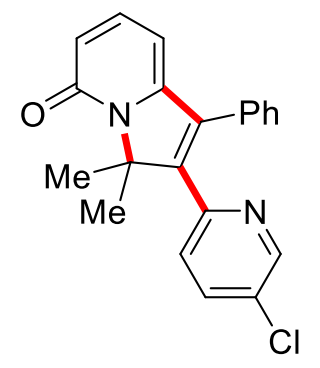

173ja

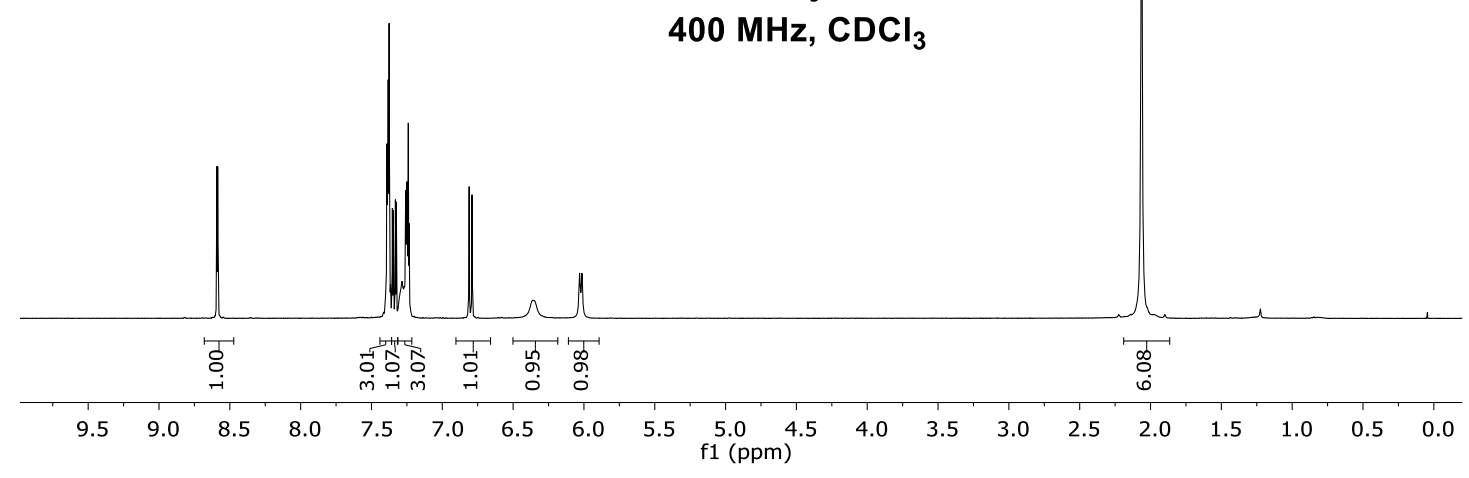

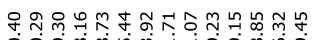

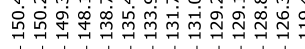

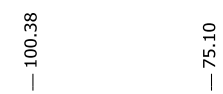

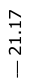

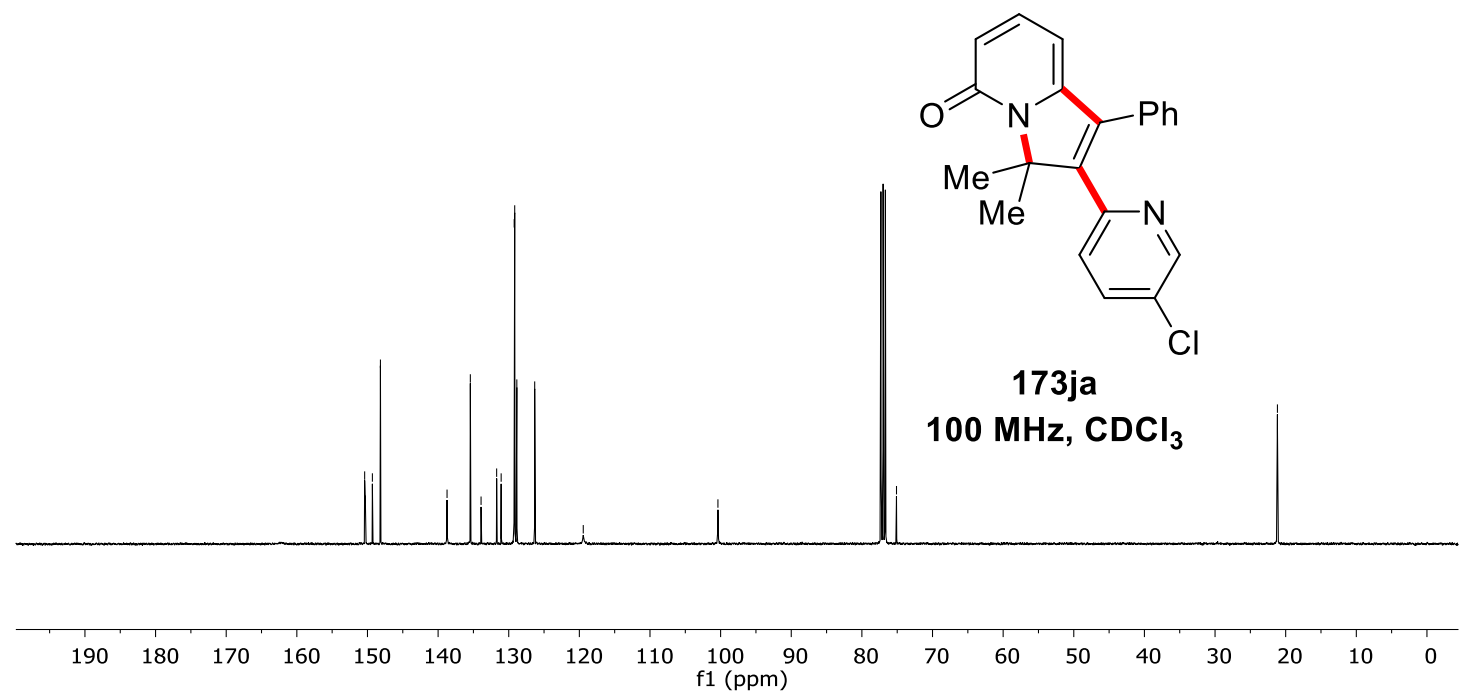



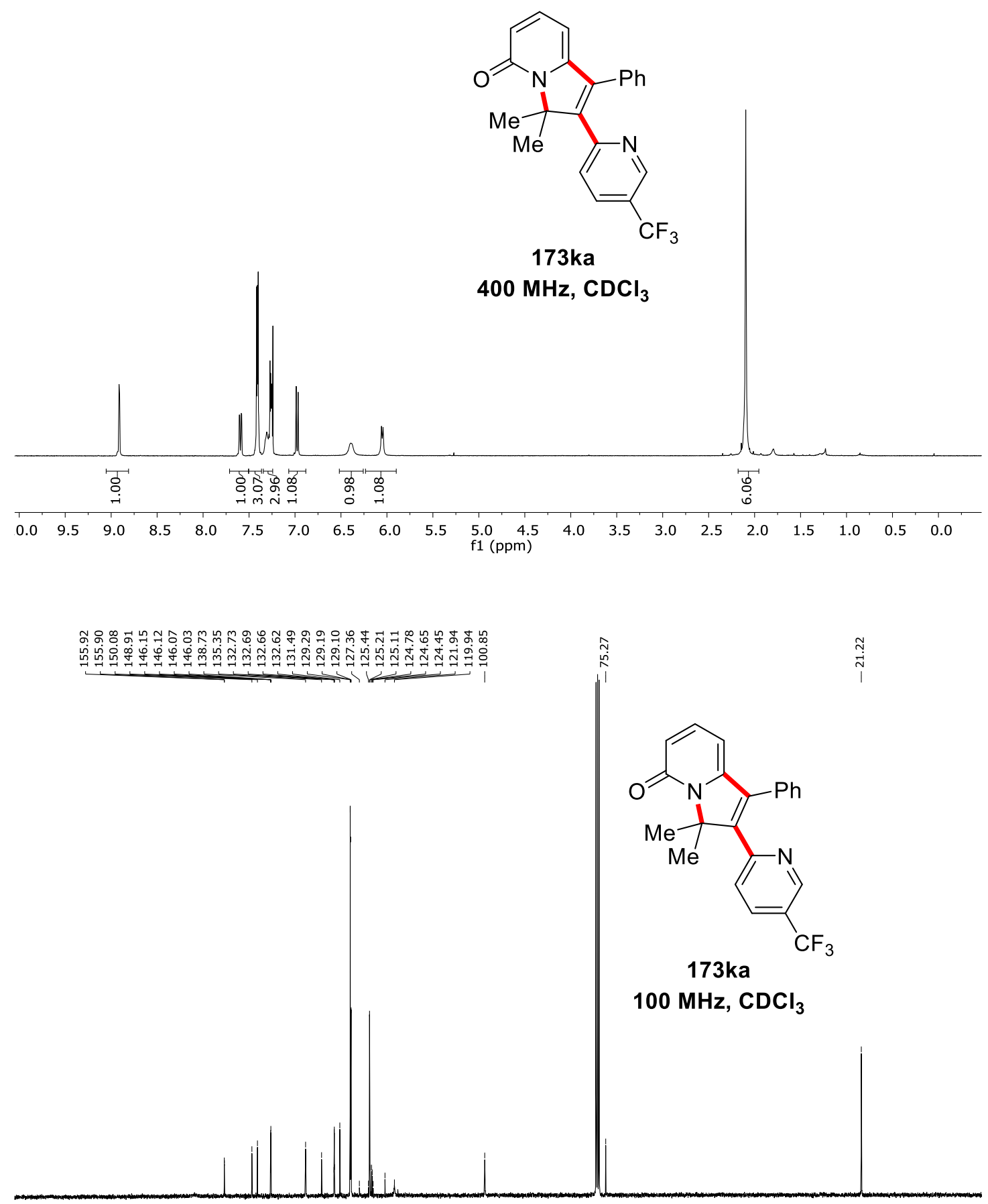

$\begin{array}{lllllllllllllllllllllllll}00 & 190 & 180 & 170 & 160 & 150 & 140 & 130 & 120 & 110 & 100 & 90 & 80 & 70 & 60 & 50 & 40 & 30 & 20 & 10 & 0\end{array}$ 


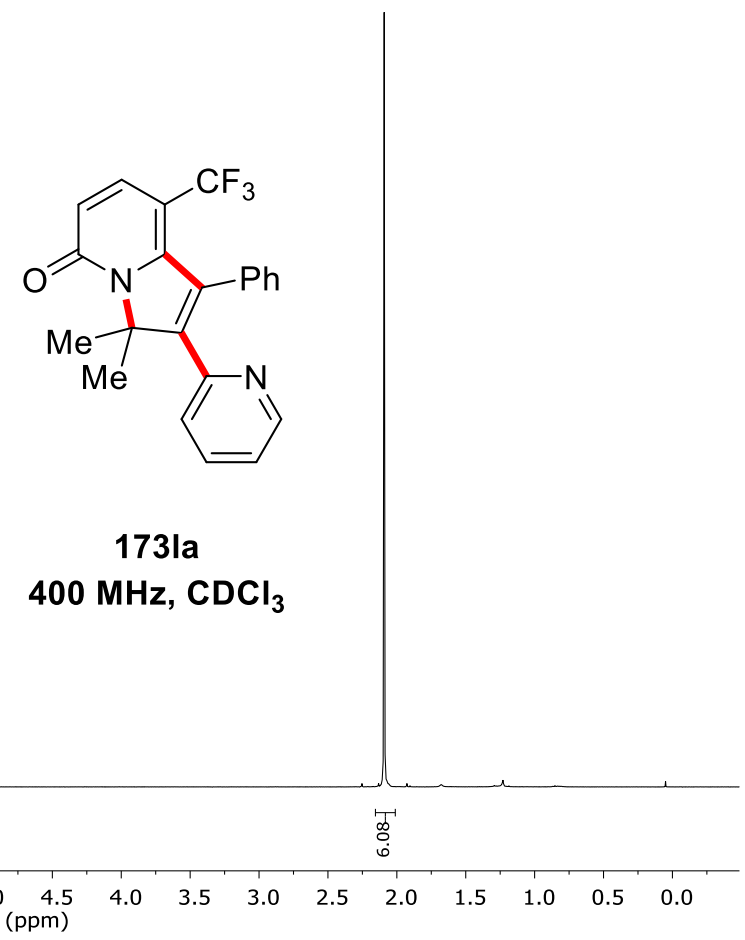

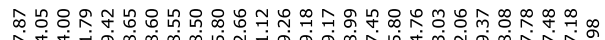

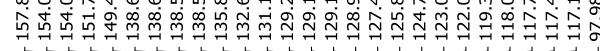

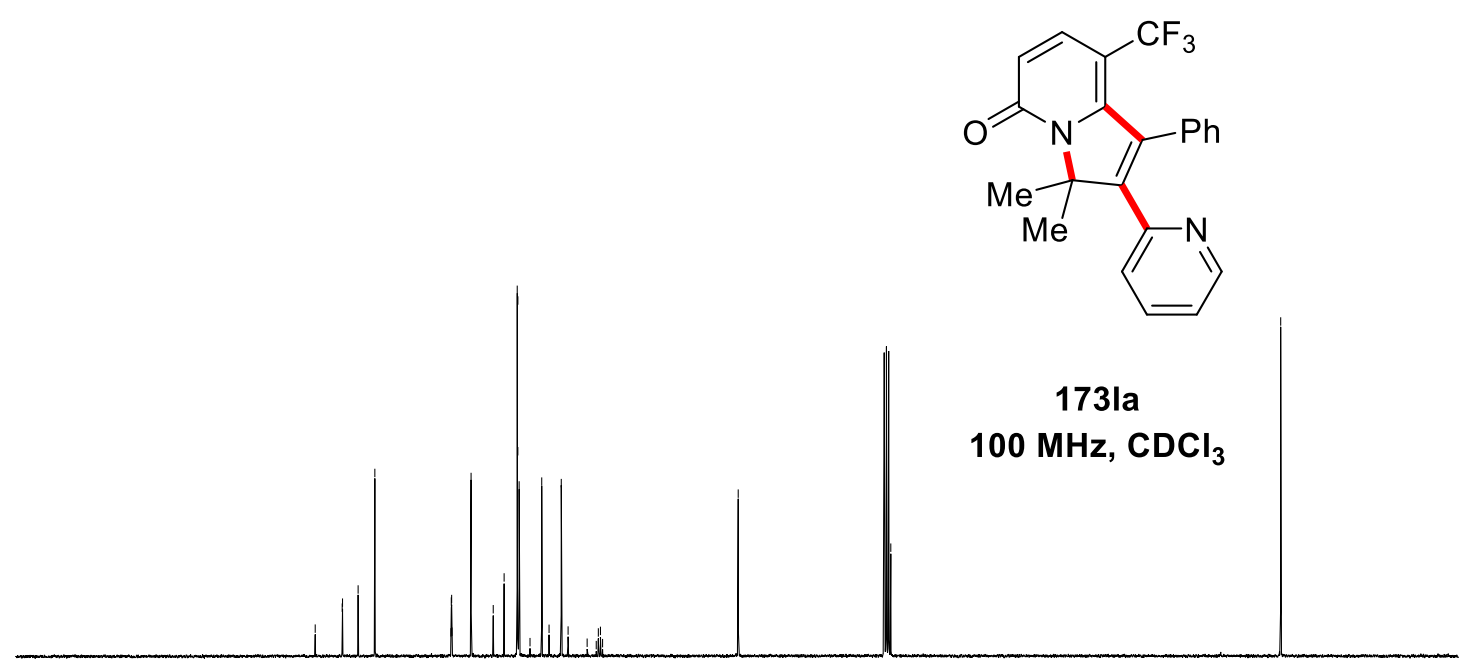

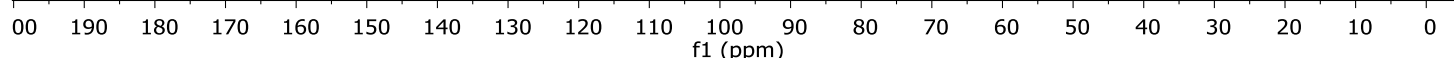




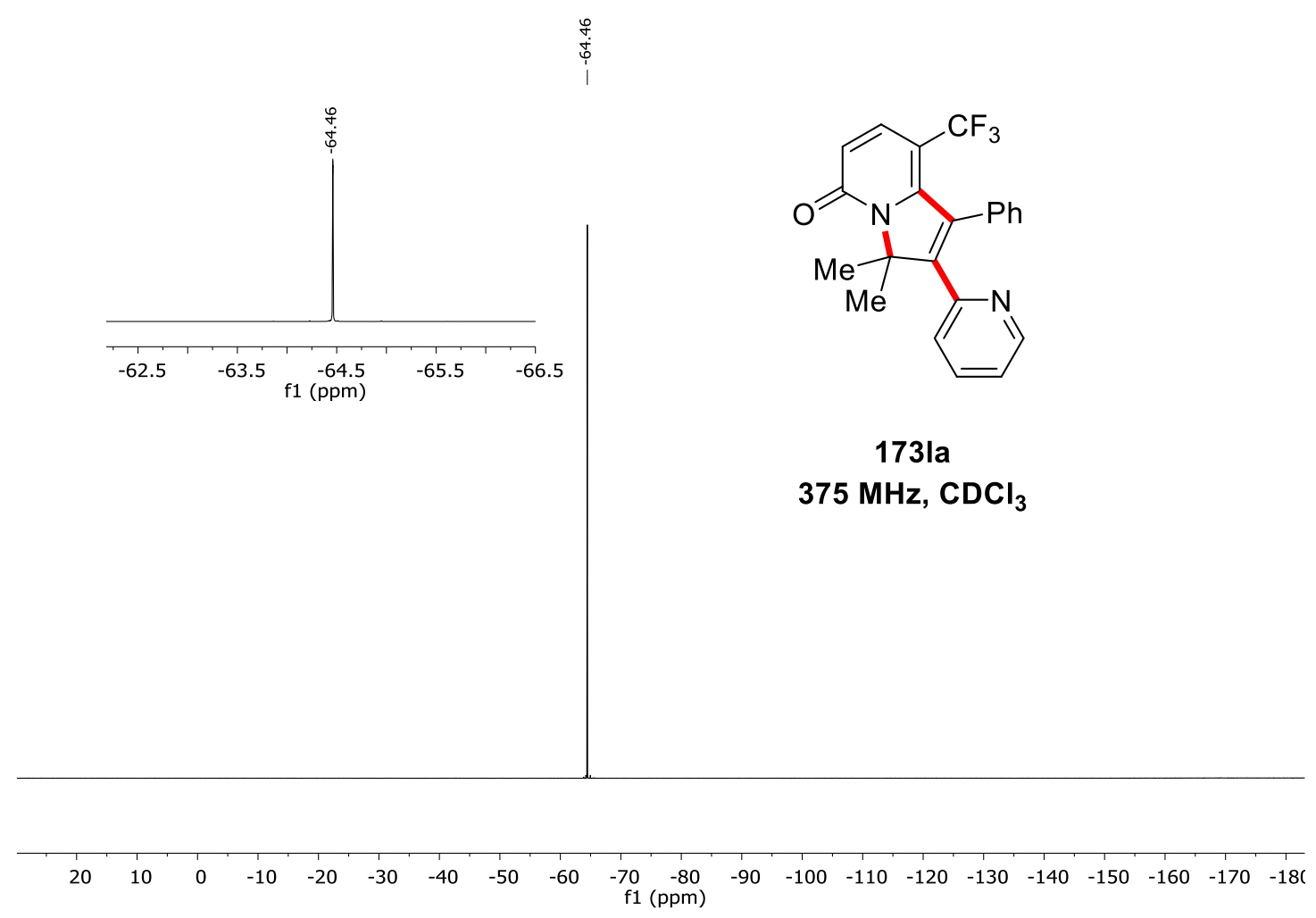



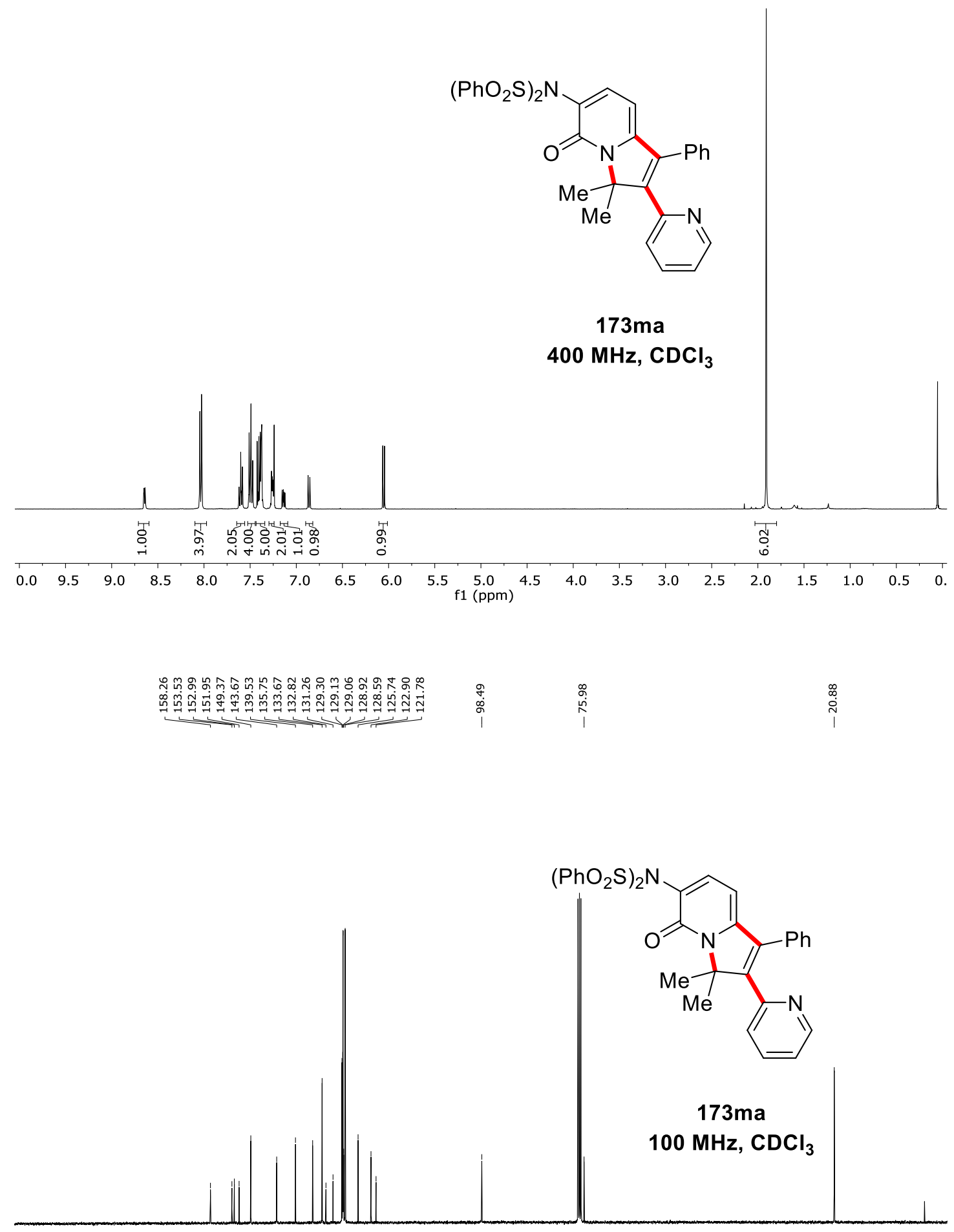

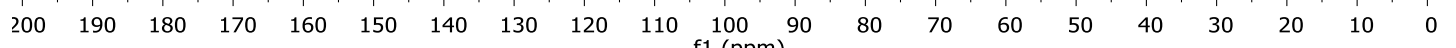




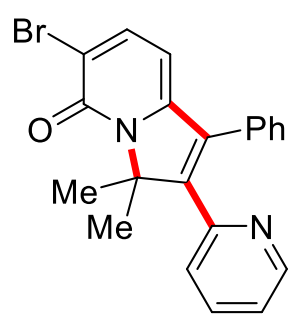

173na

$400 \mathrm{MHz}^{\mathrm{CDCl}_{3}}$

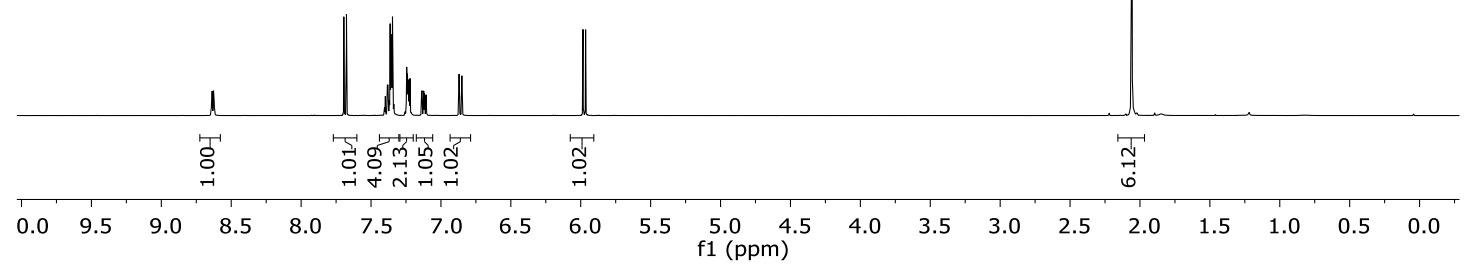

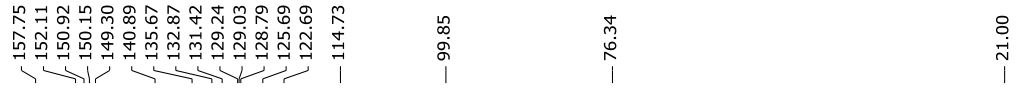

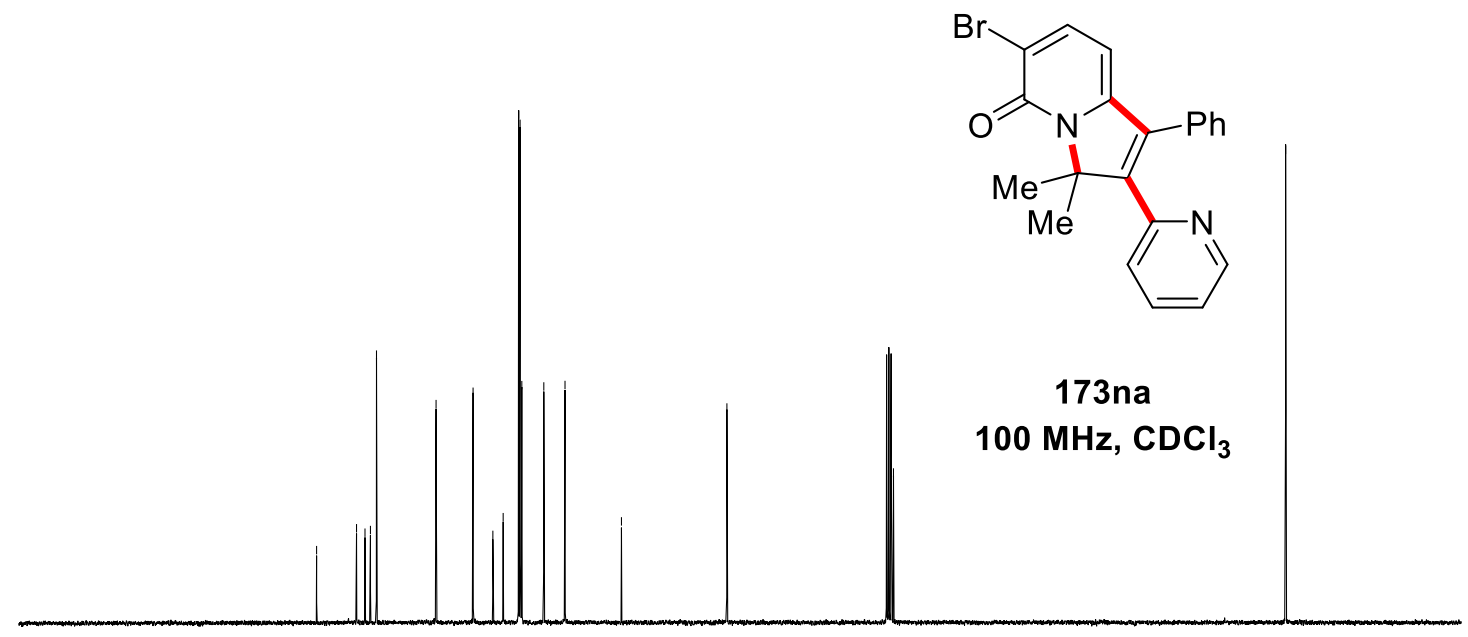

$\begin{array}{llllllllllllllllllll}190 & 180 & 170 & 160 & 150 & 140 & 130 & 120 & 110 & 100 & 90 & 80 & 70 & 60 & 50 & 40 & 30 & 20 & 10 & 0\end{array}$ 


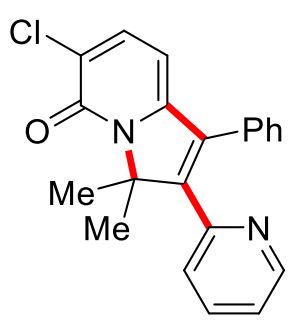

$1730 a$

$400 \mathrm{MHz}^{\mathrm{CDCl}} \mathrm{CDC}_{3}$

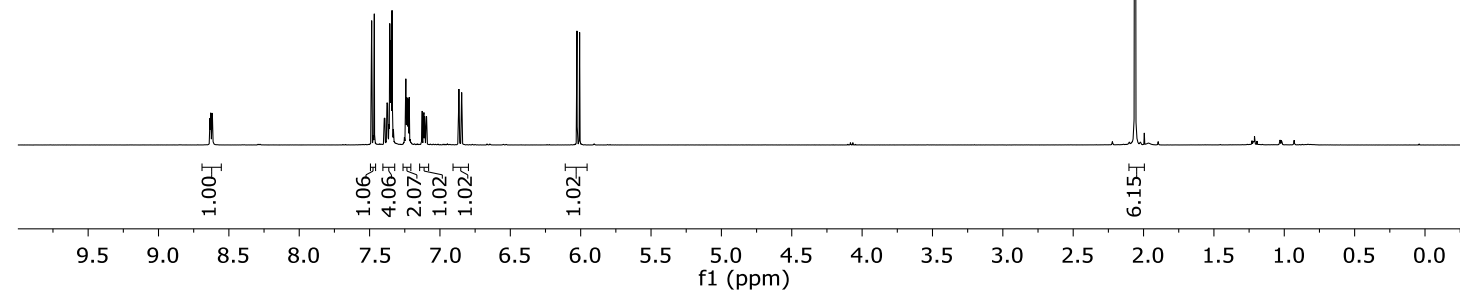

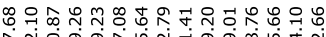

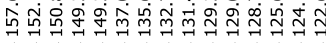
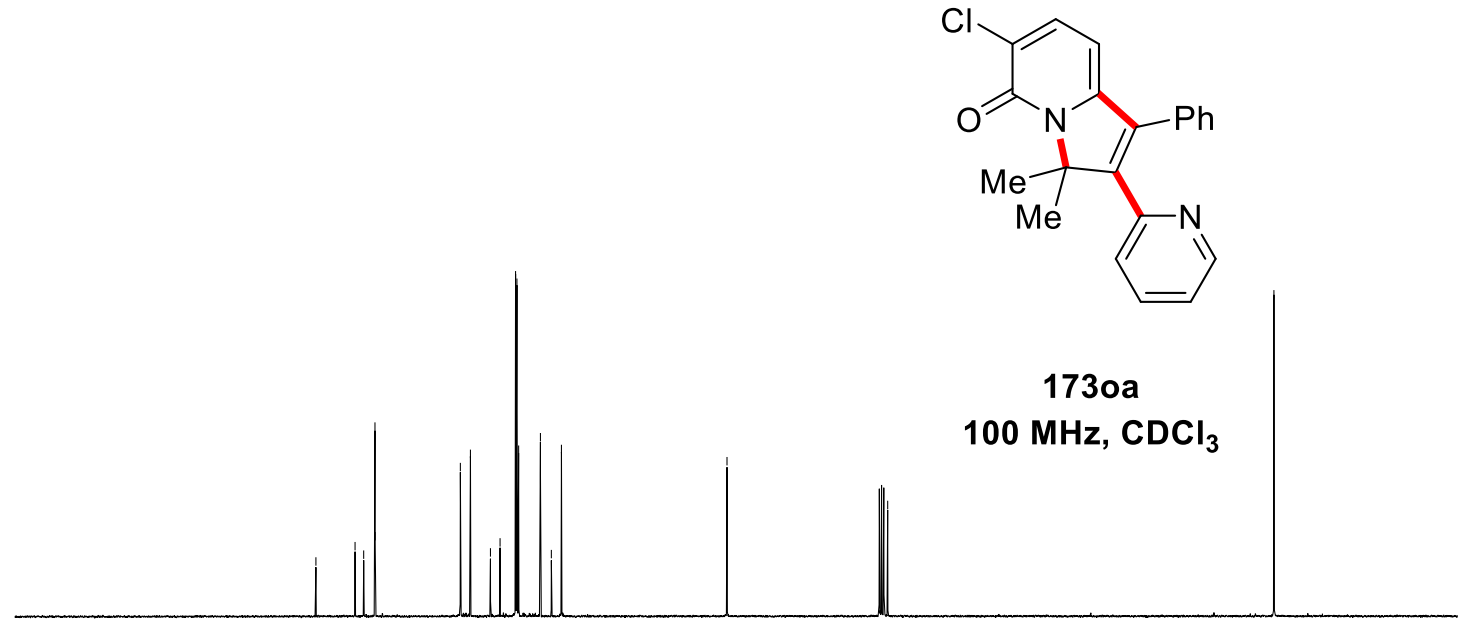

$1730 a$

$100 \mathrm{MHz}, \mathrm{CDCl}_{3}$

$\begin{array}{llllllllllll}00 & 190 & 180 & 170 & 160 & 150 & 140 & 130 & 120 & 110 & 100 & 90\end{array}$

$$
\text { f1 } 100 \text { ppm) }
$$




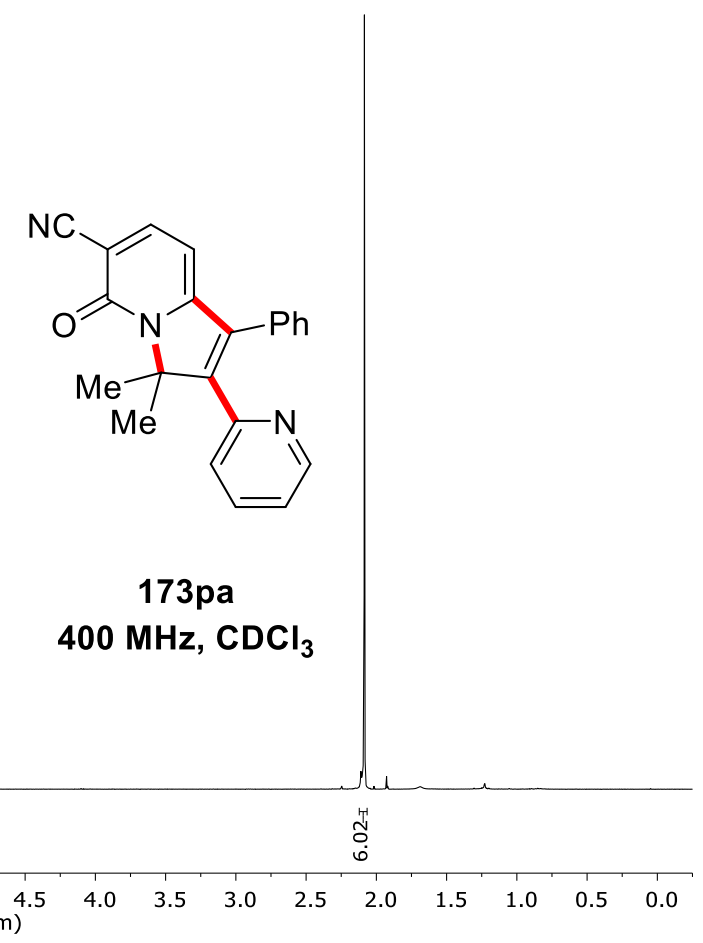

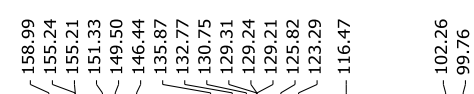

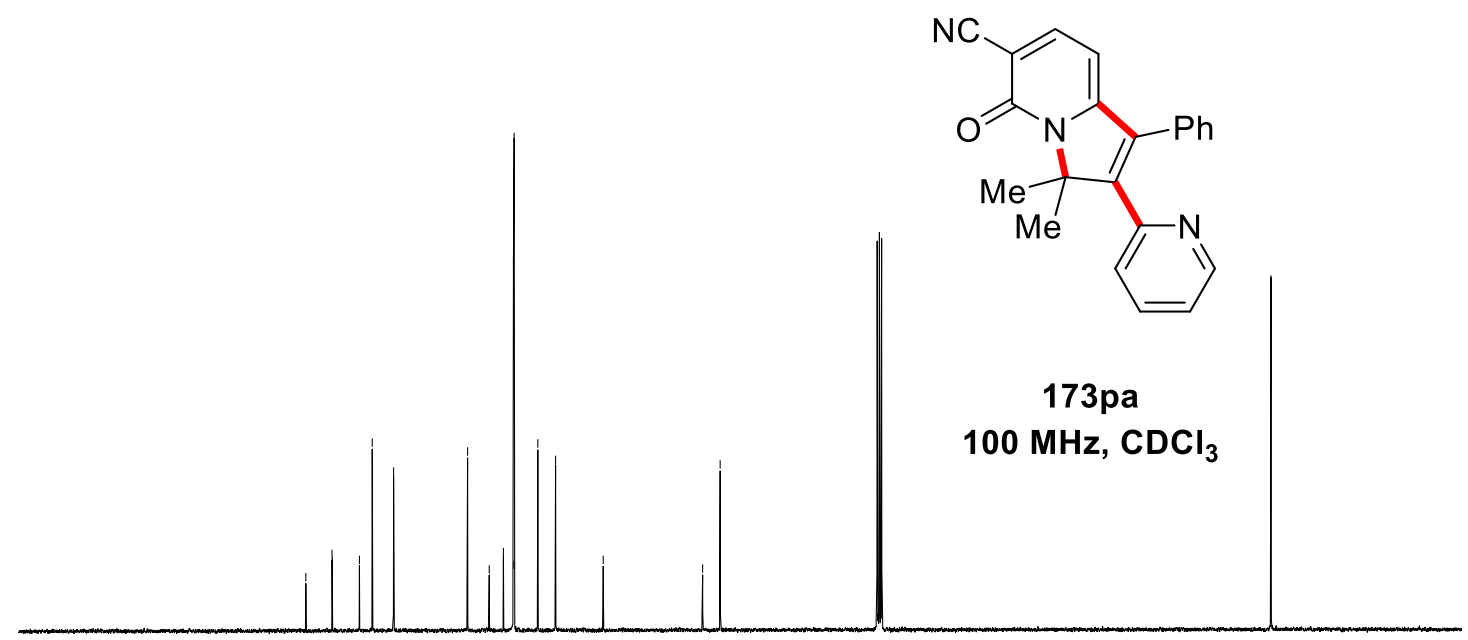

$\begin{array}{llllllllllllllllllllll}00 & 190 & 180 & 170 & 160 & 150 & 140 & 130 & 120 & 110 & 100 & 90 & 80 & 70 & 60 & 50 & 40 & 30 & 20 & 10 & 0\end{array}$ 


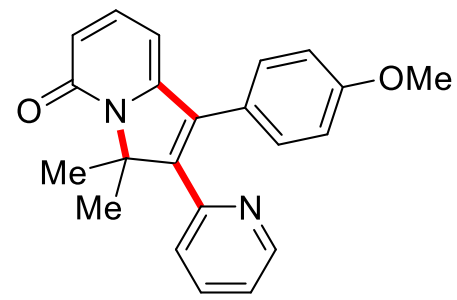

173ac

$400 \mathrm{MHz} \mathrm{CDCl}_{3}$

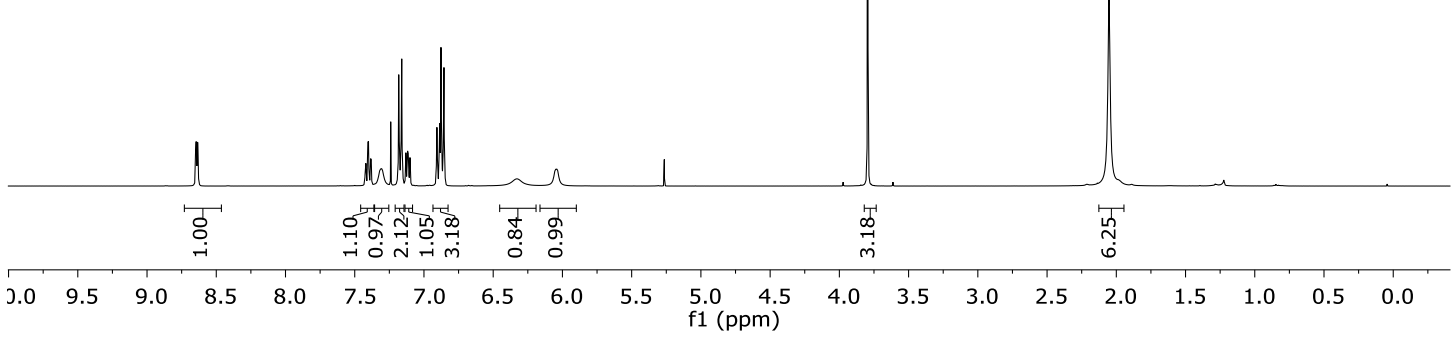

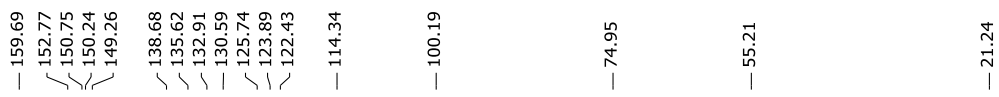<smiles>COc1ccc(C2=C(c3ccccn3)C(C)(C)n3c2cccc3=O)cc1</smiles>

173ac

$100 \mathrm{MHz}^{\mathrm{CDCl}_{3}}$

$\begin{array}{lllllllllllllllllll}190 & 180 & 170 & 160 & 150 & 140 & 130 & 120 & 110 & \begin{array}{c}100 \\ \mathrm{f} 1(\mathrm{ppm})\end{array} & 90 & 70 & 60 & 50 & 40 & 30 & 20 & 10 & 0\end{array}$

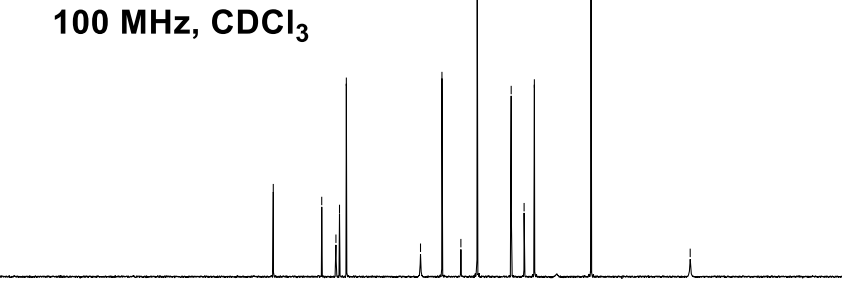




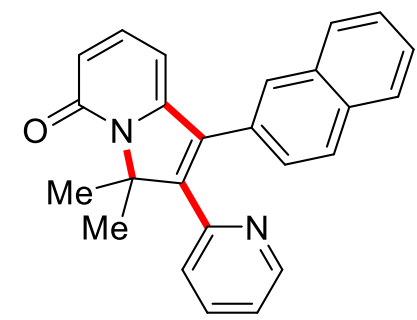

$173 \mathrm{ad}$

$400 \mathrm{MHz}, \mathrm{CDCl}_{3}$

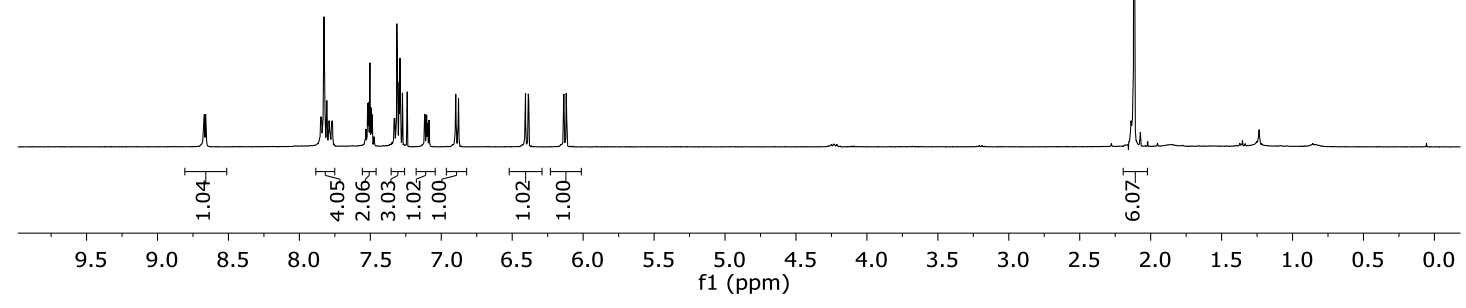

กิ

|

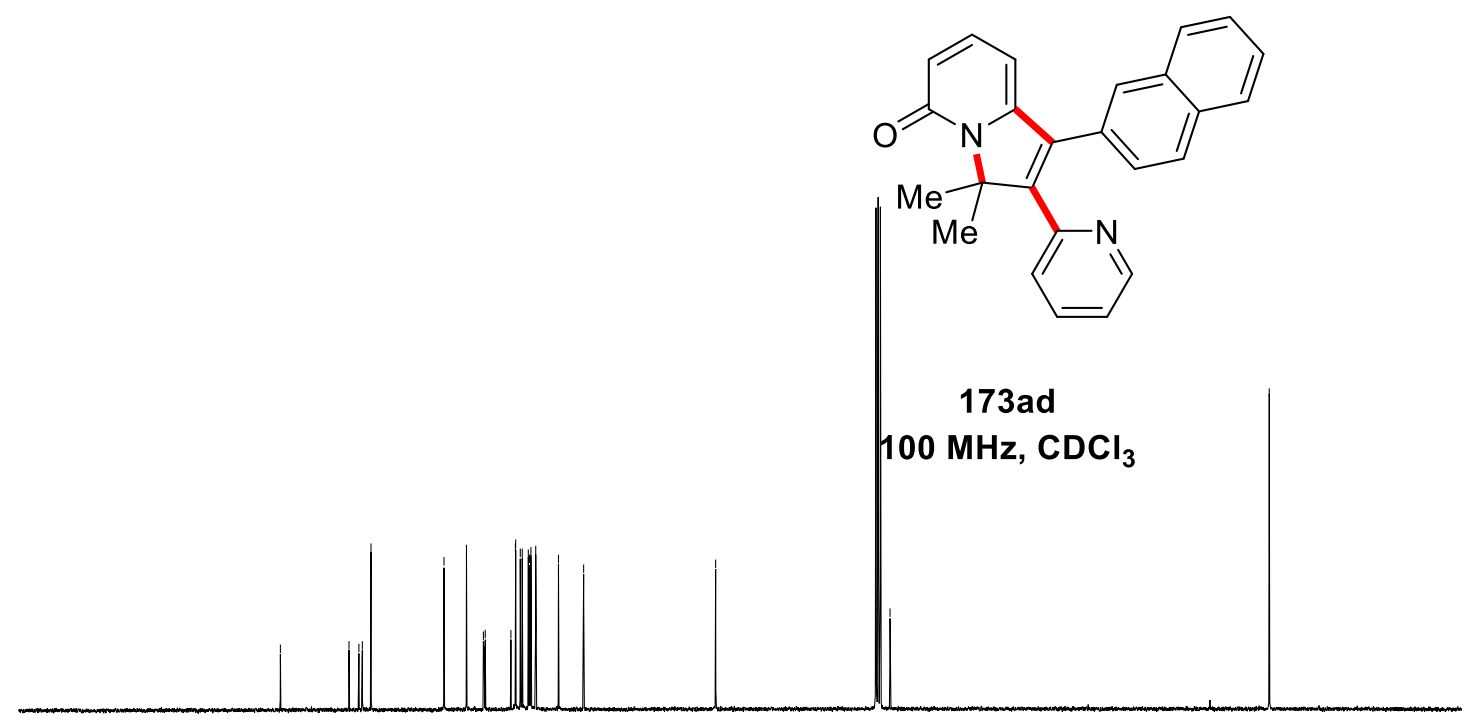

$\begin{array}{llllllllllllllllllll}190 & 180 & 170 & 160 & 150 & 140 & 130 & 120 & 110 & 100 & 90 & 80 & 70 & 60 & 50 & 40 & 30 & 20 & 10 & 0\end{array}$ 


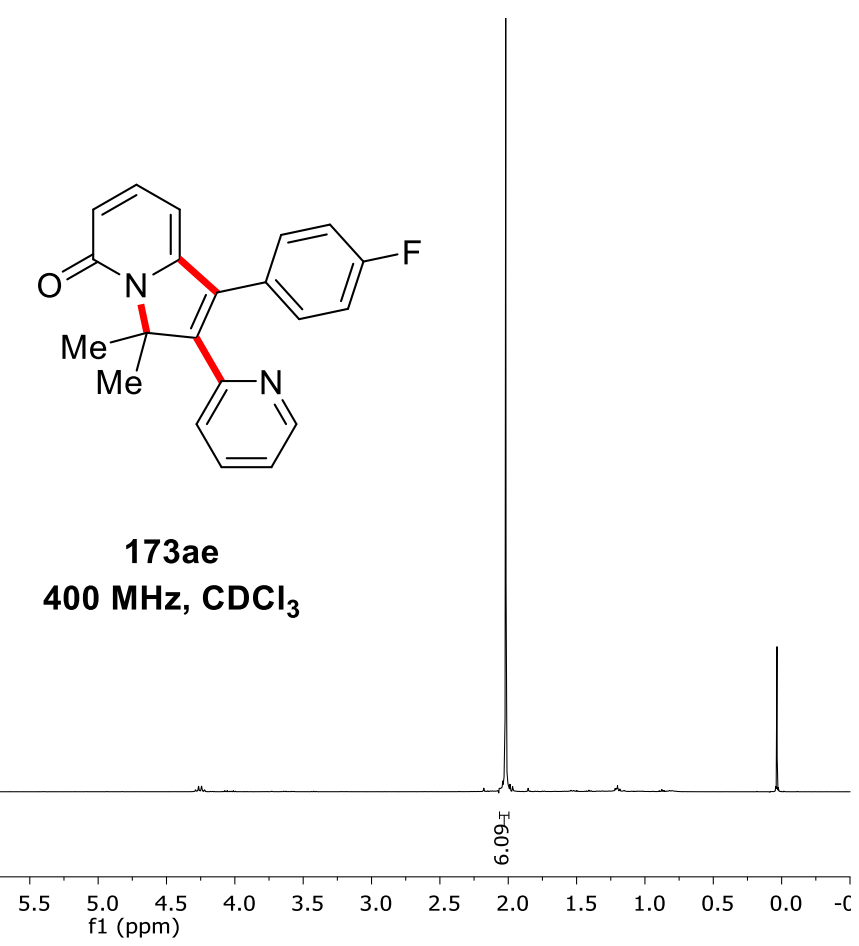

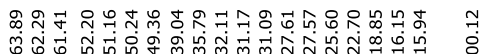

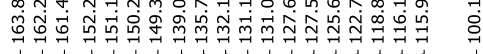
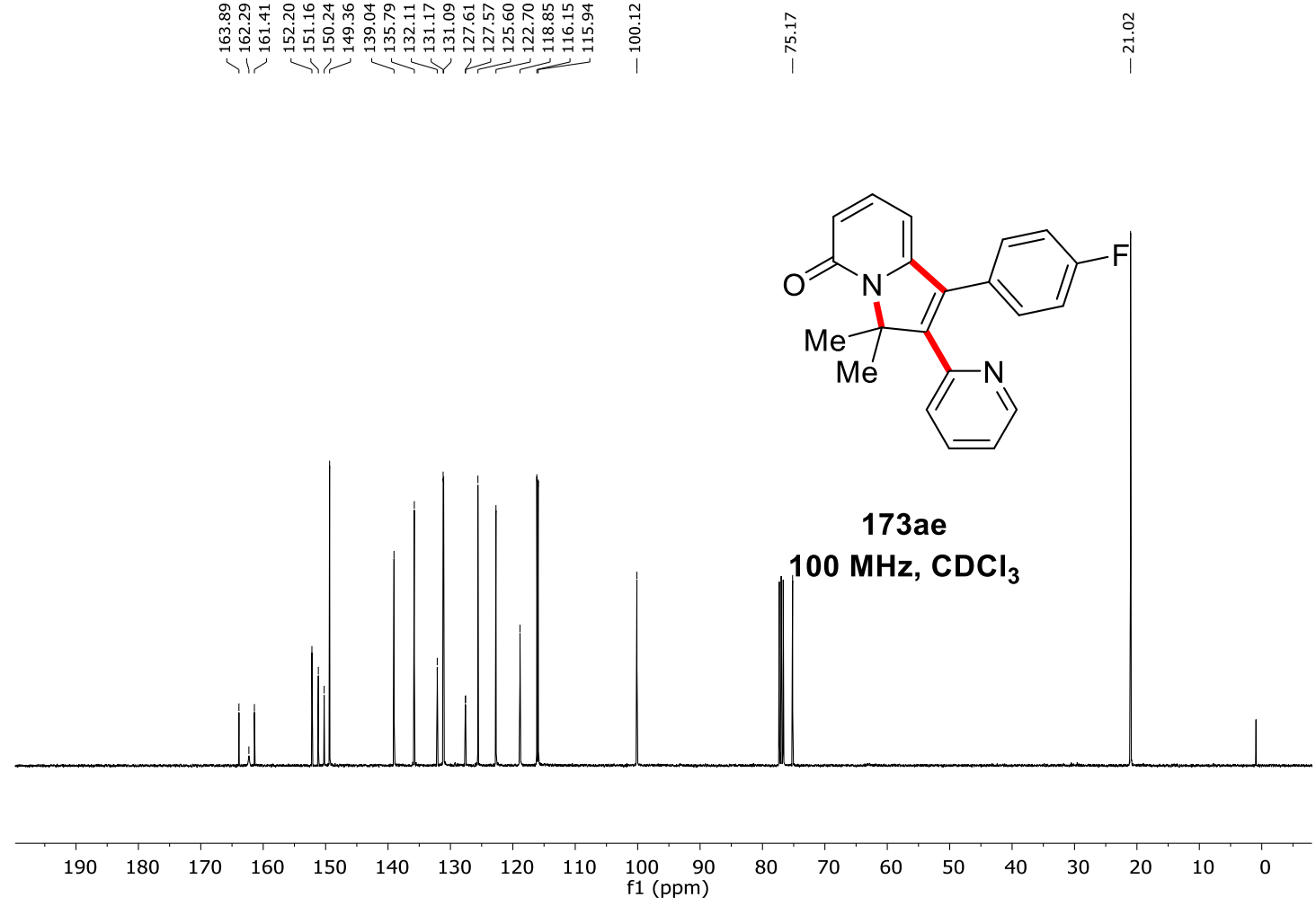
$\underset{i}{\vec{i}}$
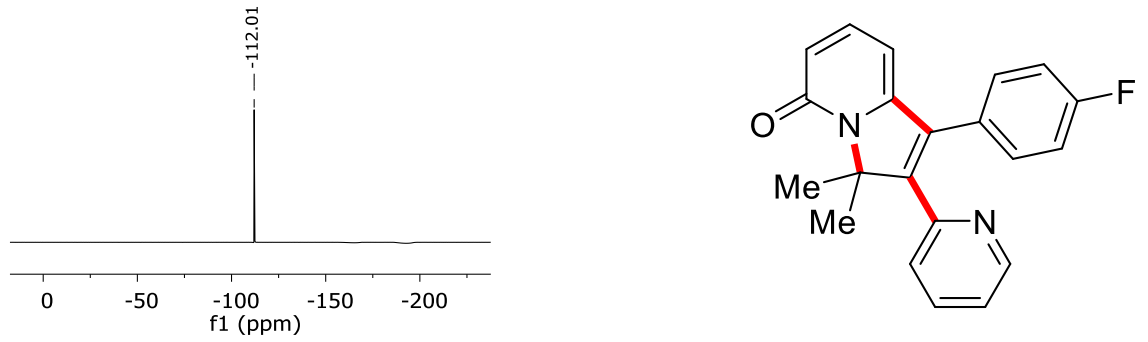

173ae

$375 \mathrm{MHz}^{\mathrm{CDCl}_{3}}$

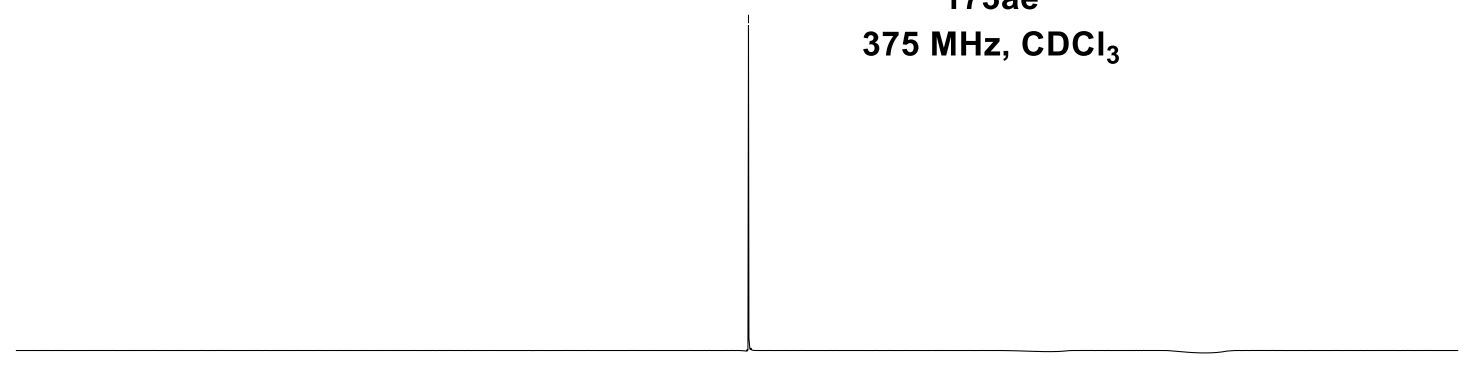

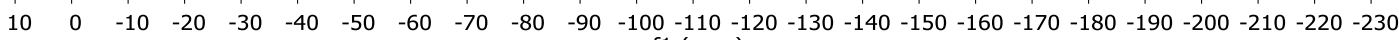
f1 $(\mathrm{ppm})$ 


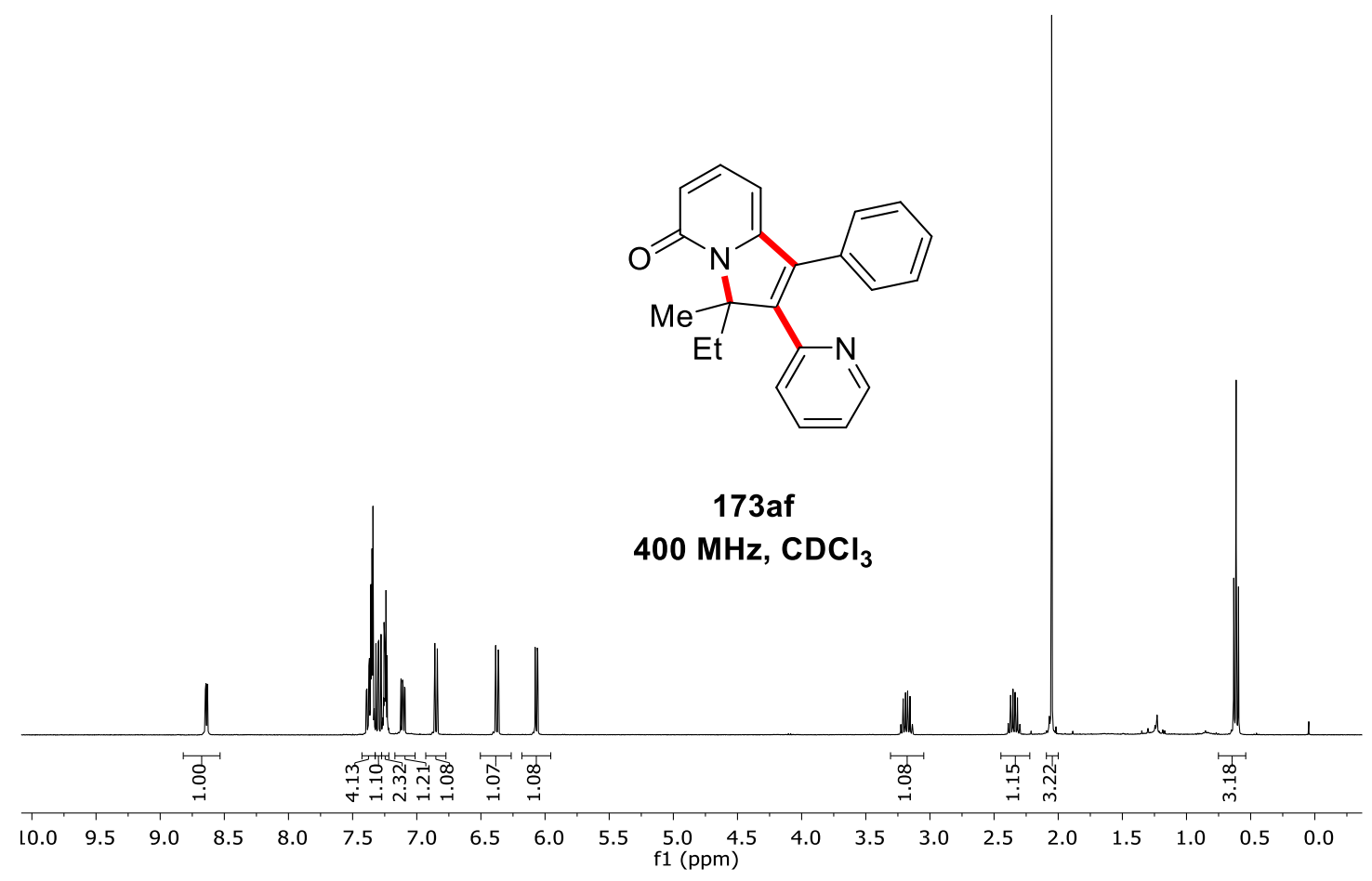

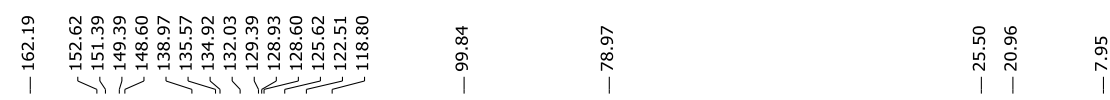

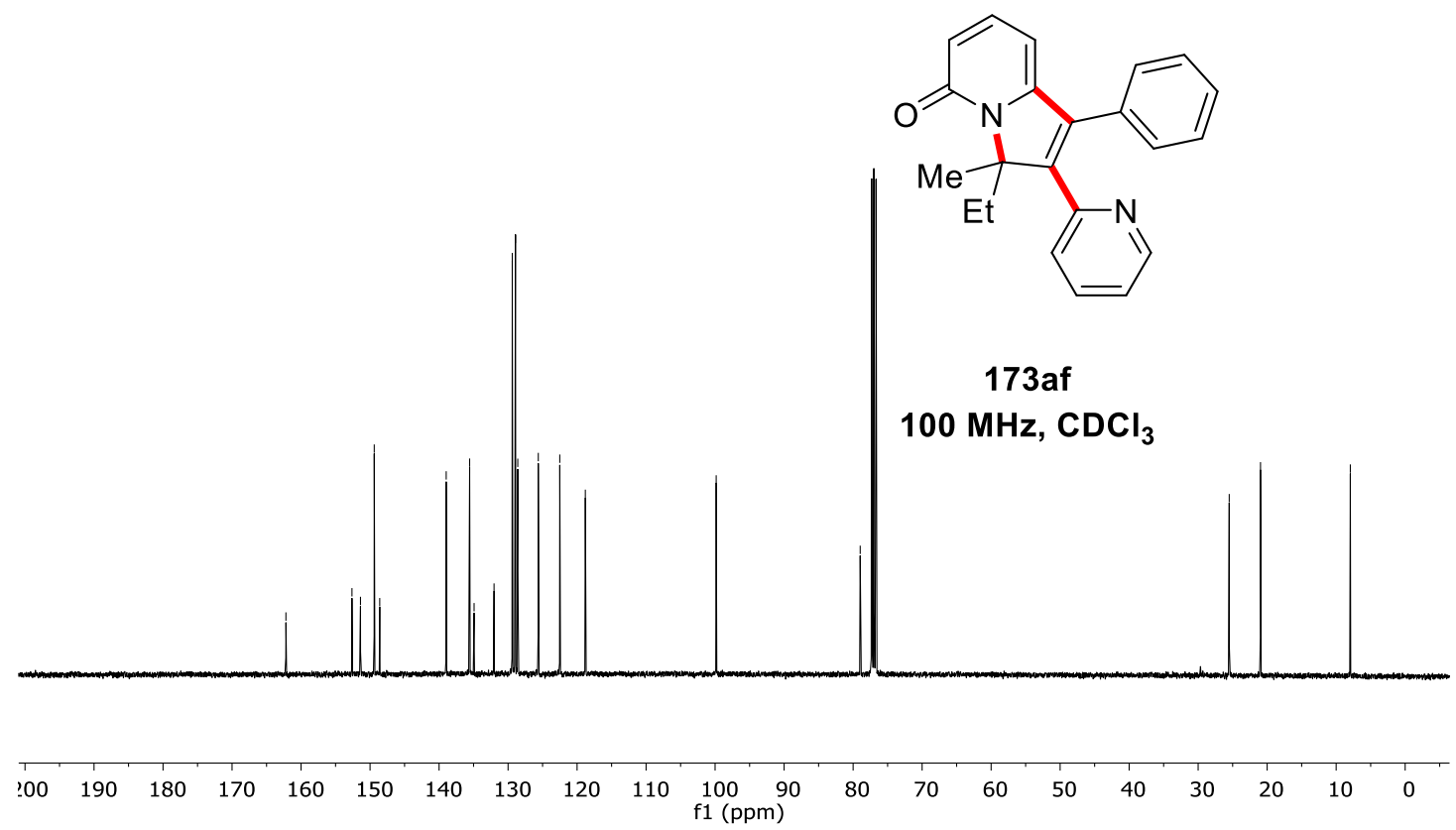




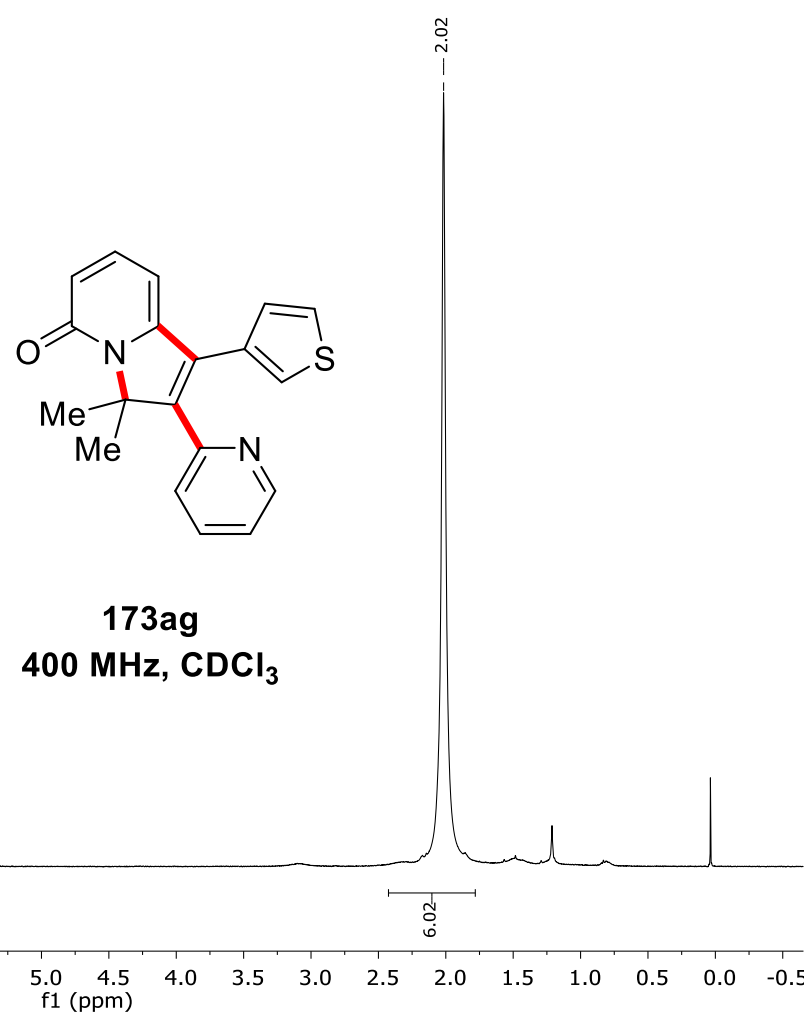

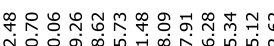

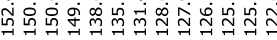

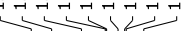

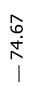

$\underset{\substack{+1}}{\stackrel{9}{1}}$

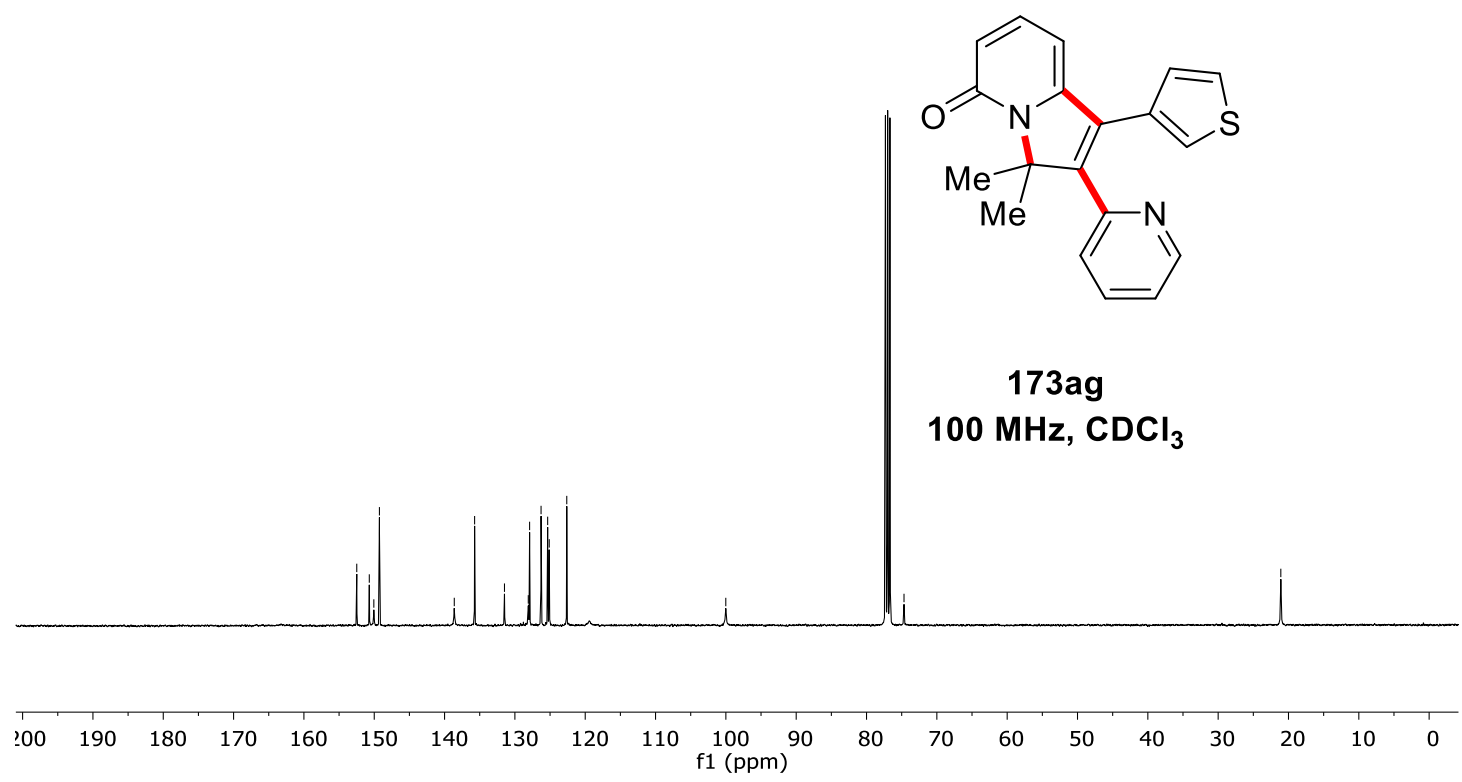




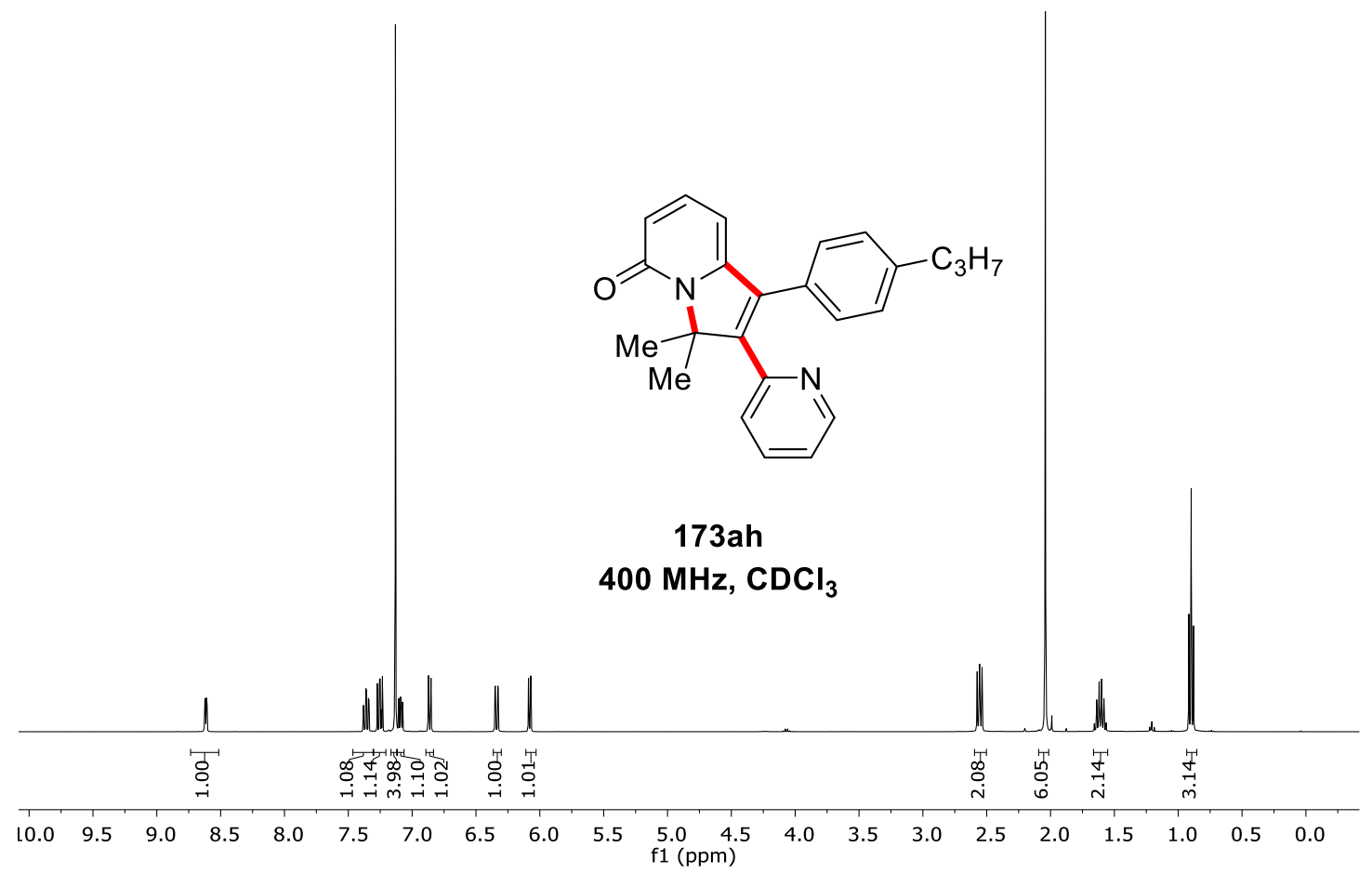

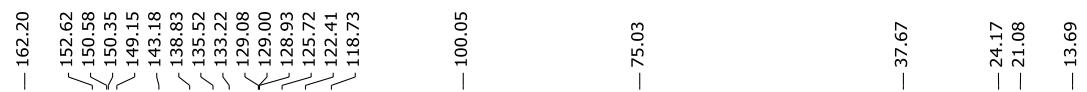

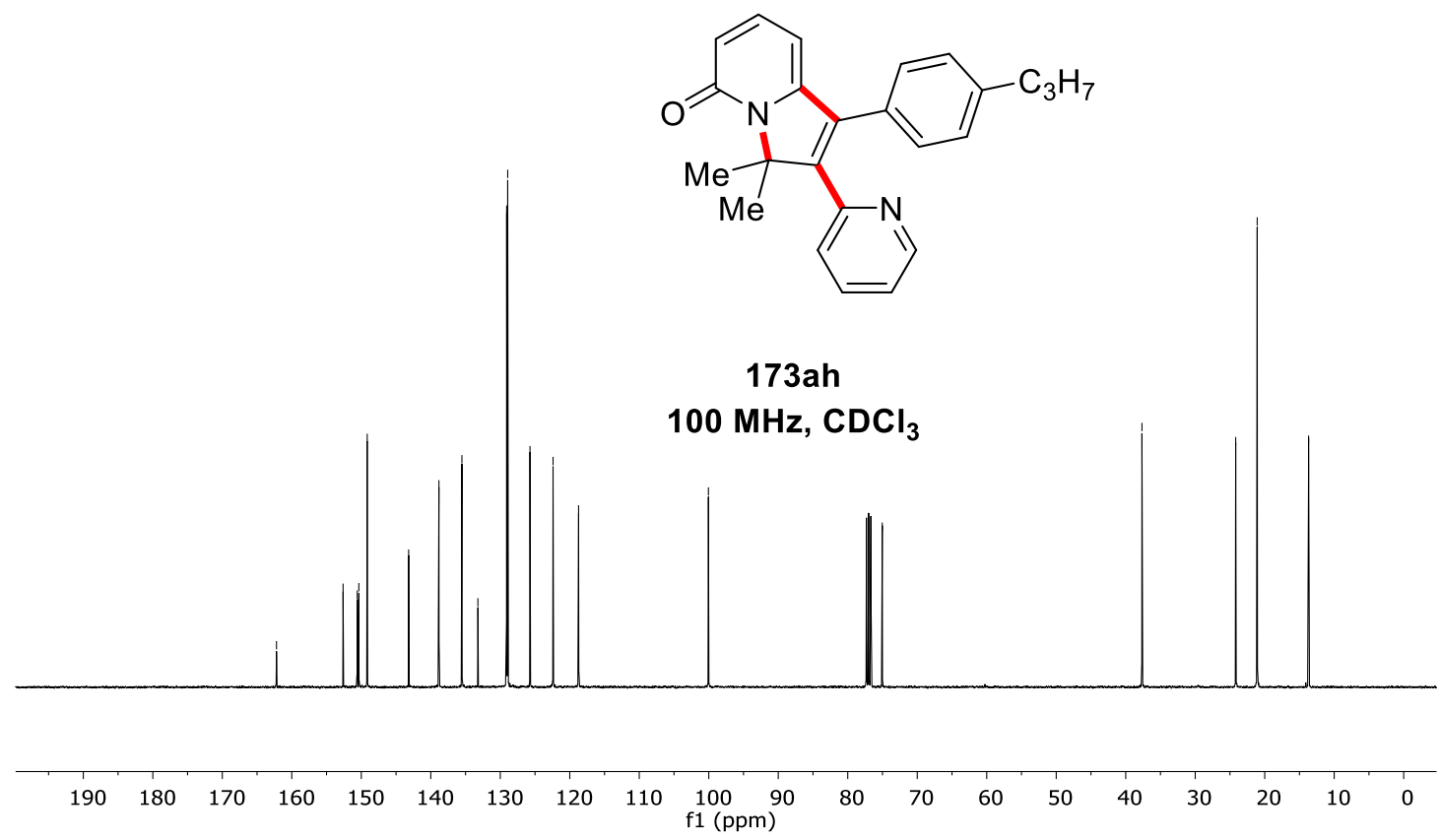



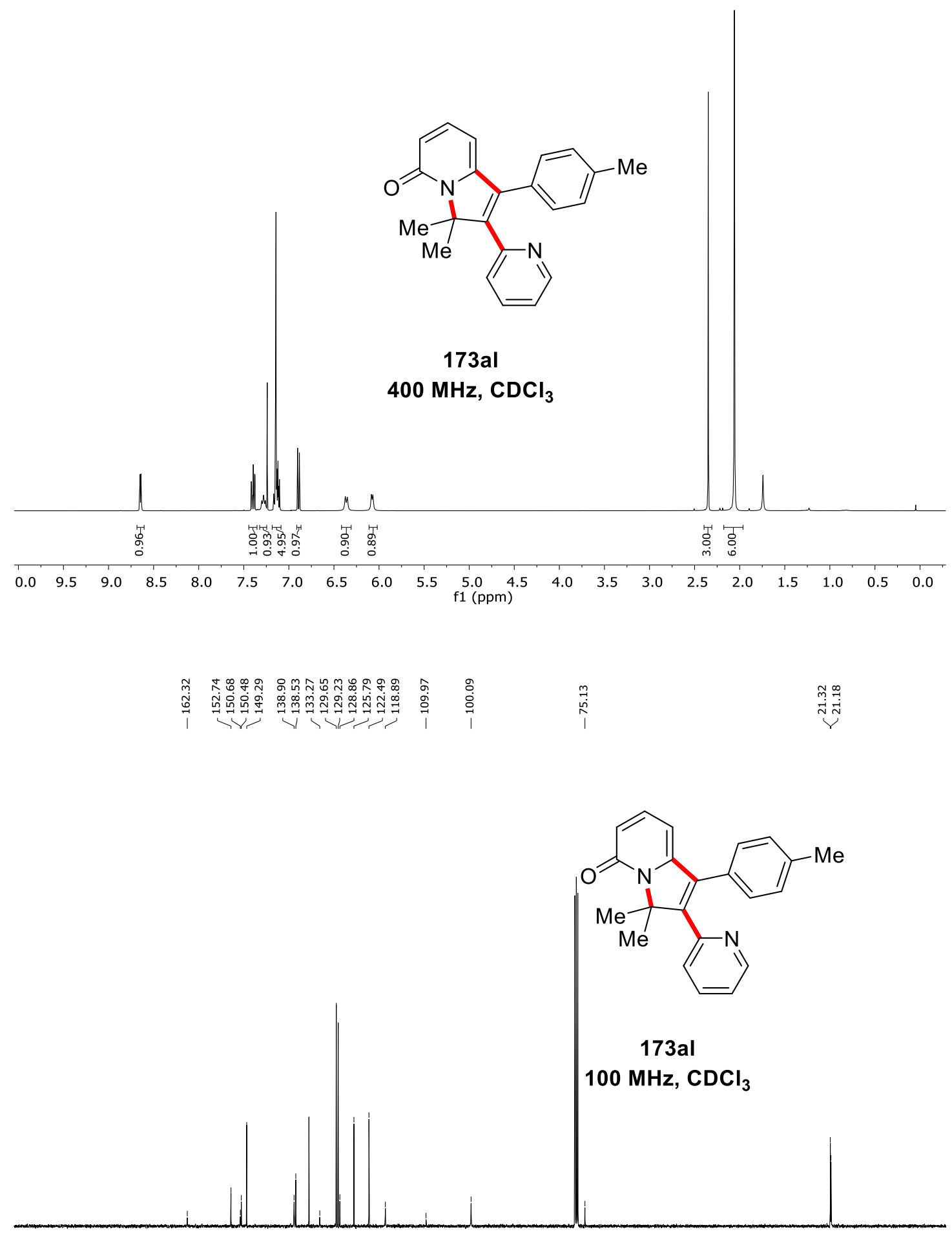

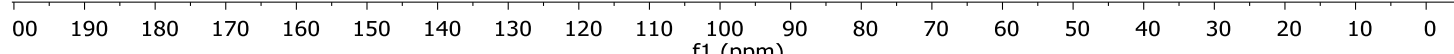



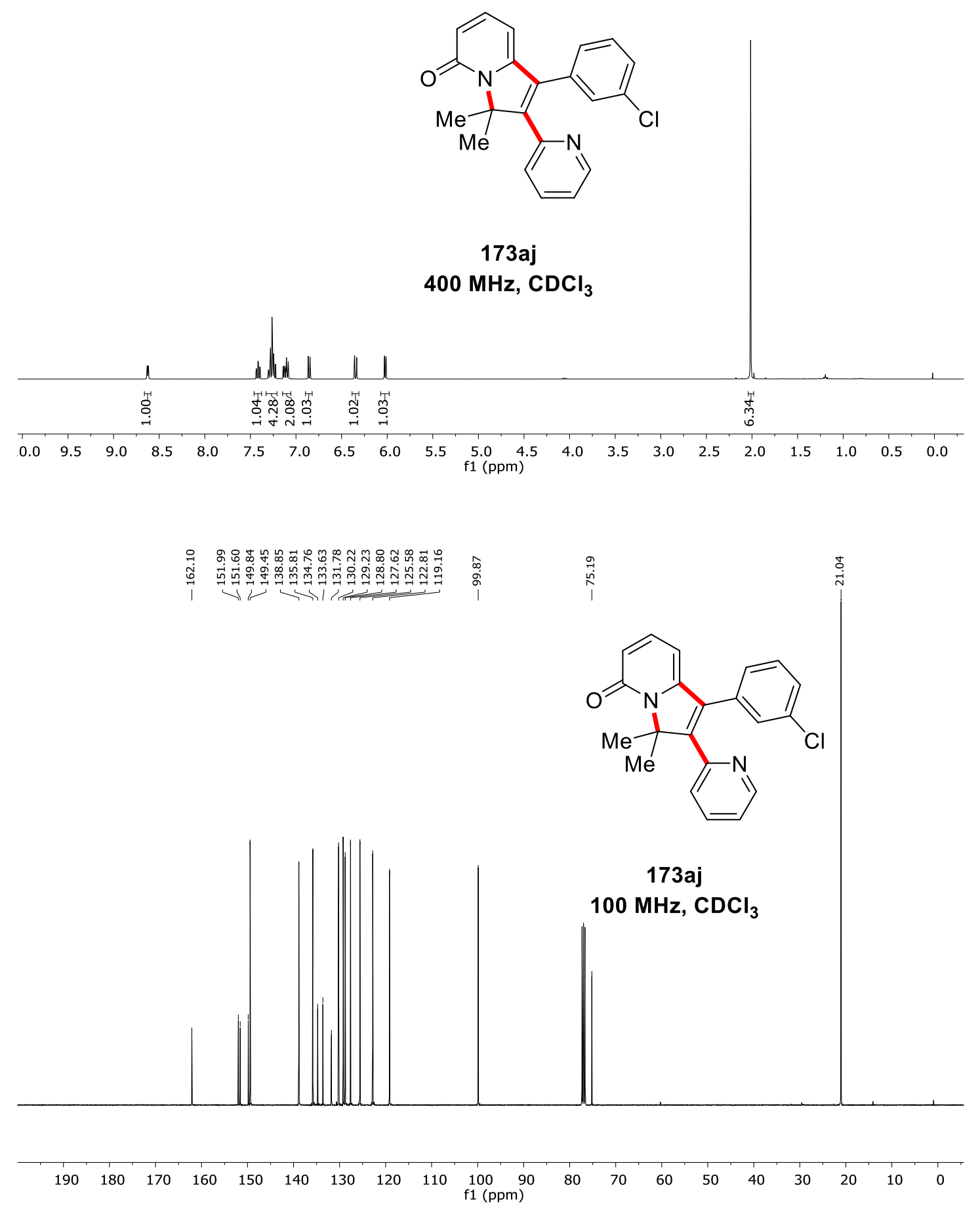


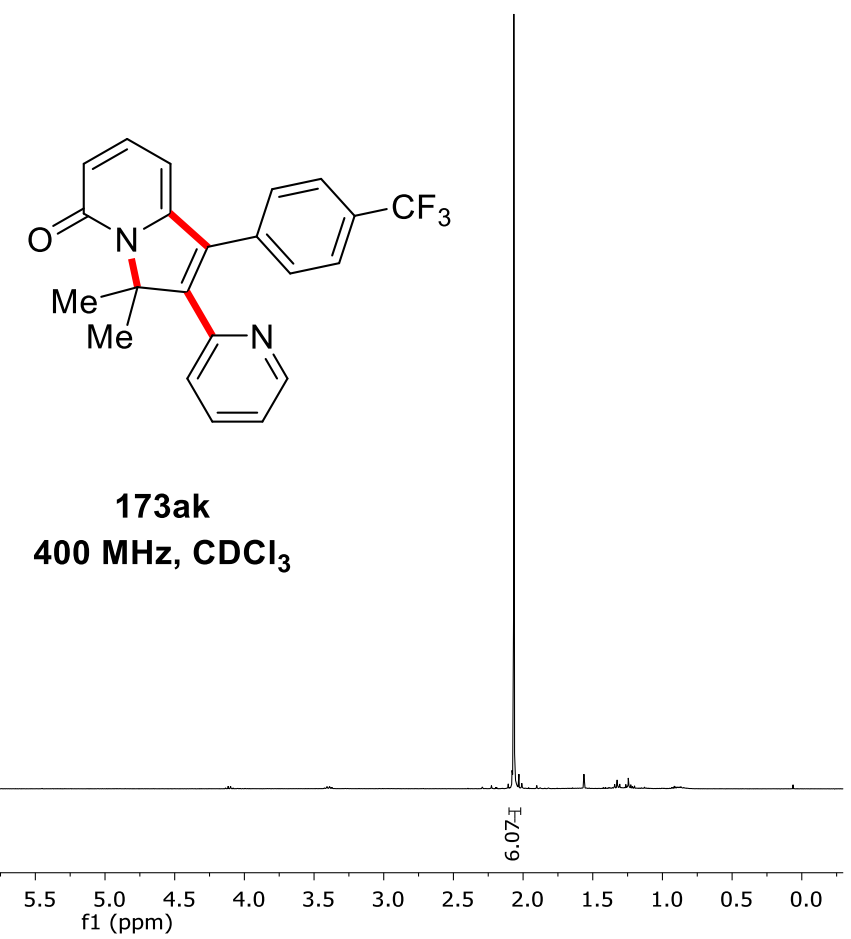

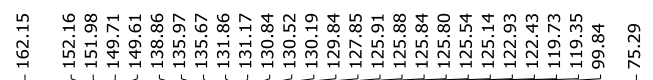
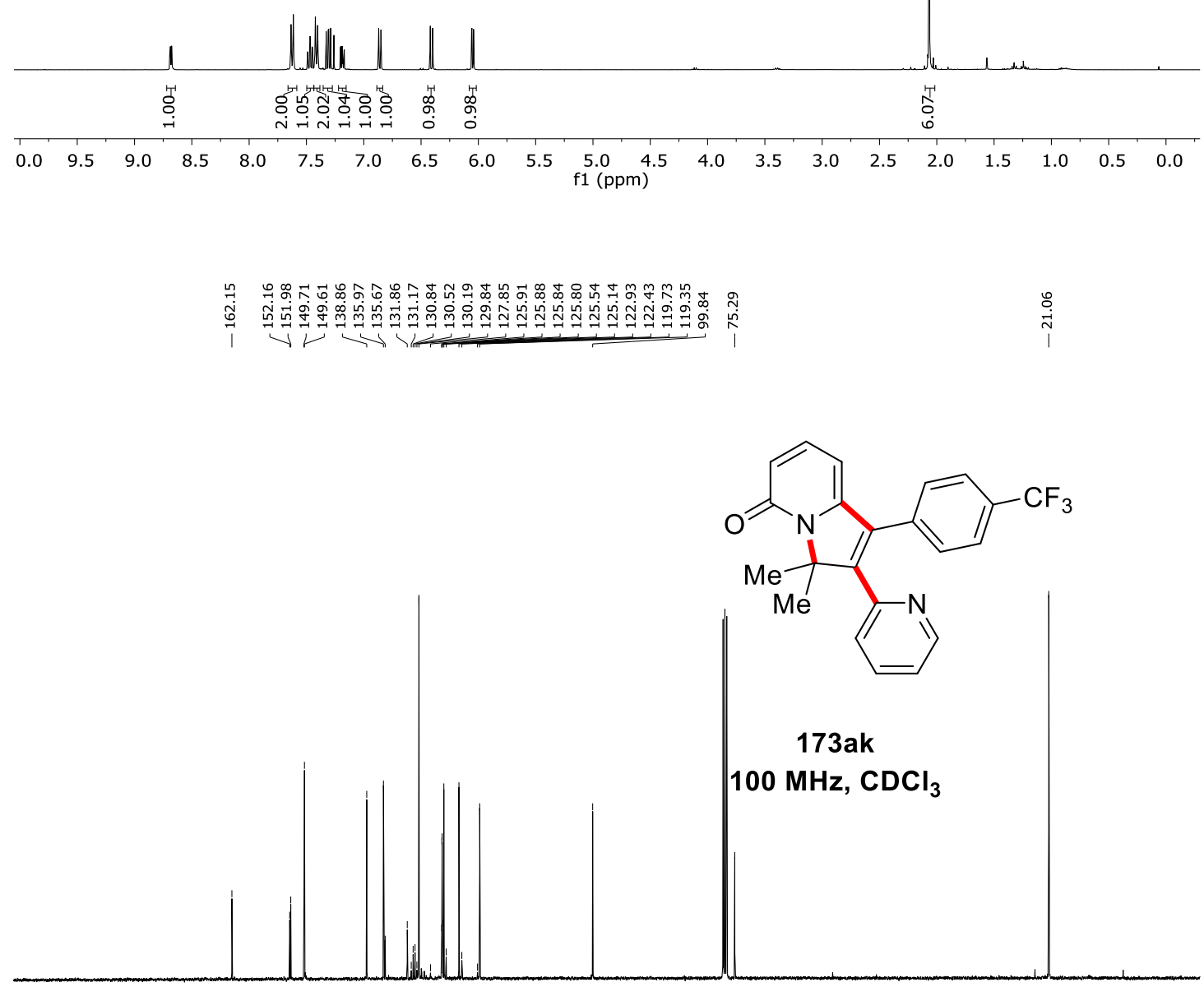

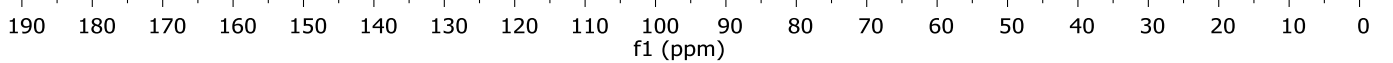



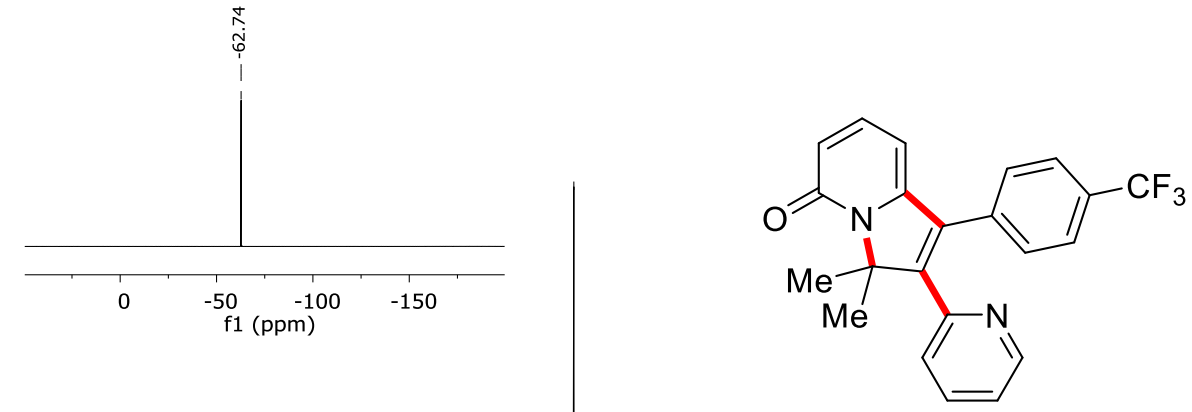

173ak

$375 \mathrm{MHz}^{\mathrm{CDCl}_{3}}$

$\begin{array}{llllllllllllllllllllllllllll}40 & 30 & 20 & 10 & 0 & -10 & -20 & -30 & -40 & -50 & -60 & -70 & -80 & -90 & -100 & -110 & -120 & -130 & -140 & -150 & -160 & -170 & -180 & -190\end{array}$ 


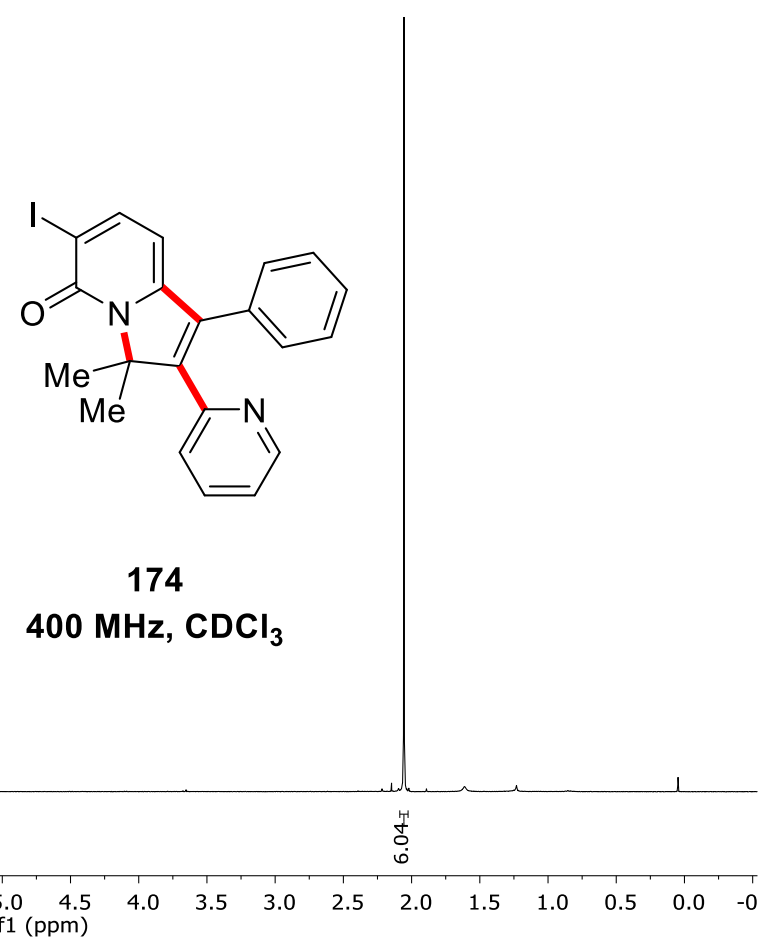

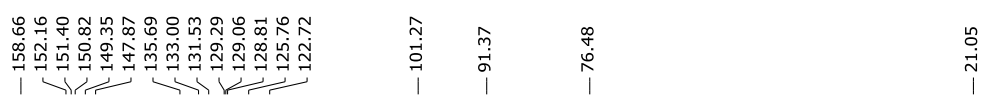

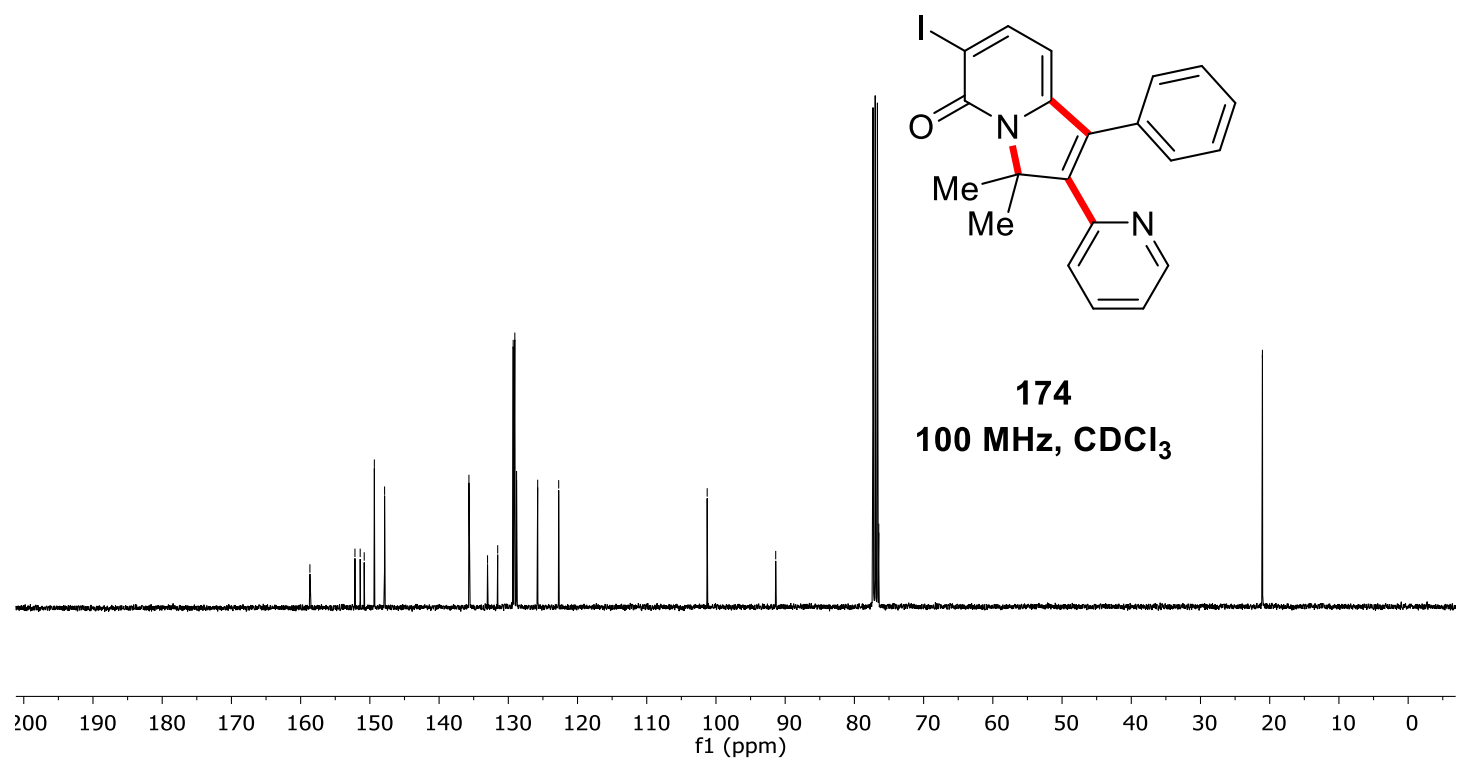




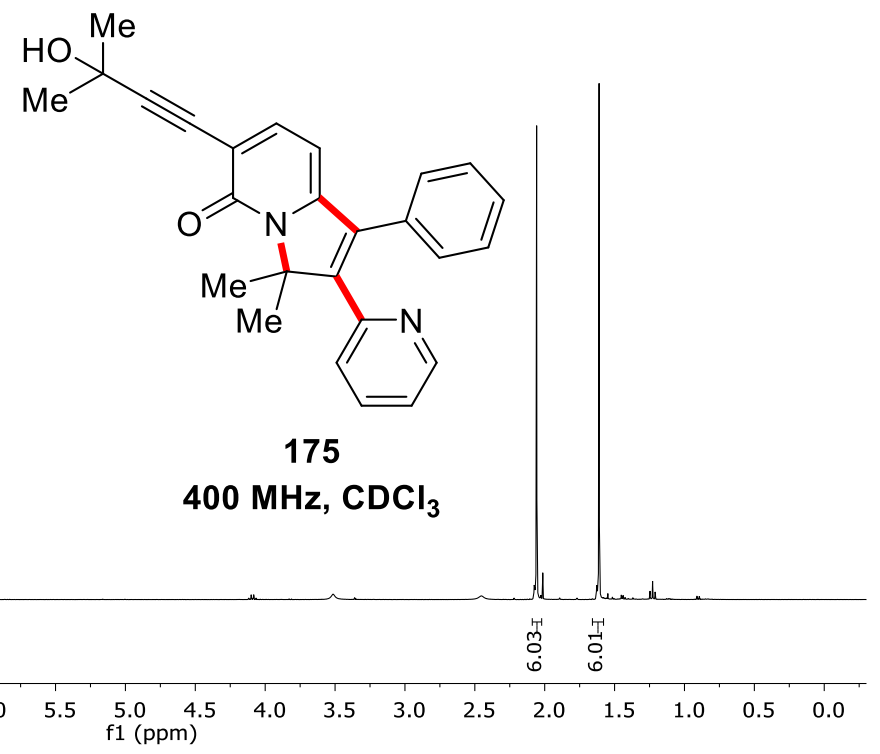

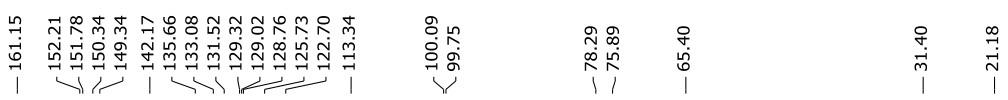

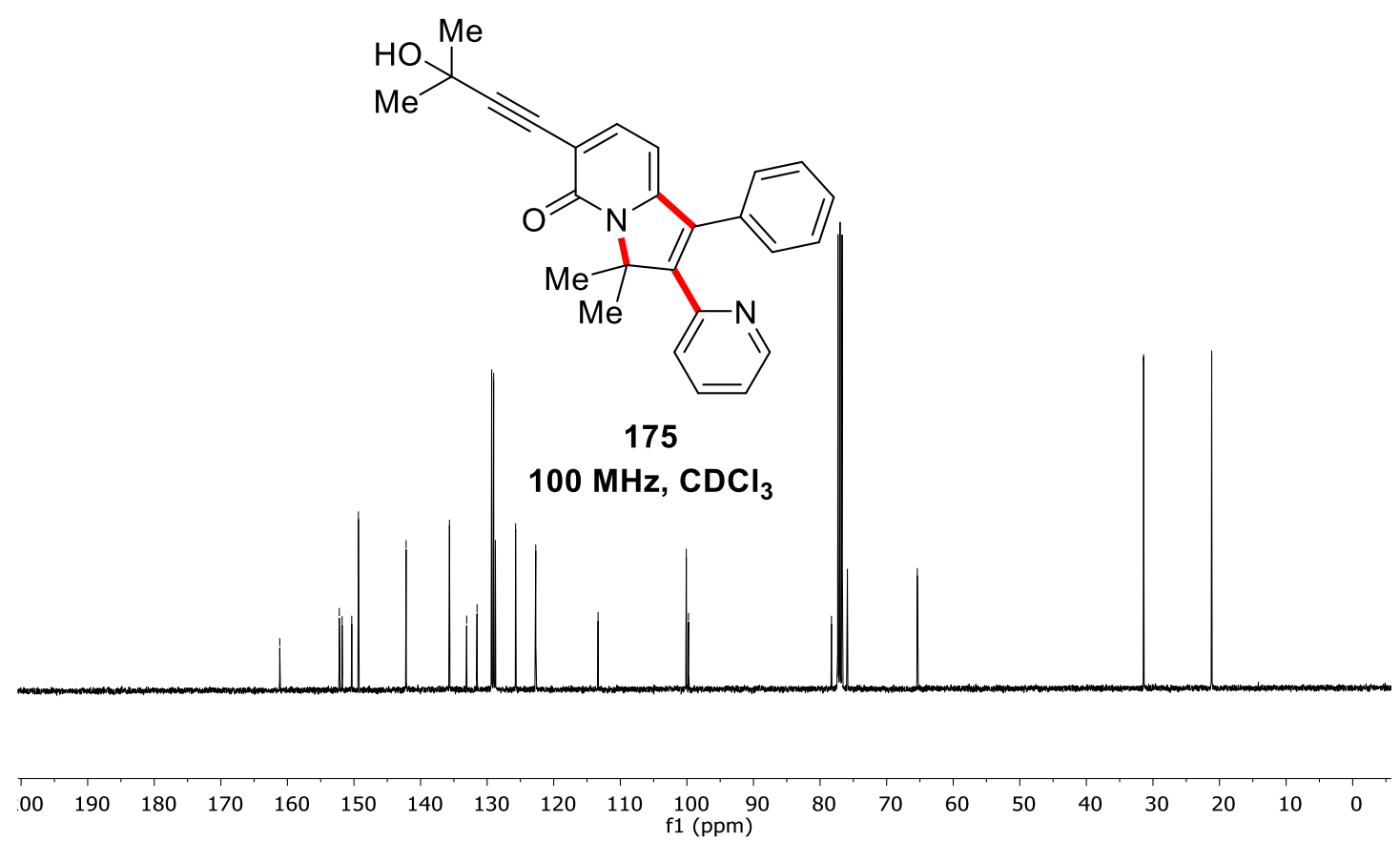



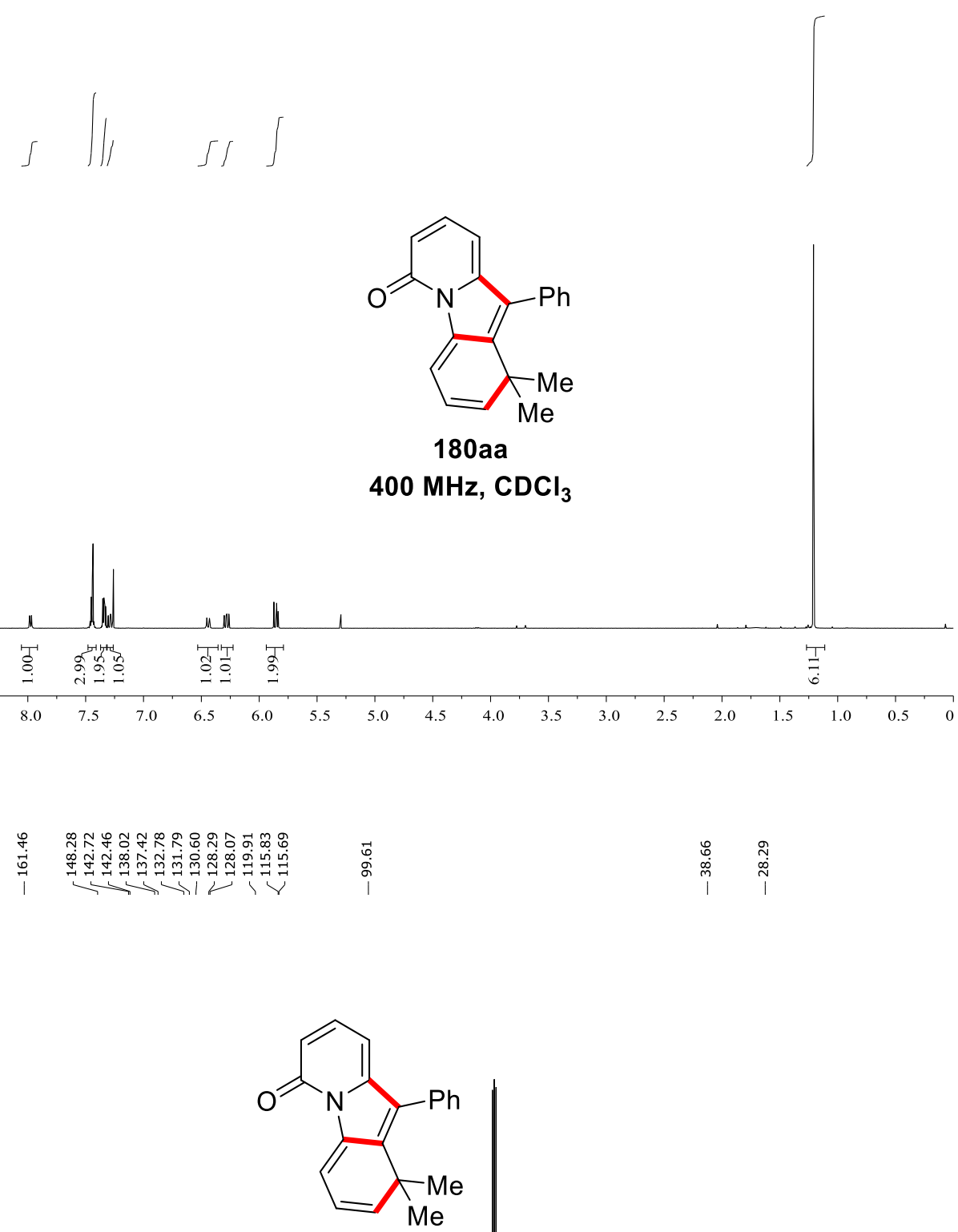

180aa $100 \mathrm{MHz}^{\mathrm{CDCl}_{3}}$

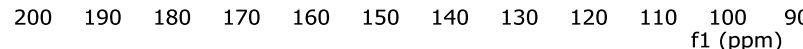



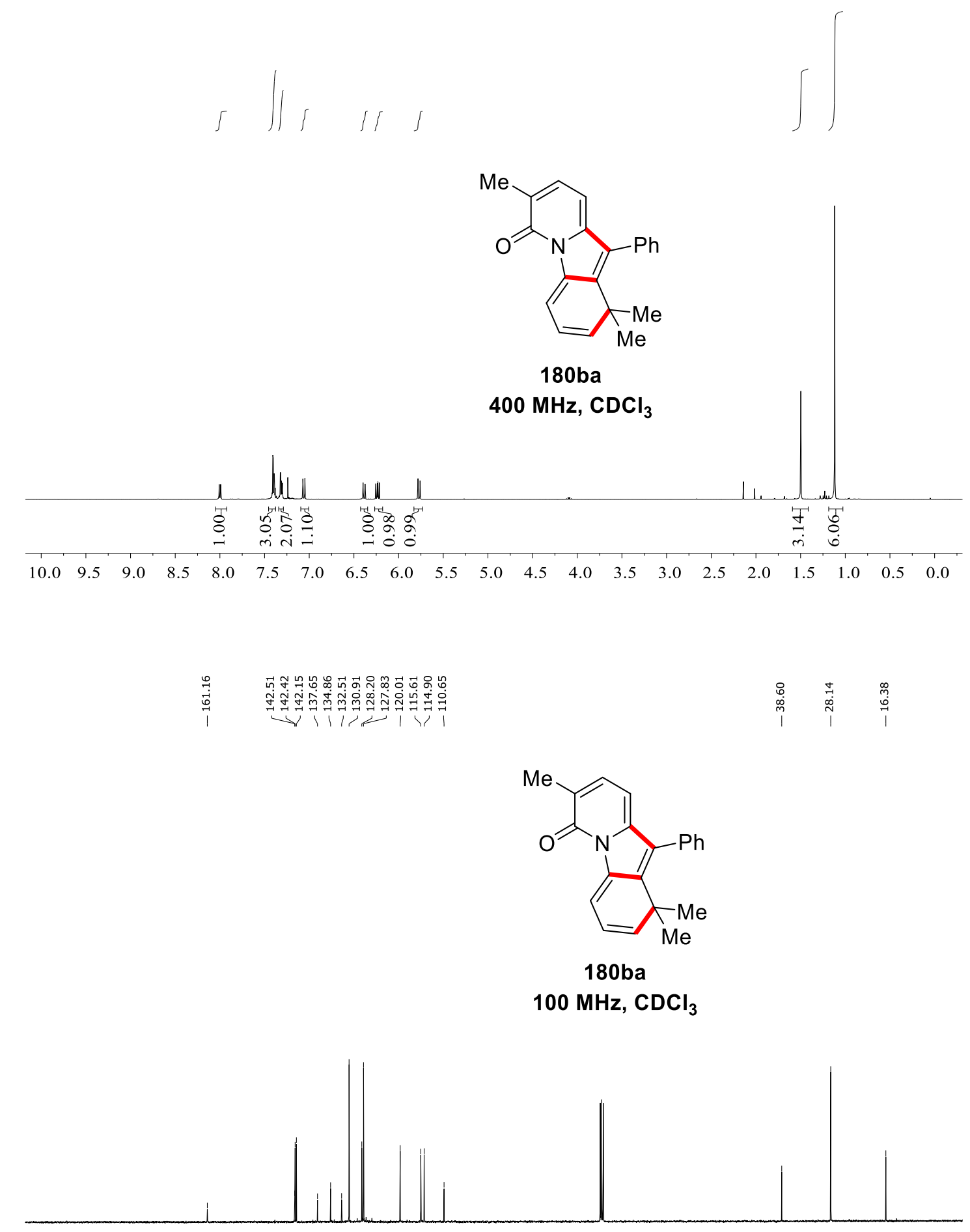

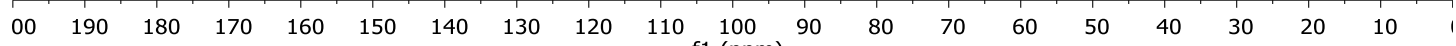



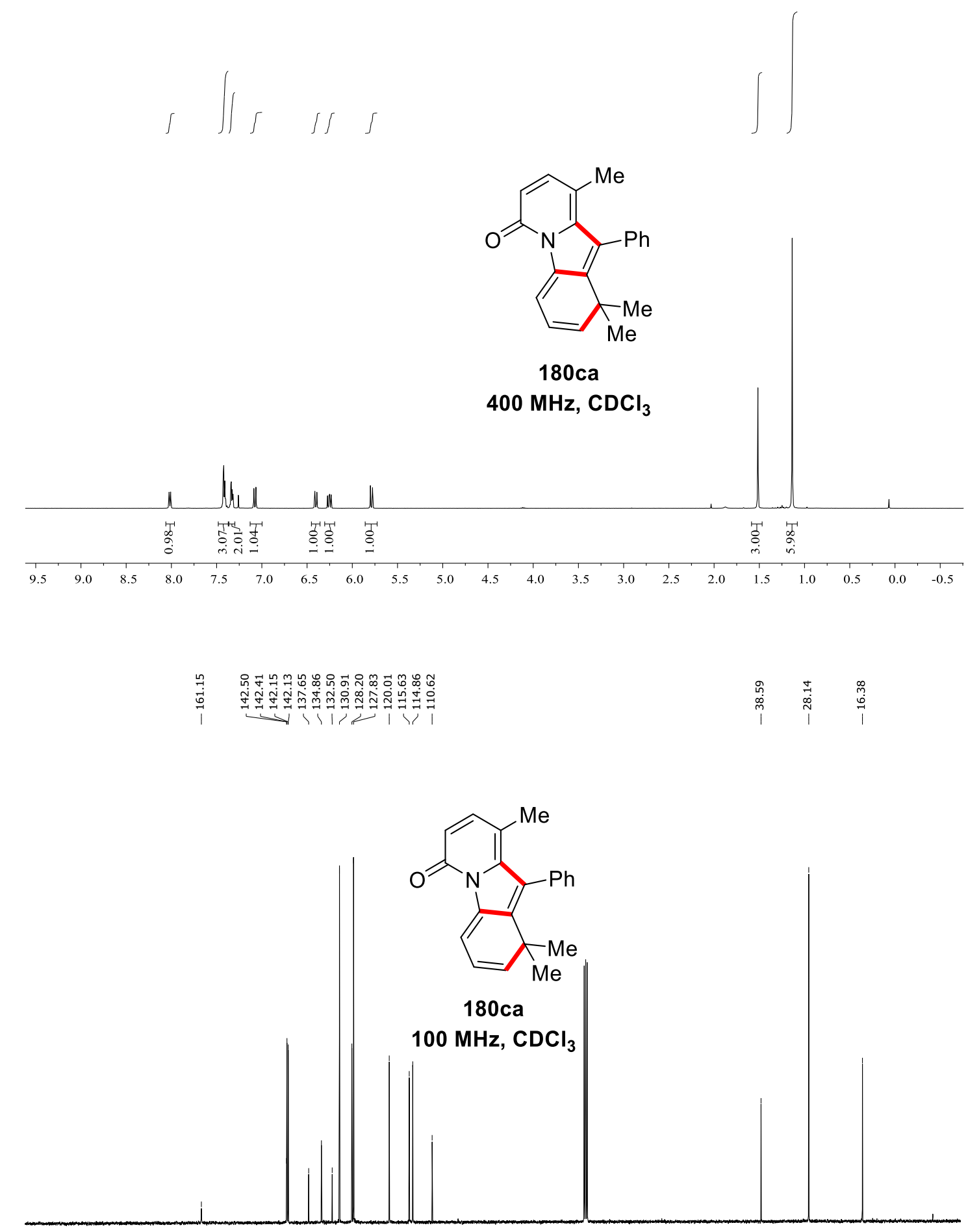

$\begin{array}{llllllllllllllllllll}190 & 180 & 170 & 160 & 150 & 140 & 130 & 120 & 110 & 100 & 90 & 80 & 70 & 60 & 50 & 40 & 30 & 20 & 10 & 0\end{array}$ 

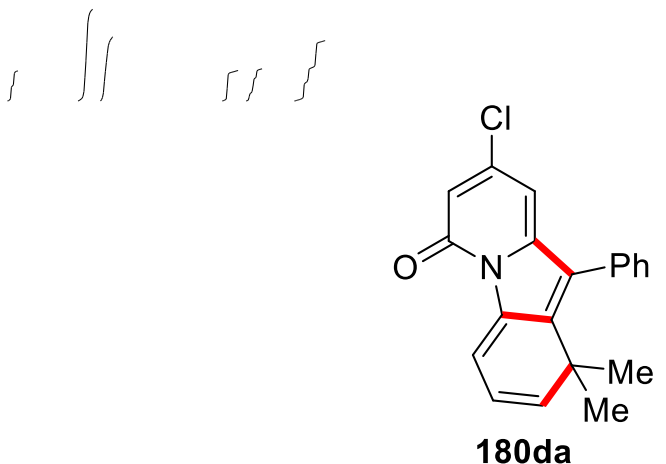

$300 \mathrm{MHz}, \mathrm{CDCl}_{3}$

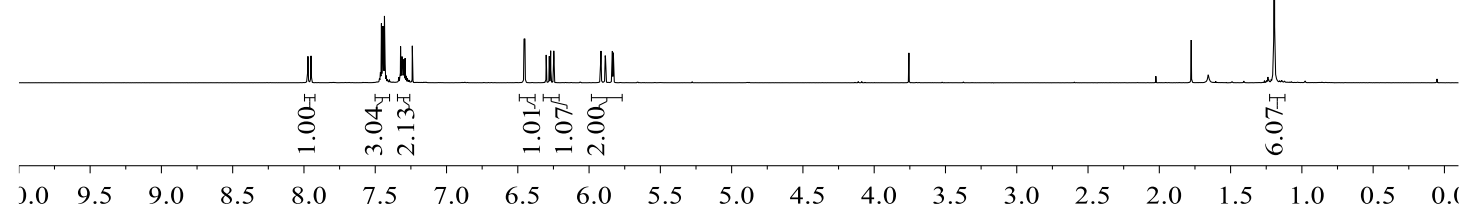

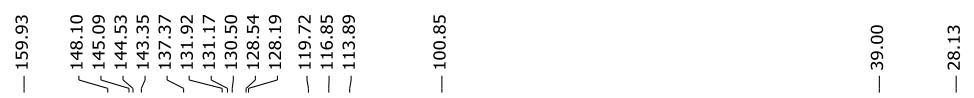

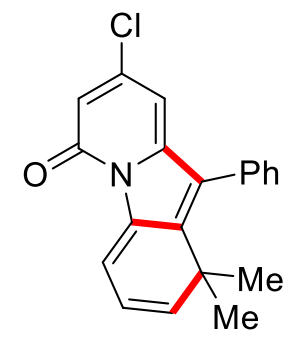

180da

$125 \mathrm{MHz}^{\mathrm{CDCl}_{3}}$

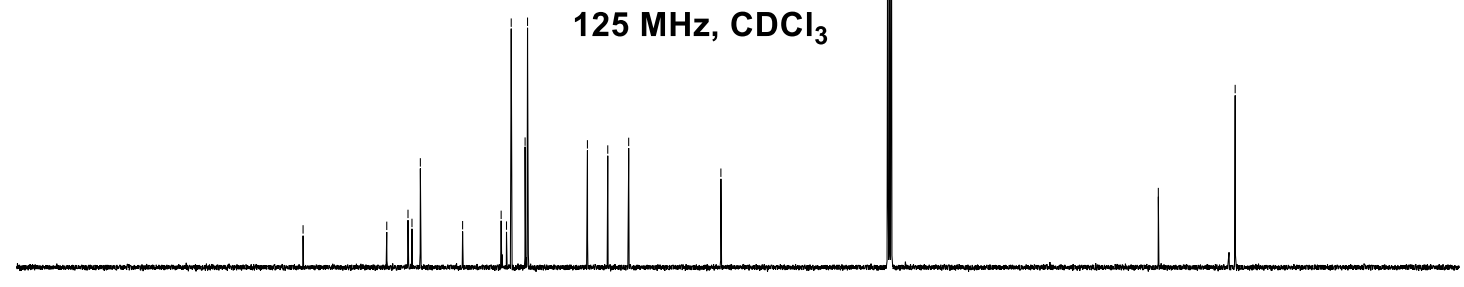

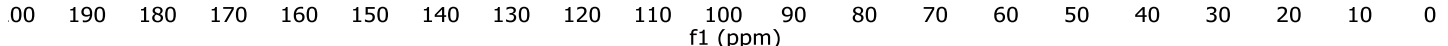




$$
\iiint \iint
$$

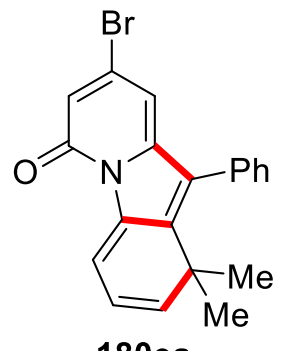

180ea

$300 \mathrm{MHz}, \mathrm{CDCl}_{3}$

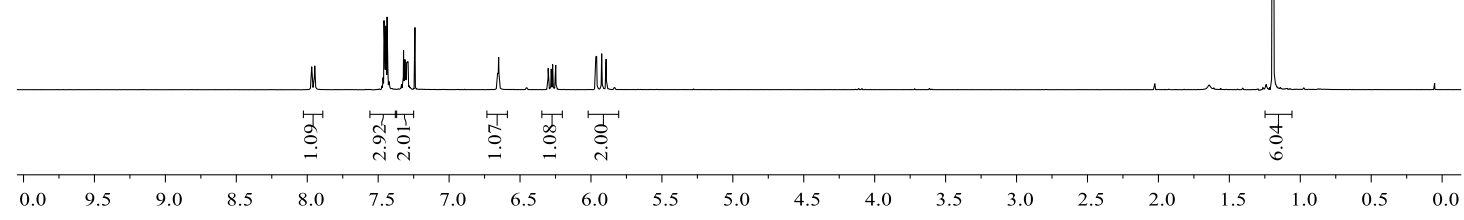

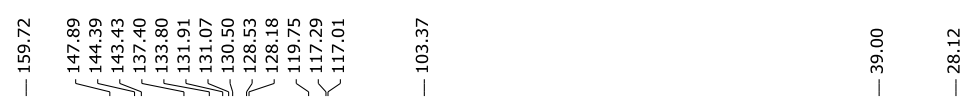

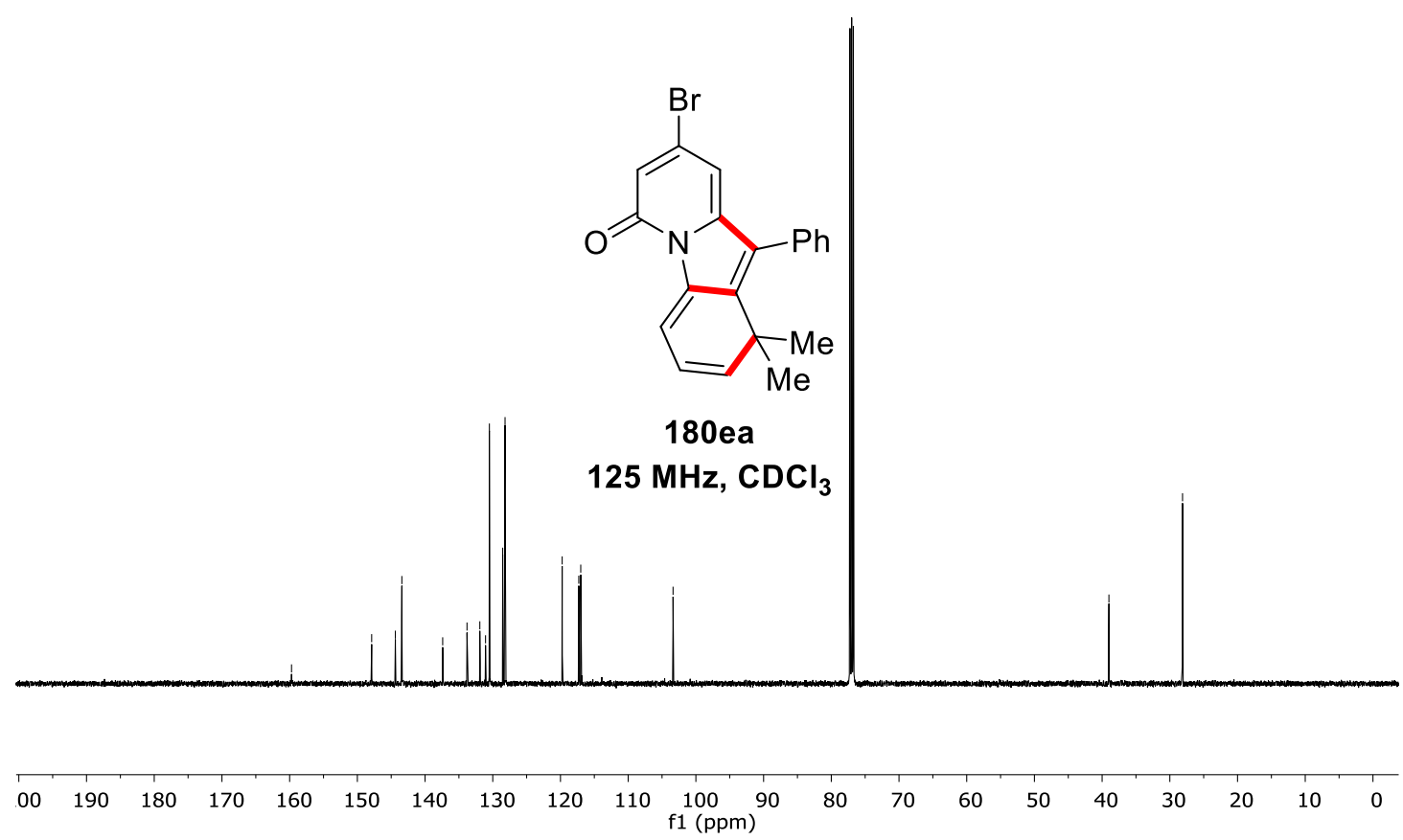



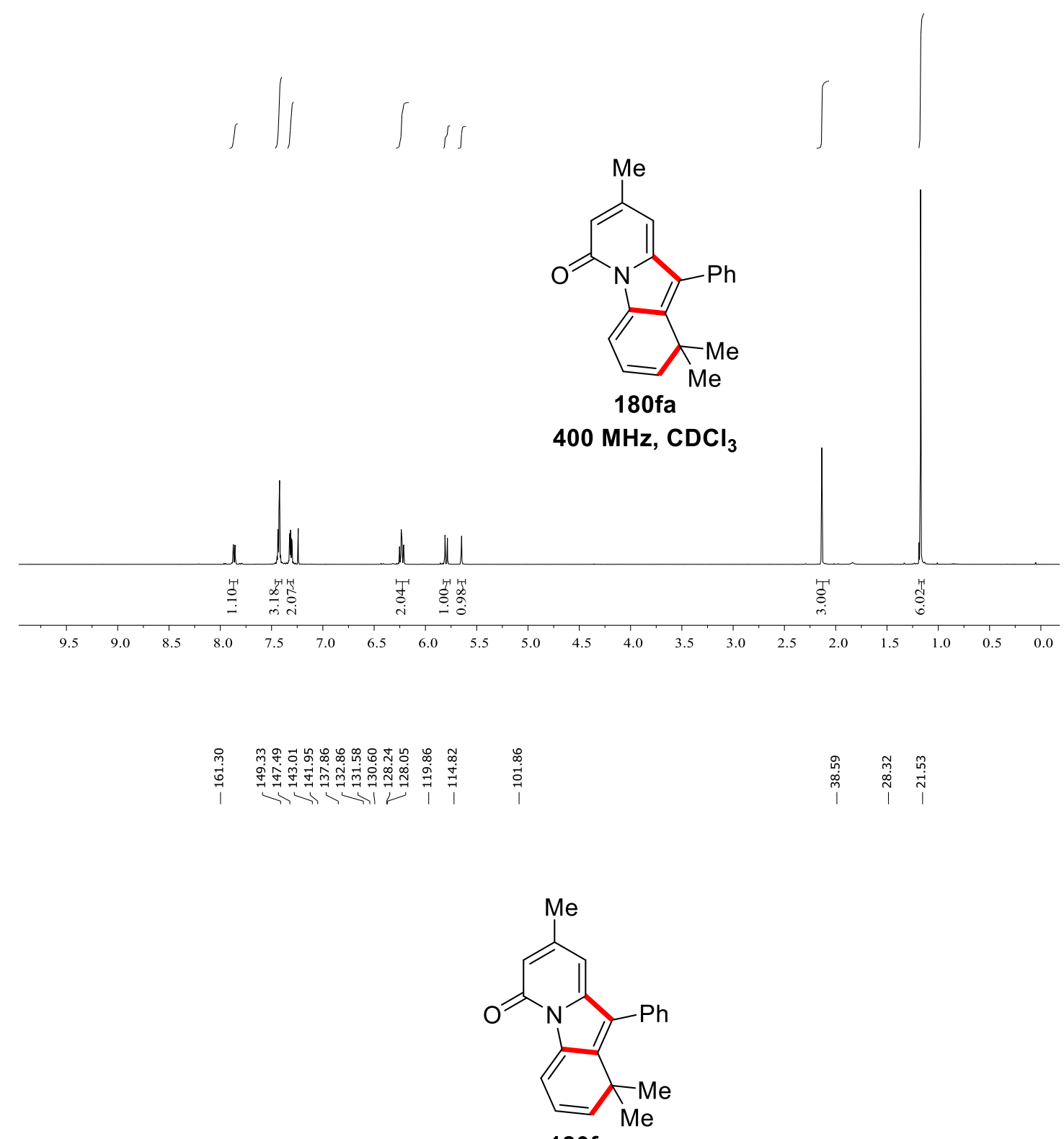

$180 \mathrm{fa}$

$100 \mathrm{MHz}^{\mathrm{CDCl}_{3}}$

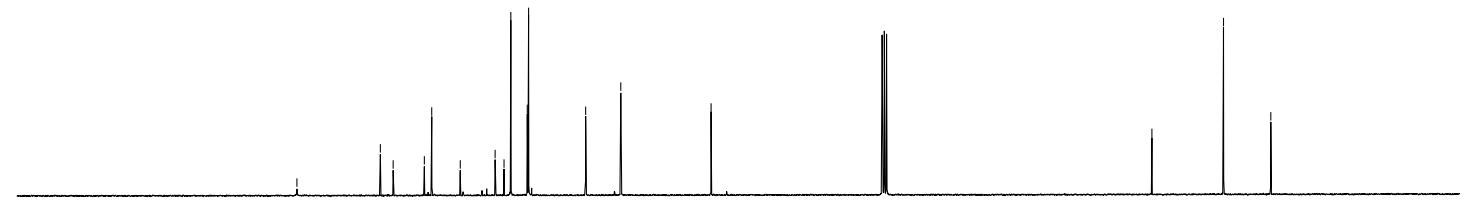

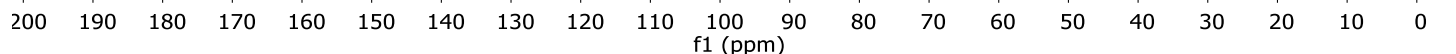


$\int \quad \int d \| \operatorname{sic}$

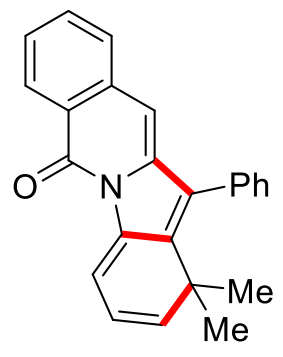

$180 \mathrm{ga}$

$400 \mathrm{MHz}, \mathrm{CDCl}_{3}$

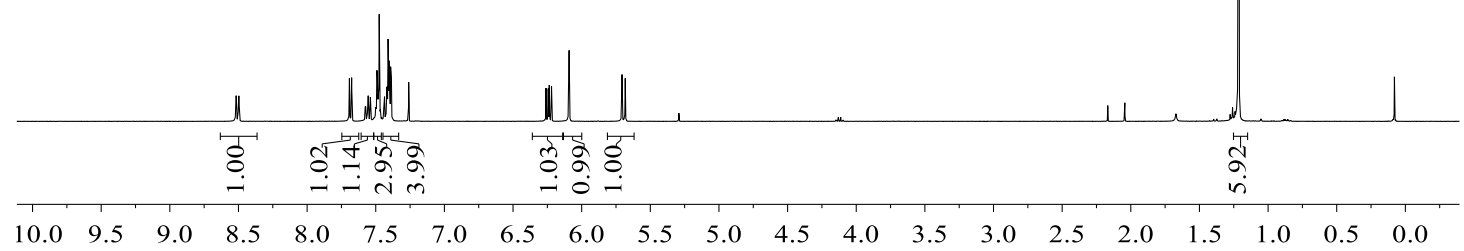

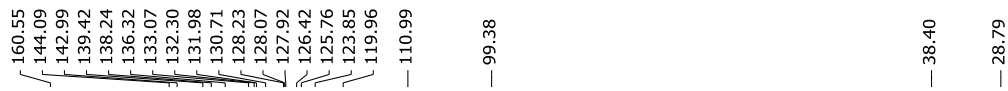

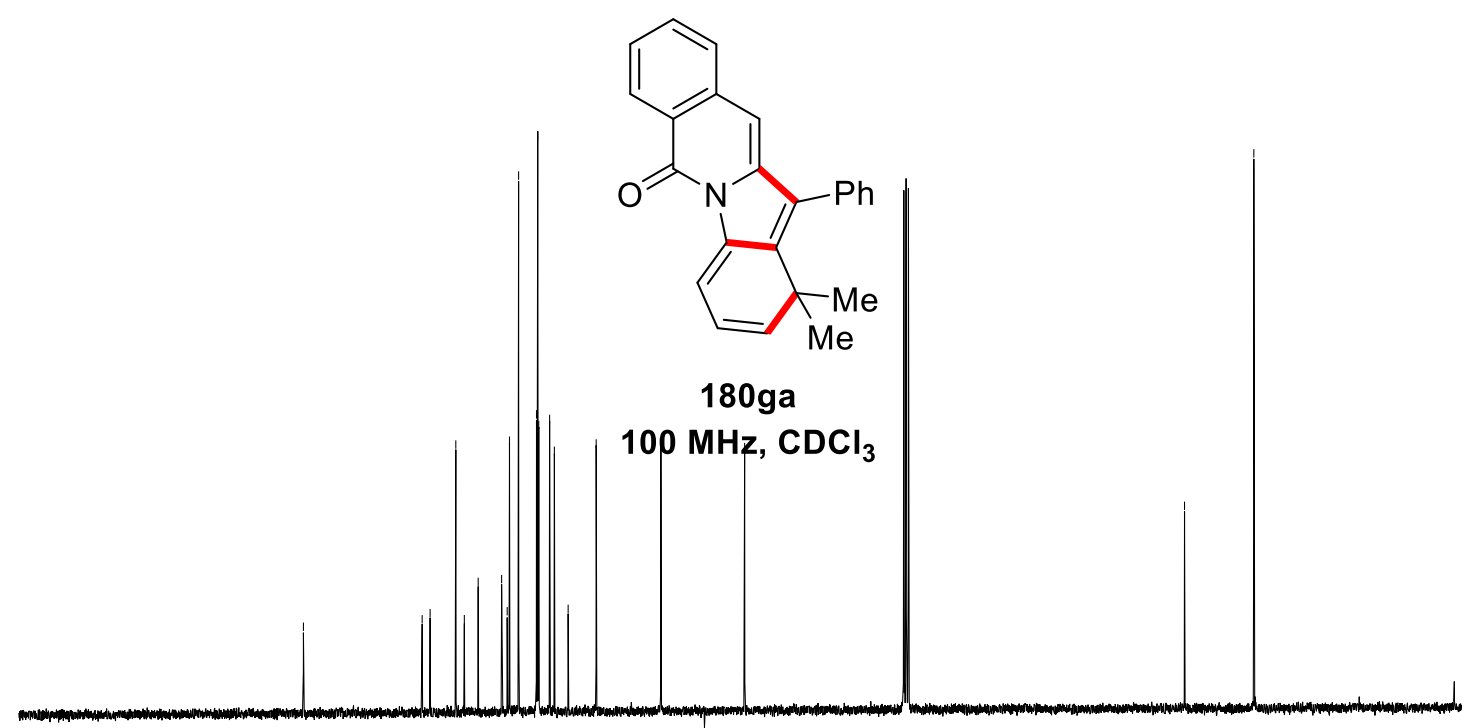

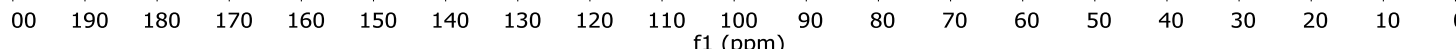




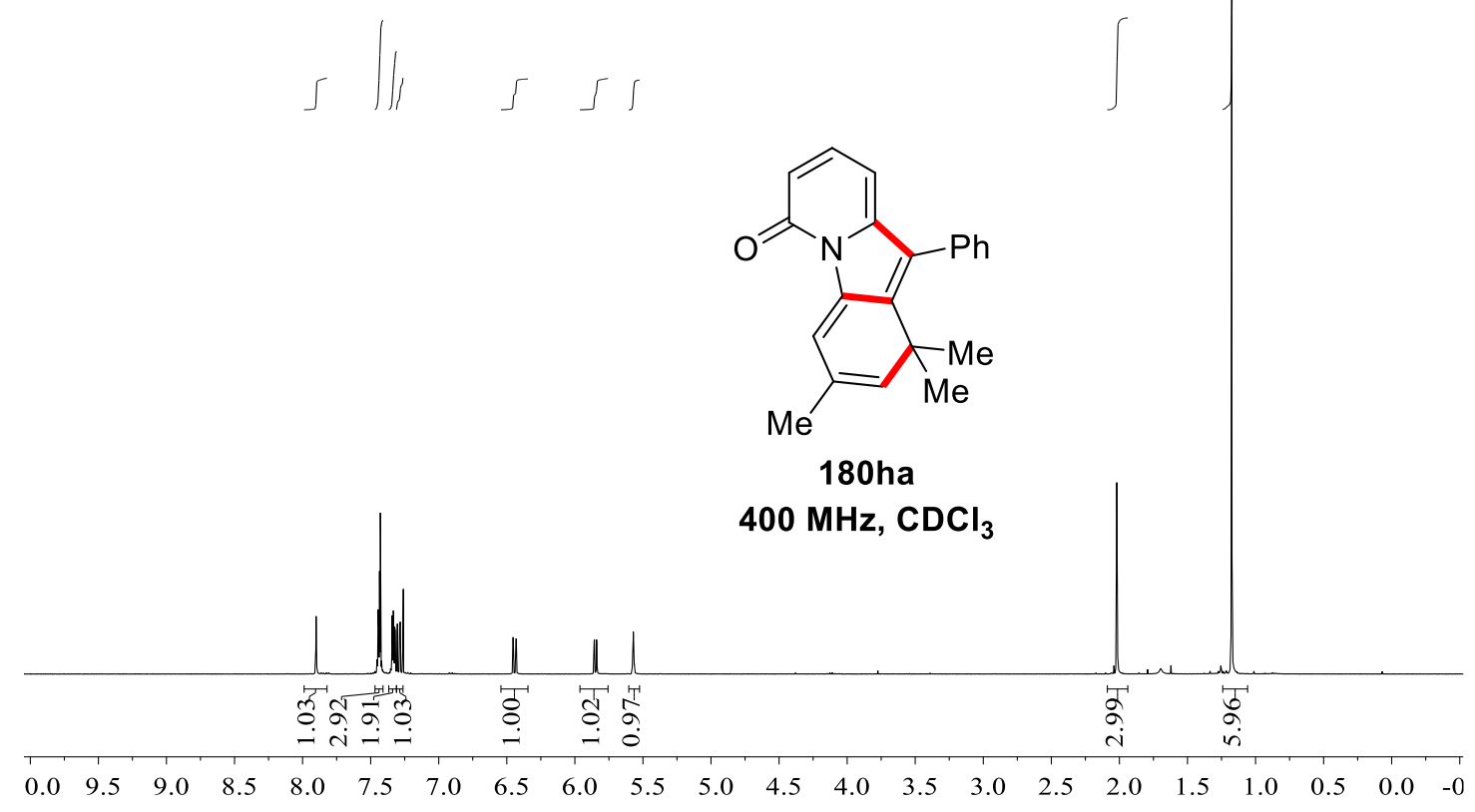

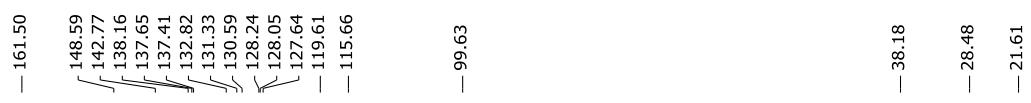

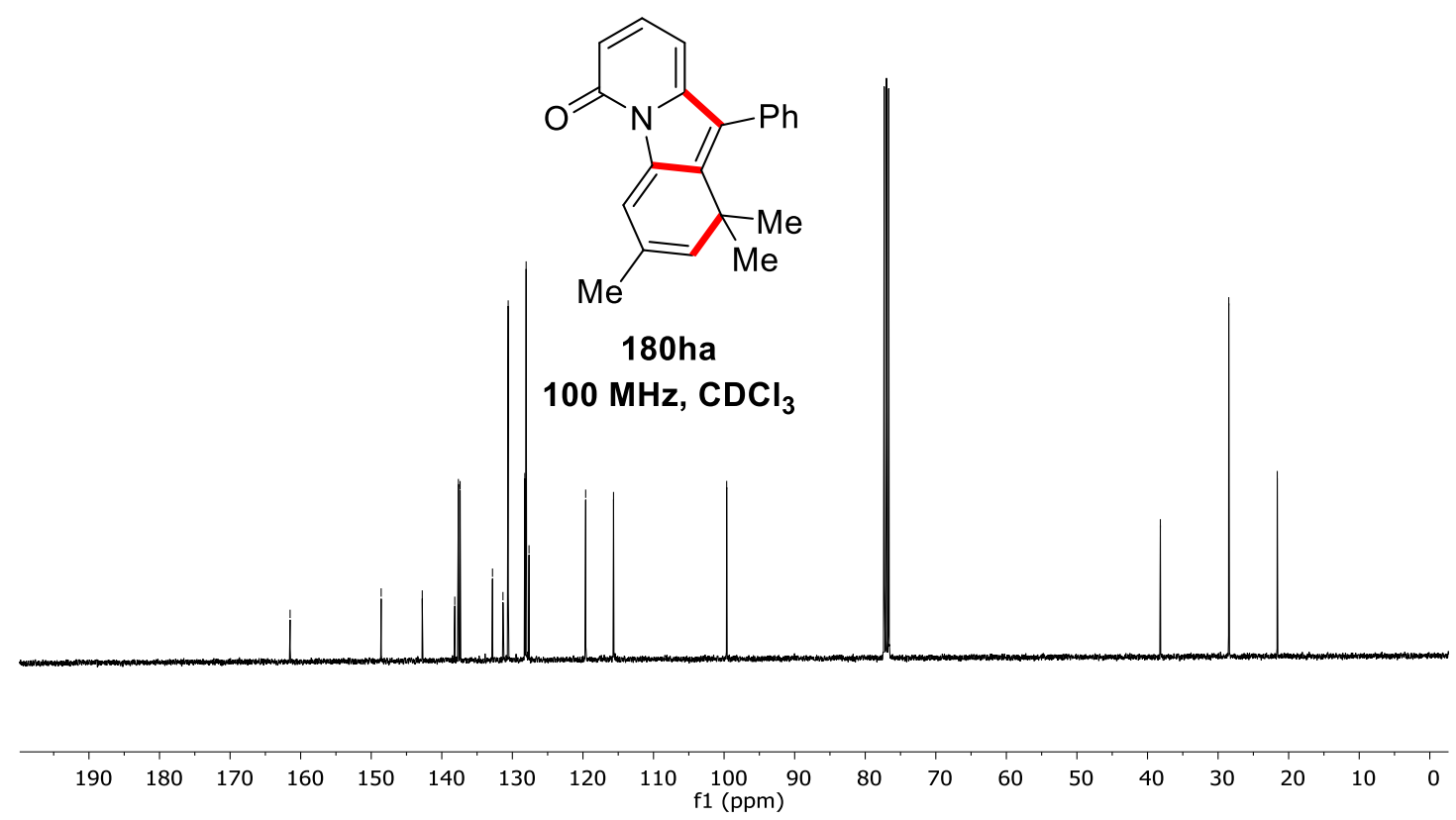



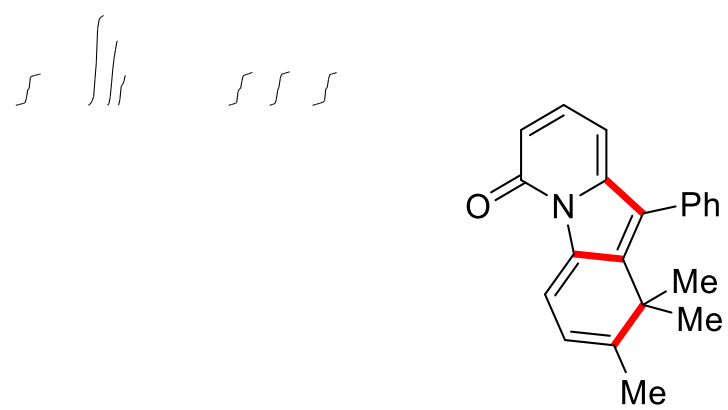

$\int$

180ia

$400 \mathrm{MHz}, \mathrm{CDCl}_{3}$

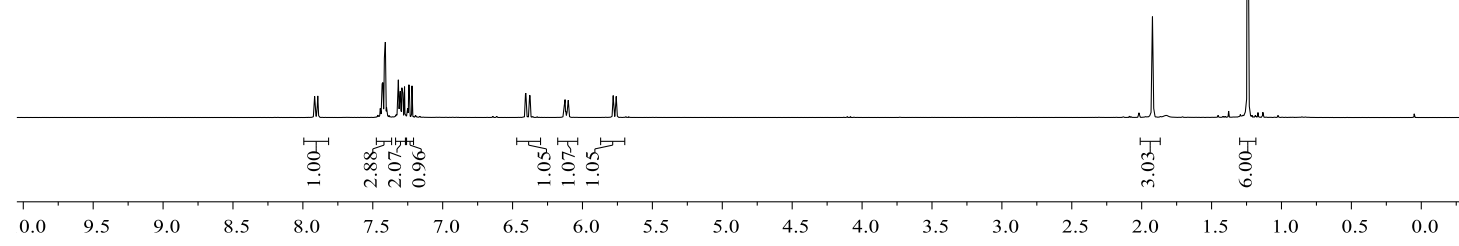

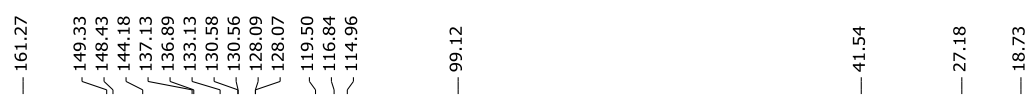

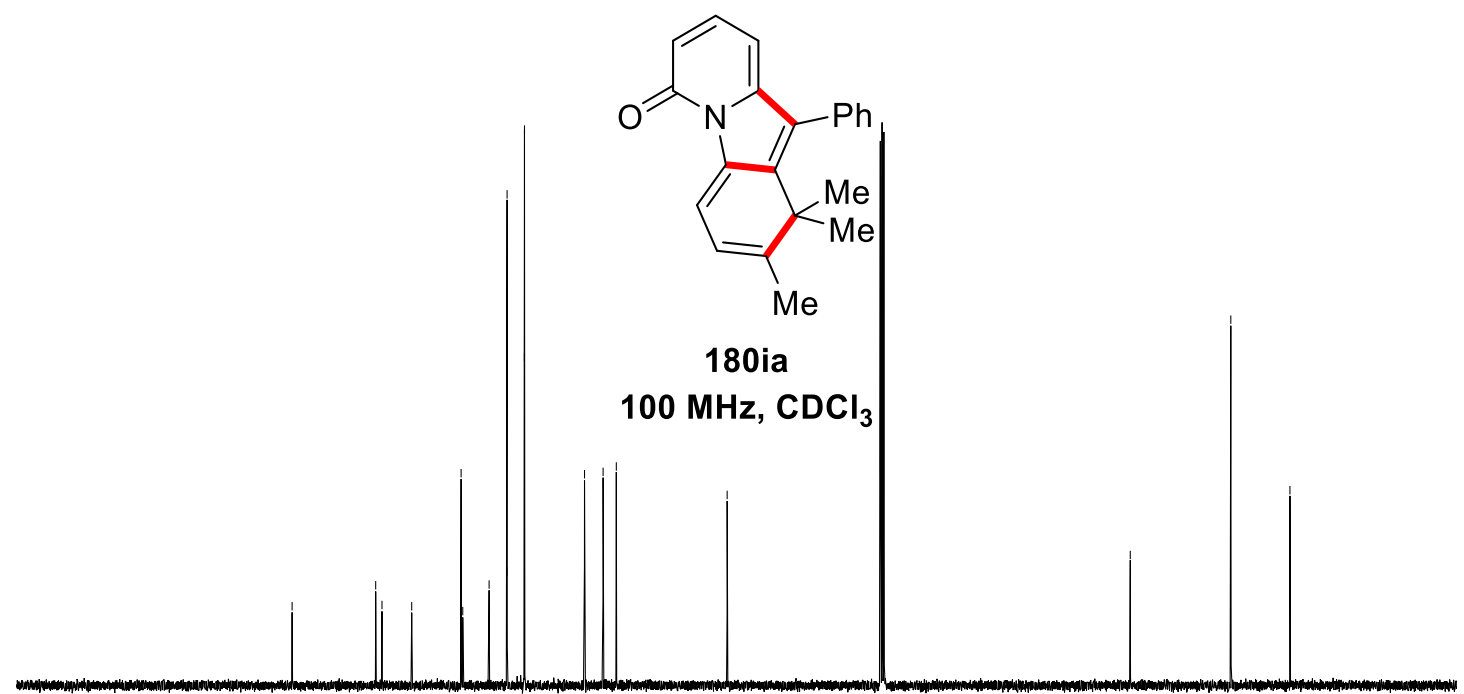

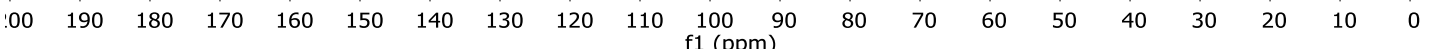




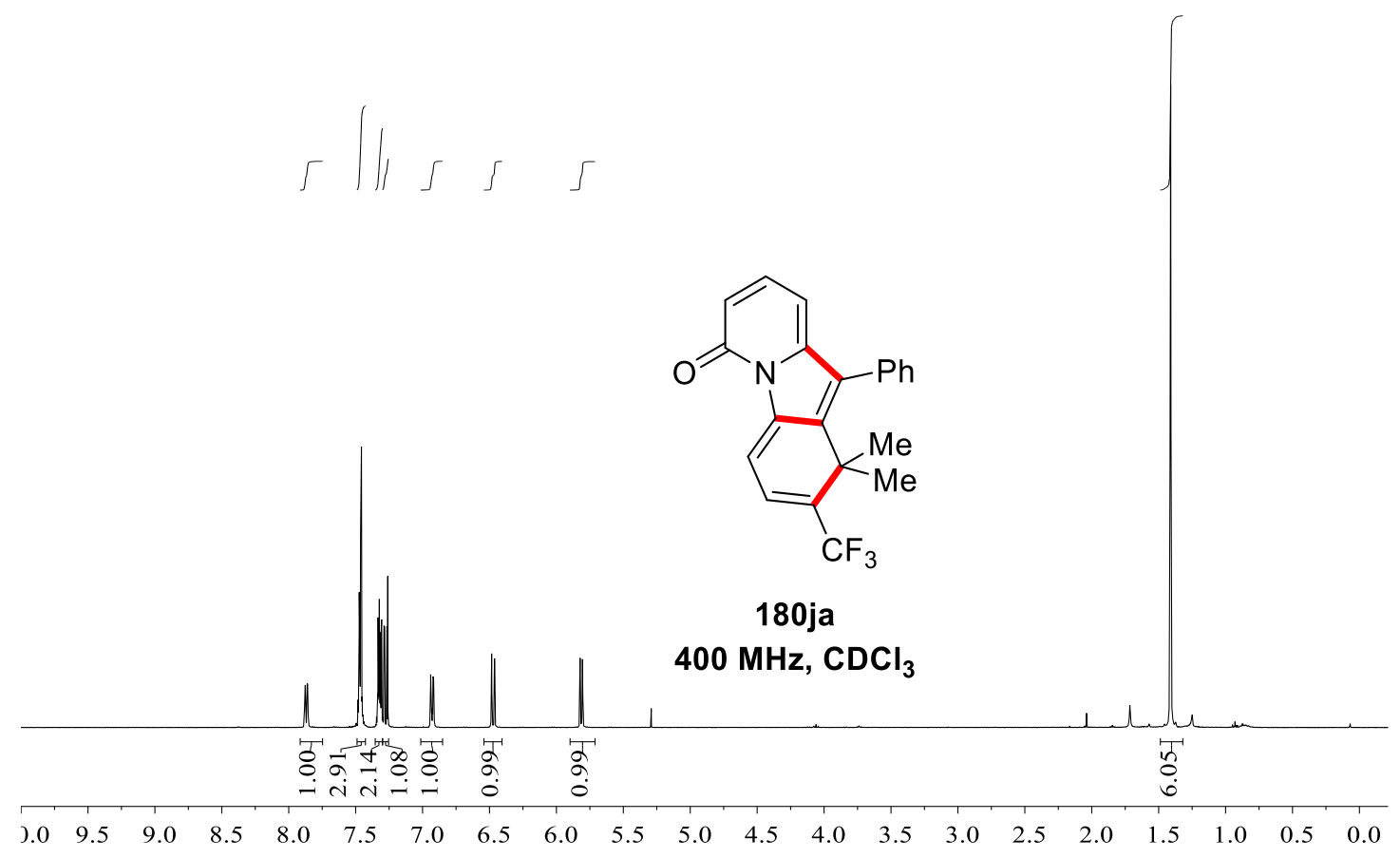

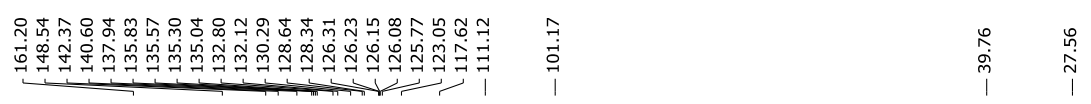

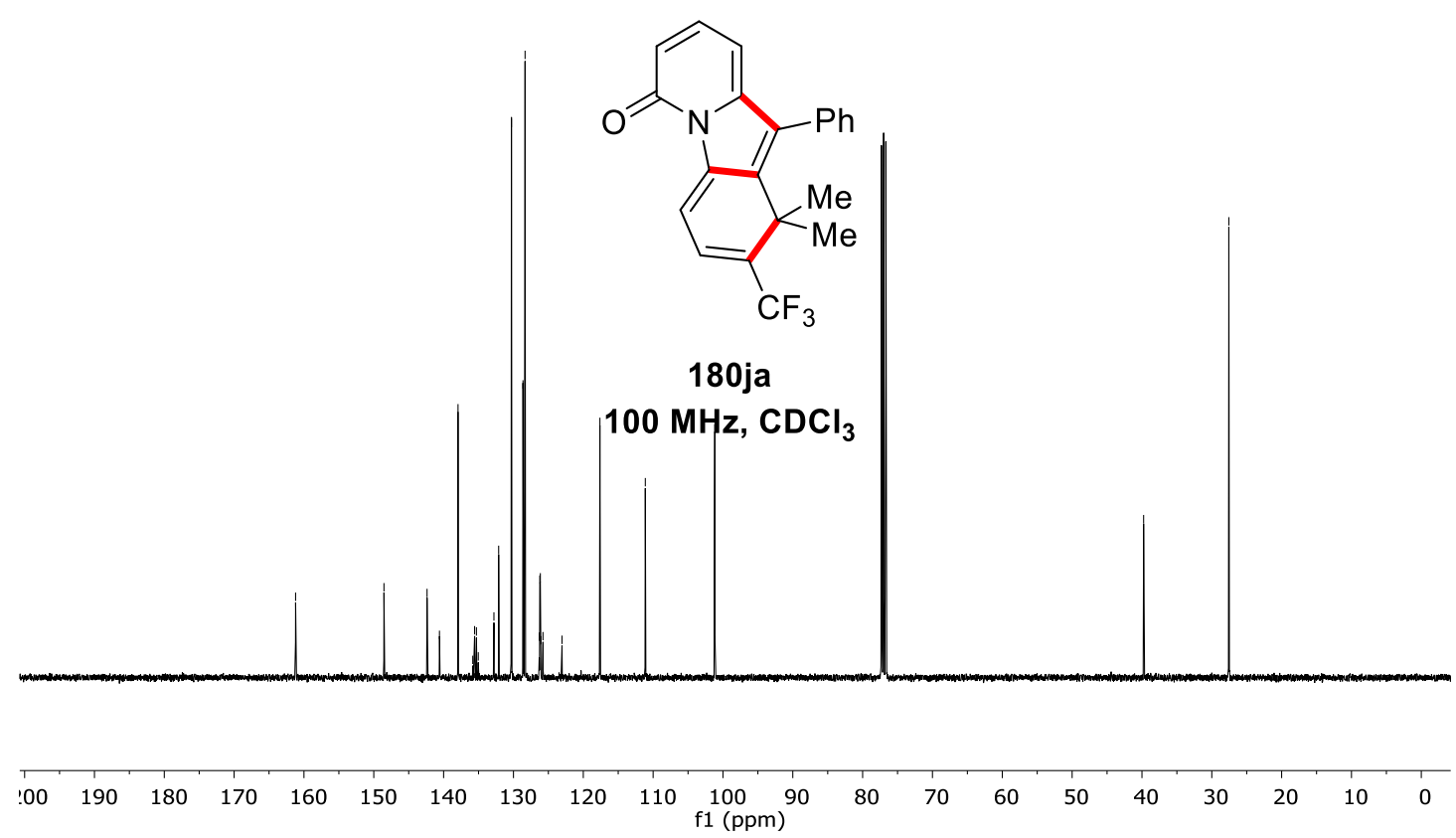


0
$\infty$
$\infty$
$n$
$i$
1

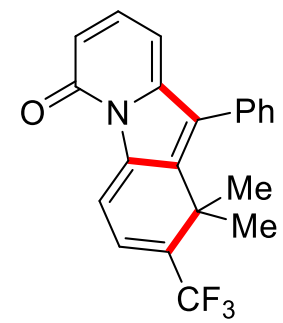

$180 \mathrm{ja}$

$375 \mathrm{MHz}, \mathrm{CDCl}_{3}$

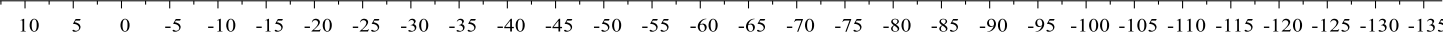




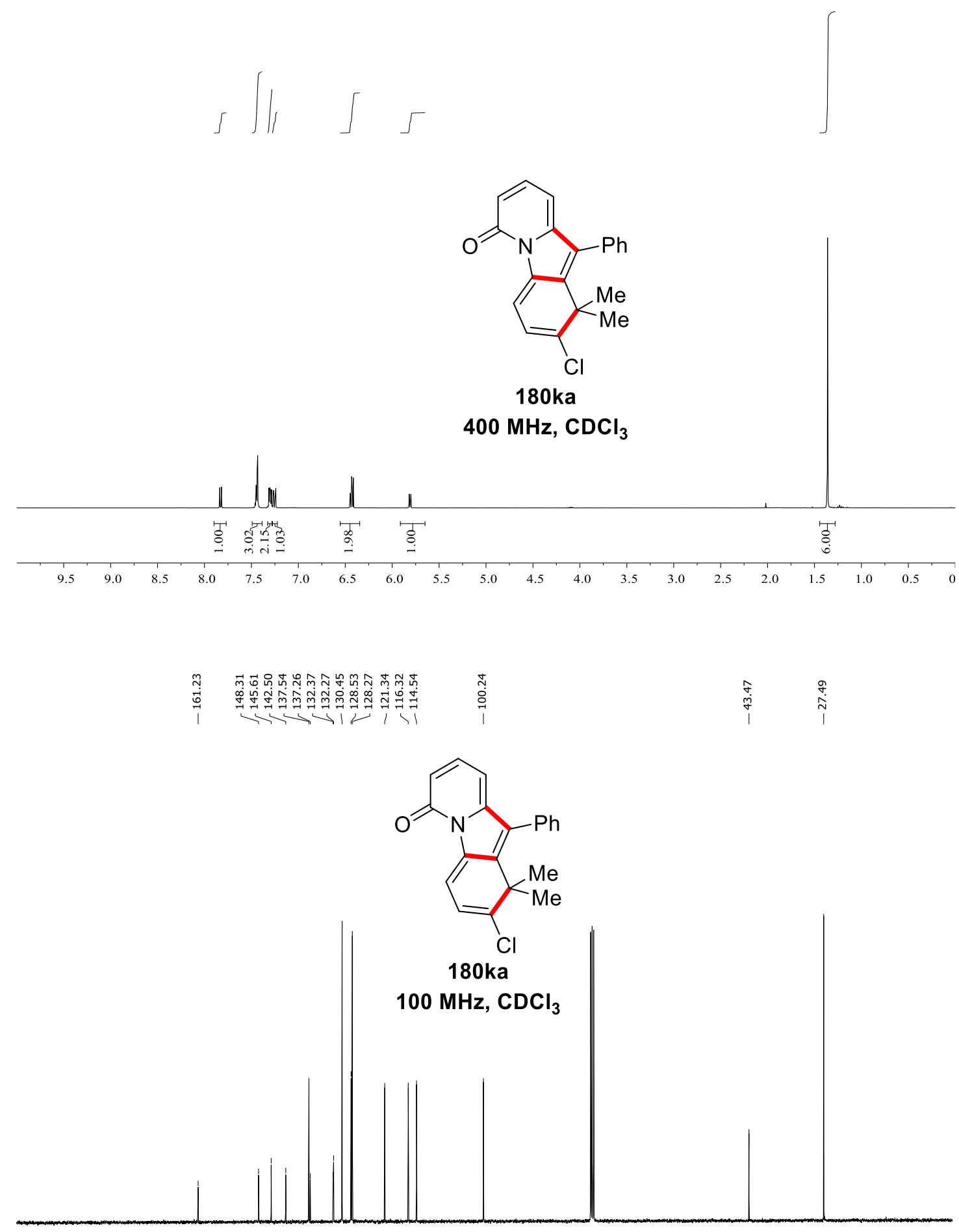

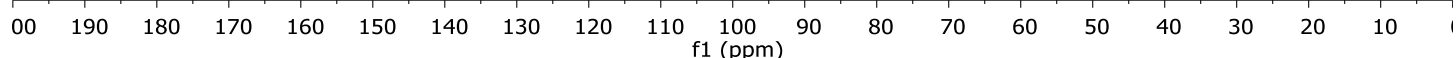



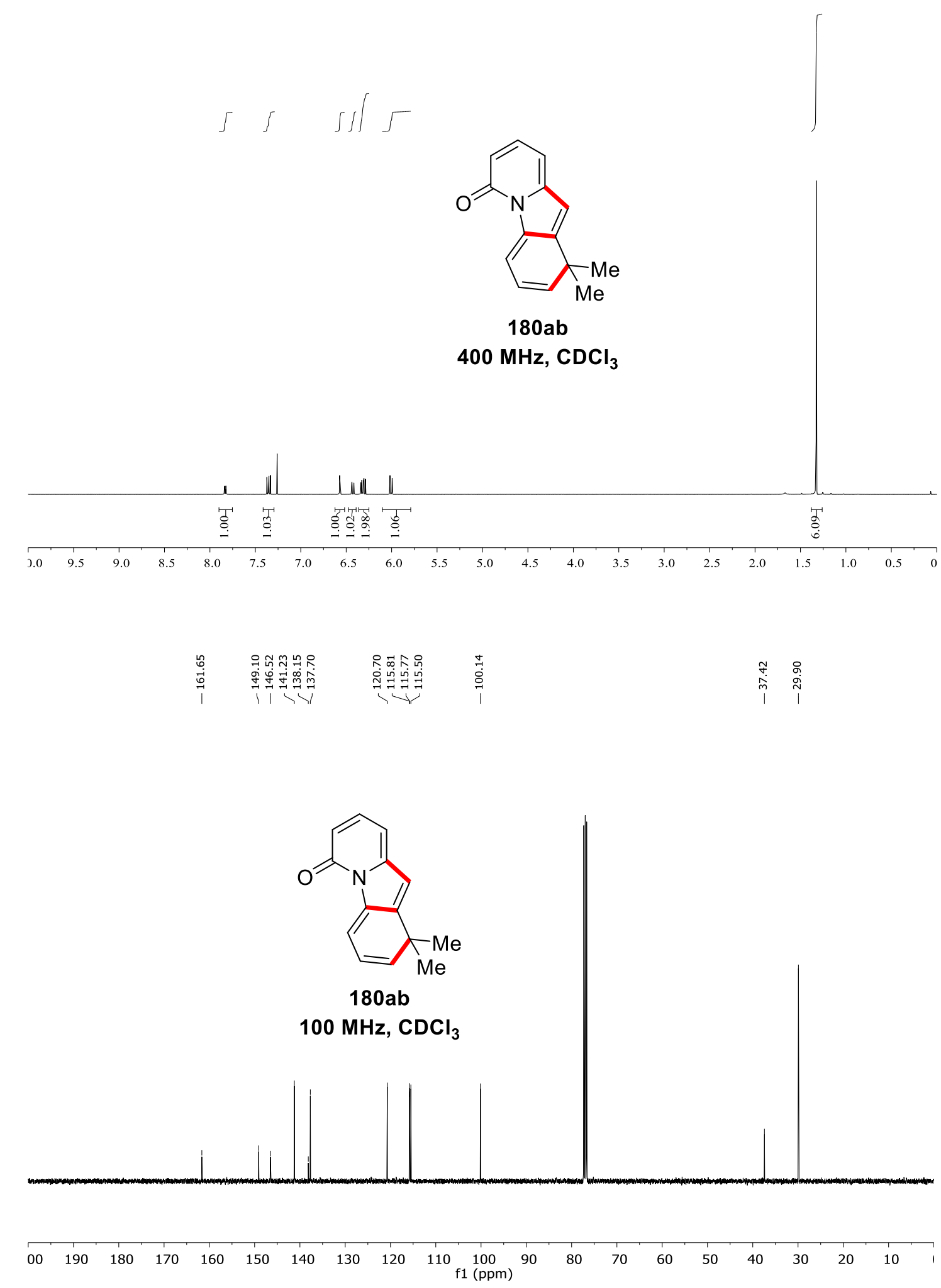


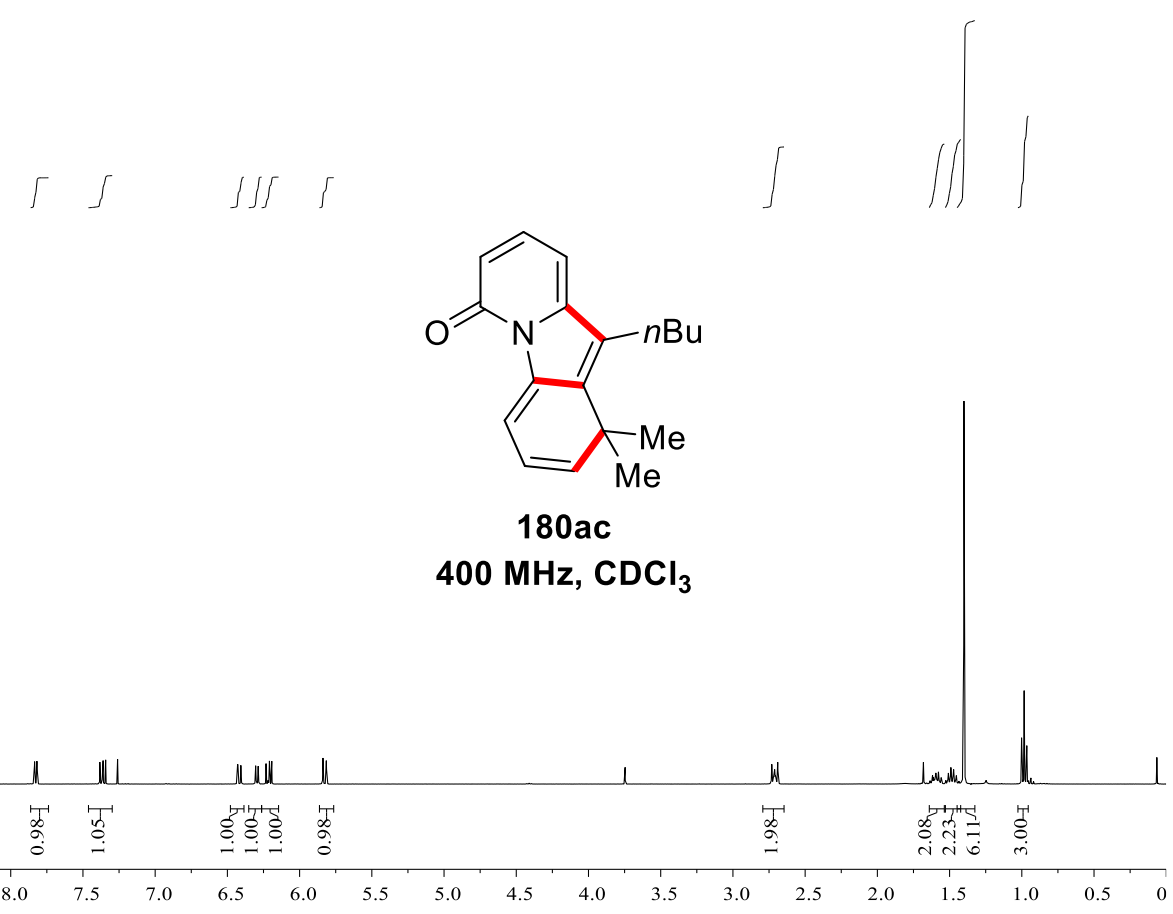

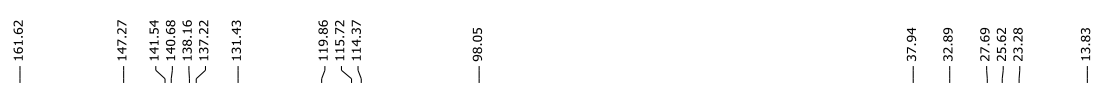

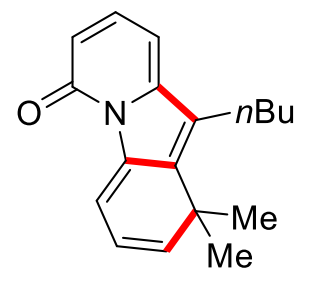

$180 \mathrm{ac}$

$100 \mathrm{MHz}, \mathrm{CDCl}_{3}$

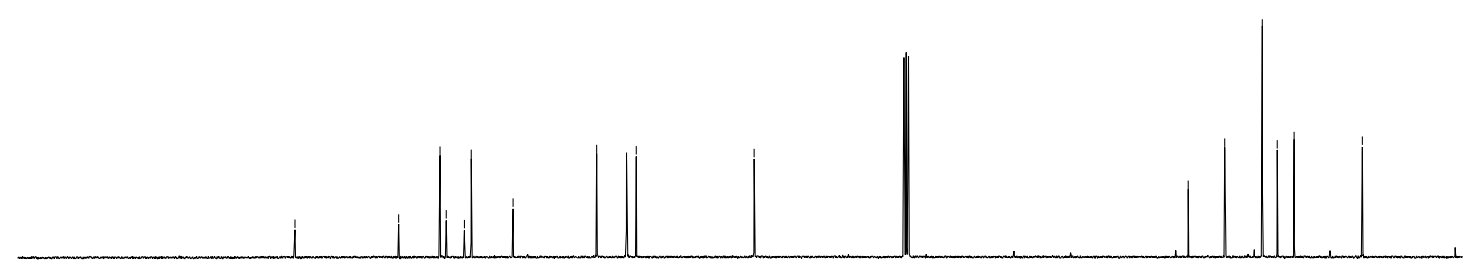

\begin{tabular}{lllllllllllllllllllll}
\hline & 190 & 180 & 170 & 160 & 150 & 140 & 130 & 120 & 110 & 100 & 90 & 80 & 70 & 60 & 50 & 40 & 30 & 20 & 10 & 1
\end{tabular} 

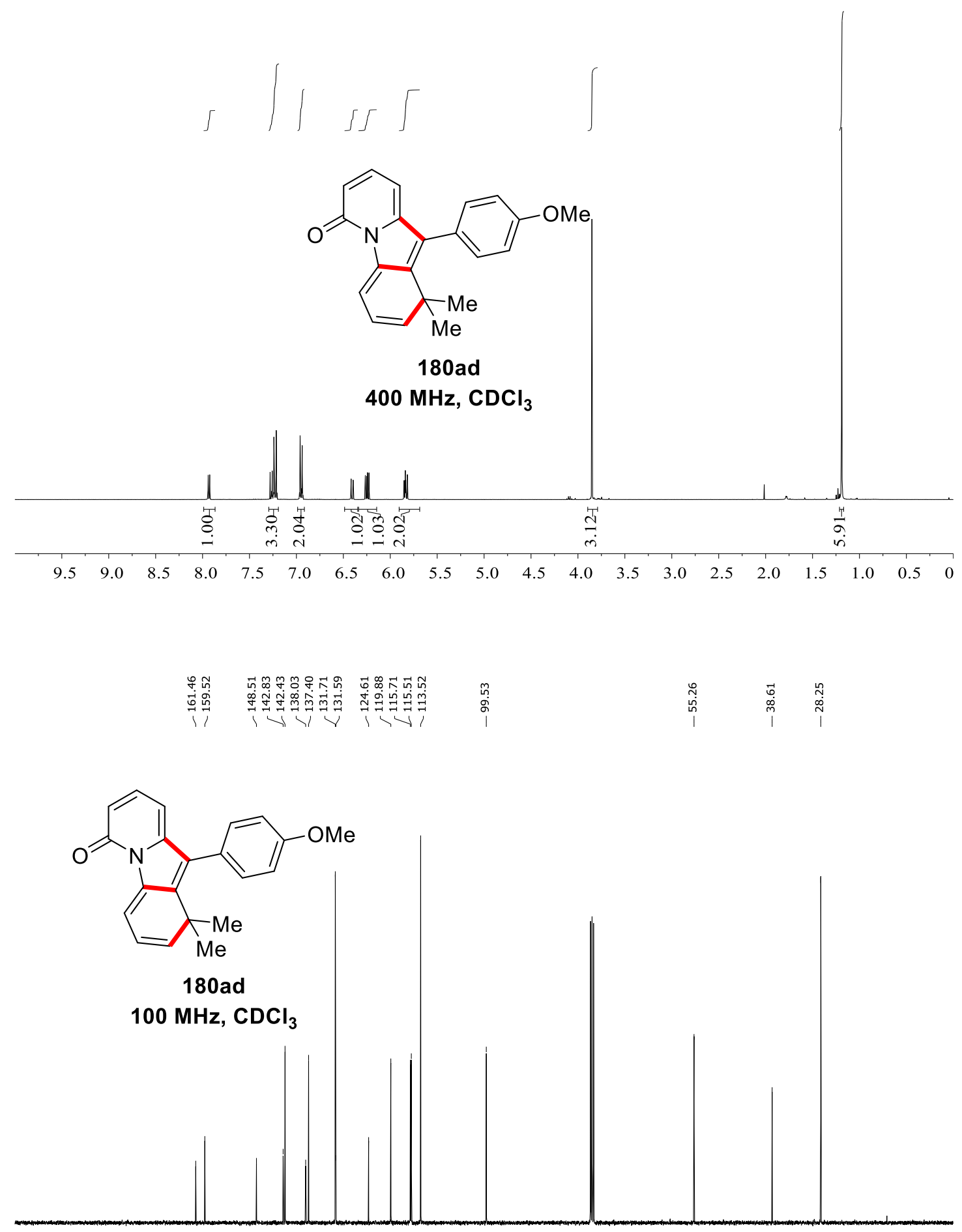

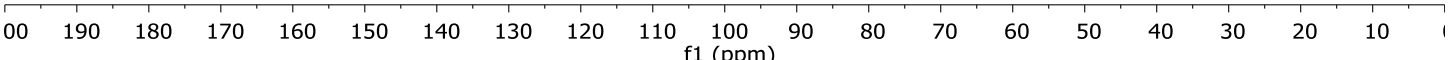



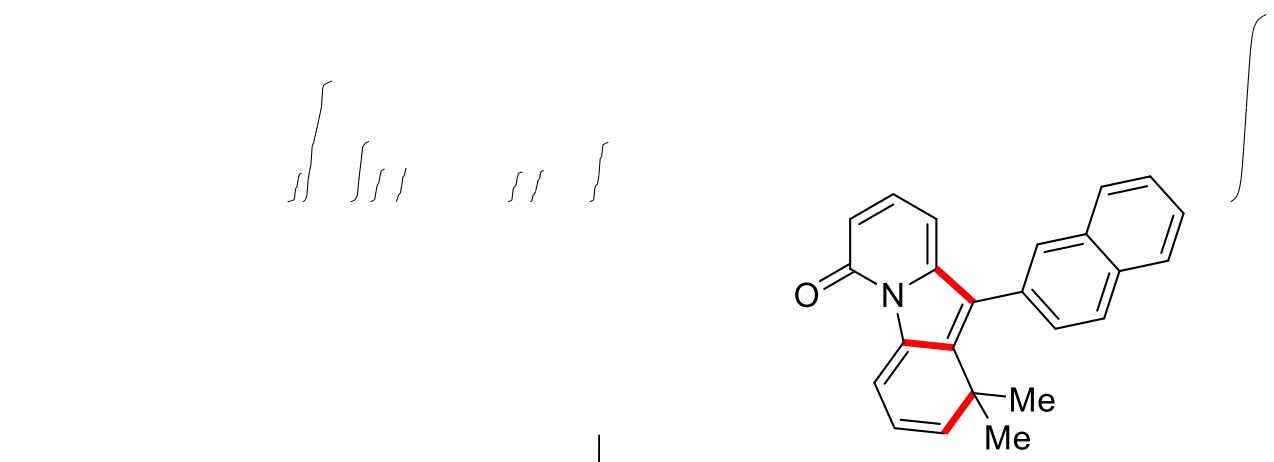

180ae

$300 \mathrm{MHz} \mathrm{CDCl}_{3}$

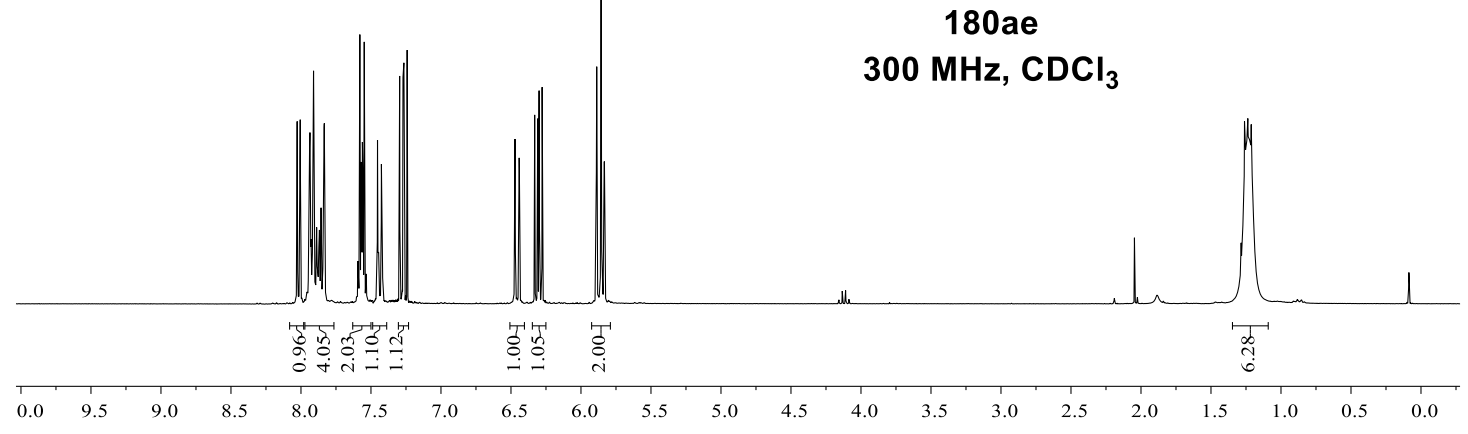

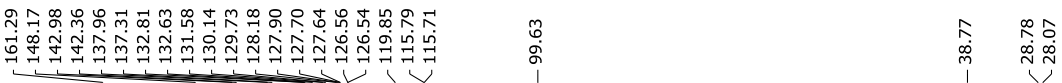

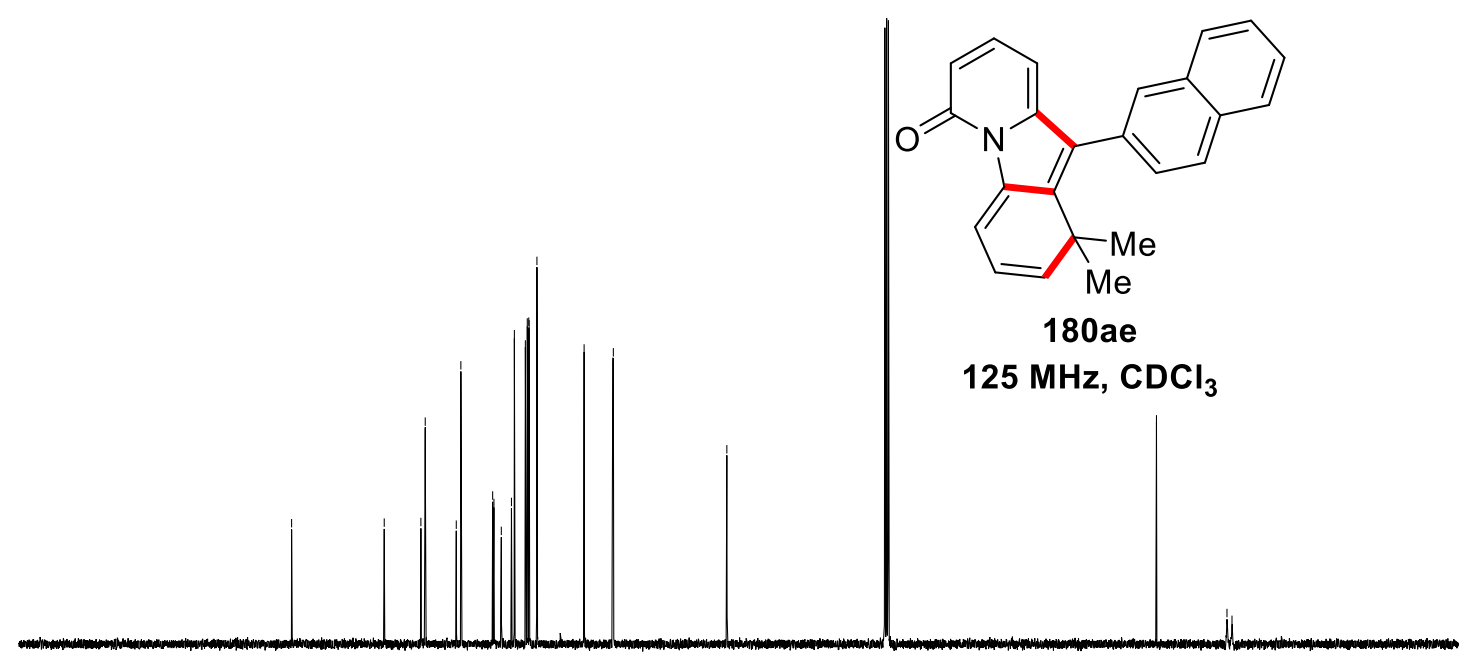

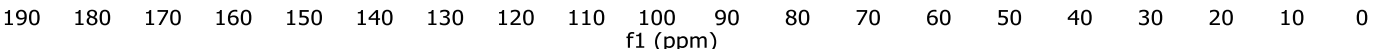




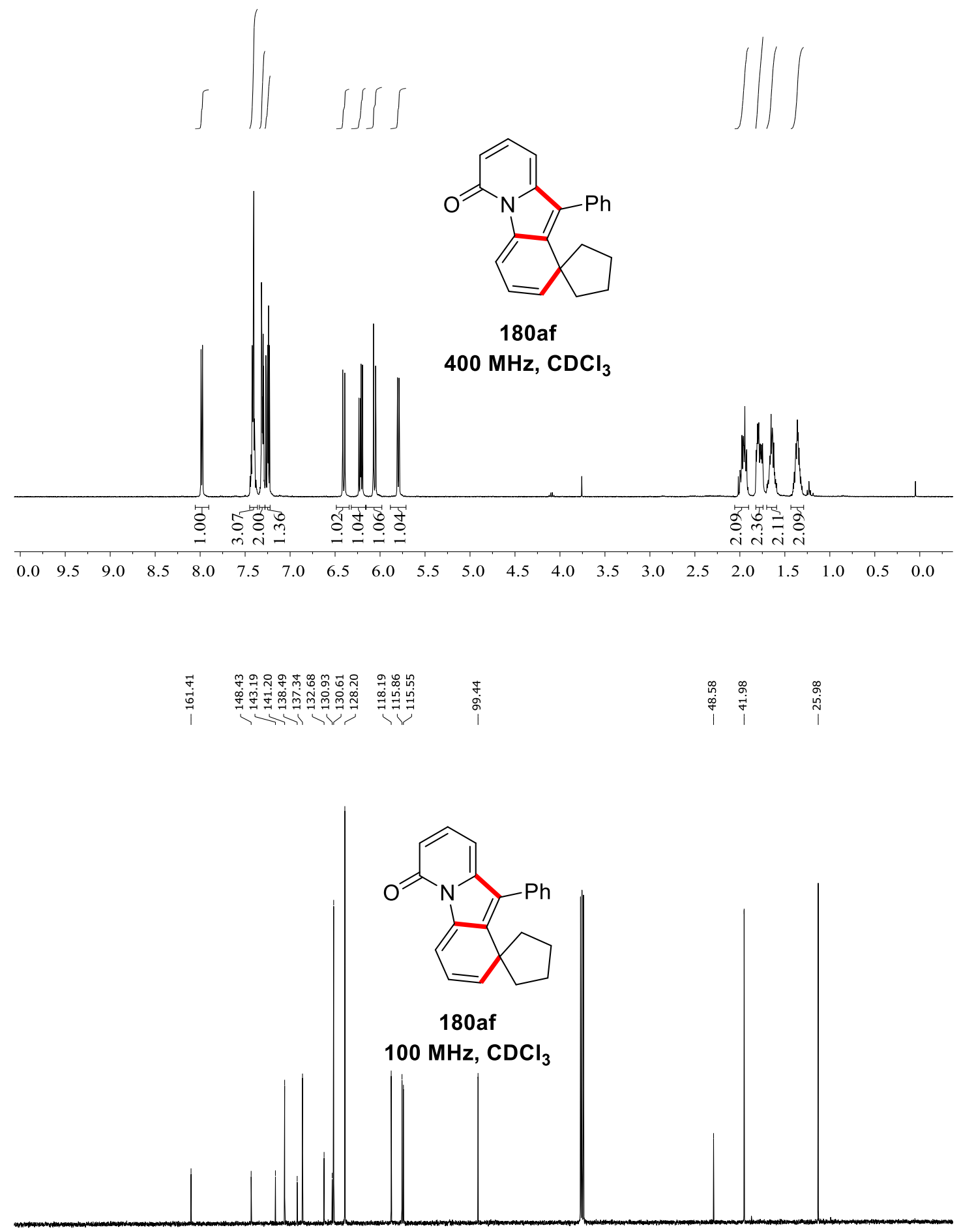

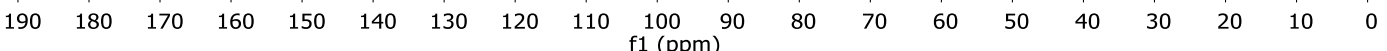



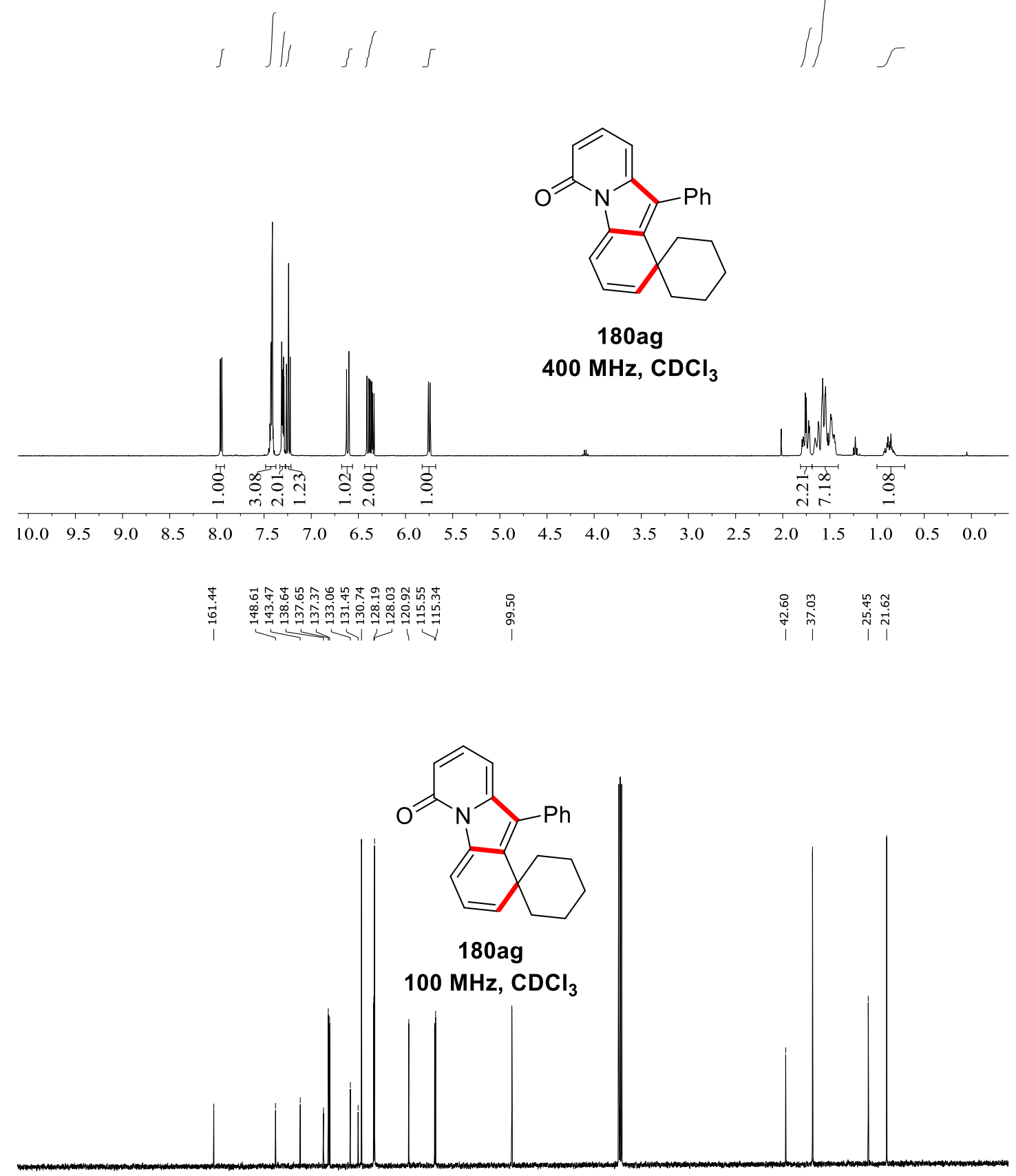

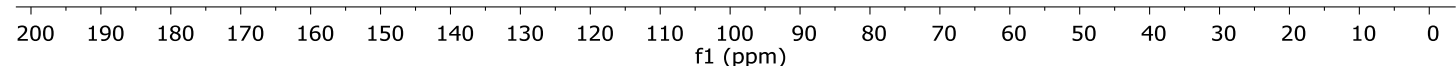



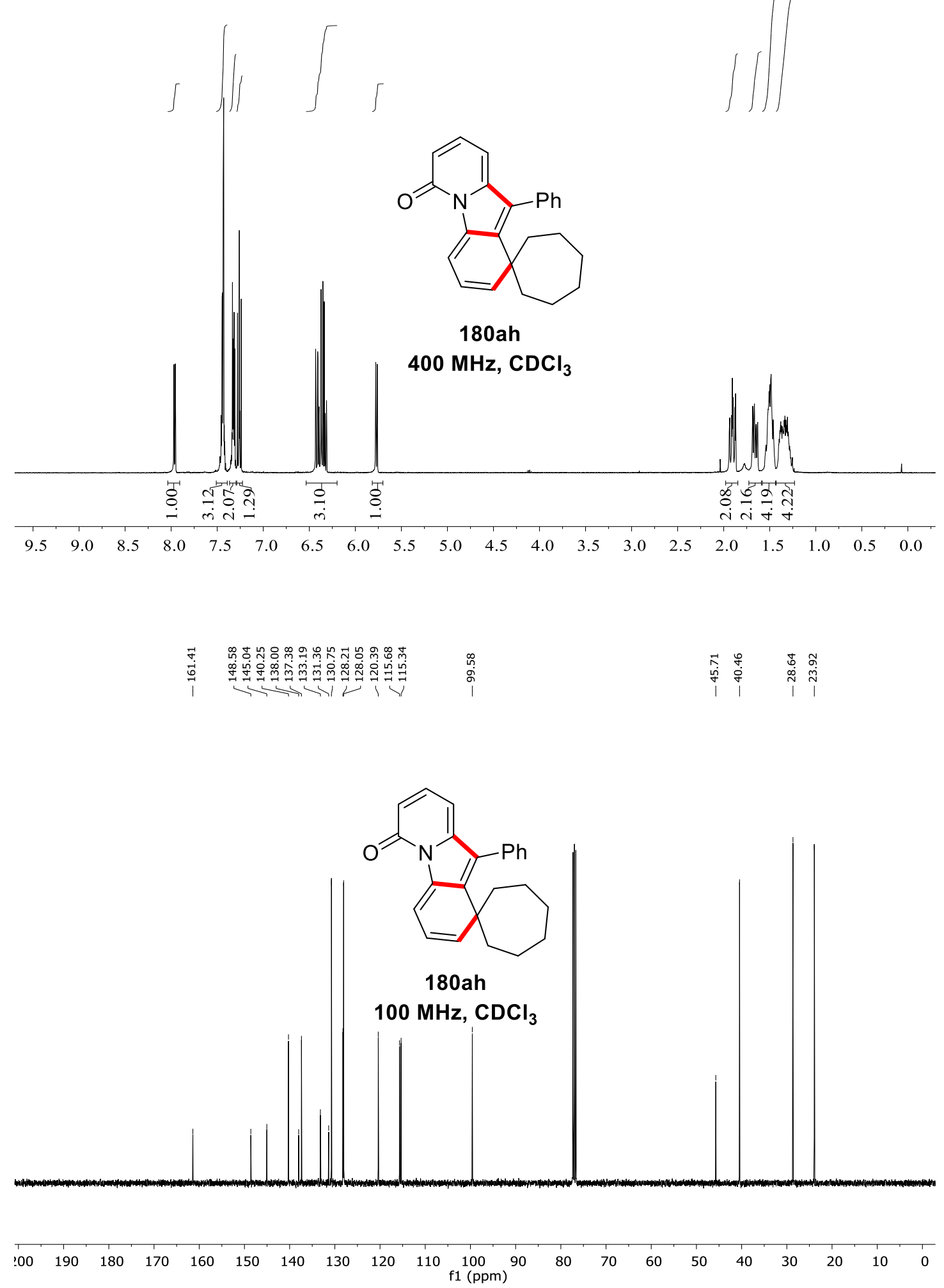


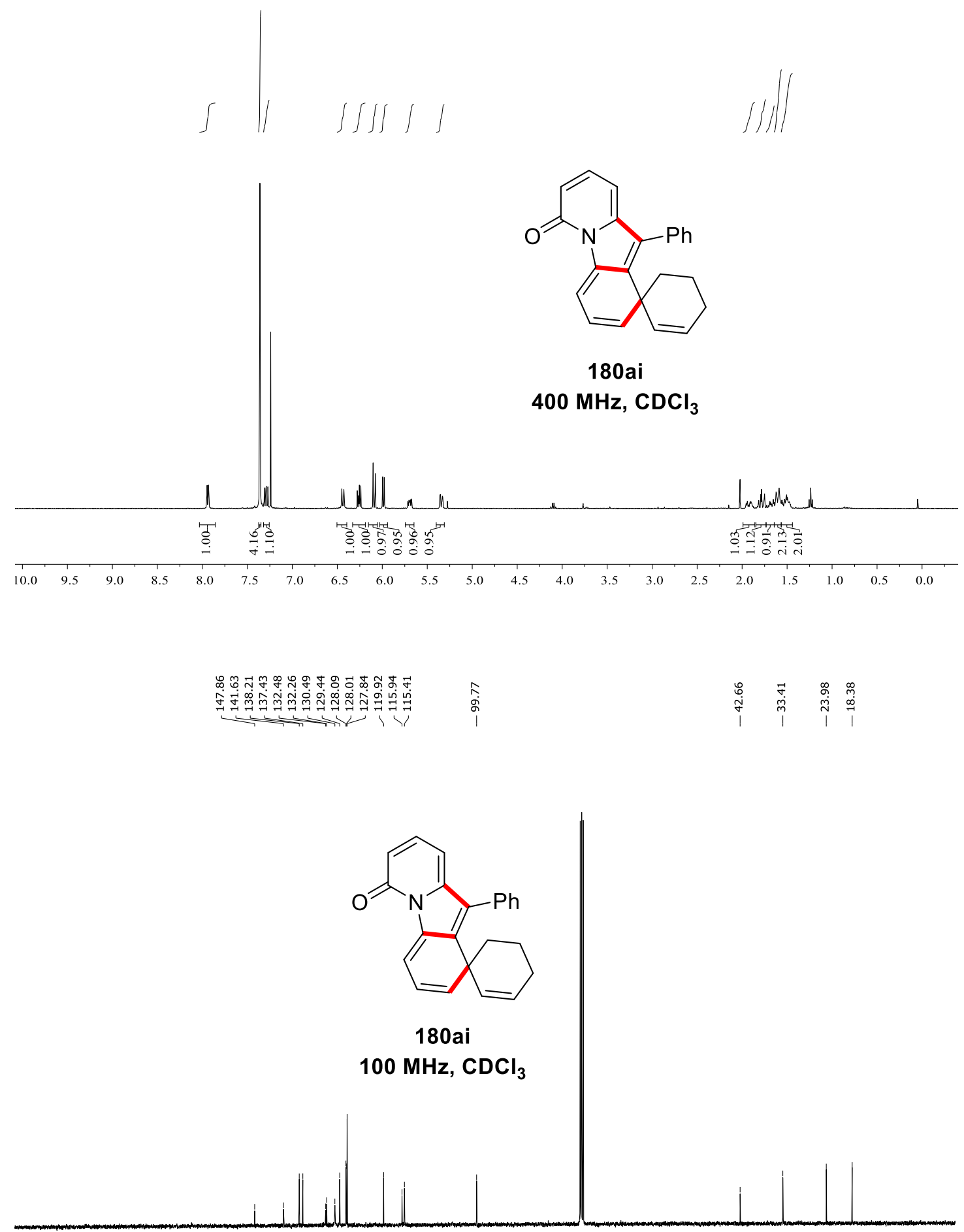

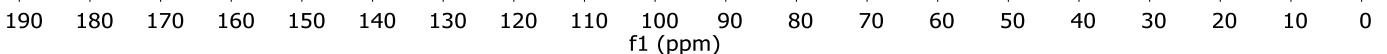



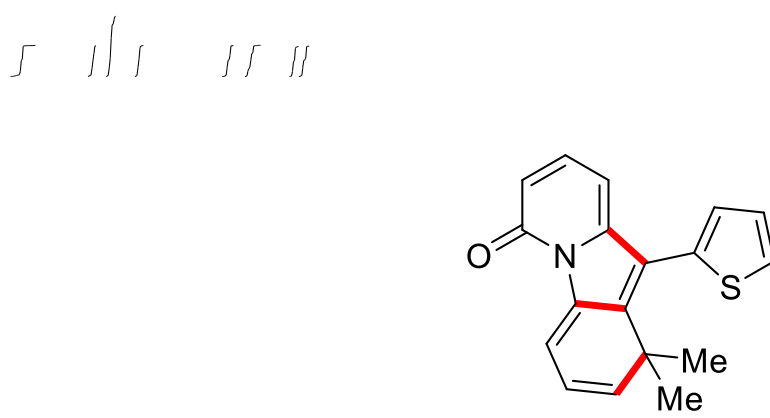

180aj

$400 \mathrm{MHz}^{\mathrm{CDCl}_{3}}$

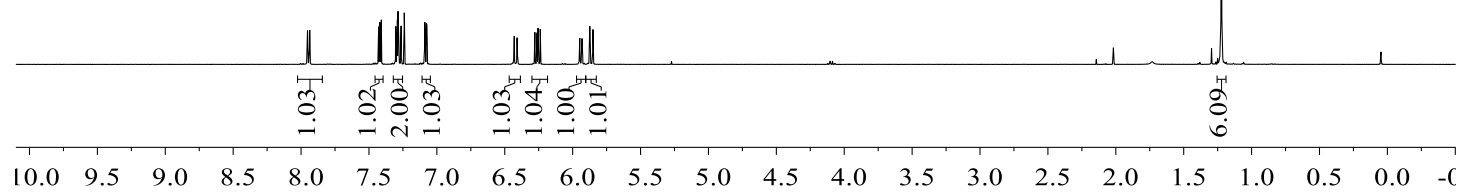

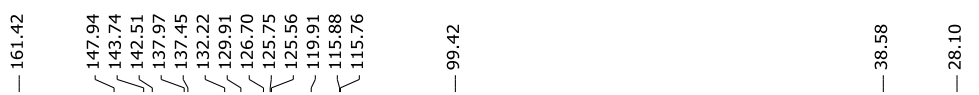

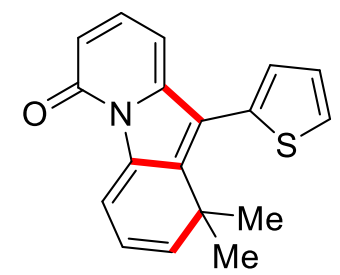

180aj

$100 \mathrm{MHz}, \mathrm{CDCl}_{3}$

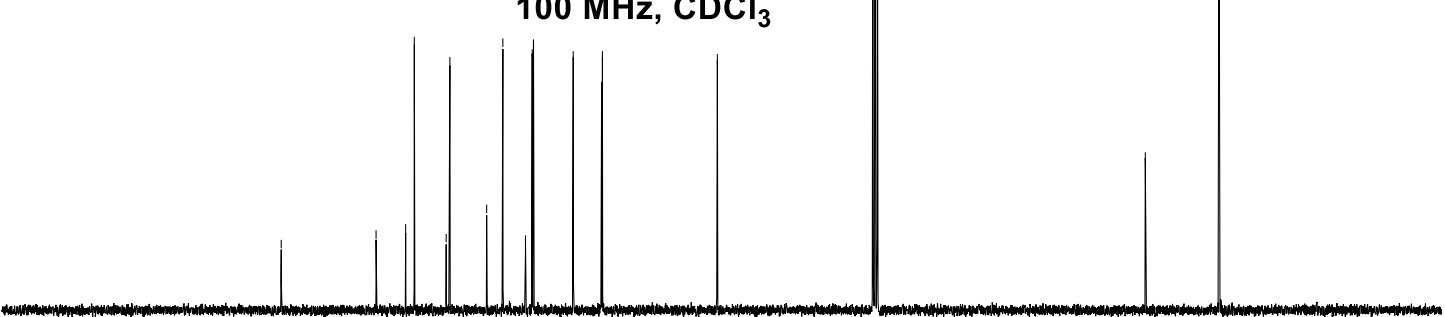

$\begin{array}{llllllllllllllllllllll}200 & 190 & 180 & 170 & 160 & 150 & 140 & 130 & 120 & 110 & 100 & 90 & 80 & 70 & 60 & 50 & 40 & 30 & 20 & 10 & 0\end{array}$ 

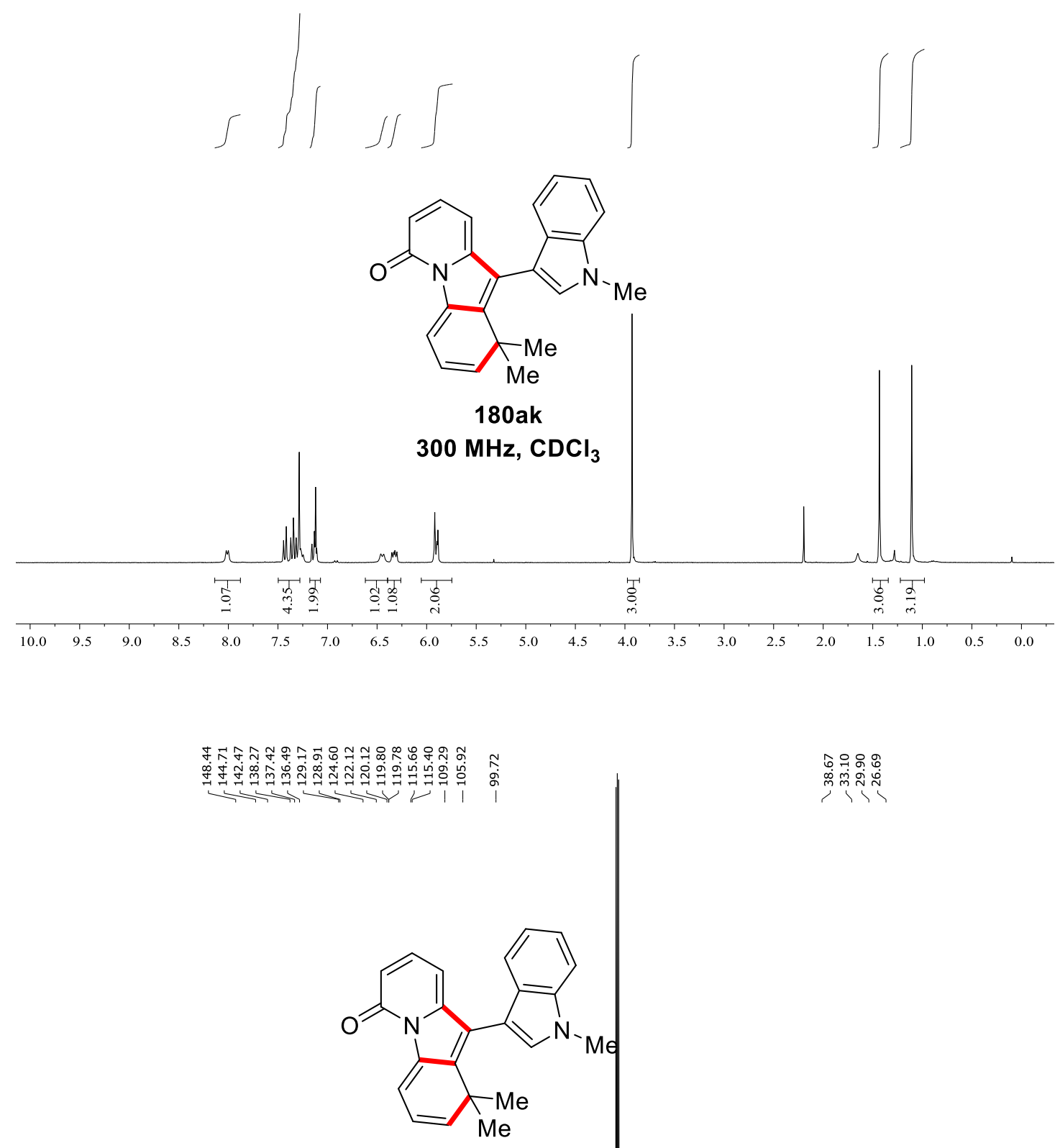

180ak

$125 \mathrm{MHz}^{\mathrm{CDCl}_{3}}$

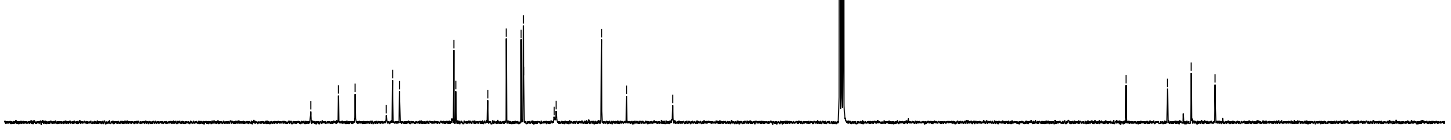

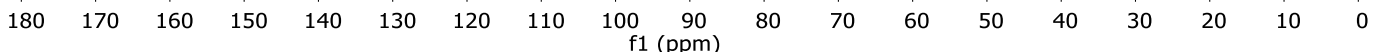




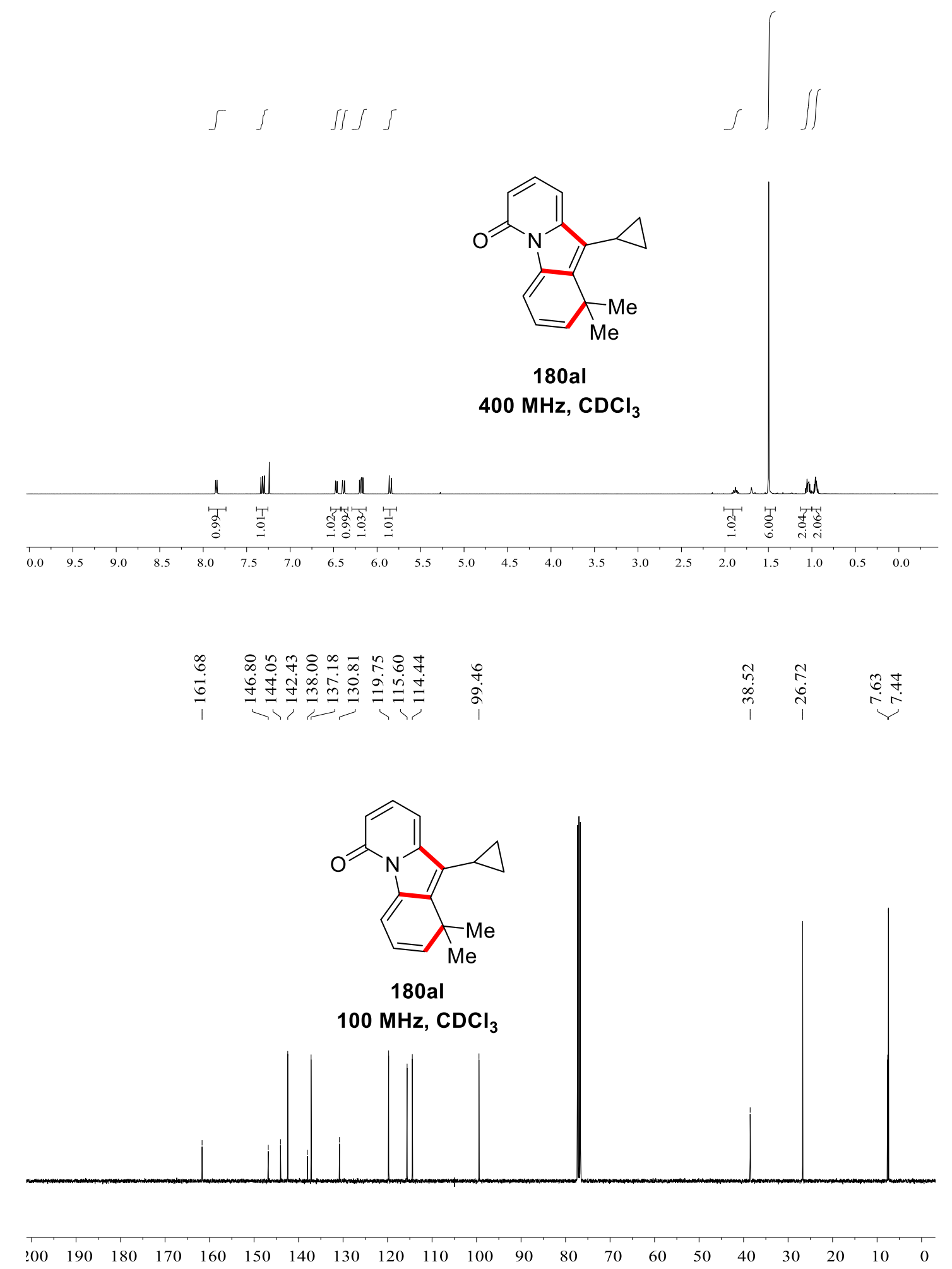




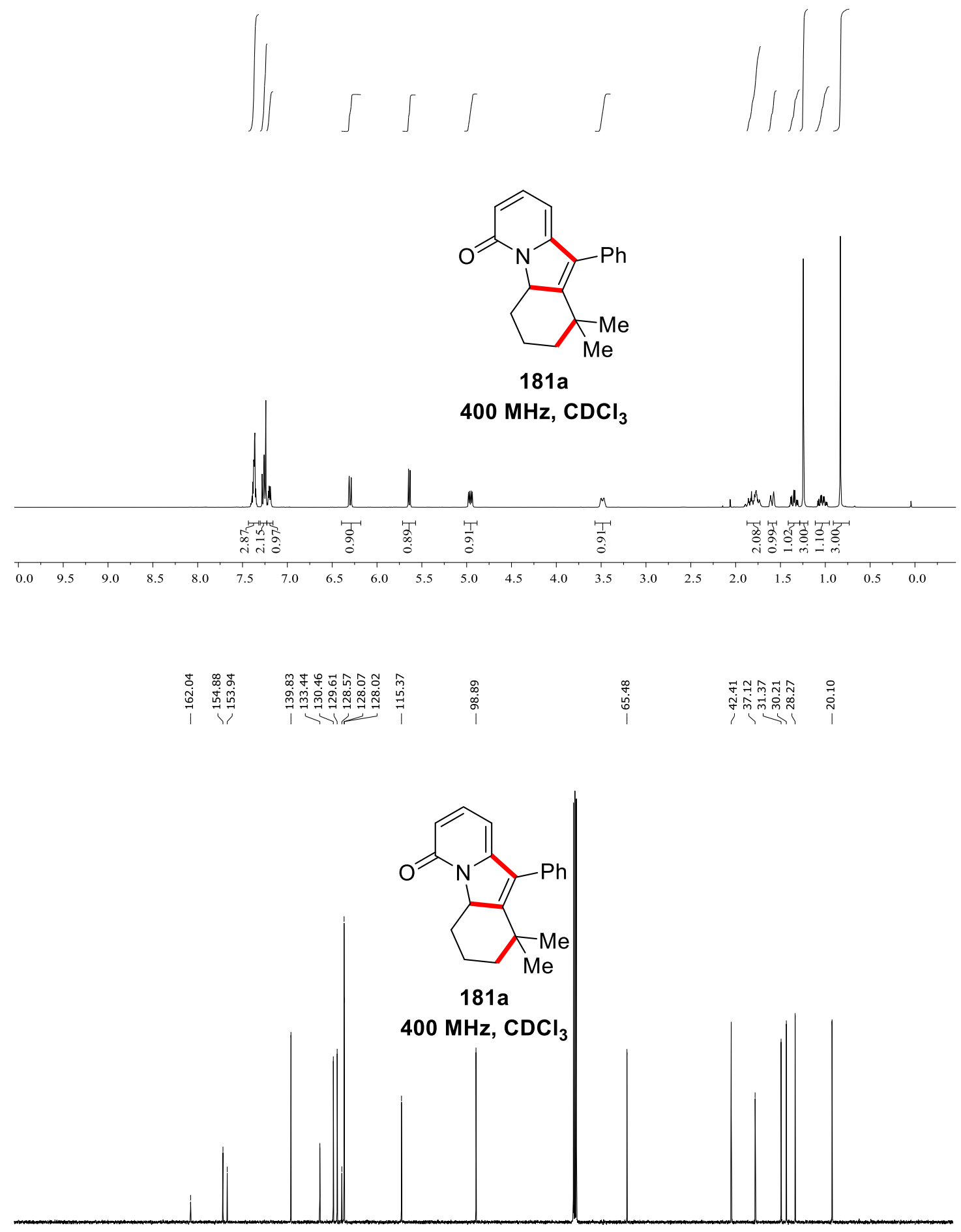

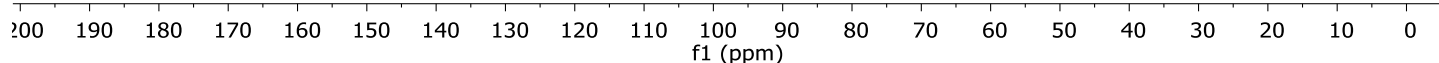




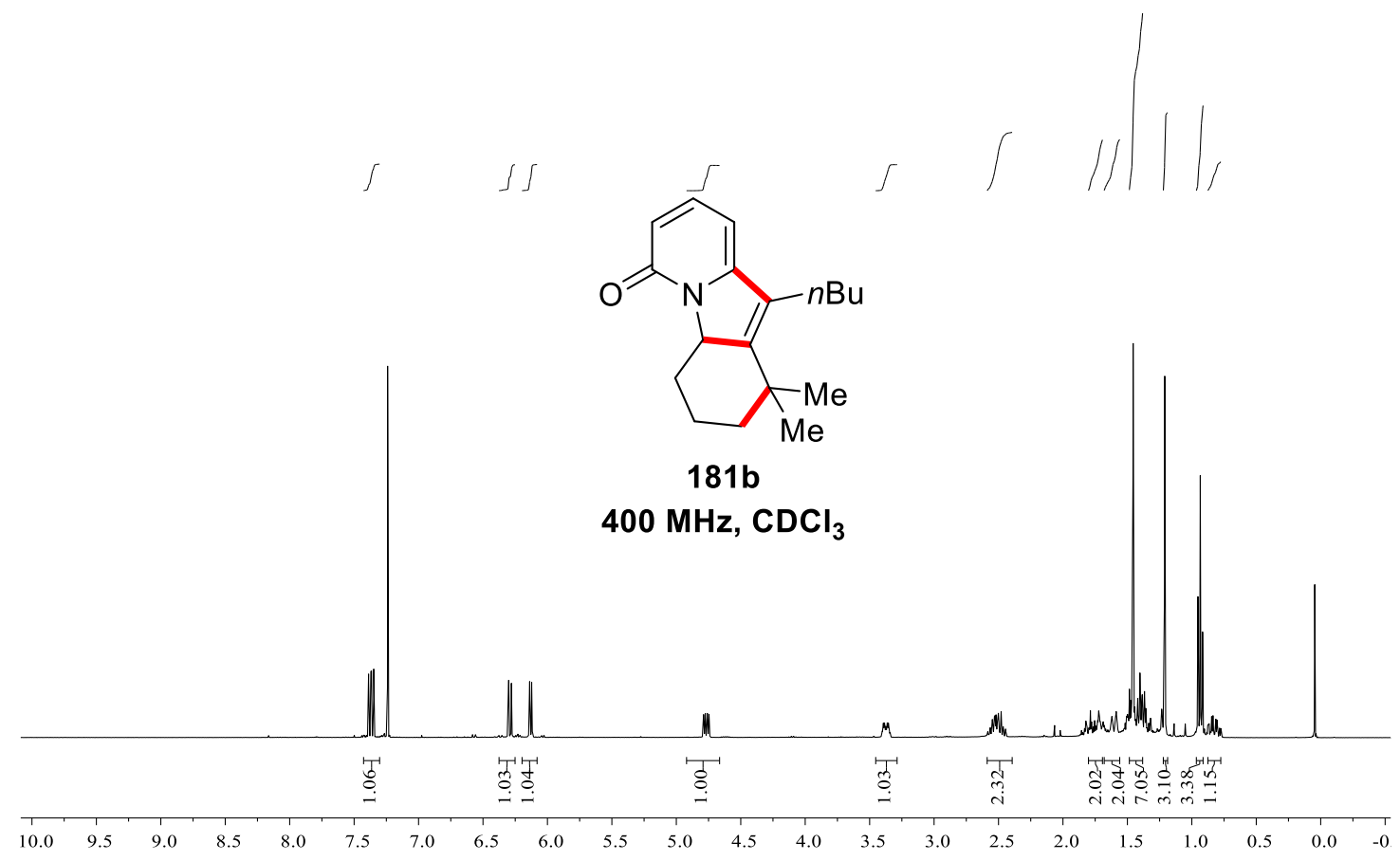




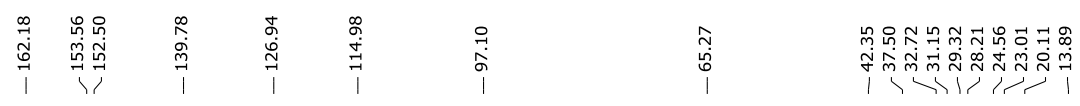

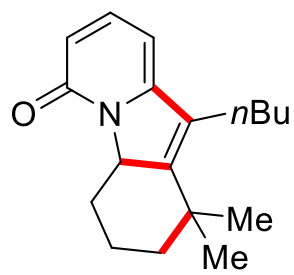

181b

$100 \mathrm{MHz}^{\mathrm{CDCl}_{3}}$

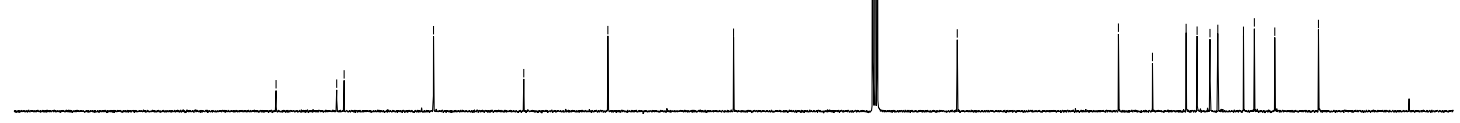

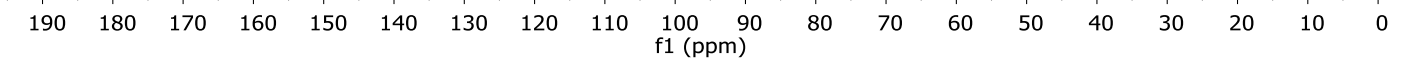
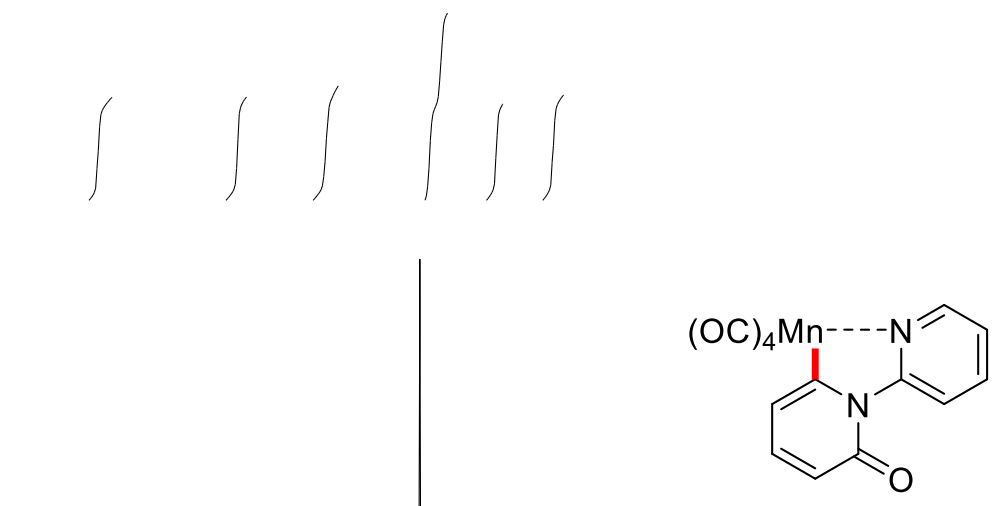

182

$500 \mathrm{MHz}^{\mathrm{CDCl}_{3}}$

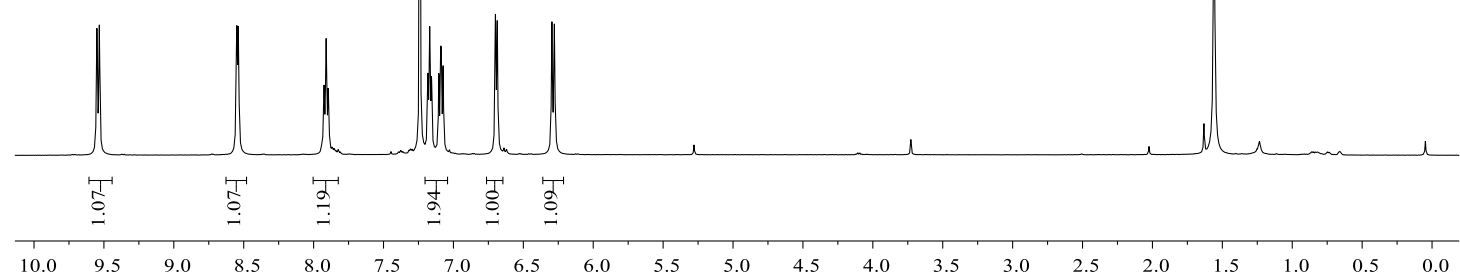




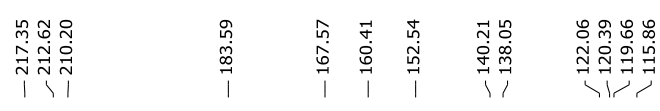<smiles></smiles>

182

$125 \mathrm{MHz}, \mathrm{CDCl}_{3}$

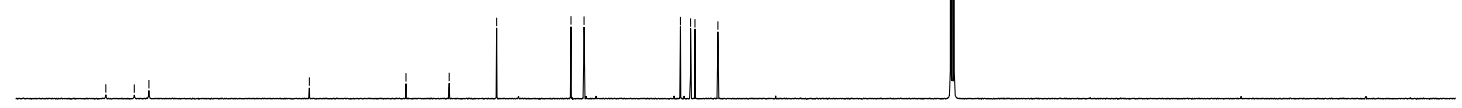

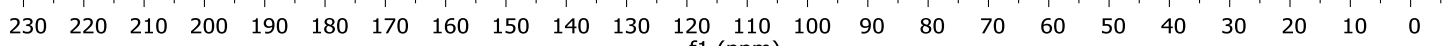
f1 (ppm)<smiles>CC(C)=C=C(c1ccccc1)c1cc(Br)cc(=O)n1-c1ccccc1</smiles>

183

$400 \mathrm{MHz}, \mathrm{CDCl}_{3}$

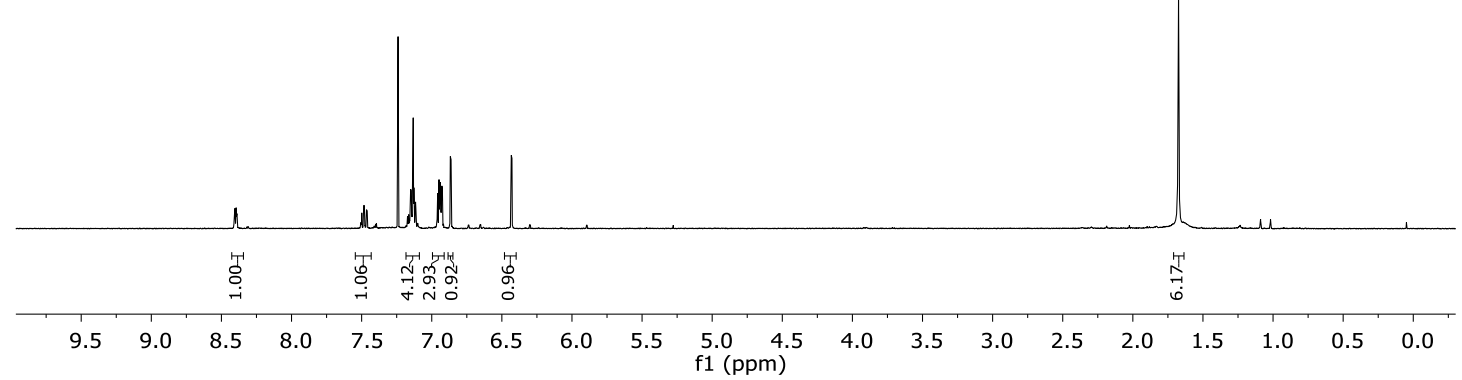




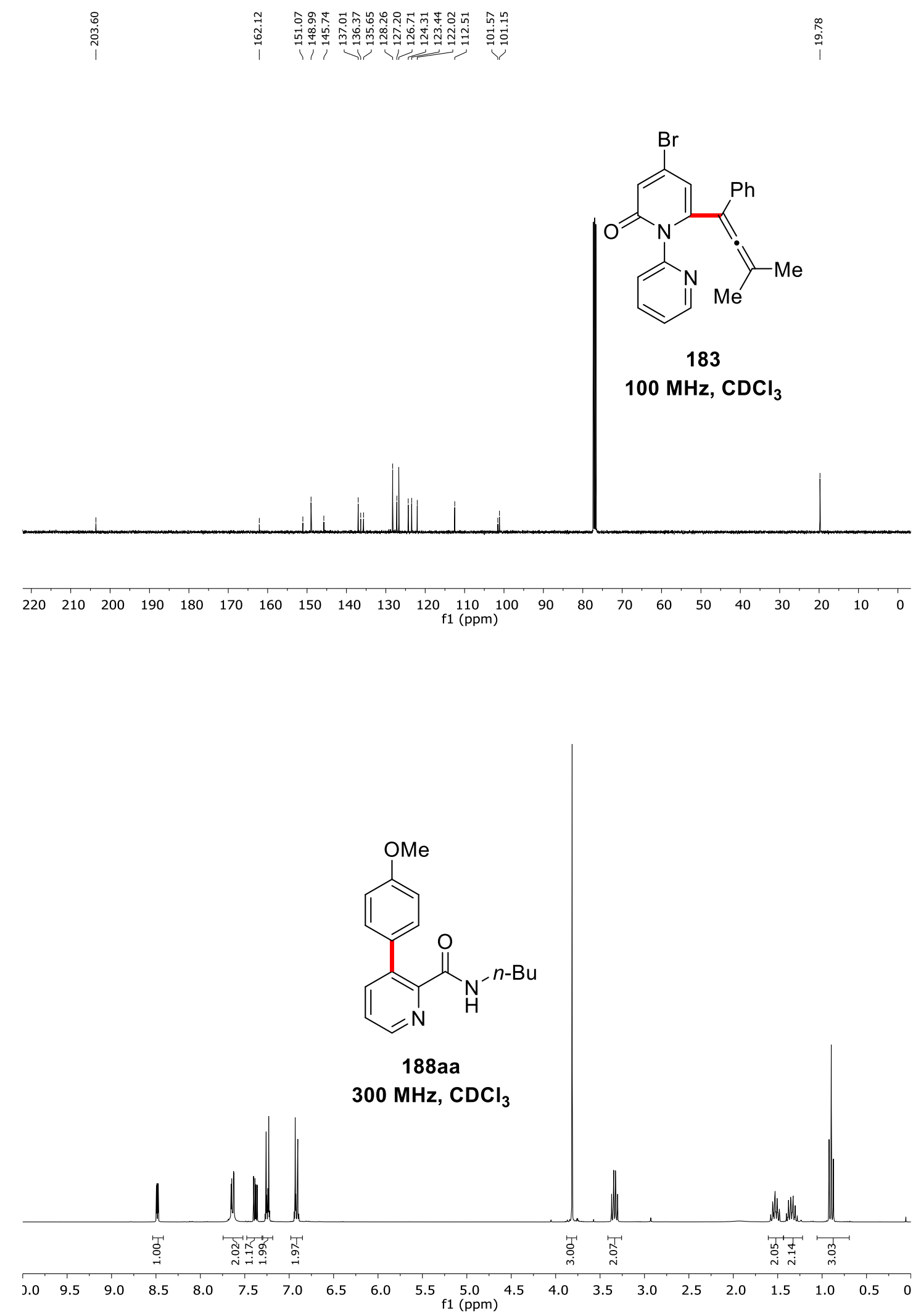




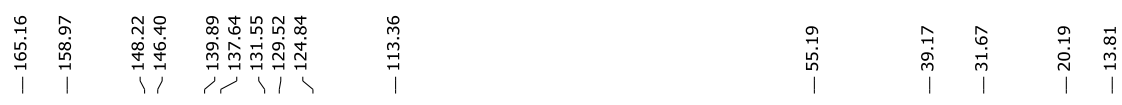

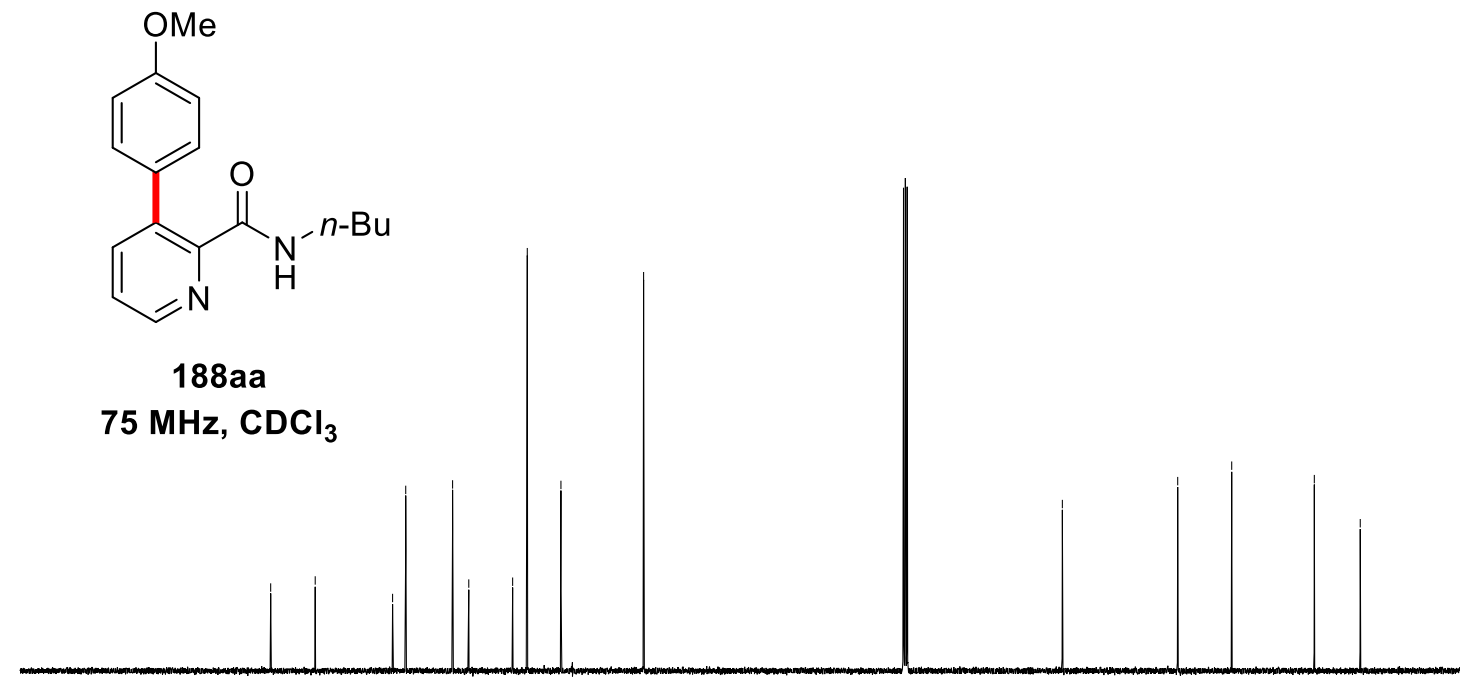

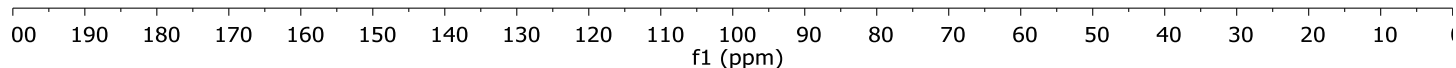<smiles>COc1ccc(-c2cccnc2C(=O)NCc2ccccc2)cc1</smiles>

$188 b a$

$300 \mathrm{MHz}^{\mathrm{CDCl}} \mathrm{CDC}_{3}$

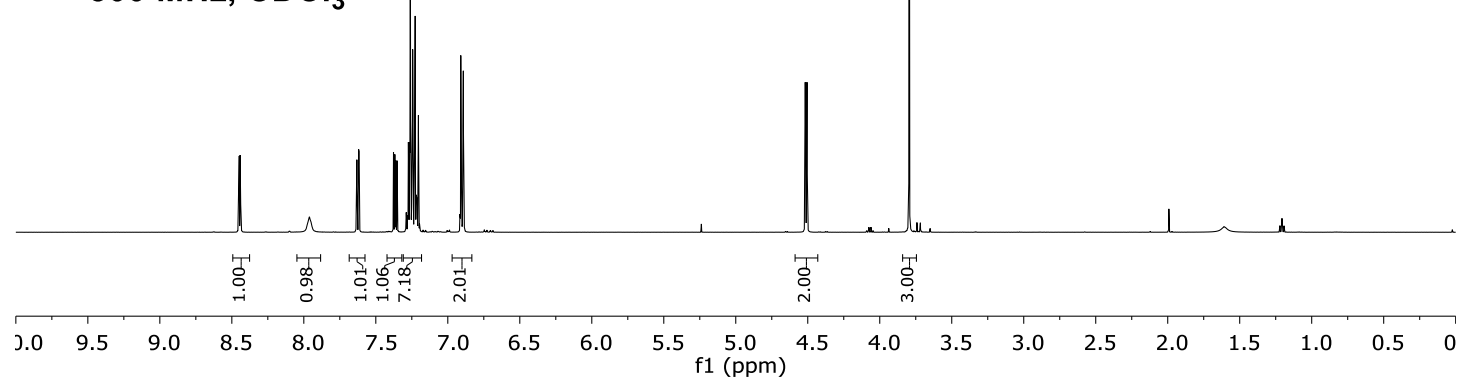




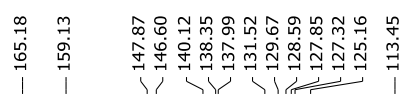

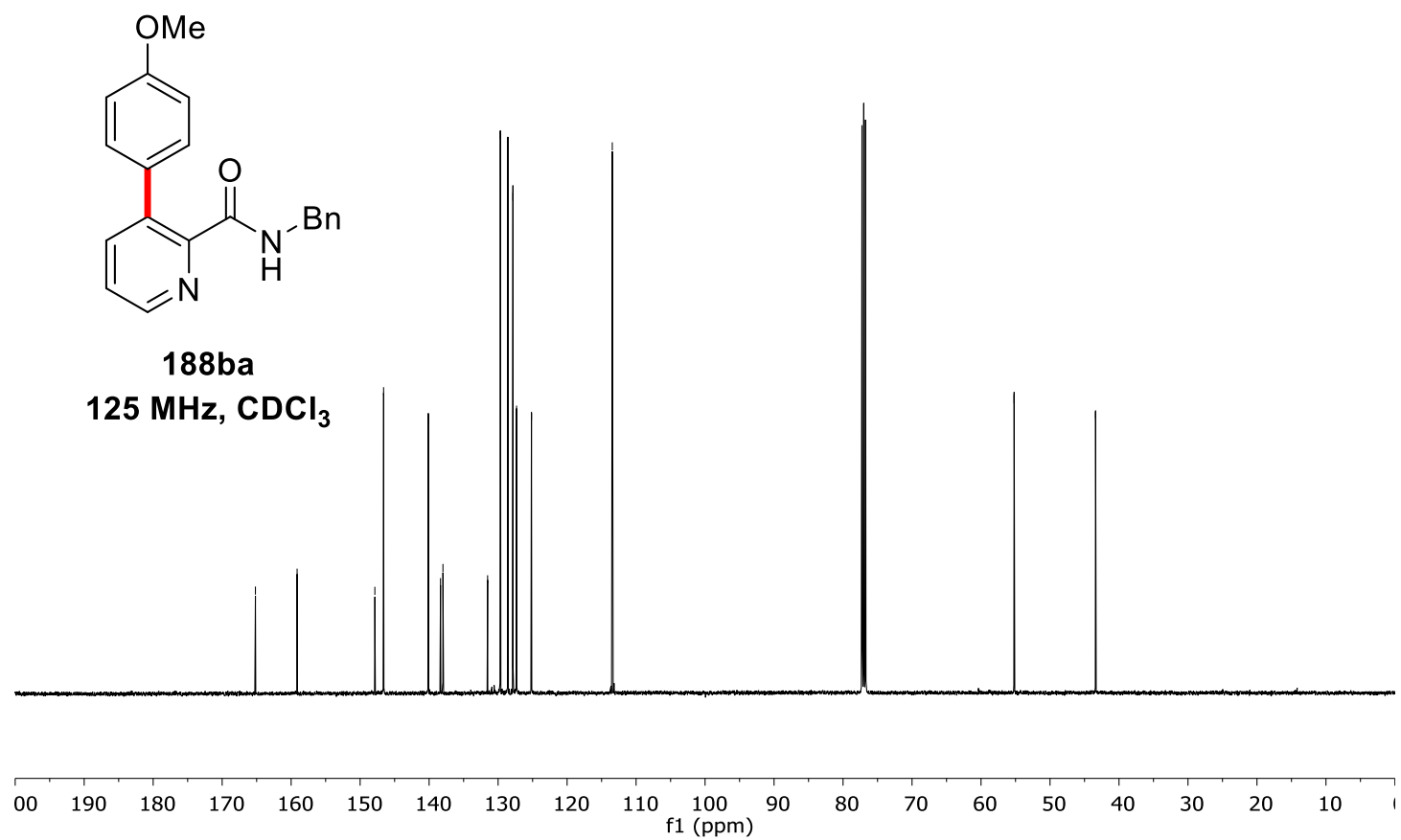<smiles>COc1ccc(-c2cccnc2C(=O)NC2CCCCC2)cc1</smiles>

188ca

$400 \mathrm{MHz}^{\mathrm{CDCl}_{3}}$

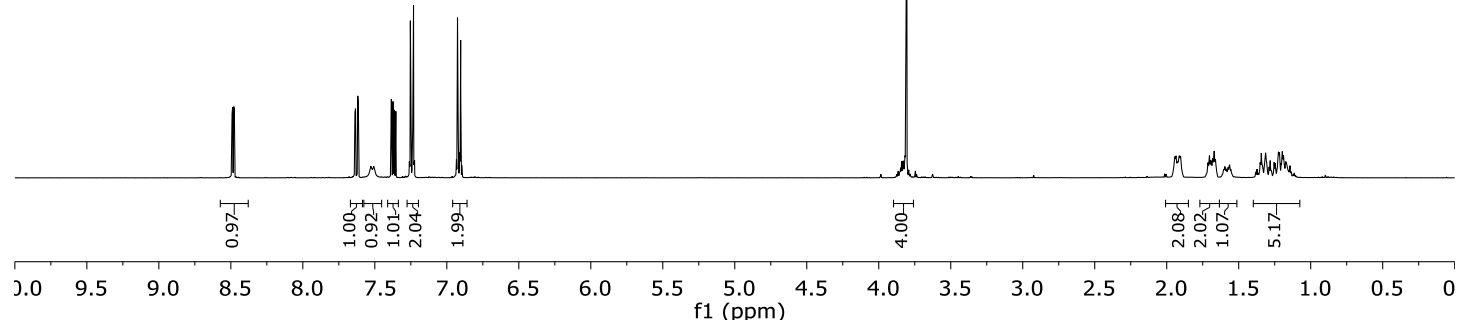




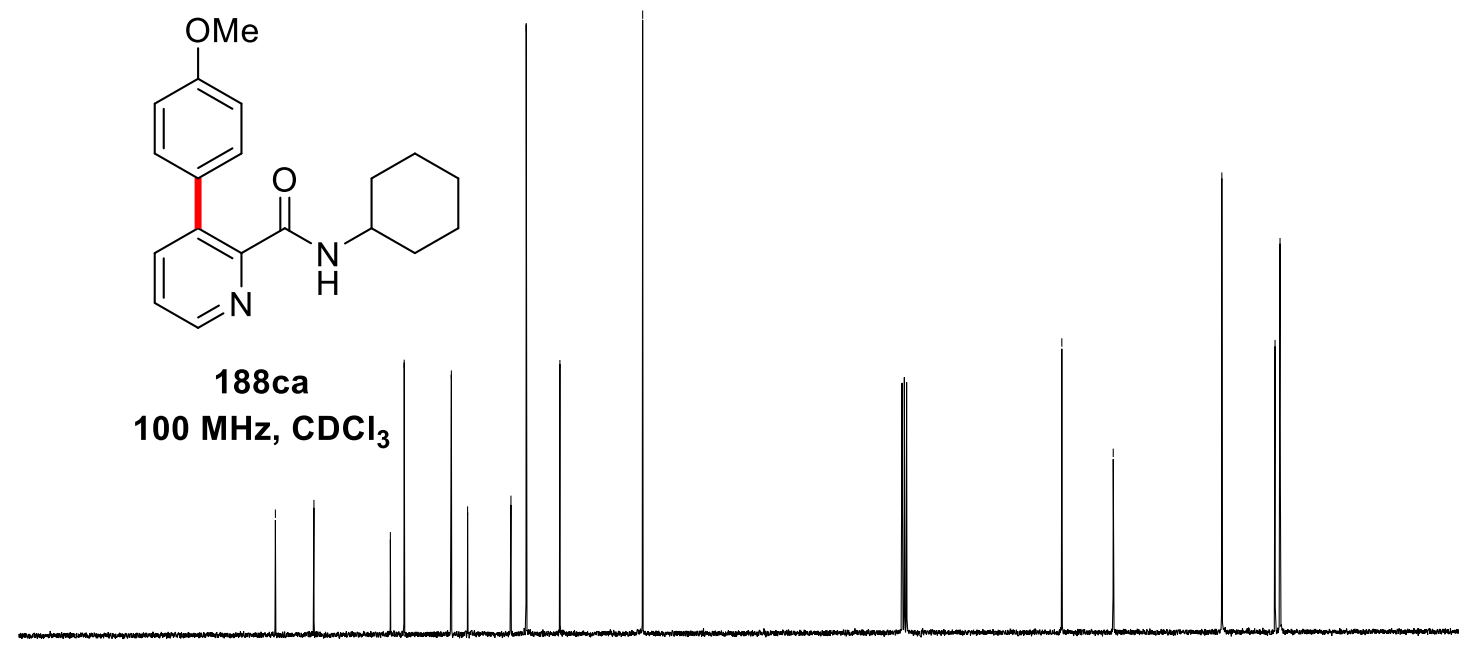

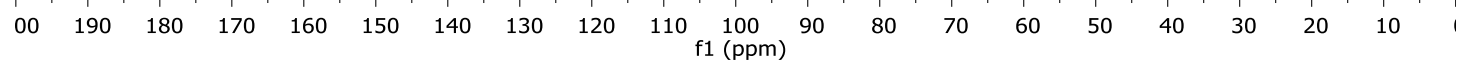<smiles>COc1ccc(CNC(=O)c2ncccc2-c2ccc(OC)cc2)cc1</smiles>

$188 \mathrm{da}$

$500 \mathrm{MHz}, \mathrm{CDCl}_{3}$

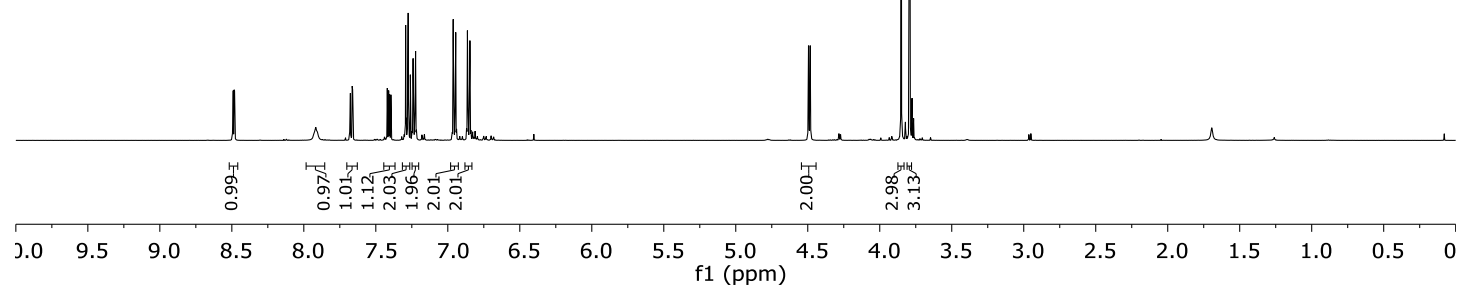




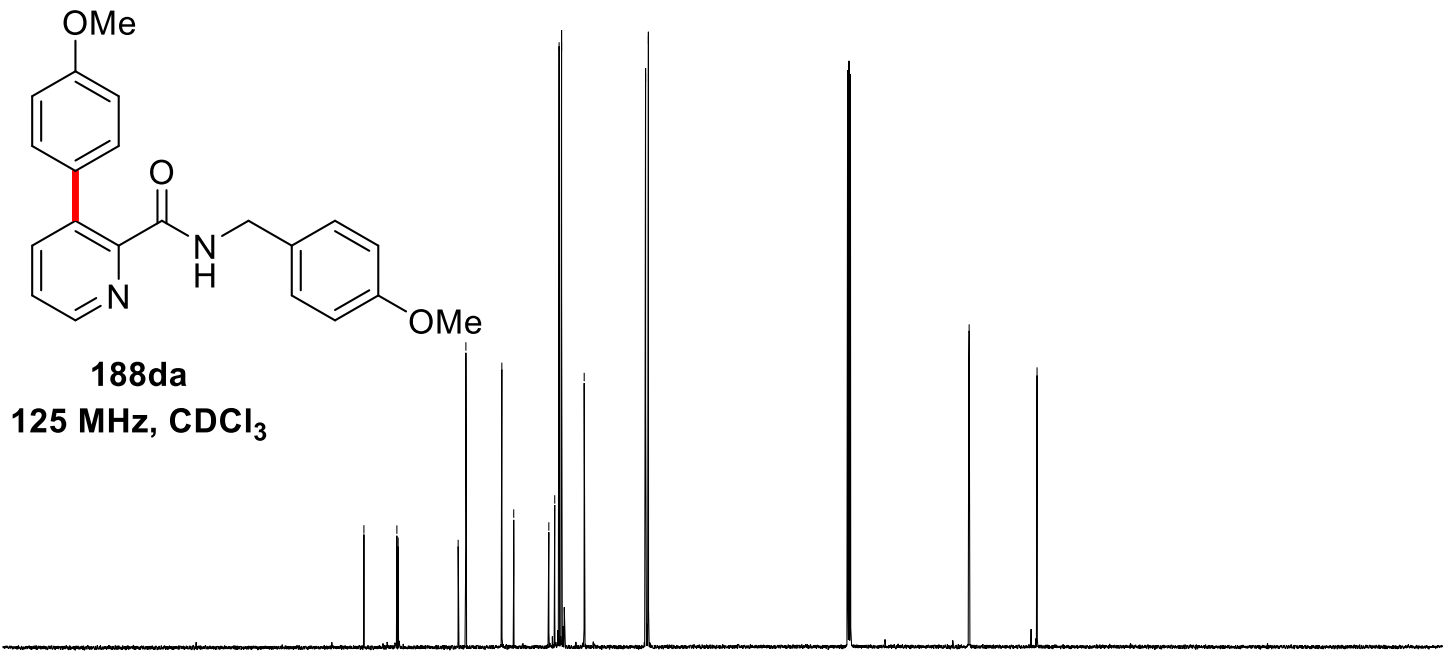

$\begin{array}{llllllllllllllllllllllllllllllll}30 & 220 & 210 & 200 & 190 & 180 & 170 & 160 & 150 & 140 & 130 & 120 & 110 & 100 & 90 & 80 & 70 & 60 & 50 & 40 & 30 & 20 & 10 & 0 & -10 & -20 & -3\end{array}$ 


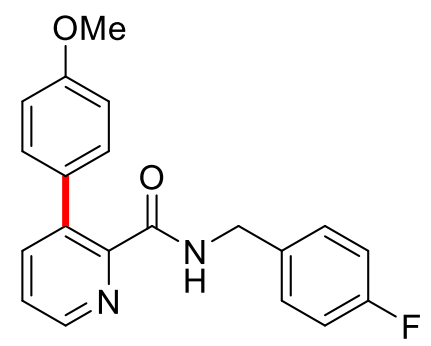

188ea

$500 \mathrm{MHz}^{\mathrm{CDCl}_{3}}$

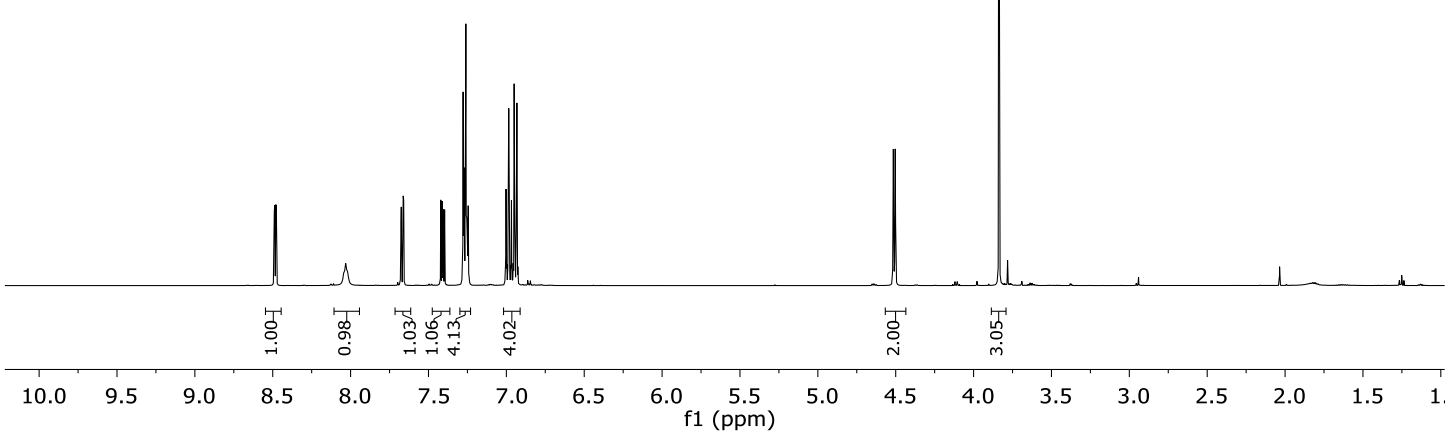

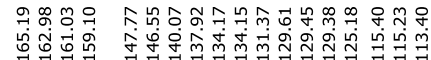

晒<smiles>COc1ccc(-c2cccnc2C(=O)NCc2ccc(F)cc2)cc1</smiles>

188ea

$125 \mathrm{MHz}^{\mathrm{CDCl}_{3}}$

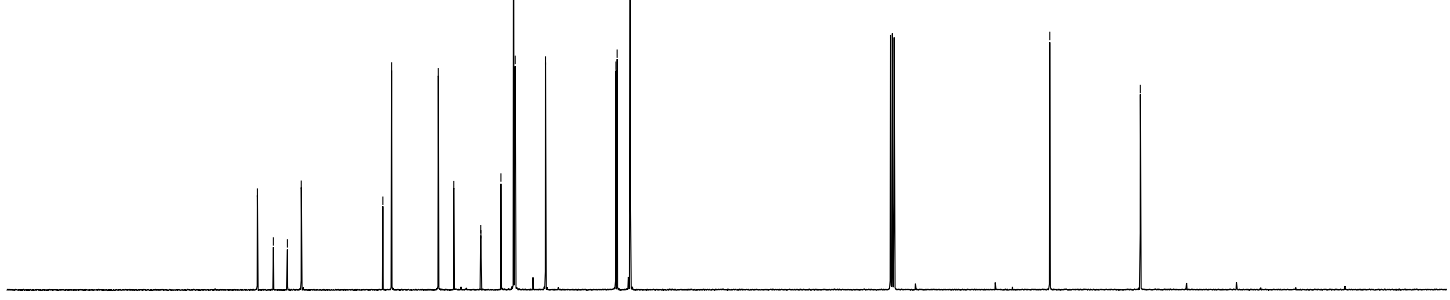

$\begin{array}{llllllllllllllllllll}00 & 190 & 180 & 170 & 160 & 150 & 140 & 130 & 120 & 110 & \begin{array}{c}100 \\ 100\end{array} & 90 & 80 & 70 & 60 & 50 & 40 & 30 & 20 & 10\end{array}$ 


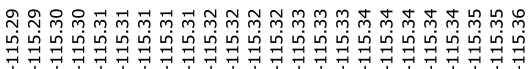
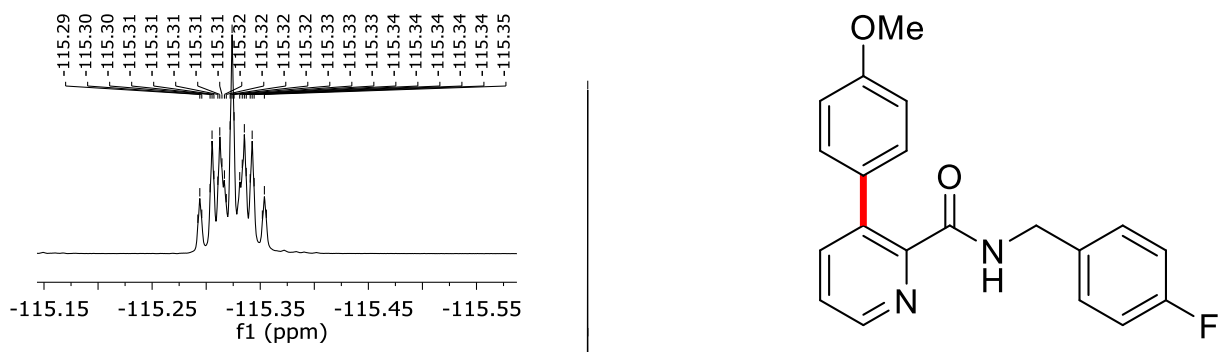

188ea

$471 \mathrm{MHz}, \mathrm{CDCl}_{3}$ $-104-105-106-107-108-109-110-111-112-113-114-115-116-117-118-119-120-121-122-123-124-125-126-127-128-129-130$
f1 (ppm)

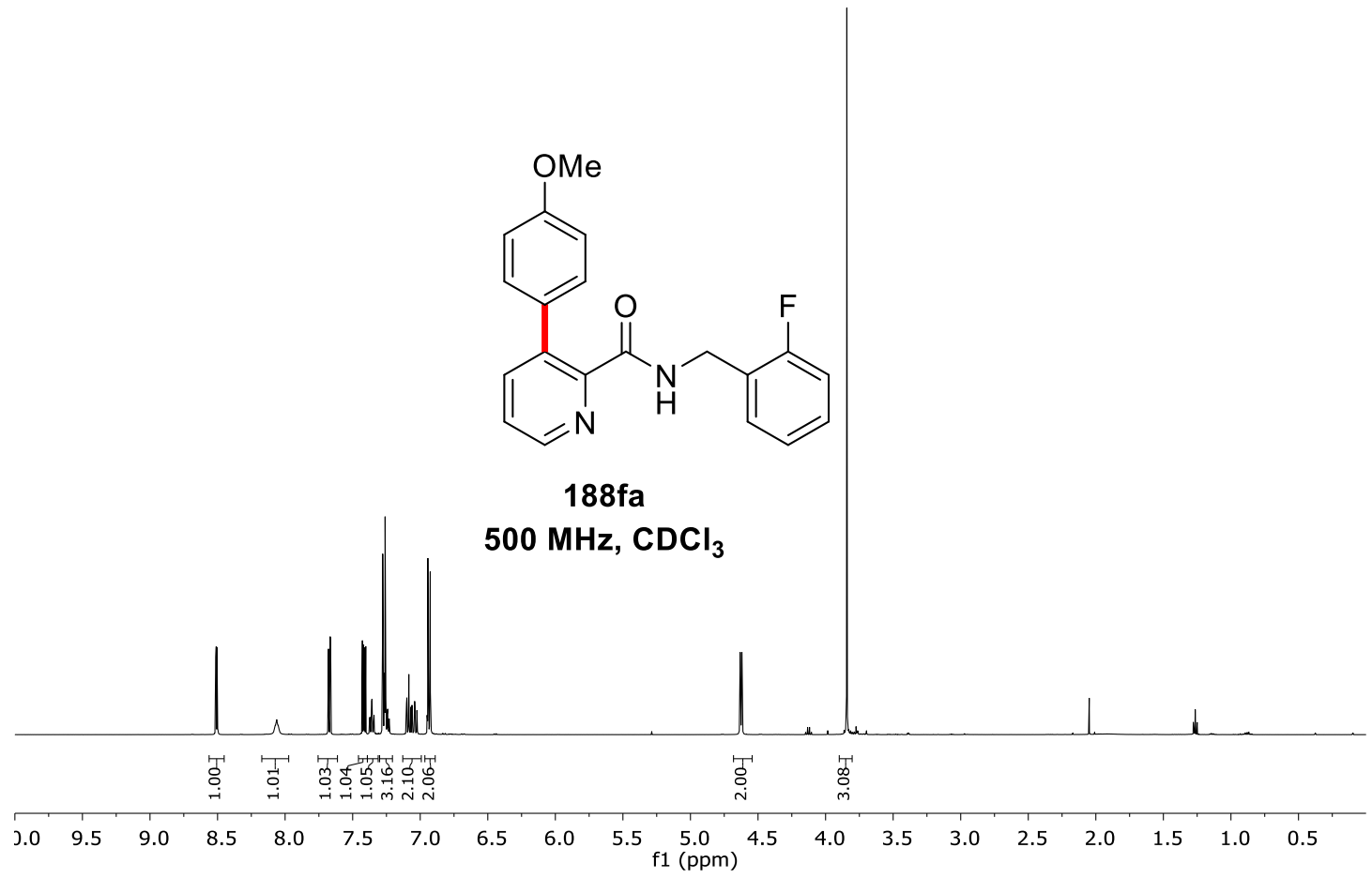




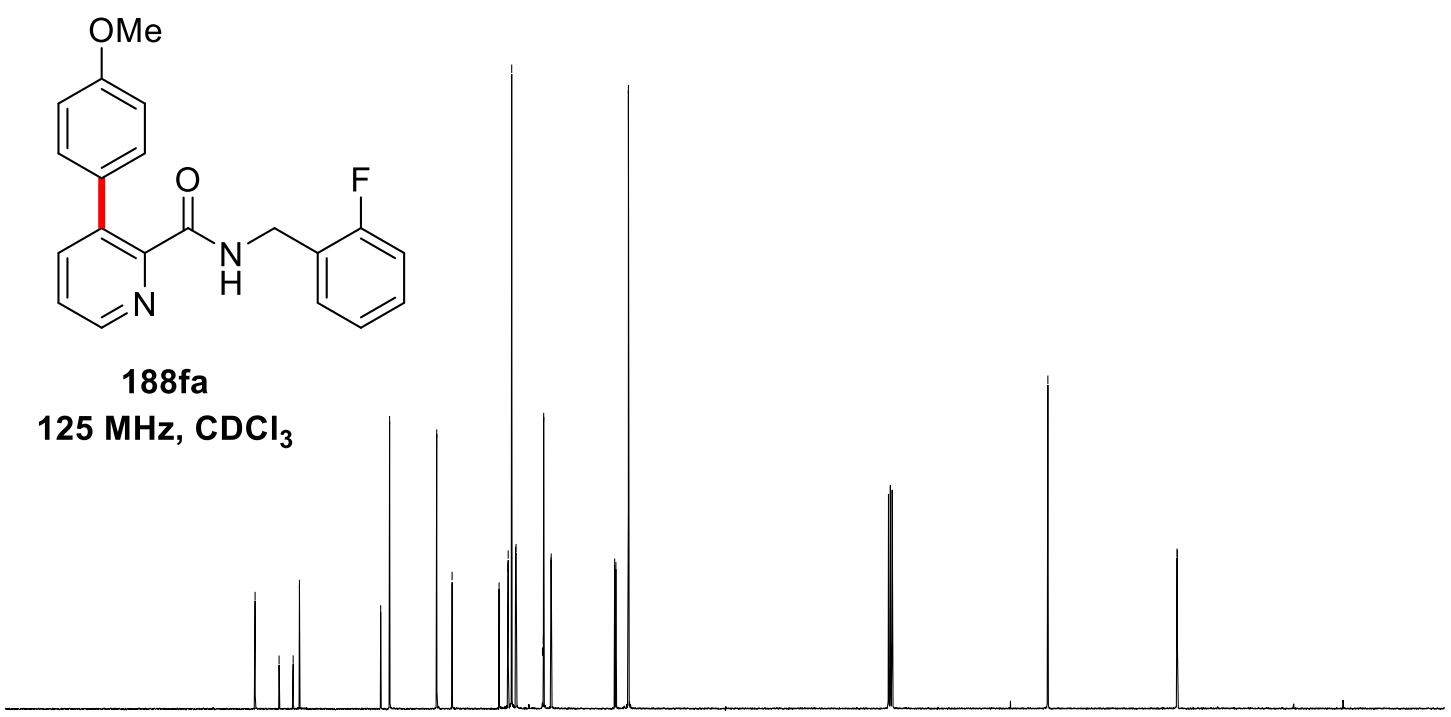

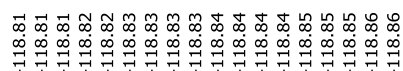
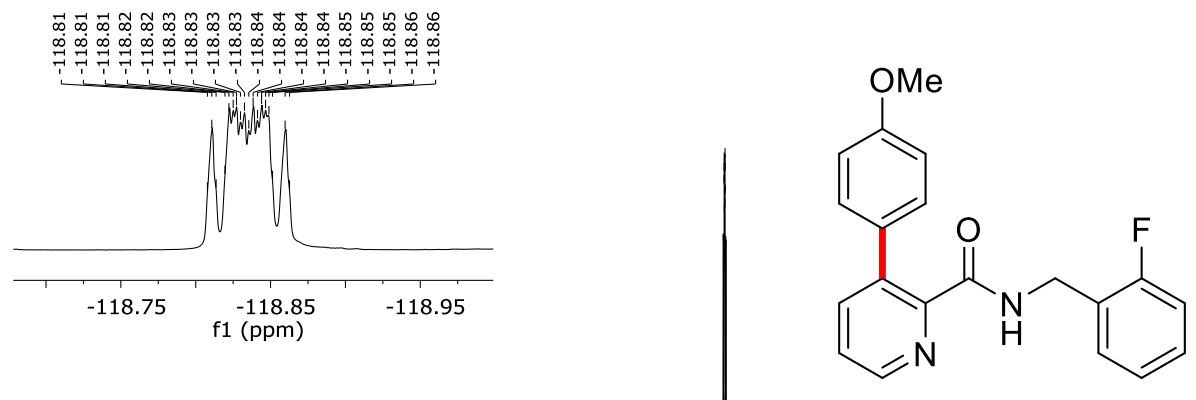

$188 \mathrm{fa}$

$471 \mathrm{MHz}, \mathrm{CDCl}_{3}$

$-104-105-106-107-108-109-110-111-112-113-114-115-116-117-118-119-120-121-122-123-124-125-126-127-128-129-130$ f1 (ppm) 
<smiles>COc1ccc(-c2cccnc2C(=O)NC2CCCc3ccccc32)cc1</smiles>

188ga

$400 \mathrm{MHz}, \mathrm{CDCl}_{3}$

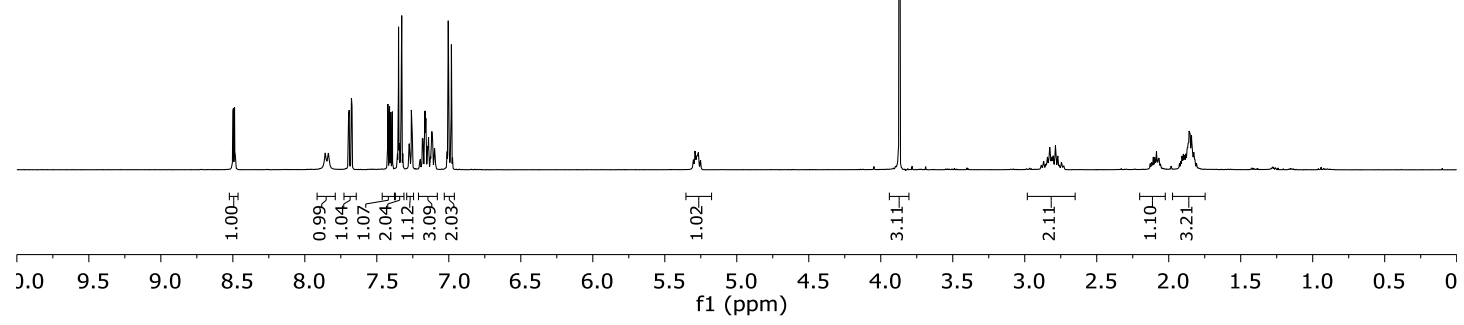

$\begin{array}{llll}0 & 0 & m & 0\end{array}$

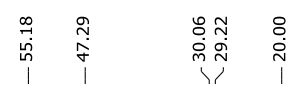

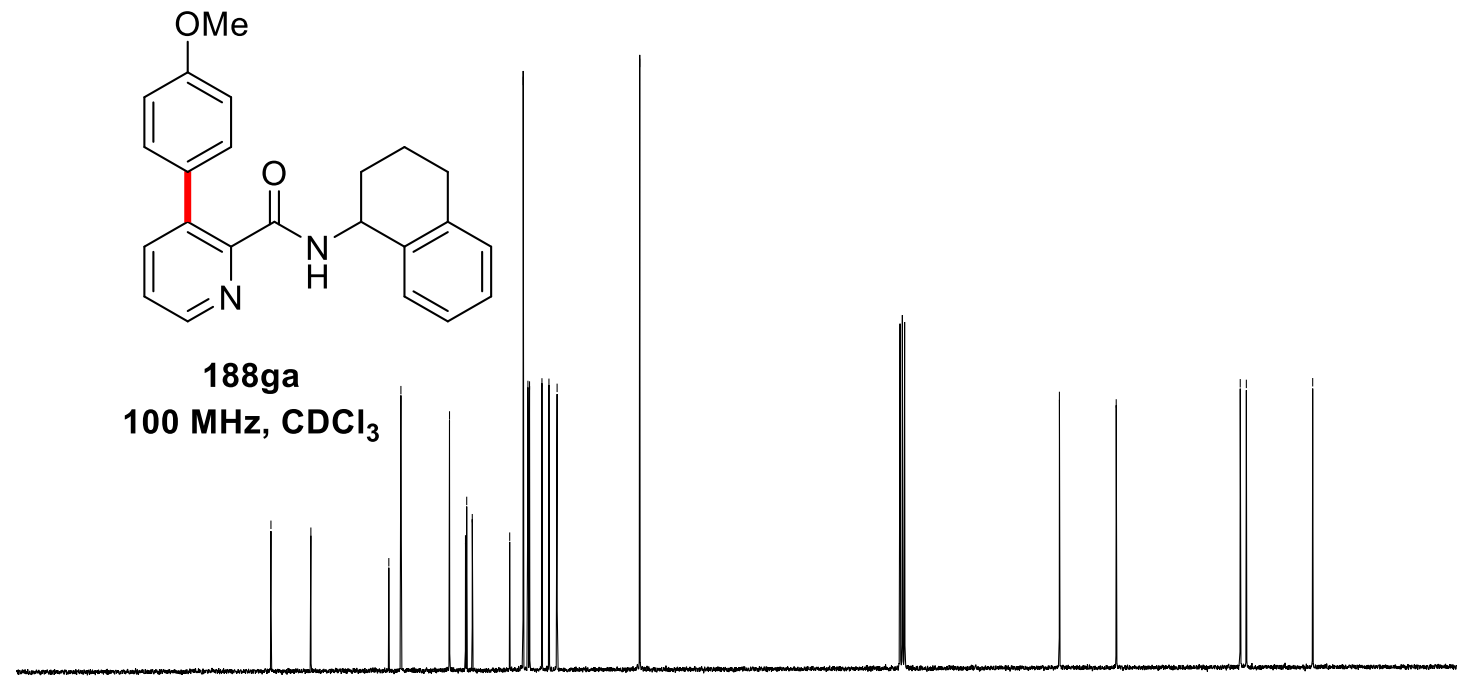

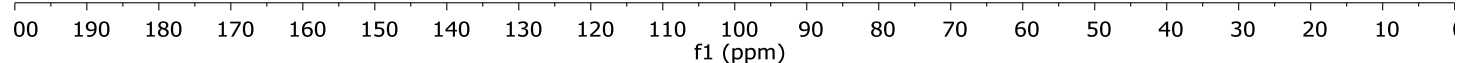


<smiles>COc1ccc(-c2cccnc2C(=O)NCCc2ccccc2)cc1</smiles>

188ha

$500 \mathrm{MHz}, \mathrm{CDCl}_{3}$

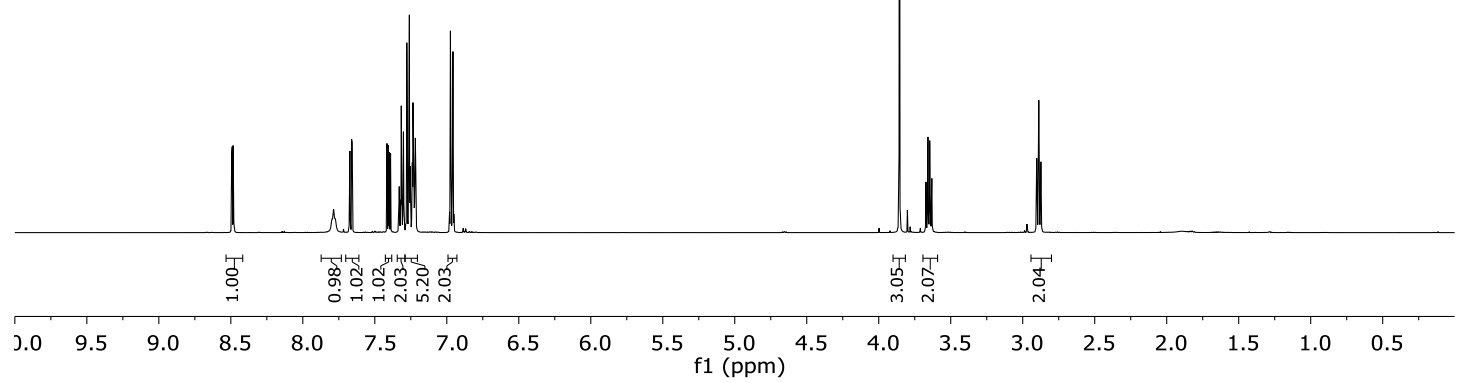

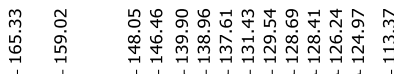<smiles>COc1ccc(-c2cccnc2C(=O)NCCc2ccccc2)cc1</smiles>

188ha $125 \mathrm{MHz} \mathrm{CDCl}_{3}$

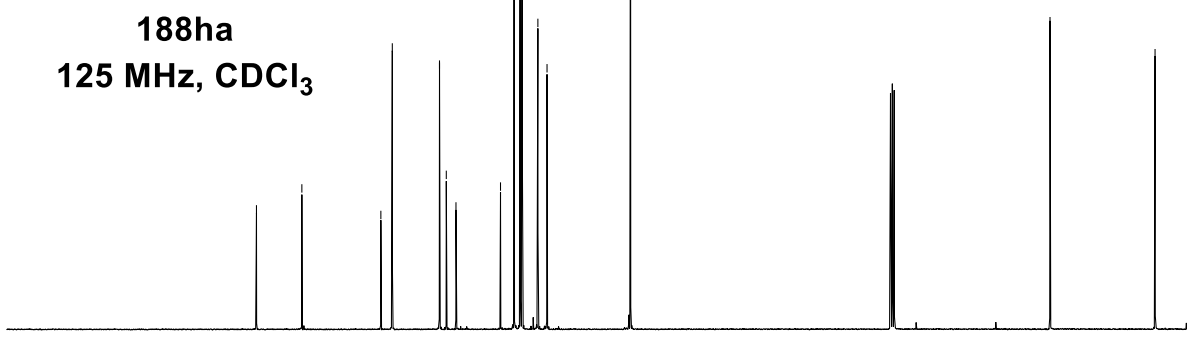

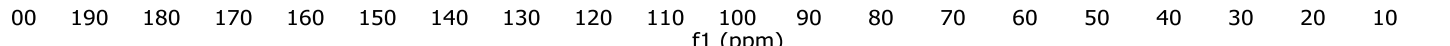



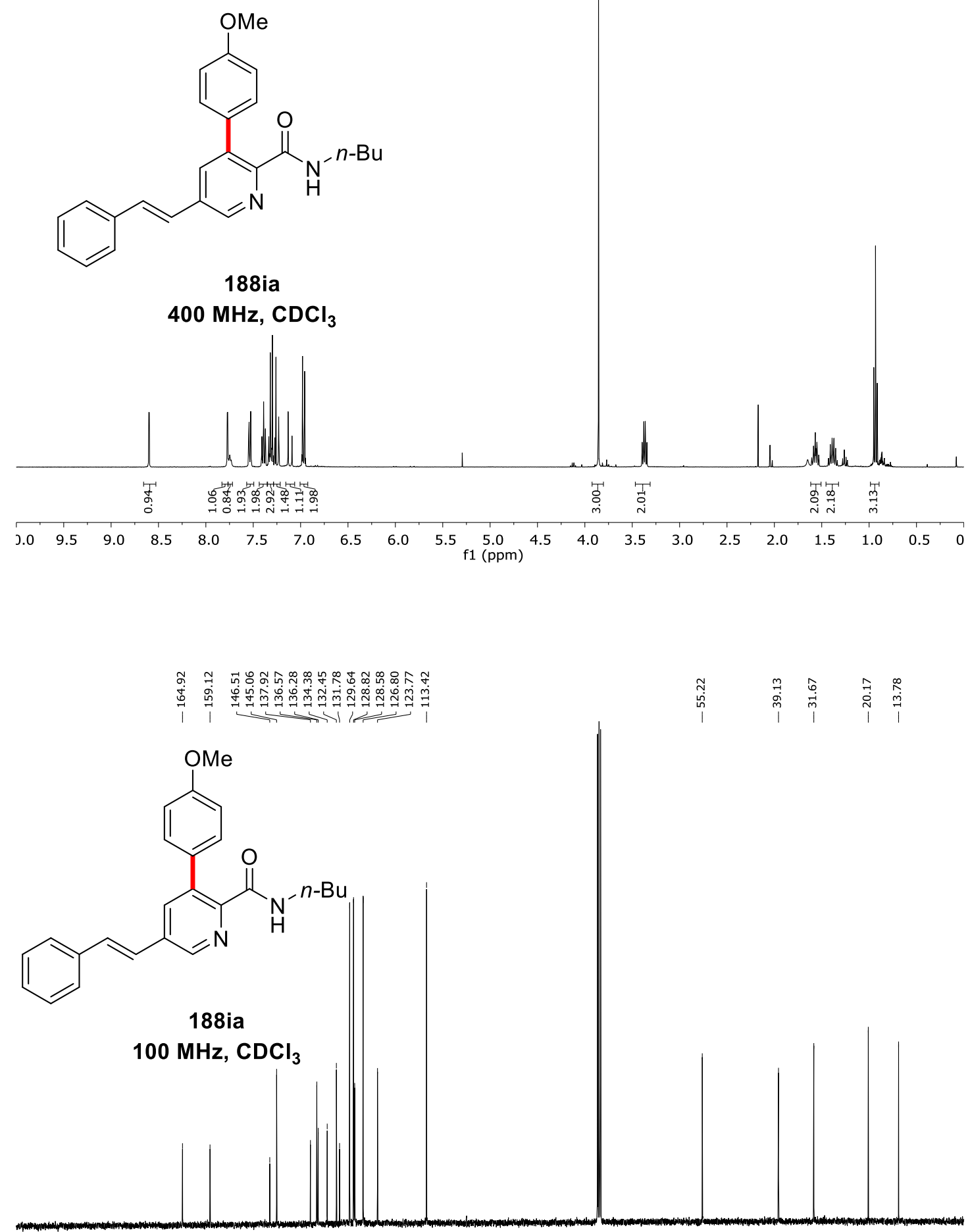

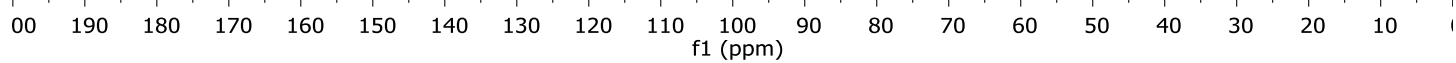


<smiles>COc1ccc(-c2cccnc2C(=O)NC(C)c2ccccc2)cc1</smiles>

188ja

$400 \mathrm{MHz}, \mathrm{CDCl}_{3}$

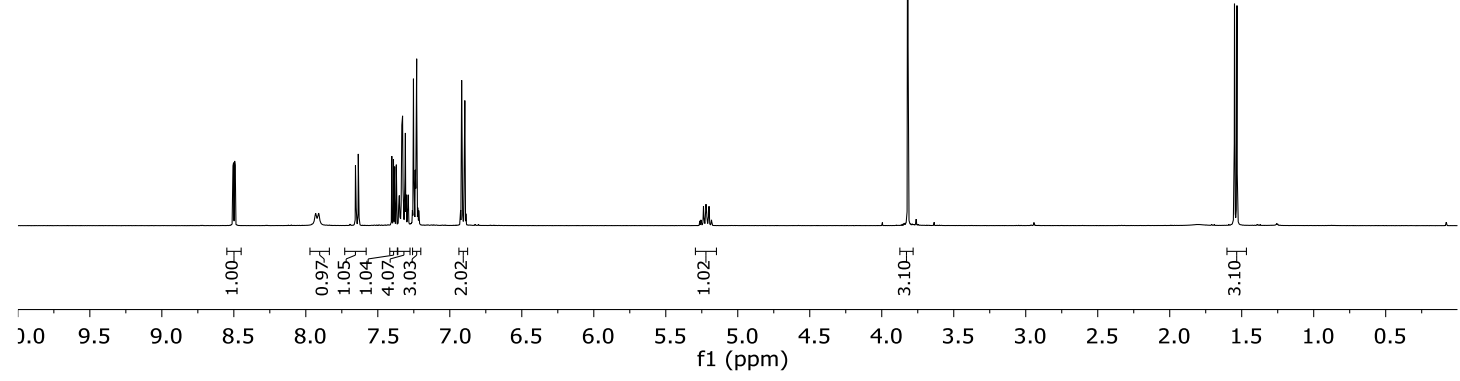

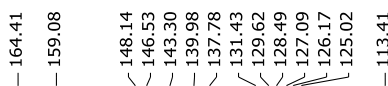

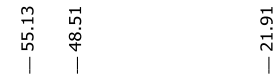<smiles>COc1ccc(-c2cccnc2C(=O)NC(C)c2ccccc2)cc1</smiles>

188ja

$100 \mathrm{MHz}, \mathrm{CDCl}_{3}$

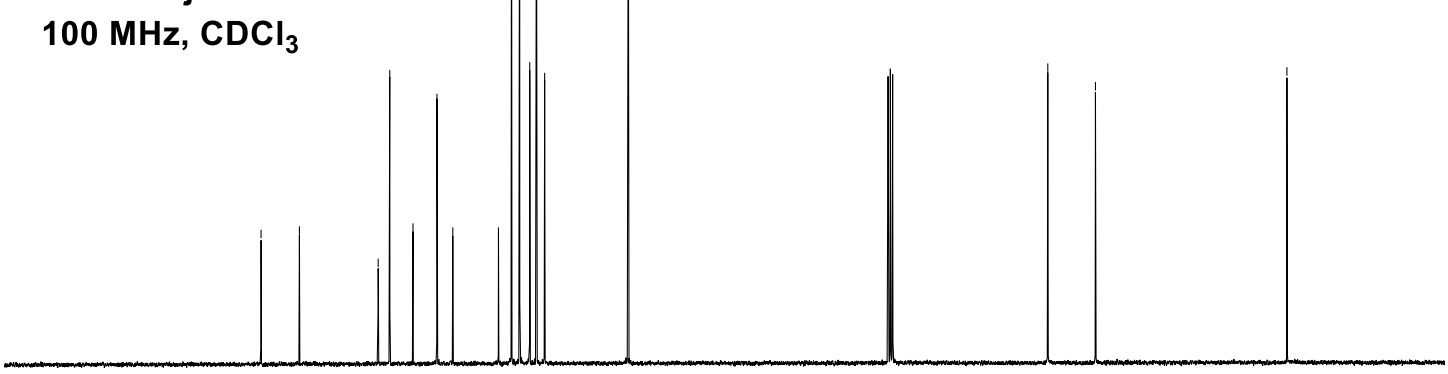

$\begin{array}{lllllllllllllllllll}00 & 190 & 180 & 170 & 160 & 150 & 140 & 130 & 120 & 110 \underset{\mathrm{f} 1(\mathrm{ppm})}{100} & 90 & 80 & 70 & 60 & 50 & 40 & 30 & 20 & 10\end{array}$ 
<smiles>CCCCNC(=O)c1ncc(-c2ccccc2)cc1-c1ccc(OC)cc1</smiles><smiles>CC[AlH2]</smiles>

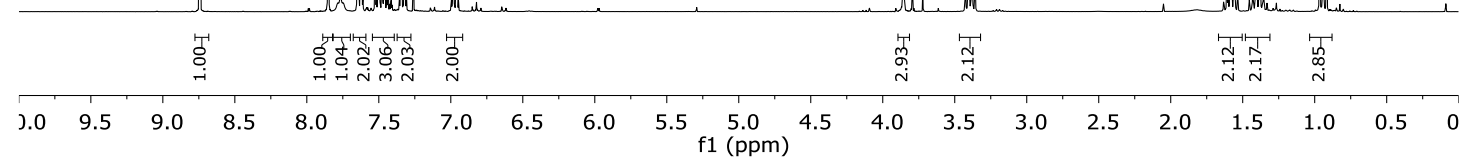

مू

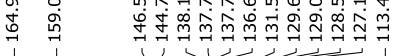<smiles>CCCCNC(=O)c1ncc(-c2ccccc2)cc1-c1ccc(OC)cc1</smiles>

$100 \mathrm{MHz}, \mathrm{CDCl}_{3}$

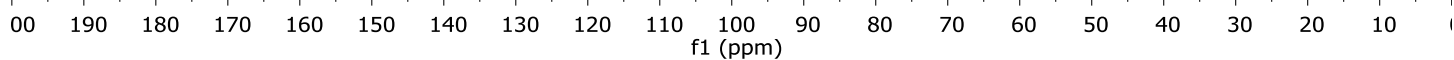


<smiles>CCCCNC(=O)c1cnccc1-c1ccc(OC)cc1</smiles>

188la

$400 \mathrm{MHz}, \mathrm{CDCl}_{3}$

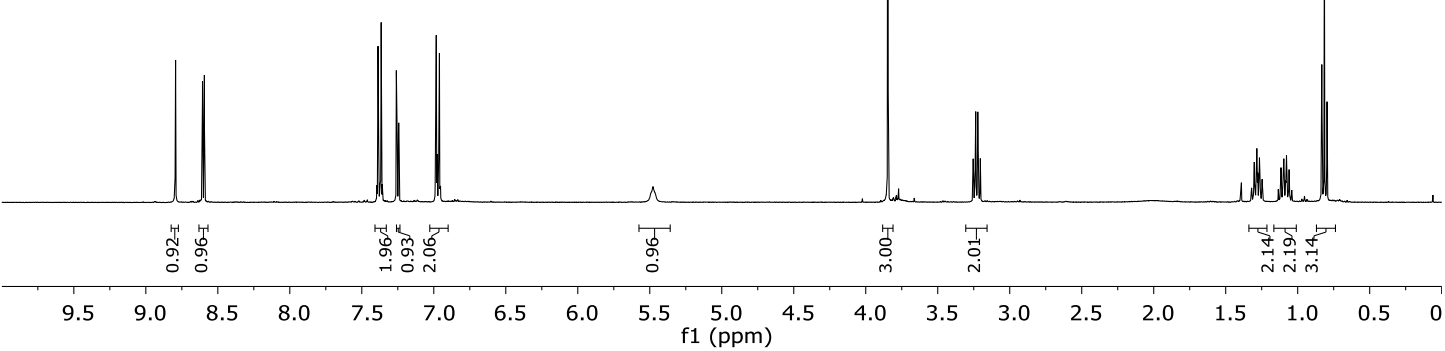

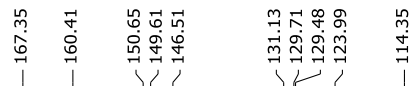

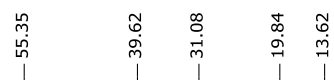<smiles>CCCCNC(=O)c1cnccc1-c1ccc(OC)cc1</smiles>

188la

$100 \mathrm{MHz}^{\mathrm{CDCl}} \mathrm{CDC}_{3}$

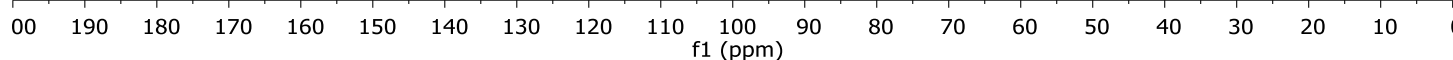


<smiles>CCCCNC(=O)c1cncc(C)c1-c1ccc(OC)cc1</smiles>

$188 \mathrm{ma}$ $400 \mathrm{MHz}, \mathrm{CDCl}_{3}$<smiles>CCCCNC(=O)c1cncc(C)c1-c1ccc(OC)cc1</smiles>

$188 \mathrm{ma}$ $125 \mathrm{MHz}^{\mathrm{CDCl}_{3}}$

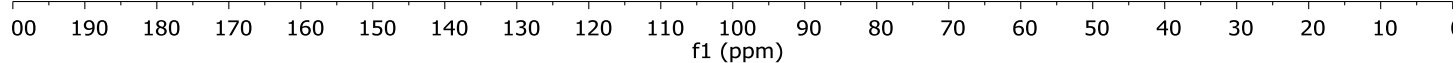


<smiles>CCCCNC(=O)c1ccncc1-c1ccc(OC)cc1</smiles>

188na

$400 \mathrm{MHz}, \mathrm{CDCl}_{3}$

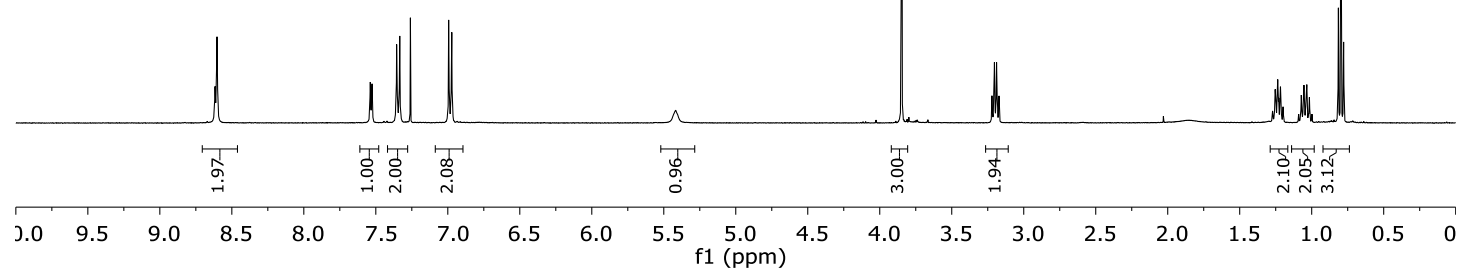

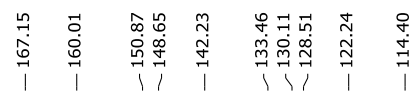<smiles>CCCCNC(=O)c1ccncc1-c1ccc(OC)cc1</smiles>

188na

$100 \mathrm{MHz}, \mathrm{CDCl}_{3}$

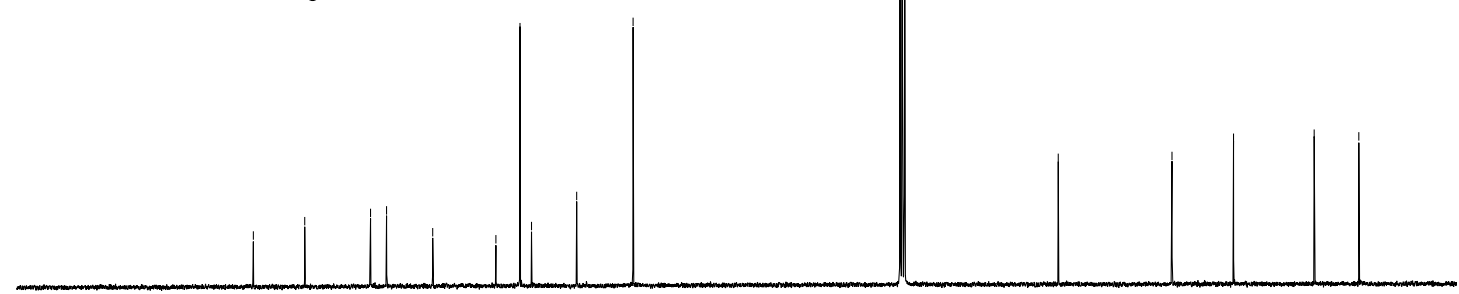

$\begin{array}{llllllllllllllllllll}00 & 190 & 180 & 170 & 160 & 150 & 140 & 130 & 120 & 110 \underset{\mathrm{f} 1}{100}(\mathrm{ppm}) & 90 & 80 & 70 & 60 & 50 & 40 & 30 & 20 & 10 & 1\end{array}$ 
<smiles>COc1ccc(-c2cnccc2C(=O)NCc2ccccc2)cc1</smiles>

$1880 a$

$400 \mathrm{MHz}, \mathrm{CDCl}_{3}$

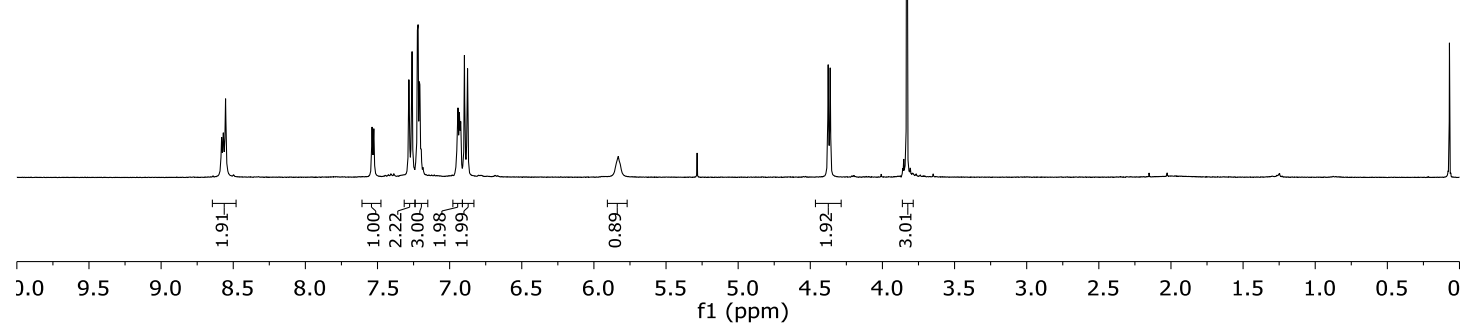

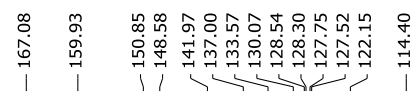<smiles>COc1ccc(-c2cnccc2C(=O)NCc2ccccc2)cc1</smiles>

$1880 a$

$100 \mathrm{MHz}, \mathrm{CDCl}_{3}$

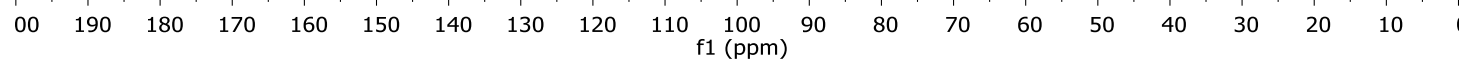


<smiles>CCCCNC(=O)c1ncncc1-c1ccc(OC)cc1</smiles>

188pa

$400 \mathrm{MHz}, \mathrm{CDCl}_{3}$

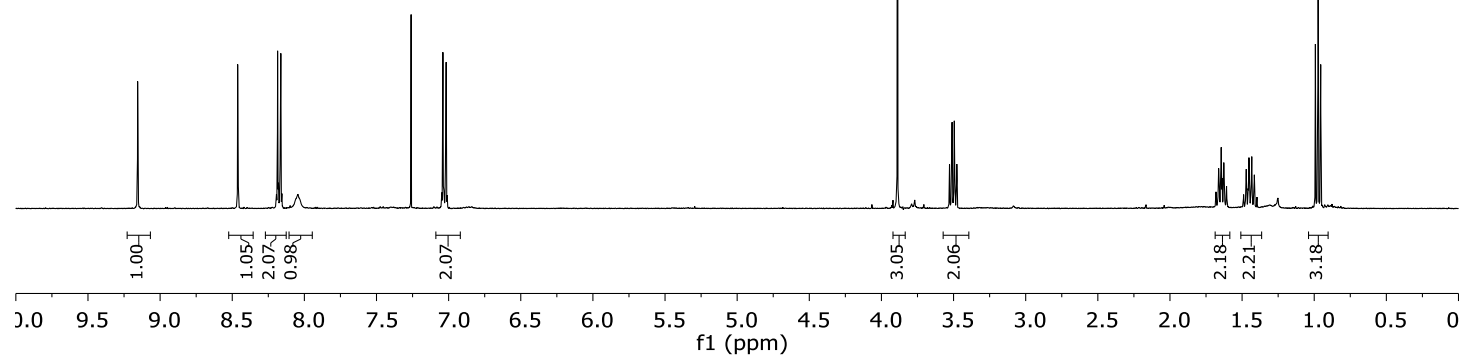

웅ํํㄴํํ유

ம்

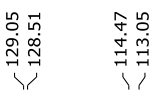

นุ

$\stackrel{m}{\sim} \stackrel{m}{\stackrel{m}{m}}$<smiles>CCCCNC(=O)c1ncncc1-c1ccc(OC)cc1</smiles>

188pa $100 \mathrm{MHz} \mathrm{CDCl}_{3}$

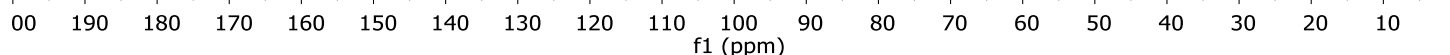




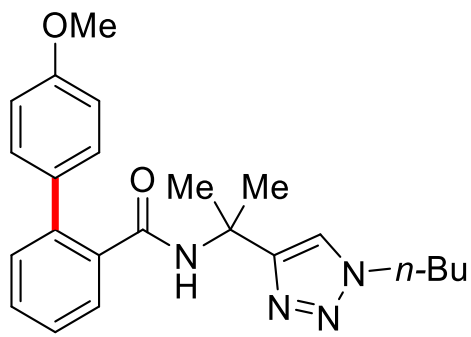

192

$400 \mathrm{MHz}^{\mathrm{CDCl}_{3}}$

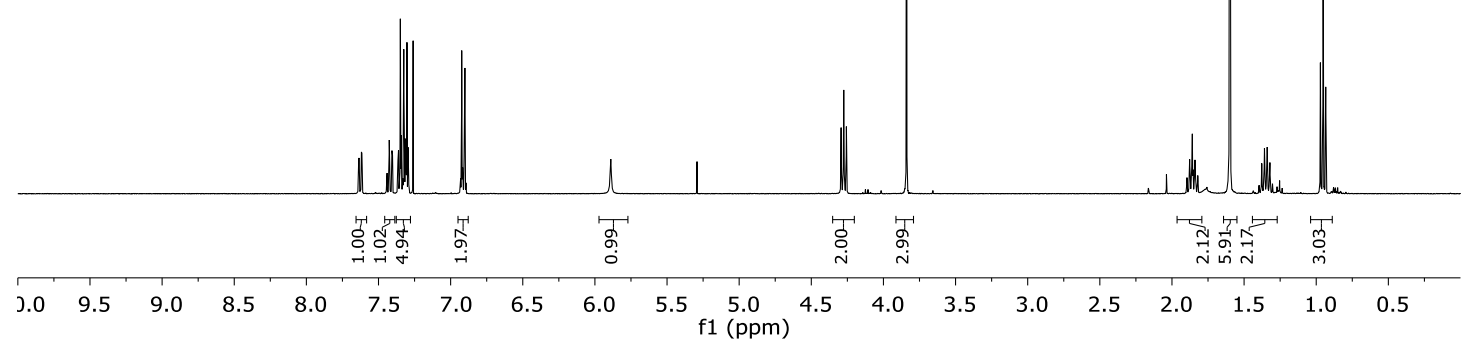

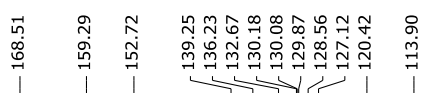

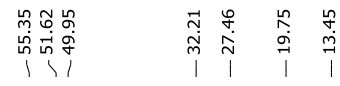<smiles>COc1ccc(-c2ccccc2C(=O)NC(C)(C)c2cn(P)nn2)cc1</smiles>

192

$100 \mathrm{MHz}^{\mathrm{CDCl}_{3}}$

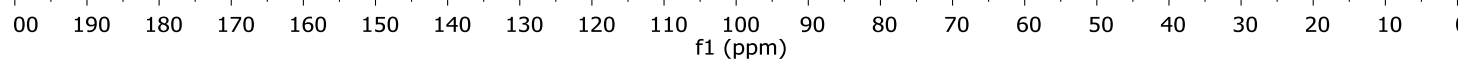




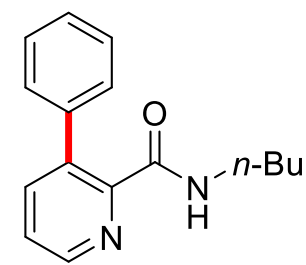

188ab

$400 \mathrm{MHz}^{\mathrm{CDCl}_{3}}$

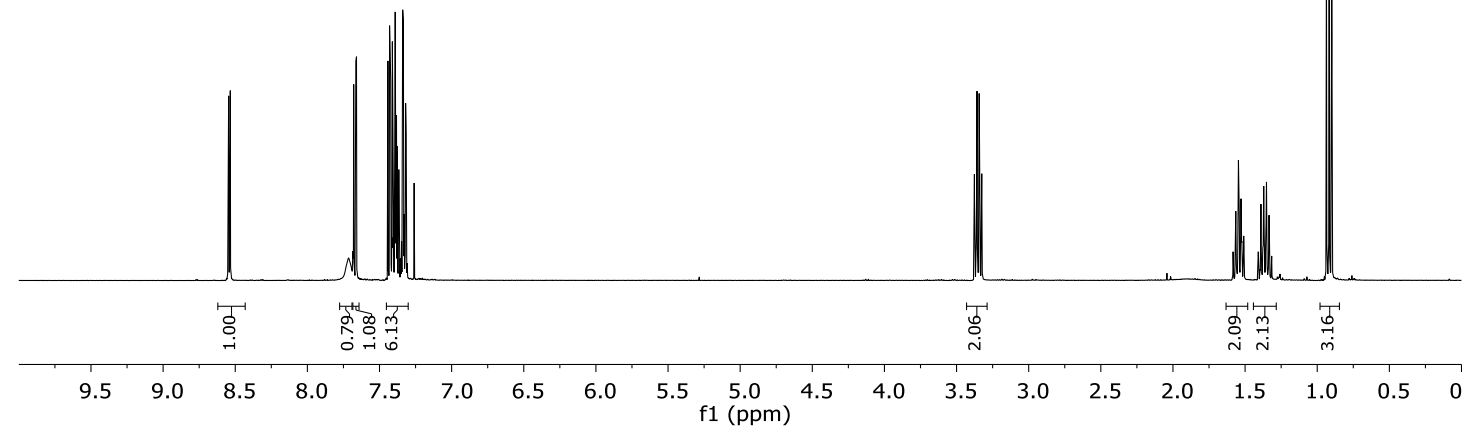

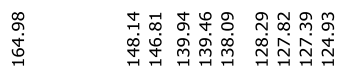

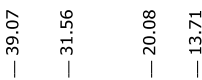<smiles>CCCCONC(=O)c1ncccc1-c1ccccc1</smiles>

188ab

$100 \mathrm{MHz}^{\mathrm{CDCl}_{3}}$

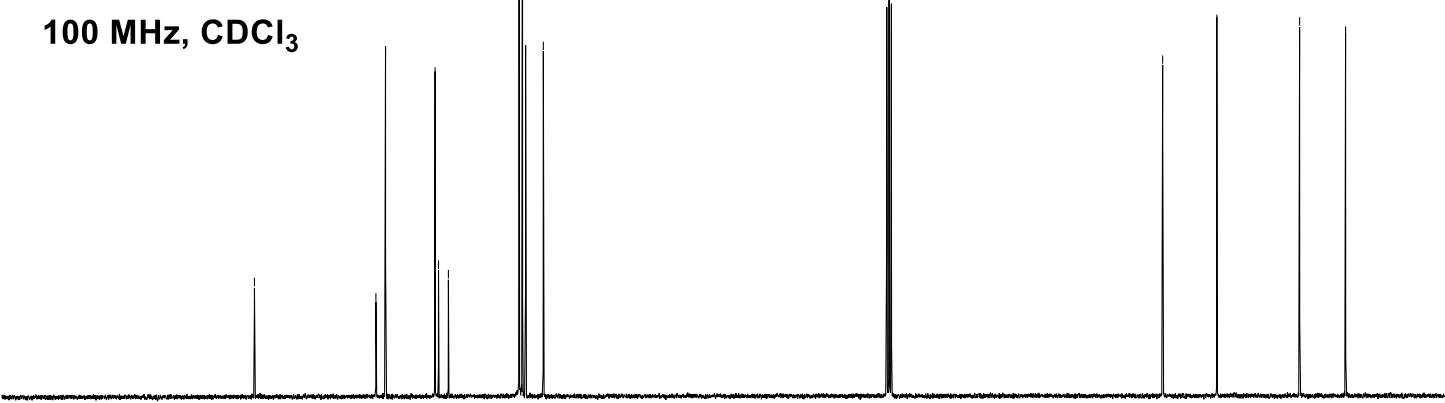

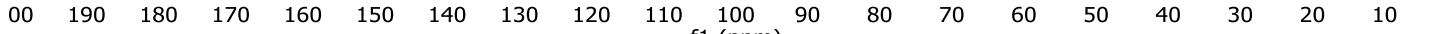



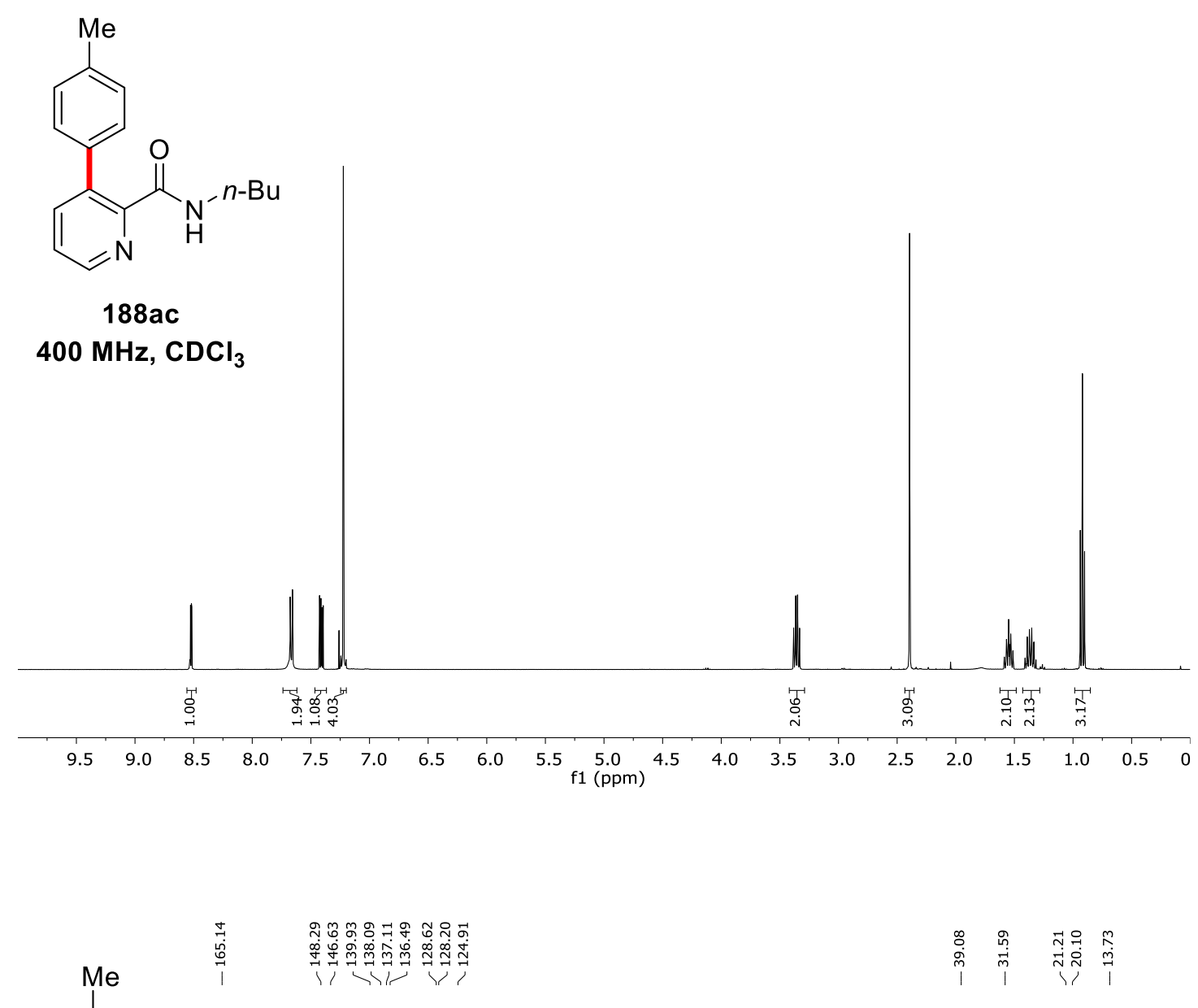<smiles>CCCCCNC(=O)c1ncccc1-c1ccc(C)cc1</smiles>

188ac

$100 \mathrm{MHz}, \mathrm{CDCl}_{3}$

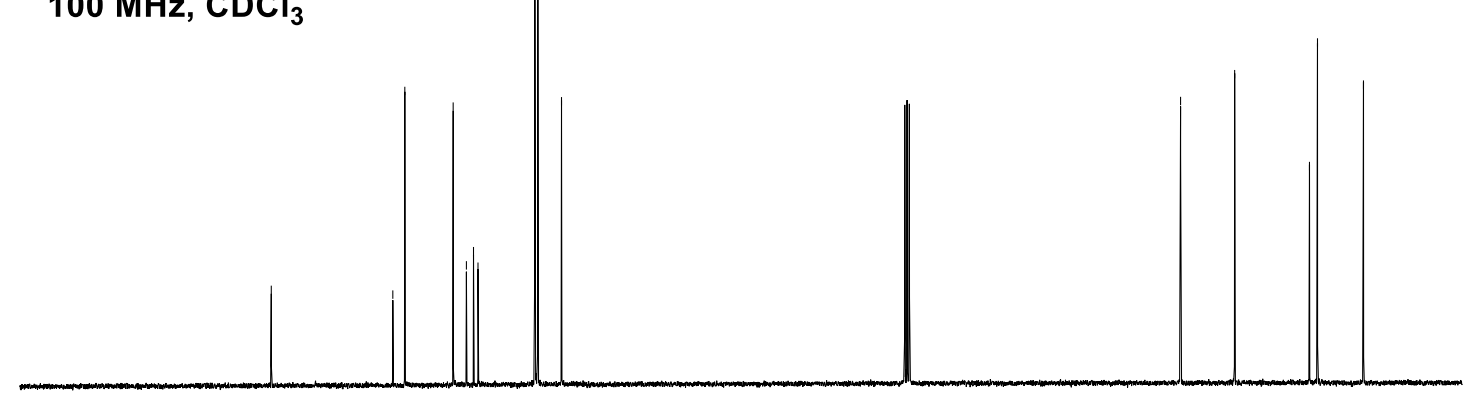

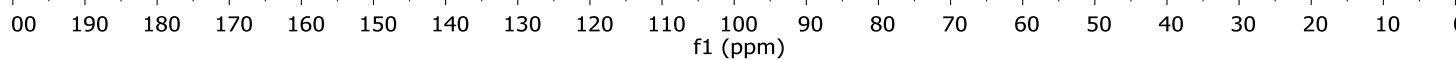


<smiles>CCCCNC(=O)c1ncccc1-c1ccc(C(C)(C)C)cc1</smiles>

188ad

$400 \mathrm{MHz}, \mathrm{CDCl}_{3}$

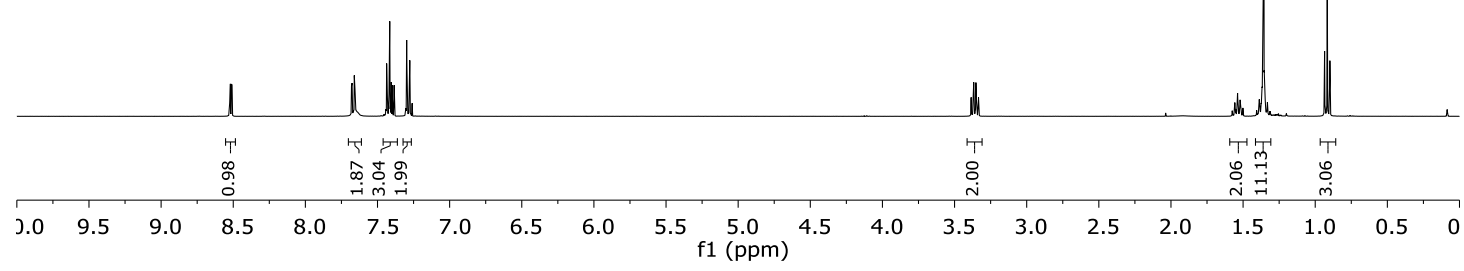<smiles>CCCCNC(=O)c1ncccc1-c1ccc(C(C)(C)C)cc1</smiles>

188ad $100 \mathrm{MHz} \mathrm{CDCl}_{3}$

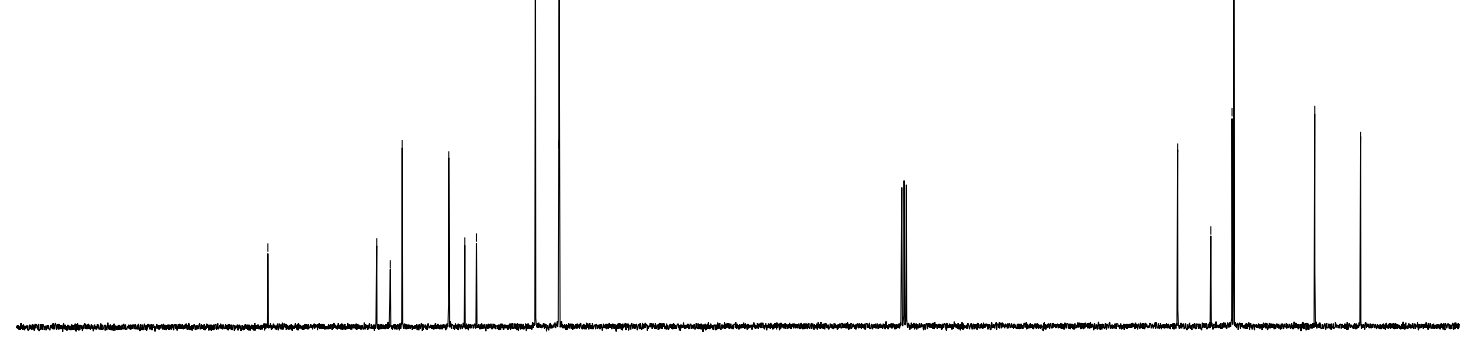

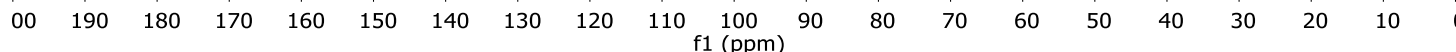




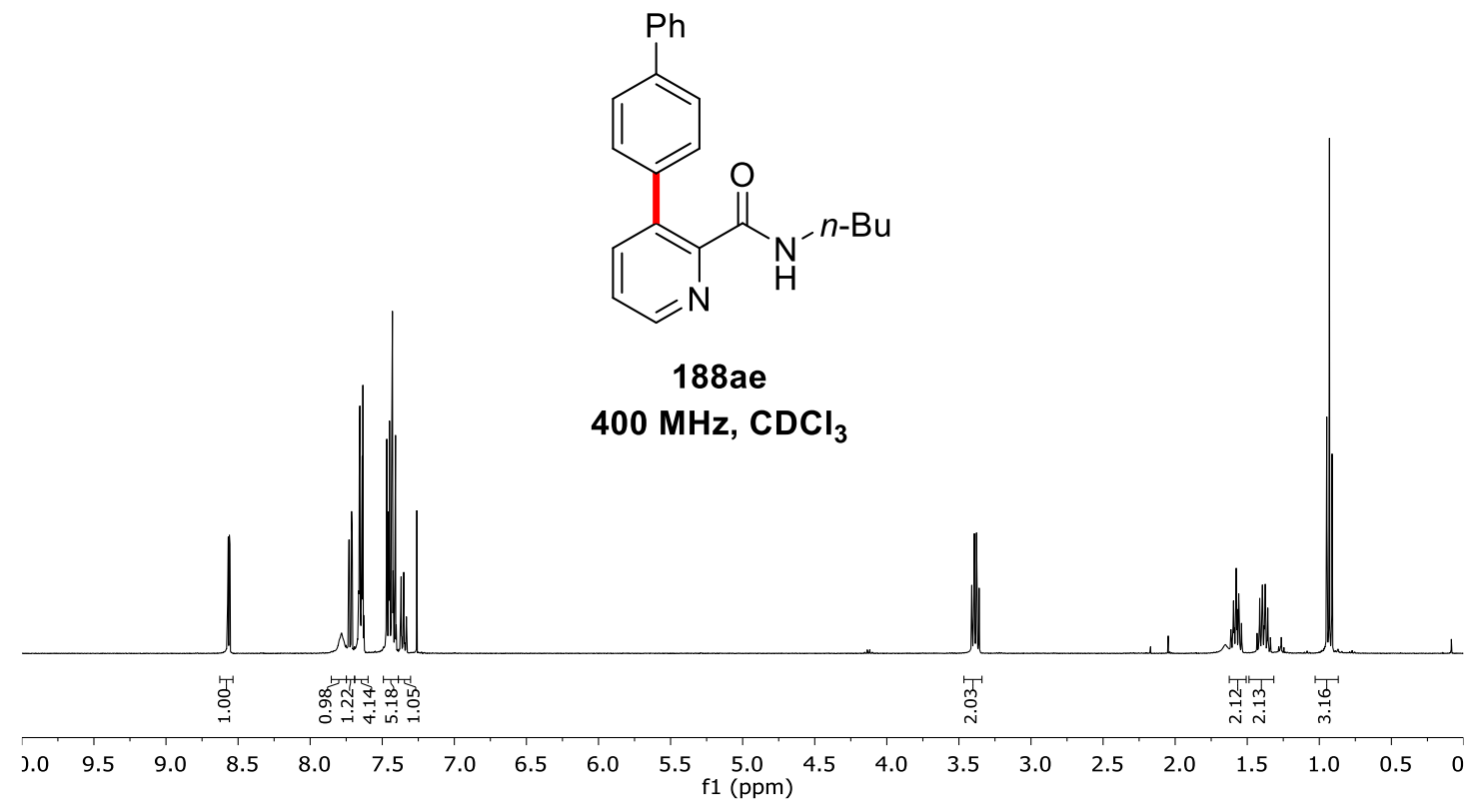

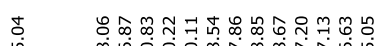

l

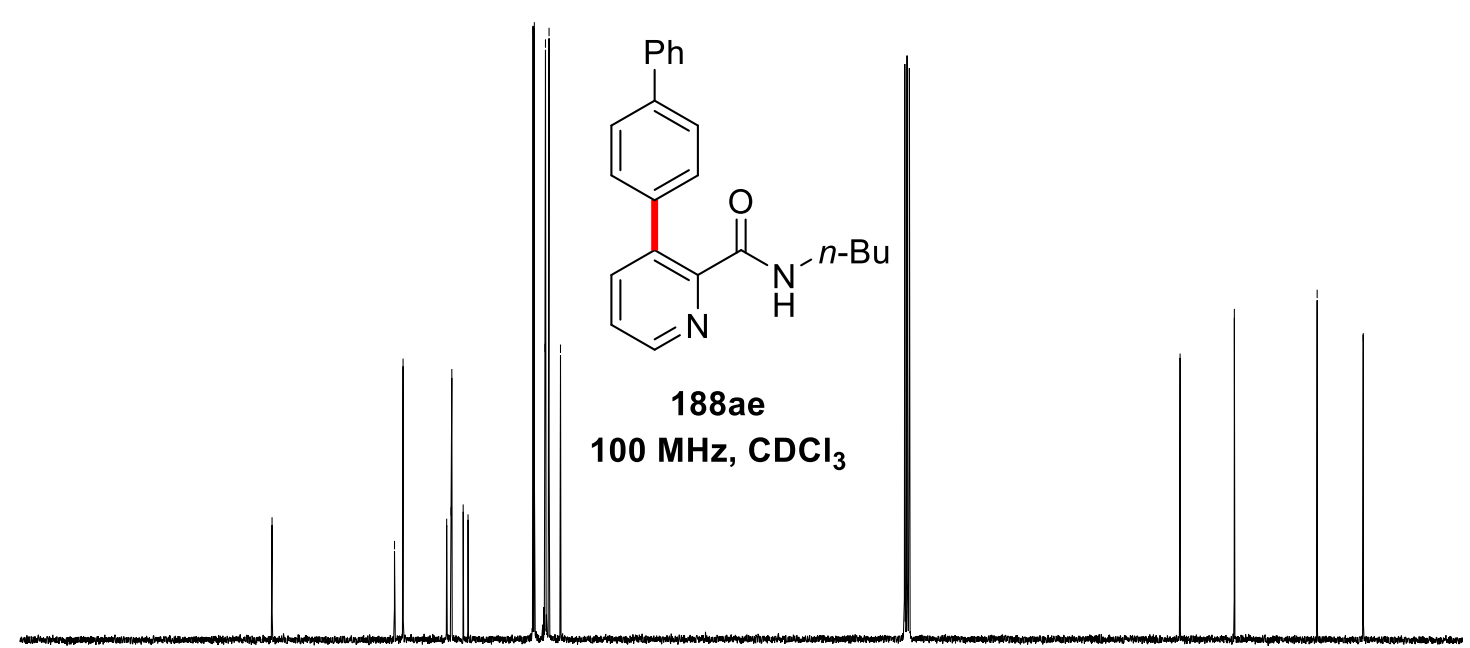

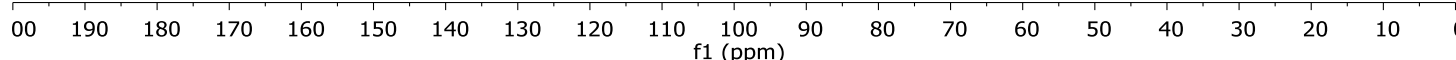



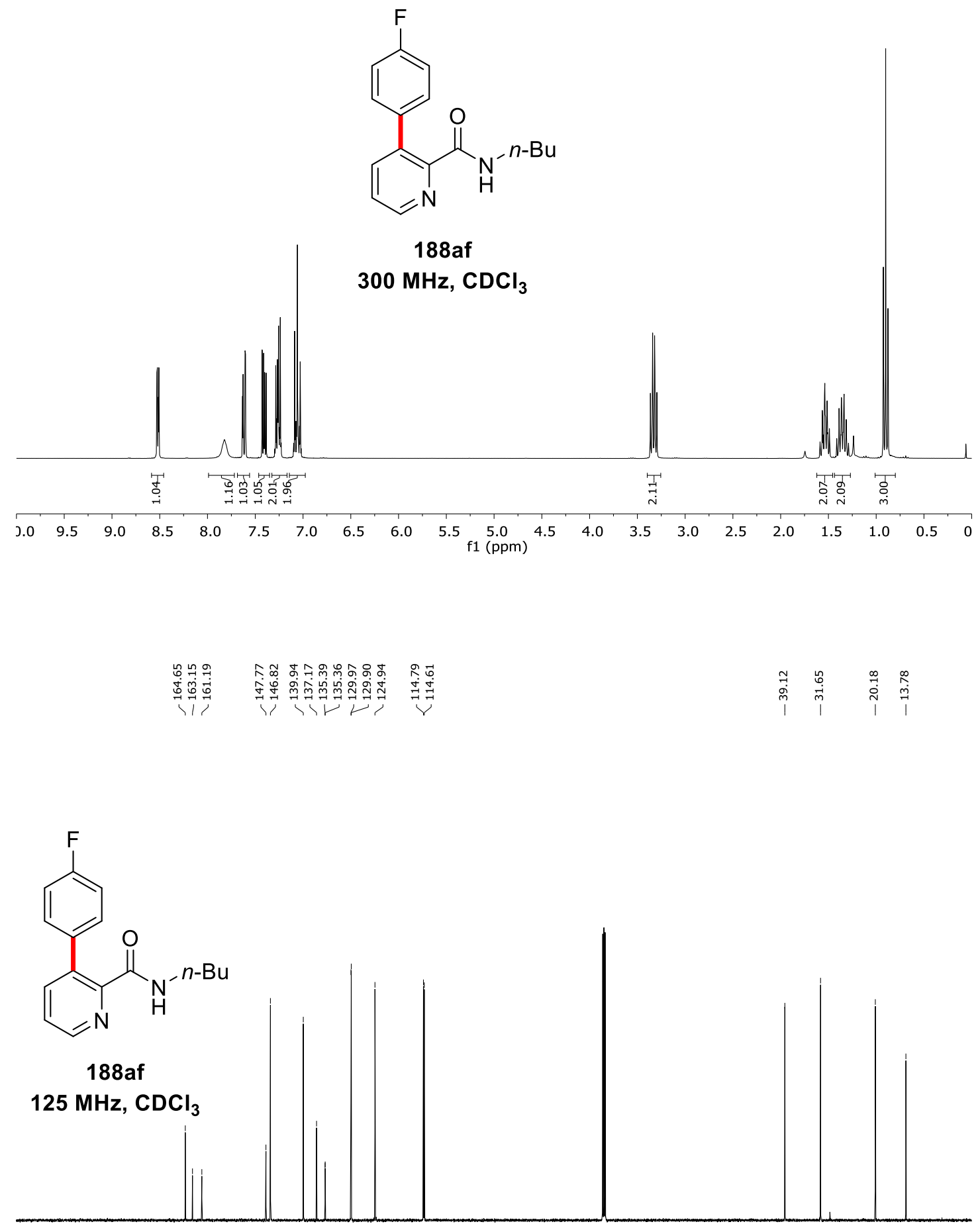

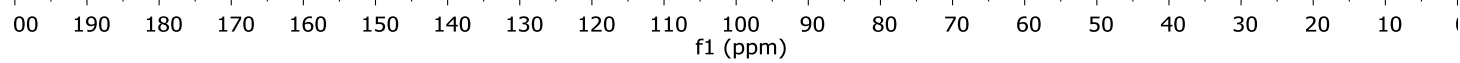




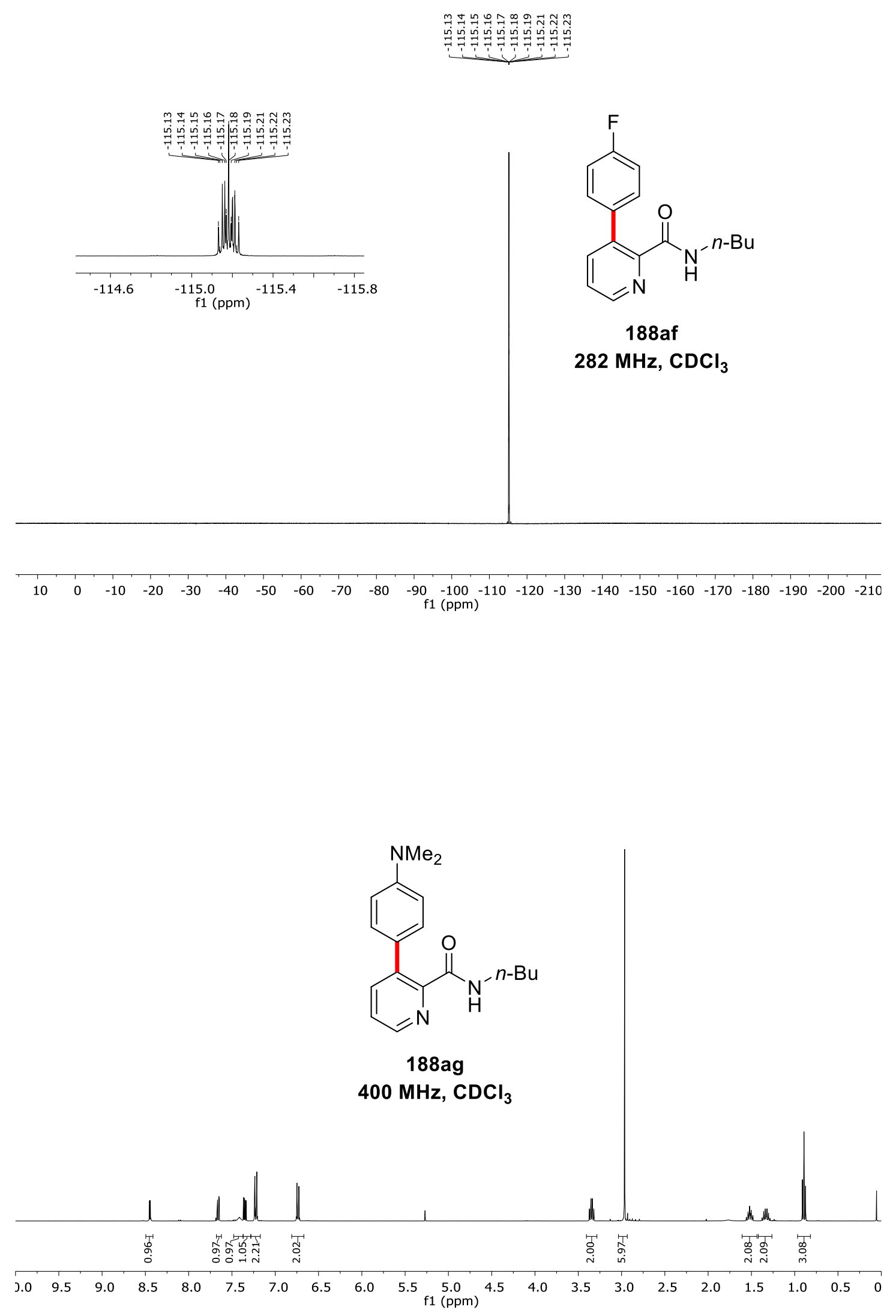




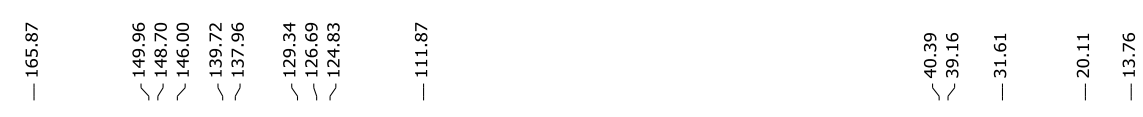

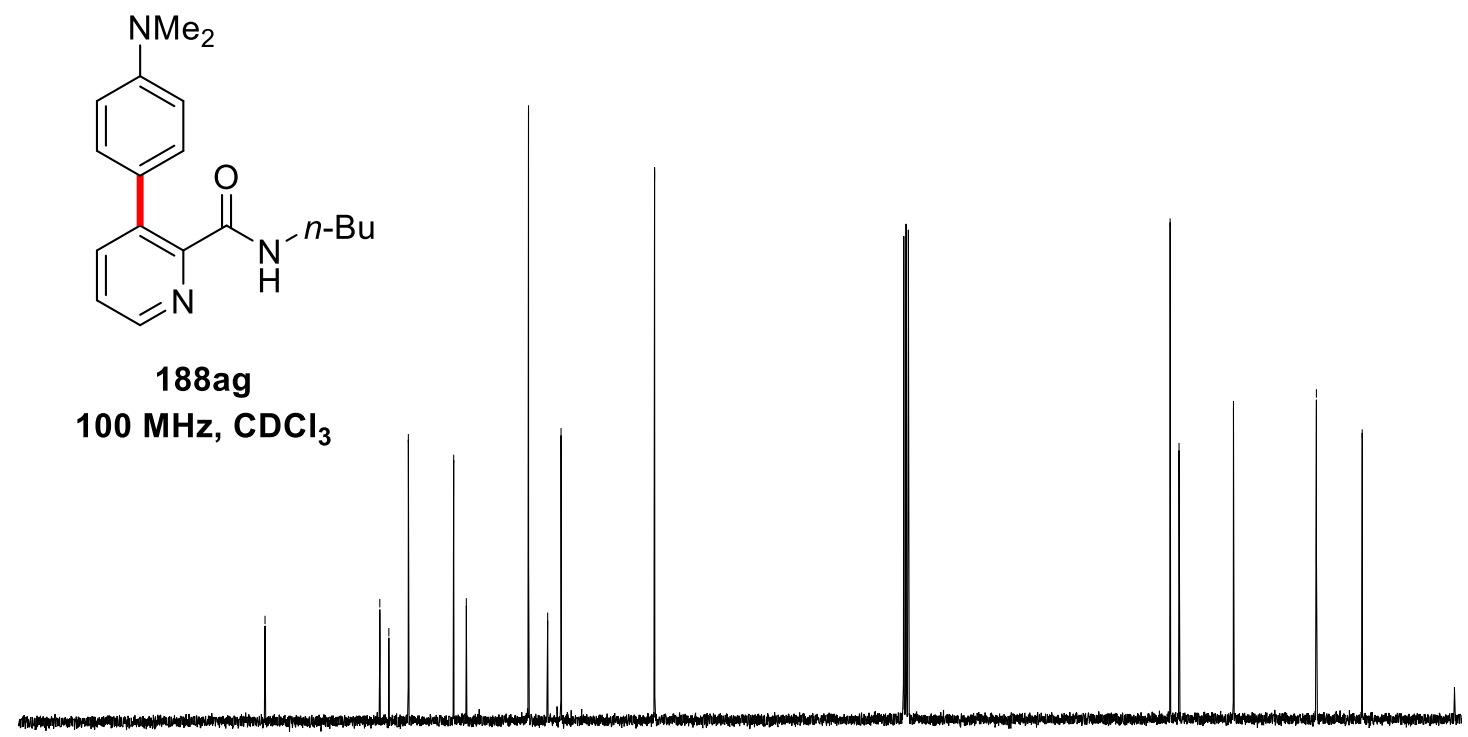

$\begin{array}{lllllllllllllllllll}00 & 190 & 180 & 170 & 160 & 150 & 140 & 130 & 120 & 110 \underset{\mathrm{f} 1(\mathrm{ppm})}{100} 90 & 80 & 70 & 60 & 50 & 40 & 30 & 20 & 10 & \end{array}$<smiles>CCCCNC(=O)c1ncccc1-c1cccc(OC)c1</smiles>

188ah

$400 \mathrm{MHz}, \mathrm{CDCl}_{3}$

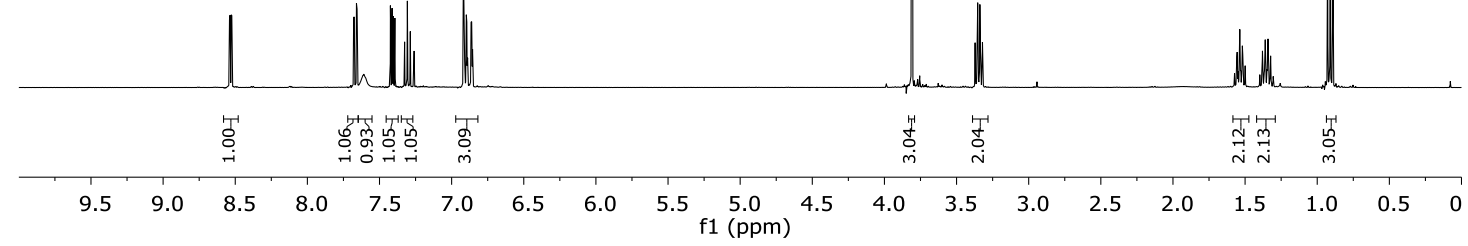




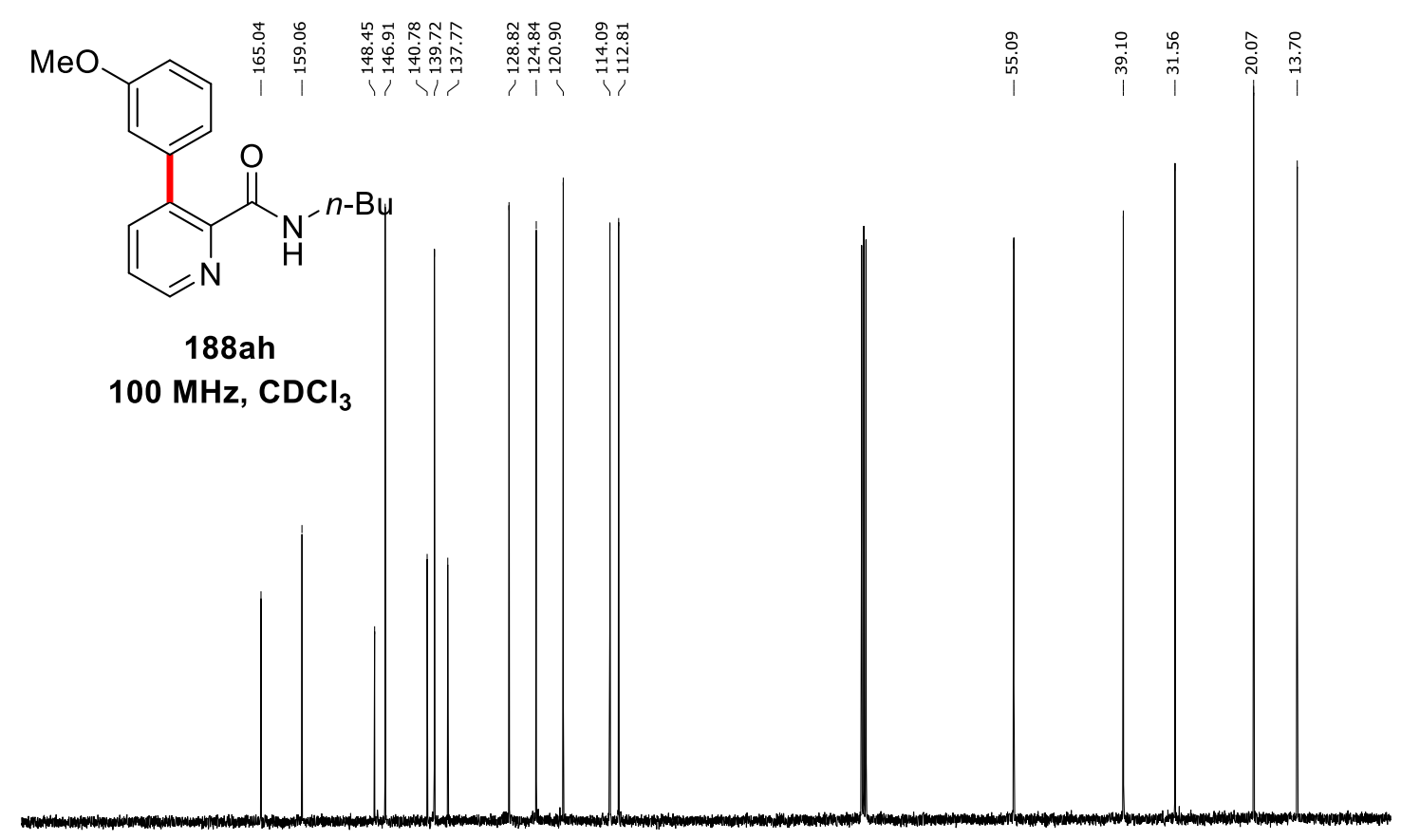

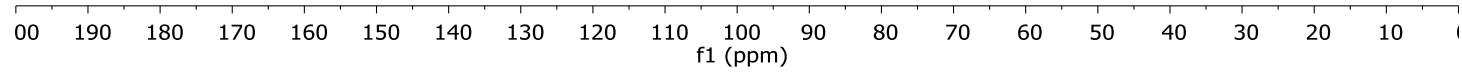<smiles>CCCCNC(=O)c1ncccc1-c1cccc(F)c1</smiles>

188ai

$400 \mathrm{MHz}, \mathrm{CDCl}_{3}$

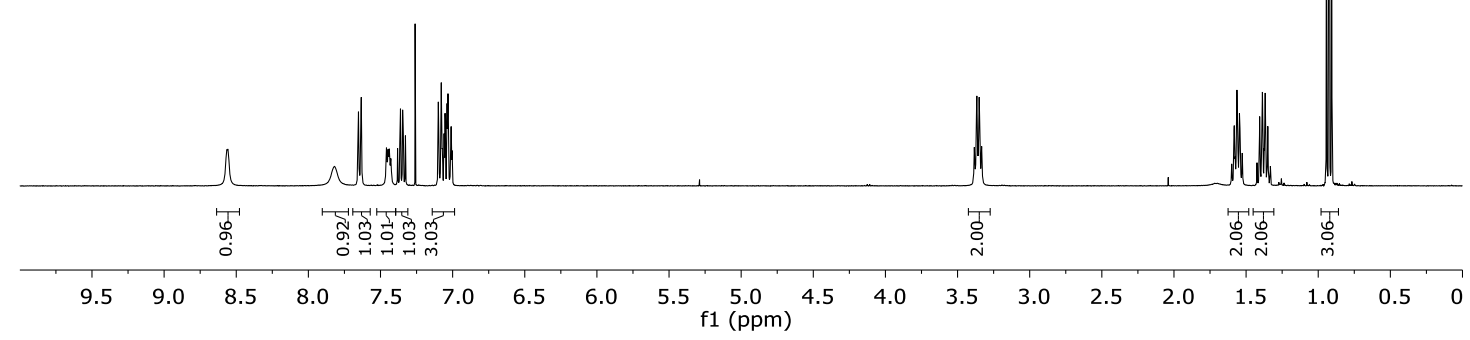




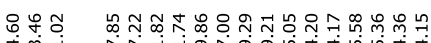

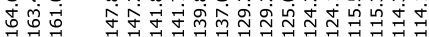

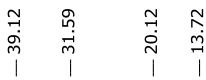

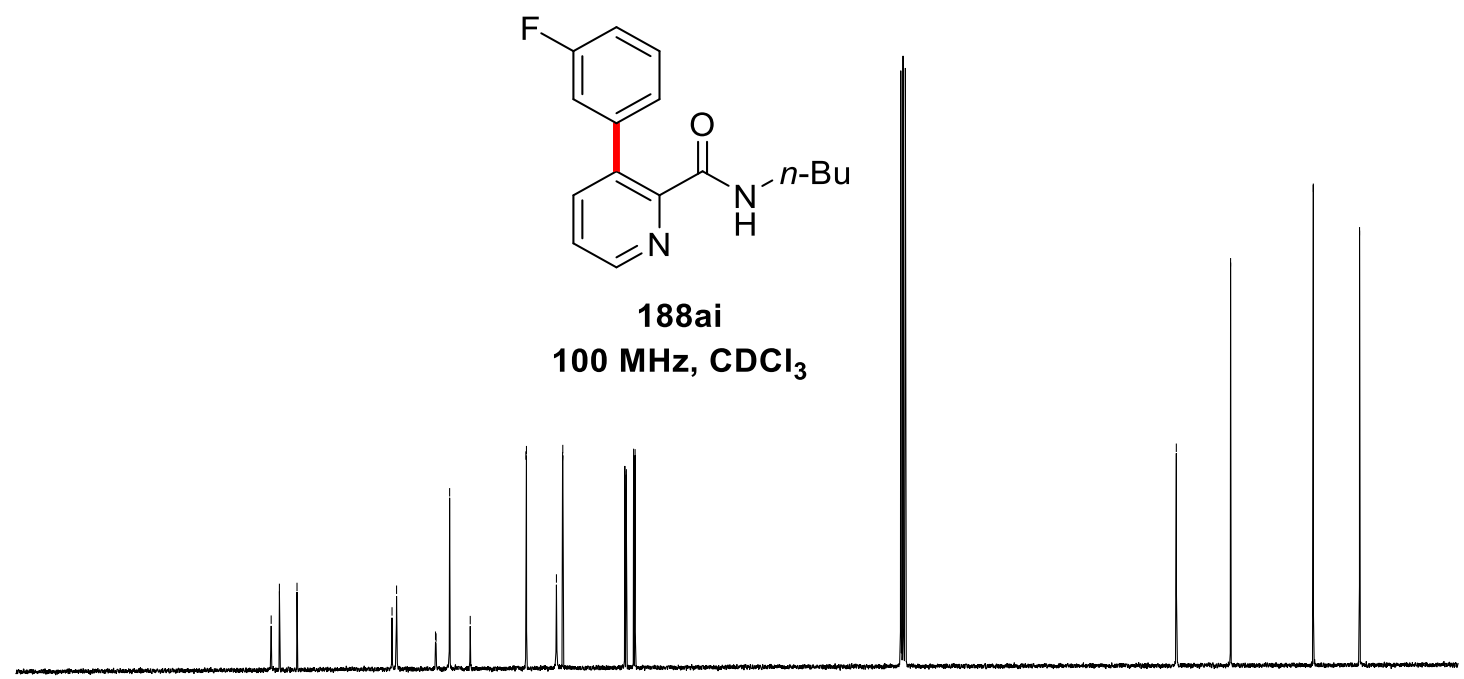

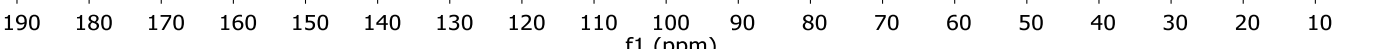

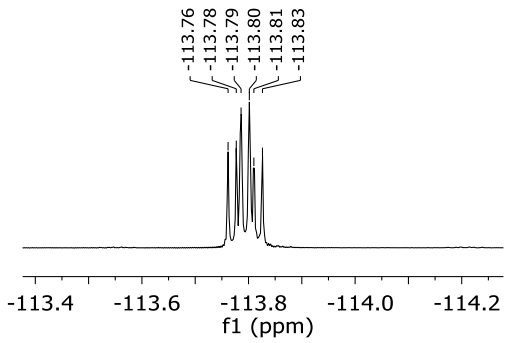<smiles>CCCCNC(=O)c1ncccc1-c1cccc(F)c1</smiles>

188ai

$376 \mathrm{MHz}^{\mathrm{CDCl}_{3}}$

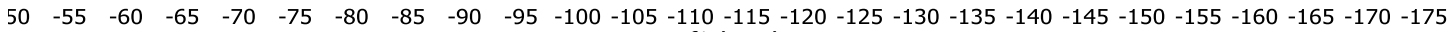
f1 (ppm) 


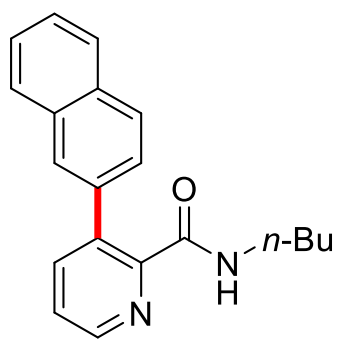

188aj

$400 \mathrm{MHz}, \mathrm{CDCl}_{3}$
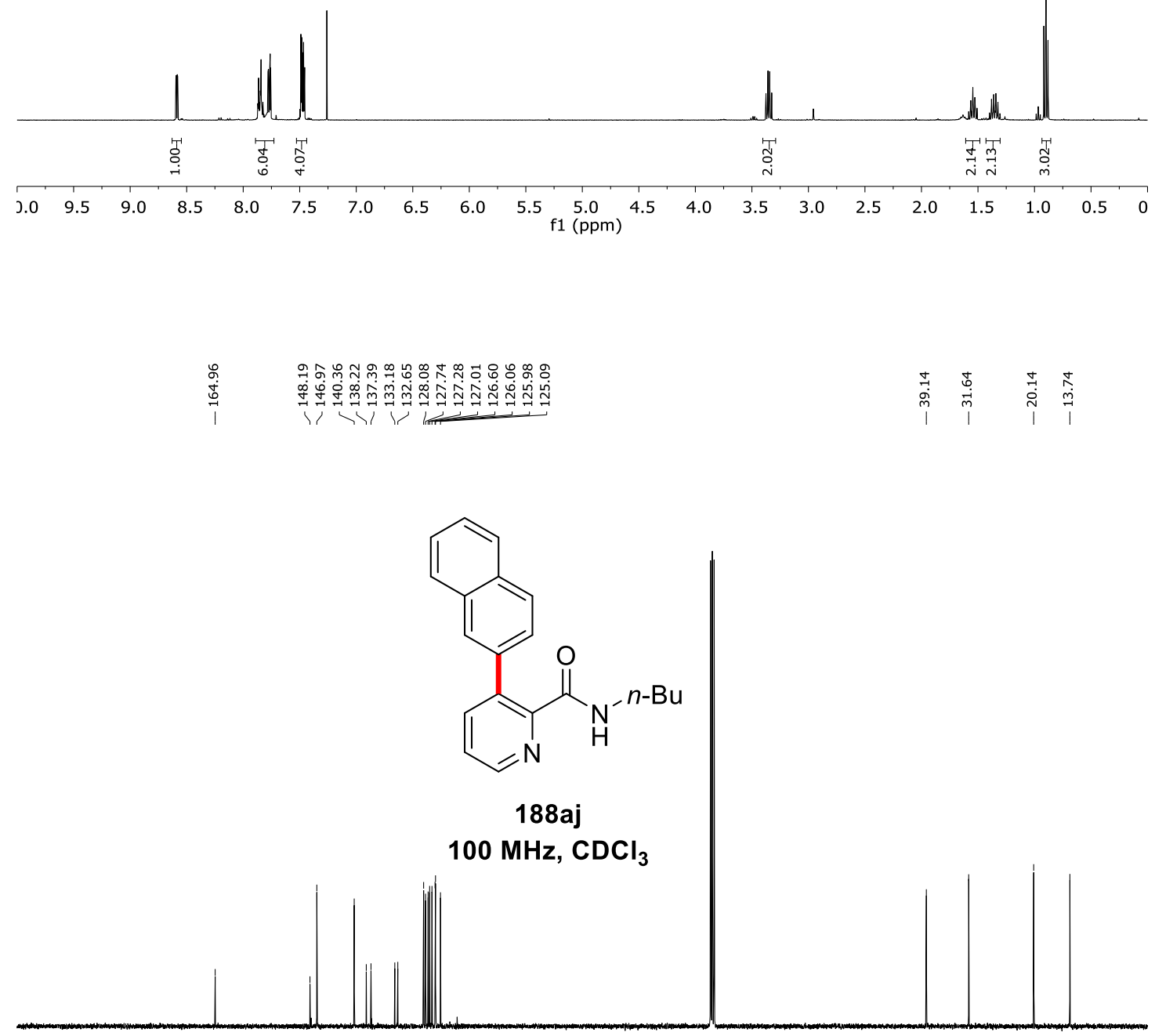

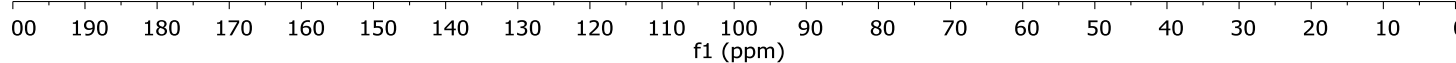


<smiles>CCCCNC(=O)c1ncccc1-c1ccsc1</smiles>

188ak

$400 \mathrm{MHz}, \mathrm{CDCl}_{3}$

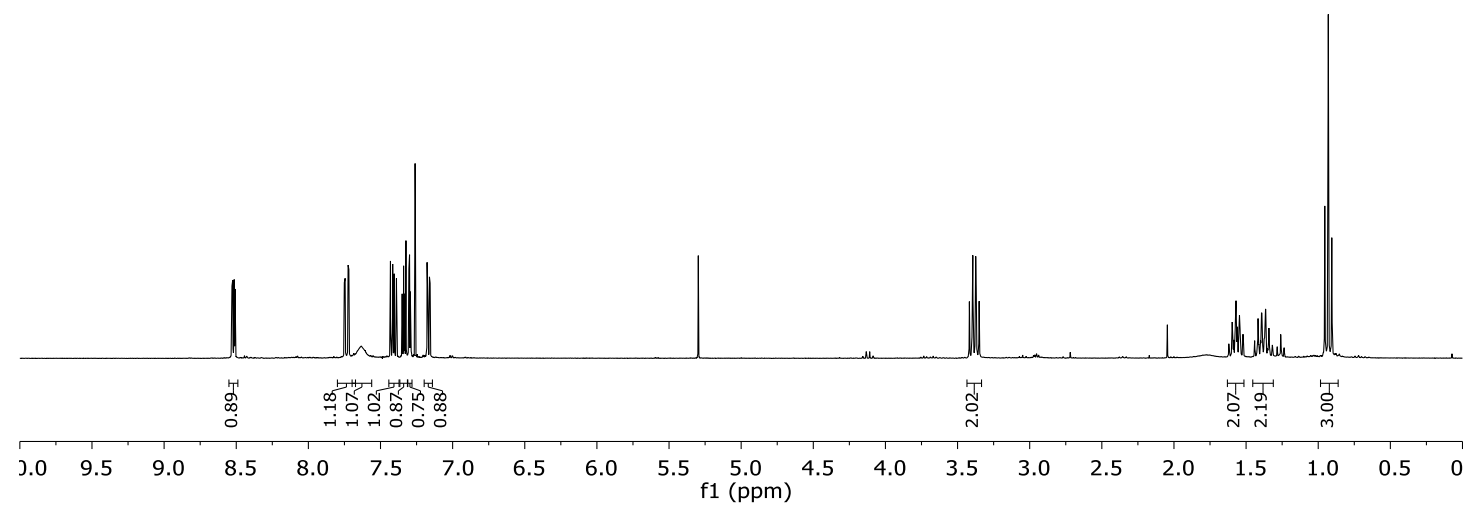

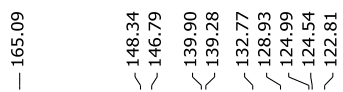

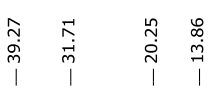<smiles>CCCCNC(=O)c1ncccc1-c1ccsc1</smiles>

188ak

$126 \mathrm{MHz}, \mathrm{CDCl}_{3}$

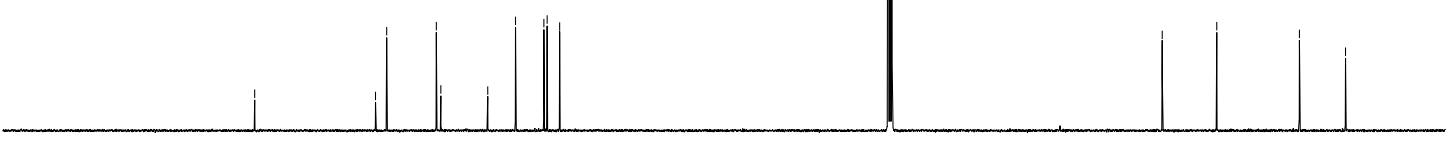

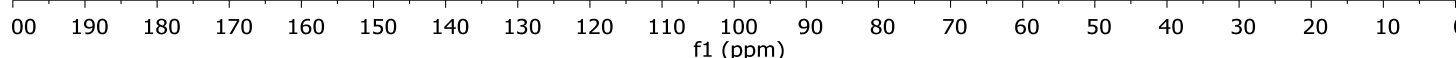



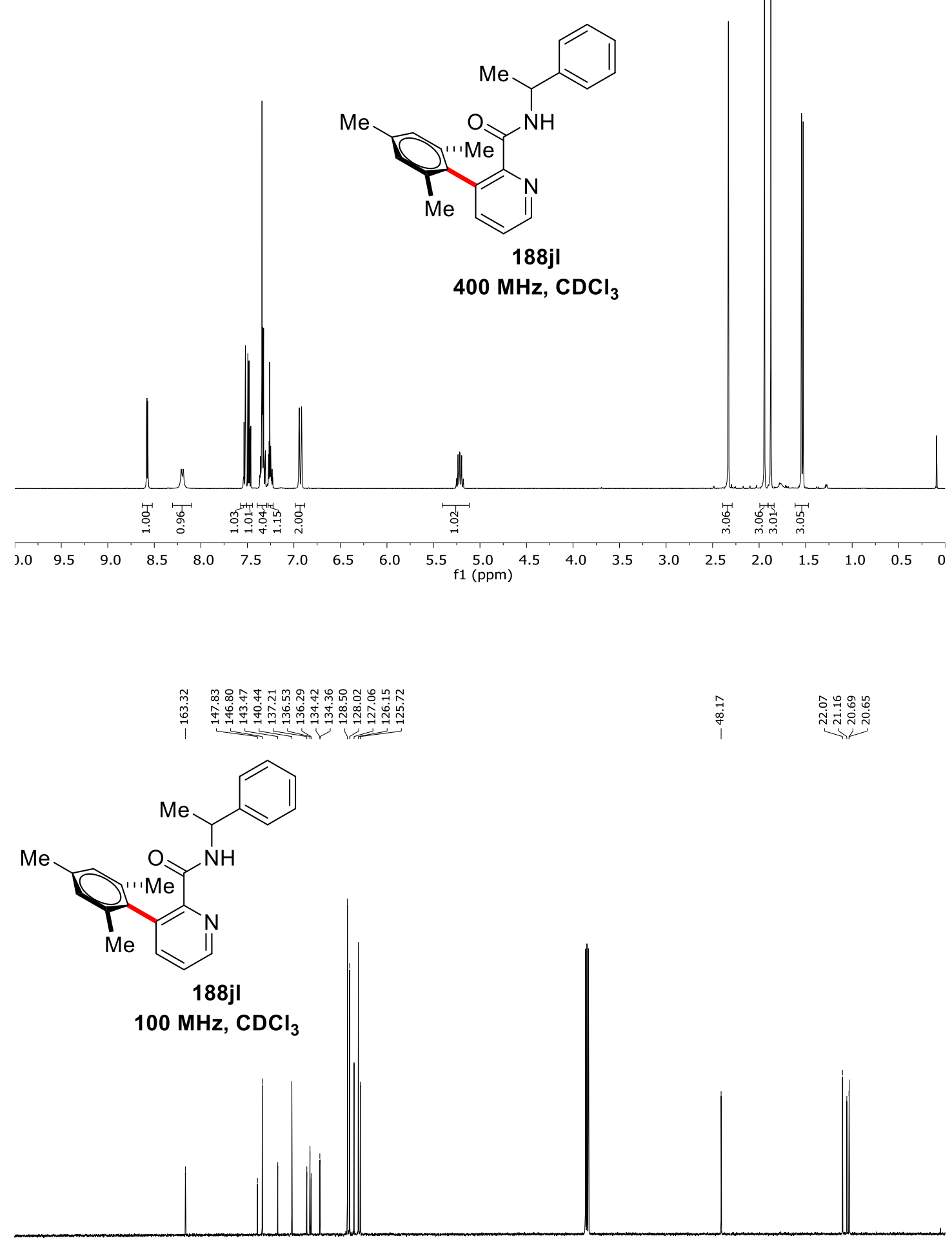

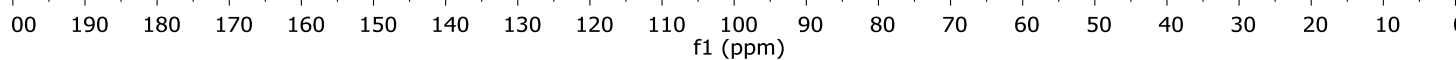


<smiles>COc1ccc(-c2cccnc2C(=O)NC(C)c2c(C)cccc2C)cc1</smiles>

190

$400 \mathrm{MHz}, \mathrm{CDCl}_{3}$
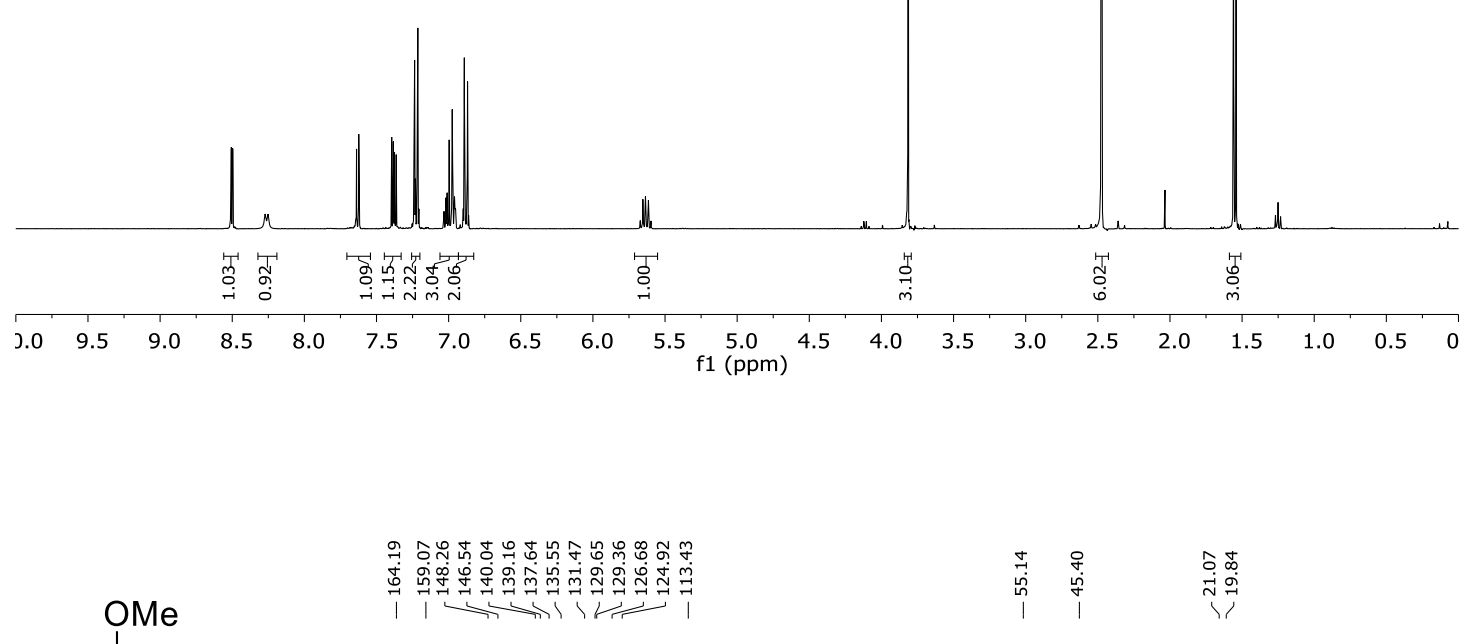<smiles>CCc1ccc(-c2cccnc2C(=O)NC(C)c2c(C)cccc2C)cc1</smiles>

190

$100 \mathrm{MHz}, \mathrm{CDCl}_{3}$

$\begin{array}{lllllllllllllllllllllllllll}30 & 220 & 210 & 200 & 190 & 180 & 170 & 160 & 150 & 140 & 130 & 120 & 110 & 100 & 90 & 80 & 70 & 60 & 50 & 40 & 30 & 20 & 10 & 0 & -10 & -z\end{array}$ f1 (ppm) 


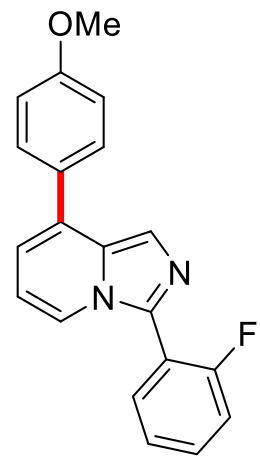

191

$400 \mathrm{MHz} \mathrm{CDCl}_{3}$

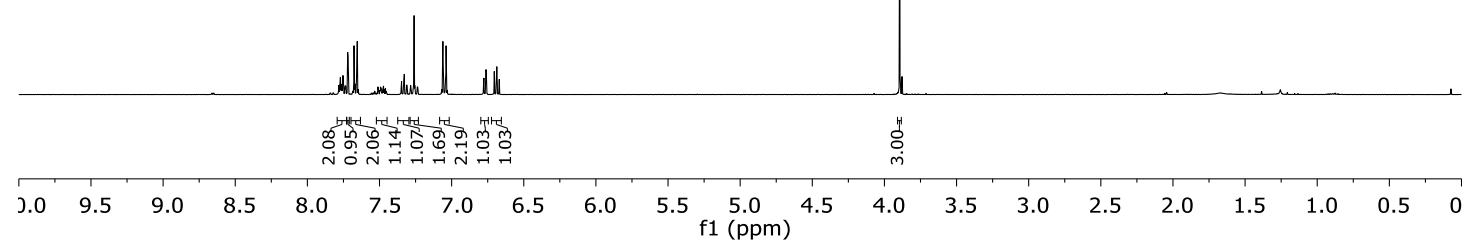

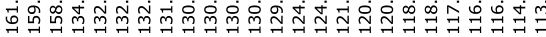<smiles>COc1ccc(-c2cccn3c(-c4ccccc4F)ncc23)cc1</smiles>

191

$100 \mathrm{MHz}^{\mathrm{CDCl}_{3}}$

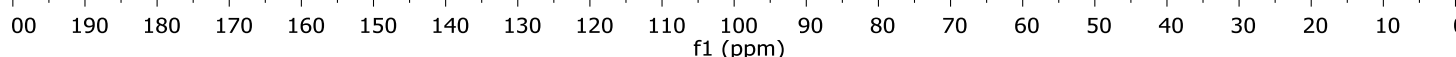




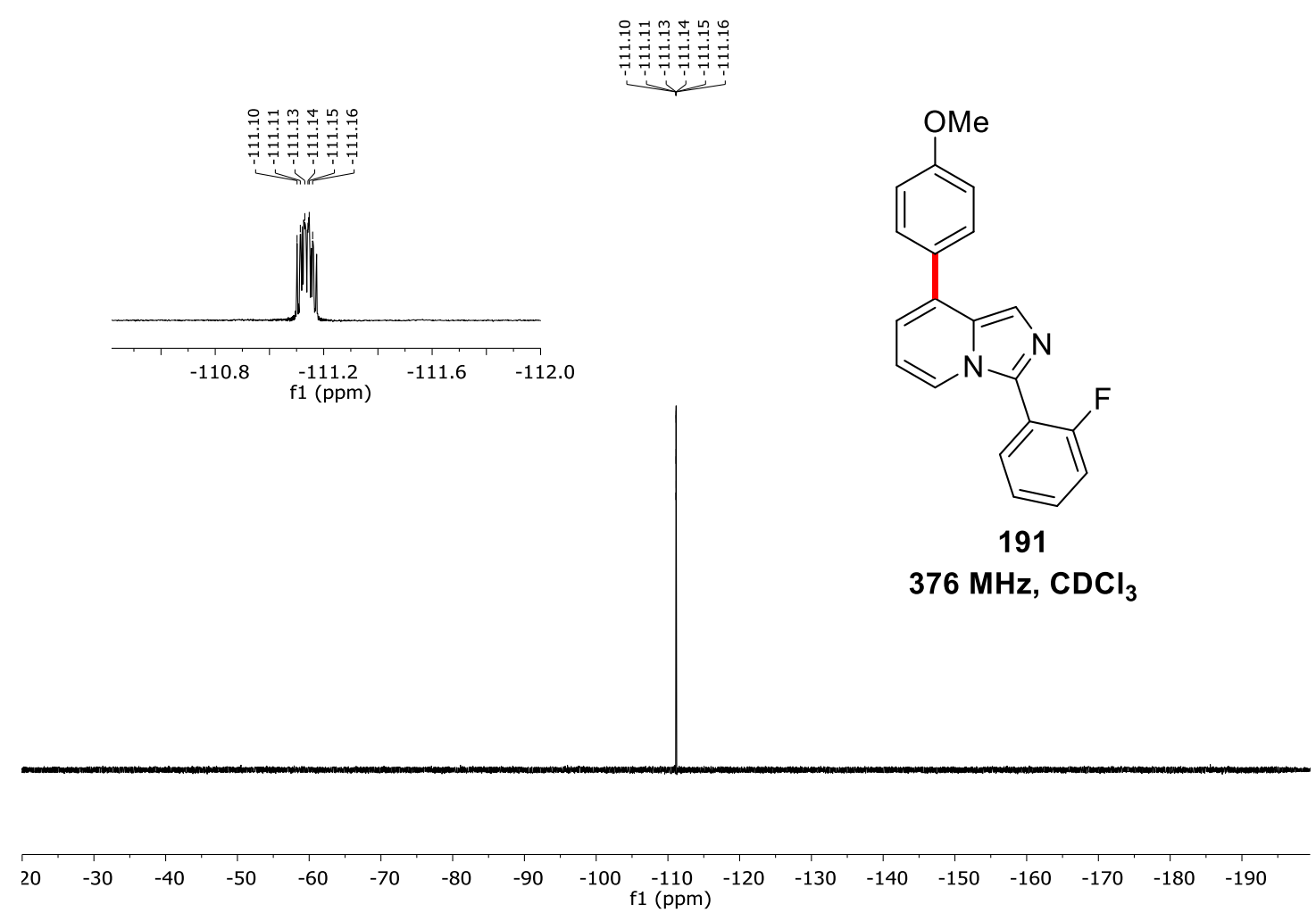


<smiles>CCCCn1cc(C(C)(C)NC(=O)c2ccccc2-c2ccc(OC)cc2)nn1</smiles>

192

$400 \mathrm{MHz}, \mathrm{CDCl}_{3}$

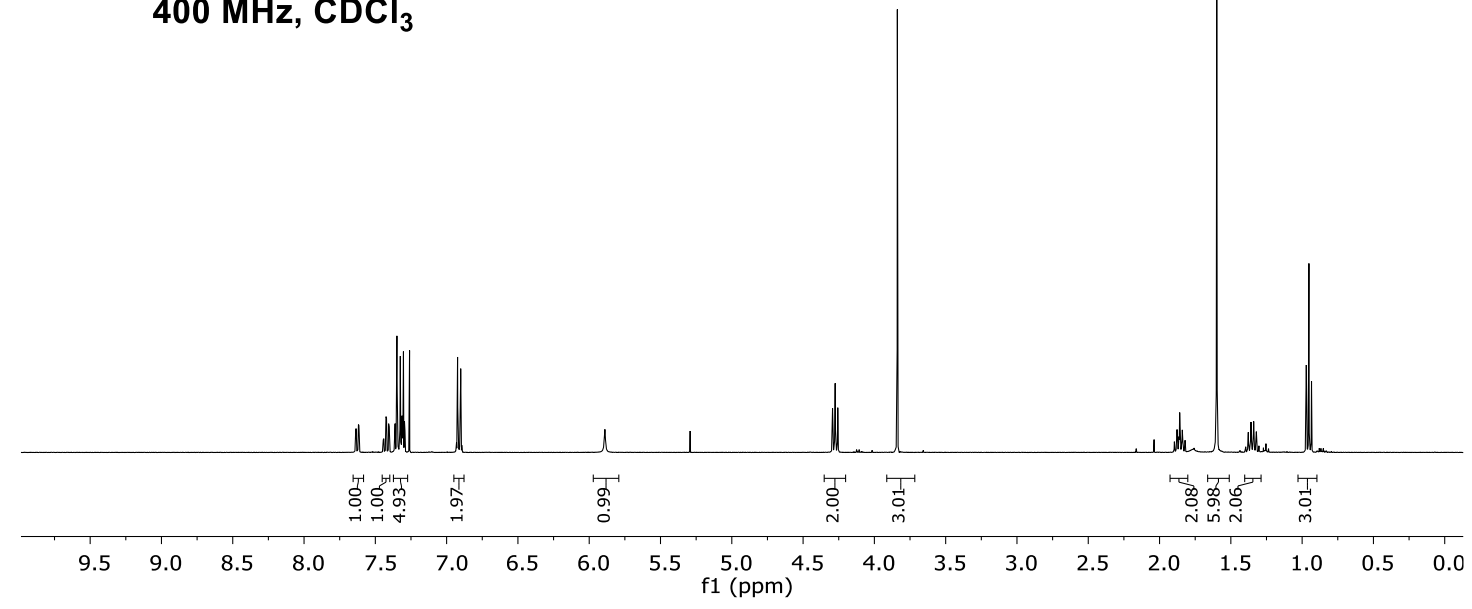

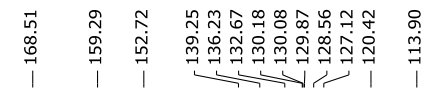

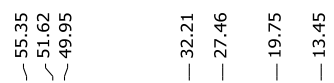<smiles>CCCCn1cc(C(C)(C)NC(=O)c2ccccc2-c2ccc(OC)cc2)nn1</smiles>

192

$100 \mathrm{MHz}, \mathrm{CDCl}_{3}$

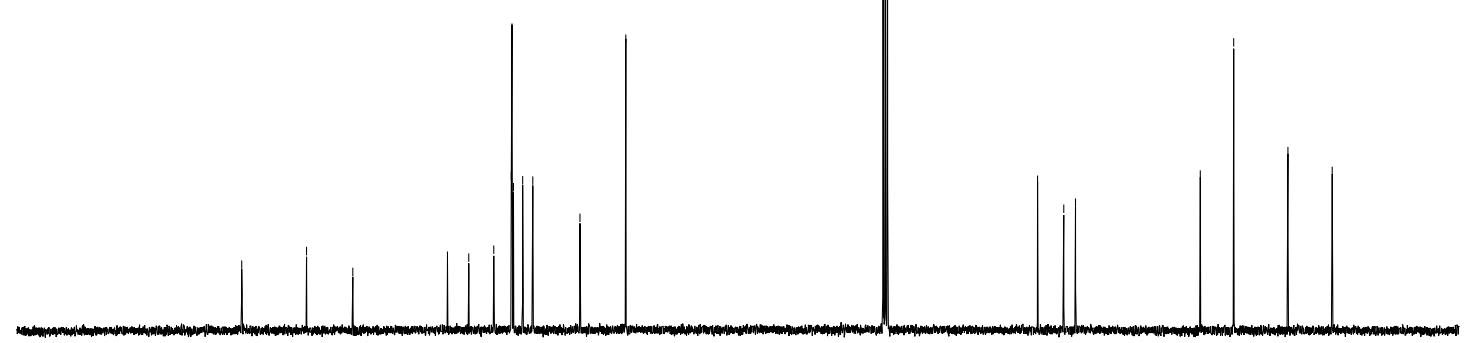

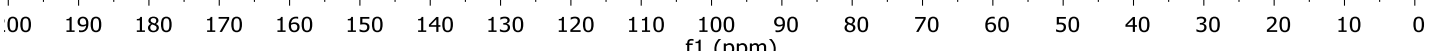




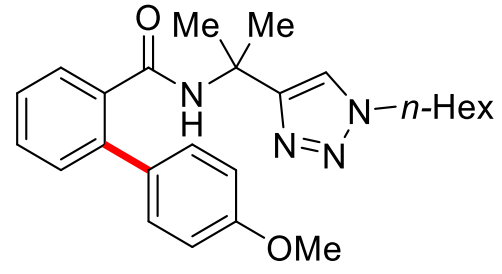

193

$400 \mathrm{MHz}^{\mathrm{CDCl}_{3}}$

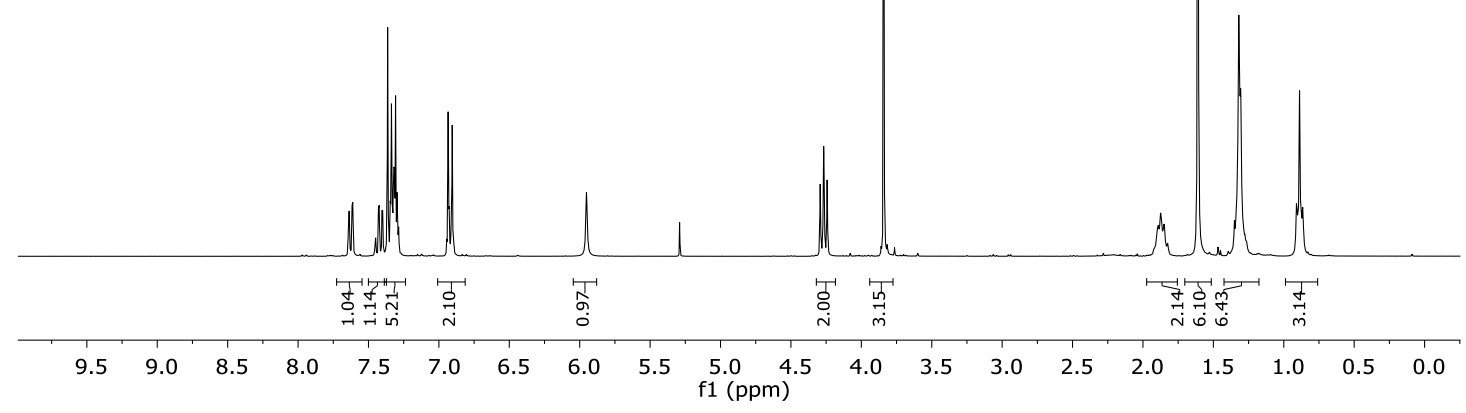

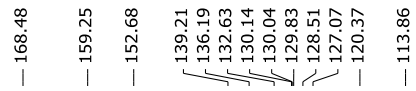

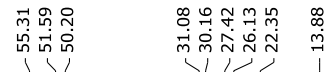<smiles>[X][Co]n1cc(C(C)(C)NC(=O)c2ccccc2-c2ccc(OC)cc2)nn1</smiles>

193

$100 \mathrm{MHz}^{\mathrm{CDCl}_{3}}$

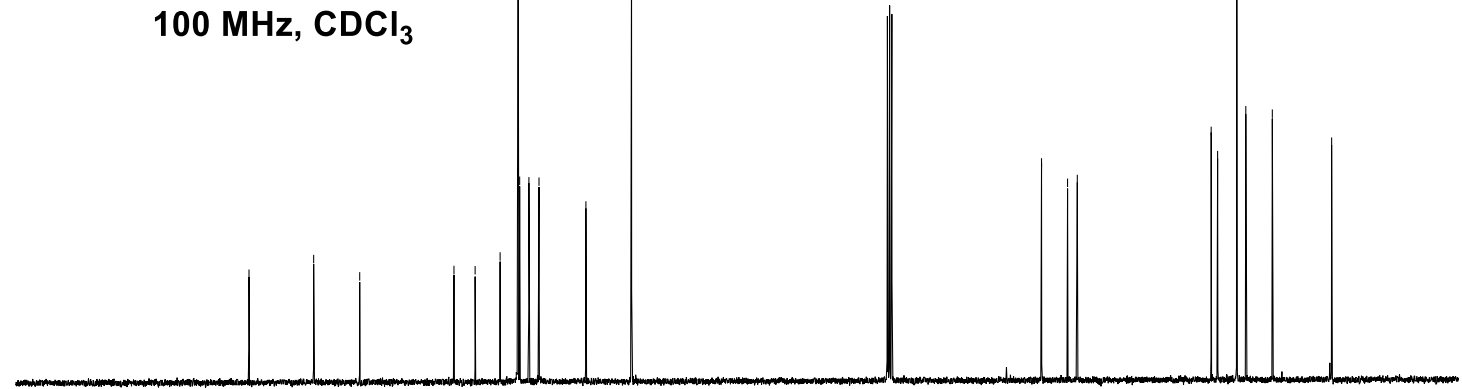

$\begin{array}{lllllllllllllllllllll}200 & 190 & 180 & 170 & 160 & 150 & 140 & 130 & 120 & 110 & 100 & 90 & 80 & 70 & 60 & 50 & 40 & 30 & 20 & 10 & 0\end{array}$ 


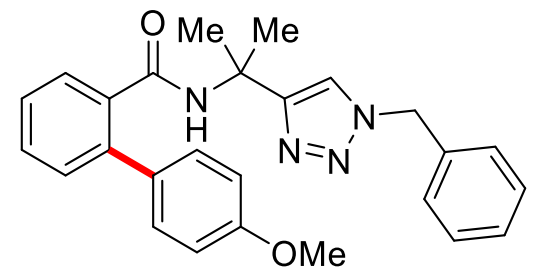

194

$400 \mathrm{MHz}, \mathrm{CDCl}_{3}$

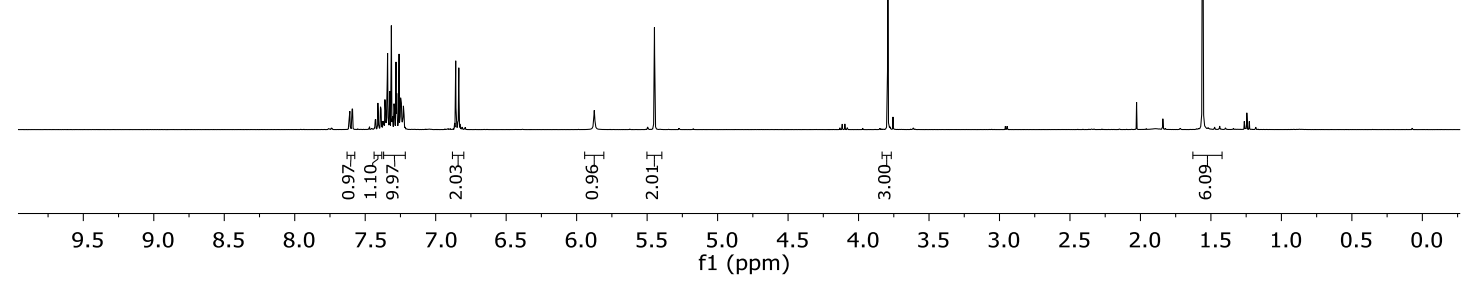

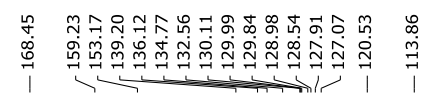

m户̃<smiles>COc1ccc(-c2ccccc2C(=O)NC(C)(C)c2cn(Cc3ccccc3)nn2)cc1</smiles>

194

$100 \mathrm{MHz}, \mathrm{CDCl}_{3}$

$\begin{array}{llllllllll}190 & 180 & 170 & 160 & 150 & 140 & 130 & 120 & 110 & 100\end{array}$

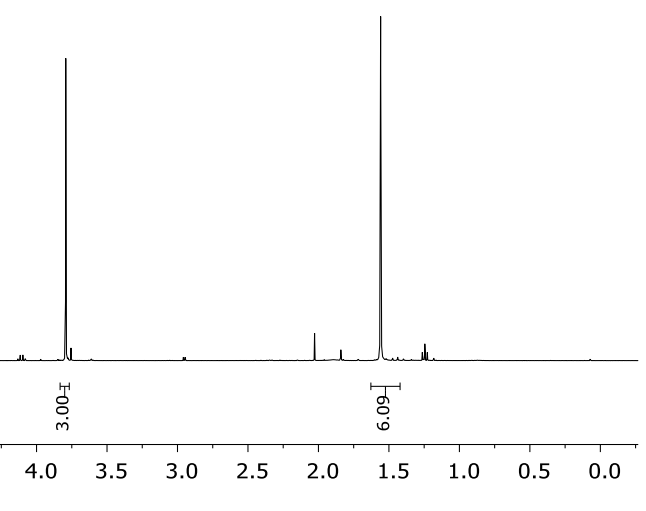


<smiles>CCCCn1cc(C(C)(C)NC(=O)c2ccc(OC)cc2-c2ccc(OC)cc2)nn1</smiles>

195

$400 \mathrm{MHz}, \mathrm{CDCl}_{3}$

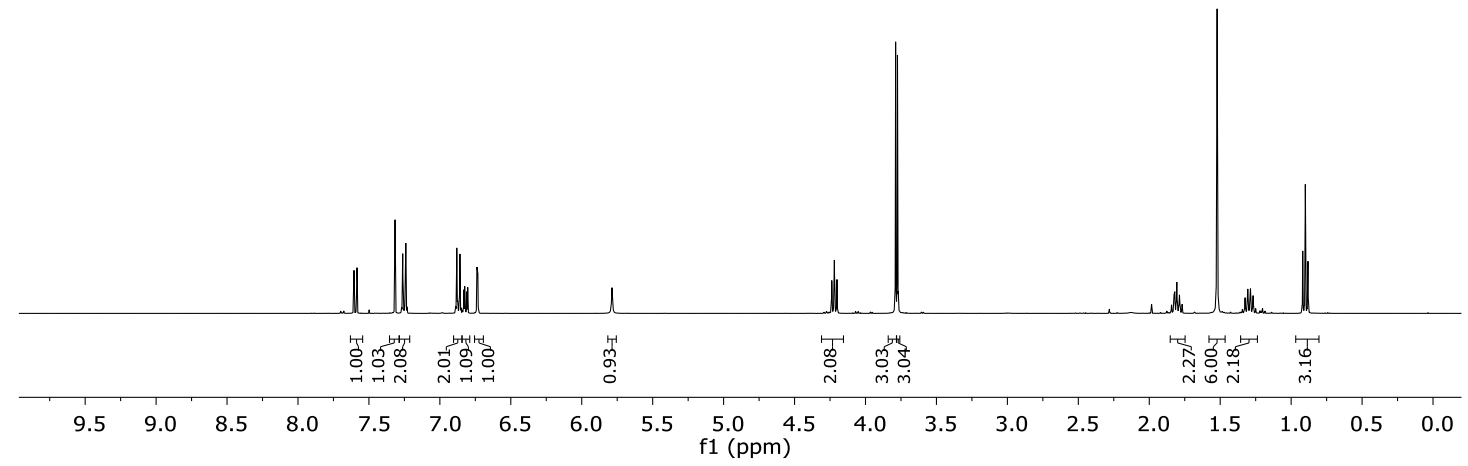

๗

它

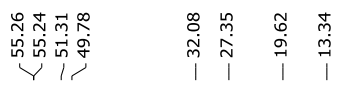<smiles>CCCCn1cc(C(C)(C)NC(=O)c2ccc(OC)cc2-c2ccc(OC)cc2)nn1</smiles>

195

$100 \mathrm{MHz}, \mathrm{CDCl}_{3}$

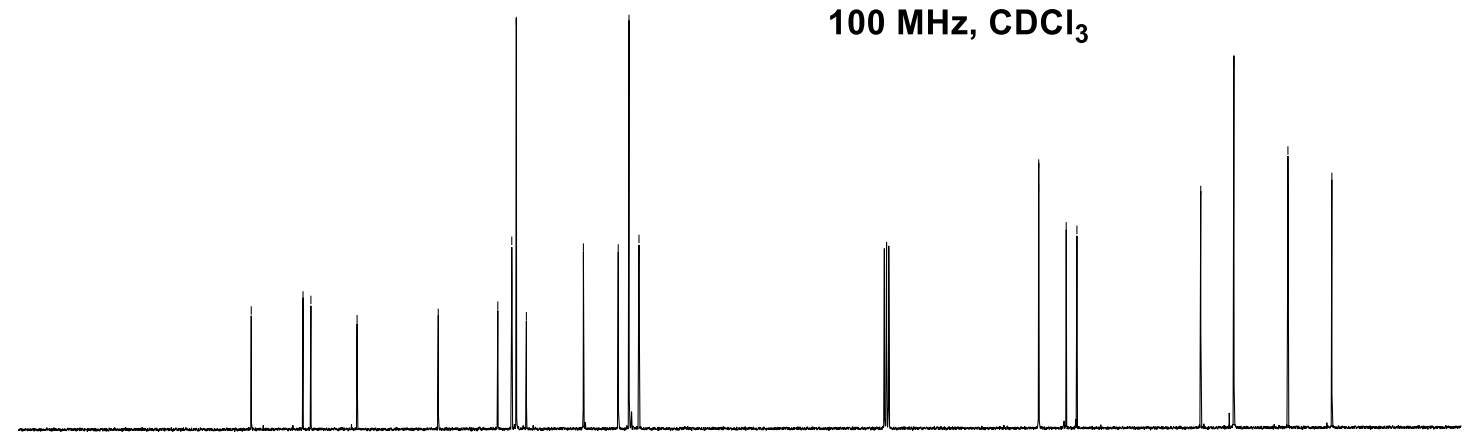

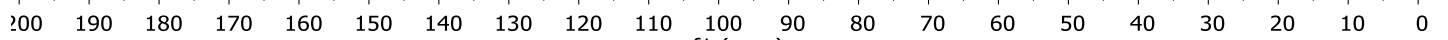


<smiles>CCCCn1cc(C(C)(C)NC(=O)c2ccc(C(C)(C)C)cc2-c2ccc(OC)cc2)nn1</smiles>

196

$400 \mathrm{MHz}, \mathrm{CDCl}_{3}$

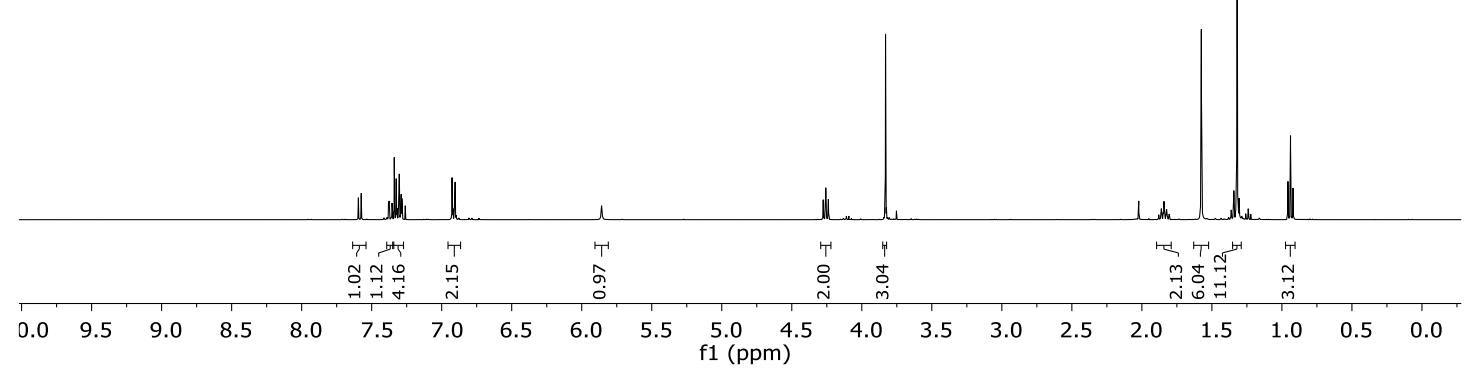<smiles>CCCn1cc(C(C)(C)NC(=O)c2ccc(C(C)(C)C)cc2-c2ccc(OC)cc2)nn1</smiles>

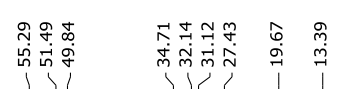

196

$100 \mathrm{MHz}, \mathrm{CDCl}_{3}$

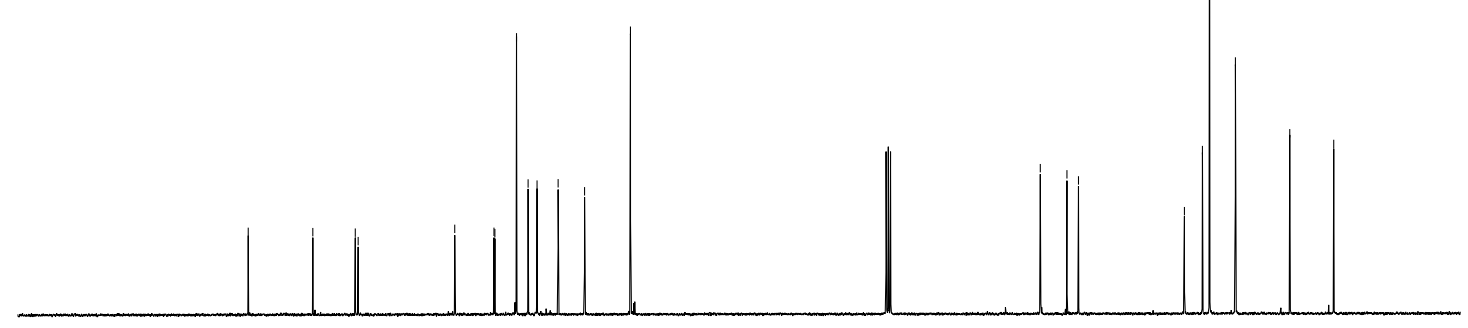

200

$\begin{array}{lllllllll}190 & 180 & 170 & 160 & 150 & 140 & 130 & 120 & 110 \quad \begin{array}{l}100 \\ \mathrm{f} 1(\mathrm{ppm})\end{array}\end{array}$

70

100 
<smiles>CCCn1cc(C(C)(C)NC(=O)c2ccc(S(C)(=O)=O)cc2-c2ccc(OC)cc2)nn1</smiles>

197

$400 \mathrm{MHz}, \mathrm{CDCl}_{3}$
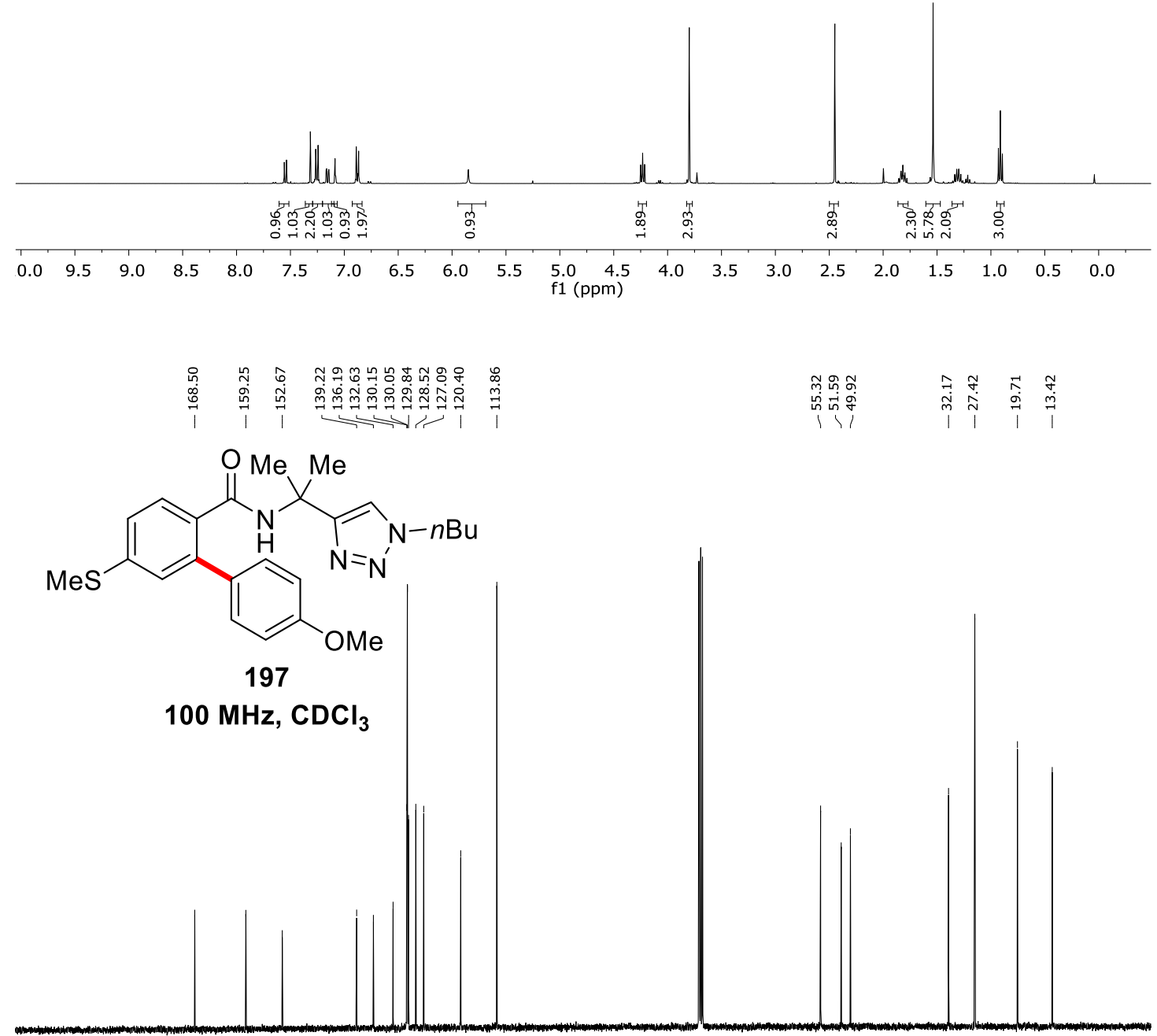

$\begin{array}{lllllllllllllllllllll}100 & 190 & 180 & 170 & 160 & 150 & 140 & 130 & 120 & 110 & \begin{array}{c}100 \\ \mathrm{f} 1(\mathrm{ppm})\end{array} & 90 & 80 & 70 & 60 & 50 & 40 & 30 & 20 & 10 & 0\end{array}$ 
<smiles>CCCn1cc(C(C)(C)NC(=O)c2ccc(F)cc2-c2ccc(OC)cc2)nn1</smiles>

198

$400 \mathrm{MHz}, \mathrm{CDCl}_{3}$

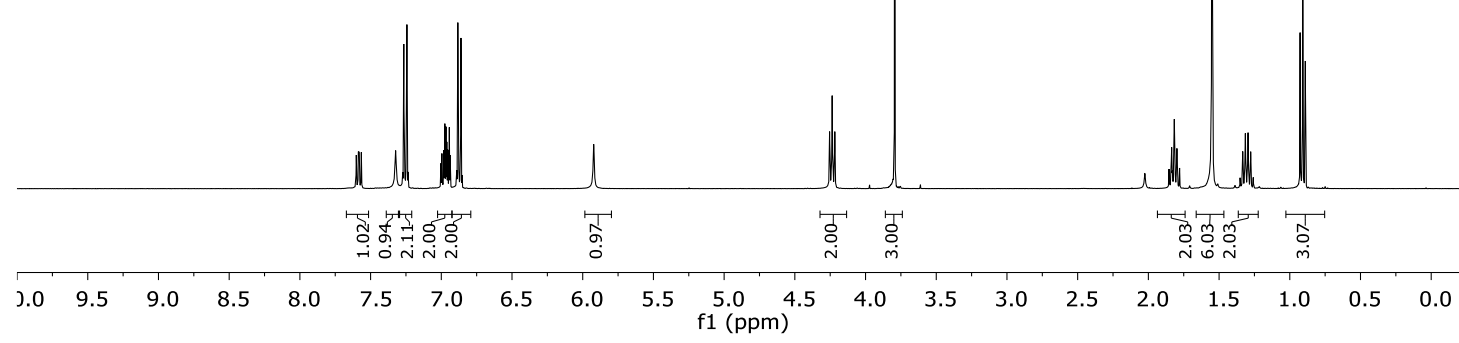

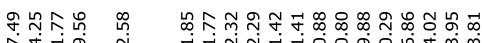

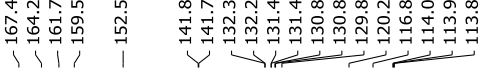

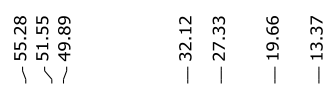

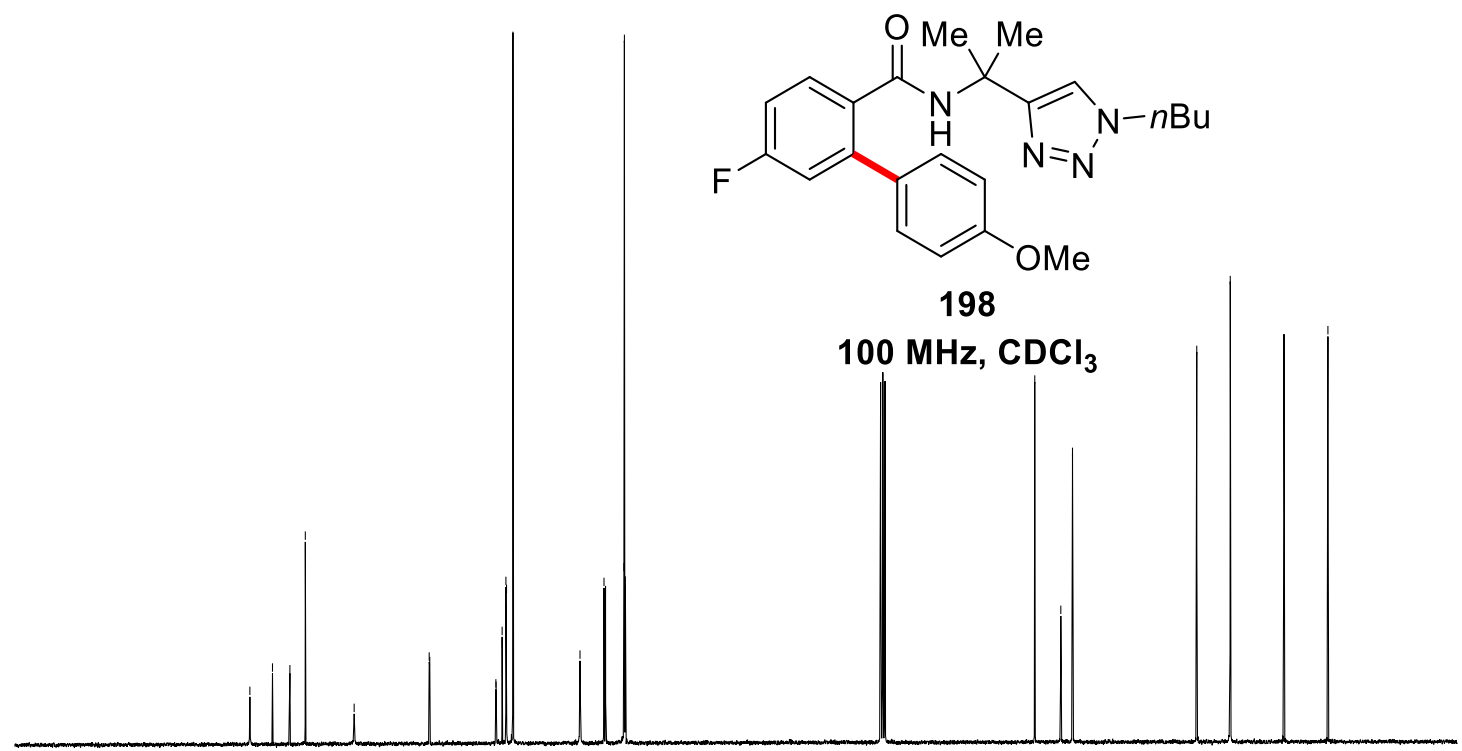

$\begin{array}{lllllllllllllllllllll}.00 & 190 & 180 & 170 & 160 & 150 & 140 & 130 & 120 & 110 & 100 & 90 & 80 & 70 & 60 & 50 & 40 & 30 & 20 & 10 & 0\end{array}$ 


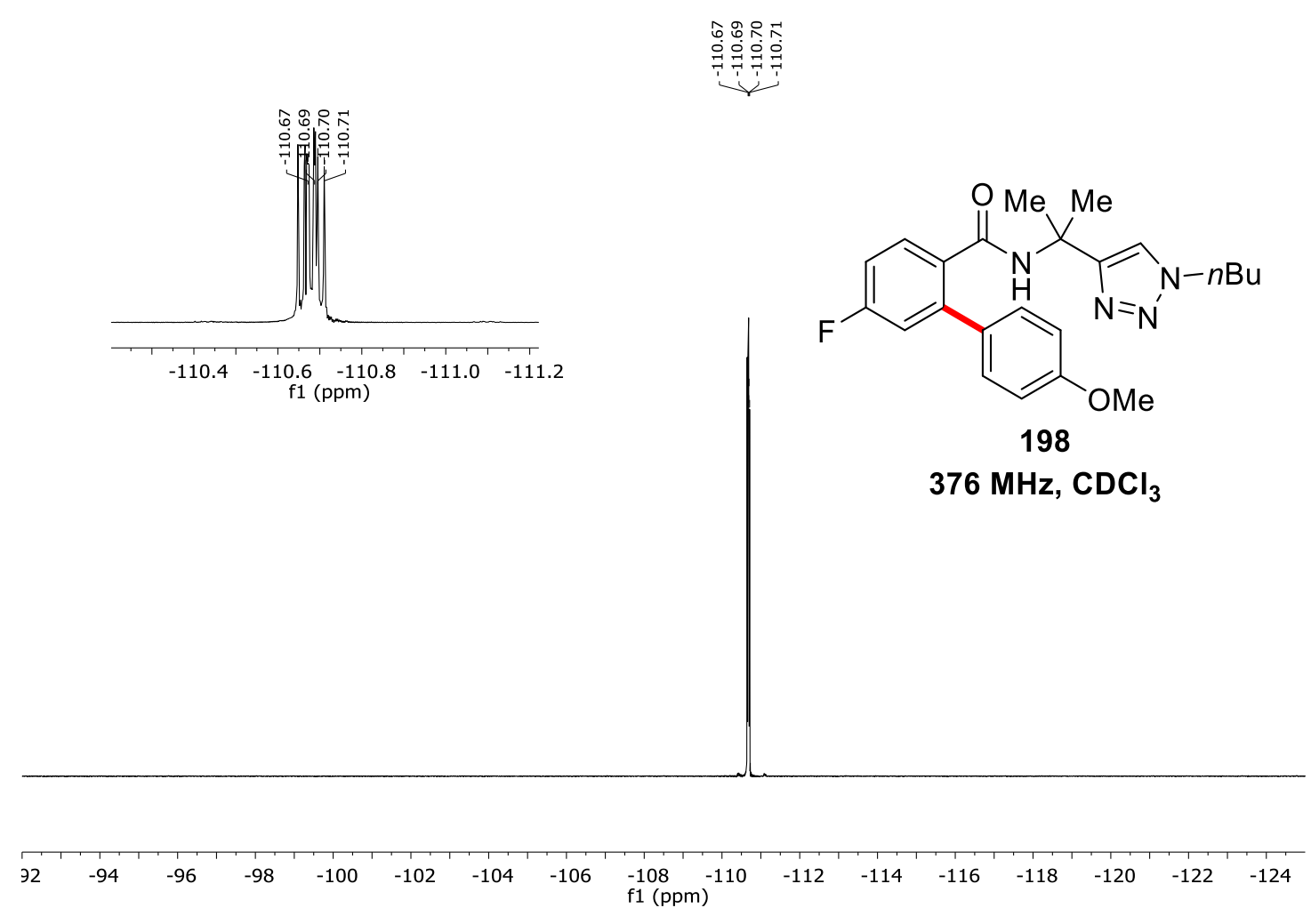


<smiles>CCCn1cc(C(C)(C)NC(=O)c2ccc(Cl)cc2-c2ccc(OC)cc2)nn1</smiles>

$400 \mathrm{MHz}, \mathrm{CDCl}_{3}$

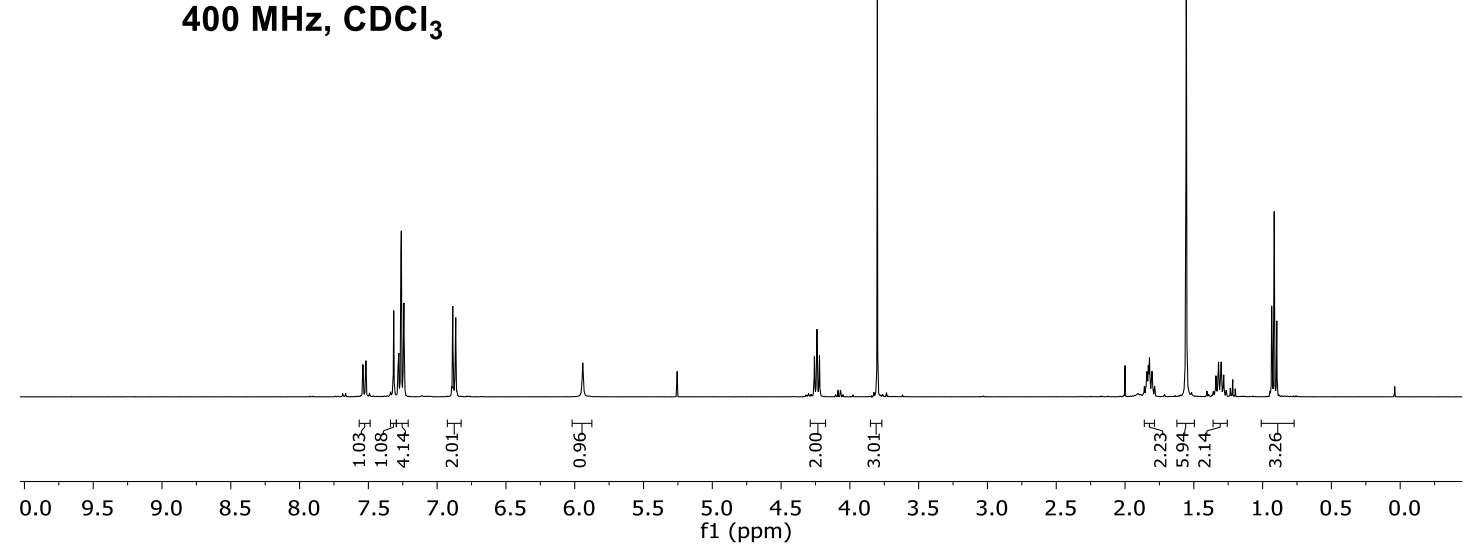

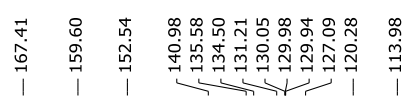

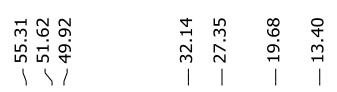

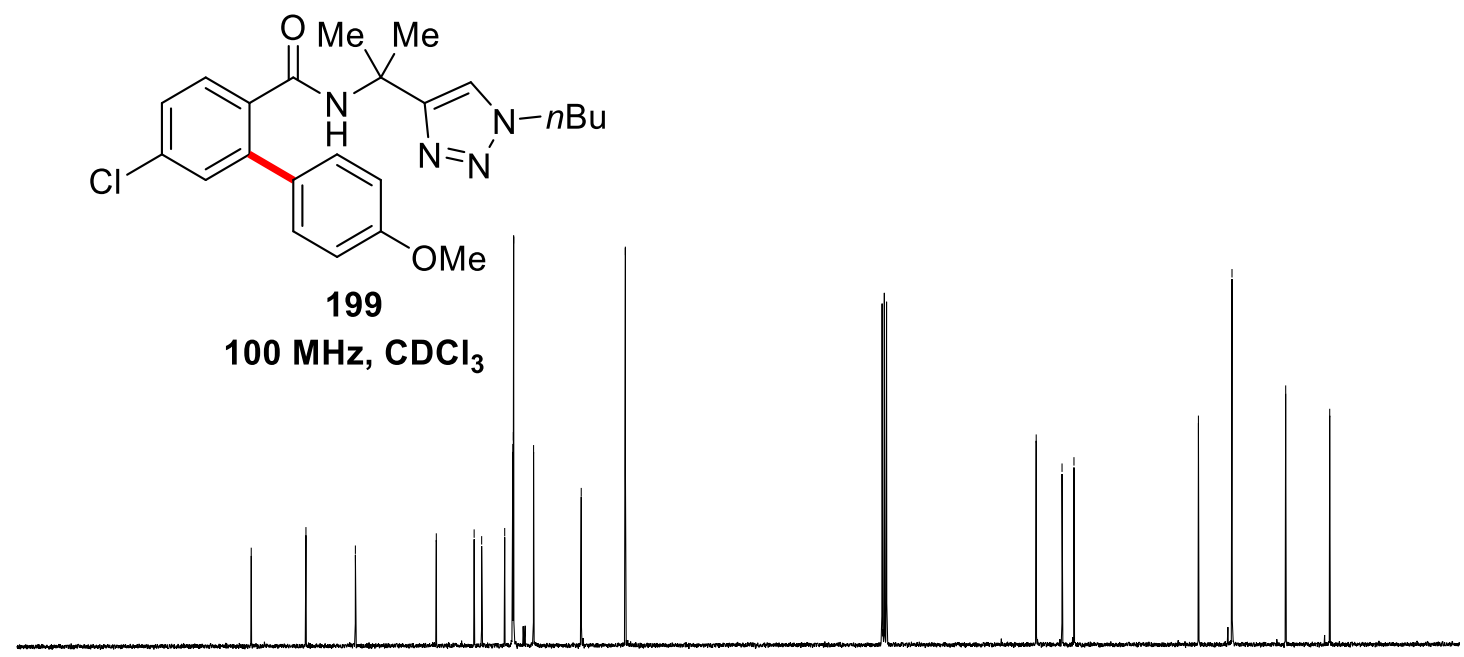

\begin{tabular}{llllllllllllllllllllll}
\hline 00 & 190 & 180 & 170 & 160 & 150 & 140 & 130 & 120 & 110 & 100 & 90 & 80 & 70 & 60 & 50 & 40 & 30 & 20 & 10 & 0
\end{tabular} 
<smiles>COc1ccc(-c2cc(C)ccc2C(=O)NC(C)(C)c2cn(Cc3ccccc3)nn2)cc1</smiles>

$300 \mathrm{MHz}, \mathrm{CDCl}_{3}$

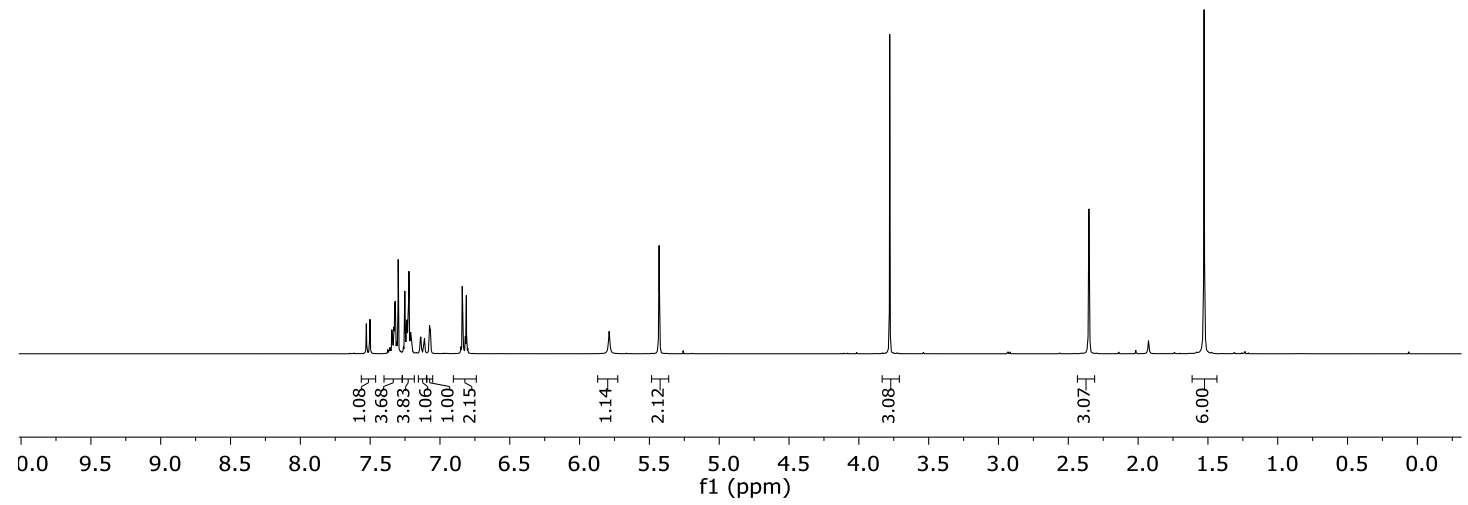

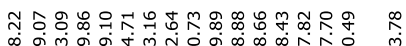

|

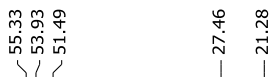<smiles>COc1ccc(-c2cc(C)ccc2C(=O)NC(C)(C)c2cn(Cc3ccccc3)nn2)cc1</smiles>

200

$125 \mathrm{MHz}, \mathrm{CDCl}_{3}$

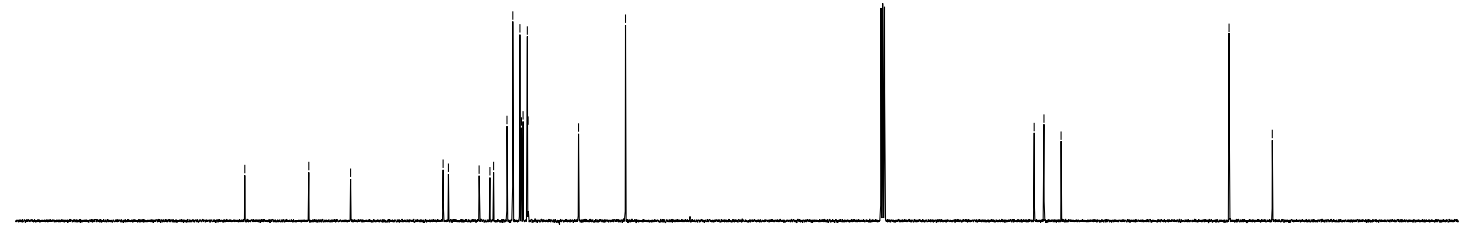

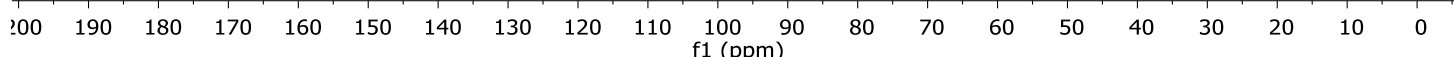


<smiles>COc1ccc(-c2cc(C(F)(F)F)ccc2C(=O)NC(C)(C)c2cn(Cc3ccccc3)nn2)cc1</smiles>

201

$400 \mathrm{MHz}, \mathrm{CDCl}_{3}$

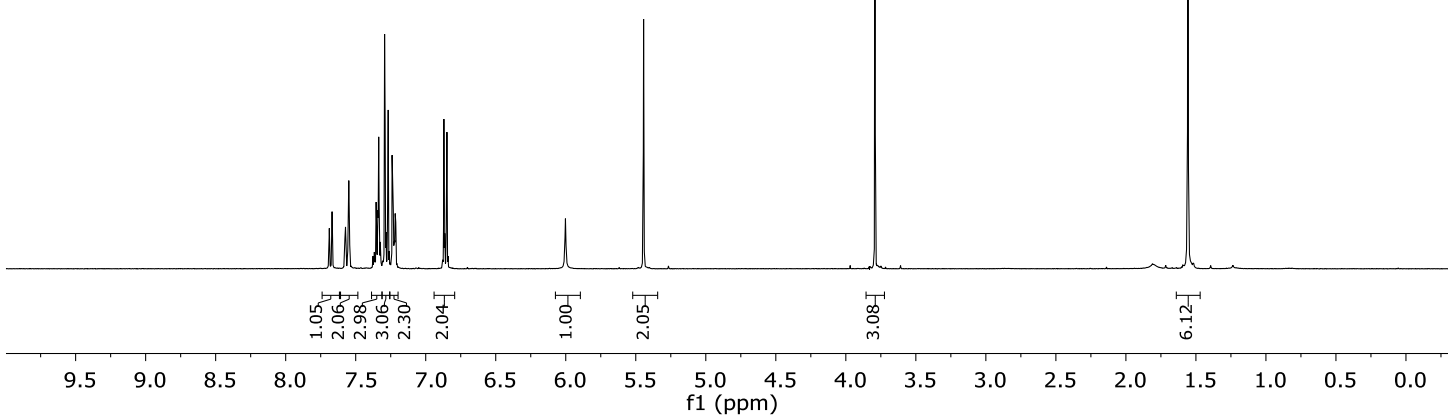

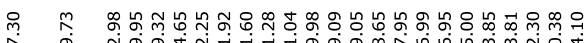

苜<smiles>COc1ccc(-c2cc(C(F)(F)F)ccc2C(=O)NC(C)(C)c2cn(Cc3ccccc3)nn2)cc1</smiles>

201

$125 \mathrm{MHz}, \mathrm{CDCl}_{3}$

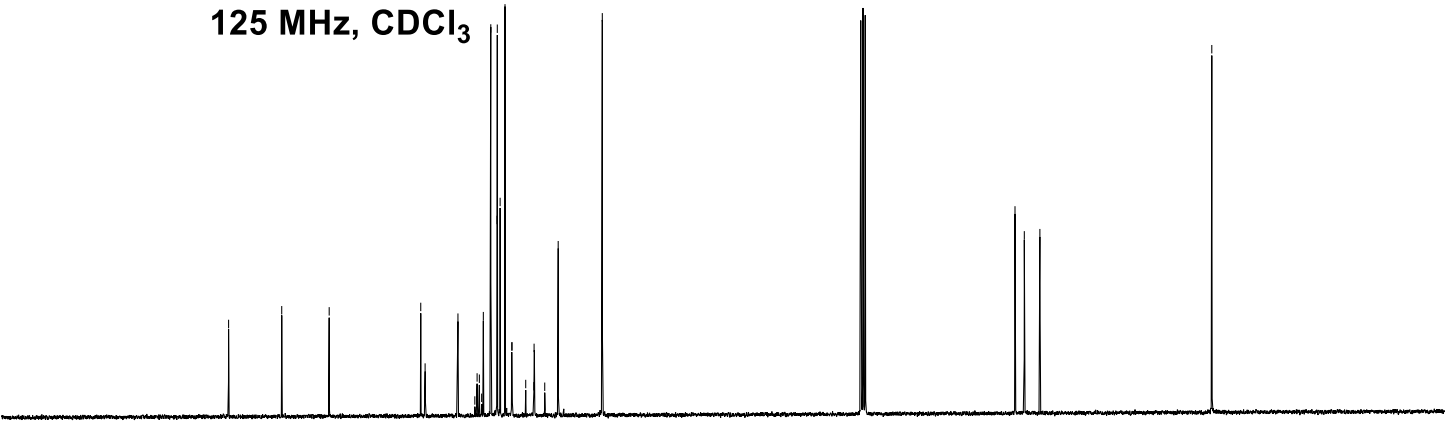

$\begin{array}{llllllllll}190 & 180 & 170 & 160 & 150 & 140 & 130 & 120 & 110 & 100 \\ \mathrm{f} 1(\mathrm{ppm})\end{array}$

80

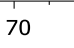

50 


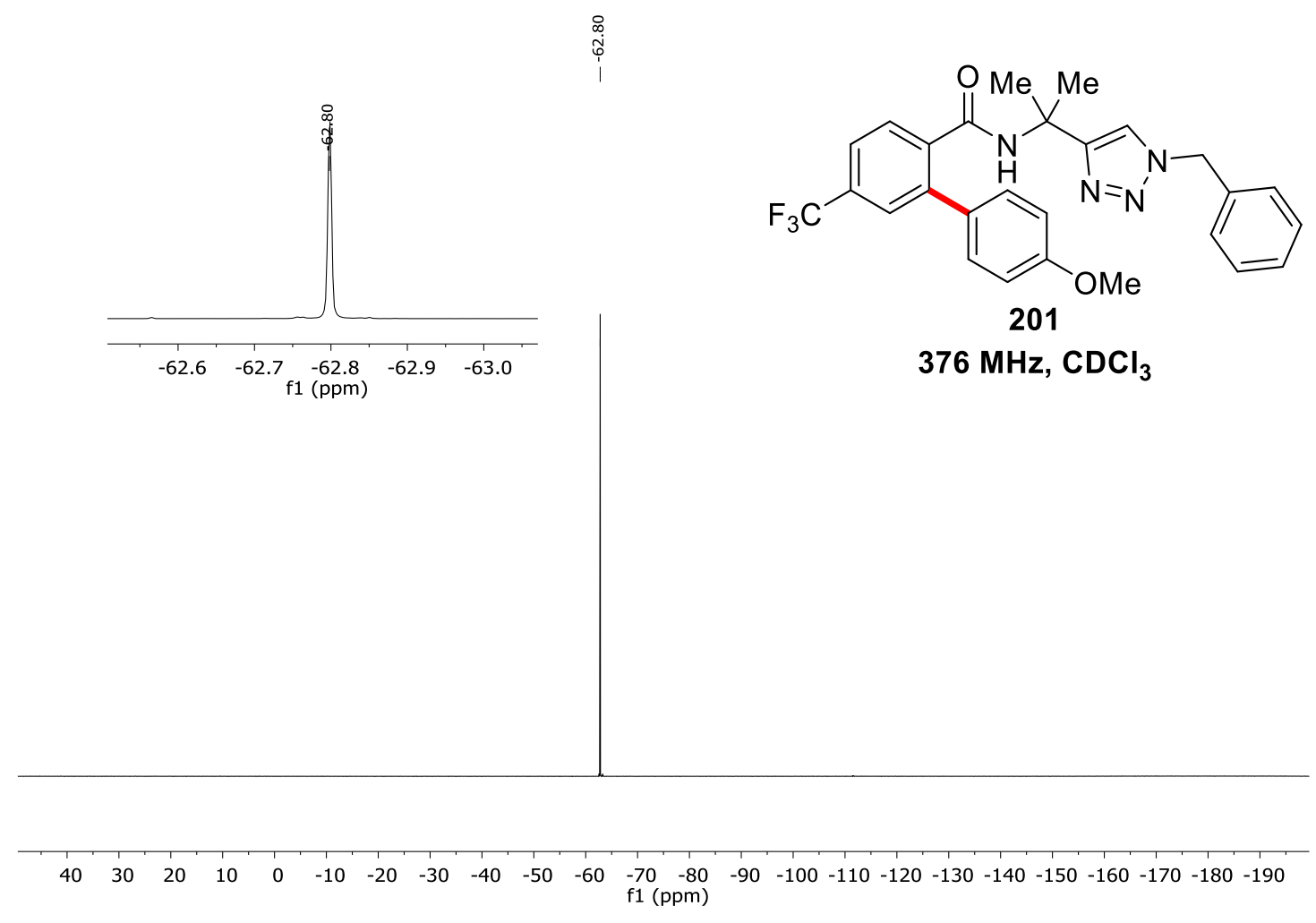




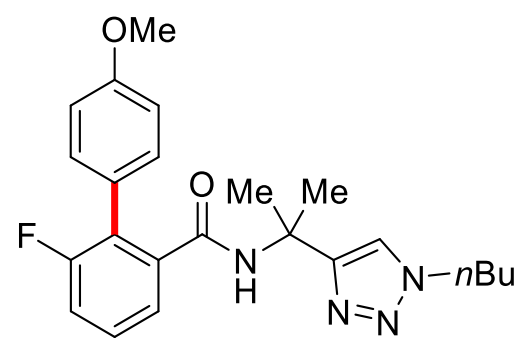

202

$400 \mathrm{MHz}, \mathrm{CDCl}_{3}$

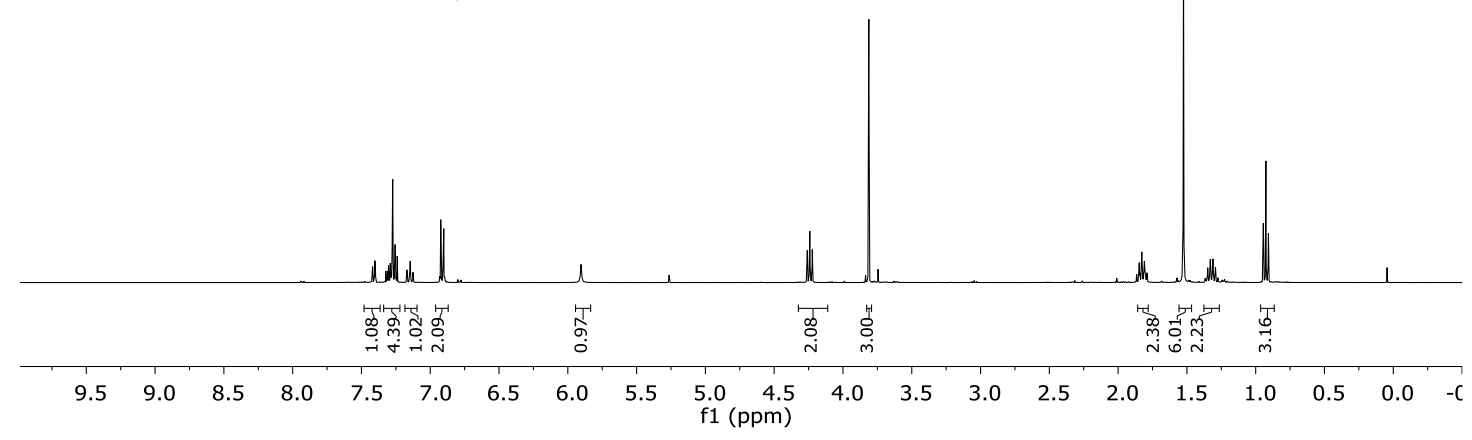

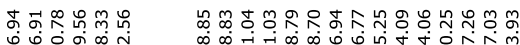

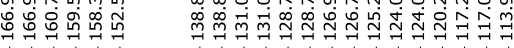

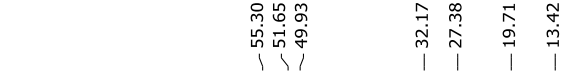

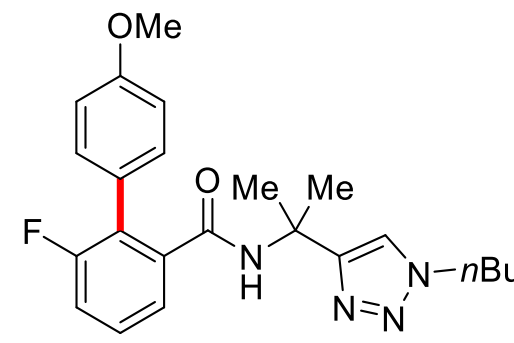

202

$100 \mathrm{MHz}, \mathrm{CDCl}_{3}$

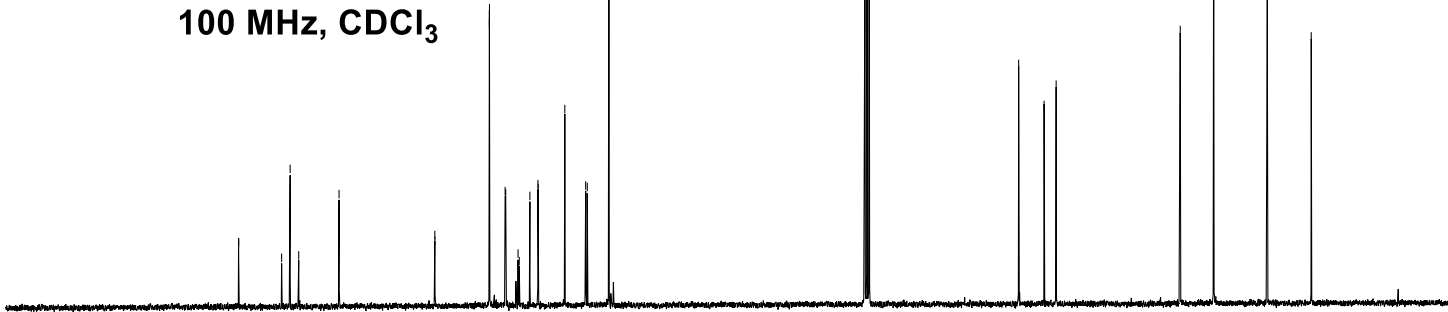

$\begin{array}{llllllllllll}00 & 190 & 180 & 170 & 160 & 150 & 140 & 130 & 120 & 110 & 100 & 90\end{array}$

80

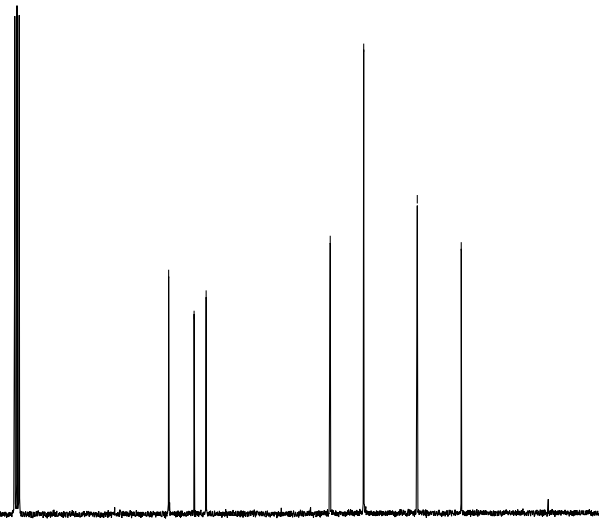




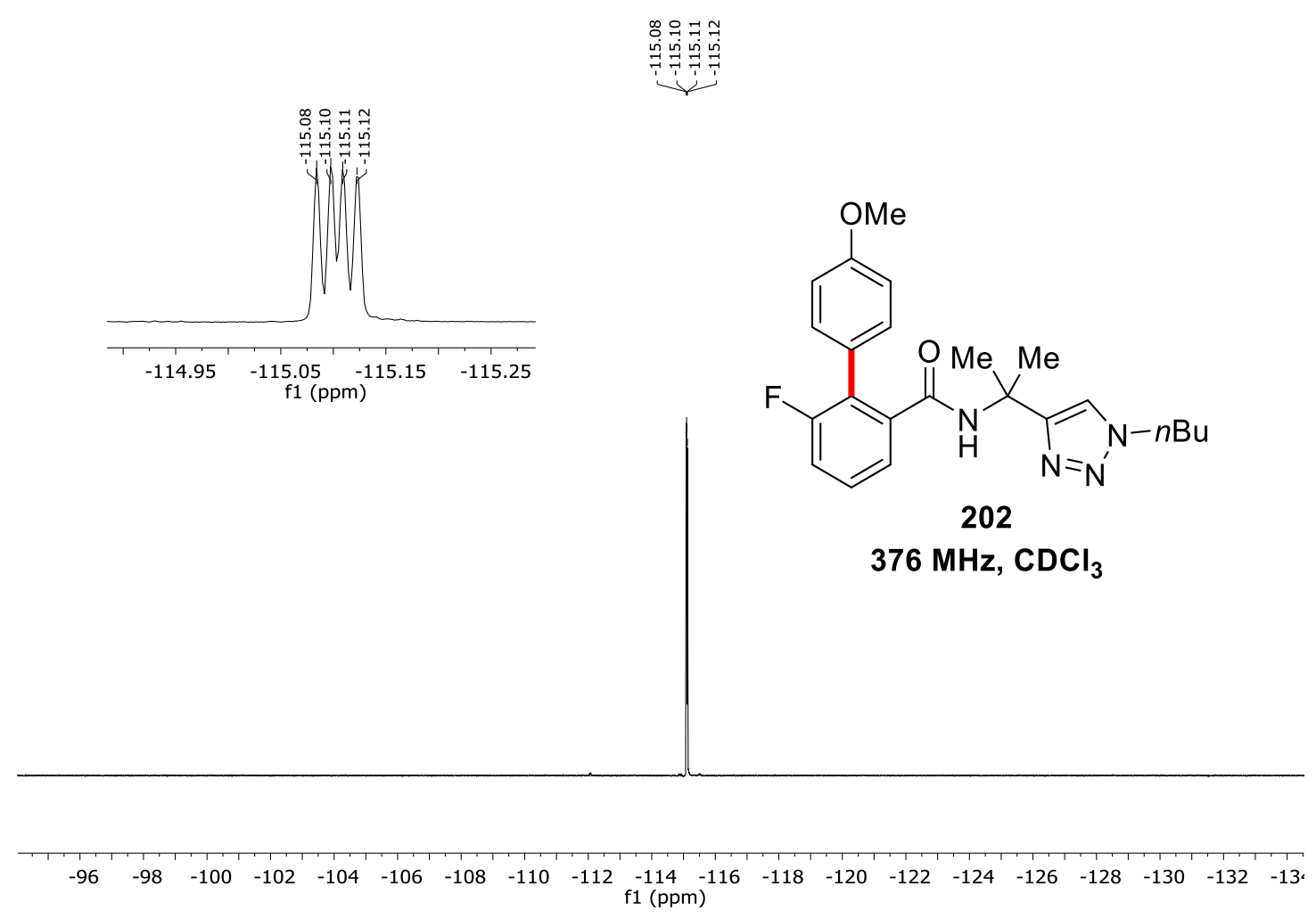




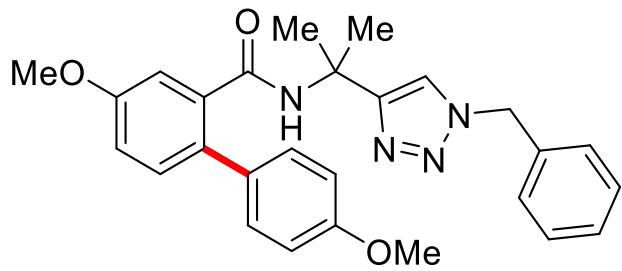

203

$300 \mathrm{MHz}, \mathrm{CDCl}_{3}$

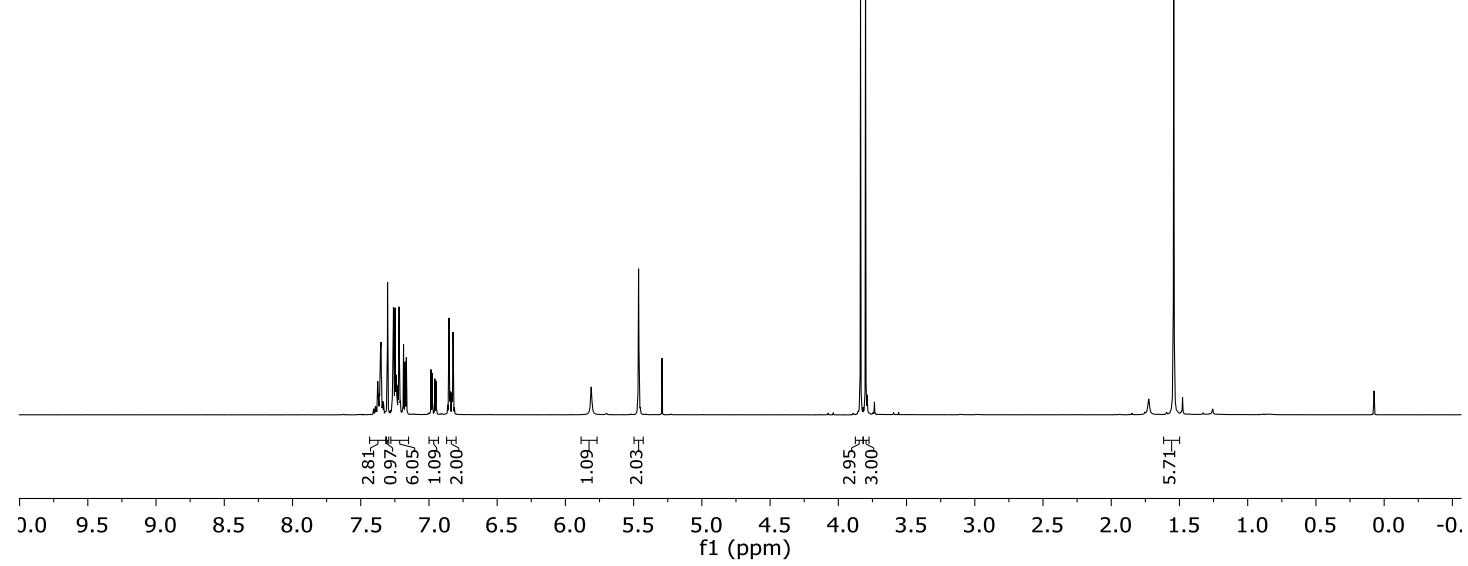

สุ.

至

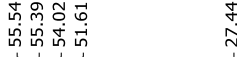<smiles>COc1ccc(-c2ccc(OC)cc2C(=O)NC(C)(C)c2cn(Cc3ccccc3)nn2)cc1</smiles>

203

$100 \mathrm{MHz}, \mathrm{CDCl}_{3}$

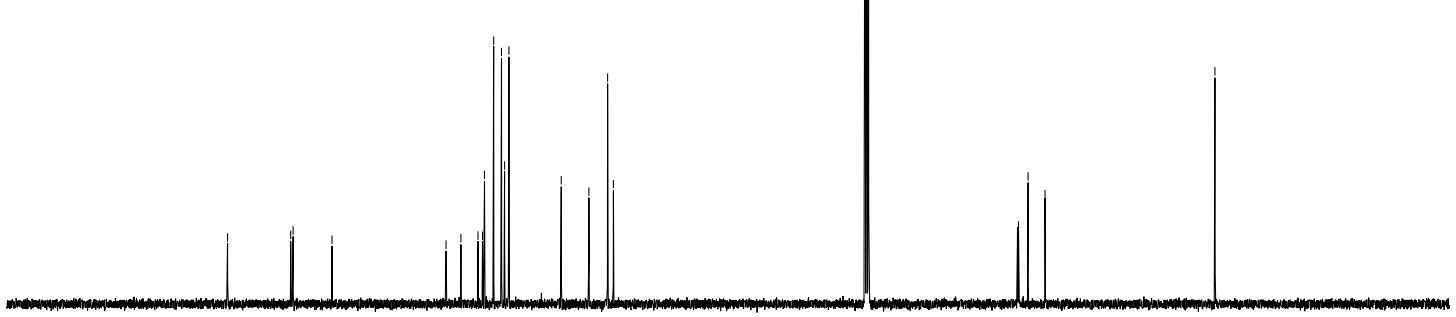

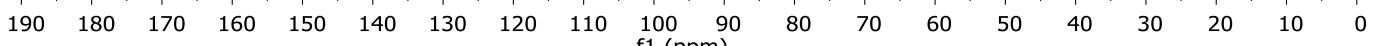




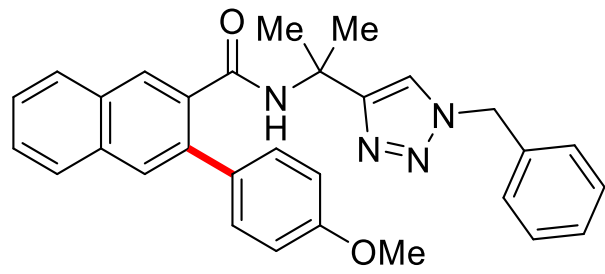

204

$400 \mathrm{MHz}, \mathrm{CDCl}_{3}$

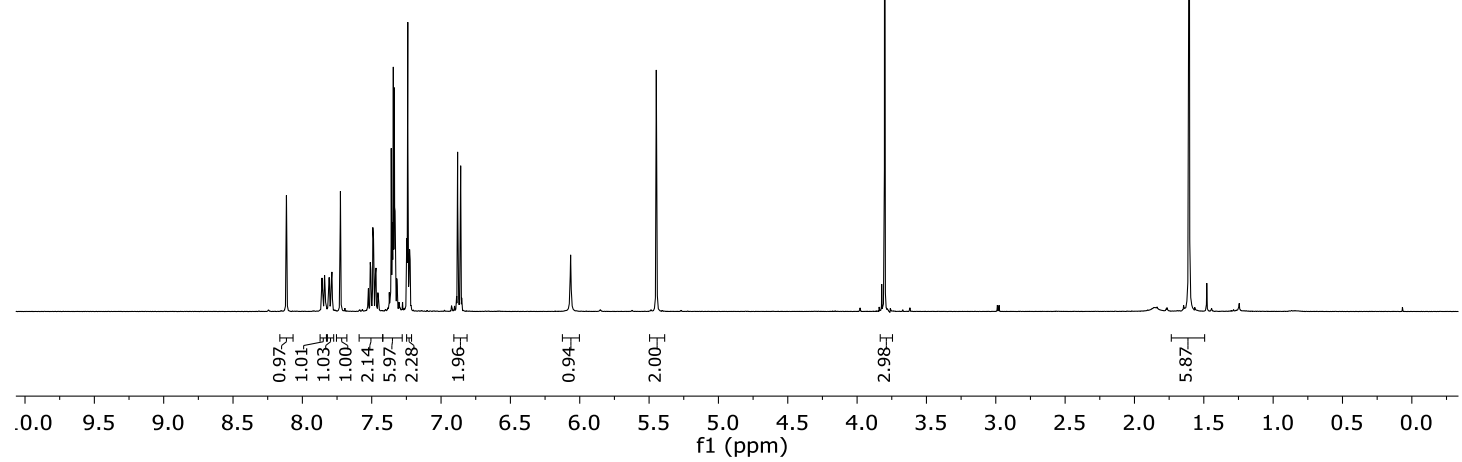

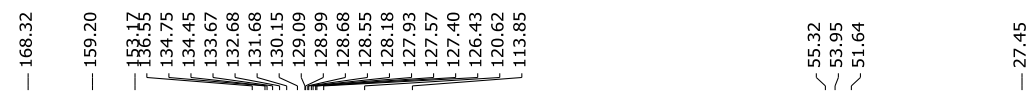<smiles>COc1ccc(-c2cc3ccccc3cc2C(=O)NC(C)(C)c2cn(Cc3ccccc3)nn2)cc1</smiles>

204

$100 \mathrm{MHz}, \mathrm{CDCl}_{3}$

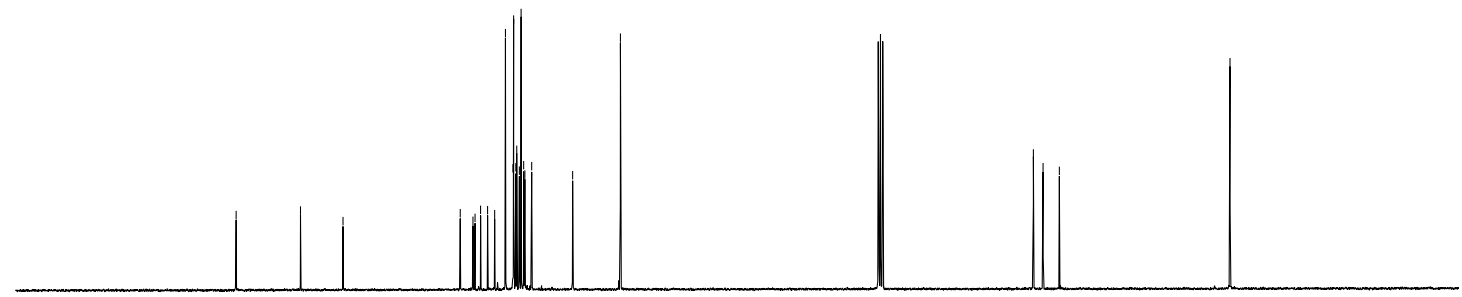

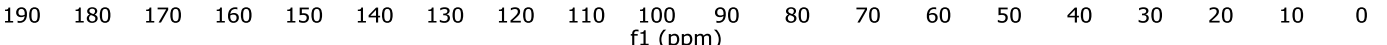




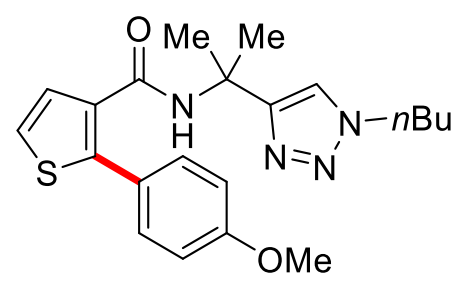

205

$400 \mathrm{MHz}, \mathrm{CDCl}_{3}$

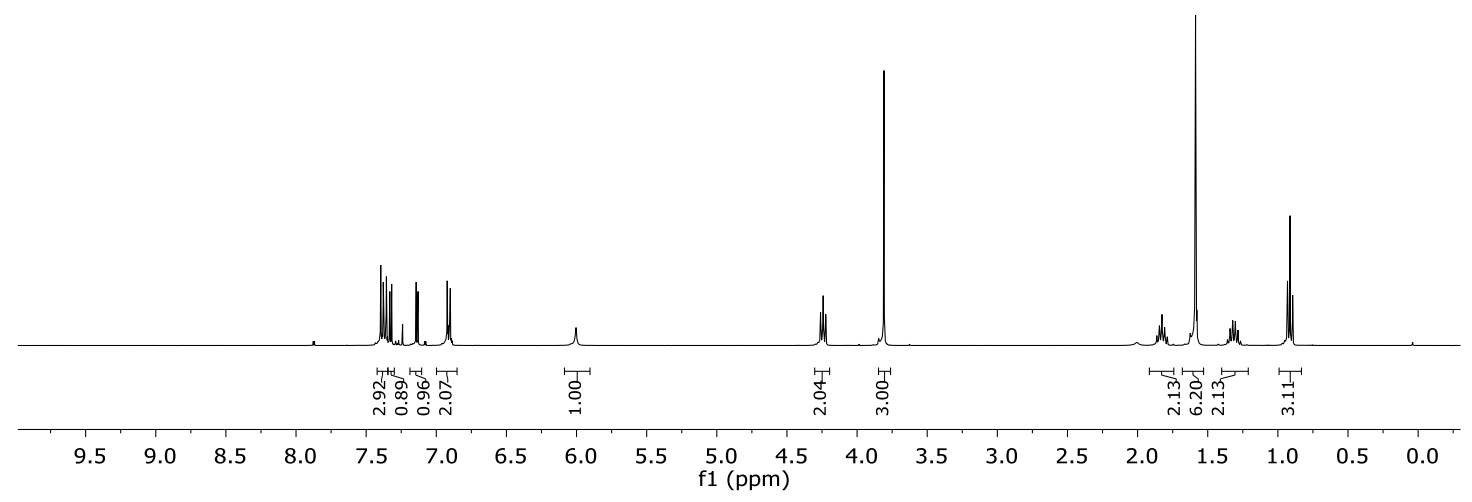

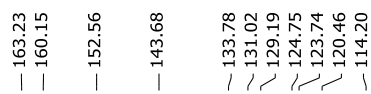

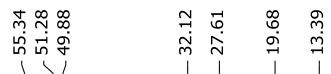<smiles>CCCCn1cc(C(C)(C)NC(=O)c2ccsc2-c2ccc(OC)cc2)nn1</smiles>

205

$100 \mathrm{MHz}, \mathrm{CDCl}_{3}$

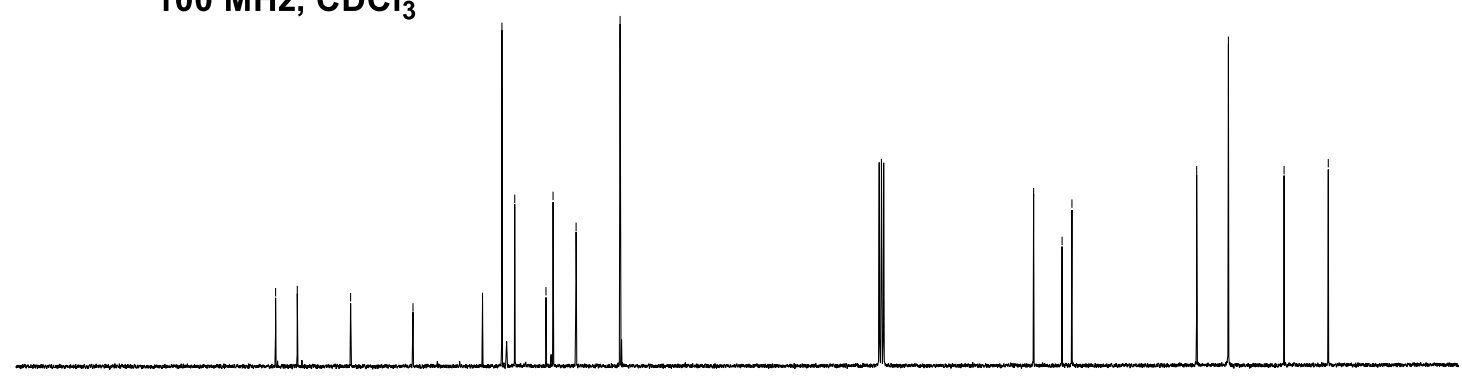

$\begin{array}{lllllllllllllllllllll}00 & 190 & 180 & 170 & 160 & 150 & 140 & 130 & 120 & 110 & \begin{array}{c}100 \\ \mathrm{f} 1(\mathrm{ppm})\end{array} & 80 & 70 & 60 & 50 & 40 & 30 & 20 & 10 & 0\end{array}$ 


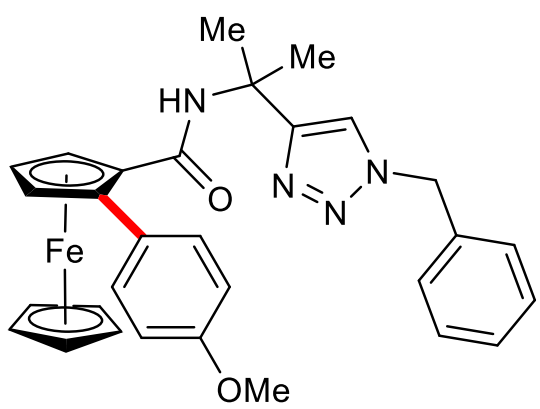

206

$300 \mathrm{MHz}, \mathrm{CDCl}_{3}$

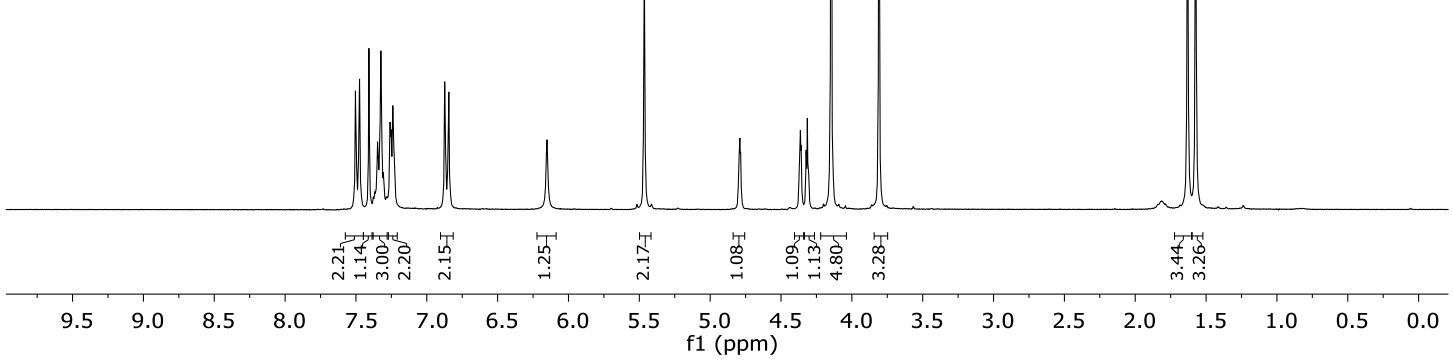

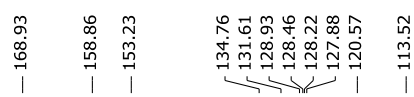

惡

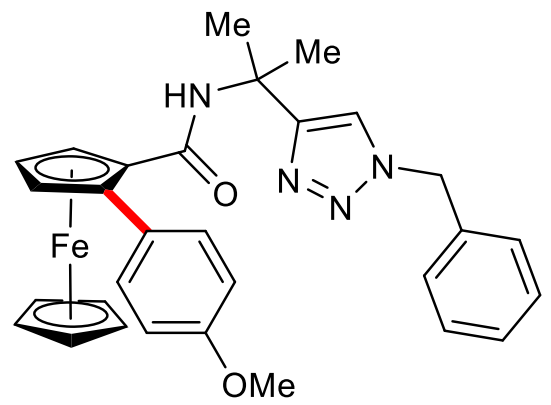

206

$125 \mathrm{MHz}^{\mathrm{CDCl}_{3}}$

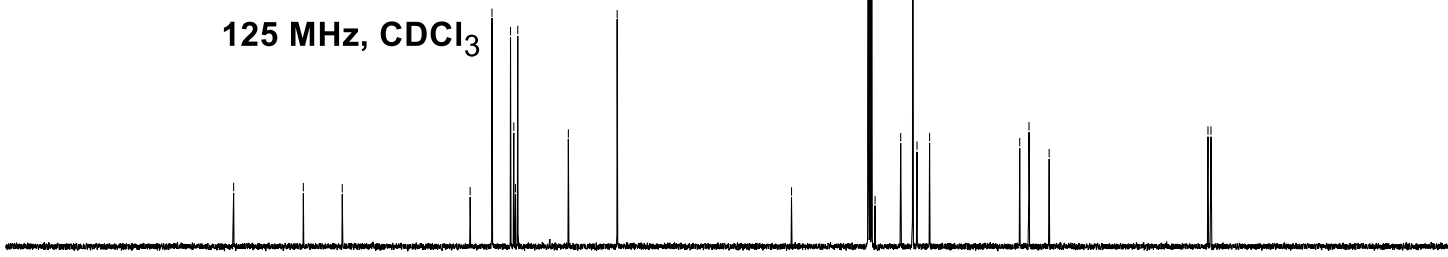

$\begin{array}{llllllllllllllllllll}200 & 190 & 180 & 170 & 160 & 150 & 140 & 130 & 120 & 110 & \begin{array}{c}100 \\ \mathrm{f} 1(\mathrm{ppm})\end{array} & 80 & 70 & 60 & 50 & 40 & 30 & 20 & 10 & 0\end{array}$ 
<smiles>COc1ccc(-c2cc(OC)ccc2C(=O)NC(C)(C)c2ccccn2)cc1</smiles>

207

$300 \mathrm{MHz}, \mathrm{CDCl}_{3}$

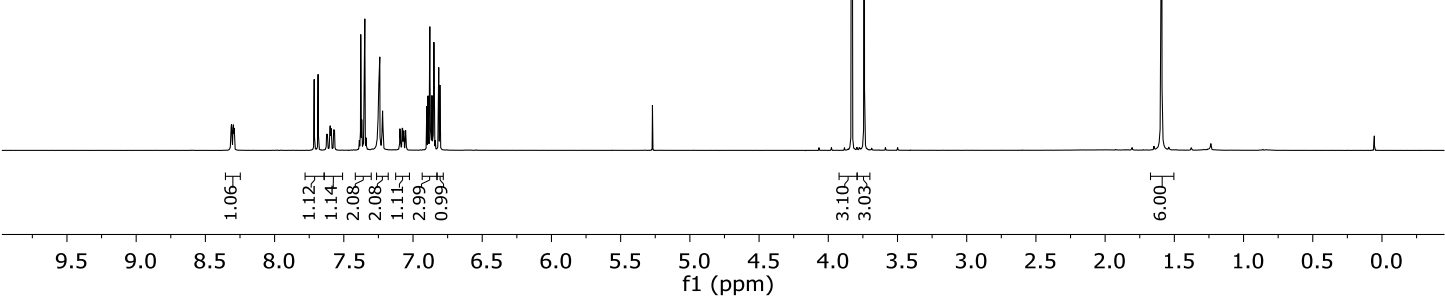

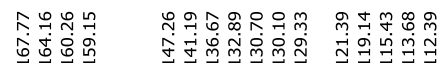

1)<smiles>COc1ccc(-c2cc(OC)ccc2C(=O)NC(C)(C)c2ccccn2)cc1</smiles>

207

$100 \mathrm{MHz}, \mathrm{CDCl}_{3}$

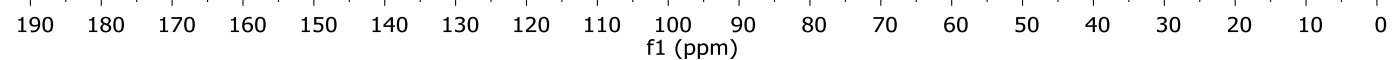


<smiles>COc1ccc(-c2ccccc2C(=O)NC(C)(C)c2ccccn2)cc1</smiles>

208

$300 \mathrm{MHz}, \mathrm{CDCl}_{3}$

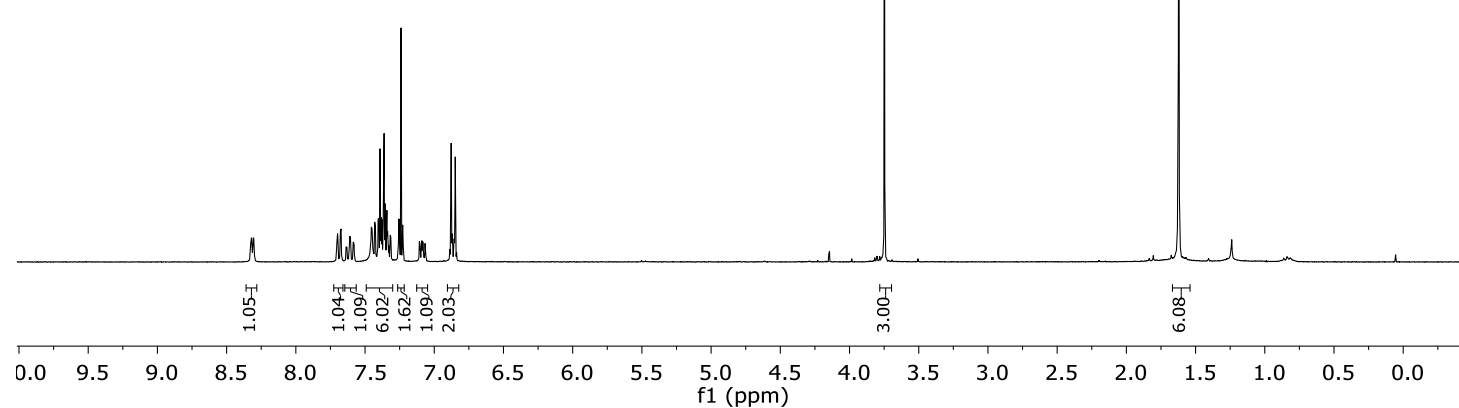<smiles>COc1ccc(-c2ccccc2C(=O)NC(C)(C)c2ccccn2)cc1</smiles>

208

$125 \mathrm{MHz}, \mathrm{CDCl}_{3}$

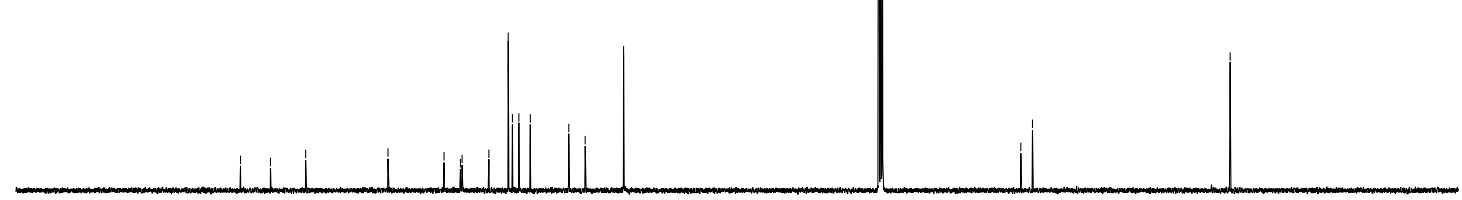

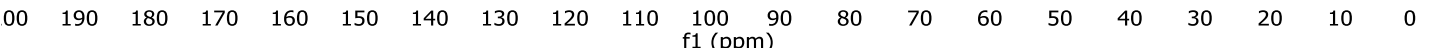




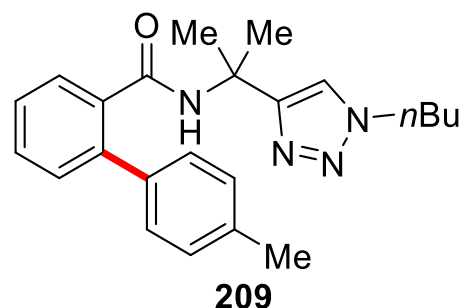

$400 \mathrm{MHz} \mathrm{CDCl}_{3}$

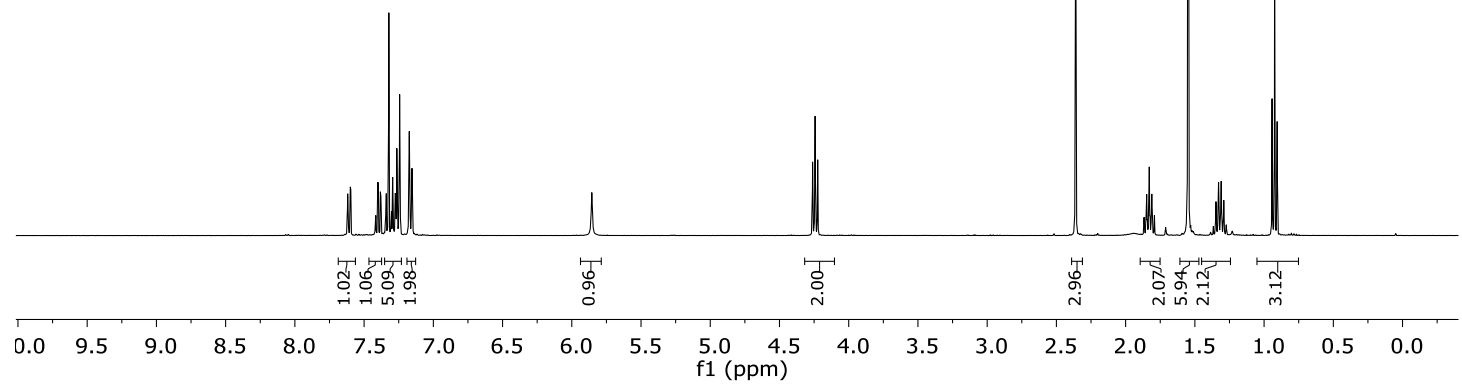

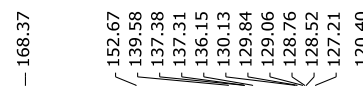

in

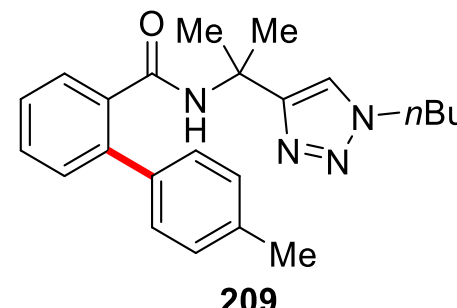

$100 \mathrm{MHz}, \mathrm{CDCl}_{3}$

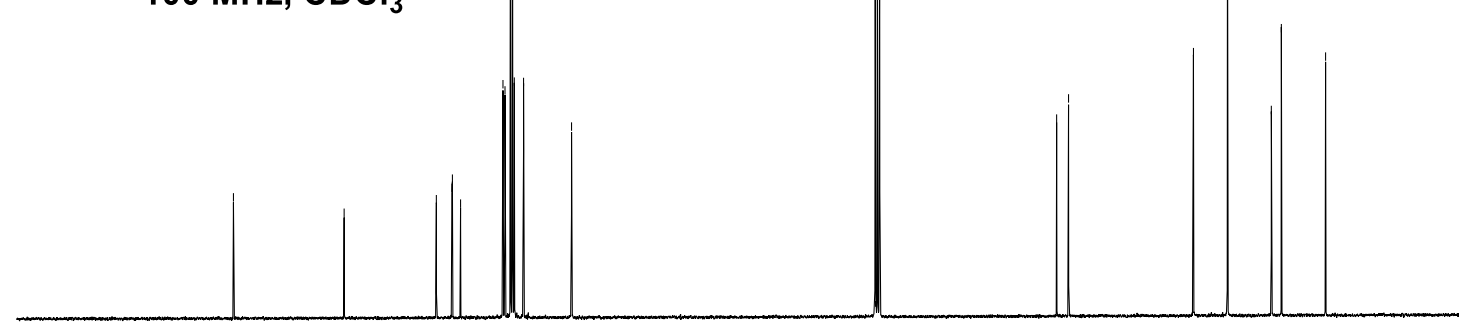

$\begin{array}{llllllllllllllllllll}190 & 180 & 170 & 160 & 150 & 140 & 130 & 120 & 110 & 100 & 90 & 80 & 70 & 60 & 50 & 40 & 30 & 20 & 10 & 0\end{array}$ 
<smiles>CCCCn1cc(C(C)(C)NC(=O)c2ccccc2-c2ccc(C(C)(C)C)cc2)nn1</smiles>

$400 \mathrm{MHz}, \mathrm{CDCl}_{3}$

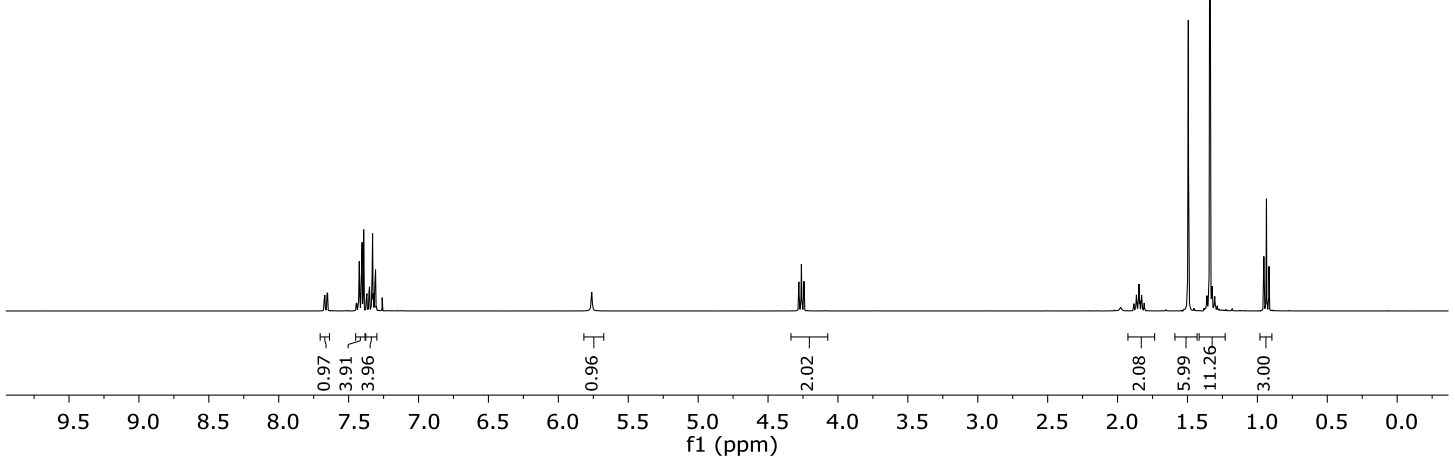

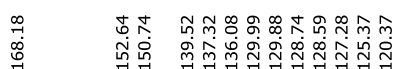

!

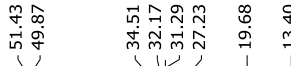<smiles>COC(=O)c1ccccc1-c1ccc(C(C)(C)C)cc1</smiles>

$100 \mathrm{MHz}, \mathrm{CDCl}_{3}$

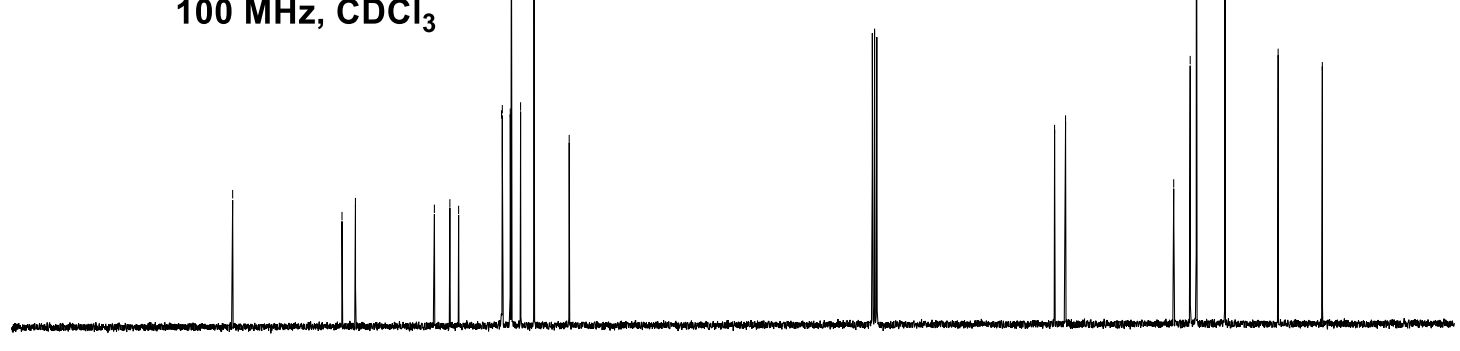

$\begin{array}{lllllllllllllllllll}190 & 180 & 170 & 160 & 150 & 140 & 130 & 120 & 110 & \begin{array}{c}100 \\ \mathrm{f} 1(\mathrm{ppm})\end{array} & 80 & 70 & 60 & 50 & 40 & 30 & 20 & 10 & 0\end{array}$ 


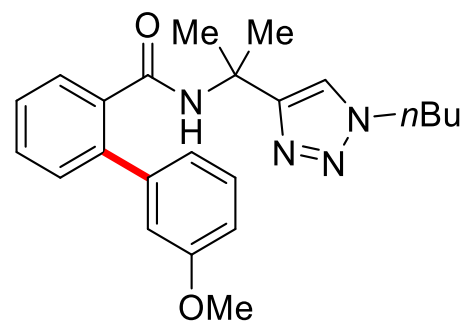

211

$300 \mathrm{MHz}^{\mathrm{CDCl}_{3}}$

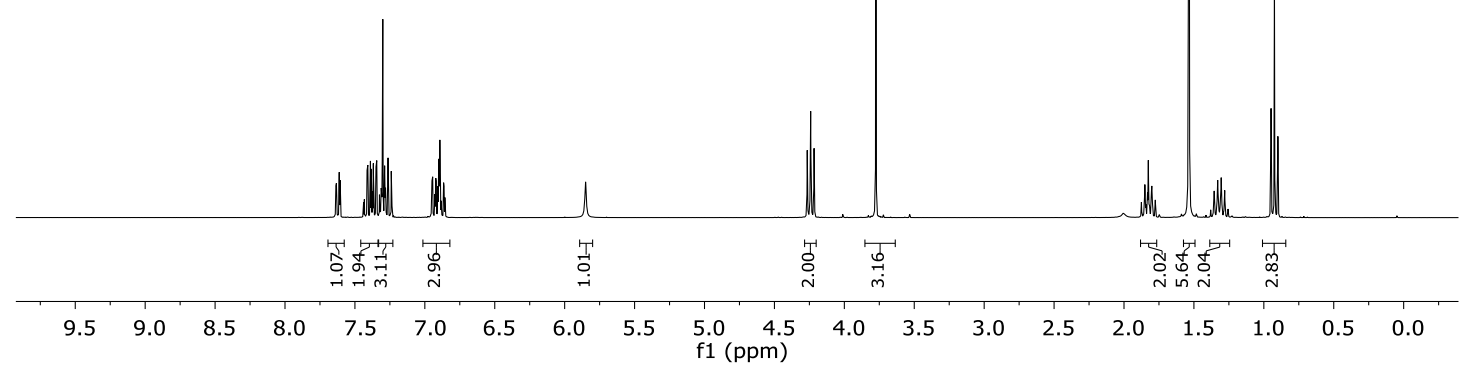

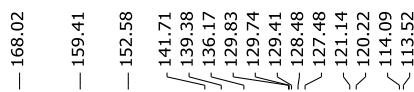

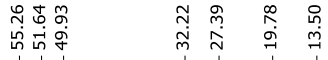<smiles>COc1cccc(-c2ccccc2C(=O)NC(C)(C)c2cn(C(C)(C)Br)nn2)c1</smiles>

211

$100 \mathrm{MHz}, \mathrm{CDCl}_{3}$

$\begin{array}{llllllllllllllllllll}190 & 180 & 170 & 160 & 150 & 140 & 130 & 120 & 110 & 100 & 90 & 80 & 70 & 60 & 50 & 40 & 30 & 20 & 10 & 0\end{array}$ 


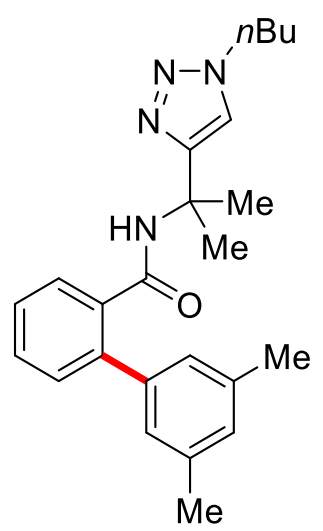

212

$400 \mathrm{MHz}, \mathrm{CDCl}_{3}$

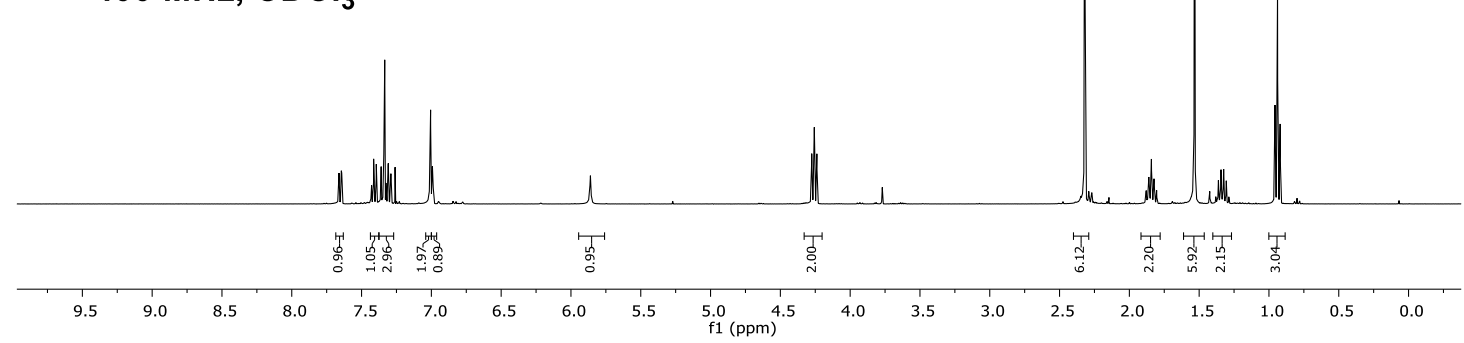

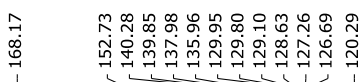

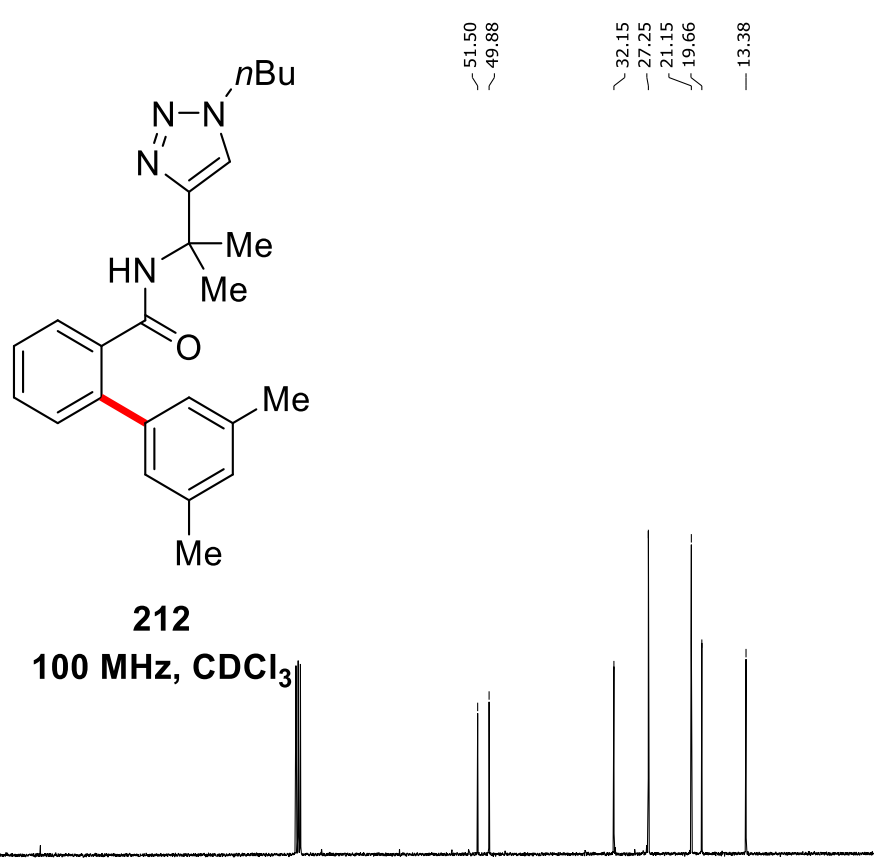

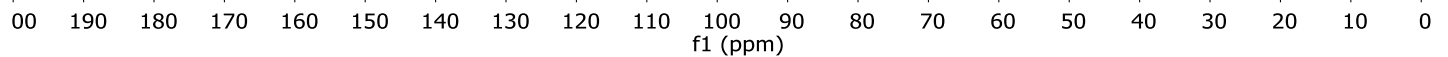


<smiles>CCCCn1cc(C(C)(C)NC(=O)c2ccccc2-c2ccc3ccccc3c2)nn1</smiles>

213

$400 \mathrm{MHz}, \mathrm{CDCl}_{3}$

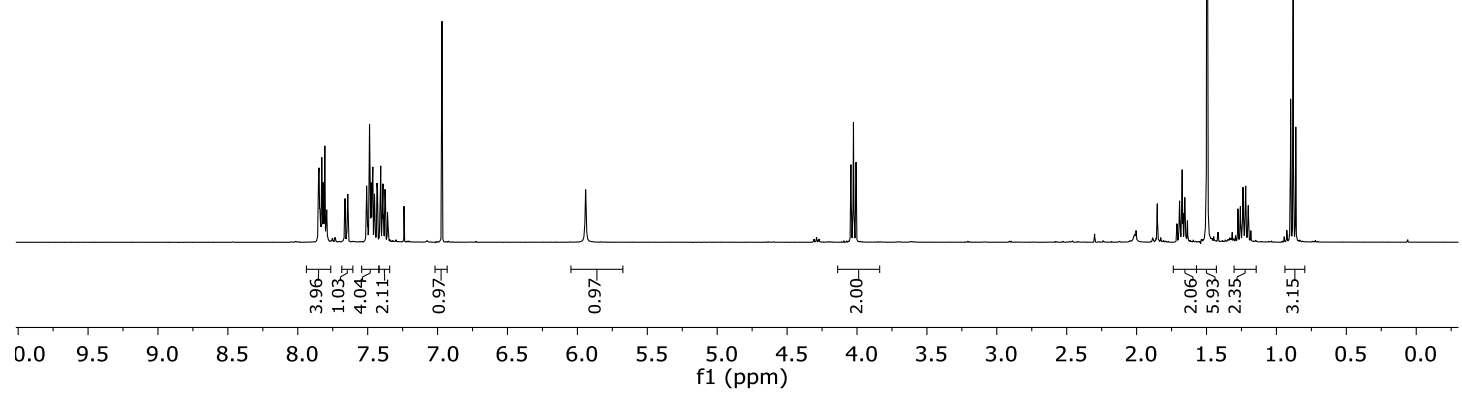

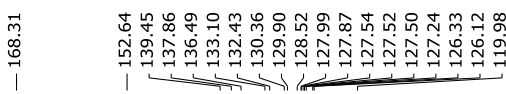<smiles>CCCn1cc(C(C)(C)NC(=O)c2ccccc2-c2ccc3ccccc3c2)nn1</smiles>

213

$100 \mathrm{MHz}, \mathrm{CDCl}_{3}$

$\begin{array}{llllllllllllllllllll}190 & 180 & 170 & 160 & 150 & 140 & 130 & 120 & 110 & 100 & 90 & 80 & 70 & 60 & 50 & 40 & 30 & 20 & 10 & 0\end{array}$ 


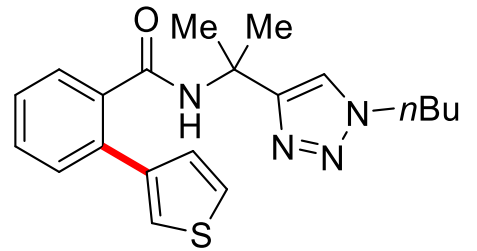

214

$400 \mathrm{MHz}, \mathrm{CDCl}_{3}$

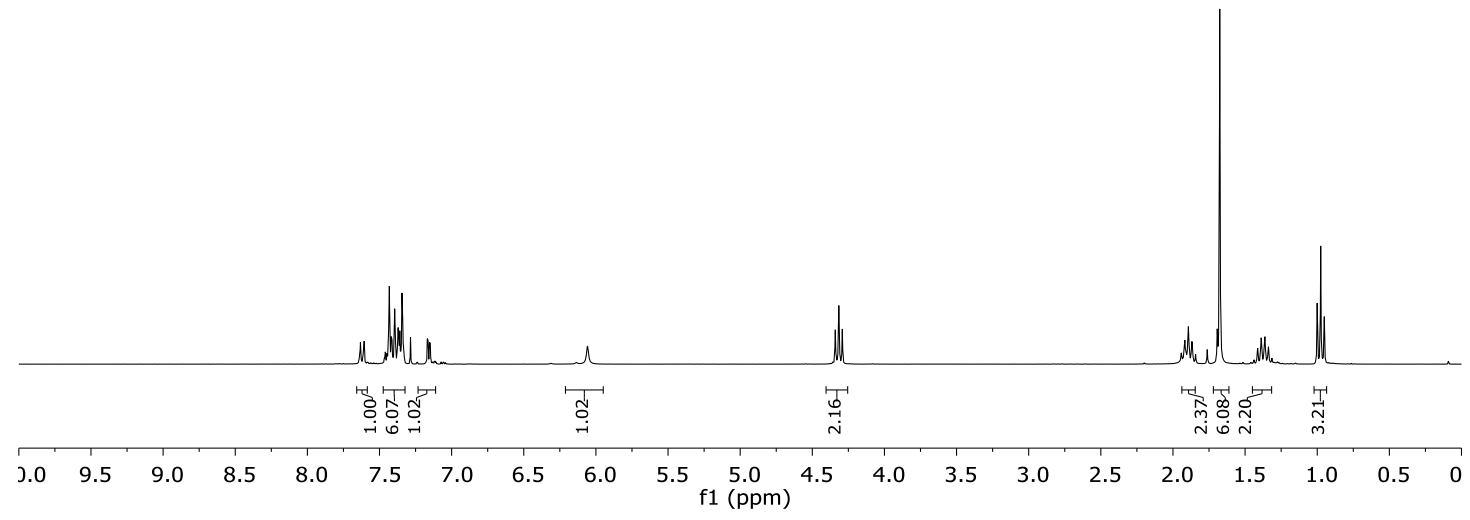

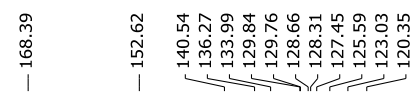<smiles>CCCCn1cc(C(C)(C)NC(=O)c2ccccc2-c2ccsc2)nn1</smiles>

214

$100 \mathrm{MHz}, \mathrm{CDCl}_{3}$

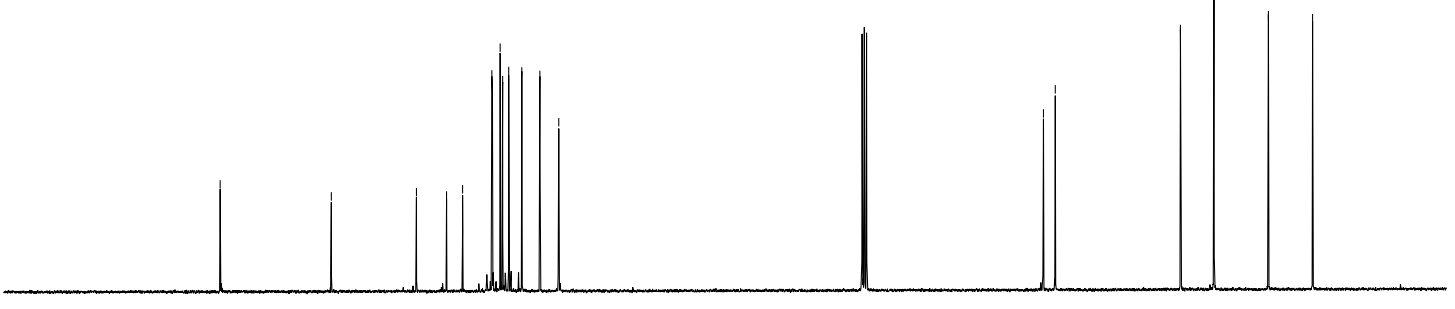

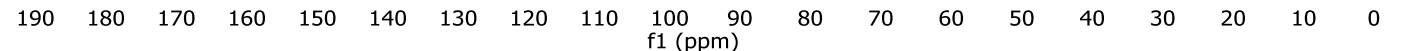




\section{Acknowledgements}

First and foremost, I would like to express my deepest gratitude to my supervisor Prof. Dr. Lutz Ackermann for giving me the opportunity to conduct my PhD in his research group. Thank you for your support, constant encouragement, your valuable guidance and your interest in my projects. His conscientious academic spirit and modest, openminded personality will inspire me in my future academic study.

I gratefully acknowledge China Scholarship Council (CSC) for the financial support during my research stay in Germany.

I am grateful to Prof. Dr. Alexander Breder for accepting to be my second supervisor. I also would like to thank Prof. Dr. Konrad Koszinowski, Prof. Dr. Manuel Alcarazo and Dr. Holm Frauendorf, Dr. Michael John for agreeing to take part in my defense.

I would like to thank the people from our research group with whom I had the opportunity to collaborate: Dr. Hui Wang, Dr. João C. A. de Oliveira, Dr. Rositha Kuniyil, Nikolaos Kaplaneris, Dr. Joachim Loup, Dr. Torben Rogge, Dr. Fabio Pescaioli, Dr. Nicolas Sauermann, Maximilian Stangier, Tjark Meyer, Leonardo Massignan, Wei Wang, Zhigao Shen, Shoukun Zhang, Dr. Youai Qiu, Dr. Weijun Kong, Dr. Weiping Liu, Korkit Korvorapun, Uttam Dhawa, Becky Bongsuiru Jei. I would also like to extend my gratitude to Dr. Christopher Golz and Prof. Dr. Manuel Alcarazo for their assistance with X-ray diffraction analysis, as well as to all the members of the analytical departments (NMR and mass spectrometry) at the IOBC for their continuous support to our research work.

I would like to thank Stefan Beußhausen for taking care of the instruments of our research group, especially the GC-MS, the glovebox and the SPS, which I used almost on a daily basis in the last four years. Thank you for your invaluable help!

My gratitude also goes to Karsten Rauch for his continuous support to our lab work, and especially for the preparation of dry solvents and catalysts.

I would like to thank Mrs. Gabriele Keil-Knepel for her continuous assistance with 
administrative tasks.

I also would like to express my gratitude to all past and present members of the Ackermann research group, especially to members of Lab 331, Korkit Korvorapun, Tjark Meyer, Leonardo Massignan, Becky Bongsuiru Jei, Cong Tian.

I would like to sincerely thank all the people who proofread this thesis: Dr. Rositha Kuniyil, Nikolaos Kaplaneris, Torben Rogge, Dr. João C. A. de Oliveira and Tjark Meyer. I also would like to thank all the people who previously corrected manuscripts, supporting information, posters, abstracts and proposals for me: Torben Rogge, Dr. Joachim Loup, Dr. Rositha Kuniyil, Tjark Meyer, Dr. Yu-Feng Liang, Dr. Hui Wang, Dr. Weiping Liu, Dr. João C. A. de Oliveira, Dr. Youai Qiu, Dr. Weijun Kong, Maximilian Stangier, Leonardo Massignan. Thank you all for your time and your patience! I also would like to express my gratitude to my former supervisors Prof. Dr. Weiping Su for teaching me so much about chemistry and giving me the opportunity to conduct research within their laboratories.

Last but not least, I would like to thank my husband, my unborn daughter and my family for their continuous support and their love throughout my life. 


\section{Curriculum Vitae}

Personal Information

\begin{tabular}{ll}
\hline Name: & Cuiju Zhu \\
Date of Birth: & 18.01 .1990 \\
Place of Birth: & Jianli, Hubei (P. R. China.) \\
Gender: & Female \\
Nationality: & Chinese
\end{tabular}

\section{Academic Education}

10/2015-12/2019 PhD Candidate in Organic Chemistry

Institut für Organische und Biomolekulare Chemie,

Georg-August-Universität Göttingen

Supervisor: Prof. Dr. Lutz Ackermann

Thesis: Sustainable Synthesis by 3d Transition Metal

Electro-Catalyzed C-H Activation

09/2011-07/2014 M. Sc. in Organic Chemistry

Fujian Institute of Research on the Structure of Matter,

Chinese Academy of Sciences

Supervisor: Prof. Dr. Weiping Su

Thesis: Metal free catalyzed $\mathrm{C}-\mathrm{O}$ and $\mathrm{C}-\mathrm{N}$ functionalization of ketones.

09/2007-07/2011 B.Sc. in Chemistry

Department of Chemistry

Sichuan Normal University 
24-29/09, 2017 Poster of the $1^{\text {st }}$ Summer School on Organic Catalysis for Energy Conversion, Göttingen, Germany.

22-24/09, 2018 Poster of the $1^{\text {st }}$ Summer School on H-CCAT Project, Perugia, Italy, Sep 22-24, 2018.

19-20/22, 2014. The $13^{\text {th }}$ International Symposium for Chinese Organic Chemists and $10^{\text {th }}$ International Symposium for Chinese Inorganic Chemists, Xiamen, China.

\section{Publications}

1. Cuiju Zhu, Rositha Kuniyil, Becky B. Jei and Lutz Ackermann*, Domino C-H Activation/Directing Group Migration/Alkyne Annulation: Unique Selectivity by $\mathrm{d}^{6}$ Cobalt(III) Catalysts, (ACS Catal. 2020, accepted)

2. Cuiju Zhu, Maximilian Stangier, João C. A. Oliveira, Leonardo Massignan and Lutz Ackermann*, Iron-Electro-Catalyzed C-H Arylations: Mechanistic Insights Into Oxidation-Induced Reductive Elimination through Spectroscopy, CV, and Computation for Ferraelectrocatalysis, Chem. Eur. J. 2019, 25, 16382-16389.

3. Cuiju Zhu, Rositha Kuniyil, and Lutz Ackermann*, Manganese(I)-Catalyzed C-H Activation/Diels-Alder/retro-Diels-Alder Domino Alkyne Annulation by Transformable Pyridines, Angew. Chem. Int. Ed. 2019, 58, 5388-5342. (highlighted in Synfacts 2019, 15 (06): 0621)

4. Cuiju Zhu, J. C. A. Oliveira, Z. Shen, H. Huang, L. Ackermann*, Manganese(II/III/I)Catalyzed C-H Arylations in Continuous Flow, ACS Catal. 2018, 8, 4402-4407.

5. R. Mei,' Cuiju Zhu,' L. Ackermann*, Ruthenium(II)-Catalyzed C-H Functionalizations on Benzoic Acids with Aryl, Alkenyl and Alkynyl Halides by Weak-O-Coordination, Chem. Commun. 2016, 52, 13171-13174. (Both authors contributed equally)

6. Y. Yang,' Cuiju Zhu,' M. Zhang, S. Huang, J. Lin, X. Pan, W. Su*, Condensation of anthranilic acids with pyridines to furnish pyridoquinazolones via pyridine 
dearomatization, Chem. Commun. 2016, 52, 12869-12872. (Both authors contributed equally)

7. Cuiju Zhu, Y. Zhang, H. Zhao, S. Huang, M. Zhang, W. Su*, Sodium lodide-Catalyzed Direct $\alpha$-Alkoxylation of Ketones with Alcohols via Oxidation of $\alpha$-lodo Ketone Intermediates, Adv. Synth. Catal. 2015, 357, 331-338.

8. Z. Shen, H. Huang, Cuiju Zhu, S. Warratz, L. Ackermann*, $\mathrm{MnCl}_{2}$-Catalyzed C-H Alkylation on Azine Heterocycles, Org. Lett. 2019, 21, 571-574.

9. F. Fumagalli, S. Warratz, S.-K. Zhang, T. Rogge, Cuiju Zhu, A. C. Stückl, L. Ackermann*, Arene-Ligand-free Ruthenium(II/III) Manifold for meta-C-H Alkylation: Remote Purine Diversification, Chem. Eur. J. 2018, 24, 3984-3988.

10. Z. Ruan,' S.-K. Zhang,' Cuiju Zhu, P. N. Ruth, D. Stalke, L. Ackermann*, Ruthenium(II)-Catalyzed meta $\mathrm{C}-\mathrm{H}$ Mono- and Difluoromethylations by Phosphine/Carboxylate Cooperation, Angew. Chem. Int. Ed. 2017, 56, 2045-2049.

11. S. Warratz, D. J. Burns, Cuiju Zhu, K. Korvorapun, T. Rogge, J. Scholz, C. Jooss, D. Gelman, L. Ackermann*, meta-C-H Bromination on Purine Bases by Heterogeneous Ruthenium Catalysis, Angew. Chem. Int. Ed. 2017, 56, 1557-1560. 


\section{Erklärung}

Ich versichere, dass ich die vorliegende Dissertation in dem Zeitraum von Oktober 2015 bis Dezember 2019 am Institut für Organische und Biomolekulare Chemie der

Georg-August-Universität Göttingen

auf Anregung und unter Anleitung von

Herrn Prof. Dr. Lutz Ackermann

selbstständig verfasst und keine anderen als die angegebenen Hilfsmittel und Quellen verwendet habe.

Göttingen, den 11.10.201 